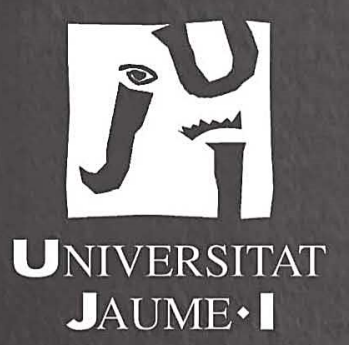

\title{
LA PROMOCIÓN ARTISTICA EN LA ESPAÑA ALFONSINA: EL MARQUÉS DE CAMPO COMO PROMOTOR, MECENAS Y COLECCIONISTA DE ARTE
}

\author{
TESIS DOCTORAL \\ Presentada por: \\ Ana María Morant Gimeno \\ Dirigida por: \\ Dr. D. Víctor Mínguez Cornelles
}





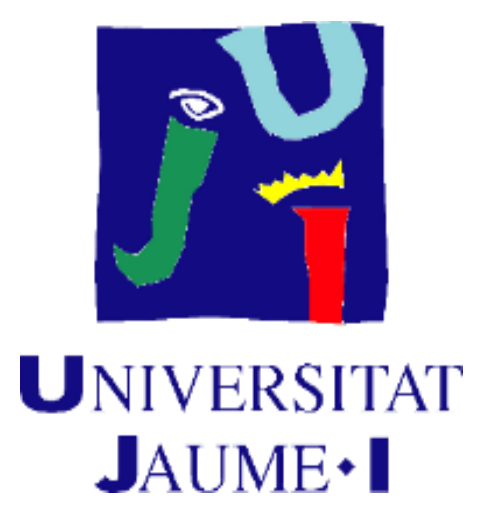

Programa de doctorado en Historia del Arte

Escola de Doctorat de la Universitat Jaume I

\section{LA PROMOCIÓN ARTÍSTICA EN LA ESPAÑA ALFONSINA: EL MARQUÉS DE CAMPO COMO PROMOTOR, MECENAS Y COLECCIONISTA DE ARTE}

Memoria presentada por Ana María Morant Gimeno para optar al grado de doctora por la Universitat Jaume I

Doctoranda

ANA MARÍA

MORANT GIMENO

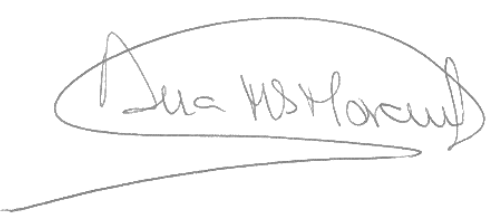

Director VÍCTOR MANUEL MÍNGUEZ CORNELLES

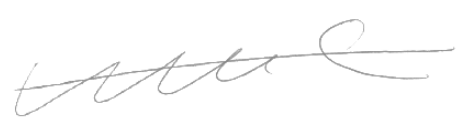


Licencia CC Reconocimiento -

Compartir igual (BY-SA).

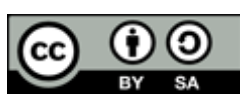

\section{Financiación recibida}

Esta tesis doctoral ha sido realizada gracias a la ayuda predoctoral para la formación de personal investigador (PREDOC/2013/03), dentro del Programa de apoyo a la formación e incorporación de personal investigador de la Universitat Jaume I. 
Esta tesis está dedicada

Al Equipo "A": Amparo, Arthur y Amparo, mi apoyo y sostén. La unión hace la fuerza.

A mi padre Francisco y a mi abuelo Vicente, que espero estén orgullosos de mí. A todos aquellos que en algún momento de sus vidas han visto como todo se iba a acabar y han logrado sobreponerse y continuar adelante. 



\section{Agradecimientos Institucionales:}

Esta tesis doctoral ha sido realizada gracias a la ayuda predoctoral para la formación de personal investigador (PREDOC/2013/03), dentro del Programa de apoyo a la formación e incorporación de personal investigador de la Universitat Jaume I. 



\section{Agradecimientos}

A Víctor Mínguez, mi director de Tesis, por creer en mí desde el primer momento en que nos conocimos en una tutoría en el bar de la Facultad de Geografía e Historia de Valencia y hablamos por primera vez del marqués de Campo. Gracias por haberme animado a hacer esta tesis, aunque mi salud se haya interpuesto en el camino. Gracias por enseñarme el apasionante mundo de la investigación y por contagiarme tu entusiasmo en todos los proyectos que realizas. Gracias por haberme dejado formar parte del grupo de investigación IHA, ejemplo de profesionalidad y rigor científico. Gracias por animarme a seguir día a día hasta el final y por darme tu confianza.

Al Departamento de Historia, Geografía y Arte de la Facultad de Ciencias Humanas y Sociales de la UJI, por su ayuda y colaboración en la realización de esta tesis. esta tesis.

Al grupo de investigación IHA, por su apoyo durante la realización de

A Telesforo Hernández, quien ha dedicado parte de su vida a estudiar a José Campo; por transmitirme su pasión por el personaje.

A Miguel Ángel Catalá Gorgues (RIP), por su confianza, su colaboración desinteresada y por regalarme un retrato inédito del marqués de Campo realizado por Nadar.

A María Barceló, directora del Museo de la Ciudad de Valencia, por su colaboración y amistad.

A Javier García Peiró, director de la Casa Museo Benlliure de Valencia, por su colaboración en la búsqueda de información.

A Elvira Mas, por su aportación de datos sobre los familiares artistas del marqués de Campo. A Cristina Rosario Franco, por su colaboración y amistad.

A los familiares del general Jovellar. por su colaboración en esta tesis dejándome estudiar en persona y fotografiar la figura de plata que le regaló el marqués.

A D. Francisco Roca, quien ha conseguido día a día recomponer mis pedazos y que hoy esta tesis sea una realidad.

A todos los que, de un modo u otro, han hecho posible este trabajo. 



\section{ÍnDICE}

RESUMEN..................................................................................15

ESTADO DE LA CUESTIÓN..........................................................17

OBJETIVOS...................................................................................35

METODOLOGÍA................................................................................39

FUENTES.................................................................................43

\section{Capítulo I}

Los retratos del marqués de Campo y su familia..............................49

1.-La imagen del marqués de Campo a través de sus retratos...............................54

2.-Los retratos de la familia del marqués de Campo............................................74

\section{Capítulo iI}

La promoción de arquitectura benéfica en Valencia del marqués de

Campo.

89

1.-El asilo de párvulos de 1863. Diseñado y construido por el arquitecto municipal Antonio Sancho y el ingeniero inglés Jaime Beatty (..-..)...................96 2.-El asilo de la calle Corona de 1882 . Arquitecto José Camaña Laymon (18501896) 100 


\section{Capítulo iII}

Otros ejemplos de la promoción arquitectónica del marqués de Campo: sus residencias.. .

1.-La casa palacio de la plaza del Arzobispo de Valencia.....................................115

2.-El palacio del paseo de Recoletos 14, Madrid...............................................142

3.-El castillo de Viñuelas en el monte de El Pardo, Madrid..................................165

4.-La residencia de verano en Arcachon, Burdeos, Francia................................176

\section{Capítulo iv}

El marqués de Campo como promotor de arte efimero....................181

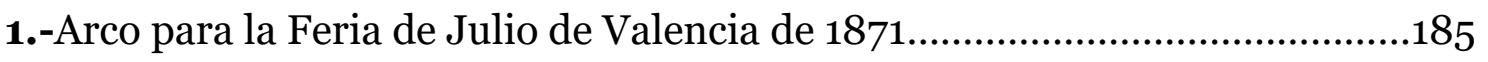

2.-Arco triunfal para la entrada de Alfonso XII en Madrid en 1875 ..................190

3.-Carro triunfal "el progreso" para la feria de julio de 1888 y $1889 \ldots \ldots \ldots \ldots . . . . . .197$

4.-Templete para la Exposición Regional de Valencia de 1883..........................204

5.-Iluminaciones efímeras en su palacio de Madrid..........................................208

5.1.-Iluminación por la entrada de Alfonso XII en Madrid en 1875......210

5.2.-Iluminación por la entrada de Alfonso XII vencedor en 1876 .........210

5•3.-Iluminación por la boda real de Alfonso XII con María de las

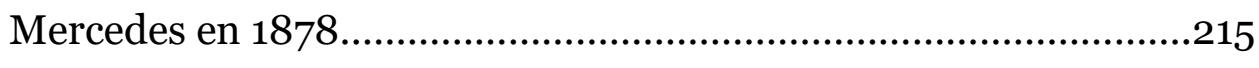

5.4.-Iluminación por la boda real de Alfonso XII con María Cristina en

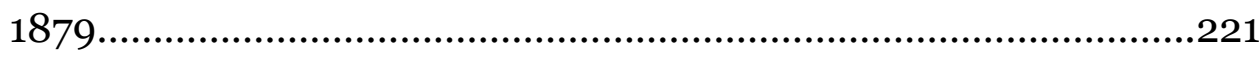

6.- Iluminaciones efímeras en su palacio de Valencia. .223

6.1.-Iluminación por el centenario de la coronación de la Virgen de los Desamparados en 1867. 223

6.2.-Iluminación por la visita del rey Alfonso XII a Valencia en 1875..225

6.3.-Iluminación por la visita de la reina regente María Cristina, Alfonso XIII y las infantas en 1888 .226

6.4.-Otras iluminaciones en Valencia con ocasión de otras celebraciones .228 


\section{Capítulo v}

El marqués de Campo como promotor y mecenas de artistas......233

1.-Promotor y mecenas de la familia Benlliure .237

2.-Promotor y mecenas de José Benlliure. 238

3.-Promotor y mecenas de Juan Antonio Benlliure...........................................245

4.-Promotor y mecenas de Mariano Benlliure ………......................................246

5.-Promotor y mecenas de otros artistas.............................................................257

\section{Capítulo vi}

EL marqués de Campo como coleccionista de obras de arte..........265

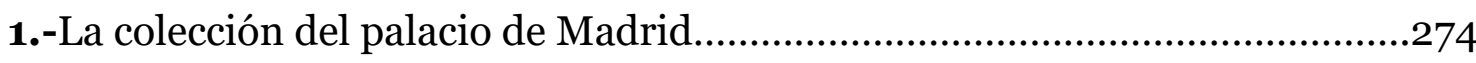

2.-La colección del palacio de Valencia..............................................................281

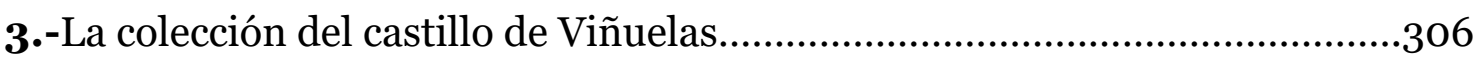

4.-La colección de la residencia de Arcachon, Francia ........................................311

\section{Capítulo vi}

El marqués de Campo y la Exposición Universal de Barcelona de 1888 . .323

\section{Capítulo vii}

La construcción de un altar con retablo en la iglesia de Torrijo del Campo, Teruel, a expensas del marqués de Campo. Interpretación iconográfica ...................................................................................351 El escudo de armas del marqués de Campo: su composición heráldica. .361 


\section{Capítulo ix}

La expedición del marqués de Campo a las obras del canal de Panamá en 1886. .371

1.-José Campo y el origen de la expedición al canal de Panamá. 371

2.-Las crónicas de la expedición a las obras del canal de Panamá. 375

3.-La medalla conmemorativa de la expedición a las obras del canal de Panamá 379

4.-La celebración del éxito de la expedición al canal de Panamá: el banquete del marqués de Campo visto por la prensa .383

\section{Capítulo X}

La promoción artística y mecenazgo de Tomás Campuzano y Aguirre (1857-1934), autor de los dibujos de la expedición a las obras del canal de Panamá. 391

1.- Grabados publicados por la Ilustración Española y Americana. 393

1.1.-Vapor Magallanes............................................................................393

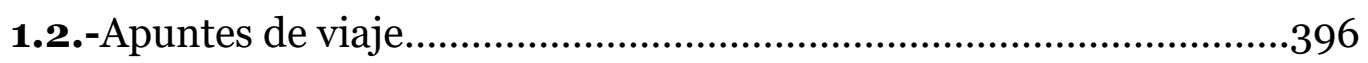

1.3.-La desembocadura del canal en el pacífico. El grupo de Colón y América.

1.4.-Secciones de las obras y vendedora de licores................................... 399

1.5.-Matachín. Lavanderas en el río Chagres............................................401

1.6.-Draga Slaven en el río Mindi...........................................................403

2.- Ilustraciones de la crónica de Francisco Peris Mencheta..............................405

2.1.-El castillo del Morro y la entrada del Magallanes en el puerto de La

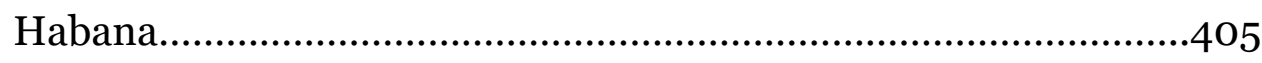

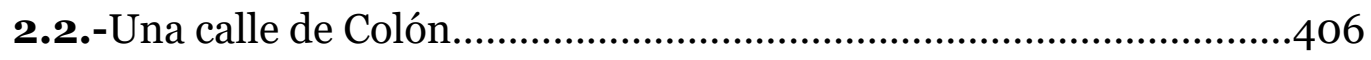

2.3.-Punta de Panamá..............................................................................407

2.4.-Draga en el Pacífico............................................................................408

2.5.-El río Chagres en Matachín................................................................409 


\section{Capítulo XI}

Un regalo del marqués de Campo al General Jovellar en 1875. Interpretación iconográfica..............................................................413

1.-Las figuras de la base y del remate.............................................................427

1.1.-La personificación de Valencia.........................................................427

1.2.-La personificación de España.............................................................431

1.3.-La personificación de los ríos Turia y Ebro.........................................435

1.4.-El remate de la escultura....................................................................437

1.5.-El escudo de armas del General Jovellar...........................................440

CONCLUSIONES......................................................................445

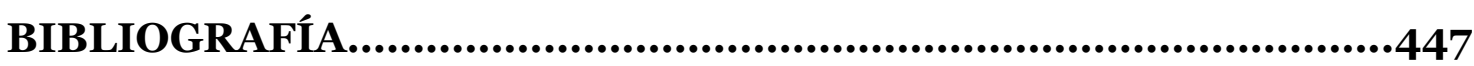

ÍNDICE DE ILUSTRACIONES......................................................473 



\section{RESumen}

La presente tesis doctoral analiza la figura de José Campo Pérez, marqués de Campo, en relación con la promoción arquitectónica, el mecenazgo de artistas y el coleccionismo de obras de arte.

Se propone la hipótesis de considerar al marqués de Campo como uno de los promotores, mecenas y coleccionistas importantes de la segunda mitad del siglo XIX, coincidiendo sobre todo con los años de vida del rey Alfonso XII, desde 1857 a 1885, y unos años más hasta su propia muerte en 1889.

En esta investigación se ha aplicado el método sociocultural y el método iconográfico, para conectar toda la actividad de José Campo relacionada con el arte con el entorno social, económico y cultural en el que se desarrollaba su vida y se ha realizado un análisis iconográfico e iconológico de las imágenes encontradas relacionadas con esas actividades. Además, se ha producido un análisis pormenorizado de todas las fuentes documentales y una lectura integrativa de la bibliografía utilizada. 
Tras este proceso se ha demostrado que el marqués de Campo no sólo fue un burgués ennoblecido por Alfonso XII que supo aprovechar su posición para avanzar social, económica y políticamente, sino que el arte formaba una parte muy importante de su vida, y dedicó parte de ella a promocionar obras arquitectónicas, ser mecenas de artistas y reunir una gran colección de obras de arte que decoraban todas las estancias de sus palacios y residencias. Demostrando así que el marqués de Campo está a la altura de otros coleccionistas como el marqués de Salamanca o Lázaro Galdiano. 


\section{Estado de la cuestión}

Uno de los personajes más influyentes política y económicamente en la Valencia del siglo XIX fue José Campo y Pérez, y hasta la actualidad siempre se ha estudiado desde su faceta de comerciante, hombre de negocios, inversor y político.

Dignos de mención son los estudios realizados por Francisco Almela y Vives, con motivo del centenario de su muerte, y los estudios de Telesforo Hernández, que es quien más ha investigado la actividad económica de José Campo y ha escrito su biografía ${ }^{1}$.

\footnotetext{
${ }^{1}$ ALMELA Y VIVES, Francisco. El Marqués de Campo, Capdavanter de la burgesia valenciana (1814-1889). Valencia: Ajuntament de València, 1989.

HERNÁNDEZ, Telesforo. Ferrocarriles y capitalismo en el País Valenciano 1843-1879. Valencia: Ayuntamiento de Valencia, 1983.

HERNÁNDEZ, Telesforo. "Los negocios ultramarinos del Marqués de Campo en Cuba y Filipinas (1880-1886)”. En: HERNÁNDEZ, Telesforo (coord.). Los valencianos y América. Valencia: Generalitat Valenciana, 1992, p. 129-147.
} 
José Campo nació en Valencia el día 22 de mayo de 1814, en una casa cerca del Mercado Central, en el seno de una familia humilde. Su madre, Vicenta Pérez Vela (1792-1866) era natural de Valencia. Su padre Gabriel Campo Arpa (1781-1851), natural de Torrijo del Campo (Teruel), era un comerciante dedicado a la venta y distribución de especias y demás alimentos, que vino a Valencia a hacer fortuna y, como dice Hernández, "se asoció con José Juste, tratante en el ramo de la especiería, el negocio que lo va a enriquecer”.

De este matrimonio monárquico, conservador y católico, nacieron además de José, dos varones más: Gabriel en 1816, que tras estudiar en la universidad ingresó en una cartuja francesa, y Andrés en 1821, que tampoco se dedicó a los negocios.

José estudió en las Escuelas Pías de Valencia, y su padre Gabriel lo instruyó en la práctica mercantil. Sus experiencias se completaron en Europa y sobre todo en Francia e Inglaterra, donde viajó con 24 años. José Campo comenzó un viaje por Europa en 1837 que duró dos años y, como dice Momblanch, "durante el viaje pudo conocer los nuevos ferrocarriles, las tecnologías más avanzadas y el funcionamiento de la banca y de la bolsa"3. Hernández dice que: "para dar el salto al mundo empresarial como hombre de negocios o banquero, necesitaba viajar al extranjero y observar el universo de

HERNÁNDEZ, Telesforo. "Tensions familiars i patrimoni: ventura i desventura de la fortuna acumulada pel marquès de Camp". Afers, fulls de recerca i pensament, Vol. VIII, La burgesia dels Països Catalans al segle XIX, 1993, p. 347-361.

HERNÁNDEZ, Telesforo. "José Campo Pérez" en VIDAL, J. (dir.). Cien Empresarios Valencianos. Madrid: Editorial Empresarial, 2005, p. 53-64.

2 MORANT GIMENO, Ana María et al. El marqués de Campo. Empresario, político y coleccionista de obras de arte. Valencia: Ayuntamiento de Valencia, 2015, p. 84.

${ }^{3}$ MOMBLANCH GARCÍA, Francisco de Paula. "Un valenciano singular: el marqués de Campo". En: Crónica de la XXX asamblea de cronistas oficiales del reino de Valencia. Valencia, 2016, p. 265. 
las contrataciones. Así mismo empaparse de los descubrimientos de la revolución industrial"4.

A su vuelta, José y su padre crearon juntos en 1839 la sociedad Gabriel Campo e Hijo dedicada a la compraventa de frutos del país y coloniales, sal, e incluyendo también operaciones de giro y banca, que pronto comenzó a dar beneficios y que le permitió independizarse en 1840, año en que se casó con Rosalía Rey Loisselet, natural de Toulouse, a quien había conocido en Marsella años atrás y con quien había tenido una hija antes del matrimonio. La boda se celebró en la iglesia de un pueblo cercano a Valencia, Benetúser, para evitar habladurías, y el matrimonio con la niña se instaló en la calle de la Yerba $n .{ }^{0} 1$ de Valencia.

En el negocio con su padre, él era el socio industrial y su padre el socio capitalista, y según Momblanch "los beneficios eran dos tercios para el padre y un tercio para José”. La bonanza del negocio le permitió mudarse a una gran casa en la calle Caballeros n. ${ }^{\circ} 41$ de Valencia.

A la vez que realizaba su actividad comercial, inició su actividad política, llevado por su interés en mejorar su ciudad. A finales de 1842, bajo el gobierno del General Espartero, fue elegido regidor del Ayuntamiento, y un año más tarde, en 1843, alcalde constitucional de la ciudad de Valencia hasta el año 1847. Como era un hombre de grandes inquietudes consiguió, durante su mandato como alcalde y posteriormente, modernizar la ciudad; si bien se le acusa de enriquecerse a la vez, no podemos sino admirar la cantidad de mejoras que se produjeron gracias a él.

\footnotetext{
${ }^{4}$ MORANT GIMENO, Ana María et al. El marqués de Campo. Empresario, político y coleccionista de obras de arte. Valencia: Ayuntamiento de Valencia, 2015, p. 109.

${ }^{5}$ MOMBLANCH GARCÍA, Francisco de Paula. "Un valenciano singular: el marqués de Campo”. En: Crónica de la XXX asamblea de cronistas oficiales del reino de Valencia. Valencia, 2016, p. 266.
} 
Tal y como dice Hernández en su biografía: "Campo tenía interés en las reformas urbanas, paralizadas por la escasez de ingresos municipales y por la política contradictoria del Gobierno de Espartero, pero también se le acusó de haber vinculado los negocios con la política sin reparo ni escrúpulo alguno"6.

En 1844, solicitó por medio de su madre, el cambio del oficio de su padre en su partida de bautismo. En ella ponía hijo de Gabriel Campo, natural de Torrijo del Campo, Tendero de salsas; y se cambió por hijo de don Gabriel Campo Arpa, del Comercio7. Esto refleja el interés de Campo por mejorar sus orígenes pensado en el futuro que tenía planeado.

En cuanto fue elegido alcalde comenzó a impulsar la modernización de la ciudad. Lo primero que hizo fue instalar el alumbrado público a gas, cuya compañía, que en principio era en sociedad con el francés Lebón, acabó siendo de su propiedad. Pero no sólo le interesaba el gas, pues cuando, casi a final de siglo llegó la luz eléctrica, Antonio Armero dice que "Campo había iniciado en 1887 la producción de energía eléctrica en su fábrica de gas, a partir de generadores de vapor, para producir corriente continua y con una potencia inicial de $500 \mathrm{~kW}$. El marqués había ganado la última subasta de alumbrado público en Valencia en el año 1888, como único postor y comprometiéndose a suministrar gratis el alumbrado de gas por 20 años (hasta 1909); pero también se había ofrecido a sustituir el alumbrado de gas por el eléctrico si el Ayuntamiento asumía una pequeña parte del coste” 8 .

\footnotetext{
${ }^{6}$ HERNÁNDEZ, Telesforo. “José Campo Pérez". En: VIDAL, J. (dir.). Cien Empresarios Valencianos. Madrid: Editorial Empresarial, 2005, p. 53-64.

${ }^{7}$ ALMELA Y VIVES, Francisco. El Marqués de Campo, Capdavanter de la burgesia valenciana (1814-1889). Valencia: Ajuntament de València, 1989, p. 30.

${ }^{8}$ ARMERO MARTÍNEZ, Antonio. EL PROCESO DE ELECTRIFICACIÓN INICIAL EN LA PROVINCIA DE VALENCIA (1882-1907). Tesis doctoral. Universidad Politécnica de Valencia, Valencia 2015. p.138 y 139. Consultada en línea el 10 de marzo de 2018. https://m.riunet.upv.es/bitstream/handle/10251/62168/Armero\%20\%20El\%2oproceso\%20de\%2oelectrificaci\%C3\%B3n\%20inicial\%20en\%2ola\%2oprovin cia\%20de\%20Valencia\%20\%281882-1907\%29.pdf?sequence=1\&isAllowed $=\mathrm{y}$
} 
José Campo también trajo el agua potable a la ciudad, promoviendo la realización de las obras de canalización. Se formó una comisión municipal, dirigida por Campo, con la colaboración de la Sociedad Económica de Amigos del País, y se fundó la Sociedad Valenciana de conducción de Aguas potables. Fundó También la Sociedad Valenciana de Fomento, que fue quien asumió las obras necesarias para el agua y además compró solares para mejorar y urbanizar la zona de la Zaidía.

Campo, como alcalde, también promovió las obras de empedrado de las calles, que estaban muy deterioradas y hacían difícil el tráfico de mercancías en carros en incluso el paso de los peatones cuando llovía, pues no había alcantarillado. También promovió la reforma del puerto de Valencia y las primeras líneas de ferrocarril, entre otras cosas; obras todas ellas que necesitaron la intervención de diferentes profesionales de la ingeniería, arquitectos, etc. y gran cantidad de mano de obra.

Siendo alcalde entró en el partido moderado y comenzó los contactos con las clases dirigentes del país. Visitó a la reina M. ${ }^{a}$ Cristina el 15 de marzo de 1844 cuando pasó por Valencia tras su exilio y se alojó en el palacio de Cervellón, lugar donde su esposo, Fernando VII, abolió la Constitución de 1812. En esa visita la reina madre le entregó a Campo las llaves de la ciudad y una carta de Isabel II. Según Hernández hay constancia de otra visita a la reina M. ${ }^{a}$ Cristina el 23 de mayo de ese mismo año, cuando volvió de nuevo a Valencia con su hija, Isabel II, a quienes acompañaba el general Narváez, presidente del Consejo de Ministros9.

Campo renunció a la alcaldía mediante escrito de 27 de octubre de 1847, habiendo aceptado la reina su renuncia y alegando problemas de salud. Tiempo después y para disipar toda sospecha publicó una Reseña de la Administración de Don José Campo como Alcalde de Valencia y la presentó ante la Corporación

\footnotetext{
${ }^{9}$ MORANT GIMENO, Ana María et al. El marqués de Campo. Empresario, político y coleccionista de obras de arte. Valencia: Ayuntamiento de Valencia, 2015, p. 128 y 129.
} 
Municipal. Como dice Hernández: "por primera vez en Valencia, un político local en su faceta de empresario, pone de manifiesto el valor de la propaganda como un medio, fundamental, para convencer a la opinión pública"1o.

Tras su fase como alcalde consiguió, junto con su padre, la concesión de la recaudación general de las contribuciones de la provincia de Valencia para 1848 , sustituyendo a los ayuntamientos en el cobro de los impuestos.

Convertido ya en un hombre de negocios, Campo alquiló y luego compró el palacio del duque de Villahermosa y que hoy lleva su nombre, marqués de Campo, que actualmente es sede del Museo de la Ciudad y está situado en la plaza del Arzobispo. Lo adquirió en 1853 y la reforma y decoración del propio edificio y de sus interiores corrió a cargo de los más afamados arquitectos y artistas del momento. Hemos de destacar en este punto los estudios realizados por autores como Miguel Ángel Catalá, quien ha escrito varias obras sobre dicho edificio, dando datos sobre su adquisición por parte de José Campo, sus reformas, y su devenir histórico ${ }^{11}$. Elvira Mas ha estudiado la biografía de dos familiares de José Campo: José Flores Vela y Vicente Pérez Vela, escenógrafos de profesión, que al parecer intervinieron en parte de la decoración de dicho palacio ${ }^{12}$. En él estableció un telégrafo y las oficinas de varias de sus empresas, como el gas o la recaudación y más tarde el periódico La Opinión cuando lo adquirió en 1861.

El periódico La Opinión, que se autodefinía como Diario político, literario y de intereses materiales, nació el 15 de julio de 1860, reinando Isabel

\footnotetext{
${ }^{10}$ MORANT GIMENO, Ana María et al. El marqués de Campo. Empresario, político y coleccionista de obras de arte. Valencia: Ayuntamiento de Valencia, 2015, p. 143.

${ }^{11}$ CATALÁ, Miguel Ángel et al. Palacio del Marqués de Campo. Museo de la ciudad. Valencia: Ayuntamiento de Valencia, 1989.

CATALÁ, Miguel Ángel. "El edificio". En: LAGARDERA, J. (coord.). Museo de la Ciudad. Valencia: Ayuntamiento de Valencia, 2013.

${ }_{12}$ PINEDO, Carmen; MAS, Elvira. Dos artistas valencianos del siglo XIX: José Vicente Pérez Vela y José Flores Vela. La familia artística del Marqués de Campo. Inédito. 2003
} 
II y con O’Donnell en el Gobierno. A cargo del periódico estaban Luis de La Loma, natural de Cádiz y muy vinculado al mundo del periodismo y la literatura, y Mariano Carreras González, natural de Zaragoza, que había trabajado ya en Madrid en varias publicaciones. El diario nació con marcado signo progresista.

Como buen comerciante y político, a José Campo le convenía tener en su poder un medio de comunicación que le sirviera de apoyo en sus proyectos y así en 1861 compró el periódico La Opinión, lo convirtió en una publicación conservadora, trasladó su sede a la calle avellanas, puso como director a Teodoro Lorente, periodista y poeta, y la impresión a cargo de José Doménech.

Según Almela y Vives ${ }^{13}$, José Campo perteneció al círculo moderado y con su periódico revolucionó la prensa valenciana porque incluía, información política, económica, literaria, artística y de todos los órdenes de la vida social. Fue el primer periódico en Valencia que publicó cartas diarias de Madrid que enviaba el corresponsal y también telegramas.

En opinión de Laguna, el periódico ideológicamente se autocalificaba como "portavoz del partido conservador de Valencia" y siempre estuvo, lógicamente al servicio de su propietario, José Campo, quien representaba un ejemplo más de la unión entre burguesía y prensa para consecución de sus propios intereses ${ }^{14}$.

\footnotetext{
${ }^{13}$ ALMELA Y VIVES, Francisco. El Marqués de Campo, Capdavanter de la burgesia valenciana (1814-1889). Valencia: Ajuntament de València, 1989, p. 74.

${ }^{14}$ LAGUNA PLATERO, Antonio. Historia del periodismo valenciano: 200 años en primera plana, Valencia: Dirección General de Relaciones Institucionales e Informativas, 1990, p. 114.
} 
Si embargo, en opinión de Pérez Puche ${ }^{15}$, cuando la política y los negocios provocan el traslado a Madrid de José Campo, ya no tenía mucho sentido seguir manteniendo un periódico y dejó de ser necesario para sus intereses. El 21 de enero de 1866 se anunció la venta del periódico La Opinión a Teodoro Llorente y éste anunció el cambio de nombre por Las Provincias, cuyo primer número se publicó el 31 de enero de 1866.

En opinión de Piqueras: "según admite su administrador, el diario $L a$ Opinión nunca llegó a significar un negocio y arrastraba considerables pérdidas. Periódico de combate y polémica, en enero de 1866, cuando la reiteración de los levantamientos progresistas permite dudar del futuro del sistema, y el diario ha sido señalado demasiado, Campo decide liquidarlo como tal y lo transforma en Las Provincias, pasando la cabecera a Teodoro Llorente y conservando él la imprenta, que tres años después, en 1869 es adquirida también por Teodoro Llorente, y es cuando el nuevo periódico emprende vida propia" ${ }^{16}$.

En 1850 solicitó los permisos para la construcción del ferrocarril para el trayecto de Valencia a Xàtiva, y para ello constituyó una sociedad con el duque de Riánsares, esposo de la reina madre M. ${ }^{\text {a }}$ Cristina, y a quien ya debía conocer dada su relación con la reina Isabel II y su madre. Rivalizó con José de Salamanca en la concesión de otros tramos de líneas y al poco tiempo se convirtió en el propietario de la sociedad de Ferrocarriles de Almansa a Valencia y Tarragona. Especialmente este tramo de línea de Valencia a Tarragona fue la que le reportó muchos beneficios por el transporte de mercancías y tropas unos años más tarde en plena guerra carlista.

\footnotetext{
15 PÉREZ PUCHE, Francisco. El impulso de Campo en el origen de LAS PROVINCIAS, 15/11/2014: $\quad$ https://www.lasprovincias.es/fiestas-tradiciones/201411/16/impulso campo-origen-provincias-20141115232309-v.html consultado en línea el 17 de enero de 2016.

${ }^{16}$ PIQUERAS, José Antonio. "De Diario Mercantil a El Mercantil Valenciano (18681874)". En: LAGUNA, Antonio; MARTÍNEZ, Francisco (coords.). Historia de LevanteEl Mercantil Valenciano. Valencia: Editorial Prensa Valenciana, 1992, p.79.
} 
Por otra parte, la actividad de José Campo no se limitó al ámbito económico y político en Valencia sino también en el resto de España; en 1864 fue nombrado senador vitalicio del reino y en pago de su actividad en favor de la subida al trono de Alfonso XII, éste le concedió el título de marqués de Campo (fue el primer título nobiliario que concedió).

Marchó a vivir a Madrid, donde se instaló en un palacete de estilo francés situado en el paseo de Recoletos número 14, que había pertenecido antes a la familia Calderón y Molina donde, según las publicaciones de la época vivía rodeado de lujos y de obras de arte, algunas de las cuales se pudieron admirar en su pabellón de la Exposición Universal de Barcelona de 188817. Noticias breves de su palacio de Madrid encontramos, a propósito de su estudio como ejemplo de la arquitectura de Madrid del siglo XIX, en obras como el Palacio Romántico y otros artículos de Pedro Navascués y en la Guía de Madrid de Fernández de los Ríos, entre otros ${ }^{18}$.

Instalado ya en Madrid, se adjudica la contrata de suministro de tabacos a las fábricas de la península y es también cuando comienza su aventura con la compañía de vapores que compra para realizar el transporte de mercancías, correo y personas a Filipinas, Cuba, Puerto rico, y Estados Unidos. Los negocios de la naviera le acarrearon rivalidades con Antonio López, marqués de Comillas, quien adquirió toda la flota cuando los negocios de Campo comenzaron a decaer. Los 25 vapores del marqués de Campo fueron pintados por Rafael Monleón y las obras exhibidas en la Exposición Universal de Barcelona de 1888.

${ }_{17}^{17}$ La Ilustración Española y Americana, núm. 403, de 22 de julio de 1888, p. 469 y 479. 18 NAVASCUÉS, Pedro. Un Palacio Romántico. Madrid 1846-1858. Madrid: Ediciones el Viso, 1983.

NAVASCUÉS, Pedro. "Castellana: quién te ha visto y quién te ve”. Lápiz, 1985, n. 28, p. 28-33.

NAVASCUÉS, Pedro. "Palacios madrileños del ochocientos". En: Casa de América, Rehabilitación del Palacio de Linares. Madrid: Editorial Electa, 1993, p. 23-28.

FERNÁNDEZ DE LOS RÍOS, Ángel. Guía de Madrid: manual del madrileño y el forastero. Madrid: Ilustración Española y Americana, 1876. 
Unánimemente lo autores destacan que, si los negocios de José Campo eran un éxito, su vida personal no lo fue tanto; antes de casarse con Rosalía Rey, tuvieron una hija, Josefa, que murió con 13 años en 1852. Años después adoptó un niño, Luis M. ${ }^{a}$ Bruna, de quien se decía que era hijo natural suyo fruto de una relación extramatrimonial con una mujer francesa llamada Amparo Bruna; este niño fue instituido heredero de todos sus bienes y de su título de marqués. En enero de 1889, al morir su esposa Rosalía, se casó tan sólo tres meses después con Luisa Solá, viuda de Recur, una mujer que ya trabajaba para él en las oficinas de Santander. Tras una larga enfermedad José Campo falleció el 19 de agosto de 1889 en su palacio de Madrid.

Historiadores, como Justo Serna y Anacleto Pons, han estudiado al marqués de Campo como personaje incardinado dentro de la burguesía valenciana, aportando datos tan interesantes como por ejemplo, que fue la muerte de su hija Josefa lo que le empujó a ejercer la beneficencia y como consecuencia mandó construir dos edificios para fundar dos asilos para niños desfavorecidos ${ }^{19}$.

El primer asilo, situado en la calle de la Beneficencia, lo construyó a sus expensas en 1863. Fue realizado por Jaime Beatty en estilo neoclásico, y toda la información sobre el mismo la encontramos en una descripción realizada por el mismo arquitecto ${ }^{20}$. El segundo asilo fue construido en 1882 en la calle de la Corona, por su protegido, el arquitecto José Camaña Laymon, quien lo realizó en estilo neogótico por expreso deseo del marqués. Cumplida noticia de ello dio la prensa del momento y una publicación que se hizo con motivo de la

\footnotetext{
19 PONS, Anacleto; SERNA, Justo. La ciudad extensa. Valencia: Diputación de Valencia, 1992.

PONS, Anacleto; SERNA, Justo. Los triunfos del burgués. Estampas valencianas del Ochocientos. Valencia: Tirant lo Blanch, 2011.

${ }^{20}$ BEATTY, James. "Descripción del Asilo Campo". En: BOIX, Vicente (coord.). Memoria leída en la inauguración del Asilo de Párvulos de D. José Campo, en el día 19 de noviembre de 1863. Valencia: Imprenta de La Opinión, 1863, p. 19-23.
} 
inauguración del edificio ${ }^{21}$. Los dos edificios han sido objeto de breve estudio dentro de las obras de Daniel Benito Goerlich y Trinidad Simó entre otros²2.

En 1885, estando todavía con vida, el Ayuntamiento de Valencia decidió hacerle un monumento en agradecimiento a todas las reformas que impulsó en la ciudad, y el diseño y realización recayó en Mariano Benlliure, artista que, como muchos otros, tenía una relación muy especial con el marqués. La relación de la familia Benlliure con el marqués de Campo ha sido objeto de breves estudios por parte de algunos autores como Victoria Bonet y Vicente Vidal23. Por otra parte, el monumento de homenaje que realizó Mariano Benlliure y que sufragó en gran parte el propio José Campo, ha sido estudiado por autores como Rafael Gil, Violeta Montoliu y Carlos Reyero entre otros ${ }^{24}$.

En Madrid, José Campo se codeaba con la alta sociedad, y adquirió en 1870 en una subasta el bosque de Viñuelas, en el monte de El Pardo, que contaba con un castillo medieval que le servía para celebrar banquetes y alojar a los invitados de las cacerías que organizaba. Dentro de este castillo albergaba

${ }^{21}$ ANÓNIMO. Biografía y descripción del prestigioso Asilo del Excmo. Señor Marqués de Campo. Madrid: Imprenta de Juan Iniesta y Lorenzo, 1888.

${ }_{22}^{2}$ BENITO GOERLICH, Daniel. La arquitectura del eclecticismo en Valencia. Vertientes de la Arquitectura valenciana entre 1875 y 1925. Valencia: Ayuntamiento de Valencia, 1992.

BENITO GOERLICH, Daniel; CERVERA, Ramón. "Ocupa y socorre: La arquitectura benéfica en la Valencia del siglo XIX. La Casa de la Beneficencia”. En: TABERNER, Francisco et al. Historia de la ciudad III. Arquitectura y transformación de la ciudad de Valencia. Valencia: Ayuntamiento de Valencia, Ícaro, Universidad de Valencia y U.P.V., 2003, p.118-142.

SIMÓ, Trinidad. La arquitectura de la renovación urbana en Valencia. Valencia: Albatros Ediciones, 1973.

23 BONET, Victoria E. José Benlliure Gil (1855-1937). El oficio de pintor. Valencia: Ayuntamiento de Valencia, 1998.

VIDAL CORELLA, Vicente. Los Benlliure y su época. Valencia: Prometeo, 1977.

${ }^{24}$ GIL SALINAS, Rafael; PALACIOS, Carmen. El ornato urbano. La escultura pública en Valencia. Valencia: Ayuntamiento de Valencia, 2000.

MONTOLIU, Violeta. "El Monumento al Marqués de Campo". En: Monumentos Conmemorativos de Valencia: Memoria esculpida de una ciudad: 1875-1936. Valencia: Real Academia de Cultura Valenciana, 2002, p. 79-84.

REYERO, Carlos. La escultura conmemorativa en España. La edad de oro del monumento público, 1820-1914. Madrid: Cuadernos de arte Cátedra, 1999. 
muchas obras de arte. Sobre esta edificación existen estudios anteriores a su ocupación por el marqués de Campo, que nos pueden servir de ayuda como la obra de Manuel Ayala y Raya, y la de Virginia Tovar Martín, ambas sobre el Real Sitio de El Pardo²5.

Según escribe Hernández, en Viñuelas se conspiró contra la República y a favor de la Restauración de Alfonso XII, pues eran habituales las cacerías a las que acudían políticos como Cánovas, Mayans, Salaverría, Silvela, el marqués de Alcañiz, el marqués de Remisa y José Salamanca, entre otros ${ }^{26}$. Si bien es cierto que Alfonso XII lo nombró marqués de Campo nada más llegar al trono, a propuesta de Cánovas del Castillo, no hay certeza exacta de cuál fue la contribución de José Campo al pronunciamiento de Sagunto. Esta cuestión ha sido abordada entre otros por el profesor Juan Antonio Piqueras, quien atribuye a Campo el papel de financiador del golpe ${ }^{27}$.

José Campo tenía además una casa de veraneo en Arcachon, Francia, donde también hacía ostentación de su posición social por su decoración y sus recepciones de invitados, entre los que se encontraban ministros, miembros de la jerarquía eclesiástica y miembros de la familia real española que iban en verano a disfrutar del lugar. La adquirió en 1880 y así completó su patrimonio inmobiliario.

Durante toda su vida participó en la promoción de actividades culturales y artísticas. Fue miembro del Ateneo y del Casino de Madrid y en Valencia orientó parte de su vida a actividades filantrópicas dando muestras de

\footnotetext{
${ }^{25}$ AYALA Y RAYA, Manuel. Crónica de los pueblos de la provincia de Madrid. Real Sitio de El Pardo. Madrid 1893. Valladolid: Editorial Maxtor, 2011.

TOVAR MARTín, Virginia. El Real Sitio de El Pardo. Madrid: Editorial Patrimonio Nacional, 1995, p. 349-362.

${ }^{26}$ MORANT GIMENO, Ana María et al. El marqués de Campo. Empresario, político y coleccionista de obras de arte. Valencia: Ayuntamiento de Valencia, 2015, p.170.

${ }_{27}$ PIQUERAS, José Antonio. La revolución democrática (1868-1874). Cuestión social, colonialismo y grupos de presión. Madrid: Ministerio de Empleo y Seguridad Social, 1992. p.741-770.
} 
generosidad. Entre otras cosas patrocinó el Ateneo Mercantil, la Escuela de Artesanos, el Ateneo Obrero, el Hospital Provincial, la Plaza Toros, y aportó cantidades para fundar la Caja de Ahorros y Monte de Piedad de Valencia. También realizó donaciones para las casas de las víctimas del incendio del Cabañal de 1875, etc., de todo ello dan noticia diferentes artículos como por ejemplo el de la revista A Todo Vapor escrito por Juan Carlos Estrela ${ }^{28}$.

En su larga vida fue condecorado con la Gran Cruz de Isabel la Católica, la Gran Cruz de Carlos III, la Cruz al Mérito Naval y la Gran Cruz de la Legión de Honor Francesa, entre otras.

Su muerte, el 19 de agosto de 1889, fue noticia en todos los periódicos nacionales y extranjeros, su funeral fue un gran homenaje y su cuerpo fue trasladado a Valencia en tren para ser enterrado en la cripta de la capilla de su Asilo de la calle de la Corona; sin embargo, en la Guerra Civil dicha cripta fue saqueada y hoy en día sus restos descansan en un panteón adosado a la iglesia del Cementerio Municipal a cuya construcción también contribuyó.

Su herencia fue objeto de pleitos y disputas entre su viuda, Luisa Solá, sus familiares y los numerosos acreedores que tenía, e incluso aún hoy en día, casi un siglo después de su nacimiento, su herencia sigue generando polémica y siendo noticia en los periódicos ${ }^{29}$.

Puedo concluir que el personaje de José Campo Pérez ha sido objeto de estudio desde una perspectiva social, económica y biográfica, pero observamos la falta de estudios sobre su faceta de promotor artístico, mecenas y amante de las artes. En las obras citadas sólo hay pequeñas referencias a su relación con

${ }^{28}$ ESTRELA, Juan Carlos. “José Campo Pérez, primer marqués de Campo”. A Todo Vapor, 2003, n. ${ }^{\circ}$ 39, p. 11.

29 Levante-emv.com jueves 12 de noviembre de 2009 http://www.levanteemv.com/comunitat-valenciana/2009/11/12/arzobispado-hizo-juzgado-propiedad-asilomarques-campo/650588.html. Consultado en línea el 18 de diciembre de 2012. 
determinados pintores y arquitectos, pero haciendo una simple recopilación nos damos cuenta de que sus intereses iban más allá y que tenía verdadero interés por el tema artístico.

El marqués de Campo fue mecenas de arquitectos, como ya he dicho, fue protector de pintores como Salvador Martínez Cubells, cuyas primeras obras adquirió; de Rafael Monleón, a quien contrató para pintar su flota de vapores; de pintores como José Gallel, quien decoró entre otros su palacio de Valencia; de Mariano Benlliure, a quien mantenía con una pensión mensual en Roma; a José Antonio Benlliure y a José Benlliure, a quienes encargó varias obras para decorar sus palacios y para su asilo30. Además, en 1886 envió a su costa, en su vapor Magallanes una expedición a las obras del canal de Panamá en la que iba un dibujante, Tomás Campuzano, quien dibujó todo el proceso de la expedición y cuyos grabados se publicaron en la revista La Ilustración Española y Americana. En 1888, para conmemorar el éxito de esta expedición, hizo acuñar en una fábrica de Barcelona una medalla en oro, plata y bronce, con su retrato en el anverso y el vapor Magallanes junto con unas alegorías de Europa y América en el reverso31.

Del inventario de todos sus bienes realizado a la muerte de su primera esposa Rosalía Rey32, queda claro que el marqués tenía una colección de obras de arte extraordinaria y que nadie ha analizado ni estudiado hasta esta tesis. Se contaban por cientos los cuadros y las esculturas que junto a otros objetos de

$3^{30}$ Breves referencias a estas actividades de promoción las encontramos por ejemplo en: BONET, Victoria. "José Gallel y Beltrán: Perspectivas y paisajes. Una profesión”. Ars longa: Cuadernos de arte, 1991, n. ${ }^{\circ}$ 2, p. 69-72.

TRAMOYERES BLASCO, Luis. "Salvador Martínez Cubells". Archivo de Arte Valenciano, $1915, \mathrm{n}^{\mathrm{O}} 1$, p. 36-37.

${ }^{31}$ La ilustración Española y Americana, año XXXII, núm. VII, 22 de febrero de 1888, p. 132.

CRUSAFONT, Miquel. Medalles conmemoratives dels Països Catalans i de la Corona Catalano-aragonesa (s. $X V$-XX). Barcelona: Sociedad Catalana d'estudis numismàtics, Institut d'estudis catalans, 2006, p. 444.

MARÍN, M. ${ }^{a}$ Isabel. L'obra medallística de l'escultor Eusebi Arnau. Barcelona: Sociedad Catalana d'estudis numismàtics, Institut d'estudis catalans, 2005. p. 99. ${ }^{32}$ AHPM, T. 36643, fols. 7439 y ss. 
arte adornaban sus residencias y que lo convierten en un coleccionista por derecho.

Por todo lo dicho he considerado necesario realizar esta tesis doctoral y analizar en profundidad la relación del marqués de Campo con el ámbito artístico del siglo XIX e intentar trazar su perfil de mecenas, coleccionista y promotor, confirmando así la hipótesis expuesta al principio: se puede considerar al marqués de Campo a la altura del marqués de Salamanca o del marqués de Comillas u otros burgueses que, enriquecidos gracias al comercio y a su actividad política, poseían también palacetes en la zona de Castellana de Madrid y hacían ostentación de su riqueza y posesión mediante la adquisición de obras de arte y objetos suntuarios que decoraban sus hogares y que mostraban al resto de la sociedad en las solemnes fiestas que ofrecían. El marqués Campo era promotor artístico, era mecenas y era coleccionista de arte, y debería ser reconocido como tal por todos aquellos que sólo lo califican como hombre de negocios y político. No hay duda de que en su vida la política y los negocios estaban presentes, pero junto con el arte y todas sus manifestaciones33.

${ }^{33}$ Las dos siguientes imágenes son: la partida de bautismo y la esquela de José Campo. 


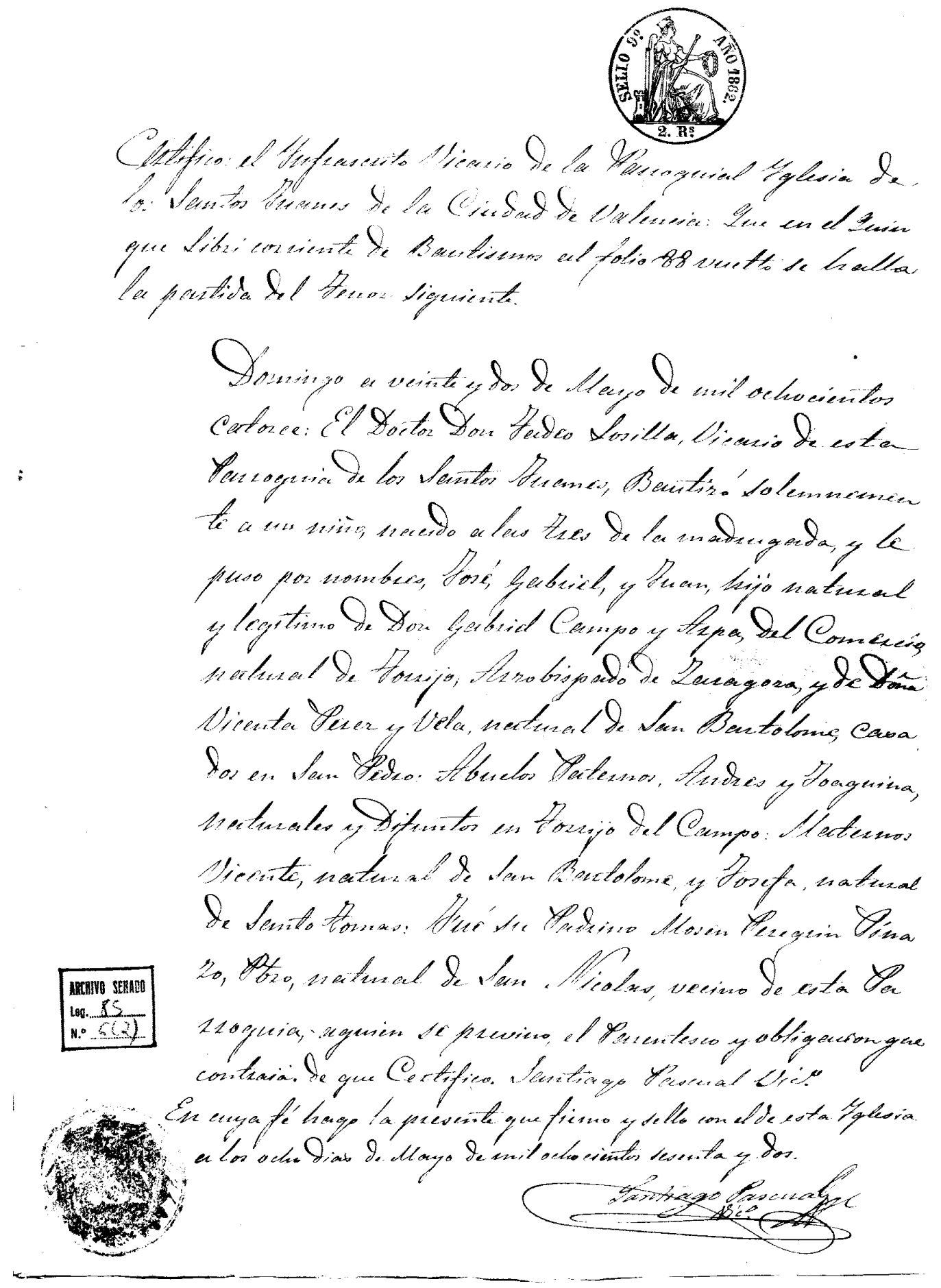




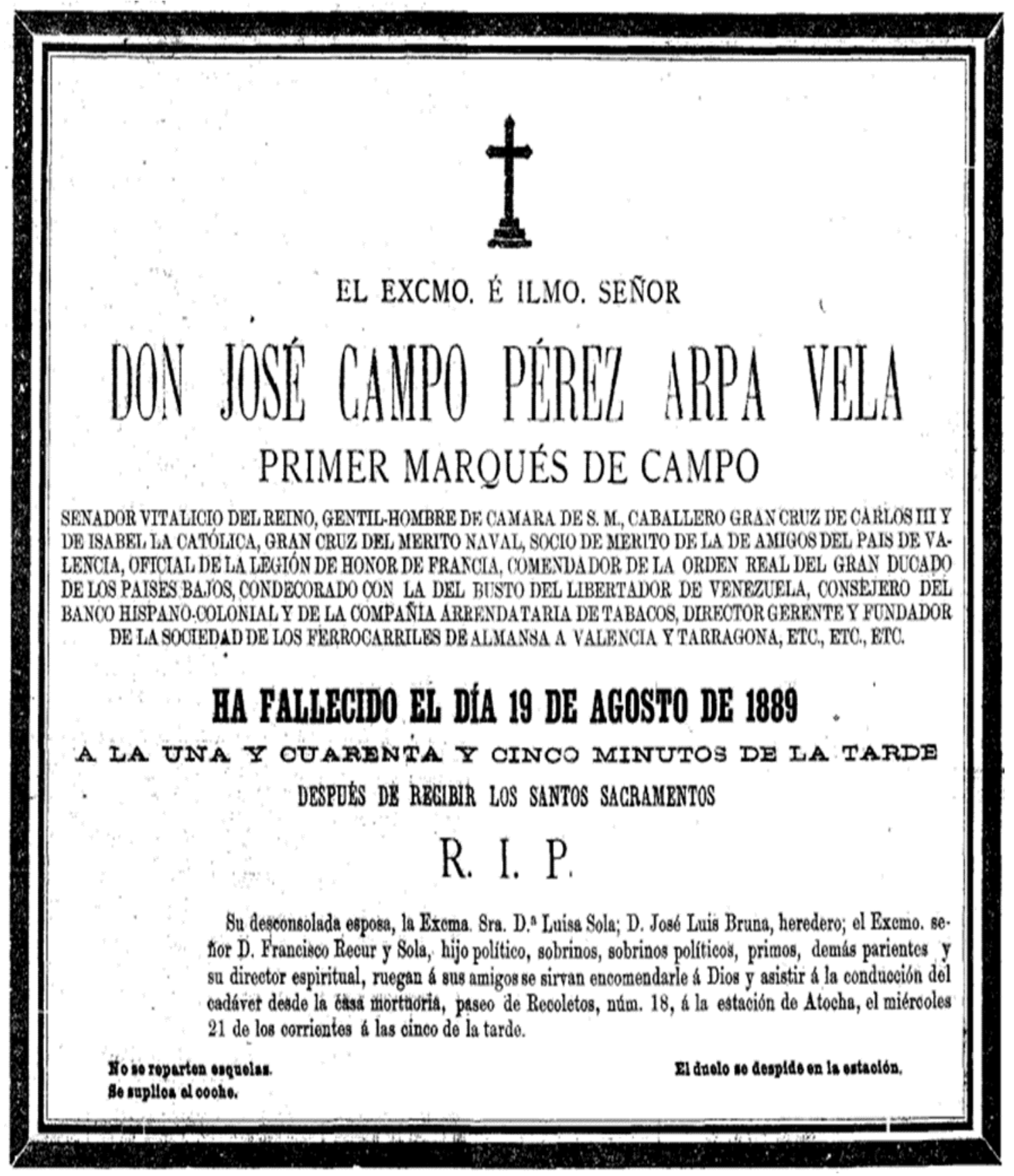





\section{OвJetrvos}

En esta tesis sobre el mecenazgo artístico y el coleccionismo del marqués de Campo podemos distinguir dos tipos de objetivos: el objetivo principal y partiendo del estado de la cuestión expuesto es dar a conocer la figura de José Campo. Pero no desde el ámbito de la política y la economía del siglo XIX, pues el marqués fue uno de los políticos y comerciantes que más huella dejó en la España de Alfonso XII, sino sacar a la luz las actividades del marqués relacionadas con las artes, tanto su faceta de coleccionista de obras de arte, desconocida hasta ahora y también como mecenas de artistas y promotor de obras de todo tipo, actividades que junto con el ejercicio de su cargo de senador vitalicio en Madrid y su título nobiliario lo convierten en la perfecta imagen del poder burgués. 
Para llevar a cabo el objetivo de esta tesis vamos a ir recorriendo a lo largo de cada capítulo las diversas actividades del marqués de Campo relacionadas con las artes y en este trabajo vamos a ver en primer lugar un estudio de su imagen a través de los diferentes retratos que se conocen de él, en pintura, en arquitectura, grabados, monedas, etc., puesto que, como buen burgués, se hizo retratar en múltiples ocasiones e incluso se hizo una fotoescultura en París y fue retratado por prestigiosos fotógrafos como Nadar y Jean Laurent. Estudiaremos también los retratos de sus familiares.

También vamos a repasar todas sus actividades desarrolladas en Valencia relacionadas con la arquitectura benéfica, mediante el estudio de los dos asilos que mandó construir en la ciudad que le vio nacer y veremos que también participó en la promoción de diferentes obras arquitectónicas como la plaza de toros de Valencia sin cuya aportación económica no se hubiera podido acabar.

Continuaremos esta tesis realizando un recorrido exhaustivo por sus residencias, empezando por el palacio que compró en Valencia, siguiendo por el palacio del paseo de Recoletos que compró en Madrid, el Castillo de Viñuelas en el monte del Pardo que compró para celebrar fiestas con las que agasajar a sus amigos y cacerías con contenido político; y también analizaremos el chalet que compró en Arcachon, Francia, para pasar los veranos y al que invitaba a personalidades influyentes del mundo de la política y que la mismísima reina Isabel II utilizó como caseta de baño. En todos esos edificios realizó reformas y los decoró con objetos de arte de gusto exquisito y lujo y que reflejaban muy bien el gusto de la época y su estatus social. Para todas las reformas que realizó en sus residencias contrató a numerosos artistas del momento que trabajaron para saciar sus demandas y convertir esos espacios en verdaderos escaparates del lujo para deleite de visitantes.

En relación al mecenazgo de artistas estudiaremos en profundidad la relación especial que el marqués mantuvo con la familia Benlliure ya que fue mecenas y promotor de Mariano y su hermano José, a quienes mantenía con 
una pensión en Roma y a quienes encargó varias obras; pero también compró varias obras a Juan Antonio Benlliure, y todas ellas adornaban sus palacios. En el mismo capítulo analizaremos la relación epistolar entre José Campo y Mariano Benlliure con motivo de la realización por éste de una escultura en su honor por decisión del ayuntamiento de Valencia y que hoy se encuentra en la plaza Cánovas de dicha ciudad.

Veremos también que, aparte de promocionar la actividad de aquellos artistas a quienes contrató para la construcción de los asilos y la reforma de sus palacios: decoradores, pintores, escultores, escenógrafos, etc., promovió la actividad artística y favoreció la carrera de algunos como por ejemplo el pintor Rafael Monleón, el pintor Martínez Cubells, el dibujante Tomás Campuzano, etc.

Analizaremos la construcción y la iconografía de un altar con retablo que José Campo mandó construir en la iglesia de san Pedro de Torrijo del Campo, Teruel, de donde era originaria la familia de su padre. Y dentro de este retablo analizaremos el escudo de armas del marqués.

También estudiaremos la relación del marqués con el arte efímero. José Campo mandó construir dos arcos efímeros, uno lo colocó a la entrada de la feria de julio de Valencia de 1871 y el otro lo situó delante de su palacio del paseo de Recoletos con motivo de las celebraciones por la entrada de Alfonso XII en Madrid en 1875. Analizaremos las decoraciones de iluminación de sus palacios de Valencia y Madrid con motivo de diferentes celebraciones, e incluso analizaremos la construcción de un carro triunfal para una cabalgata ferial.

Además de estudiar estas actividades del marqués relacionadas con el mundo de las artes, analizaremos, en el capítulo correspondiente, su faceta de coleccionista, desconocida hasta ahora y que le otorga a José Campo una categoría dentro del coleccionismo comparable a la del marqués de Salamanca o a la de Lázaro Galdiano. José Campo poseía cientos de obras de arte en cada una de sus residencias y algunas de mucho valor, sobre todo pinturas, esculturas, 
tapices, muebles, y demás objetos. Algunos de ellos, fueron llevados por orden del marqués a Barcelona para ser expuestos en su pabellón de la Exposición Universal de 1888, y esa exhibición será analizada en otro capítulo aparte, pues como buen burgués, estaba deseoso de exhibir su poder económico y su posición social. No podemos olvidar que nació siendo hijo de un comerciante de salsas que vino a Valencia en busca de trabajo y llegó a ser senador vitalicio del reino y marqués.

Además, en 1875 mandó realizar a la platería Meneses una escultura de plata de gran tamaño, cuyo paradero e imagen hasta este momento era desconocida y cuyas fotos pude realizar en una visita al domicilio del dueño actual y donde pude observar de cerca tan maravillosa pieza. La mandó hacer como presidente de la Sociedad de Ferrocarriles para regalarla al General Jovellar en agradecimiento por la pacificación de la zona de Sagunto, hecho que posibilitó que los ferrocarriles del marqués pudieran circular sin sufrir atentados en las vías y que impedían el transporte de mercancías, soldados y civiles.

José Campo es un personaje fascinante y por ello no podemos dejar de estudiar otras actividades realizadas por él siempre en interés de su amada España, como por ejemplo el hecho de mandar, a su costa, en un vapor de su flota, una expedición de técnicos españoles al canal de Panamá para la inspección de las obras, que será objeto de otro capítulo de esta tesis puesto que supuso la publicación de dos libros de la crónica del viaje y la promoción del dibujante enviado para cubrir la expedición.

Todo este estudio se ha hecho teniendo en cuenta en todo momento que como todo burgués José Campo estaba interesado en proyectar en cada una de sus actuaciones su posición social y su nivel económico, y que todo ello contribuyó a proyectar hacia el exterior una imagen absoluta de poder. 


\section{Metodología}

En esta investigación se ha aplicado el método sociocultural y el método iconográfico, para conectar toda la actividad de José Campo relacionada con el arte con el entorno social, económico y cultural en el que se desarrollaba su vida y se ha realizado un análisis iconográfico e iconológico de las imágenes encontradas relacionadas con esas actividades. Además, se ha producido un análisis pormenorizado de todas las fuentes documentales y una lectura integrativa de la bibliografía utilizada.

\section{Para la elaboración de esta tesis se han realizado las siguientes} actividades:

a) Realizar labores de vaciado de la prensa y publicaciones del siglo XIX en la Hemeroteca de Valencia y en la de la Biblioteca Nacional de España (ésta última a través de la web).

b) Visitar el Asilo de la calle de la Beneficencia y al Asilo de la calle de la Corona, construidos por el marqués de Campo, para buscar documentación y hacer fotografías. 
c) Visitar en varias ocasiones el Archivo Histórico Municipal de Valencia.

d) Visitar el Archivo Histórico Nacional de Madrid (visita realizada el 23 de mayo de 2013).

e) Visitar el Museo de Historia de Madrid para el estudio de su fondo fotográfico y solicitar el permiso para la publicación de las imágenes encontradas. (autorización recibida en fecha 11 de julio de 2014).

f) Visitar y realizar trabajos de documentación en el archivo de la Casa Museo Benlliure de Valencia para localizar y analizar la correspondencia entre el marqués de Campo y varios miembros de la familia Benlliure.

g) Visitar y realizar trabajos de documentación en el archivo del Museo de la Ciudad de Valencia, sito en el Palacio del marqués de Campo, para localizar información e imágenes del edificio.

h) Un estudio en profundidad de la figura José Campo y Pérez y la sociedad burguesa del siglo XIX en Valencia y las otras ciudades donde tenía intereses y ejercía sus actividades financieras y políticas, como Barcelona, Madrid o Arcachon (Francia).

i) Una recopilación de los retratos, esculturas, fotografías, grabados y medallas donde aparece la imagen de José Campo, para analizar cómo se refleja en su imagen el poder de un burgués con gran poder económico, su poder político y su prestigio social.

j) Una investigación y análisis pormenorizado de sus viviendas en Valencia, Madrid, El Pardo y Francia.

k) Un estudio detallado de las obras artísticas de todo tipo promovidas por José Campo: las arquitectónicas, las escultóricas, las pictóricas, etc., estudiando a sus artífices y su relación con él. 
l) En relación con la actividad de mecenazgo del marqués, analizar las figuras de artistas como Rafael Monleón, Mariano Benlliure, José Benlliure, Juan Antonio Benlliure, José Gallel, Plácido Francés, Salvador Martínez Cubells, José Vela y Vicente Pérez Vela.

m) Un estudio e investigación a fondo la participación de José Campo en la Exposición Universal de Barcelona de 1888, para aproximarnos a la colección de obras de arte del marqués.

n) Intentar llevar a cabo la identificación y localización de las obras de la colección de arte que poseía el marqués de Campo: la identificación de las obras es muy complicada dada la somera descripción que de ellas se hace en el inventario de sus bienes; y la localización de las mismas, casi imposible salvo alguna excepción. Ello es debido a que el marqués murió en un estado económico muy perjudicado, con tantos acreedores y tantas deudas que fue necesaria la celebración de una almoneda para poder pagar parte de ellas y de esa forma ha resultado casi imposible seguir la pista de los bienes.

o) Consultar el expediente del marqués de Campo en el Archivo del Senado de España (a través de la web).

p) Solicitar por escrito al Excelentísimo Ayuntamiento de Valencia de autorización para publicar la documentación e información encontrada en el archivo de la Casa museo Benlliure (autorización recibida mediante certificado del Servicio de Patrimonio Histórico y Cultural de fecha 31 de mayo de 2013).

q) Solicitar por escrito al Excelentísimo Ayuntamiento de Valencia de autorización para publicar la documentación e información encontrada en el archivo del Museo de la Ciudad (autorización recibida mediante certificado del Servicio de Patrimonio Histórico y Cultural de fecha 15 de mayo de 2013). 
r) Lectura, interpretación y análisis de todas las fuentes citadas.

s) Lectura e interpretación de toda la bibliografía que aparece en este trabajo.

t) Redacción de esta tesis doctoral. 


\section{Fuentes}

Para llevar a cabo esta investigación se han utilizado las siguientes:

1.- La prensa del siglo XIX, tanto local de Valencia como nacional, mediante las visitas a hemerotecas de manera presencial y en línea.

2.- Documentación sobre José Campo, encontrada en los siguientes archivos: Archivo Histórico Municipal de Valencia.

Archivo Histórico Nacional de Madrid.

Archivo documental de la Casa Museo Benlliure.

Archivo de la villa de Madrid.

Archivo Histórico de Protocolos Notariales de Madrid.

Archivo del Senado de España.

Museo de la Ciudad de Valencia.

3.- La bibliografía enumerada al final de esta tesis. 



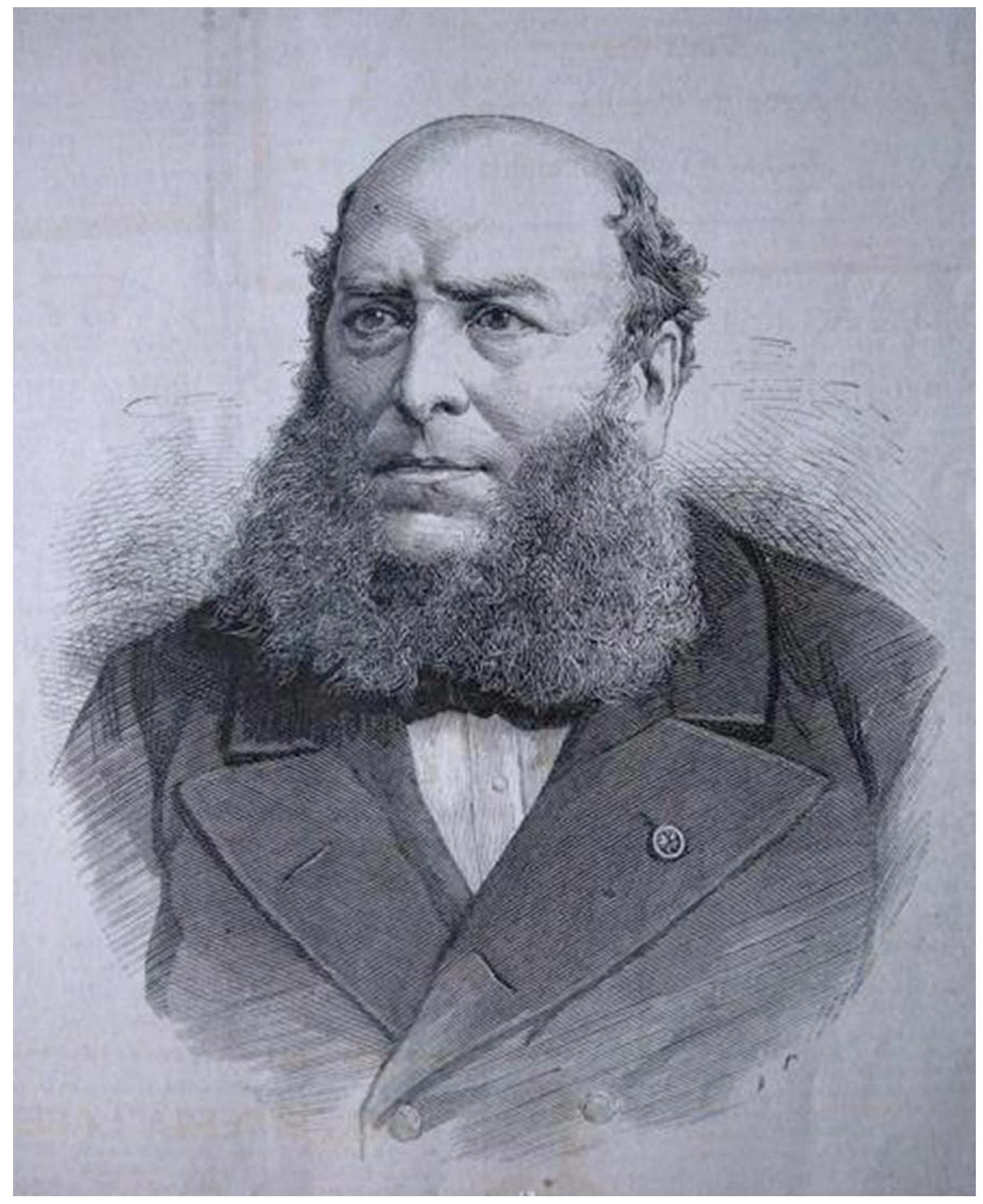





\section{Capítulo I}

LOS RETRATOS DEL MARQUÉS DE CAMPO Y SU FAMILIA

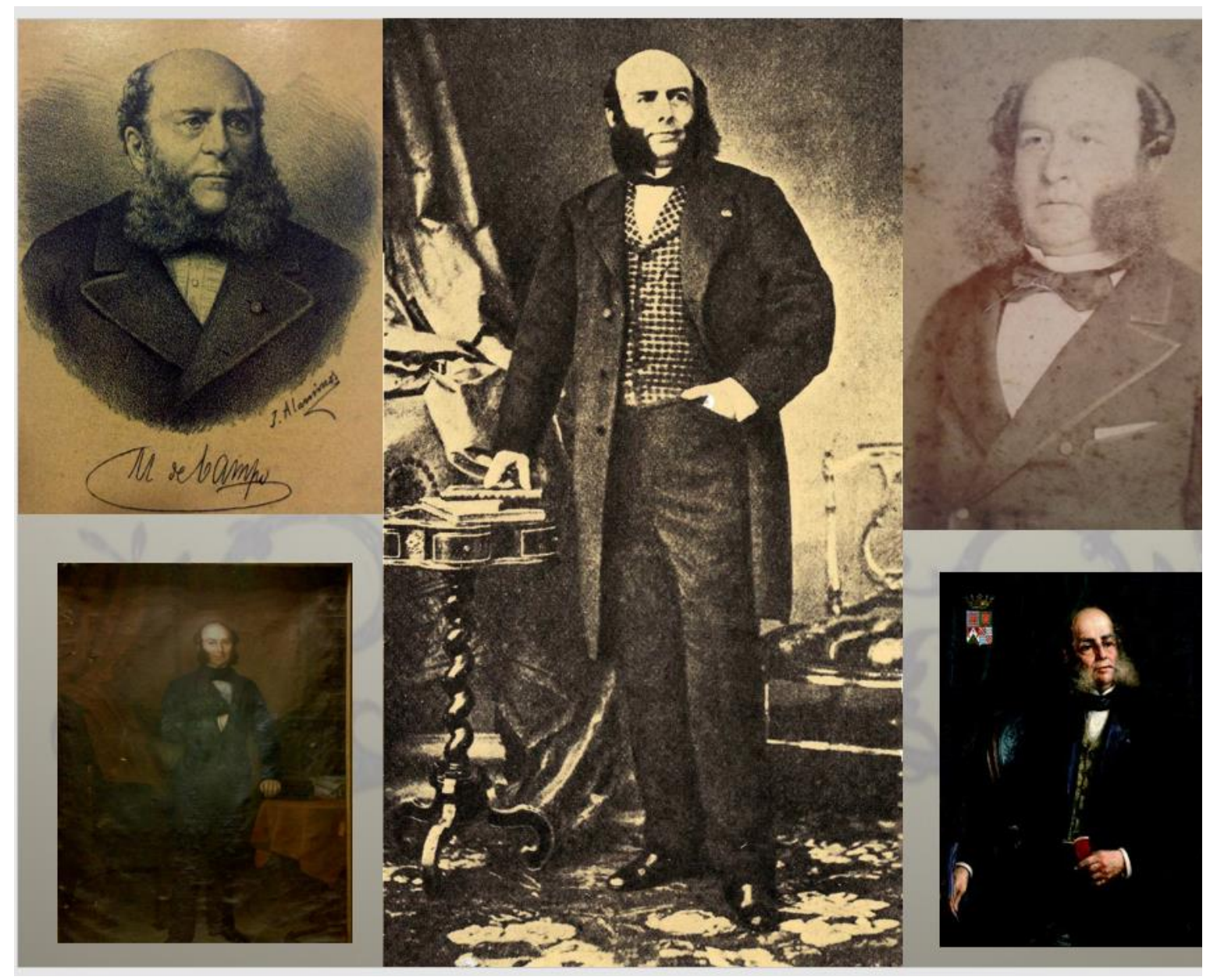





\section{Capítulo I}

\section{LOS RETRATOS DEL MARQUÉS DE CAMPO Y SU FAMILIA}

En opinión de Gaya Nuño", "los hechos políticos que tuvieron lugar desde finales del siglo XVIII, hubieron de repercutir forzosa y naturalmente en la plasmación de un arte muy vario, de progreso y evolución veloces”.

El retrato es un género con origen en Egipto que nace como un continente del alma del difunto; en Grecia el interés estaba en los tipos: el estratega, el filósofo, el atleta; y en Roma el retrato es heredado por la cultura occidental y crea "imágenes maiorun" a partir de máscaras de cera sacadas de las caras de los difuntos y que desfilaban en procesión en los enterramientos. Del retrato romano deriva el parecido absoluto y el retrato de cabeza o de busto; y del retrato personal deriva el retrato cortesano en la época medieval, que incluía a los donantes en las escenas religiosas.

\footnotetext{
${ }^{1}$ GAYA NUÑO, Juan Antonio. Arte del Siglo XIX. Ars Hispaniae. Historia Universal del Arte Hispánico, Vol. XIX. Madrid: Editorial Plus Ultra, 1956, p. 15.
} 
En el siglo XVI el retrato representa a clientes, a gremios y cofradías; es una pintura laica y se suele representar los personajes de perfil. En el siglo XVII el retrato cortesano se caracteriza por la fidelidad de los rasgos fisionómicos, al rango social y a la función; es lo que se conoce como retrato cortesano de ostentación. En cualquier caso, una gran influencia en el género del retrato tuvo el libro de Palomino (1655-1726) Museo pictórico y la Escala óptica de 1723² ; que en su libro VI, capitulo II, establece lo que se debe observar en los retratos y al copiar del natural, y dice que el retrato funciona por el parecido y por las manchas cromáticas, estableciendo que la luz y la sombra son muy importantes. Distingue varias tipologías: el retrato de ostentación en el que se representa al individuo en el ejercicio de sus funciones e inspirado en la vera efigie, pero representado a lo divino; el retrato de $3 / 4$ que tiene contaminación de las fórmulas del cuadro de género y del retrato y el retrato de busto que muestra la preocupación por lograr el parecido y que desde un punto de vista económico es la solución más ventajosa.

Los retratos mayoritariamente son de aparato y complacientes, en los que el pintor falsea algunos defectos del modelo para dar una imagen más agradable, y posteriormente va cambiando hacia un retrato más realista, en el que el pintor trabaja los rasgos, las manos y utiliza una técnica minuciosa y un dibujo preciosista. Sería por ejemplo el caso del artista Vicente López (1772-1850), pintor de cámara de Fernando VII que realizó el inventario del Museo del Prado. López va a ser el último pintor contemporáneo de la escuela española que va a contar con discípulos en el sentido tradicional, con una escuela de seguidores, pues a partir del segundo tercio del siglo XIX, la mayor parte de los artistas buscarán una identificación propia y no la dependencia de un maestro3.

\footnotetext{
2 PALOMINO DE CASTRO Y VELASCO, Antonio. El museo pictórico y escala óptica, (1715-1724). Madrid: Aguilar, 1988. Ésta es la edición que he manejado.

3 NAVASCUÉS, Pedro. El siglo XIX, bajo el signo del romanticismo. Madrid: Editorial Sílex, 1992, p. 238 y ss.
} 
En el siglo XIX como consecuencia de la corriente romántica, además del paisaje y la pintura de historia, cobra una especial relevancia el retrato. El cambio del modelo social español que se afianzó a lo largo del XIX y la pujanza de la clase burguesa, determinó que el género del retrato alcanzara un reconocimiento general y los parámetros de Palomino sobre las características que debía tener el retrato eran cumplidos, pero en la medida en que la obra era un encargo privado, la norma era susceptible de ser obviada, pues en realidad el retrato debía agradar a la persona que lo había encargado, priorizando a veces el dibujo sobre el color, utilizando iluminaciones artificiales, falseando el fondo para embellecer la escena y resaltar la figura del retratado, etc.

En España el género del retrato será consolidado por Federico de Madrazo (1805-1894) a mediados del siglo XIX4. Federico nació en Roma, era hijo de José de Madrazo, quien vivía en Roma con Carlos IV. En 1853 fue nombrado director del Museo del Prado y poco después de la Real Academia de Bellas Artes de san Fernando y pintor de cámara de Isabel II. Federico se había formado también en París, siguiendo las directrices de Ingres, y su pintura es considerada más francesa que española. Obtuvo malas críticas por su obra La condesa de Vilches en 1855, pero en realidad es considerada una obra de referencia de la pintura española de todos los tiempos.

El retrato evoluciona a lo largo del siglo a una pintura más colorista con un realismo más intuitivo; es una pintura de intenciones y no de concreciones. Se utilizan más artificio que la clientela acepta para obtener el resultado deseado. Como dice pedro Navascués 5 , políticos y literatos, banqueros e industriales, van haciéndose sitio en aquella galería de retratos y asomándose a los lienzos con el porte y la dignidad que antes parecía ser sólo privilegio de la realeza y de la más alta aristocracia. Madrazo pinta, siempre seguro, cuadros en los que la belleza

\footnotetext{
4 REYERO, Carlos et al. Federico de Madrazo y Kunt (1815-1894). Madrid: Ministerio de Cultura, 1994.

5 NAVASCUÉS, Pedro. 1992, p. 239.
} 
formal es la meta primordial; destinados a ser ornato principal de los bellísimos salones de aquellos palacios románticos como el que habitaba el marqués de Campo en el paseo de Recoletos.

La fotografía, que empieza a utilizarse mucho más, copia los enfoques y escenarios con los de la pintura, como por ejemplo cortinajes, balaustres, mesas, alfombras, etc., como luego veremos en los retratos de pintura y fotografías de José Campo.

La burguesía tiene mucho poderío económico y social mientras va retrocediendo el trono, la iglesia y la aristocracia, y eso también afecta a la pintura, pues el cliente por excelencia es la nueva clase social que visita museos, exposiciones y desea comprar obras para comenzar su colección, puesto que los burgueses no tienen una colección de obras heredada de antepasados y tampoco tienen una galería de retratos familiar que es una de las principales partes de la colección personal. Y dentro de la galería de retratos destacan como veremos más adelante lo que se denominan pendant, que son dos obras enfrentadas que cierran una composición. Este tipo de obras se realizaban por ejemplo para retratos de matrimonios de la burguesía, que normalmente compartían el fondo, la enmarcación y se utilizaban para adornar los muros de al lado de las puertas, formando simetría en un muro o encima de un aparador. Un ejemplo de retratos pendant de un matrimonio lo encontramos en el Museo de Bellas Artes San Pío V de Valencia, en las dos obras de Luis López: Doña Dolores Caldas de Montserrat y Don Francisco Ignacio de Montserrat.

Digno de mención en el tema del retrato del siglo XIX es la creación de la Junta de Iconografía Nacional que ha sido estudiada por Inmaculada Rodríguez ${ }^{6}$, quien conecta la importancia del retrato en su vertiente de documento y la

\footnotetext{
${ }^{6}$ RODRÍGUEZ MOYA, Inmaculada. 'La Junta de Iconografía Nacional (1876- 1961) y el retrato del poder'. En: Víctor Mínguez (ed.). Las artes y la arquitectura del poder, Castellón: Universitat Jaume I, 2013, p. 271-296.
} 
creación de museos en varias ciudades de España, con la iniciativa por parte de Francisco Queipo de Llanos (1840-1890), conde de Toreno, de crear una Junta de Iconografía Nacional que luego se transformará en la Museo Iconográfico Nacional. Dicha junta fue creada el 13 de agosto de 1876, en su creación fue decisivo el comportamiento y el apoyo del nuevo rey Alfonso XII, que había pasado su juventud en Francia, Inglaterra y Viena, donde ya contaban con ese tipo de colecciones nacionales de retratos de personajes ilustres, cuya creación era el principal objetivo de la junta. Dicha junta reunió un gran número de retratos a base de compras, donaciones y encargos a artistas; y algunos de ellos se conservan hoy en día en el Museo del Prado7.

Como ya hemos dicho la clase burguesa y los nuevos nobles desean tener un retrato, que era considerado como algo indispensable y necesario para afianzar su privilegiada posición. Su intención de equipararse con los personajes ilustres de la historia, la nobleza y realeza hizo que el género del retrato fuera uno de los más demandados.

Para acabar con esta pequeña introducción sobre el retrato, es perfecta la frase inicial del prólogo de la obra de Inmaculada Rodríguez y Víctor Mínguez, $E l$ retrato del poder ${ }^{8}$ que dice lo siguiente: "Retratos. El testimonio físico de seres humanos que vivieron en el pasado o que nos acompañan en el presente. Hombres y mujeres que desearon y desean sobrevivir a su breve existencia mundana a través del arte. Hablar de retrato es hablar de arte con mayúsculas".

\footnotetext{
7 Alfonso XII estaba interesado en el arte; era un visitante habitual de las exposiciones de Bellas Artes, como luego veremos incluso a una de ellas fue acompañado de José Campo y los dos encargaron y compraron obras. No es extraño que no dudara en apoyar la creación de dicha junta.

8 RODRÍGUEZ MOYA, Inmaculada; MÍNGUEZ CORNELLES, Víctor. El retrato del poder. Castellón: Universitat Jaume I, 2019, p. 9 y 10.
} 


\section{1- La imagen del marqués de Campo a través de sus retratos}

En este capítulo vamos a analizar unos cuantos retratos de José Campo de diferentes épocas que nos ayudarán a completar su imagen porque como acabamos de decir, el retrato ha sido un género, tanto en pintura como en fotografía, que ha interesado desde siempre a las clases adineradas y, en el siglo XIX, siguiendo el gusto de la época, la burguesía consolidada demandaba retratos que magnificasen su persona y su presencia.

Como todo buen burgués, José Campo se hizo retratar en múltiples ocasiones, tanto en pintura como en fotografía; y en la actualidad se conservan en diferentes lugares algunos de esos retratos que siempre lo mostraban en actitud seria y pensativa, con mirada directa o bien mirando hacia el horizonte.

Por desgracia se desconocen bastantes datos de los retratos del marqués, como los autores o las fechas en que se realizaron, pero voy presentarlos por orden cronológico comenzando por las pinturas, luego las fotografías, y posteriormente las esculturas y las medallas que llevan grabadas su efigie.

El retrato más antiguo que conocemos es uno que hoy conserva la fundación Marqués de Campo, y es un óleo obra del pintor Ricardo Balaca9. El cuadro (Fig. 1.1) se encuentra en muy mal estado de conservación y tiene varios agujeros. Nos muestra a José Campo joven y esbelto, de pie al lado de una mesa de patas curvas, cubierta por un mantel marrón y en la que hay documentos y unos libros sobre los que el marqués apoya su mano izquierda. Va vestido con un traje negro e introduce su mano derecha por dentro de la levita en actitud como de tocarse el corazón. Su mirada amable y su rostro sereno aparece ya caracterizado con esas enormes patillas que le acompañarán toda su vida. En el fondo aparecen unos cortinajes y una silla que complementan este tipo de retrato

${ }_{9}^{9}$ Según referencia dada por Felipe Garín a Miguel Ángel Catalá Gorgues. 
de aparato. Si bien es cierto que desde la corte se marcan gustos y tendencias sobre los retratos, es la clientela, es decir, el propio retratado quien decide cómo quiere mostrarse y lo que quiere transmitir al espectador, y el artista adapta su imaginación y creatividad al gusto de la época.

Desconocemos cuándo fue pintado, pero por la juventud del rostro de José Campo y por los títulos de los libros en los que apoya la mano puedo deducir que este retrato debió de realizarse poco después de abandonar su puesto de alcalde de Valencia en 1847. En un libro pone "Alumbrado de Gas" que se inauguró en octubre de 1844, en otro pone "Aguas Potables de Valencia" que también comenzaron en $1844 \mathrm{y}$ en el tercero podemos leer "Sociedad Valenciana de Fomento" que él mismo fundó en 1846. La relevancia del momento y del lugar donde se realizó este retrato son elementos que lo completan para expresar en este caso el afán con que trabajaba el marqués para mejorar las condiciones de vida de su ciudad.

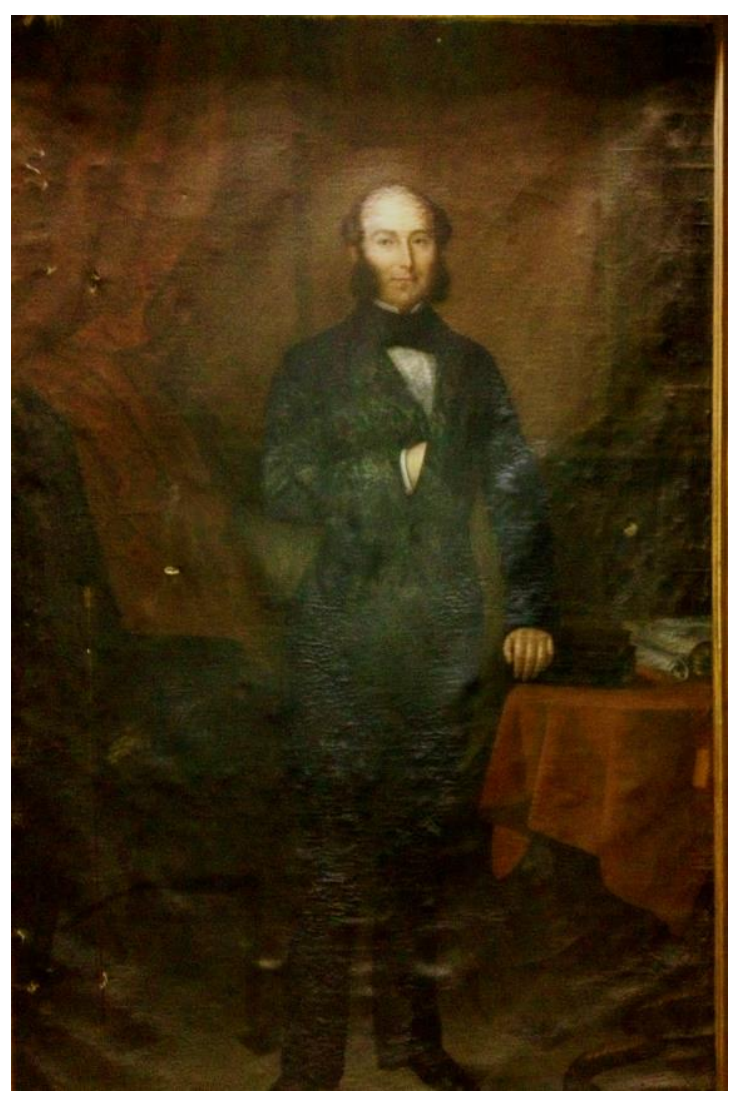

Fig.1.1 José Campo. Obra de Ricardo Balaca. Fundación Marqués de Campo. Valencia. 
También conocemos grabados que retratan a José Campo con la roseta de la Legión de Honor Francesa en su solapa (Fig. 1.2), como el que publicó La Ilustración Española y Americana con motivo de su muerte, del cual desconocemos también su autor ${ }^{10}$. Sin embargo, me atrevería a decir que este grabado, puede estar basado en la litografía realizada por Juan Alaminos Pérez (Fig. 1.3) después de 1850 , dada la gran similitud entre ambos ${ }^{11}$. Y otra imagen muy parecida, pero con menos detalles en su ejecución, fue publicada en la crónica de la expedición a Panamá escrita por Francisco Peris Mencheta en 1886.

En todos los retratos que hemos visto de José Campo siempre aparece ataviado con levita larga y de color negro. Su mirada perdida en el horizonte refleja la mentalidad de un hombre que mira siempre hacia el futuro y sus grandes patillas son su seña de identidad; según relata Almela y Vives: "servían para que su poseedor las acariciara mientras cavilaba en búsqueda de soluciones en momentos difíciles"12.

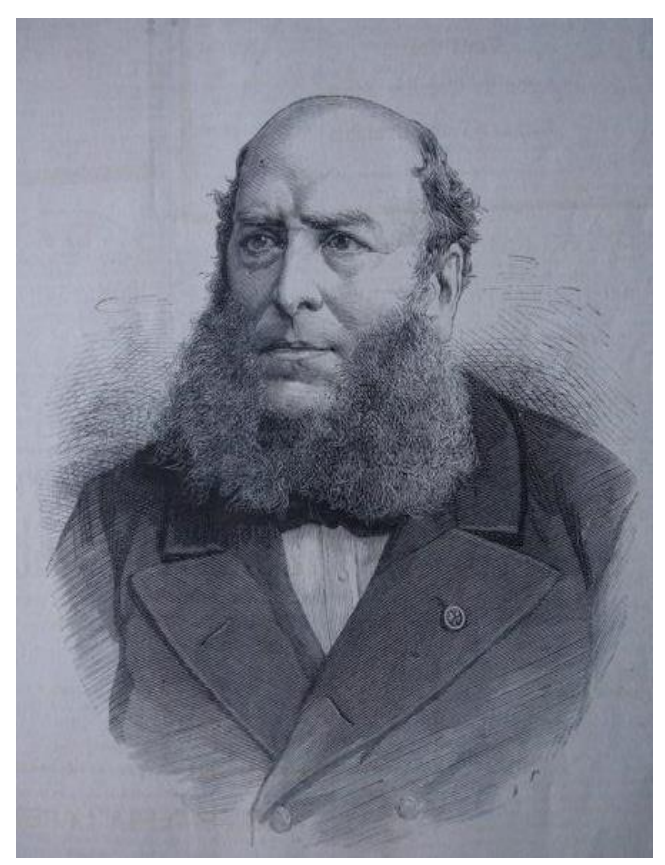

Fig.1.2 José Campo. La Ilustración Española y Americana. 1888.

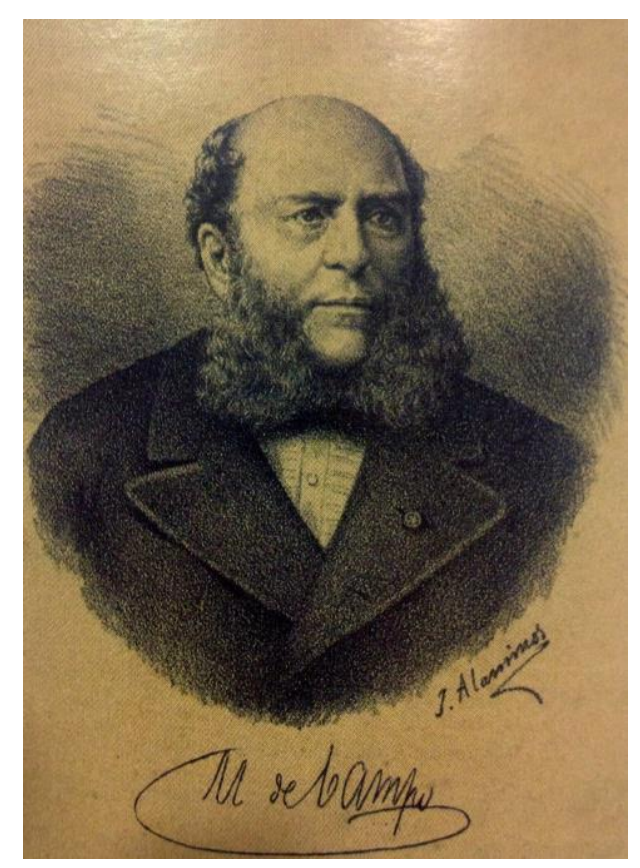

Fig.1.3 José Campo. Litografía de Juan Alaminos. Posterior a 1850.

\footnotetext{
${ }^{10}$ La Ilustración Española y Americana, año XXXIII, núm. XXII, 30 de agosto de 1889, portada.

${ }^{11}$ Retrato publicado en RIDAURA, Concha. Vida cotidiana y Confort en la Valencia burguesa (1850-1900). Valencia: Generalitat Valenciana, 2006, p. 34.

12 ALMELA Y VIVES, 1989, p. 109.
} 
Los retratos del marqués reflejan un hombre maduro, en la plenitud de su vida, con dureza de gesto y una personalidad fuerte, que impone, como corresponde a un personaje como él, un emprendedor hombre de negocios con una voluntad férrea que no conocía los límites de su ambición y de sus iniciativas; que le llevó a triunfar en sus negocios y a ser capaz de realizar grandes empresas como enviar a su costa una expedición formada por científicos españoles para intervenir en las decisiones referentes a la construcción del canal de Panamá. O de proponer al gobierno comprar Gibraltar con una suscripción popular13.

Muy similar a estos dos retratos es el pintado por José Struch, en óleo sobre tabla de forma oval (Fig. 1.4) ${ }^{14}$, y que fue utilizado para la ornamentación de su pabellón de la fábrica de gas en la feria de julio de 1883. La misma vestimenta, el mismo gesto, las características patillas, la misma forma de mirar, etc., casi se podría decir que el grabado de la (Fig. 1.2), publicado en La Ilustración Española y Americana fue el origen o el modelo de esta obra.

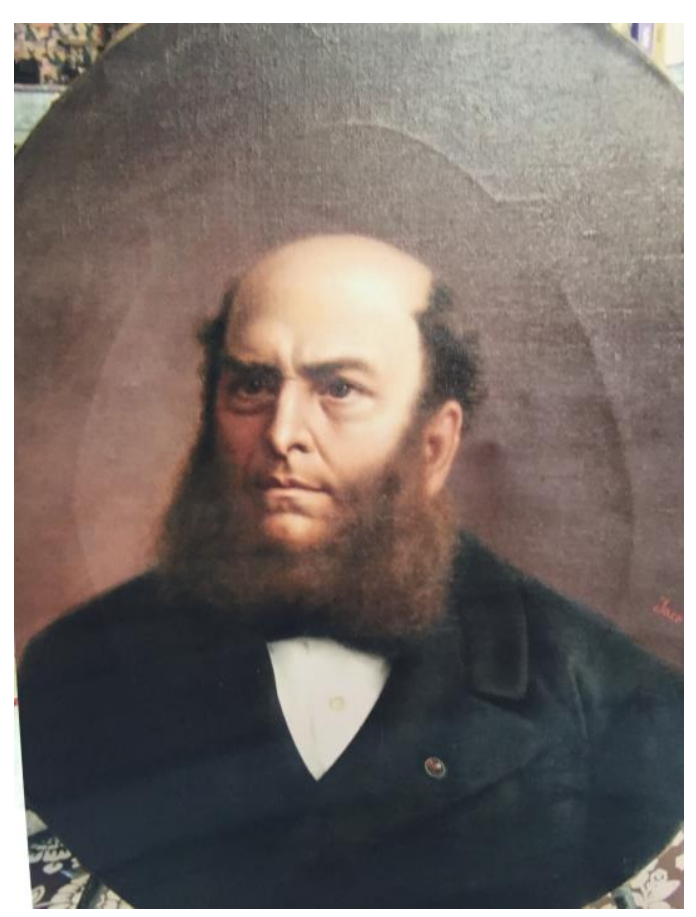

Fig.1.4 José Campo. Obra de José Struch, Colección particular.

\footnotetext{
13 ALMELA Y VIVES, 1989, p. 87 y ss.

14 Imagen publicada en: MORANT GIMENO, Ana María et al. El marqués de Campo. Empresario, político y coleccionista de obras de arte. Valencia: Ayuntamiento de Valencia, 2015 .
} 


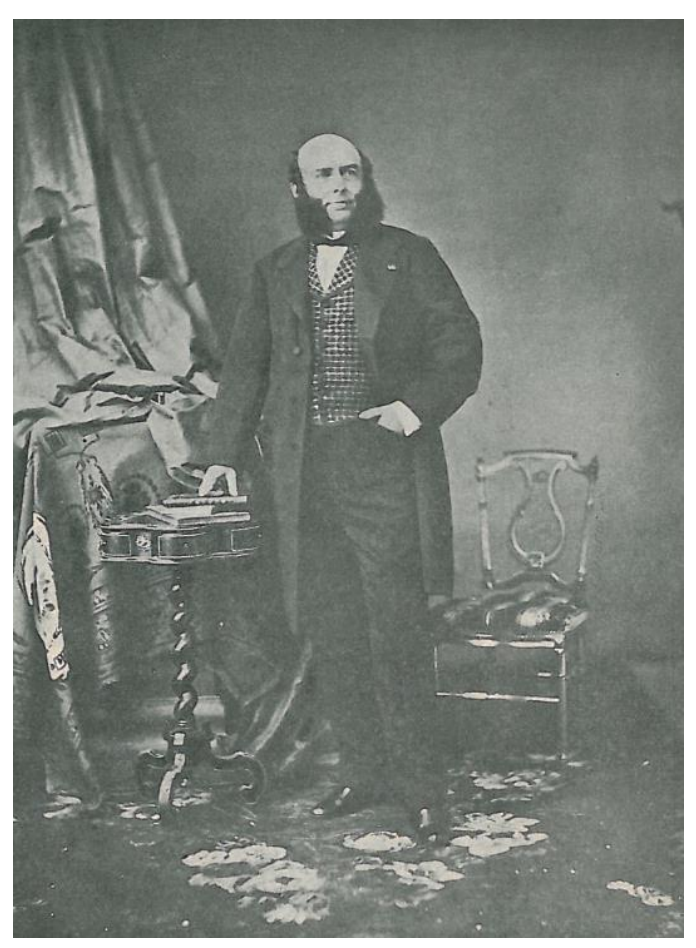

Fig.1.5 José Campo. Fotografía publicada en El Dominical 1884

Esta imagen que vemos del marqués (Fig. 1.5) se publicó en un ejemplar de El Dominical en 1884, pero indudablemente es una imagen de fecha muy anterior por la juventud de su rostro. José Campo aparece de pie, con una mano en el bolsillo y la levita un poco abierta; el fondo lo forman una pared neutra, un cortinaje, un pequeño velador y una silla; desconocemos el nombre del autor y si es una pintura o un grabado (por la mala calidad de la imagen de que disponemos). La mirada del marqués se dirige una vez más hacia el futuro sin entrar en contacto con el espectador; ¿significa que era un hombre inaccesible? ¿qué tenía un carácter fuerte? Por sus numerosas actividades benéficas se infiere que era una persona concienciada con la situación que vivía el pueblo, y posiblemente lo que quería expresar era que su mente estaba siempre pensando en cuestiones importantes para la ciudad y el país, pero sin duda esa faz tensa y seria revela a la vez una preocupación y una obsesión por sus negocios y empresas, que en muchas ocasiones le quitaban el sueño. 
Era un trabajador infatigable, el alba le sorprendía resolviendo asuntos ya en su despacho y la noche lo encontraba ensimismado o cavilando en sus asuntos que él mismo resolvía la mayoría de las veces, no por falta de empleados sino por voluntad propia de encargarse personalmente de todo.

Otra serie de retratos de José Campo la forman un conjunto de fotografías que le hizo Jean Laurent (1856-1861) en Madrid ${ }^{15}$.

Entre los años 1860 y 1872, Jean Laurent realizó álbumes de retratos de las élites de su tiempo y también de todo el mosaico social de la época, desde artistas, cantantes, tipos populares y la aristocracia ${ }^{16}$. La constante renovación de los miembros de la clase política, de la que a veces forma parte la nueva nobleza, conlleva la realización de fotografías de ministros, diputados, senadores, y grandes políticos, para hacer frente a la imagen de la pintura que no siempre era un fiel reflejo del retratado. Sin embargo, en la fotografía no hay trampa ni cartón y el retratado sale al natural, sin adulteraciones pictóricas. El grabado o la pintura puede favorecer, pero la fotografía transmite la verdad, y los políticos del momento necesitaban volver a gozar de credibilidad ante el pueblo.

Jean Laurent llegó a Madrid en 1844 y comenzó su carrera profesional en nuestro país como fotógrafo oficial de la reina Isabel II desde 1861 a 1868. Eso le dio fama y pasó a ser el fotógrafo de la alta aristocracia madrileña, pero también fotografió ciudades y monumentos e incluso algunas de las obras del Museo del Prado. Fue un innovador en diferentes técnicas de fotografía, y realizó reportajes de la construcción de las líneas ferroviarias, de ahí pudo venir la relación con José Campo.

15 Dichas fotografías se encuentran en la colección permanente del Museo de Historia de Madrid. Números de referencia: 1991/18/1-481, 1991/18/4-137, 1991/18/4.138, 1991/18/4.140, 1991/18/4-142, 1991/18/4-145, 1991/1871-484, 1991/18/1-482, 1991/18/4-144, 1991/1874-141

${ }^{16}$ TUDA RODRÍGUEZ, Isabel (ed.). Jean Laurent en el Museo de Historia de Madrid. Retratos Políticos, "tomo IV". Madrid: Editorial del Museo Municipal de Madrid, 2011. 
Su estudio de Madrid estaba en la Carrera de san Jerónimo, y tanto en él como en su tienda de París vendía retratos de personajes ilustres, políticos, artistas, y fotografías de España y Portugal17.

Vamos a analizar diez fotografías realizadas por Laurent a José Campo. Las cuatro primeras fotografías que hizo son de busto, ataviado con levita negra y destaca sobre todo su rostro de mediana edad adornado con sus eternas patillas (Figs. 1.6, 1.7, 1.8 y 1.9). En la primera fotografía está mirando al objetivo de frente y observamos una mirada inquisitiva, sin concesiones, pero a la vez un poco inquieta que da muestras de su incomodidad al mirar a la cámara, sin embargo, las otras tres son diferentes posiciones hasta llegar al perfil y su rostro se va relajando.

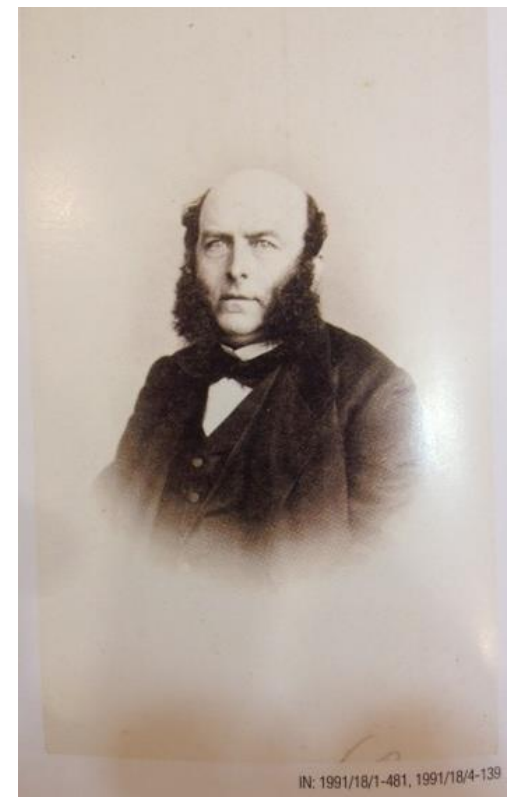

Fig.1.6 José Campo.

Fotografía de Laurent. Museo

de Historia de Madrid.

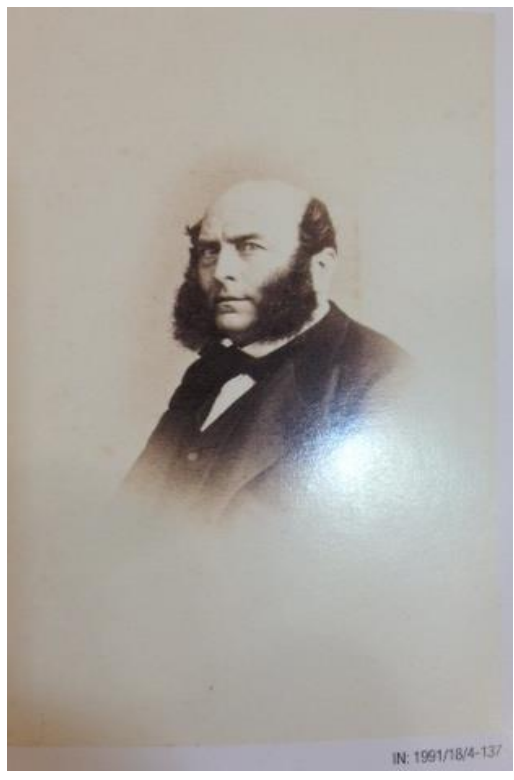

Fig.1.7 José Campo. Fotografía de Laurent. Museo de Historia de Madrid.

\footnotetext{
${ }_{17}$ DIAZ FRANCÉS, Maite, J. Laurent (1816-1866) un fotógrafo entre el negocio y el arte. Madrid: Ministerio de Educación, Cultura y Deporte, Instituto de patrimonio Cultural de España, 2016.

Catálogo de los retratos que se venden en la casa de J. Laurent. Fotógrafo de S.M. La Reina. Madrid: Imprenta de Manuel de Rojas, 1861.
} 


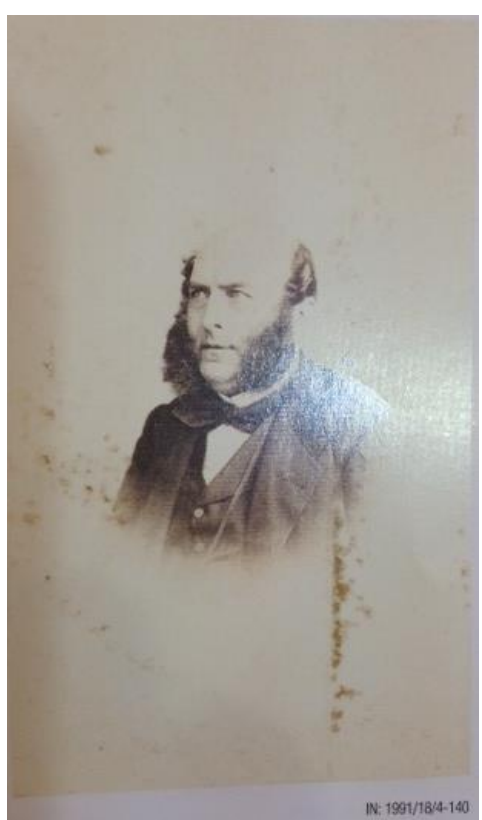

Fig.1.8 José Campo.

fotografía de Laurent. Museo de historia de Madrid.

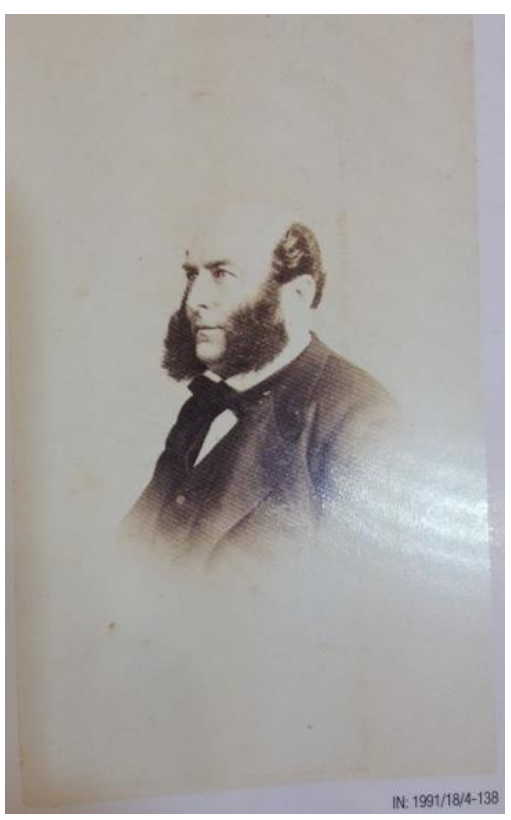

Fig.1.9 José Campo. Fotografía de Laurent. Museo de Historia de Madrid.

Las siguientes cuatro fotografías son de pie (Figs. 1.10, 1.11, 1.12, y 1.13). El pantalón es del mismo color que la levita, lo que da seriedad y sobriedad a la figura y lleva en la mano un sombrero de copa que le aporta elegancia y demuestra que va vestido a la moda y con arreglo a su posición social.

En ellas aparece en diferente actitud y con diferente fondo. En la primera un decorado artificial y una silla hacen que la figura se vea grandiosa y recta, sin embargo, en la siguiente la figura destaca sobre un fondo neutro sin ningún adorno y así se centra más el interés en el personaje retratado. Siempre se deja ver la dureza de su gesto, su actitud poderosa y su personalidad burguesa que le lleva a prosperar en su negocios y empresas. 


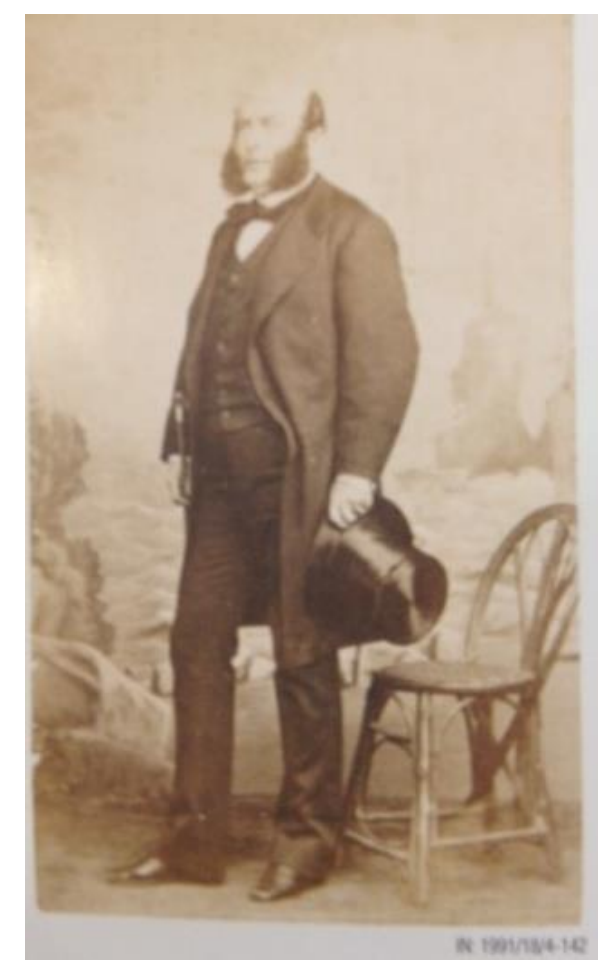

Fig.1.10 José Campo. Fotografía de Laurent. Museo de Historia de Madrid.

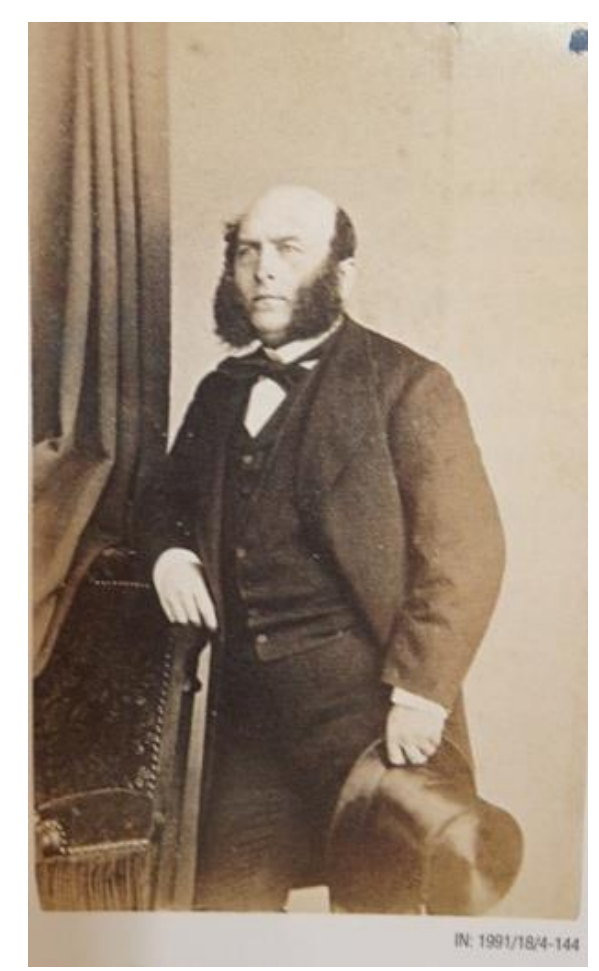

Fig.1.12 José Campo. Fotografía de Laurent. Museo de Historia de Madrid.

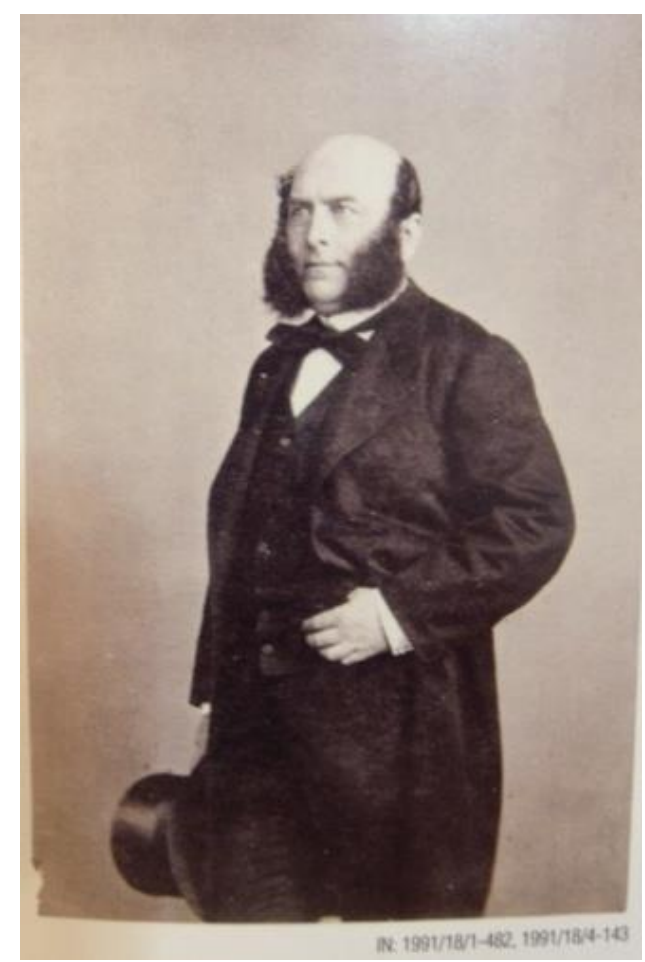

Fig.1.11 José Campo. Fotografía de Laurent. Museo de Historia de Madrid.

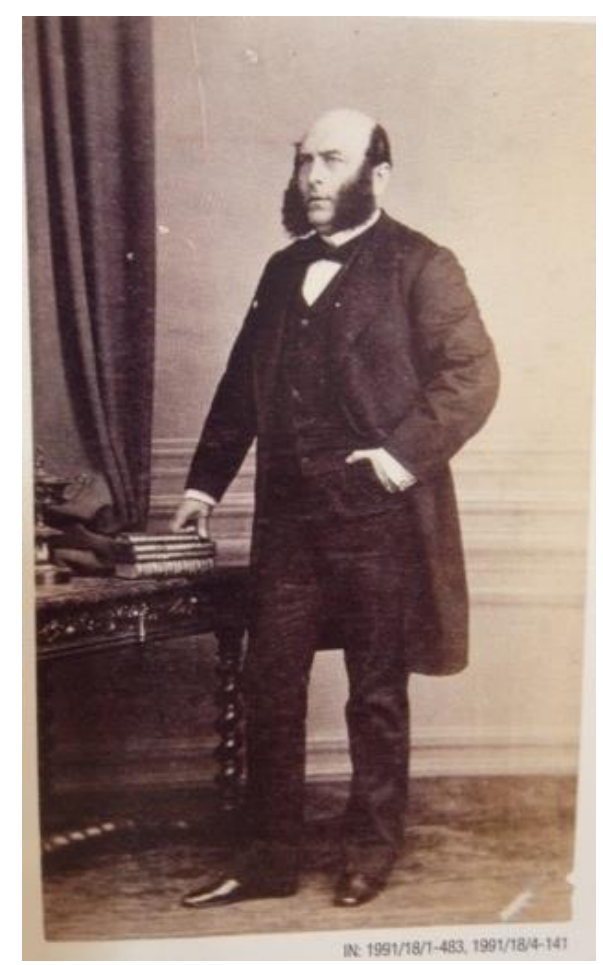

Fig.1.13 José Campo. Fotografía de Laurent. Museo de Historia de Madrid. 
Y ya las dos últimas fotografías del grupo realizado por Laurent son dos instantáneas del marqués trabajando en lo que parece ser un despacho (Figs. 1.14 y 1.15), en una de ellas sentado a una mesa con la mano apoyada en un libro abierto, simula que ha estado leyendo y se ha detenido con la mirada en el infinito para reflexionar y cavilar en sus múltiples negocios; y en la otra aparece sentado en la misma mesa con la cabeza sostenida con la mano y el codo apoyado sobre unos libros para transmitir una imagen de hombre de negocios y político ocupado en temas importantes que piensa en cada una de sus acciones y que pasa parte de su tiempo cavilando para no dar un paso en falso.

Jean Laurent supo captar perfectamente en estas fotografías la personalidad del marqués de Campo y en ellas su mirada y su actitud se erigen en protagonistas. De manera que nos acercan más al personaje y nos parece más real y cercano que en un cuadro. La captación psicológica del retratado es más inmediata y ello beneficia al espectador.

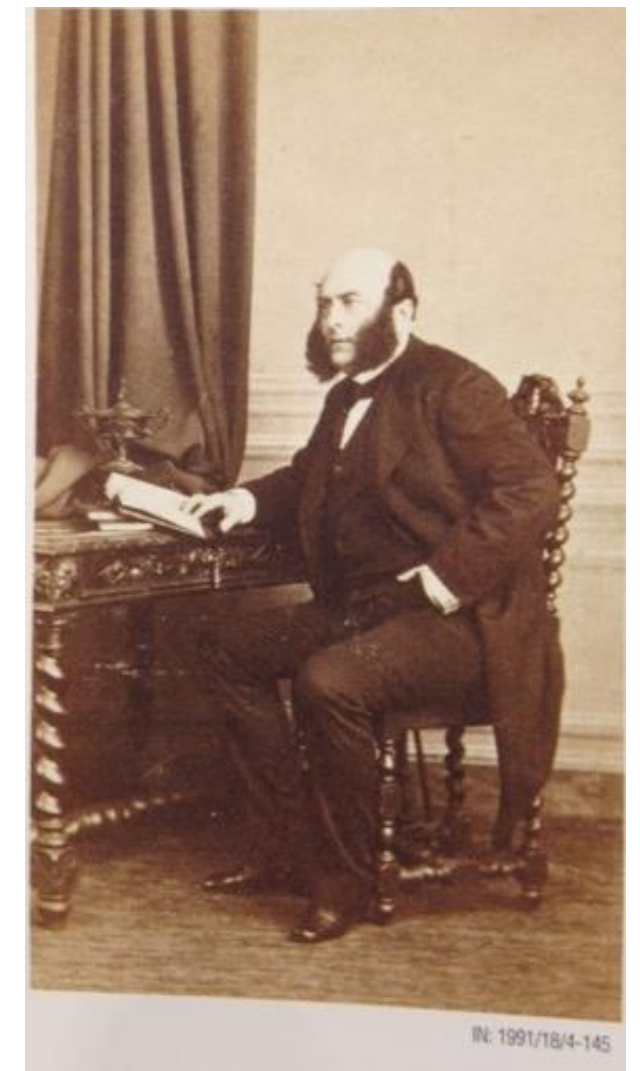

Fig.1.14 José Campo. Fotografía de Laurent. Museo de Historia de Madrid

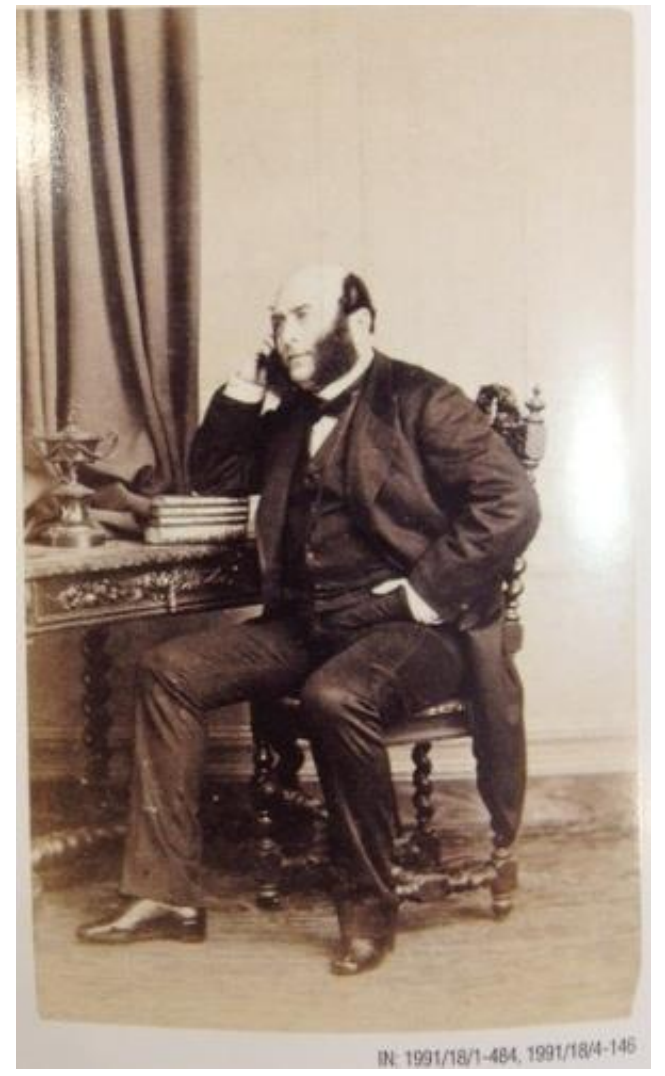

Fig.1.15 José Campo. Fotografía de Laurent. Museo de Historia de Madrid. 
Una imagen hasta ahora desconocida e inédita del marqués es la realizada por el fotógrafo Gaspard-Félix Tournachon, conocido por el sobrenombre de Nadar, en su estudio de la rue D’Anjou St. Honoré n. ${ }^{0} 51$ de París ${ }^{18}$. Nadar se hizo famoso por retratar a todos los personajes más representativos de la época y José Campo posó para su cámara en una de sus numerosas visitas a la capital francesa (Figs. 1.16 y 1.17). Desconocemos la fecha exacta de realización, pero si tenemos en cuenta que el prestigioso fotógrafo trasladó su estudio desde el Boulevard des Capuchines a la rue D’Anjou St. Honoré en 1870, y nos fijamos en el aspecto maduro del retratado, no hay duda de que el retrato es posterior a esta fecha. Siempre ataviado con levita negra cruzada con doble fila de botones, el marqués, esta vez sin elementos de attrezzo y con el sólo uso de la luz para revelar su gesto, mira otra vez hacia el horizonte y no establece contacto visual con el fotógrafo (pose muy diferente al retrato que el mismo fotógrafo realizó por ejemplo de Julio Verne, donde éste mira al espectador con gesto amable y sonriente) ${ }^{19}$.

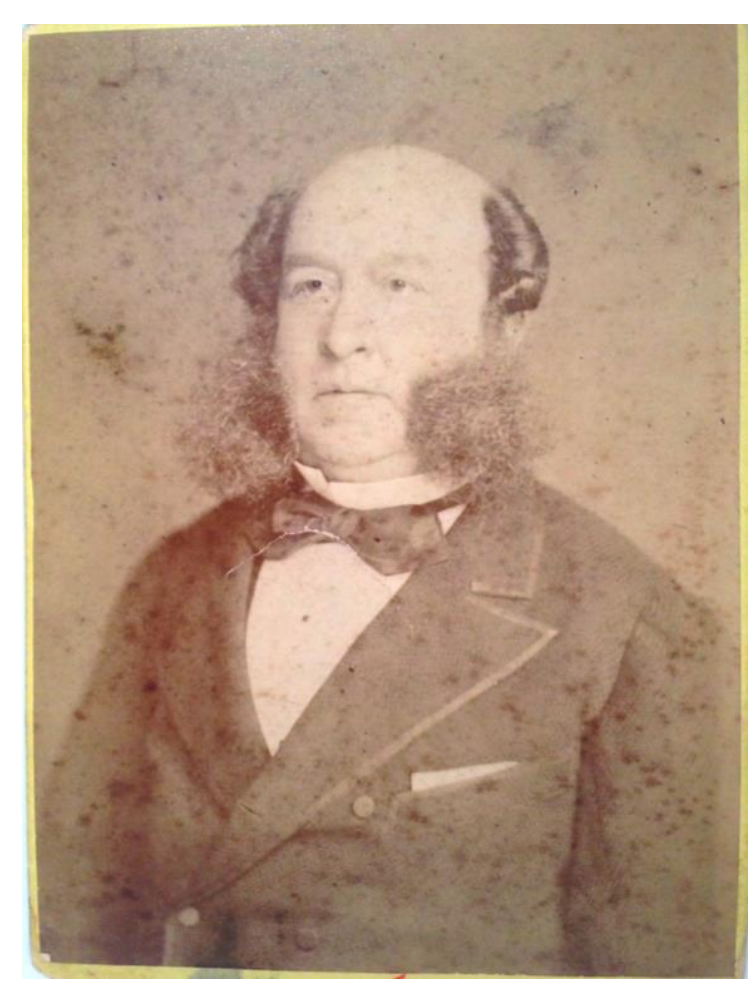

Fig. 1.16 José Campo. Fotografía de Nadar. Posterior a 1870.

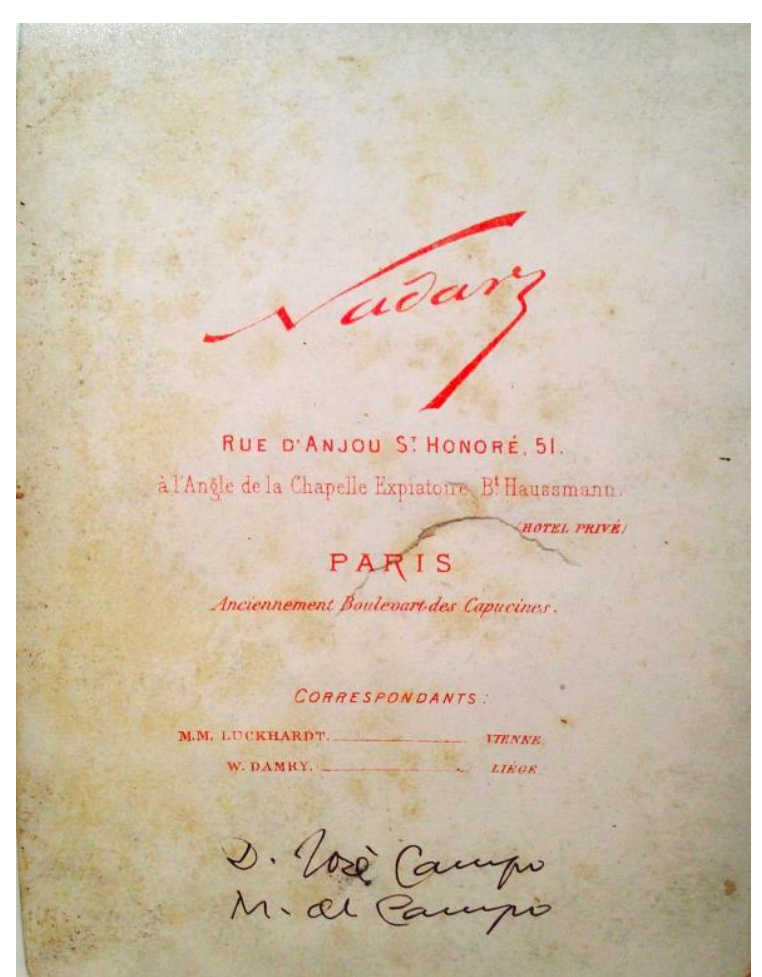

Fig. 1.17 Reverso de la fotografía. Imagen de la autora.

${ }^{18}$ La imagen ha sido cedida por Miguel Ángel Catalá Gorgues (RIP).

19 Ver imagen en: www.aloj.es/galba2/BERAUD/Capucines Nadar.htm consultado en línea el 15 de junio de 2013. 
José Campo también aparece retratado en un cuadro que encargó a José Benlliure en 1881 para el salón de actos del Asilo de la calle de la Corona. La pintura representa la entrega de premios a las niñas del Asilo y no sólo aparece retratado el marqués sino también su esposa, Rosalía Rey y su hijo adoptivo, Luis María Bruna ${ }^{20}$, de los que luego hablaremos. Vemos a José Campo entrado ya en años presidiendo junto al arzobispo de Valencia y su esposa la ceremonia (Fig.1.18). Este cuadro y a la relación del marqués con José Benlliure serán estudiados con más detenimiento en otro capítulo de esta tesis.

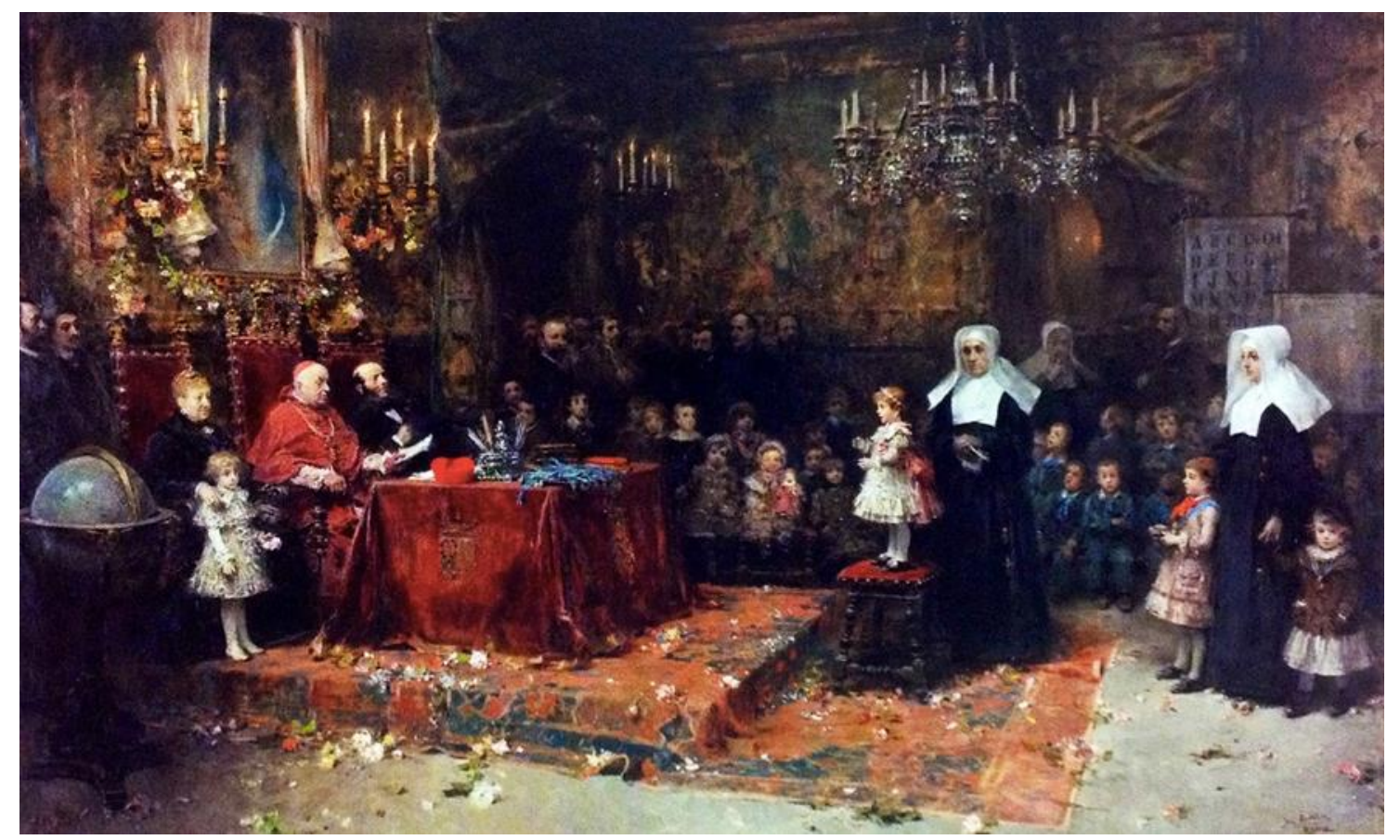

Fig.1.18 Distribución de premios en el Asilo del Marqués de Campo. José Benlliure. (1881-1886). Óleo sobre lienzo. Fundación Marqués de Campo.

${ }^{20}$ Publicado en La Ilustración Española y Americana, año XXX, núm. XXXIX, p. 2 y 9. y en BONET, Victoria et al. José Benlliure Gil (1855-1937), Catálogo de exposición. Valencia: Generalidad Valenciana, 2008. 
Otro retrato de José Campo es el que actualmente cuelga en la pared de la escalera principal de asilo de la calle de la Corona, hoy sede de la Universidad Católica san Vicente Mártir de Valencia (Fig. 1.19). De autor desconocido, sigue las mismas líneas que el resto que hemos visto. El marqués ataviado de negro, de pie, sobre un fondo neutro y una especie de cortina o paño al lado izquierdo que lo convierte en un retrato de aparato, y una mesita, pero en este caso su gesto no es tan serio como en otras ocasiones e incluso las manos en los bolsillos le dan un aspecto más relajado y amable. Este retrato hace pareja con el de su esposa Rosalía del que hablaremos más adelante.

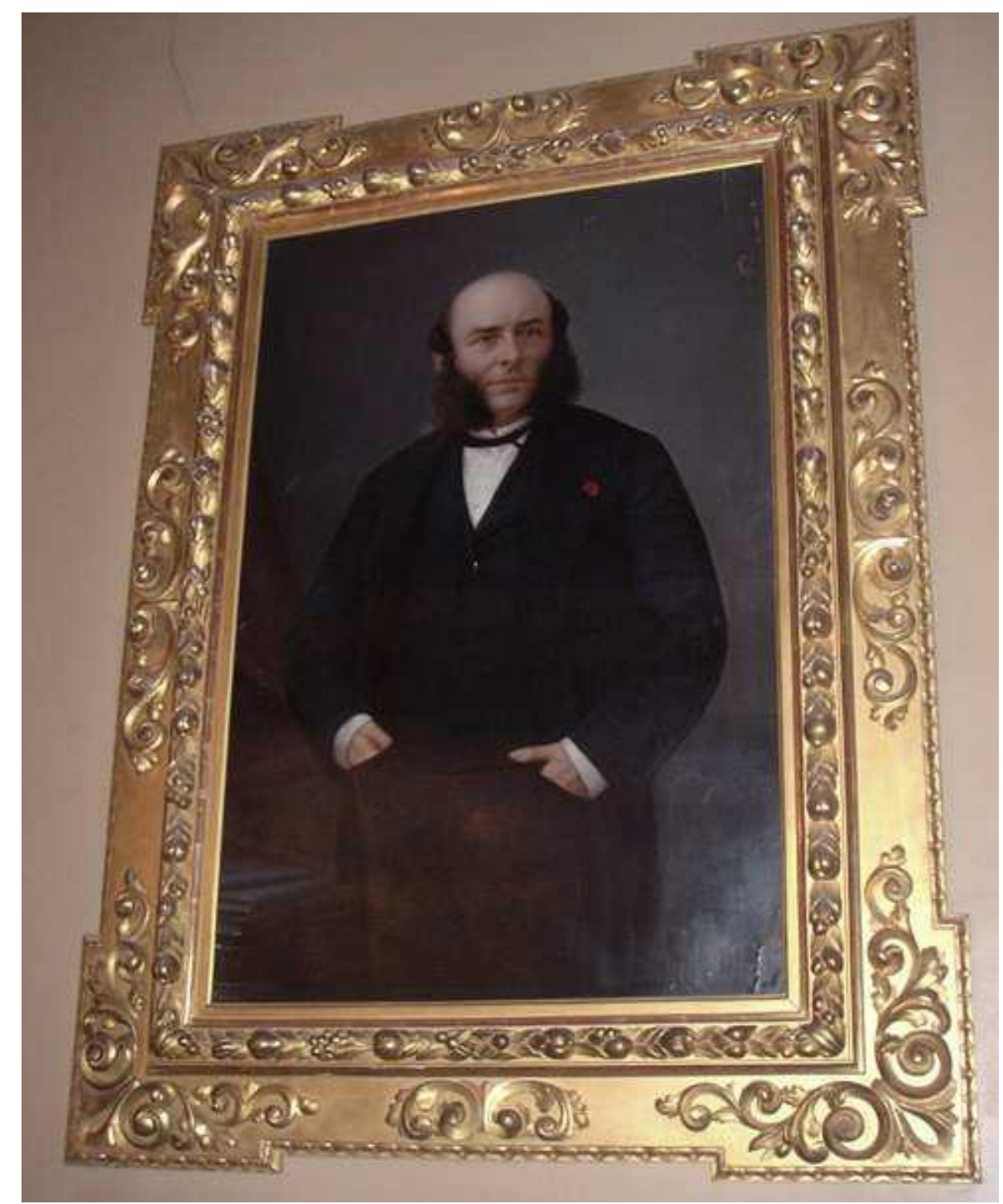

Fig. 1.19 José Campo. Inventario Asilo Campo. Dirección General de Cultura 
Conocemos otro retrato de José Campo, pero en este caso fue realizada mucho después de su muerte y que conserva hoy en día la Fundación Bancaja (Fig. 1.20); se trata de un retrato al óleo del marqués realizado por Manuel Moreno Simarro en 1964. En él aparece una vez más sobre fondo neutro y oscuro, vestido con levita negra, una pluma en su mano derecha y un guante en la izquierda, y su mirada al frente, siempre hacia el futuro.

Desconozco si la fuente es otro retrato más antiguo, una fotografía, o un grabado, pero se le representa con más edad que en el resto de los retratos que he analizado y además le acompaña su escudo heráldico con la corona de marqués en el extremo superior izquierdo, que será analizado más adelante en otro capítulo de esta tesis.

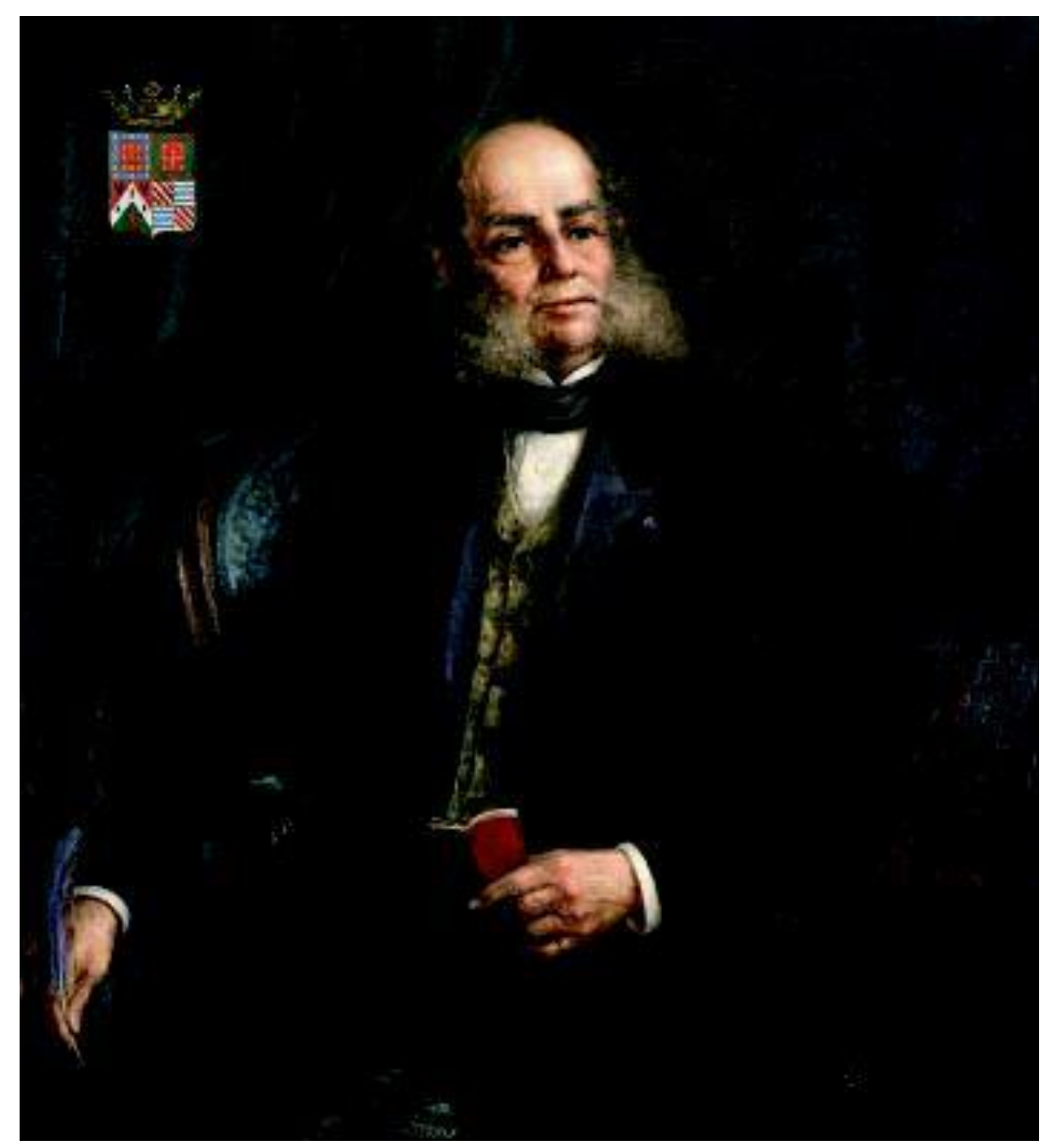

Fig.1.20 El marqués de Campo. Obra de Manuel Moreno Simarro 1964. Fundación Bancaja 
Para finalizar con los retratos de José Campo vamos a ver ahora dos esculturas que se conocen actualmente del marqués y una moneda con su rostro en relieve. En el inventario de sus bienes, que será analizado más adelante, aparecen descritas muchas más fotografías, cuadros y esculturas de diversos materiales del rostro del marqués, pero no han llegado hasta nuestros días.

La escultura más conocida del marqués de Campo forma parte del monumento que el Ayuntamiento de Valencia le erigió en agradecimiento por toda la labor que realizó en beneficio de la ciudad, cuyo diseño y realización corrió a manos de Mariano Benlliure ${ }^{21}$. En el monumento situado en la plaza Cánovas de Valencia (Figs. 1.21 y 1.22), el marqués aparece de pie, ataviado con levita, la postura erguida y una pierna adelantada; su mirada al frente como siempre y acompañado de un niño que se ha identificado en ocasiones como su hijo adoptivo Luis María Bruna o como su hija Josefa que murió de corta edad, o también se le ha identificado como una personificación de la ciudad de Valencia, a la que siempre amó y ayudó. Mariano Benlliure, con su gran maestría, supo plasmar a la perfección la personalidad de su amigo Campo, su fuerte carácter y su paso serio y firme, de manera que hoy en día aparece en actitud vigilante ante lo que pasa ante sus ojos en la ciudad. Esta escultura y la relación de Mariano Benlliure con Campo será analizada en otro capítulo de esta tesis.

\footnotetext{
${ }^{21}$ Archivo Histórico Municipal de Valencia: Libro de actas, 1885, Sesión de 21 de enero. Y Libro de actas, 1885, Sesión ordinaria por segunda convocatoria del día 28 de enero de 1885 .

Monumento estudiado entre otros por:

FERRER, Vicente. Monumentos a valencianos ilustres en la ciudad de Valencia. Valencia: 1987, p. 61-63.

GIL, Rafael; PALACIOS, Carmen. 2000, p. 114-121.

REYERO, Carlos. 1999, p. 62.
} 


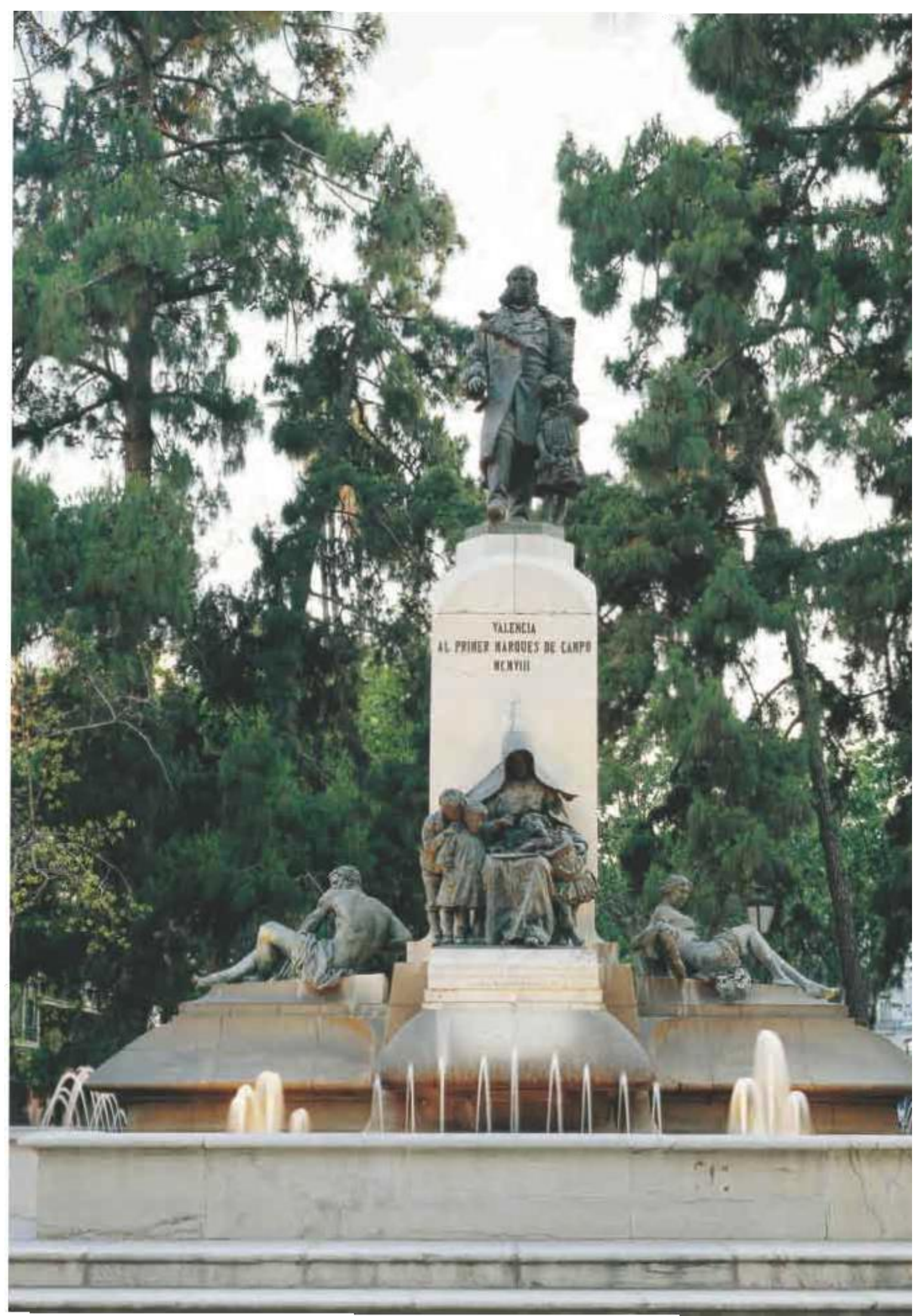

Fig. 1.21 Monumento a José Campo. Mariano Benlliure. 1885. Foto de la autora. 


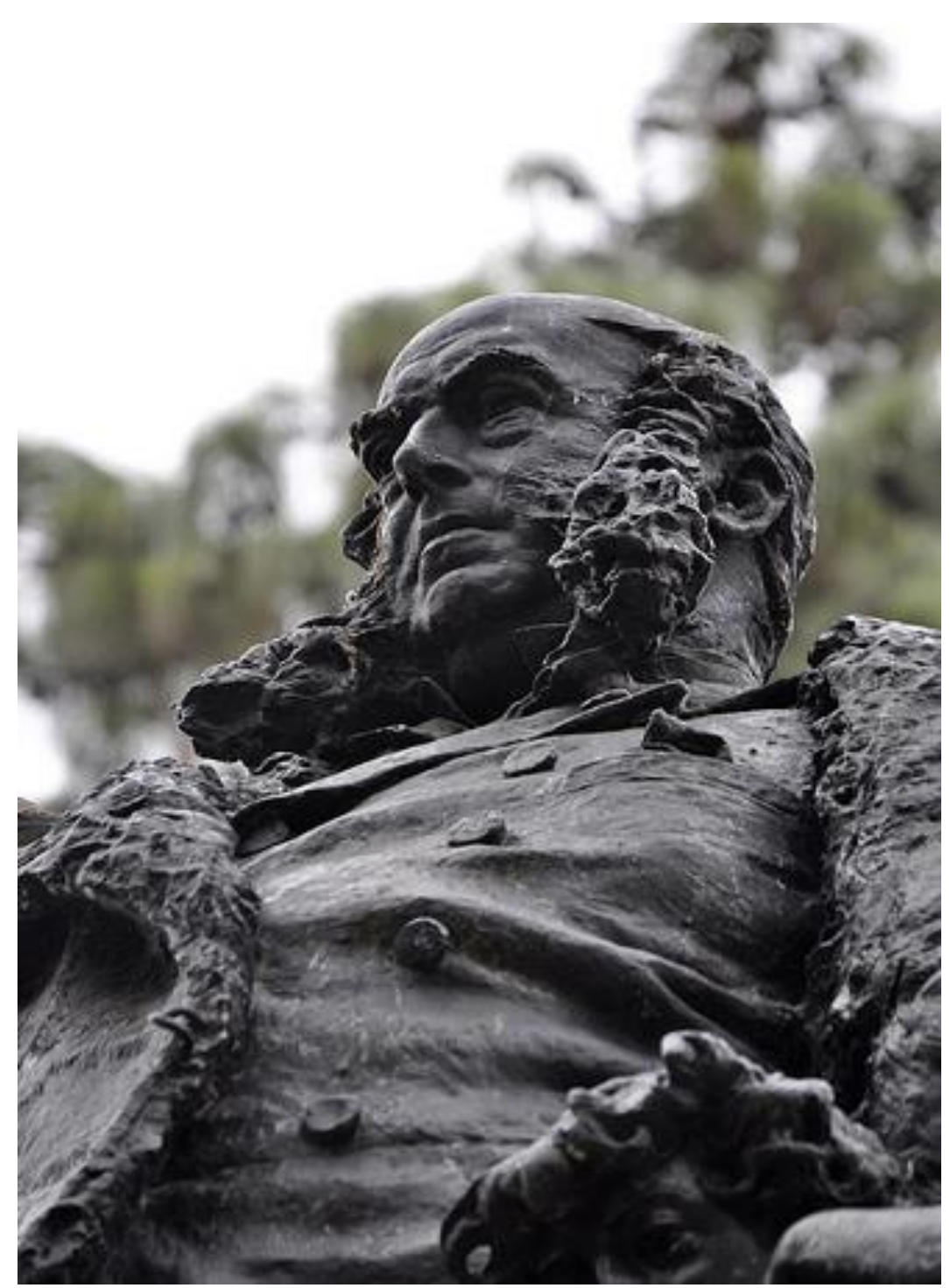

Fig.1.22. Monumento a José Campo. Detalle. Mariano Benlliure.1885. Foto de la autora.

La otra escultura desconocida hasta el momento es un busto de bronce propiedad de la familia del marqués y que fue exhibida en 2015 en el que fuera su palacio en Valencia con motivo de unas jornadas para conmemorar el segundo centenario de su nacimiento (Figs. 1.23, 1.24 y 1.25).

El busto está realizado en bronce y sin duda es uno de los dos bustos de bronce del marqués que aparecen en el inventario de sus bienes realizado en 188922. En dicho inventario, relativo al palacio de Recoletos de Madrid aparece un busto de bronce del señor marqués sobre la chimenea de un despacho nuevo,

${ }^{22}$ AHPM, T. 36643, fols. 7439 y ss. 
y el otro aparece en el castillo de Viñuelas descrito como un busto de metal bronceado del señor. marqués.

En ninguna de las dos descripciones de hace referencia al autor del busto, pero gracias a que fue expuesto, pude contemplarlo de cerca y pude ver que en la parte de detrás aparece grabado el nombre de Giovanni Antonio Lanzirotti. Y además del nombre del artista aparece grabada la aclaración de que en realidad es una fotoescultura ${ }^{23}$.

Lanzirotti, (1839-1921) trabajó en Italia y Francia. Fue el director de los estudios de fotoescultura de la Sociedad General de Fotoescultura de Francia, situados en el Boulevard de los Capuchinos de París debajo mismo de los estudios del famoso fotógrafo Nadar. Como hemos visto José Campo fue fotografiado por Nadar, y cabe la posibilidad de que conociera el trabajo de Lanzirotti y la novedad de la fotoescultura; y no dudara en hacerse una como hombre moderno que era y favorecedor de todo avance, progreso y novedad.

${ }^{23}$ La Fotoescultura es una fotografía que reproduce esculturas u obras plásticas mediante la aplicación de la fotografía, con lo que se pretende conseguir la tridimensionalidad que confiere el soporte original. En realidad, se trata de una fotografía tomada como escultura, donde sus autores se sienten más escultores que fotógrafos. A través de este sistema, se obtenían los negativos fotográficos colocando el original en un espacio iluminado por el sol; se preparaban después los correspondientes positivos fotográficos para su proyección mediante la linterna mágica; a partir de ahí, comenzaba el trabajo del escultor con las materias primas para modelar una nueva figura de barro o yeso. Se realizaba con veinticuatro cámaras fotográficas que fotografiaban a la vez al modelo, y que eran dispuestas a igual distancia en la pared circular de una rotonda de diez metros de diámetro. Los veinticuatro negativos se proyectaban uno tras otro con un lampadoscopio y, a partir de la proyección, se modelaba la escultura con ayuda de un pantógrafo. Con este sistema se hacían esculturas y medallones en distintos materiales. Se desarrolló en la década de los sesenta del siglo XIX y entre sus investigadores se encuentran François Willème (1830-1905), que presentó sus trabajos en la Exposición de la Sociedad Francesa de Fotografía en 1863 y patentó el método. http://tesauros.mecd.es/tesauros/bienesculturales/1181017.html. Consultado en día 17 de junio de 2019. 


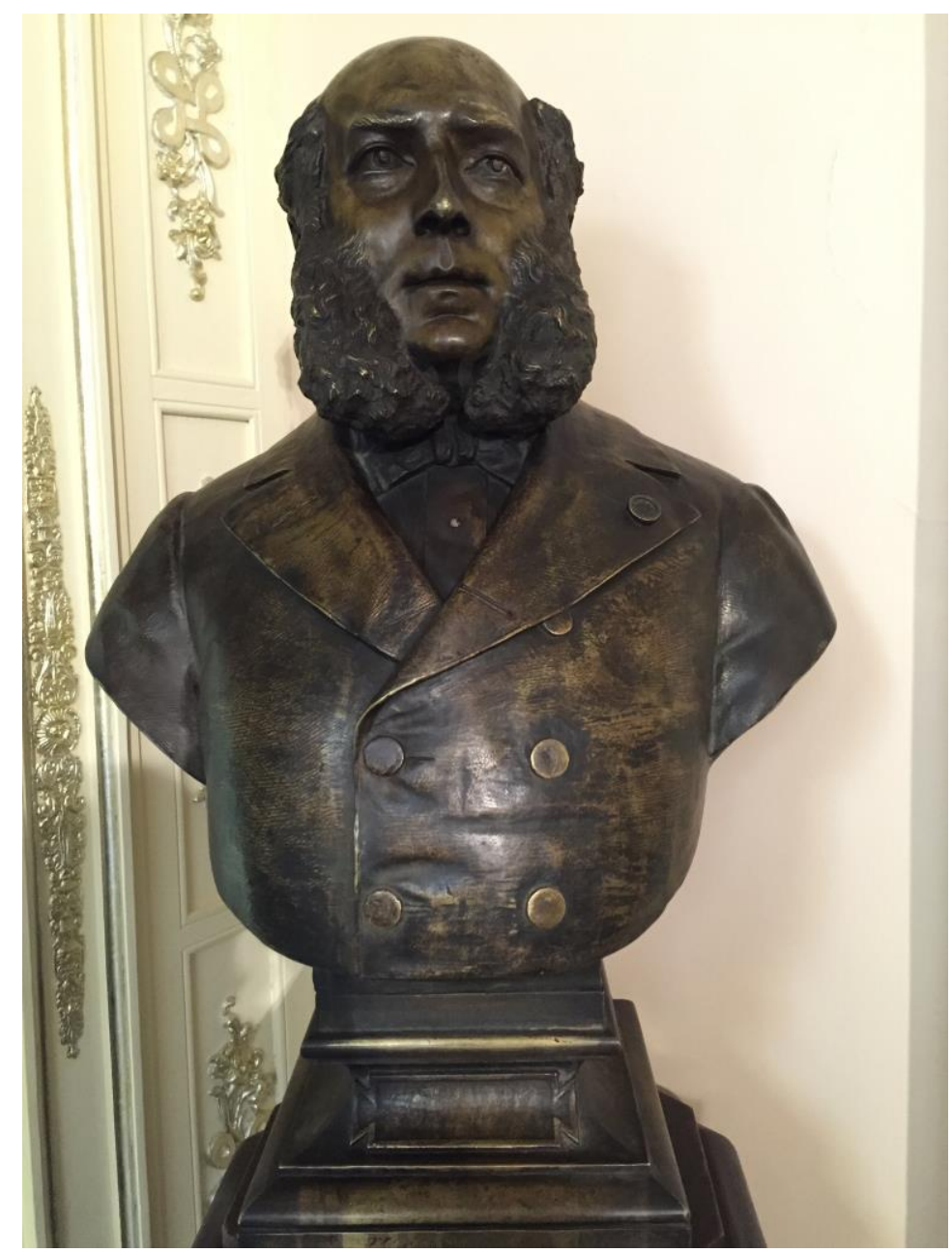

Fig.1.23. José Campo, fotoescultura en bronce, obra de Giovanni Antonio Lanzirotti. Colección particular. Fotografía de la autora.

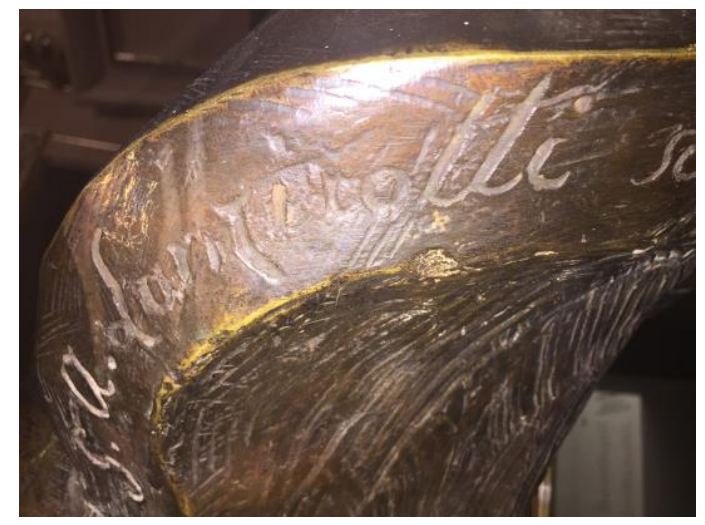

Fig.1.24. Fotoescultura, detalle de la firma del autor. Fotografía de la autora.

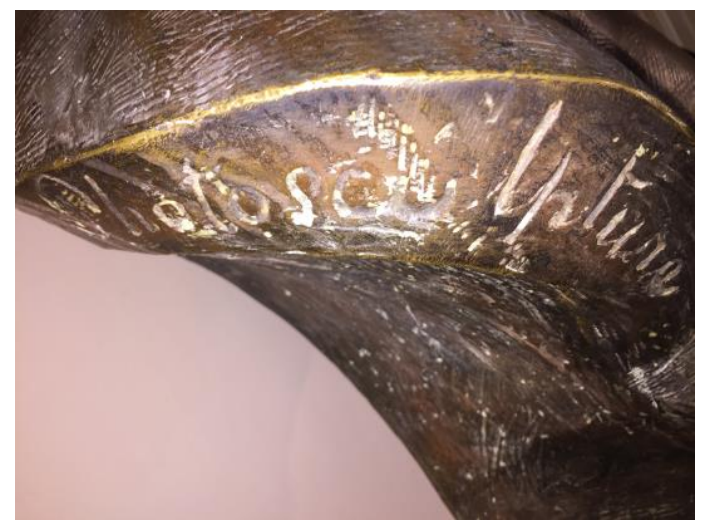

Fig.1.25. Fotoescultura, detalle. Fotografía de la autora. 
Un relieve con el rostro de José Campo lo encontramos en la medalla de bronce que hizo acuñar con motivo de la expedición que mandó a su costa al istmo de Panamá en 1886 para que España participara en las decisiones sobre la construcción del canal24. La expedición a Panamá y el análisis iconográfico de la medalla conmemorativa serán objeto de análisis en otro capítulo de esta tesis. En el anverso podemos ver el retrato del marqués en edad madura, pero esta vez, como se suele hacer en las monedas y medallas, su mirada al frente ha dejado paso a su perfil con sus grandes y características patillas (Fig. 1.26). Colocar el rostro de perfil se corresponde con el prestigio que da esa postura, típica de los poderosos en las medallas conmemorativas, en las monedas; y que se viene haciendo desde la antigua Roma y se sigue haciendo en la actualidad. Su gesto es serio y va ataviado como siempre con una levita de grandes solapas apreciándose en la de su izquierda la roseta de la Legión de Honor Francesa a la que nos hemos referido anteriormente 25 .

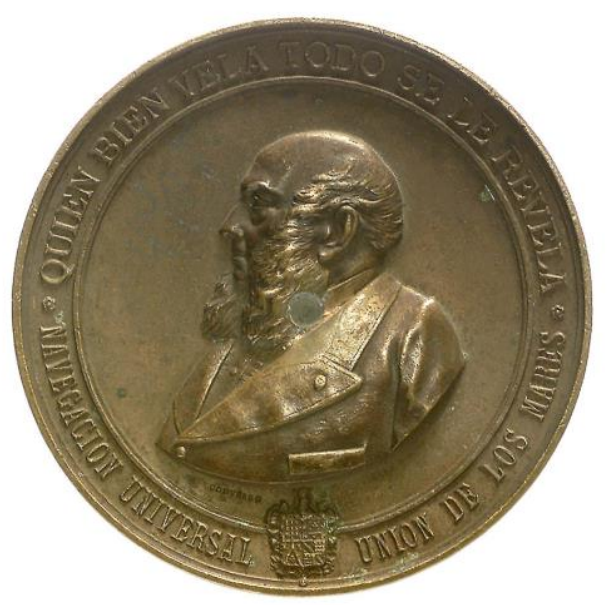

Fig.1.26 Medalla conmemorativa de la expedición del marqués de Campo a las obras del canal de Panamá. 1886. Imagen de la web del Museo del Prado²6.

24 Sobre esta medalla ver: La Ilustración Española y Americana, año XXXII, núm. VII, 22 de febrero de 1886, p. 132.

ALMELA Y VIVES, Francisco. 1989, p. 95.

CRUSAFONT, Miquel. 2006, p. 444.

MARÍN, M. a Isabel. 2005, p. 99.

${ }^{25}$ MORANT GIMENO, Ana María. "El conocimiento de otros mundos a través de la literatura de viajes: crónicas y dibujos de las obras del Canal de Panamá en 1886”. En: Actas del Congreso Nacional del CEHA. Toledo: 2014.

26 https://www.museodelprado.es/coleccion/obra-de-arte/al-marques-de-campo-en-laprimera-expedicion/a3a13ab6-9901-4652-bcab-f2dogefg95ee. Consulta realizada el 10 de enero de 2016. 


\section{2.- Retratos de la familia del marqués de Campo}

No podemos terminar este capítulo dedicado al marqués y sus retratos sin nombrar a otros miembros de su familia que jugaron un papel muy importante en su vida. Su primera esposa Rosalía Rey Loisselet, era una joven nacida en Toulouse un año antes que José Campo, en 1813, y a quien conoció en Marsella en uno de sus viajes a Francia. De su aventura de amor, sin boda previa, nació una hija, Josefa, y cuando Campo volvió a Valencia con mujer y una criatura, la familia tuvo que adaptarse a la situación y la boda se celebró sin anuncio y en la intimidad en un pueblo de las afueras de Valencia, en Benetúser ${ }^{27}$, en la iglesia parroquial de Nuestra Señora del Socorro en 1840.

Cuando Rosalía se casó con José Campo no era todavía el gran político y hombre de negocios en que se convirtió con los años. Ella siempre estuvo a su lado y supo guardar un papel secundario en todo momento. Su felicidad se vio truncada con la muerte de su hija Josefa hacia 1856. Fue una mujer devota, con director espiritual ${ }^{28}$, dedicada a las obras de beneficencia y caridad y cada vez que se requería su participación para algún acto de beneficencia o para recaudar fondos era la primera en acudir y prestar su ayuda. Como ya hemos dicho en otra parte de esta tesis, al morir su hija es cuando el matrimonio Campo decide construir el primer asilo en Valencia y de esa manera ayudar a los más necesitados.

${ }_{27}$ MOMBLANCH GARCÍA, Francisco de Paula. "Un valenciano singular: el marqués de Campo". En: Crónica de la XXX asamblea de cronistas oficiales del reino de Valencia. Valencia: 2016, p. 265.

${ }^{28}$ La Correspondencia de España, 15 /1/ 1889, p. 4. 
Los marqueses adoptaron un hijo que José Campo había tenido en una aventura extramatrimonial y Rosalía no puso ningún impedimento; el niño se llamaba Luis María y es el niño que aparece al lado de la marquesa en el cuadro que pintó José Benlliure para el segundo asilo, que hemos visto en la figura 1.18 y del que luego hablaremos.

Los actos de la marquesa de Campo también eran objeto de publicaciones de prensa que daban cuenta de sus idas y venidas. Vamos a ver algunos de ellos y nos podremos hacer una mejor idea de cómo era su día a día.

En su palacio de Recoletos se celebraron, con gran actividad por parte de la marquesa, grandes bailes y fiestas pero, no sólo para amigos y políticos, sino también bautizos y bodas de amigos y familiares. En diciembre de 1875 en la capilla del palacio se celebró la boda de su sobrina, Concepción Moreno Campo, con el primogénito de los marqueses de Dos Aguas. El marqués de Campo la condujo al altar y la madrina de dicho enlace fue la marquesa. Al enlace y fiesta posterior acudieron muchos nobles y personalidades del Madrid del momento, que disfrutaron de un gran banquete ${ }^{29}$.

Fue la madrina del cuarto hijo de los señores Maicas, y el bautizo también se celebró en el palacio ${ }^{30}$.

Rosalía tenía habitaciones en el Gran Hotel de París, donde viajaba por placer muy a menudo ${ }^{31}$. Iba al teatro con asiduidad y tenía un palco propio en el Teatro Real de Madrid ${ }^{2}$. Fue protectora del escritor José Zorrilla, célebre por su obra Don Juan Tenorio; la marquesa actuaba de mecenas y le pagaba una

${ }^{29}$ La Correspondencia de España, 10/12/1875, p. 1.

La Época, 10 /12/ 1875, p. 3.

${ }^{30}$ Época, 19 /11/ 1886, p. 2.

${ }^{31}$ La Dinastía, 30 /10/ 1883, p. 359.

${ }^{2}$ Época, 16 /4/ 1886, p. 3. 
pensión para promocionar su carrera 33. Como la mayoría de la burguesía madrileña, los marqueses pasaban los veranos fuera de la capital y visitaban Biarritz y otros lugares hasta que compraron su residencia de Arcachon, Francia, y tras pasar la temporada relajadamente en la playa, su vuelta a la capital también era publicada 34 .

La marquesa realizaba donaciones para todas las causas benéficas que solicitaban su colaboración y participaba en la organización de festejos y cabalgatas junto a otras damas de la alta sociedad 35 .

La salud de la marquesa también era objeto de comentario en la prensa; por ejemplo, en 1886 estuvo aquejada de graves males durante unos meses y las noticias eran continuas ${ }^{36}$. También sus actividades piadosas en la iglesia se publicaban ${ }^{37}$. Igual que su esposo, su vida estaba sometida a la opinión pública, y cuando su estado de salud se agrava y llegan sus últimos días, la prensa sigue la noticia de cerca dando todo tipo de detalles hasta el día de su fallecimiento el 3 de enero de 1889 a la una y media de la madrugada ${ }^{38}$.

33 Época, 19 /12/ 1885, p. 3.

La Iberia, $19 / 12 / 1885$, p. 2.

El Siglo Futuro, $19 / 12 / 1885$, p. 3.

La Unión, 19 /12/ 18885, p. 3.

La Ilustración Española y Americana, año XXIX, núm. XVLIII, de 22 de diciembre de 1885, p. 2

34 La Correspondencia, 13 /9/ 1886, p. 3.

35 EL Cabecilla, 6 /11/ 1886, p. 3.

${ }^{6} 6$ Época, 9 /11/ 1886, p. 3.

La Unión, 9 /11/ 1886, p. 2.

Época, 12 /11/ 1886, p. 3

${ }^{37}$ La Correspondencia de España, 18 /12/ 1888, p.4.

${ }^{38}$ La Correspondencia, 3 /1/ 1889, p. 3.

El Día, 3 /1/ 18889, p. 2.

Iberia, 4 /1/ 1889, p. 2.

La Correspondencia, 4 /1/ 1889, p. 2.

El Día, 4 /1/ 1889, p. 4. 
La Correspondencia de España publicó: "Después de una larga y penosa enfermedad, ha fallecido, a la una y media de la madrugada de Ayer la Excma. Sra. Doña Rosalía Rey, marquesa de Campo, a la avanzada edad de 76 años. El vacío que deja esta ilustre señora en la alta sociedad de esta corte es sólo comparable a sus esclarecidas prendas y relevantes virtudes. Por lo que hace al respetable señor marqués, la pérdida de su distinguida esposa es uno de esos infortunios para los cuales sólo caben los consuelos y la resignación cristiana.

La ilustre marquesa, alma noble y corazón abierto a todos los sentimientos amorosos, ha bajado al sepulcro rodeada de las bendiciones de los pobres; ha pasado su vida consagrándose sin descanso al ejercicio de la caridad cristiana, derramando el bien a manos llenas y viviendo sólo para su familia y para sus queridos párvulos, los desvalidos huérfanos del grandioso asilo que la piedad de los marqueses ha hecho construir en Valencia.

Los restos mortales de la señora marquesa de Campo, por expresa voluntad de la finada, serán conducidos a Valencia donde recibirán cristiana sepultura en el panteón de la capilla del Asilo-Campo.

Acompañamos al respetable señor marqués en su sentimiento y le deseamos fortaleza de ánimo para sobrellevar la gran desgracia que le aflige" 39 .

Tras su fallecimiento el cadáver fue velado en la capilla del palacio y luego trasladado en tren a Valencia para su entierro en la cripta del nuevo asilo Campo que a tal efecto había hecho construir el marqués bajo del altar. La prensa relata las exequias en Madrid y la misa y entierro en Valencia, a los que acudieron grandes personalidades del momento, nobles y políticos. Días después de su entierro, el 15 de enero, se celebró en Madrid un funeral en la iglesia de san Jerónimo, y según relata la prensa se situó en el centro un catafalco de madera adornado ${ }^{\circ}$. Todos los comentarios confluyen en la amabilidad, bondad y virtuosismo de la marquesa41, que pocos meses después vería "desde lo alto" ocupar su puesto a Luisa Solá, viuda de Recur, quien se casó con el marqués,

${ }^{39}$ La Correspondencia de España, 4/1/1889, p. 3.

${ }^{40}$ La Época, 5 /1/ 1889, p. 2.

La Dinastía, 6 /1/ 1889. p. 2.

La Época, 15 /1/ 1889. p. 3.

41"Descanse en paz la que tanto bien hizo en tierra" El Pabellón Nacional, 6/1/1889, p. 2. 
previa dispensa concedida por el Ministerio de Justicia ${ }^{42}$ y por las autoridades eclesiásticas43, el día 9 de marzo, sólo 5 meses antes del fallecimiento de José Campo en agosto de ese mismo año44.

De la marquesa de Campo conservamos dos retratos: uno que hoy en día cuelga de la escalera principal del asilo de la calle de la Corona y el otro es parte del cuadro que pintó José Benlliure para el marqués recreando una escena de entrega de premios en el asilo al que ya nos hemos referido (Fig. 1.18) y del que hablaremos en otro capítulo de esta tesis (Figs. 1. 27, 1.28).

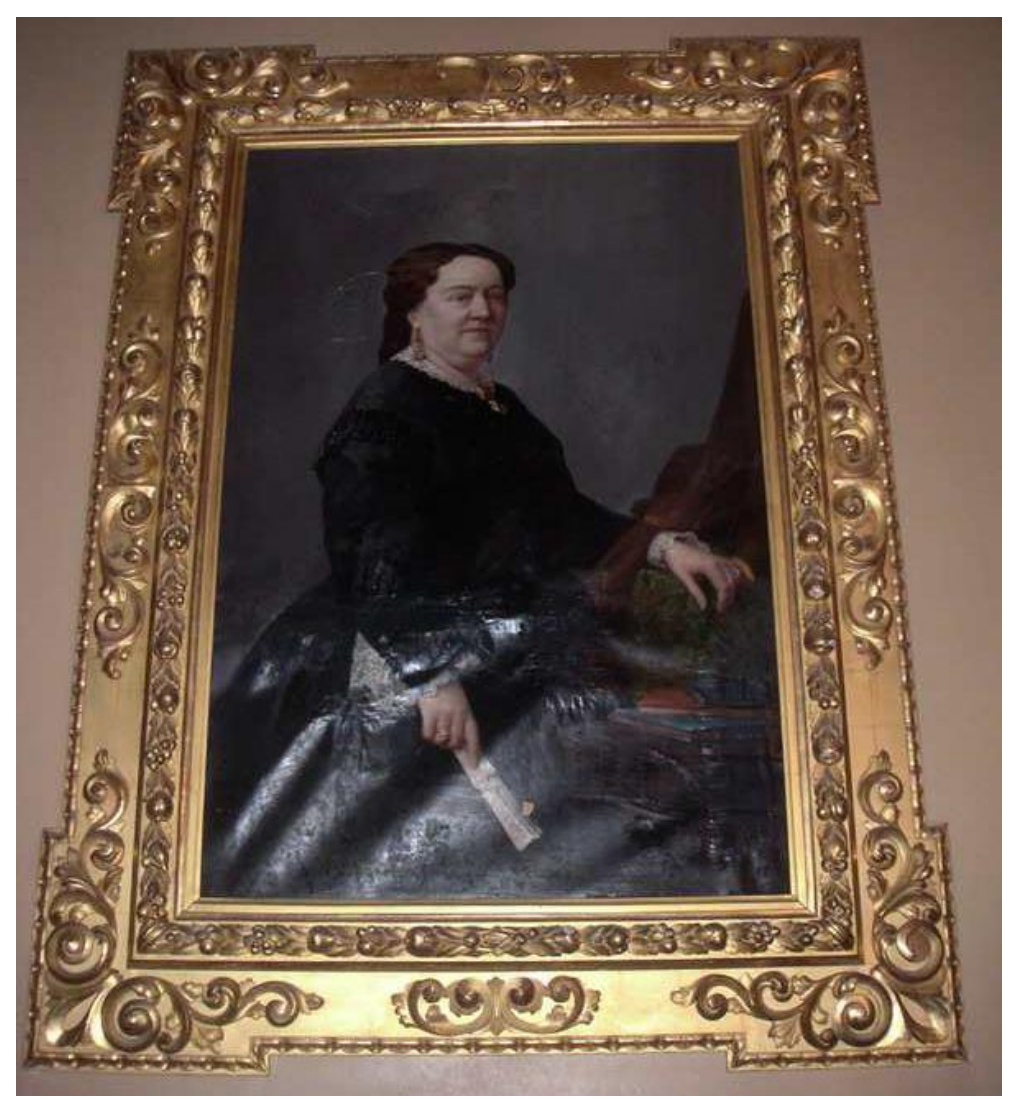

Fig.1.27 Rosalía Rey Loisselet. Marquesa de Campo. Imagen del Inventario del Asilo Campo. Dirección General de Cultura

${ }^{42}$ La Época, 1 /2/ 1889, p. 3.

El Día, 2 /2/ 1889, p. 3.

43 El Imparcial, 9 /3/ 1889, p. 2.

${ }^{44}$ Luisa falleció el 20 de julio de 1892. El Día, 21 /7/ 1892, p. 2.

Su entierro se narra en La Época, 21 /7/ 1892, p. 3 
Rosalía Rey aparece en este retrato, que forma pareja con el del marqués que hemos visto antes, de pie sobre un fondo neutro del mismo color y un cortinaje ficticio en el lado contrario. Era muy común hacer retratos de matrimonios en lienzos separados y haciendo juego en el fondo y en la postura, y en este caso si ponemos el retrato del marqués y el de la marquesa juntos uno al lado del otro, podrían adornar perfectamente por ejemplo los dos muros laterales de una puerta (Figs. 1.28 y 1.29), como los que hemos comentado al principio de este capítulo.

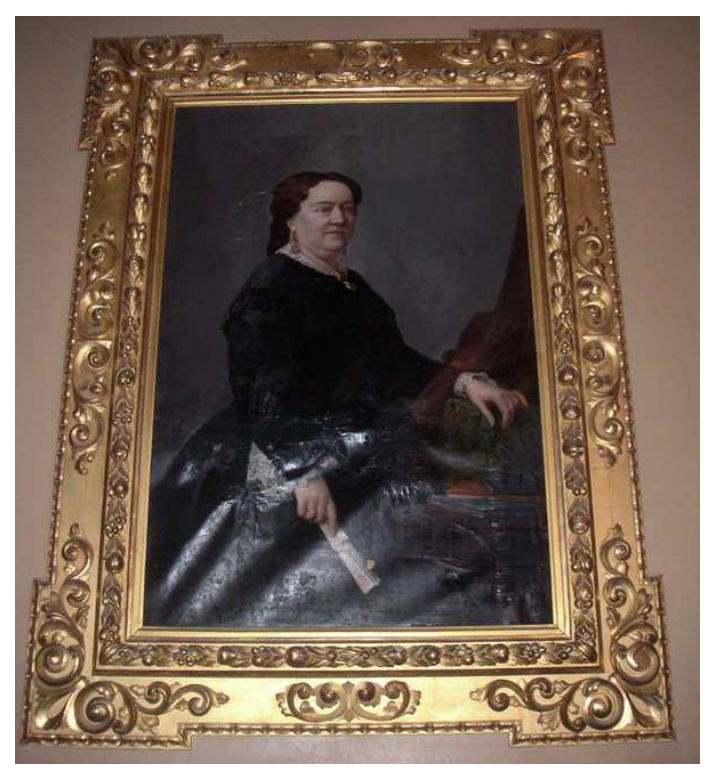

Fig.1.28 La marquesa de Campo. Imagen del Inventario asilo Campo.

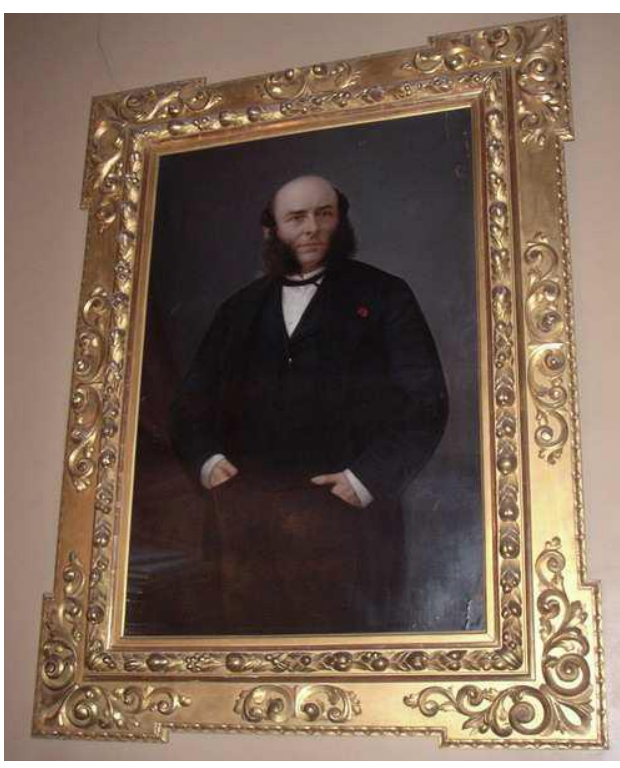

Fig.1.29 El marqués de Campo. Imagen del Inventario Asilo Campo

La marquesa va vestida de negro, posiblemente por el luto perpetuo por la muerte de su hija Josefa. El vestido aparenta ser de seda o de otro rico tejido como moaré por el brillo; es de manga larga con adornos en la unión de la sisa con el cuerpo y encajes en los puños y en el cuello que, por su valor en el mercado, denotan la clase económica y social de la portadora. La marquesa se adorna con pocas joyas, era una mujer más bien austera e interesada más en lo espiritual que en lo material. Lleva unos pendientes de oro en forma de lámpara colgante, que recuerdan los pendientes que ya en el siglo XVIII llevaban las valencianas en sus ricos aderezos de orfebrería. En el centro del escote lleva prendido en el vestido un pequeño broche que puede ser un camafeo por ejemplo o incluso una pequeña 
miniatura del retrato de su hija, dos adornos que estaban muy de moda en la época. En el dedo anular de su mano derecha lleva un anillo de oro muy sencillo también, sin piedras ni brillantes. Aparece sujetando un abanico, éste era un gesto muy común en los retratos de damas y nobles, como artificio para colocar las manos de forma elegante. La marquesa tenía muchos abanicos, de hueso, de marfil, de madreperla, etc., y los países eran escenas románticas o paisajes pintados por artistas del momento. Además, poseía muchos encajes de Chantilly y de Valenciennes en diferentes muebles de sus habitaciones.

Podemos conocerlos gracias al inventario de los bienes de los marqueses realizado a la muerte de Rosalía45, pero desgraciadamente no han llegado hasta nosotros o desconocemos su paradero.

En el cuadro de Benlliure (Fig. 1.18) aparece vestida de negro, con el pelo recogido en lo alto de la cabeza y con más joyas, pero hay que tener en cuenta que no sabemos en qué modelo se basó el pintor para realizar el retrato de la marquesa y además como era una ocasión de celebración, pudo vestirse y llevar joyas algo más recargadas.

Como último apunte de los retratos de Rosalía decir que el rostro de $L a$ Caridad del monumento al marqués de Campo, que realizó Mariano Benlliure, es el de la marquesa por expreso deseo del marqués, que así lo solicitó por carta, pero de esta obra, como ya se ha dicho, se tratará en otro capítulo de esta tesis.

45 AHPM, T36643, fols. 7439 y ss. 
Josefa Campo Rey, hija de José y Rosalía nacida antes del matrimonio, murió en el palacio de Valencia el 7 de marzo de 1852, a los 13 años de edad. Según dice Hernández, "en casa tenía una profesora particular, pero también estuvo interna durante algún tiempo en Las Salesas en Madrid46.

De Josefa sólo conocemos un retrato pintado al óleo. En el retrato la joven aparece de pie (Figs.1.30 y 1.31), como en un interior de una casa, que solía ser un decorado preparado por el pintor, como en todo retrato de aparato, en el que aparece un cortinaje de fondo y una mesa con un jarrón de flores sobre las que la niña reposa su mano derecha. Su cuerpo aparece entero, de pie sobre una alfombra muy decorada, con un ligero escorzo y su mirada se dirige hacia algo lejano. En su mano izquierda lleva un pañuelo de encaje que era una moda del momento y que, como ya hemos dicho, denotaba riqueza por el alto precio que tenían los encajes, sobre todo los de Bélgica y los de Francia; llevar encajes era signo de riqueza en las damas. Josefa lleva un conjunto de ropa azul, hecho a medida por su modista, formado por una falda, una blusa y una chaqueta abrochada; que nos muestra un ejemplo perfecto de la moda de clase alta de la segunda mitad del siglo XIX. Lleva además el sombrero de calle puesto, como si estuviera preparada para salir a dar un paseo. Todo en este retrato refleja la categoría social y económica de José Campo y su familia, pero su felicidad se vio truncada por la temprana muerte de la joven.

Según el inventario de bienes de los marqueses realizado a la muerte de Rosalía Rey, este cuadro estaba colgado de una pared en la sala-dormitorio de la marquesa, situada en el primer piso del palacio de Valencia de la plaza del Arzobispo. El inventario en su folio 7641 dice: 2876- Un retrato de cuerpo entero con marco dorado; la hija del Sr. Marqués47.

${ }^{46}$ MORANT GIMENO, Ana María et al. El marqués de Campo. Empresario, político y coleccionista de obras de arte. Valencia: Ayuntamiento de Valencia, 2015, p. 149.

47 AHPM, T. 3663, fol. 7641. 


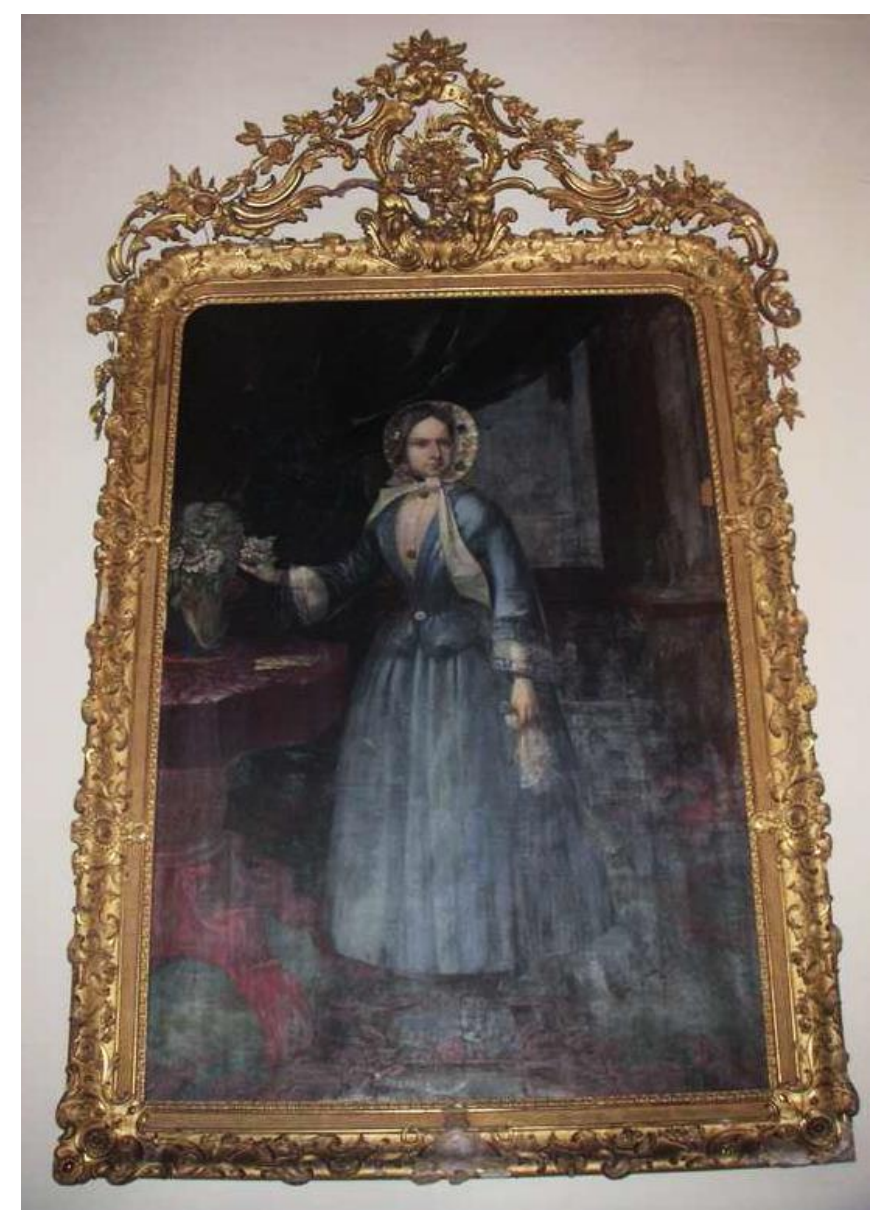

Fig. 1.30 Josefa Campo Rey, hija de los marqueses de Campo. Imagen del Inventario Asilo Campo. Dirección General de Cultura

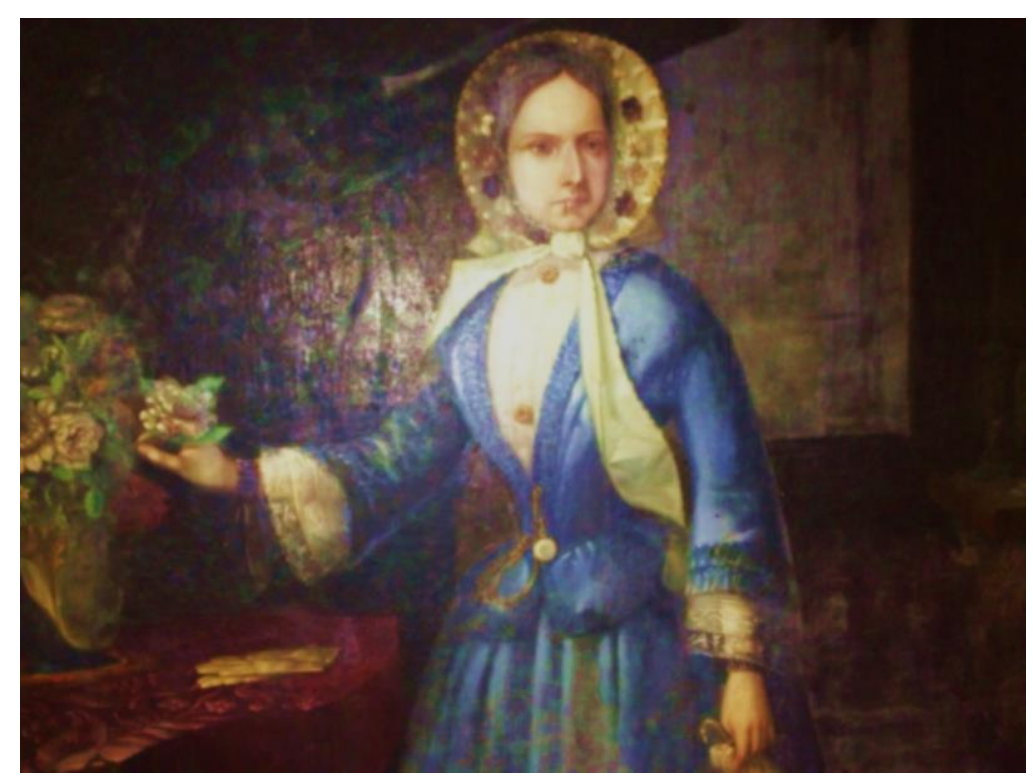

Fig.1.31 Josefa Campo Rey, hija de los marqueses de Campo (detalle). Asilo Campo. Fotografía de la autora. 
Del hijo adoptivo del marqués de Campo tenemos dos retratos (figs. 1.32 y 1.33): uno retrato de aparato en el que parece sentado y erguido en una silla apoyando el codo derecho sobre una mesa. Va vestido a la moda, de seda y terciopelo negro, y con el cabello rizado. Tiene una expresión de orgullo en su rostro y una actitud un poco estirada para ser un niño, pero como era hijo de un marqués pues a lo mejor esa debía ser la actitud de superioridad que debía tener, afianzado su posición social. El otro es el del niño que aparece en el cuadro de José Benlliure (Fig. 1.10) que ya hemos comentado. El niño que acoge por los hombros la marquesa es Luis María, que en esta ocasión aparece vestido de encajes blancos y con una ropa un poco femenina para ser un niño, pero era la moda. Luis María Bruna heredó el título del marqués de Campo a la muerte de su padre mediante autorización de la Casa Real.

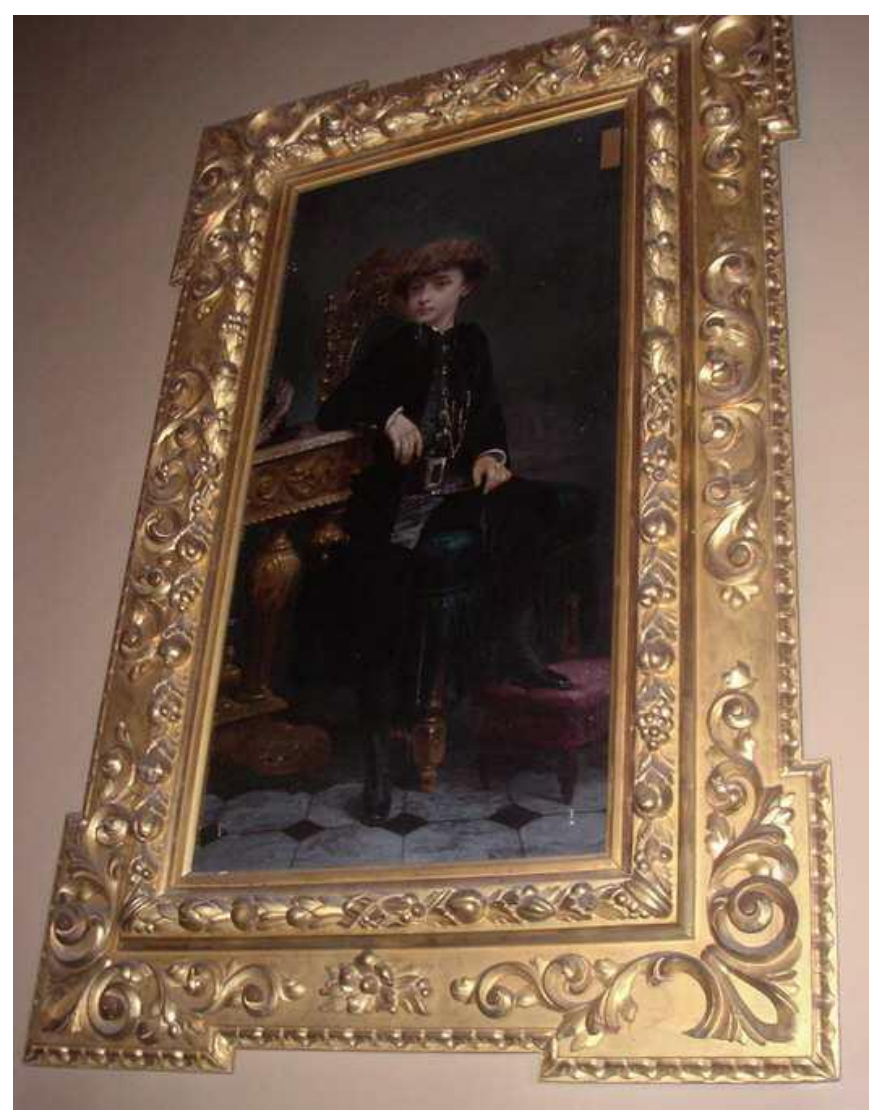

Fig. 1.32 Luis María, hijo adoptivo de los marqueses de Campo. Imagen del Inventario del Asilo Campo. Dirección General de Cultura. 


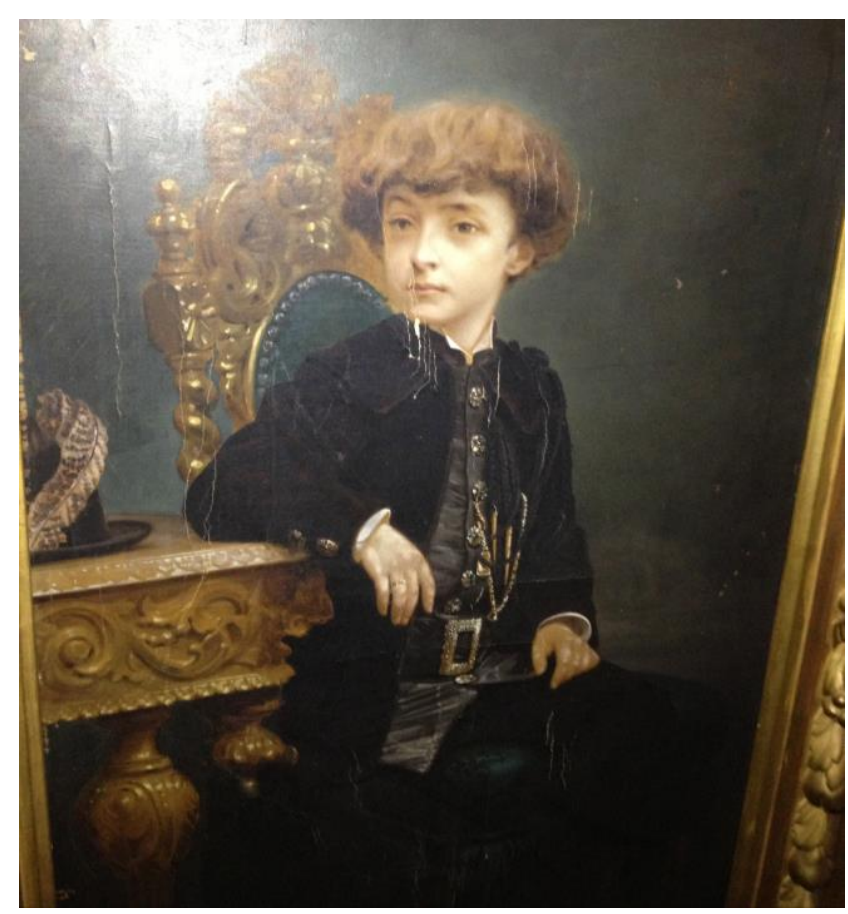

Fig. 1.33 Luis María, hijo adoptivo de los marqueses de Campo (detalle). Imagen del Inventario del Asilo Campo. Dirección General de Cultura

El resto de retratos que se encuentran en el coro de la iglesia del asilo Campo, son de familiares cuyo nombre y autor desconocemos (Fig.1.34, 1.35, 1.36, 1.37 y 1.38) y están en pésimas condiciones de conservación. Las cuatro imágenes son del Inventario del Asilo Campo; realizado por la dirección General de Cultura.

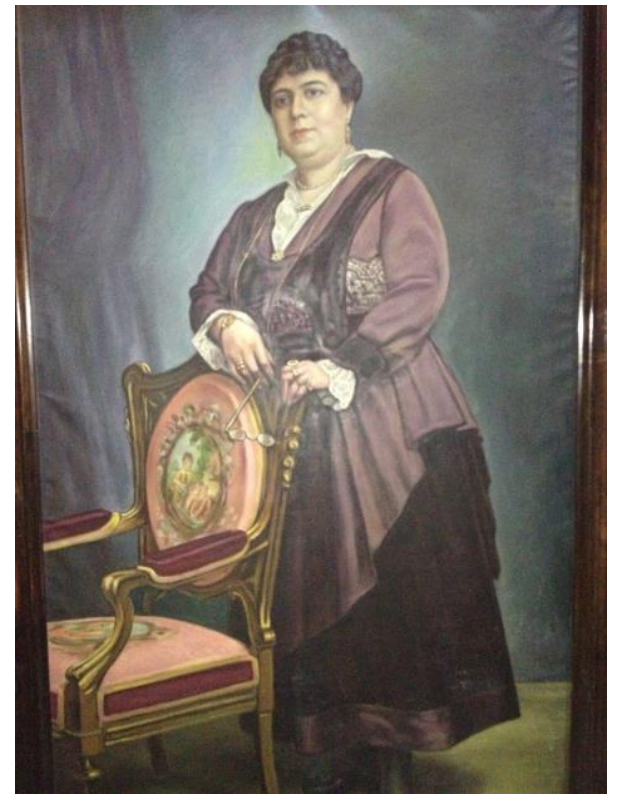

Fig. 1.34 Familiar de José Campo. Fecha y autor desconocido.

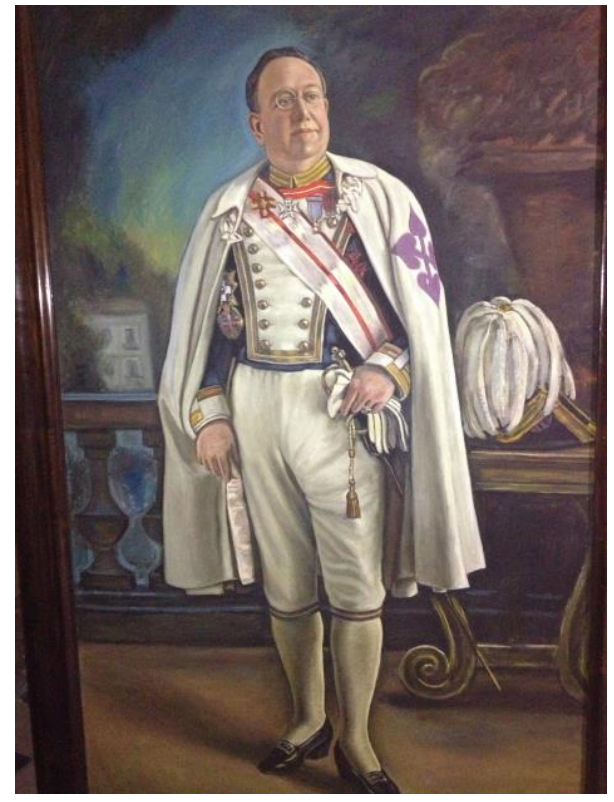

Fig. 1.35 Familiar de José Campo. Fecha y autor desconocido. 


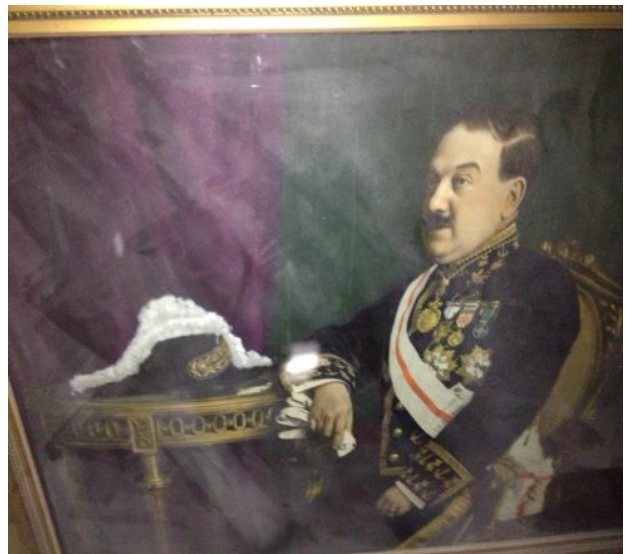

Fig. 1.36 Familiar de José Campo. Fecha y autor desconocido.

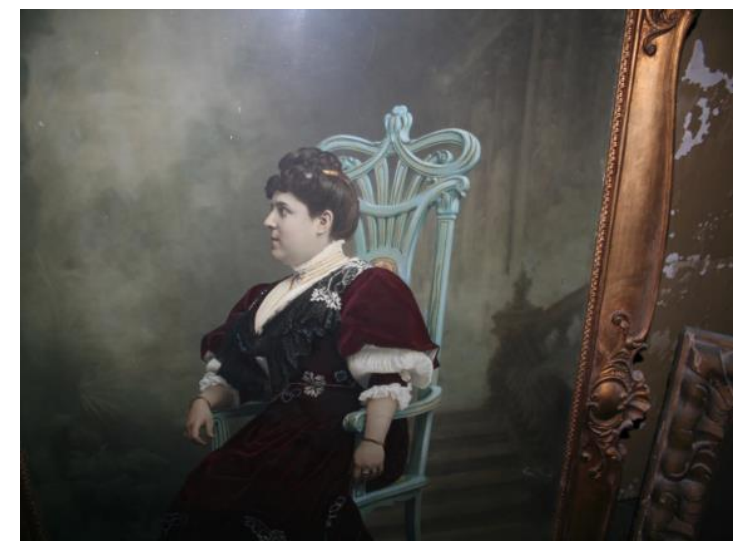

Fig. 1.37 Familiar de José Campo. Fecha y autor desconocido.

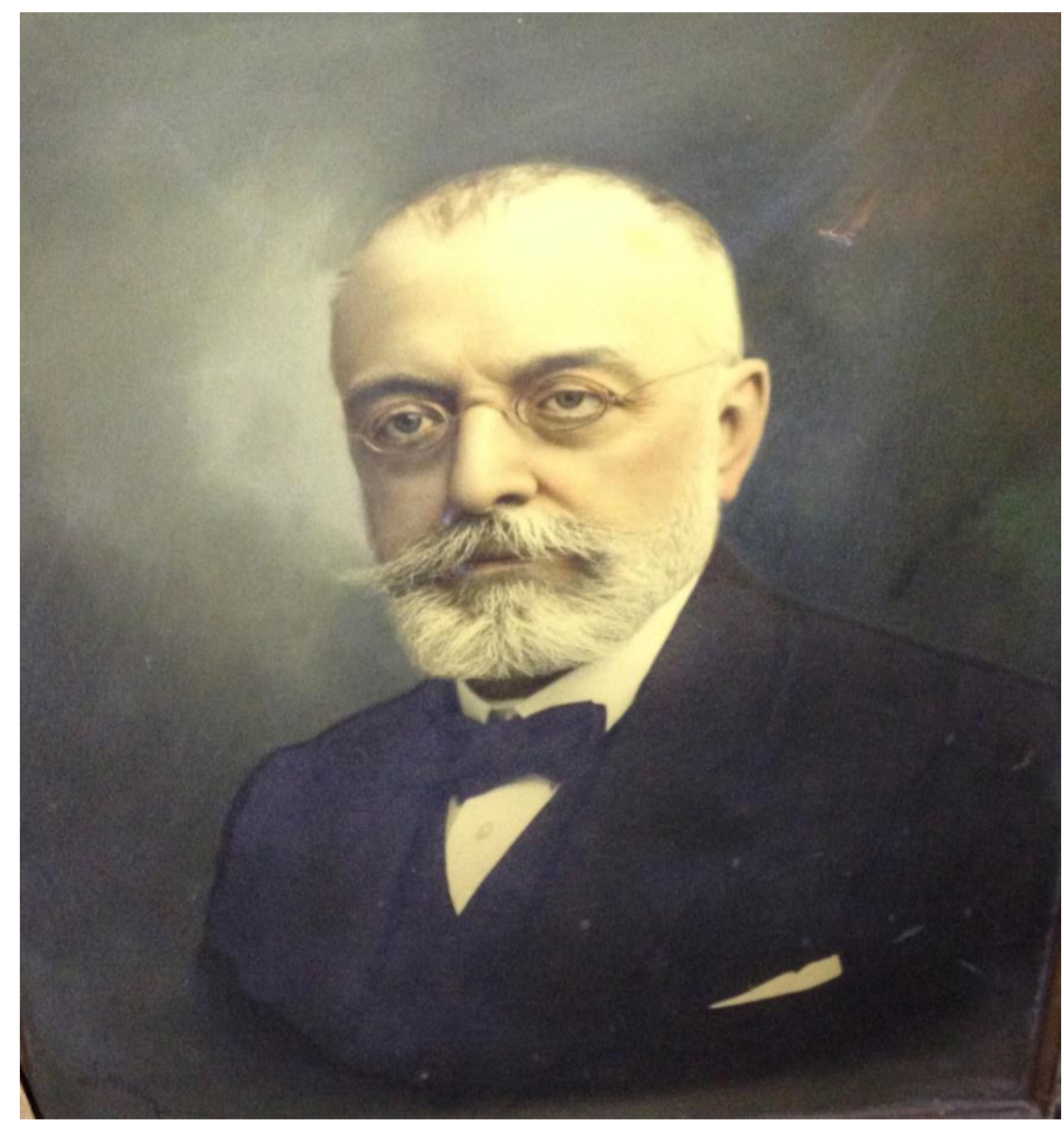

Fig. 1.38 Familiar de José Campo. Fecha y autor desconocido. Imagen del Inventario del Asilo Campo. Dirección General de Cultura 
Por el inventario de los palacios del marqués sabemos que en Valencia en Madrid y en Viñuelas, había muchos retratos de toda la familia decorando las diferentes estancias, tanto fotografías como cuadros, pero lamentablemente sólo nos han llegado los que hemos visto antes y que no son de calidad ni se encuentran en buen estado de conservación. Esta circunstancia es una pena porque ya hemos hablado antes de la importancia de las galerías de retratos de las familias.

Los retratos solían estar agrupados y a veces diferenciados en distintas salas y solían pasar a los herederos; pero en el caso del marqués de Campo, la especial relación con su hijo, por ser adoptivo, y no haber más descendientes, no es comparable con otras familias de la nobleza en las que las generaciones siguientes de descendientes conservan el patrimonio familiar.

Hubiera sido muy gratificante encontrar alguno de esas decenas de retratos del marqués y su familia que decoraban sus residencias, pero con los que hemos recopilado nos hemos podido hacer una idea de su imagen y de lo que quería expresar y transmitir a través de ellos: magnificencia, riqueza y poder. Como dice Inmaculada Rodríguez48: "Los retratos del poder no buscan empatizar con los que los van a contemplar, sino impactarles, e incluso amedrentarles, buscando su admiración y lealtad".

${ }^{48}$ RODRÍGUEZ MOYA, Inmaculada; MÍNGUEZ CORNELLES, Víctor. El retrato del poder. Castellón: Universitat Jaume I, 2019, p. 11. 


\section{Capítulo iI}

LA PROMOCIÓN DE ARQUITECTURA BENÉFICA EN VALENCIA DEL MARQUÉS DE CAMPO
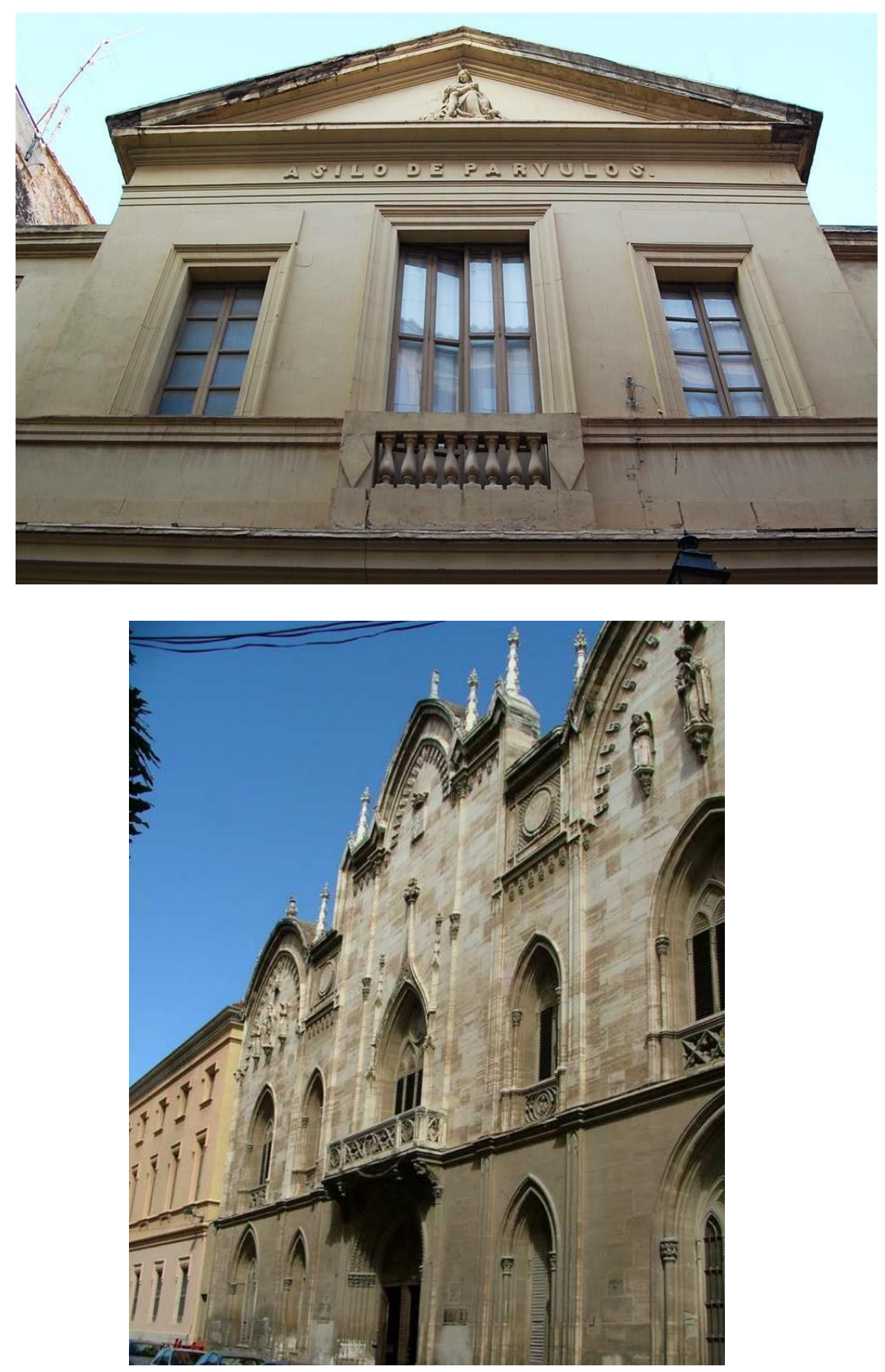



\section{Capítulo iI}

\section{LA PROMOCIÓN DE ARQUITECTURA BENÉFICA EN VALENCIA DEL MARQUÉS DE CAMPO'}

Antes de centrarnos en la construcción de dos asilos por el marqués de Campo, debemos referirnos brevemente a la tradición europea de arquitectura hospitalaria y benéfica, que tiene sus orígenes en un pasado que se remonta al Imperio Romano de Oriente, Siria y Asia menor, donde ya existía una religión cristiana dedicada en parte a establecer centros de peregrinos, albergues o casas de enfermos y que dieron lugar a fundaciones hospitalarias con el paso del tiempo.

Durante la Edad Media aumentaron este tipo de establecimientos benéficos donde se atendía a enfermos, leprosos, que normalmente estaban asociados a monasterios, catedrales, conventos, y que se ubicaban dentro de las ciudades. Dos claros ejemplos muestran la realidad del momento: el Hôtel Dieu de París, que data del 829, y el plano ideal, de 820, de la distribución de los diferentes edificios de la abadía de Saint Gall.

Estas instituciones eran en ocasiones mantenidas por donaciones o legados de la caridad cristiana, y también las ordenes militares, como la de San Juan de Jerusalén u Hospitalarios, fundaron hospitales como por ejemplo el de Acre y el de Jerusalén.

\footnotetext{
${ }^{1}$ Parte de este capítulo formó parte de una comunicación presentada en el congreso del CEHA de 2012, las artes y la arquitectura del poder, celebrado en la Universidad Jaime I de Castellón.

MORANT GIMENO, Ana María. "La arquitectura benéfica privada valenciana del siglo XIX como muestra del poder burgués". En: Actas del Congreso Nacional del CEHA 2012. Castellón: Universidad Jaime I, 2012, pp. 545-560.
} 
Según dice Clavijo Hernández, “Todas estas fundaciones hospitalarias fueron respaldadas por personajes nobles de la sociedad del momento, así como ciudades o villas, e incluso congregaciones religiosas, movidos por una mentalidad donde primaba la caridad en Cristo"2.

En Valencia el primer hospital fue fundado en 1409 por iniciativa del padre Jofré para proteger a los locos e inocentes que iban por las calles de la ciudad mendigando.

Los siglos pasan, pero esta tradición no deja de existir y se fundan a lo largo de Europa muchos establecimientos de beneficencia y hospitalidad para paliar las malas condiciones de vida de los más desfavorecidos. Ejemplo de estos hospitales son por ejemplo Hôtel Dieu de París, compuesto por cuatro grandes salas de dos naves, el Hospital de Santa María Nuova de Florencia fundado en 1286, el Ospedale Maggiore de Milán o el Hospital de los Inválidos de París, obra proyectada por Brunt en 1670. Y en cada uno de ellos se va perfilando el modelo arquitectónico que prevalecerá: la forma de cruz y salas radiales, que dan cabida a más enfermos y facilitan la comunicación y los cuidados.

Una vez entramos en el siglo XIX, se produce un aumento de la preocupación por la higiene y la salud de los ciudadanos y eso conlleva la creación de nuevos establecimientos hospitalarios y benéficos que, en ocasiones siguen estando a cargo de las instituciones religiosas pero que a veces son una iniciativa privada guiada y provocada por motivos personales como la muerte de un hijo por una enfermedad o por alguna otra desgracia familiar; sin olvidar, claro está, el papel filántropo que adquiere el donante, que le vale de propaganda y para escalar puestos en la fama social.

\footnotetext{
${ }^{2}$ HERNÁNDEZ CLAVIJO, F. El Hospital de San Salvador de Sevilla en el siglo XV. En: III Coloquio de Historia Medieval Andaluza. Jaén, 1982, pp. 78-83.
} 
A mediados del siglo XIX la situación económica de los trabajadores en Valencia era muy dura, la mayor parte de la población estaba en una situación miserable, y las malas condiciones higiénicas hacían que la ciudad estuviera llena de pobres y gente pedigüeña. Lo explica perfectamente José Luis Barona cuando habla de que las familias lo tenían muy complicado para poder subsistir dignamente; los varones de mediana edad trabajadores se veían amenazados continuamente por los accidentes laborales, las enfermedades y la muerte prematura; los niños y las mujeres no estaban por lo general integrados en el mercado laboral por lo que, si al padre de familia le sucedía algo que le impidiera trabajar, la pobreza era inminente. Por otro lado, las condiciones de vida eran duras, había epidemias de gripe y se padecían enfermedades de gran importancia como la sífilis o la tuberculosis. Para las viudas con hijos a cargo, y las mujeres solteras, la situación era todavía peor y se veían en la miseria y necesitadas de ayuda para poder subsistir y sacar los niños adelante3.

La alimentación tampoco era buena, los alimentos no eran de calidad, y aunque los de primera necesidad no eran caros, eran malos, se vendían en malas condiciones y en algunos casos adulterados, ocasionando enfermedades 4 . De esta asistencia se habían ocupado siempre los asilos relacionados con la iglesia y los de carácter público, llevando a cabo la acogida de niños, mujeres, viudas, ancianos y vagabundos. En esos momentos, esa asistencia se vuelve insuficiente, y gracias a la voluntad de unos cuantos hombres y mujeres adinerados y compasivos, se fundaron otras instituciones de carácter privado que pasaron a engrosar la lista de los establecimientos de beneficencia con que contaba la ciudad de Valencia.

Diversos escritos que tenemos de esas fechas nos corroboran estas condiciones en las que vivía la clase trabajadora.

3 BARONA, Javier. Salud, enfermedad y muerte. La sociedad valenciana entre 1833 y 1939. Valencia: Institució Alfons el Magnànim, 2002, p. 105.

4 BARONA, Javier. 2002, p. 107. 
Según relatan Anacleto Pons y Justo Serna: "la Valencia del ochocientos es una ciudad burguesa pero también una ciudad de pedigüeños, la ciudad de los que piden con insistencia e inoportunidad, la ciudad de los que acosan lastimeramente, la ciudad de los que pordiosean con sus penas y sus pústulas, con sus llagas, sus estigmas y sus úlceras, reales o fingidas. El espectáculo de la miseria y de la enfermedad está en la calle y los vecinos acomodados se apiadan y se protegen, erigen barreras de defensa y acogen al pobre" 5 .

Existen noticias de la situación en que se vivía en la ciudad de Valencia a mediados del XIX como por ejemplo un texto que escribió la Condesa Gasparín, tras visitar la ciudad, y en el que dijo: “¿por qué se mata la gente en Valencia? Quienes conocen a los valencianos dicen que son vagos, malgastadores y reñidores. Pocas semanas transcurren sin que haya un homicidio en la ciudad. El obrero trabaja para recoger unos cuantos reales, y en cuanto los tiene se sienta en cualquier sitio, se fuma un cigarrillo, mira lo que sucede, se va a la taberna, se emborracha, riñe y como está mal alimentado, se acalora y se pelea...Y así sucede que...el valenciano pasea por las calles sus andrajos, exhibe sus miembros enfermos o mutilados, extiende su mano a los transeúntes para pedir y de vez en cuando coge también el cuchillo"6.

Esta situación descrita tan precaria en la que vivía la población trabajadora y sus familias, contrasta con la modernización física que estaba sufriendo la ciudad en esas mismas fechas: se realizó el empedrado de las calles y las aceras, el alumbrado de las vías públicas con farolas de gas, la línea del tranvía del Grao, se creó la línea de ferrocarril Almansa-Valencia-Tarragona, se comenzaron la obras del puerto, se inauguró el teatro Principal y el teatro de la Princesa, y se construyó la plaza Redonda, entre muchas otras mejoras.

5PONS, Anacleto; SERNA, Justo. La ciudad extensa. Valencia: Diputación de Valencia, 1992, p. 473.

${ }^{6}$ SANCHIS GUARNER, Manuel. La ciudad de Valencia: Síntesis de Historia y Geografía Urbana. Valencia: IRTA, 2009, p. 331. 
Pero esas reformas no llegaban a los barrios más pobres, y en realidad la situación y el modo de vida de la población no adinerada era bastante preocupante.

Las familias vivían en casas mal construidas, sin agua potable, sin higiene y sin ventilación suficiente. Como dice José Luis Barona7: el servicio de agua potable empezó a llegar a las zonas más alta de la ciudad a partir de 1890. No todos los niños iban al colegio, y ello hacía que pasaran las horas en la calle, haciendo pillerías, insultando a la gente, pidiendo limosna y convirtiéndose a veces en futuros delincuentes. En los momentos de crisis económica, cuando el trabajo escaseaba, esta situación se agudizaba aún más y por las calles vagabundeaba todo tipo de gente sin recursos, que eran ayudadas en las distintas instituciones de beneficencia a las que me he referido anteriormente.

En Valencia era necesaria una continua y amplia actividad benéfica para ayudar a toda la gente necesitada que no podía subsistir. Como hemos dicho había instituciones públicas ${ }^{8}$, como por ejemplo la Casa de la Misericordia, la Casa de la Beneficencia, estudiada en profundidad por Daniel Benito9, la de los Pobres Desamparados, la Casa de la Caridad, el Asilo de Lactancia para los niños de las trabajadoras de la Tabacalera, etc.

Los burgueses, inmersos en una tradición mediterránea católica que no aprueba el enriquecimiento por contraposición a la permisión de la religión protestante, son conscientes de la situación de precariedad de gran parte de la

\footnotetext{
7 BARONA VILAR, José Luis. 2002, p. 110.

8 PERDIGUERO, Enrique (coord.). SALVAD AL NIÑO. Estudios sobre la protección de la infancia en la Europa mediterránea a comienzos del siglo $X X$. Valencia: Seminario de Estudios sobre la Ciencia, 2004, p. 143.

9 BENITO GOERLICH, Daniel; CERVERA, Ramón. "Ocupa y socorre: La arquitectura benéfica en la Valencia del siglo XIX. La Casa de la Beneficencia”. En: TABERNER, Francisco. "Historia de la ciudad III. Arquitectura y transformación de la ciudad de Valencia”. Valencia: Ayuntamiento de Valencia, Ícaro, Universidad de Valencia y U.P.V., 2003, p. 118-142.
} 
población y aunque la ciudad está modernizándose y mejorando poco a poco no es suficiente y decidieron intervenir en la medida de sus posibilidades.

La aristocracia y la burguesía valenciana crearon desde 1850 hasta 1899 cuatro instituciones de beneficencia privada que fueron, por orden cronológico de creación ${ }^{10}$ :

1) La Gran Asociación de Beneficencia Domiciliaria Nuestra Señora de los Desamparados, creada en 1853 por iniciativa de Vicente Fillol (18081926) y otros nobles de la ciudad.

2) El Asilo de Párvulos creado en 1863 por José Campo (1814-1889) y ampliado después con otro gran asilo en $1882^{11}$.

3) El Asilo de San Juan Bautista, creado en 1868 por iniciativa de Juan Bautista Romero Almenar (1807-1872) y su esposa Mariana Conchés Benet ${ }^{12}$.

4) El Asilo de San Eugenio, creado en 1886 a iniciativa del doctor José Sanchis Bergón (1860-1976) tras una epidemia de cólera en Valencia.

De este modo, dice Barona, tuvo lugar un cambio del modelo asistencial basado en conventos e instituciones religiosas, y la beneficencia, poco a poco se fue secularizando, para acabar respondiendo a los valores y necesidades de una burguesía urbana que se servía de él para dar destino a los excluidos ${ }^{13}$.

${ }^{10}$ MORANT GIMENO, Ana María. "La arquitectura benéfica privada valenciana del siglo XIX como muestra del poder burgués". En: La arquitectura del poder. Actas del Congreso Nacional del CEHA 2012. Castellón: Universidad Jaume I, p. 545-560.

${ }^{11}$ PANIAGUA, Javier. Diccionario biográfico de políticos valencianos 1810-2003. Valencia: Institució Alfons el Magnànim, 2004, p. 125.

12 PANIAGUA, Javier. 2004, p. 479.

${ }^{13}$ BARONA, José Luis. 2002, p. 173. 
Todas estas instituciones, cuyo objetivo era ejercer la caridad en el sentido amplio de la palabra, necesitaban una sede desde donde poder actuar, y dieron lugar a la construcción de unos edificios que cambiaron definitivamente la fisonomía y el aspecto de los lugares en que se erigieron. Era un momento en el que el eclecticismo arquitectónico hacía acto de presencia y los estilos medievales y clásicos se volvían a utilizar junto con innovaciones técnicas como el uso del hierro, que irrumpía con fuerza ${ }^{14}$.

Hoy en día, con el paso de los años y la gran transformación que ha sufrido la ciudad de Valencia y su población, la utilización de esos edificios ha cambiado y se ha eliminado todo rastro de imagen benéfica excepto en uno de ellos. Sólo el primer Asilo de Párvulos de José Campo sigue desarrollado funciones de asistencia benéfica.

Una vez contextualizado el momento en que se producen estas arquitecturas veamos los dos asilos del marqués de Campo.

\footnotetext{
${ }^{14}$ Sobre arquitectura ecléctica véase entre otros: BENITO GOERLICH, Daniel. La arquitectura del eclecticismo en Valencia. Vertientes de la Arquitectura Valenciana entre 1875 y 1925. Valencia: Ayuntamiento de Valencia, 1992.

CHUECA GOITIA, Fernando. Historia de la Arquitectura Occidental. Tomo X: El Eclecticismo. Madrid: Dossat Bolsillo, 1979.
} 


\section{1 - El asilo de párvulos de 1863. Diseñado y construido por el arquitecto municipal Antonio Sancho y el ingeniero inglés Jaime Beatty}

Antes de hablar de la arquitectura y decoración del edificio construido en la calle Beneficencia hay que resaltar que su situación geográfica no fue casual, sino que el edificio construido por Jaime Beatty se situó en un extremo de la ciudad, lejos del centro y por tanto sin provocar molestias a la gente y bien ventilado, como hizo referencia el propio arquitecto en la descripción que realizó del edifico con motivo de su inauguración ${ }^{15}$. En un lugar exento de pozos de putrefacción y lejos de donde las personas acomodadas se dedican a profanos estudios y pudieran ser molestados en los ratos de expansión de los niños del asilo. Estaba regentado por la Hermanas de San Vicente de Paul.

La fachada posterior del edificio daba al huerto de la Casa de la Beneficencia, y la fachada principal recaía sobre la calle del mismo nombre. Las fachadas laterales colindaban una de ellas con un huerto perteneciente a la testamentaria de Vicente Llopis, y sobre la otra se adosarían los edificios que se fueran construyendo.

Respecto a la decoración, James Beatty dijo también que debía comunicar al transeúnte a primera vista para qué estaba destinado y sus menores detalles debían corresponder al mismo fin; la arquitectura debía ser serena y grave, porque grande era el objeto a que estaba destinada: la caridad, uno de los mandatos de la religión cristiana ${ }^{16}$.

\footnotetext{
15 BEATTY, James. “Descripción del Asilo Campo”. En: BOIX, Vicente (coord.). Memoria leída en la inauguración del Asilo de Párvulos de D. José Campo, en el día 19 de noviembre de 1863. Valencia: Imprenta de La Opinión, 1863, p. 22.

16 BEATTY, James. 1963, p. 20.
} 
Entrando ya en la descripción del edificio (Fig. 2.1) diremos que la fachada principal, de estilo clásico academicista, se dividió en tres cuerpos, el principal almohadillado de poco resalte para que no resultase pesado y tres vanos, siendo puerta el del medio y las otras dos ventanas. Los dos cuerpos laterales solo tenían una ventana en el centro y pilastras dóricas colocadas en los ángulos.

Los cuerpos laterales se elevaban hasta la altura del primer piso, dejando su espacio para dos galerías, el del centro seguía elevándose hasta la altura necesaria y en él se abrían otros tres vanos que se correspondían verticalmente con los del cuerpo inferior. El vano del centro era un balcón con un antepecho formado por balaustres de alfarería, las ventanas laterales, algo más estrechas y bajas que el vano del balcón, tenían como decoración unos recuadros encima de ellas y unas molduras que recorrían sus aristas. Todo el edifico lo coronaba una cornisa sobre la que se apoyaba un ático que figuraba la cubierta a dos aguas, y en el hueco del ático se colocó un relieve representativo de la caridad. Por el contrario, las fachadas laterales eran completamente lisas hasta la altura de las galerías, ya que con el tiempo se adosarían otras construcciones, pero a la altura del segundo piso tenía vanos para luz y ventilación. 


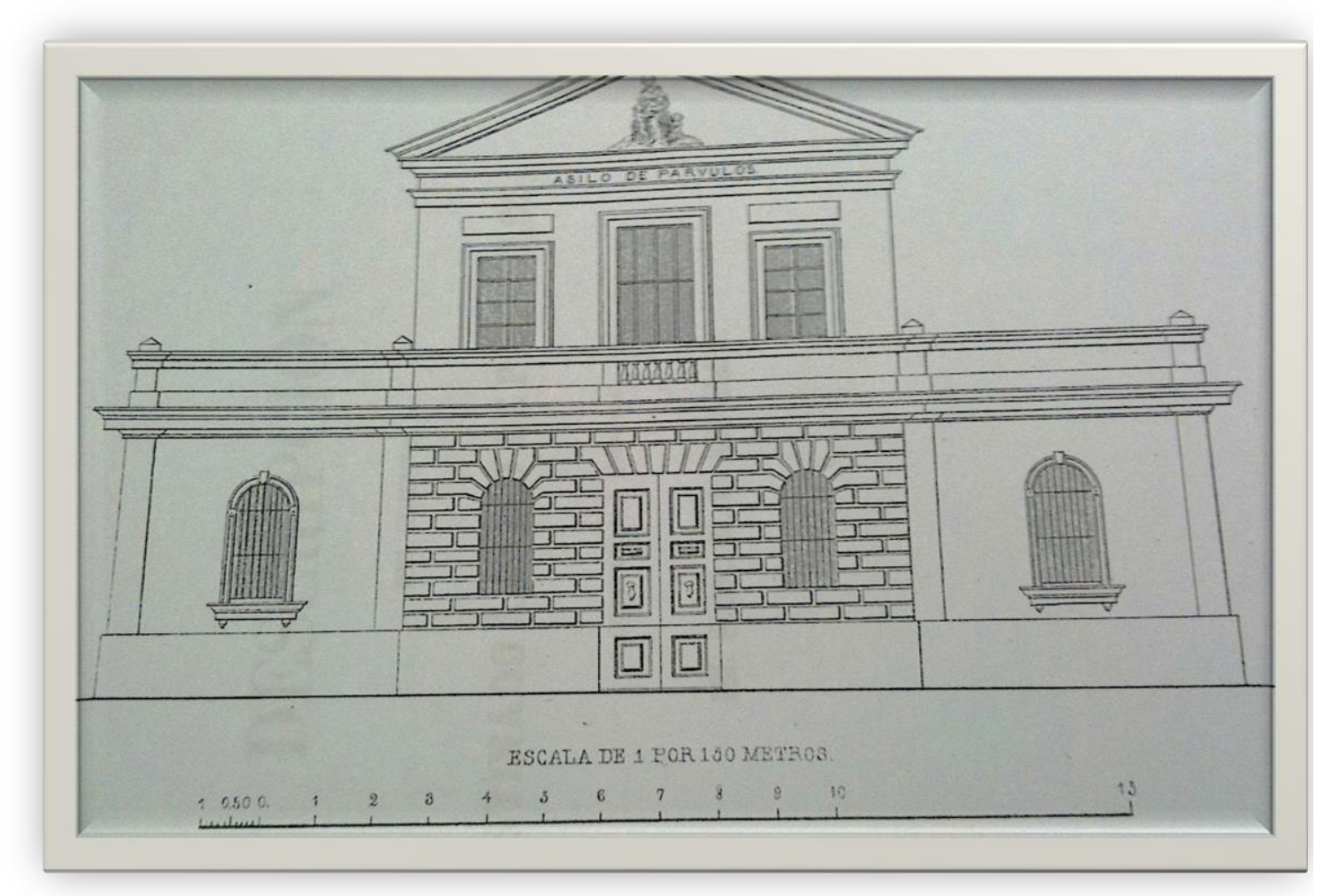

Fig. 2.1 Asilo de párvulos del Marqués de Campo, Jaime Betty. 1863. Valencia.

Cuando se llevó a cabo el diseño del interior del edificio, se tuvo en cuenta todo lo necesario para poder llevar a cabo la función de oración y enseñanza de los párvulos. En la planta baja la puerta de entrada daba paso a un vestíbulo-cocina y despensa, y a uno de los lados estaba el oratorio y la sacristía. Había un comedor de niñas y uno de niños, y entre ambos comedores estaba situada la clase, muy espaciosa y ventilada. A ambos lados de los comedores había sendos grandes deslunados para solaz de los pequeños. Al fondo del edificio estaban los cuartos de baño. Subiendo una escalera se llegaba a la primera planta, donde había un gran recibidor que comunicaba mediante dos puertas dos galerías con claraboyas para dar luz a los comedores de la planta baja. Además, había una habitación para la enfermería, una cocina, el refectorio de las hermanas y un departamento para dormitorio de las mismas. 
$\mathrm{El}$ arquitecto dio al edificio la comodidad y sencillez necesarias a su naturaleza y función, y tuvo presentes para hacerlo las condiciones de toda buena composición, que como él mismo refirió son: proporción entre las partes y el todo, proporción de éstas según el uso a que están destinadas y preferencia y situación de las mismas respecto unas de otras ${ }^{17}$.

Este edificio, que fue inaugurado el 19 de noviembre de 1863, acogió desde sus comienzos a niñas y niños que se habían quedado sin padres, y en poco tiempo el número de asilados fue de 200 niñas y 200 niños, lo que hizo necesario su ampliación mediante la construcción de otro asilo.

El primitivo Asilo de Párvulos de la calle Beneficencia, ha seguido cumpliendo las funciones de ayuda a los más desfavorecidos. Actualmente está regentado por la Asociación Internacional de la Caridad, y las Hermanas de la Caridad de San Vicente de Paul. El edificio se mantiene tal y como estaba, sólo se han realizado las mínimas obras de restauración por daños derivados del paso del tiempo como: la pintura, el cambio de alguna ventana y la modificación de algunas habitaciones en el piso superior.

${ }^{17}$ BEATTY, James. 1963, p. 22. 


\section{2.- El asilo de la calle Corona de 1882. Arquitecto José Camaña Laymon (1850-1896)}

José Camaña Laymón era hijo de José Zacarías Camaña Burcet, arquitecto que realizó, entre otras muchas obras, la conducción del agua potable para la cuidad, construyó el teatro Princesa 1853 y terminó la fachada del Teatro Principal en 1854.

Este segundo asilo se construyó en 1882 también a expensas de José Campo, quien mandó construir lo que se calificó como un "palacio para la desgracia y la pobreza"18, y para ello tuvo que adquirir los terrenos colindantes, que en realidad eran un espacio de la mancebía medieval que se conocía como el huerto de Cameta llamado así porque en ese huerto se cultivaba un hongo llamado "Cameta de perdiu” (pata de perdiz).

La licencia para la reforma y ampliación del Asilo de Párvulos se solicitó el 17 de enero de 1881 al Ayuntamiento de Valencia, Sección de Policía Urbana ${ }^{19}$. En la petición se presentó un diseño de las fachadas principal y lateral y se determinaban las líneas de fachadas y los rasantes de niveles. Dicha petición fue revisada por el arquitecto municipal concediéndose la licencia a los pocos días. Cuando se finalizó la construcción del asilo, se comunicó al mismo organismo que se habían tomado de la vía pública 13’16 metros y por otro lado habían cedido a la vía pública 2’20 metros, por lo que se realizó la compensación necesaria y se pagaron las tasas correspondientes.

\footnotetext{
${ }^{18}$ ANÓNIMO, Biografía y descripción del prestigioso Asilo del Excmo. Señor Marqués de Campo. Madrid: Imprenta de Juan Iniesta y Lorenzo, 1888, p. 86.

${ }_{19}$ Archivo Histórico Municipal de Valencia, Sección Policía Urbana 1881, exp. 84. 
El edificio fue proyectado por el arquitecto José Camaña Laymón (18501926) ${ }^{20}$. Éste presentó a José Campos un primer proyecto de edificio de estilo neoclásico basado en parte en el anterior Asilo de Párvulos de Beatty, y sobre todo basado en el modelo del recién inaugurado Asilo de San Juan Bautista, fundado por los marqueses de Romero y que estaba muy próximo. Pero José Campo no lo admitió y le hizo cambiarlo por otro de estilo neogótico, por entender el marqués que el estilo medieval era más indicado para los edificios de carácter caritativo y religioso como su asilo, donde además de comida e instrucción se les daba a los pequeños una sólida formación religiosa ${ }^{21}$.

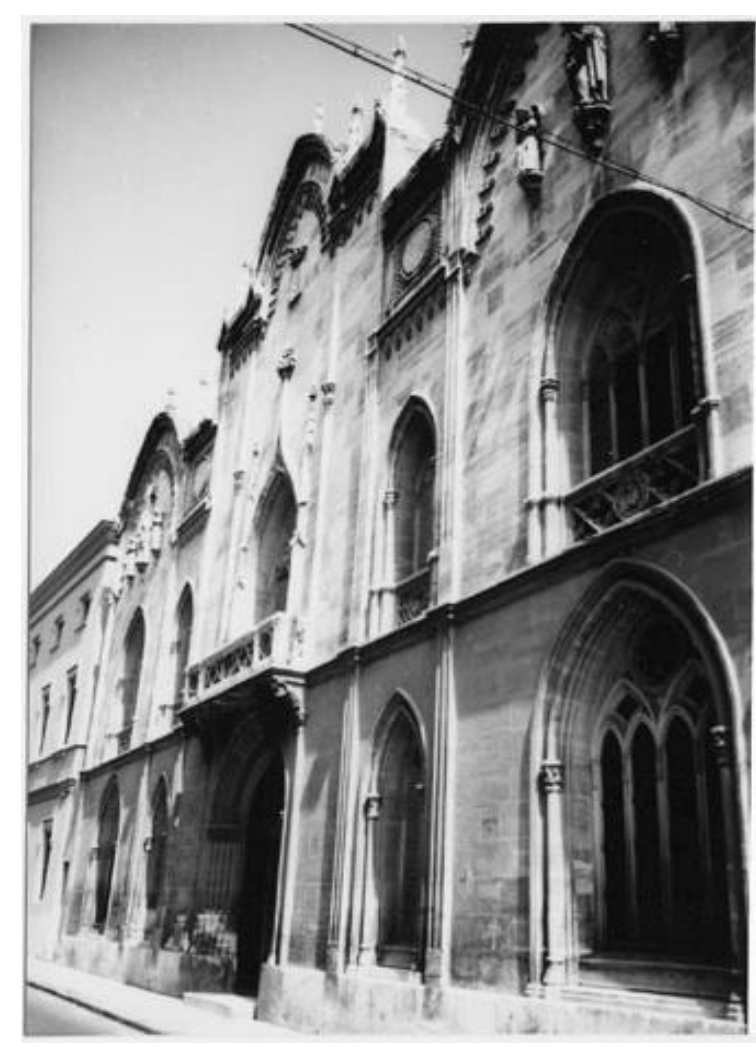

Fig. 2.2 Asilo Marqués de Campo. 1888. Fachada principal. Valencia

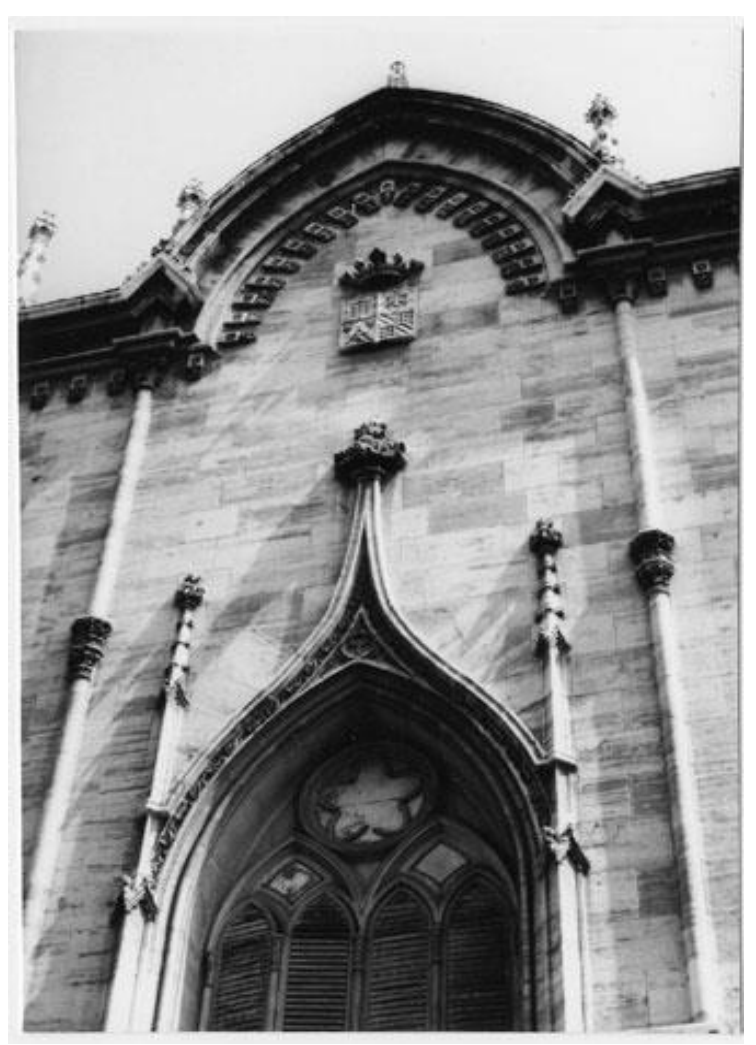

Fig. 2.3 Asilo Marqués de Campo. 1888. Fachada principal (detalle). Valencia.

${ }^{20}$ DELICADO, Francisco Javier. "Historicismo y Racionalismo en la Arquitectura de José Camaña Laymón (1850-1926)”. Archivo de Arte Valenciano, 1991, n. ${ }^{\circ}$ 72, p. 8898.

${ }^{21}$ BENITO GOERLICH, Daniel. La arquitectura del eclecticismo en Valencia. Vertientes de la Arquitectura Valencia entre 1875 y 1925. Valencia: Ayuntamiento de Valencia, 1992, p. 37. 
En opinión de Martínez Aloy: "el alarife don José Camaña trazó un proyecto de exquisito gusto y moderna inspiración...Efectivamente fue rechazado el proyecto y su autor, impelido mal de su grado, por la corriente, hubo de recurrir al arte antiguo. Bien es verdad que, mediante un buen estudio del resurgimiento gótico alemán, con atrevimientos de construcción y sentido estético, logró levantar el monumental y soberbio edificio que sorprende agradablemente a todo aquel que transita por la calle de la Corona”22.

Así pues, José Camaña cambió el proyecto según el gusto de su patrono y construyó un edificio de estilo neogótico²3, con una fachada de 30 metros sobre la calle de la corona y otra de 31 metros sobre la calle de la Beneficencia. "Con piedra de sillería de las canteras de Alcudia y labrada y unida con verdadero arte. ¿Quién se acuerda del dinero existiendo miles de dolores y de lágrimas? Responda por nosotros el Sr. Marqués de Campo con su asilo de Valencia, valorado en algunos millones" 24 .

En el centro de la fachada principal (Figs. 2.2 y 2.3) ${ }^{25}$ está la entrada constituida por un gran arco ojival, adornado por molduras que sostiene pilastras cuyas basas y capiteles dan un carácter de gusto gótico al edificio. Sobre la puerta del edificio descansa un gigantesco balcón con fajas de piedra, en cuyo centro se destaca en bajo relieve la preciosa imagen de la Pureza de la Virgen, titular del templo interior.

${ }^{22}$ MARTÍNEZ ALOY, Javier. "Provincia de Valencia”. En: CARRERAS Y CANDÍ (dir.). Geografía General del Reino de Valencia. Barcelona: Alberto Martín, 1918, p. 583. ${ }^{23}$ MARTÍNEZ ALOY, Javier. 1918, p. 583.

${ }^{24}$ ANÓNIMO. Biografía y descripción del prestigioso Asilo del Excmo. Señor Marqués de Campo. Madrid: Imprenta de Juan Iniesta y Lorenzo, 1888, p. 87.

${ }^{25}$ Las imágenes 2.2, 2.3, 2.4, 2.5, 2.6 y 2.9, pertenecen al Inventario del Asilo Campo. Dirección General de Cultura. Inventario de bienes patrimoniales de la Comunidad Valenciana. 
En lo alto de la fachada se ven las armas heráldicas del marqués de Campo, (Fig. 2.4) y a los lados, en alto relieve las figuras de San José (Fig. 2.5) y de Santa Rosalía de Palermo, que son los nombres de los santos del fundador y su esposa. Estas figuras son obra del escultor valenciano Damián Pastor y Micó (1845-1904) de estilo neoclásico que destacó siempre por la talla de cabezas.

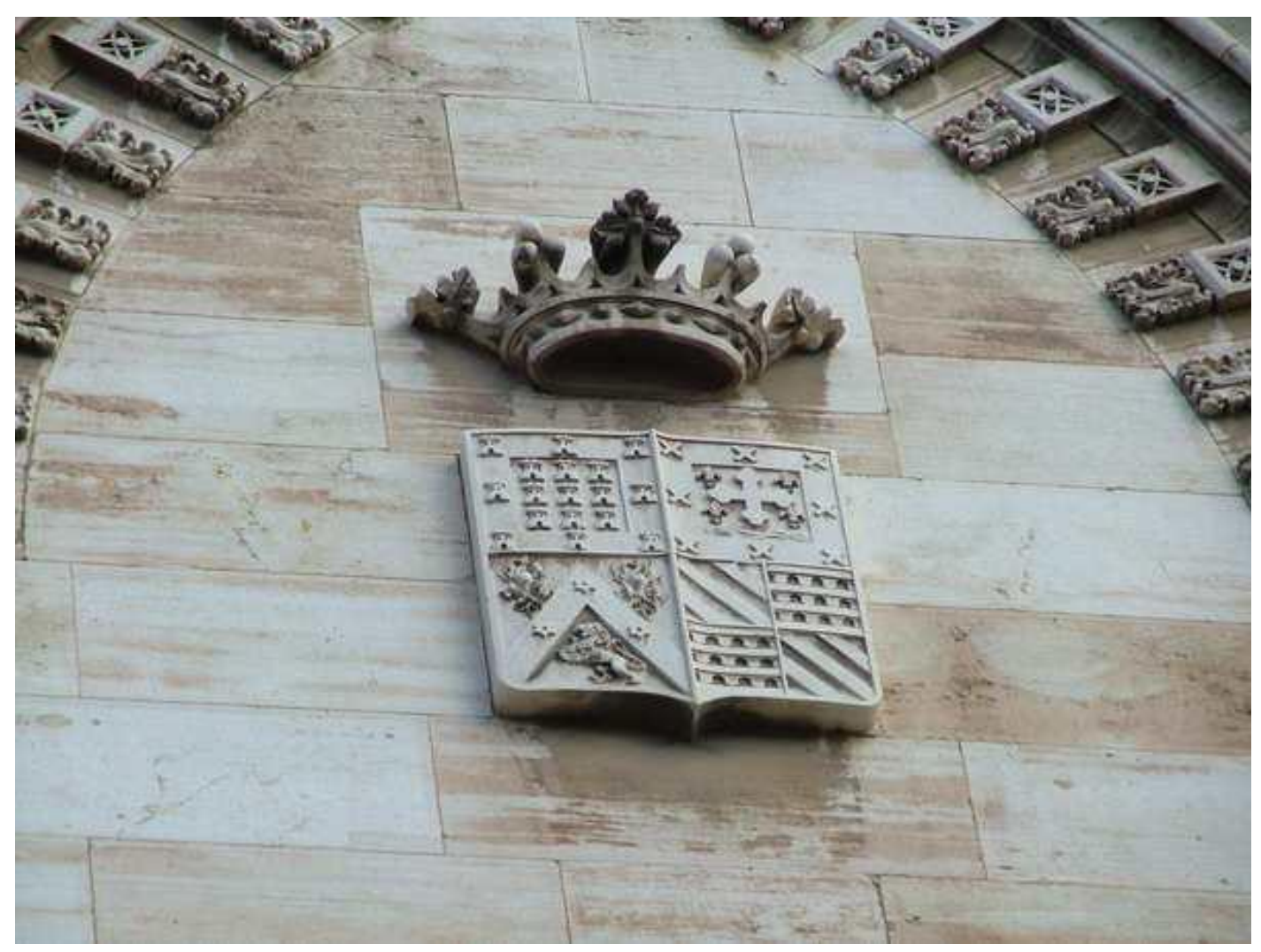

Fig. 2.4 Asilo Campo. Detalle. Escudo de armas del marqués de Campo 


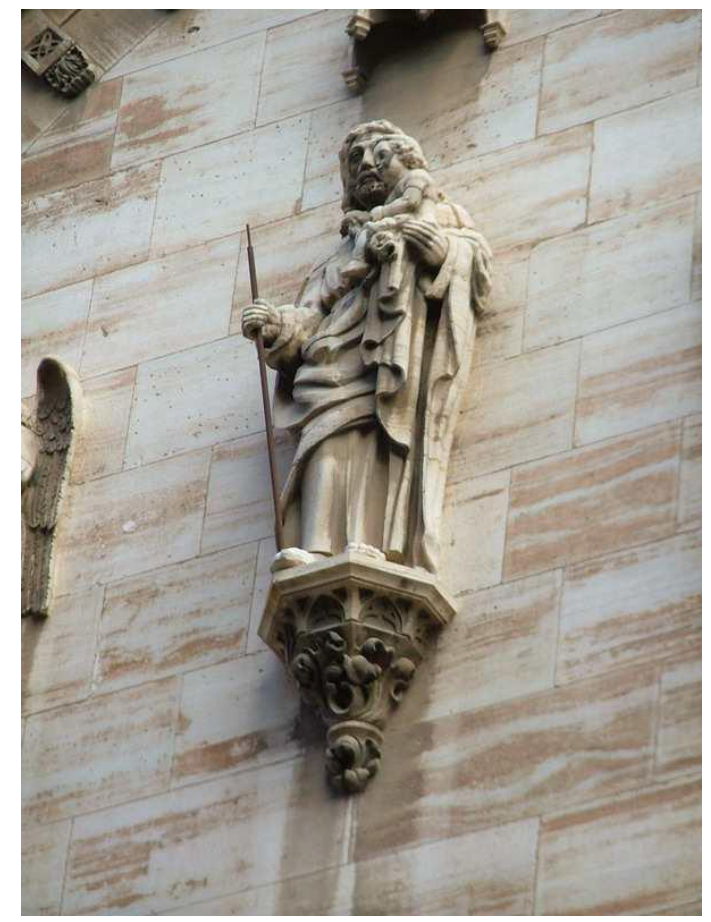

Fig. 2.5 Asilo Campo.

Detalle de la fachada. San José

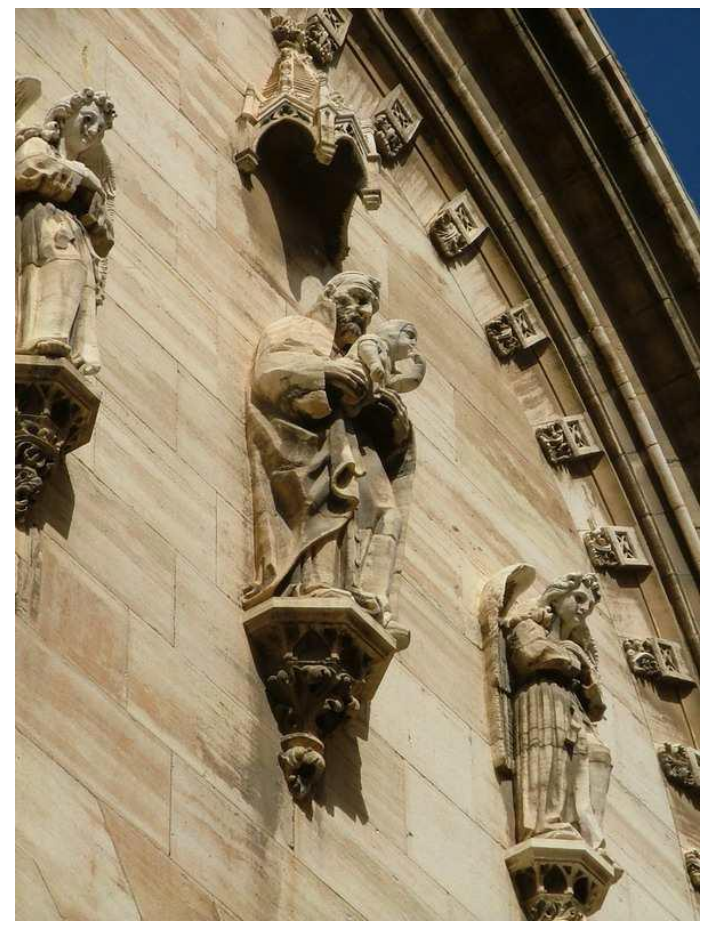

Fig. 2.6 Asilo Campo. Detalle de la fachada. San Vicente de Paul.

Ojivas y simétricas ventanas de puertas caladas, bordan la fachada principal, notándose en todo lo alto y próximo a la esquina de aquella un san Vicente de Paul (Fig. 2.6) de alto relieve, que armoniza el más perfecto conjunto, envuelto todo él entre tallados y labores que acusan la inteligencia de José Camaña ${ }^{26}$.

El asilo estaba separado del antiguo Asilo de Párvulos de la calle Beneficencia, construido en 1863, por un patio rectangular de 30 metros de largo por 21 metros de ancho, encerrado por un claustro de columnas y arcos de hierro fundido, obra del industrial Vicente Ríos.

${ }^{26}$ ANÓNIMO. Biografía y descripción del prestigioso Asilo del Excmo. Señor Marqués de Campo. Madrid: Imprenta de Juan Iniesta y Lorenzo, 1888, p. 91. 
La obra nueva estaba formada en su interior por un rectángulo y un claustro. En el centro del rectángulo, existía un vestíbulo que daba a la entrada a la capilla. A los laterales salas espaciosas para las escuelas y la escalera principal, que era de mármol.

El pavimento de todo el asilo era de tupido y rico mármol blanco y negro traído de Italia. Existían cocinas y refectorios, un gran patio a modo de claustro y varias dependencias más. Sobre el vestíbulo y en derredor de la capilla se situó un magnifico salón para juntas, embaldosado en mármol, y en el segundo piso había preciosas habitaciones para las niñas internas. "Lujo en las puertas, los herrajes, el pavimento, los utensilios, hornillas, mesas y bancos de jaspe en la cocina y comedor, por todas partes comodidades para el pobre proporcionadas por el rico" 27.

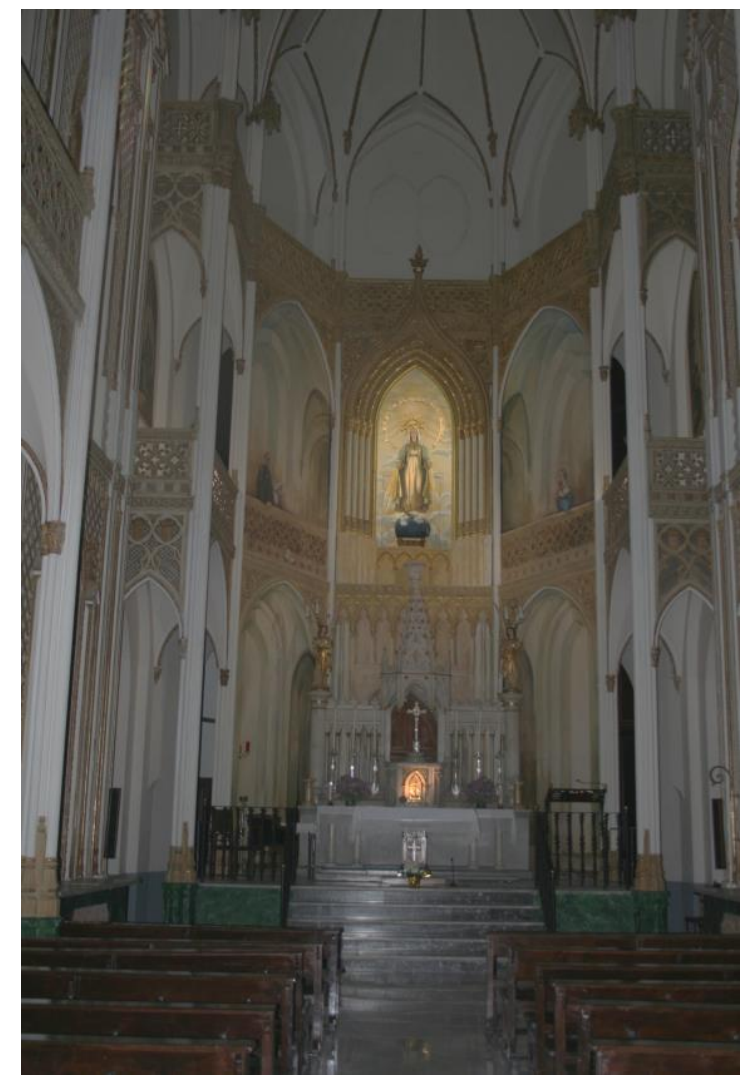

Fig. 2.7 Capilla del Asilo Marqués de Campo. Vista actual.

Fotografía de la autora

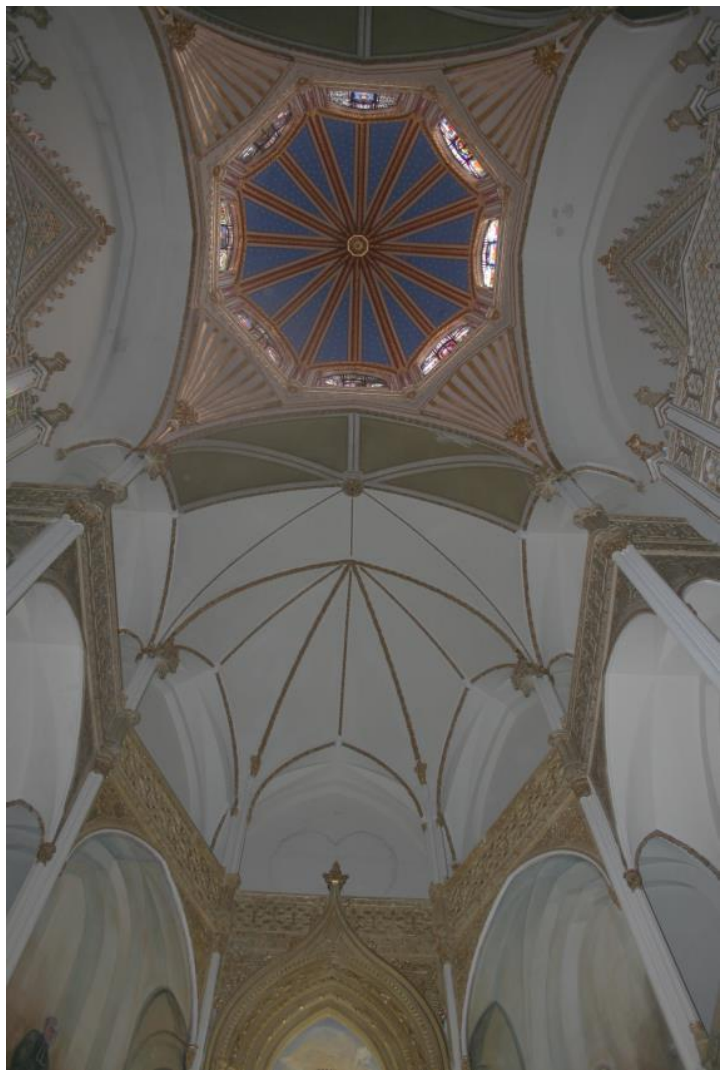

Fig. 2.8 Capilla del Asilo Marqués de Campo. Vista actual.

Fotografía de la autora

${ }^{27}$ ANÓNIMO. Biografía y descripción del prestigioso Asilo del Excmo. Señor Marqués de Campo. Madrid: Imprenta de Juan Iniesta y Lorenzo, 1888, p. 96. 
La capilla, que hoy en día sigue existiendo, era la pieza más importante del asilo, suntuosa, elegante y atrevida, en un estilo "gótico alemán moderno"28. Las obras fueron bendecidas por el Sr. Arzobispo de Valencia el 12 de junio de 1882, y el 14 de octubre de 1884 se celebró la primera misa con asistencia de los marqueses y autoridades de Valencia 29.

En palabras del orador anónimo de un discurso de 1888 conmemorando el sexto aniversario del nuevo asilo se dice: “...la capilla enorgullecería a un monarca pero sublimiza al huérfano"3o.

La capilla está colocada en el centro rectangular anterior del edificio, semejaba que Dios presidía el pequeño mundo de los niños del asilo. La capilla, de forma rectangular pero muy elongada en relación a la poca anchura que tiene, tiene tres naves (Figs. 2.7 y 2.8) y en toda ella está muy presente la utilización del hierro tanto en su estructura como en su decoración. Las naves se sustentan en columnas góticas, con estructura de hierro, de 14 metros de altura por 15 centímetros de diámetro, en cuyas repisas se colocaron los doce santos del apostolado, todos de hierro fundido y casi a tamaño natural, obra de Luis Gilabert (1848-1930), Antonio Yerro, José Aixa (1840-1920), Bondía, Manuel Chambó (1848-..) y Vicente Pellicer (actualmente desaparecidas).

Los pisos en que se apoyan las columnas forman en el presbiterio y en el resto de la capilla, exceptuando el crucero, dos cuerpos de preciosas tribunas cuajadas de tallados y calados con un coro saliente en el testero principal y otro más interior en el segundo piso, para la asistencia a los oficios de las hermanas

${ }^{28}$ ANÓNIMO. Biografía y descripción del prestigioso Asilo del Excmo. Señor Marqués de Campo. Madrid: Imprenta de Juan Iniesta y Lorenzo,1888, p. 97.

29 ANDRÉS, D. "El asilo de los marqueses de Campo". En: Almanaque de Las provincias 1885, Valencia: 1886, p. 104.

3o ANDRÉS, D. "El asilo de los marqueses de Campo". En: Almanaque de Las provincias 1885. Valencia: 1886, p. 99-100. 
de la Caridad, los asilados y la colocación de los demás invitados. Al presbiterio se accede por una escalera de mármol.

La bóveda que cubre las naves es sencilla, correcta y elegante; y la alta cúpula o ábside recibe por sus ventanas la luz, a través de vidrieras de colores, obra de Juan Mártires, armonizando lo bello y lo severo de la decoración.

El retablo del altar (Fig. 2.9) era un rico conjunto de dibujos y molduras, en forma de un gran libro del más primoroso y florido gótico, y coronado por triángulos del estilo ojival, que contenía una imagen de la titular de la capilla, una Inmaculada Concepción, obra de Gilabert, cubierta por una cortina de seda azul con la corona y el nombre de María bordado en realce, obra de Felipe y Mariano Garín. (en la actualidad alberga una imagen de la Virgen Milagrosa, advocación de la capilla).

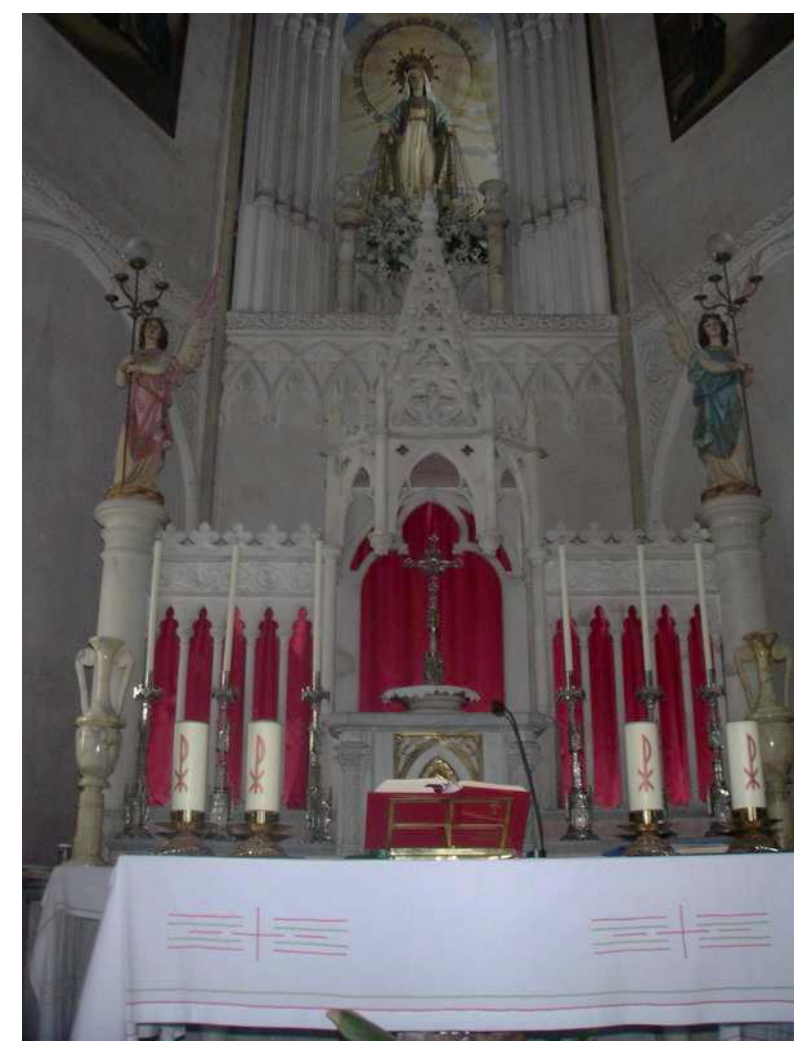

Fig. 2.9 Altar de alabastro de la capilla del asilo Campo. Imagen del Inventario del Asilo Campo. 
Columnas, balaustradas, arcos, doseles, minaretes y todos los primores del arte gótico con sus calados, tallados, molduraje y modelado fueron fundidos por Vicente Ríos. Dentro de la capilla, que era de formas góticas para no romper la armonía del conjunto, había un altar reservado para la familia del fundador, con candelabros, viril, cruz, sacras y todo el servicio de altar de plata labrada. Como luego veremos en otro capítulo algunos de estos objetos fueron expuestos por José Campo en la Exposición Universal de Barcelona de 1888.

El linaje del marqués exigía un lugar de enterramiento apropiado y por ello bajo el presbiterio se construyó una cripta a la que se accedía por dos escaleras de mármol, que albergaba un panteón lo suficientemente grande para enterrar a toda la familia. El cuerpo del marqués fue enterrado allí tras ser trasladado desde Madrid, donde murió en 1889, pero tras el saqueo sufrido en la Guerra Civil, sus restos fueron trasladados al cementerio de Valencia, y hoy en día se encuentran enterrados en un panteón situado a uno de los lados de la iglesia del propio cementerio, que también contribuyó a construir el marqués.

Su primera esposa Rosalía también fue enterrada en la cripta en enero de 1889. Podríamos pensar que la contribución económica a la construcción del cementerio reflejaría el deseo de tener como última morada un lugar cerca de un templo, cerca de las oraciones y donde se conserve el recuerdo de él mismo y de su familia; pero en este caso no fue así porque cuando contribuyó a la construcción del cementerio y su iglesia, no podía saber que sus restos no descansarían en la cripta de su querido asilo.

Acorde con el interés del marqués de ayudar a los artistas de su tierra, todos los artífices de la obra fueron valencianos ${ }^{31}$. La fundición de hierro estuvo

\footnotetext{
${ }^{31}$ ANDRÉS, D. "El asilo de los marqueses de Campo". En: Almanaque de Las Provincias 1885. Valencia: 1886, p. 110. 
a cargo de Vicente Ríos. La talla en alabastro a cargo de Golanich ${ }^{2}$. La carpintería fue obra de Laguarda. La talla en madera obra de Salarich33. La cerrajería corrió a cargo de Rafael Valero. Las vidrieras de colores y cristales a cargo de Juan Mártires. Los mármoles fueron de la fábrica de la Viuda de Germán Larruy. La cristalería de Vicente Lleó. Los aparatos de gas fueron fabricados por el industrial José Ferrándiz, y el terno bordado a relieve en oro corrió a cargo de Felipe y Mariano Garín. Usando el genio artístico y la verdad en la copia arquitectónica, el asilo se realizó en el difícil y primoroso estilo ojival y gótico. Todos estos datos los hemos podido conocer gracias a la descripción que se realizó del asilo en la obra anónima de 188834.

En agradecimiento por las obras del asilo, José Campo le regaló al arquitecto José Camaña un cuadro de San Dionisio, pintado por Jerónimo Jacinto de Espinosa, que será analizado en otro capítulo de esta tesis.

Este asilo de la calle de la Corona hoy es una de las sedes de la Universidad Católica de Valencia, San Vicente Ferrer, y ha sido objeto de una restauración integral para poder convertirlo en un centro universitario; el interior está toralmente irreconocible, salvo por la existencia de la capilla, y en el exterior se han utilizado criterios estilísticos que han conseguido que el edificio aparezca como nuevo.

32 Si bien el Sr. Golanich aparece como autor de la talla de alabastro en el libro anónimo de 1888; en el Almanaque de las Provincias de 1885 se dice que el autor de la talla en alabastro es el Sr. Puig y Plá, p. 108

33 ANDRÉS, D., "El asilo de los marqueses de Campo". En: Almanaque de Las Provincias 1885. Valencia: 1886, p. 108.

34 ANÓNIMO. Biografía y descripción del prestigioso Asilo del Excmo. Señor Marqués de Campo. Madrid: Imprenta de Juan Iniesta y Lorenzo, 1888. 



\section{Capítulo iII}

OTROS EJEMPLOS DE LA PROMOCIÓN ARQUITECTÓNICA DEL MARQUÉS DE CAMPO: SUS RESIDENCIAS
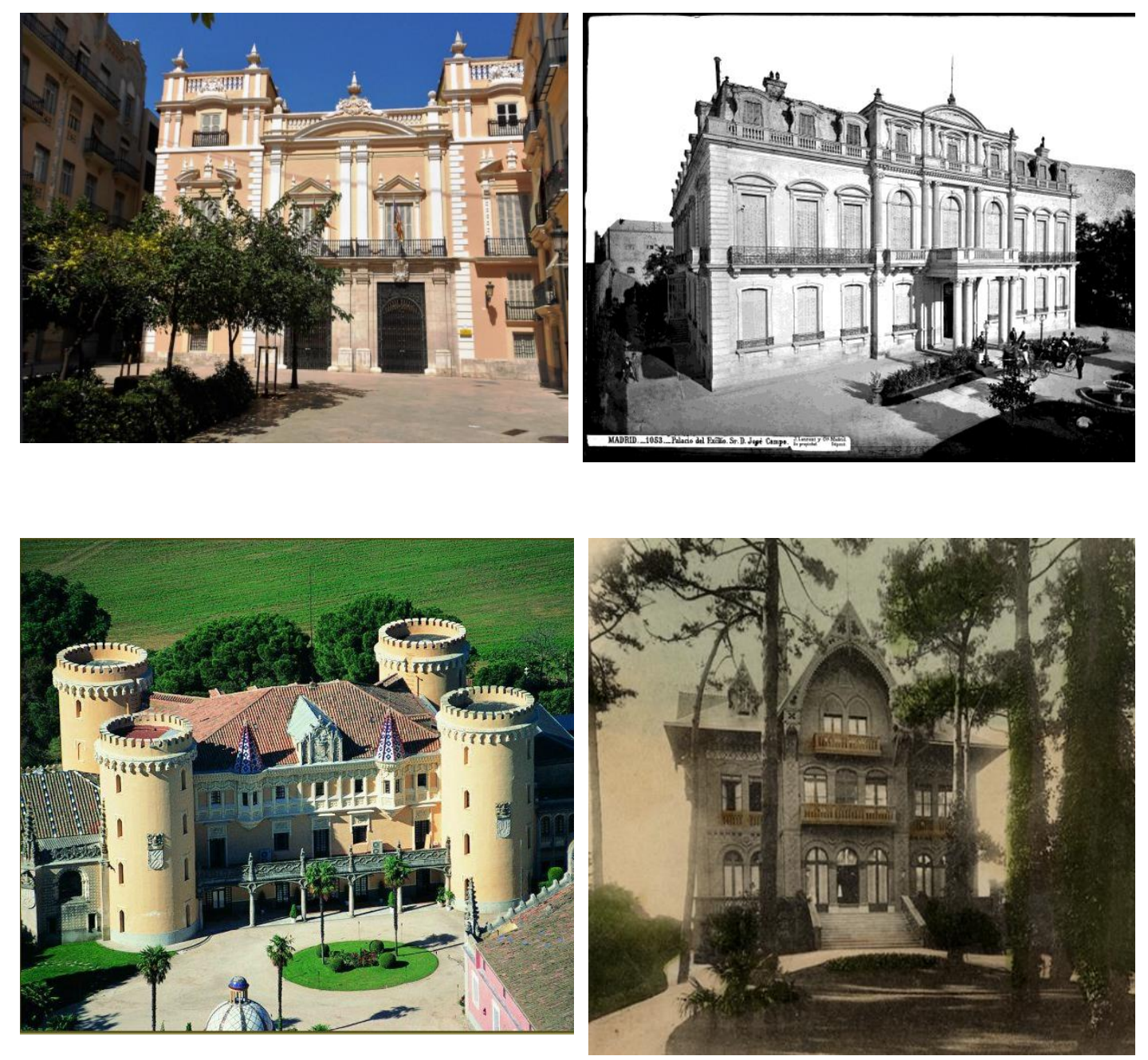



\section{Capítulo iII}

\section{OTROS EJEMPLOS DE LA PROMOCIÓN ARQUITECTÓNICA DEL MARQUÉS DE CAMPO: SUS RESIDENCIAS}

El caso de la transformación arquitectónica de Valencia en el siglo XIX no es distinto del de Madrid, pues como dice Trinidad Simó1, "La arquitectura como cualquier producto artístico, proviene de una historia y de una sociedad, y su actual mayor valor reside en su carácter de testimonio histórico. La obra importa no sólo como portadora de placeres o desagrados estéticos sino como portadora de ideas, su dimensión semiótica, de significados históricos".

En Valencia en el siglo XIX se dio una gran expansión económica, con una mejora de la agricultura y una mejora de la industria artesanal. El nacimiento de una burguesía liberal y emprendedora, obligará a tomar medidas para reformar una ciudad que se ha quedado pequeña dentro de sus murallas y cuya población vive hacinada y en unas condiciones de salubridad nada buenas, que causan miles de muertes al año y mucha pobreza.

\footnotetext{
${ }^{1}$ SIMÓ, Trinidad. La arquitectura de la renovación urbana en Valencia. Valencia: Ediciones Albatros, 1973, p. 20 y 21.
} 
A partir de 1830 se produce una etapa en la que se llevan a cabo mejoras de la ciudad y en las que participa de lleno José Campo cuando llega a la alcaldía en 1843. Se construyen nuevos edificios públicos como escuelas; se modifica la tipología de las viviendas gracias al asesoramiento de los higienistas que ponen el interés en la limpieza, el aire libre, los jardines, etc. ${ }^{2}$ Se utilizan nuevos materiales constructivos como el hormigón, el acero, el vidrio, que serán utilizados sobre todo en las viviendas de la burguesía que no dudará en pagar su alto precio para construir las nuevas casas señoriales de la zona del ensanche.

El desarrollo urbanístico de Valencia del XIX llevará a la demolición de las murallas a partir de 1958 ensanchando la ciudad en tres anillos concéntricos aplicando el concepto de los bulevares que ya se había hecho en Madrid3; también se anexiona y amplia la zona marítima y el puerto; y se descongestiona el centro urbano, conectándolo con las zonas del ensanche por medio de calles nuevas. Al derribar las murallas se intenta que la otra orilla del río Turia forme también parte de la ciudad, y todas esas mejoras se acompañan de la canalización de las aguas residuales, la iluminación pública de las calles 4 , el empedrado de la mismas y la llegada del agua a las fuentes y viviendas, reformas en las que interviene de manera directa José Campo como ya hemos visto anteriormente. Y se crean jardines y paseos como el Parterre y la Glorieta5, donde pasear y dejarse ver.

Las casas señoriales que se construyen en la nueva zona del ensanche tendrán una fachada noble a la que daban el comedor, el salón y el despacho; y los dormitorios y servicios se establecerán en la parte trasera. Algunas de ellas tendrán patio interior $\mathrm{y}$ las dependencias del servicio seguirán una

${ }^{2}$ LÓPEZ PIÑERO, José María et al. Medicina y sociedad en la España del siglo XIX. Madrid: Sociedad de estudios y publicaciones, 1960. p. 299 - 311.

3 AYUNTAMIENTO DE VALENCIA, Memoria para el ensanche de Valencia. Valencia: Ajuntament de València, 1859.

4 LLORENTE, P. "El alumbrado público en Valencia". En: Almanaque de Las Provincias 1895.

5 TORMO, Elías. Guía de Levante. Madrid: Editorial Calpe, 1923. 
jerarquización que continúa desde el barroco. Los nuevos palacetes se construyen más hacia las afueras de la ciudad, como en el paseo de la Alameda, pero en el centro neurálgico de la misma continúan los más importantes como el del marqués de Dos Aguas, el del conde de Parcent, el de los condes de Cervelló, y como no, el que ocupará José Campo en la plaza del Arzobispo, llamada así por estar al lado del Palacio Arzobispal, cerca de la Catedral y del centro político y religioso de la ciudad desde la edad media.

\section{1.- La casa-palacio de la plaza del Arzobispo de Valencia}

Aunque ya vivía allí de alquiler desde hacía tiempo, José Campo adquirió mediante escritura pública de fecha 18 de mayo de 1853 por 500.000 reales una casa-palacio en la plaza del Arzobispo número 6 de Valencia ${ }^{6}$. La imagen más antigua que tenemos del palacio es la del plano del Padre Tosca, de 1704, donde se observa la existencia ya entonces del patio de honor y la gran cúpula de la escalinata, elevada sobre un tambor, que hoy en día permanecen (Fig. 3.1).

\footnotetext{
${ }^{6}$ En una restauración de la cúpula del palacio llevada a cabo en 2012, apareció la fecha de 1669 como posible fecha de construcción. Dato ofrecido por María Barceló, directora del Museo de la Ciudad.
} 


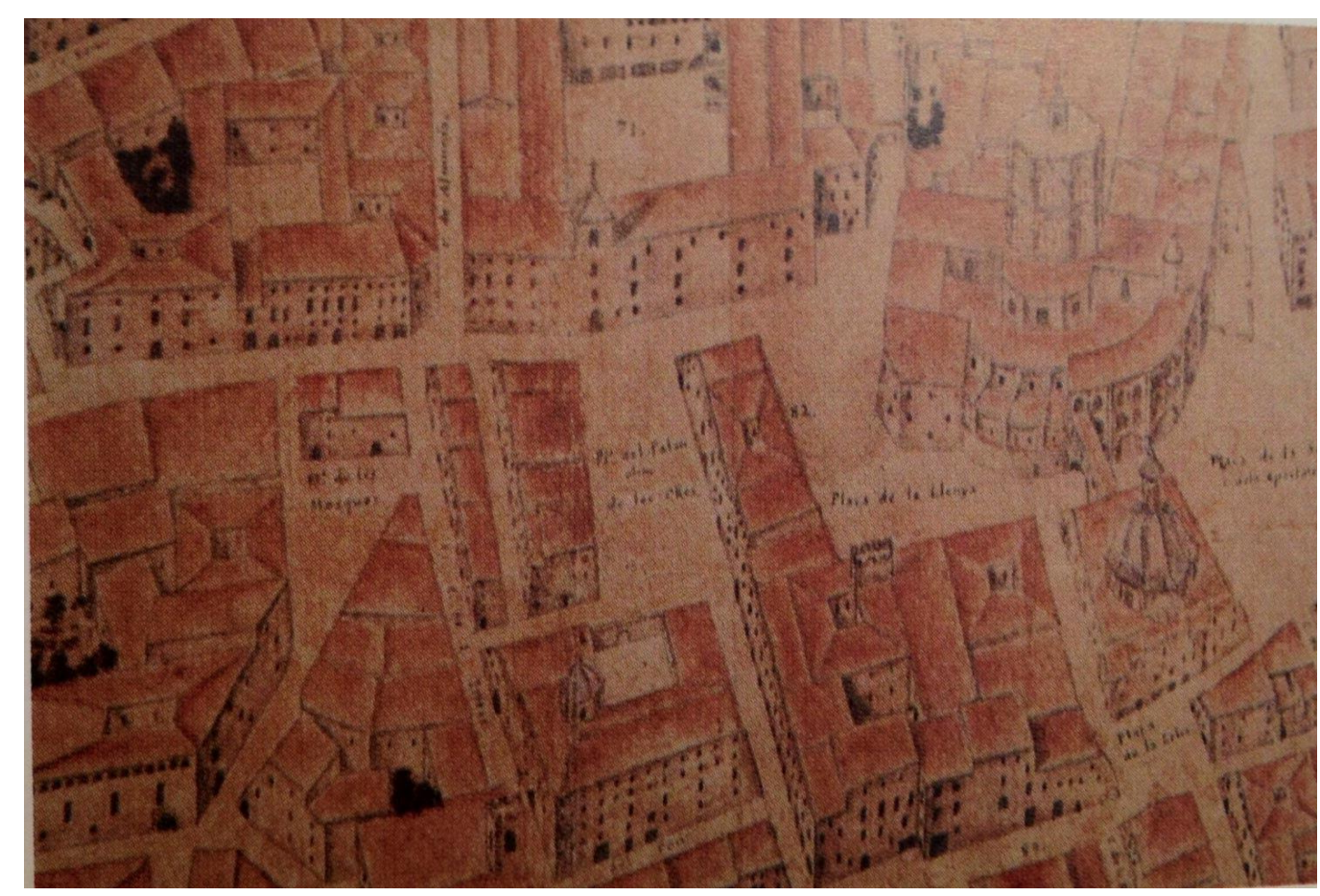

Fig. 3.1 Plano del padre Tosca (1704). Detalle en el que se muestra el aspecto qu ofrecía el antiguo palacio de los Duques de Villahermosa a principios del siglo XV.

El palacio pertenecía a los Duques de Villahermosa y ocupaba parte de una manzana. Estaba formado por: planta baja destinada a vestíbulo de ingreso, oficinas, cuadras y cocheras; piso entresuelo destinado a oficinas y vivienda; piso principal y piso segundo con habitaciones; y piso tercero con dependencias para criados y desvanes.

El palacio fue sede de la Capitanía General tras la Guerra de la Independencia y alojamiento del Excmo. Sr. Capitán General del Reino; para su adecuación a tal fin fue objeto de reformas; sin embargo, en 1840 comenzaron las obras en el convento de Santo Domingo para convertirlo en la nueva Capitanía General y se abandonó el palacio hasta que José Campo lo alquiló y comenzó a vivir en él unos cuantos años antes de comprarlo.

José Campo adquirió no sólo el palacio sino la manzana entera de edificios y realizó una gran reforma que supuso la construcción de una nueva 
planta del cuerpo central de la fachada de manos de los arquitectos Manuel Ferrando y Jaime Beatty7. Su decoración corrió a cargo de artistas de prestigio. Participaron entre otros José Flores Vela, Vicente Pérez Vela, Plácido Francés, Rafael Montesinos y José Gallel, quienes también habían participado en la decoración del palacio del marqués de Dos Aguas que se estaba realizando en la misma época. Los dos dueños rivalizaban en los negocios y en el poder y no escatimaron en gastos para embellecer sus casas y así demostrar su superioridad

Además de su residencia, el palacio se convirtió en sede de sus empresas y del periódico La Opinión, luego llamado Las Provincias. A la muerte de José Campo el palacio fue adquirido por los Condes de Berbedel, quienes lo sometieron a una nueva reforma muy comentada en la prensa por su grandiosidad y lujo. A finales de 1937, con motivo del traslado del gobierno de la República a Valencia, el palacio fue incautado para alojar el Ministerio de Sanidad. En mayo de 1959 se celebró en él una recepción en honor del futuro Rey de España, D. Juan Carlos de Borbón.

Fue declarado monumento histórico artístico de carácter local en 1973, y en el B.O.E. del 19 de noviembre de 1982 se publicó el Decreto de incoación de monumento histórico artístico de carácter provincial. Hoy en día, tras la decisión del Ayuntamiento de rehabilitar y adecuar el edificio para convertirlo en sede del Museo de la Ciudad, el aspecto que luce el edificio es fruto de la última reforma llevada a cabo en 1988 por Manuel Portaceli y Juan José Estellés. La (fig. 3.2), muestra el plano del palacio tras la reforma realizada por el marqués y antes de la intervención de 1988.8.

\footnotetext{
7 Archivo Histórico Municipal de Valencia. Reparaciones Cuartel del Mar, 1857, exp. n. ${ }^{\circ} 4$.

${ }^{8}$ CATALÁ, Miguel Ángel et al. Palacio del Marqués de Campo. Museo de la ciudad. Valencia: Ayuntamiento de Valencia, 1989.
} 


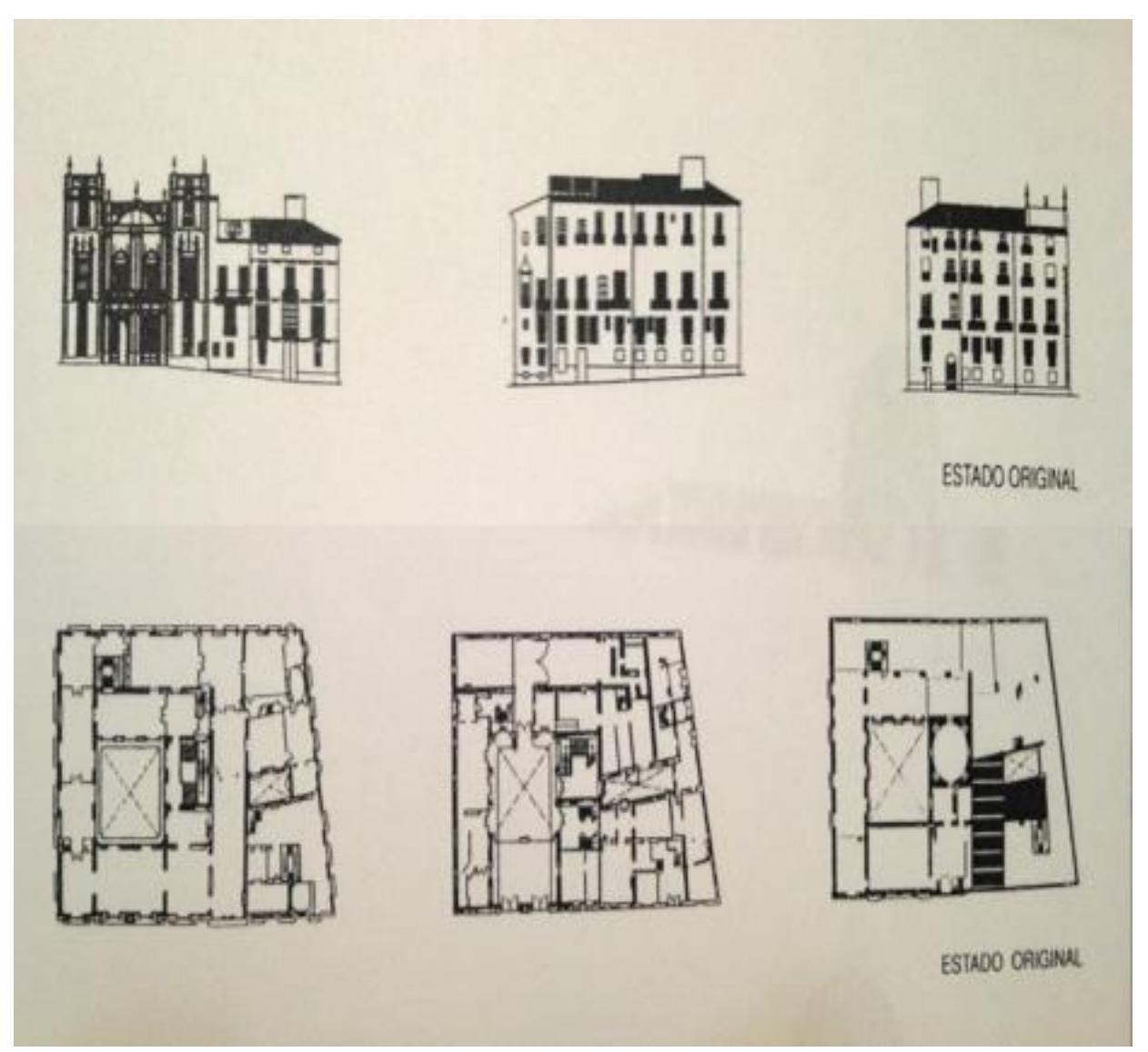

Fig. 3.2 Plano original del palacio antes de la reforma de 1988

Dicha reforma, que tuvo muchos detractores, fue Premio de Arquitectura 1988/89 y en ella se intentó respetar al máximo la estructura del edificio, pero fue necesario llevar a cabo una nueva articulación de espacios para adecuarlos a los fines expositivos y conseguir una independencia funcional. Las pinturas originales de los techos que seguidamente serán comentadas, fueron sustituidas por obras del pintor Jordi Teixidor y se alteraron las dimensiones de las estancias para buscar un recorrido apto para exposición aprovechando la variedad de volúmenes y de alturas9.

Aunque el aspecto que luce hoy el palacio no se parezca mucho al que lució en tiempos del marqués de Campo, gracias a la investigación de

9 BORCHA, Boro (coord.). Arquitectura de la Comunidad Valenciana: menciones de arquitectura 1973, premios de arquitectura 1985-89. Valencia: Colegio Oficial de Arquitectos, 1991. p. 98-101. 
documentos, bibliografía, material fotográfico etc., podemos hacernos una idea de cómo era ${ }^{10}$.

En la fachada (Fig. 3.3), sobre las torres, se conservan elementos barrocos de decoración como los geniecillos que las coronan con atributos como el caduceo o la antorcha (Figs. 3.4 y 3.5) en referencia a la actividad comercial de José Campo. Además, vemos los escudos de armas de las familias PratBrucelli y Dasí-Puigmoltó con la corona condal que sustituyeron al del marqués de Campo al ser vendido.

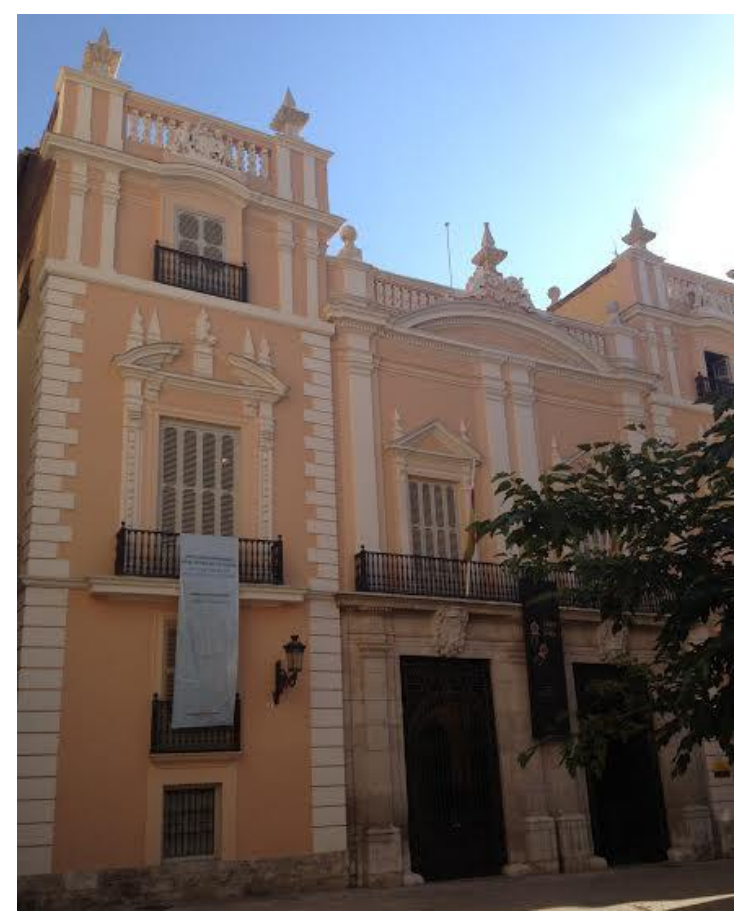

Fig. 3.3 Palacio del Marqués de Campo. Valencia. Estado Actual. Fotografía de la autora.

${ }^{10}$ CATALÁ, Miguel Ángel. "Palacio de Berbedel”. En: Catálogo monumental de la ciudad de Valencia. Valencia: Caja de ahorros de Valencia, 1983, p. 146-148.

CATALÁ, Miguel Ángel. "El Museo histórico de la Ciudad. Su pasado, su presente y proyección de futuro”. En: Actes del I Congreso d'Història de la Ciutat de València. Valencia: 1988, III, 2.2.

CATALÁ, Miguel Ángel. El museo de la Ciudad. Su historia y colecciones. Valencia: Ajuntament de València, 1997.

LOHENGRIN. "El palacio de Los condes de Berbedel”. Valencia Atracción, 1974, Núm. 479, Año XLIX, p. 8-12. 


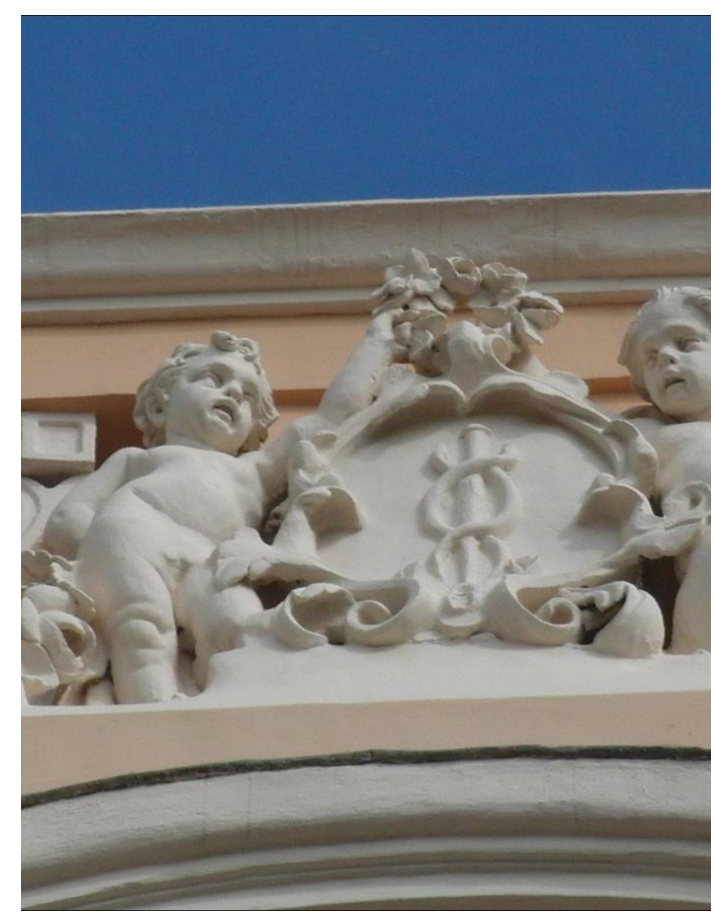

Fig.3.4 El caduceo referido a la activid comercial del marqués. Fotografía de la autora.

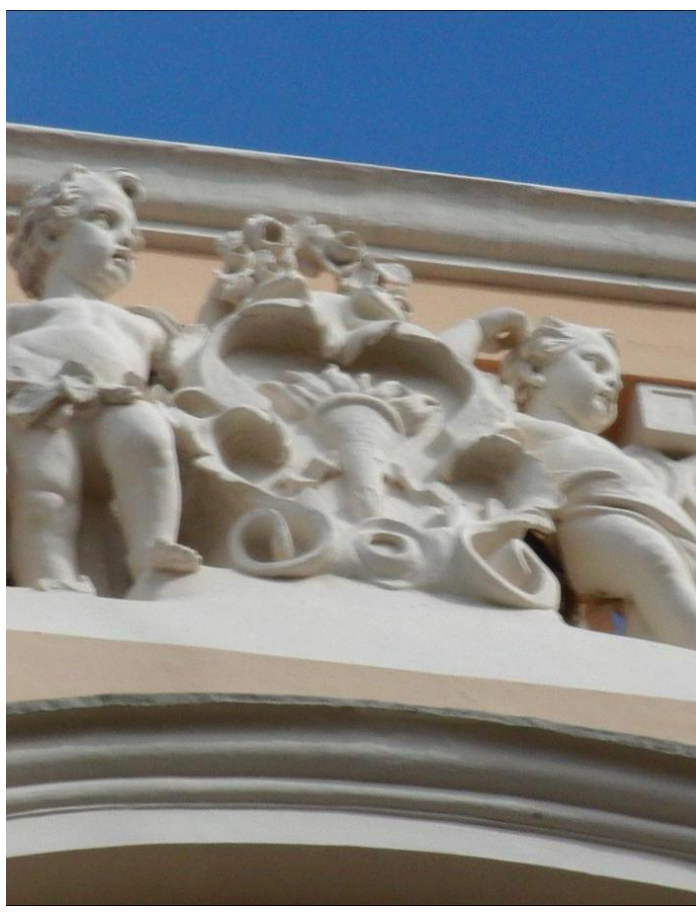

Fig.3.5 La antorcha referida al gas y a industria del marqués. Fotografía de la autora.

En la planta baja destaca el patio de armas (Fig. 3.6) ${ }^{11}$, núcleo de la edificación originaria del siglo XVII. Es de planta rectangular y sus cuatro crujías se articulan a base de arcos de medio punto entre pilastras toscanas, conformando un espacio abierto de sobria elegancia. En la época en que era habitado por José Campo y su familia, se accedía a la primera planta a través de una monumental escalera (Fig. 3.7) cubierta por una cúpula (Fig. 3.8) que hoy aparece decorada con esgrafiados y las pechinas sobre las que se apoya están ornamentadas con escudos de los últimos moradores y propietarios. Junto al patio de armas estaban situadas las cocheras y las caballerizas.

\footnotetext{
${ }^{11}$ Imagen publicada en: BORCHA, Boro (coord.). Arquitectura de la Comunidad Valenciana: menciones de arquitectura 1973, premios de arquitectura 1985-89. Valencia: Colegio Oficial de Arquitectos, 1991, p. 98.
} 


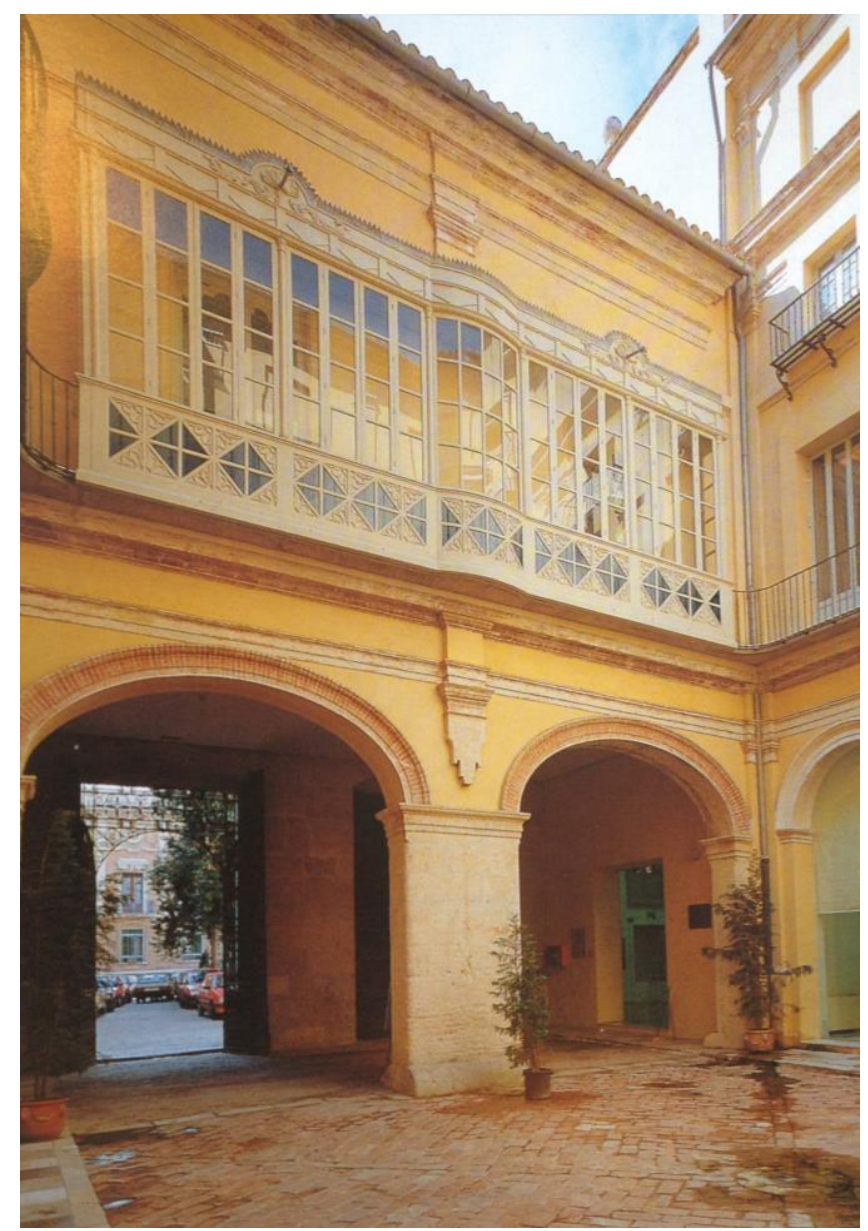

Fig. 3.6 Palacio del marqués de Campo. Valencia. Patio de armas. Imagen tras la reforma de 1988.

En el siglo XIX, las viviendas acomodadas tenían numerosas habitaciones y estancias con funciones muy concretas. Cada cuarto se encontraba destinado a una función y ésta determinaba la ornamentación, la decoración mural, los complementos y el mobiliario.

El palacio de José Campo seguía estas reglas y gracias en parte al inventario de sus bienes realizado a la muerte de su primera esposa Rosalía Rey ${ }^{12}$, podemos conocer las estancias que había y su decoración, permitiéndonos hacernos una idea de su modo de vida.

${ }^{12}$ AHPM, T.36643, fols. 7439 y ss. 
En la planta baja del palacio y en el entresuelo estaba situado el despacho de José Campo y el resto de dependencias de sus empresas. Ya hemos dicho que parte de sus empresas tuvieron su sede en este palacio por comodidad para el señor. Campo, pues tenía tantos negocios y tantas ocupaciones que era mejor dirigirlas desde su domicilio, ya que según se decía, la noche lo encontraba trabajando y el día lo sorprendía ya en su despacho.

Para acceder a la planta de arriba se utilizaba la escalera principal que ya hemos descrito y se llegaba a un recibidor donde había unos bancos de roble tallado para sentarse y una decoración a base de alfombras, jarrones y brazos de bronce con mecheros para iluminar la estancia que ya daba una idea del lujo y riqueza del resto de la casa.

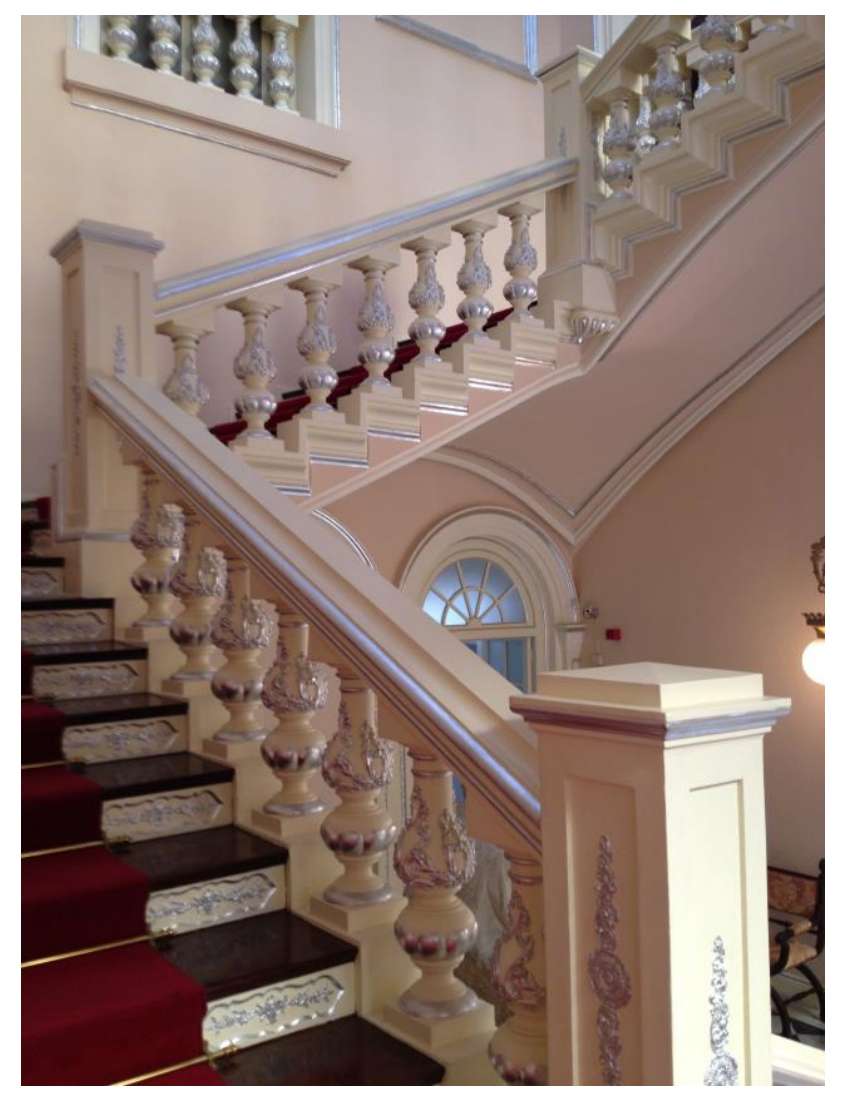

Fig. 3.7 Palacio del marqués de Campo. Valencia. Escalera principal. Estado actual. Fotografía de la autora. 


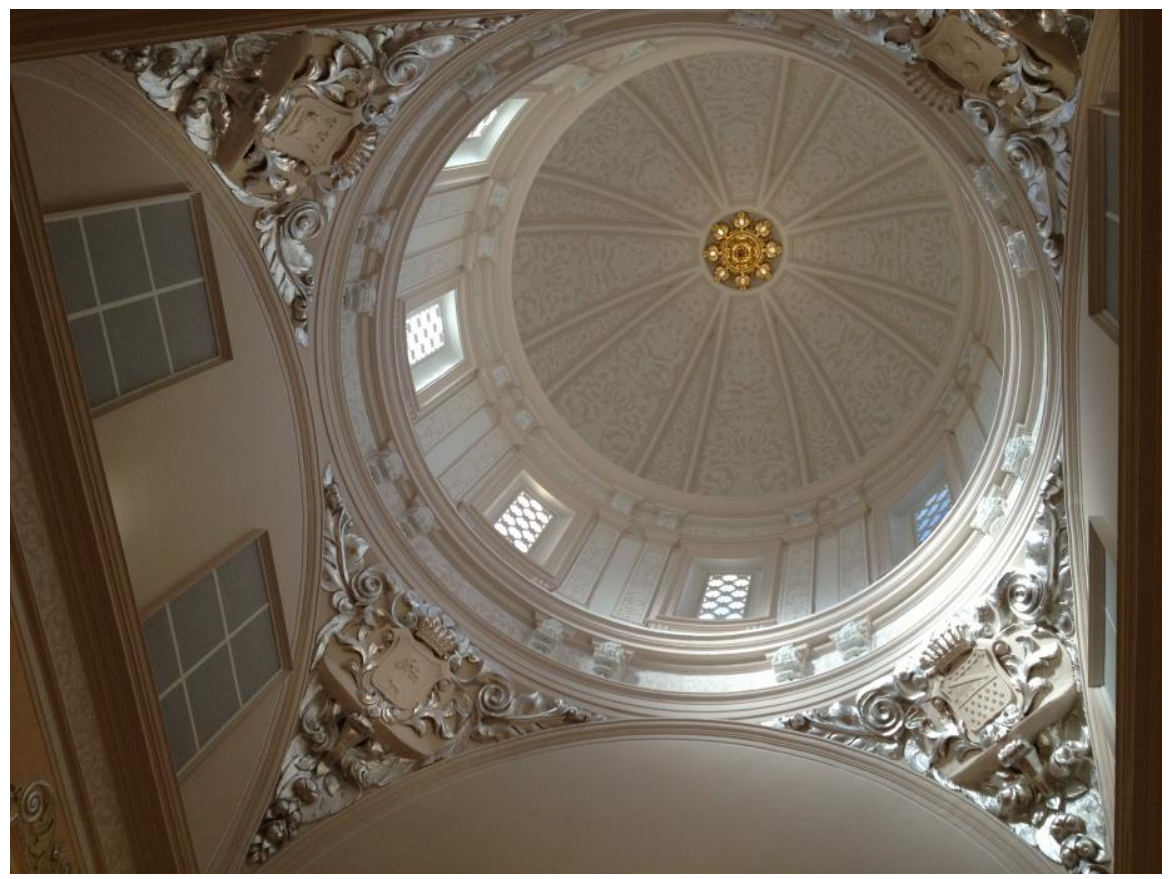

Fig. 3.8 Palacio del marqués de Campo. Valencia.

Cúpula con pechinas. Estado Actual. Fotografía de la autora.

Del recibidor se pasaba al salón árabe, que tenía tres puertas de estilo mudéjar, con inscripciones y dibujos de oro viejo sobre fondo granate. Sobre las puertas había pintados grandes pavos reales, y en el centro de la sala una lámpara de bronce extraordinaria. Había otomanas tapizadas con tela oriental para sentarse, y una alfombra tapiz de Smirna que cubría el suelo de toda la sala. De ahí se pasaba a la galería, en la que había como una especie de invernadero con plantas y jardineras y una rica decoración a base de esculturas, alfombras, muebles de la mayor calidad, cortinajes, un piano y todas las comodidades posibles para que los moradores se sintieran a gusto en su palacio y los invitados disfrutaran de las visitas y admiraran el entorno.

Había también una sala de cuadros, pero de la colección de pinturas, esculturas y objetos suntuarios del marqués en este palacio se hablará detenidamente en otro capítulo de esta tesis. 
También en la primera planta estaba el dormitorio del marqués, su toilette y su ropero. Cerca de los aposentos del marqués estaban los de la marquesa, formados por la toilette, la sala y el dormitorio de la señora. Estas estancias tenían todas las comodidades posibles para descansar, asearse, pasar ratos de descanso, etc., y los muebles y la decoración era exquisita. Camas de palosanto, cortinas de terciopelo, armarios, cómodas, sillas tapizadas de damasco, joyeros, espejos, y por supuesto cuadros, esculturas y retratos de la familia en pinturas y fotografías.

El comedor, (Fig. 3.9) tenía una magnífica chimenea Luis XV de mármol blanco con aplicaciones de bronce y porcelana inglesa ${ }^{13}$. En el techo había un lienzo que representaba a Adán y Eva en el Paraíso pintado por Plácido Francés, y rematado por una orla estilo Luis XV que, con otras molduras llegaba hasta la escocia, del más puro renacimiento. Estaba decorado también con cuadros y otras obras de arte que, como ya se ha dicho, luego veremos y en él había una mesa grande de caoba, tres aparadores de caoba también, biombos, chimeneas, y todo lo necesario para dar grandes banquetes a los amigos que iban a las fiestas que celebraba José Campo en su palacio y que en ocasiones especiales eran finalizadas con baile en el gran salón.

${ }^{13}$ Imagen publicada en: LOHENGRIN. "El palacio de Los condes de Berbedel". Valencia Atracción, 1974, Núm. 479, Año XLIX, p. 8-12. 


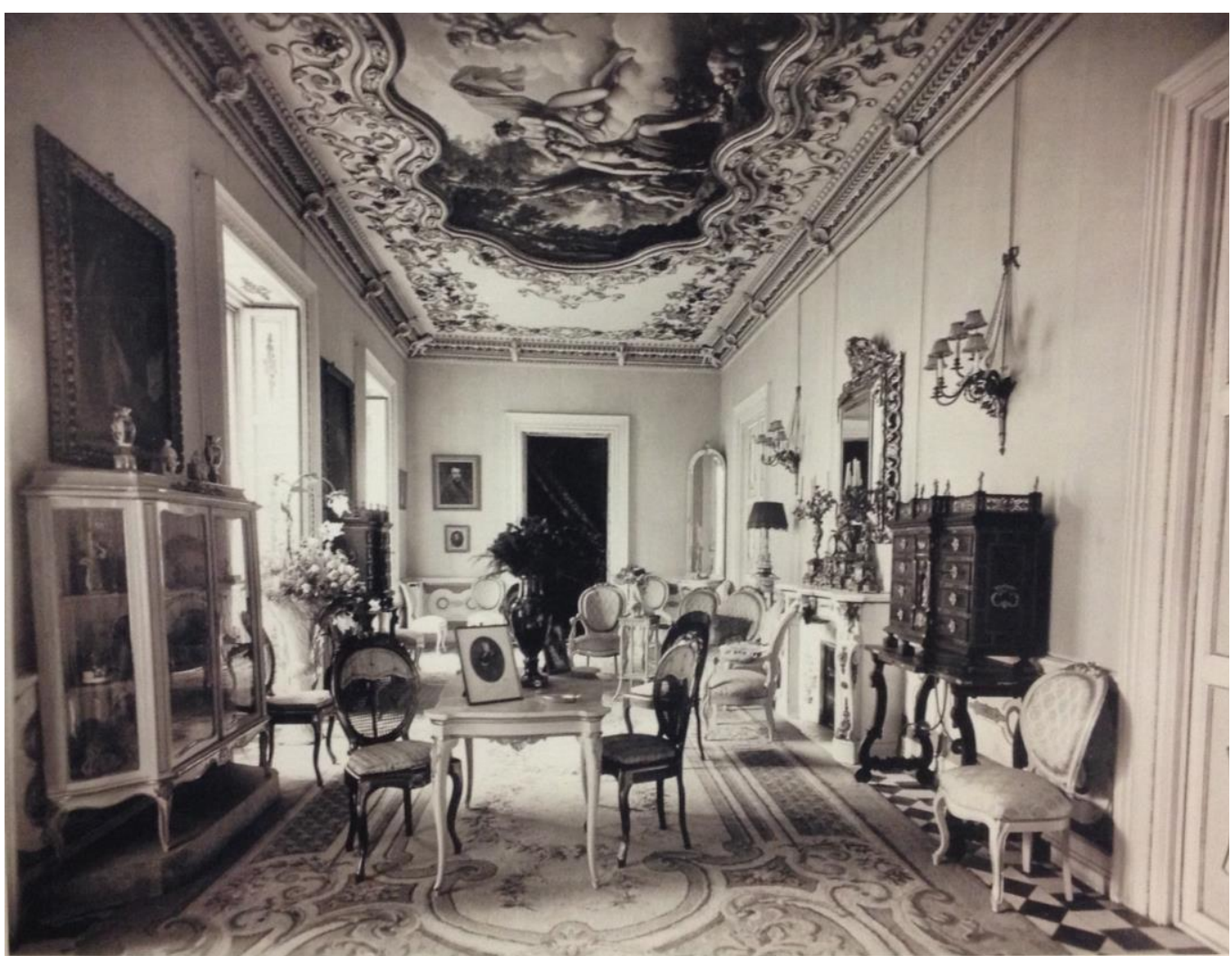

Fig.3.9 Palacio marqués de Campo.

El comedor en la época de los Condes de Berbedel.

Había una sala llamada Fumoir, donde los caballeros se reunían tras las comidas o cenas a tomar el café, a conversar sobre negocios o política y a fumar, lejos de la presencia de las damas. Tenía el techo rodeado de dorada talla con cuatro medallones con composiciones alegóricas sobre las cuatro estaciones (Figs. 3.10, 3.11, 3.12 y 3.13) ${ }^{14}$. Había también una chimenea de mármol verde y zócalo de madera con relieves de oro. Era un lugar acogedor para disfrute de los caballeros.

14 Imágenes cedidas por la Biblioteca Valenciana. 


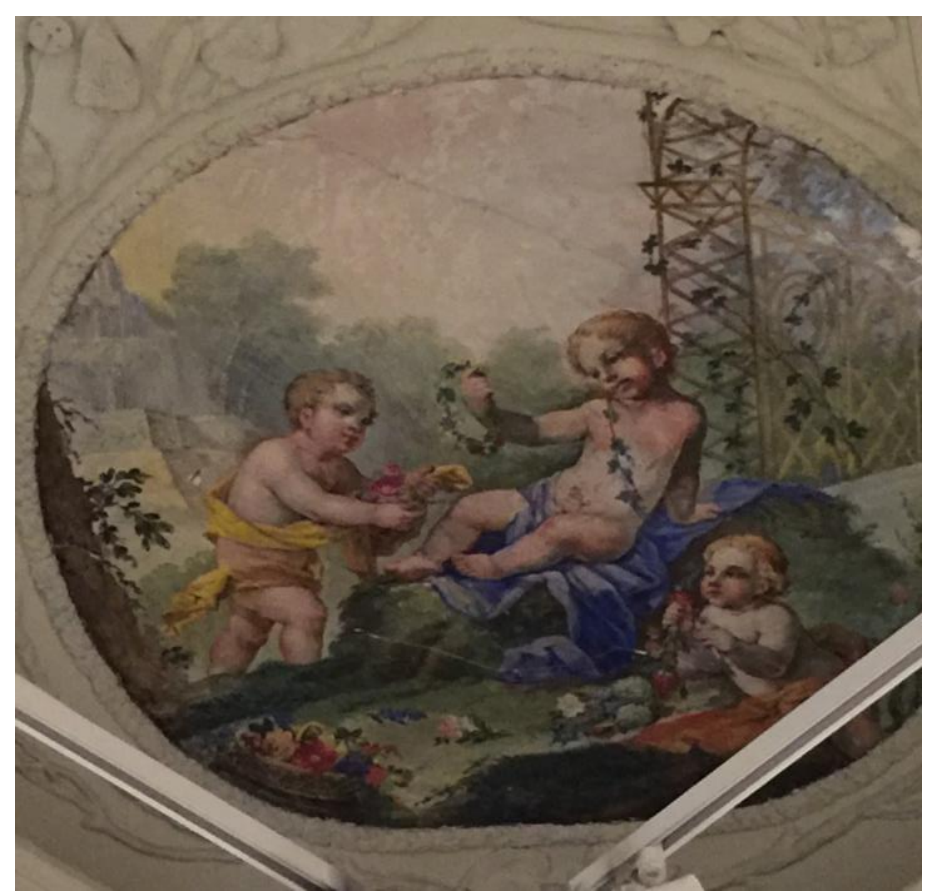

Fig. 3.10 Alegoría de la primavera. Sala Fumoir.

Palacio del marqués de Campo. Estado actual. Imagen de la autora.

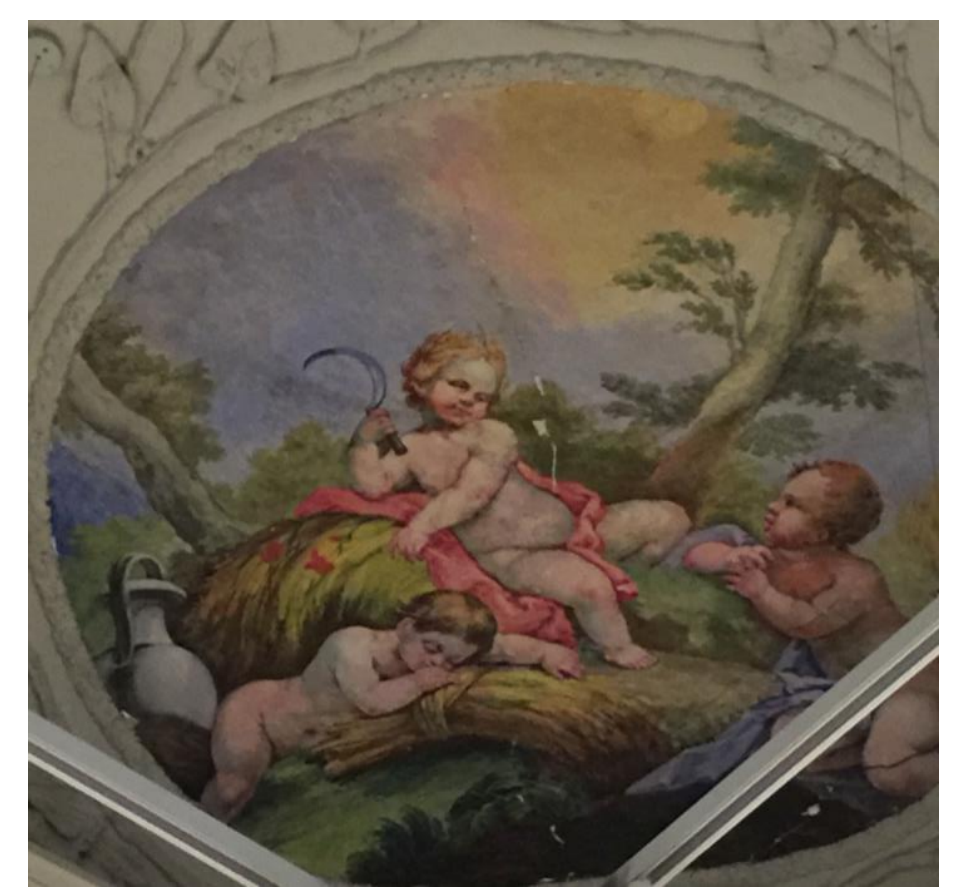

Fig. 3.11 Alegoría del verano. Sala Fumoir. Palacio del marqués de Campo. Estado actual. Imagen de la autora. 


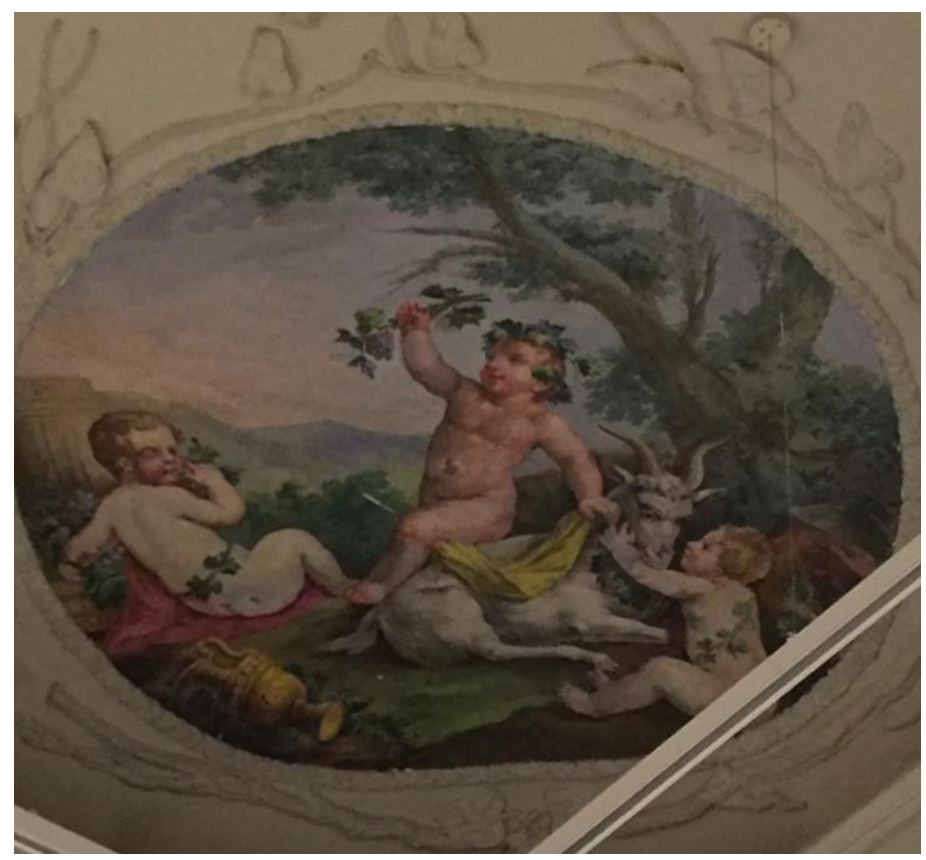

Fig. 3.12 Alegoría del otoño. Sala Fumoir. Palacio del marqués de Campo. Estado actual. Imagen de la autora.

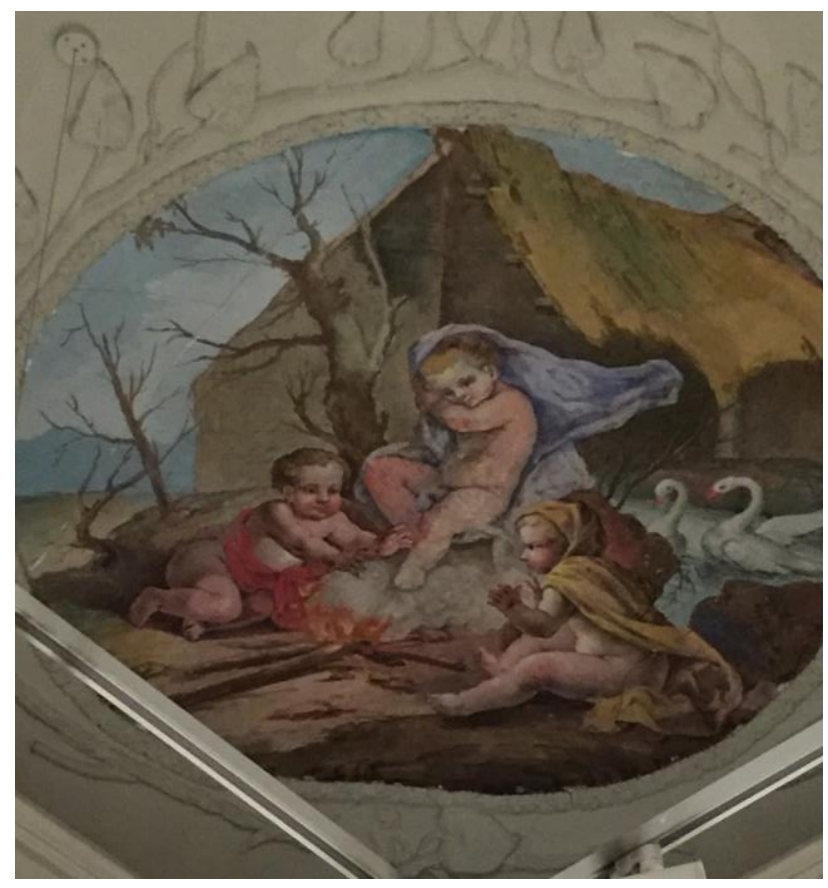

Fig. 3.13 Alegoría del invierno. Sala Fumoir. Palacio del marqués de Campo. Estado actual. Imagen de la autora. 
José Campo y sus amigos que también disfrutaban en el salón de billar ${ }^{15}$ (Fig. 3.14), en el que había todo lo necesario para practicar dicho juego, mientras las damas podían tomar café en el salón chinesco destinado a tal efecto. Siempre se ha dicho que jugando al billar se podían hacer buenos negocios y de eso el señor Campo entendía mucho.

La decoración de sillas y divanes tenía motivos chinescos, los cortinajes tenían el mismo tapiz de las sillas, había un gran servicio de café con numerosas piezas para grandes ocasiones y poncheras grandes, todo ello también con decoración chinesca. Toda la sala estaba tapizada de tela de lana y seda con dibujos tejidos y alfombrada.

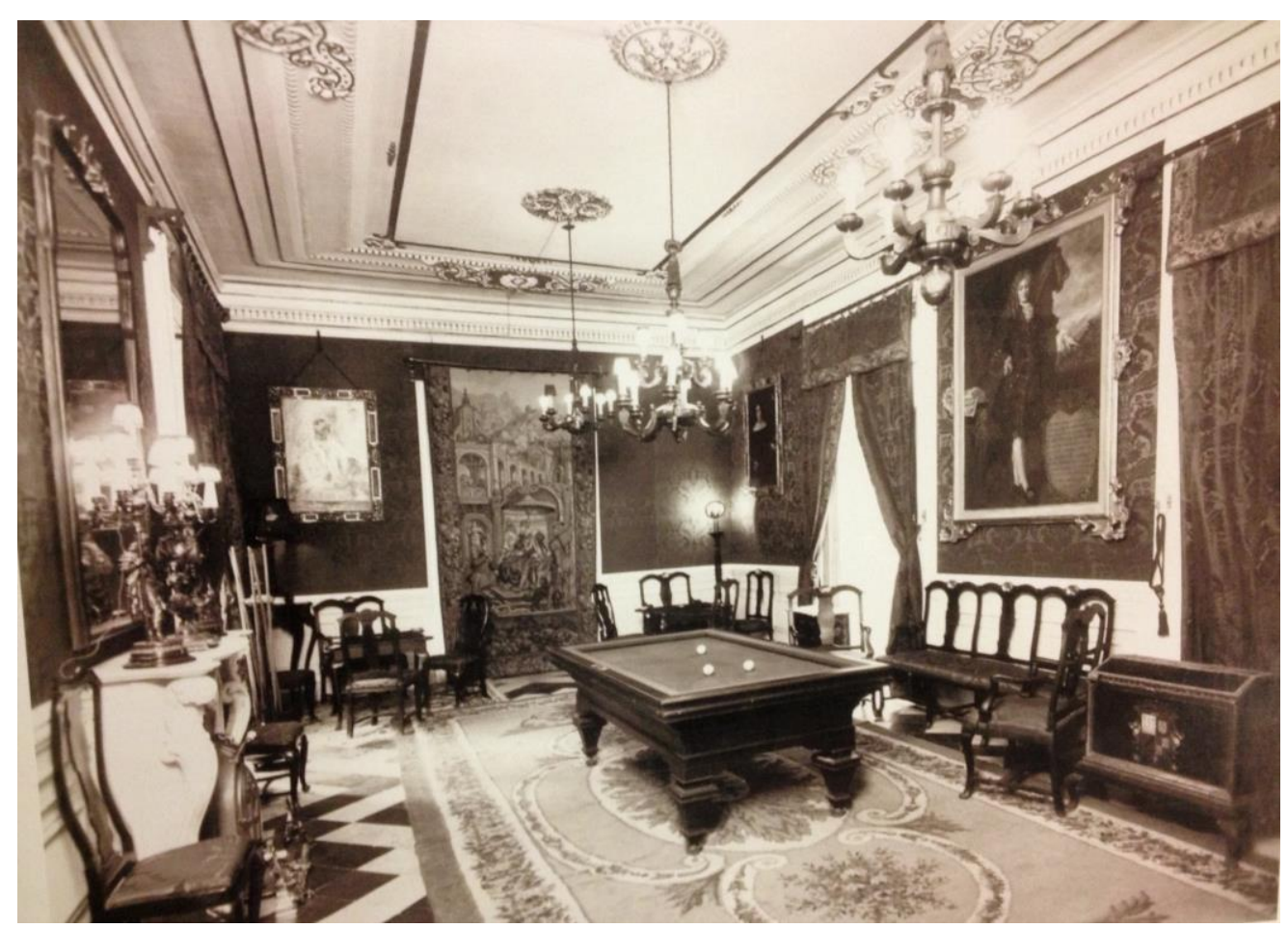

Fig. 3. 14Palacio del marqués de Campo.

Sala de billar en la época de los condes de Berbedel.

${ }^{15}$ Imagen publicada en: LOHENGRIN. "El palacio de Los condes de Berbedel". Valencia Atracción, 1974, Núm. 479, Año XLIX, p. 8-12. 
El palacio también contaba con una sala de armas, con un techo artesonado de escayola, en la que había como su nombre indica, 4 armaduras de hombre completas y estuches con pistolas y otras armas. La sala estaba alfombrada y también tenía sillones y una mesa grande con tapete de terciopelo azul.

La llamada sala de artistas (Fig. 3.15) era una pequeña sala donde se situaba la orquesta cuando se celebraba un baile en el palacio y así en el gran salón de baile quedaba más espacio para los invitados. La sala en cuestión estaba alfombrada, con las paredes tapizadas de moaré y las cortinas a juego, pero lo que llama la atención es el techo; tiene forma de bóveda esquifada y está decorado completamente en escayola con alegorías de las artes y otras figuras. La importancia de la decoración del techo de esta sala ha merecido que se le dedique un estudio iconográfico completo y será expuesto al final de la descripción del palacio.

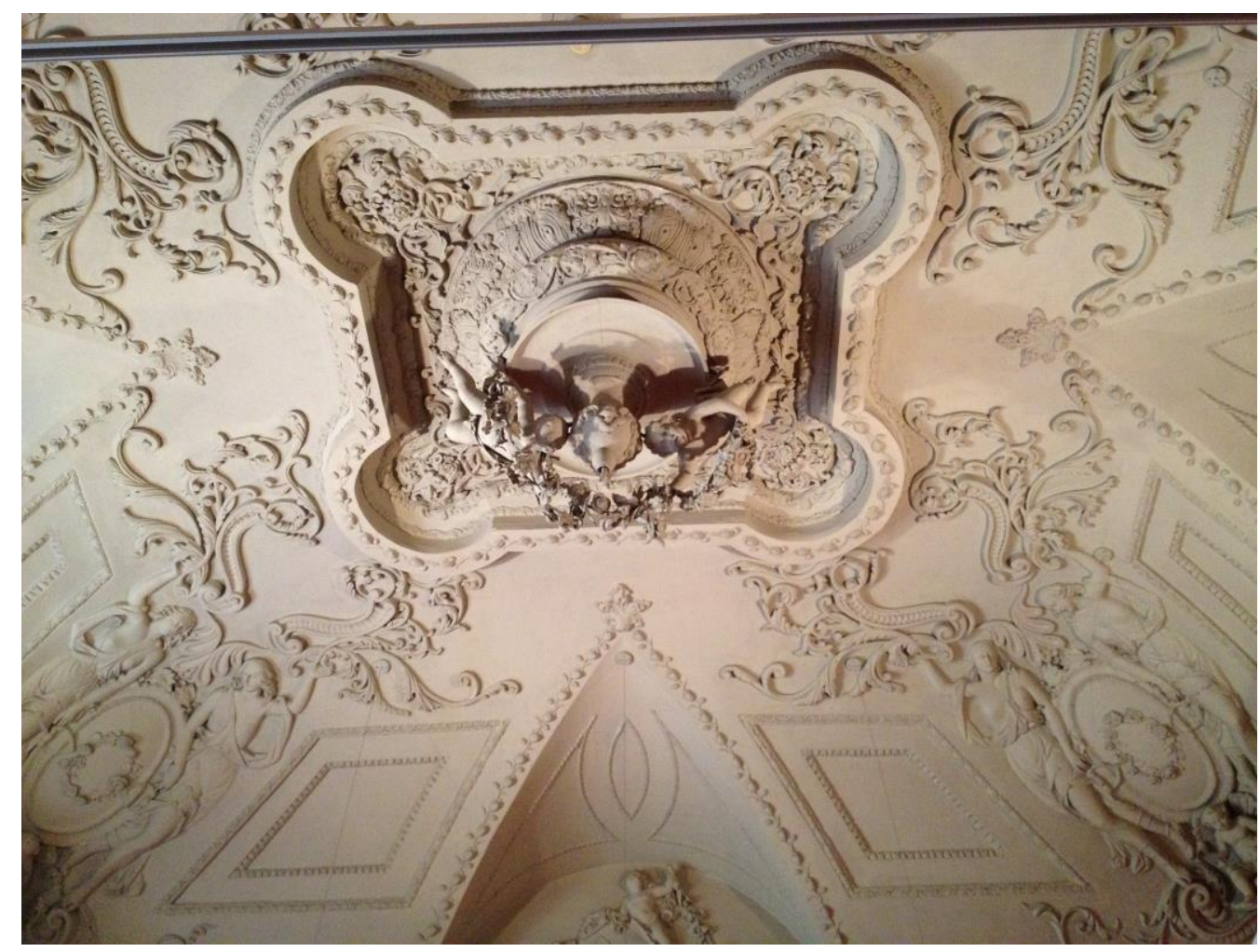

Fig. 3.15 Decoración de la bóveda de la sala de artistas.

Palacio del marqués de Campo. Estado actual. Fotografía de la autora. 
El Salón de Honor o de Baile (Fig. 3.16) ${ }^{16}$ estaba decorado en blanco y oro, estilo Luis XVI, su techo era una maravilla de talla artística, con ángeles y cuatro águilas en los ángulos. Varios lienzos con pinturas alegóricas están situados en el techo alrededor de otros dos lienzos grandes con Vulcano y Neptuno. También había muebles de estilo Luis XVI, brocados de seda azul con ramilletes de colores en tapicerías y cortinas, enormes espejos, candelabros de bronce, una alfombra gobelina para todo el salón, asientos góndola y otros muebles de madera dorada copiados del palacio de Versalles.

El salón era magnífico y debía ser la admiración de cuantos lo visitaban. Todo en el palacio era de una riqueza y un lujo exagerado, que ponía en evidencia la bonanza económica y la ascendencia en el panorama social y político del que años antes había comenzado siendo el alcalde de la ciudad.

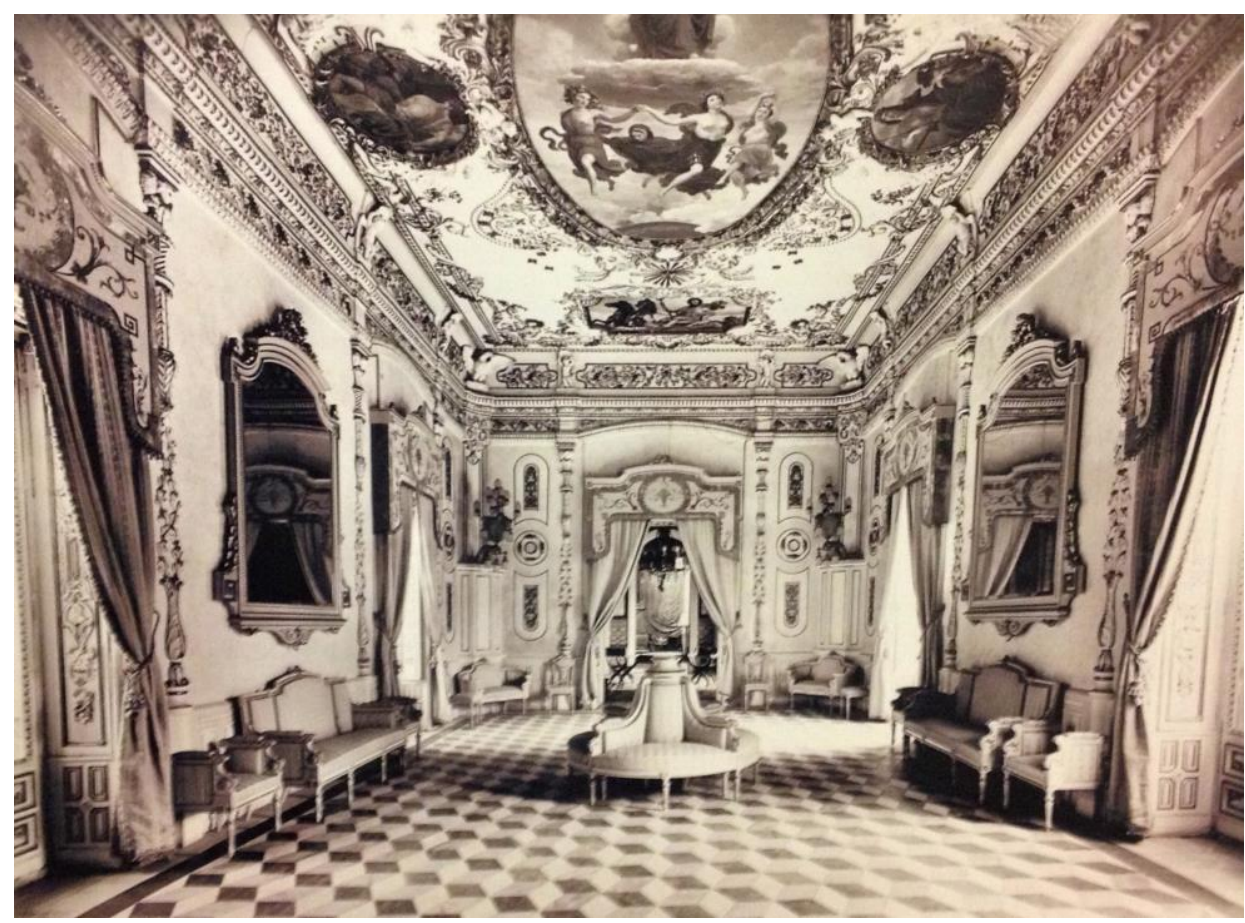

Fig.3.16 Palacio del marqués de Campo.

El gran salón de baile. Época de los condes de Berbedel.

El oratorio y la sacristía (Fig. 3.17) también formaban parte de los palacios de la nobleza, que celebraban misa en privado con el capellán de la

${ }^{16}$ Imagen publicada en: LOHENGRIN. "El palacio de Los condes de Berbedel”. Valencia Atracción, 1974, Núm. 479, Año XLIX, p. 8-12. 
familia, y José Campo estaba decidido a convertirse en uno de ellos. Siempre se le ha considerado un hombre religioso y su esposa era una mujer muy devota. Por ello se hizo construir en el palacio una capilla dedicada a san José. Estaba situada en la segunda planta, con cubierta abovedada y adornada con una magnífica talla renacentista. En la sacristía había todo lo necesario para celebrar misa diaria: armarios, una cómoda con ornamentos sacerdotales, purificadores, navetas, incensarios, etc., y en la capilla había candeleros, reclinatorios, bancos, imágenes religiosas, sacras con marco, un crucifijo y una pila para agua bendita. Todo el oratorio estaba cubierto por una alfombra.

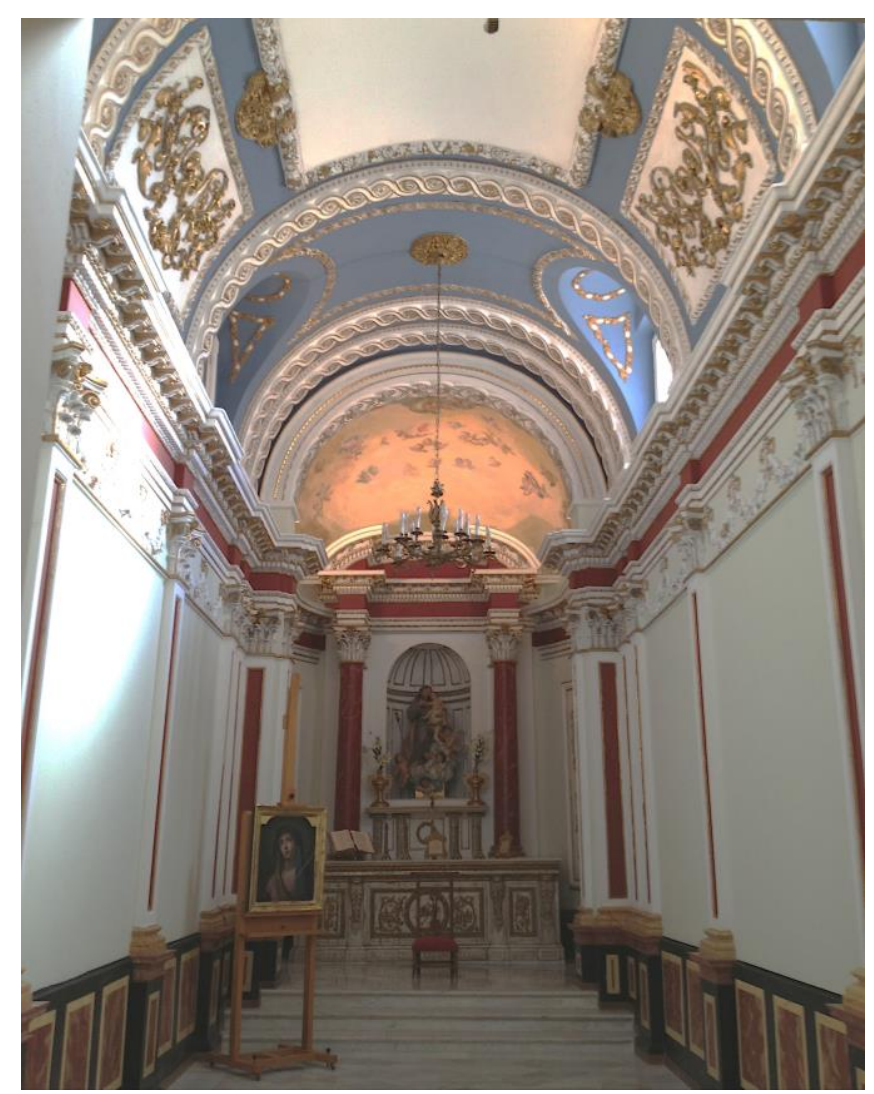

Fig. 3.17 Palacio del marqués de Campo. Oratorio. Estado actual. Fotografía de la autora.

En el segundo piso, además del oratorio, había 5 habitaciones completamente decoradas y preparadas para familia e invitados, y los cuartos de 
la servidumbre, que estaba formada por un portero, un tartanero y siete domésticos, según refleja el padrón de la época ${ }^{17}$.

En conclusión, podemos decir que la riquísima decoración que tenía el palacio en tiempo del marqués de Campo, era el perfecto reflejo de su posición social y económica y, por consiguiente, motivo de admiración. Los diferentes estilos de decoración: gótico, renacentista, regencia, Luis XV, Luis XVI, árabe, bizantino, etc., llegaron a tener una connotación precisa, como en arquitectura, y por ejemplo el estilo francés evocaba un gusto aristocrático y el gótico una cierta melancolía y una línea genealógica remota y un tono respetable ${ }^{18}$. Este tipo de asociaciones estaban dirigidas a un grupo social muy reducido, la aristocracia del dinero, que eran quienes tenían capacidad adquisitiva para permitirse estos lujos.

El sistema de iluminación del palacio era una novedad del momento, gracias a las relaciones de José Campo con empresas en Inglaterra. Esos sistemas de iluminación también fueron utilizados en diversas ocasiones con motivo de celebraciones y festividades en la ciudad, y el palacio lucía una fachada profusamente decorada que era objeto de admiración pública. Vicente Boix, su cronista, nos informa de los adornos que puso en la fachada en mayo de 1867 con motivo del segundo centenario del traslado de la imagen de la Virgen de los Desamparados a la nueva basílica, y que sorprendieron a todos por el sistema de iluminación de diamante, que había importado de Londres, utilizado para resaltar los emblemas de María19. Pero de estas iluminaciones hablaremos con más detenimiento en otro capítulo de esta tesis.

\footnotetext{
${ }^{17}$ AMV. Padrones 1848 y 1851. En 1862 hay mayordomo, ama de llaves....

${ }^{18}$ COURDALE, C. Historia de la decoración. Barcelona: Stylos, 1983, p. 213.

${ }^{19}$ CATALÁ, Miguel Ángel. 1997, p. 35. 


\section{1.-Sala de artistas. Interpretación iconográfica}

Nos vamos a detener en esta sala del palacio para realizar una interpretación iconográfica de la decoración del techo, que hoy en día se conserva en bastante buen estado y está llena de alegorías y simbología. Como ahora veremos, toda la decoración, hasta el más mínimo detalle no se hizo por azar, sino cumpliendo un plan trazado por José Campo para dejar constancia de su persona y su categoría económica y social.

La sala se llama sala de artistas en el inventario de los bienes de los marqueses realizado a la muerte de la primera esposa del marqués en 1889, y la sala está situada después de la sala de armas y antes del gran salón donde se realizaban los bailes. Posiblemente se llame así por su decoración de la que ahora hablaremos y porque parece que en esa sala se colocaban los músicos que deleitaban a los invitados en los bailes que se celebraron, como ya he dicho. Es cierto que el marqués, una vez se estableció en su palacio del paseo de Recoletos de Madrid, pocos bailes celebró en el palacio de Valencia, pero sí que pudo celebrarlos en ocasiones espaciales como el segundo centenario del traslado de la Virgen de los Desamparados en 1867, fecha en que adornó toda la fachada del palacio por las celebraciones y que veremos en otro capítulo de esta tesis.

La bóveda esquifada plana o de plafón de la sala de artistas está decorada en estuco y tiene en realidad dos programas iconográficos diferentes. Podríamos decir que las figuras que encontramos en las aristas entrantes hacen referencia a la faceta del marqués como mecenas de las artes y los medallones que encontramos en los cuatro paños hacen referencia al marqués como hombre de negocios con grandes empresas (Fig. 3.18). 


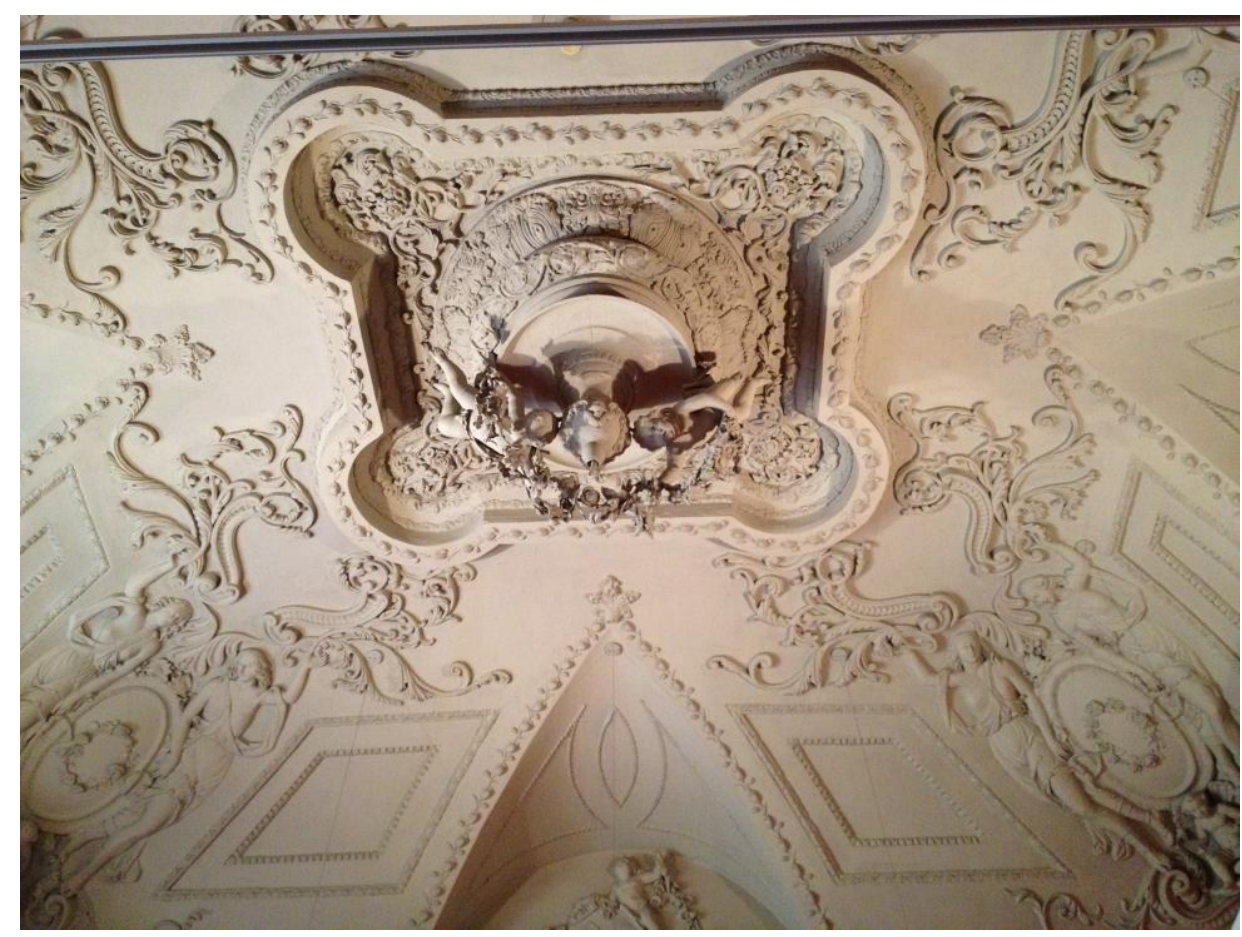

Fig. 3.18 Palacio del marqués de Campo. Bóveda esquifada de la sala de artista Estado Actual. Fotografía de la autora.

José Campo fue promotor, mecenas y coleccionista de arte. Estas tres cualidades son las que quedan patentes en esta tesis por su gran implicación en la construcción de edificios y la promoción de arquitectos, escultores y decoradores. Por ello entra dentro de la lógica que en la decoración de la sala de artistas aparezcan en las aristas las personificaciones de la escultura, la pintura, la música y la arquitectura, pero ésta última no conserva los atributos. (Figs. $3.19,3.20,3.21$ y 3.22$)$.

La alegoría de la escultura (Fig. 3.19) lleva en sus manos un busto y un martillo, es decir, la herramienta y el resultado del proceso del artista, la obra de arte.

La alegoría de la pintura (Fig. 3.20) lleva una paleta de pintor y en la otra mano no sabemos lo que llevaba porque no se conserva, pero en otras alegorías en la otra mano lleva un pincel. 
La alegoría de la música (Fig. 3.21) lleva una lira, para realizar las composiciones musicales

Y el otro amorcillo (Fig. 3.22), que debía de representar a la arquitectura, podía llevar por ejemplo un compás, un plano, un pequeño edificio, etc., ya que en otras representaciones y alegorías de este tipo los atributos son esos.

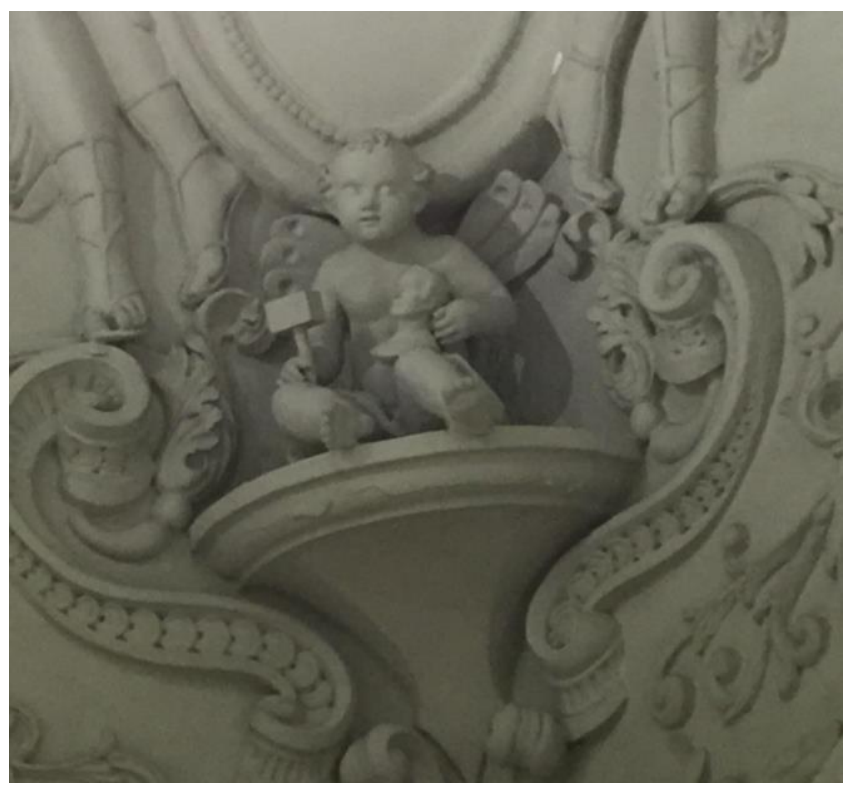

Fig.3.19 Alegoría de la escultura. Fotografía de la autora.

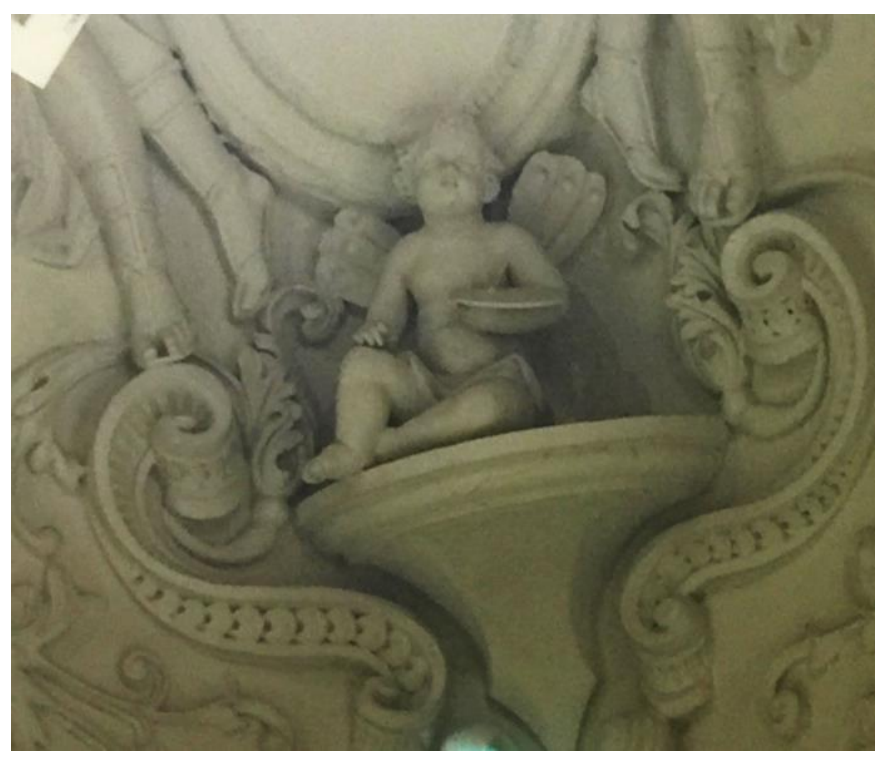

Fig.3.20 Alegoría de la pintura. Fotografía de la autora. 


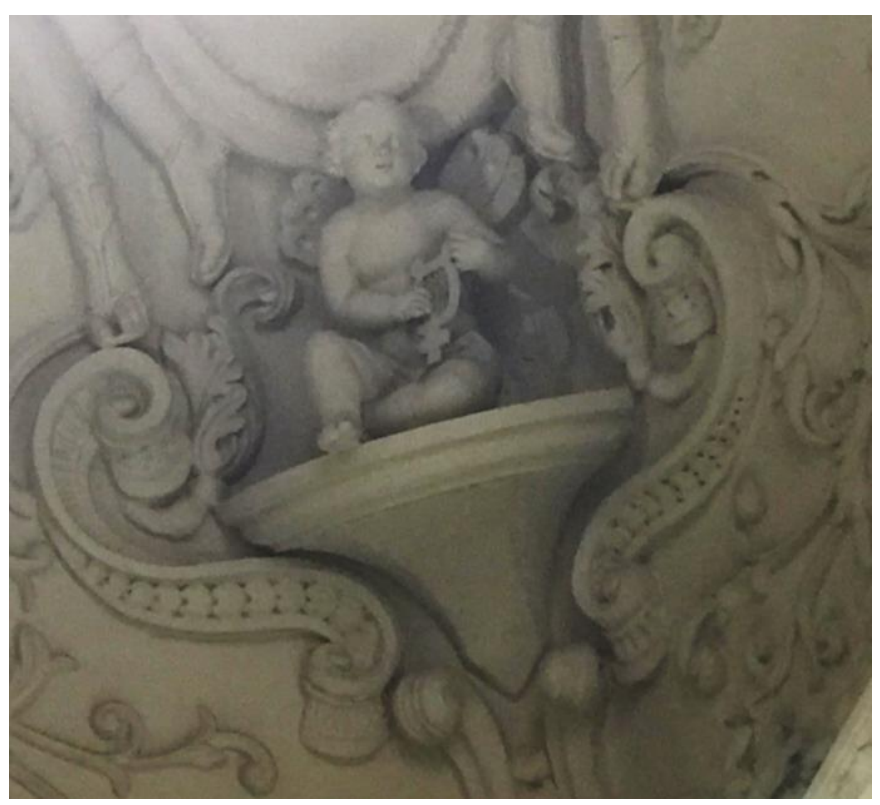

Fig. 3.21 Alegoría de la música. Fotografía de la autora.

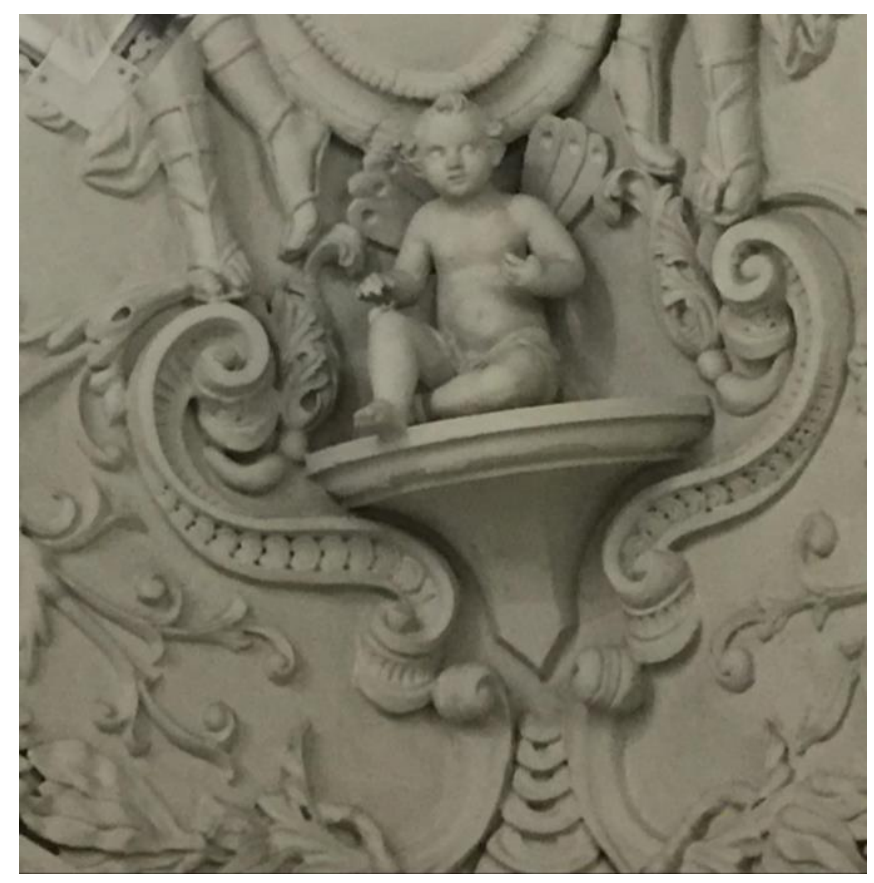

Fig. 3.22 Posible alegoría de la arquitectura. Fotografía de la autora. 
Estas alegorías son similares a las que realizó José del Castillo (Madrid 1737-Madrid 1793) para el gabinete de la Princesa de Asturias en el palacio Real del Pardo. Son seis lienzos para tapicería que representan amorcillos en alegorías de la pintura, la música, la fama, la astronomía, la aritmética, y la arquitectura. Reproducimos dos ejemplos: la pintura y la música ${ }^{20}$ (Figs. 3.23 y $3.24)$.

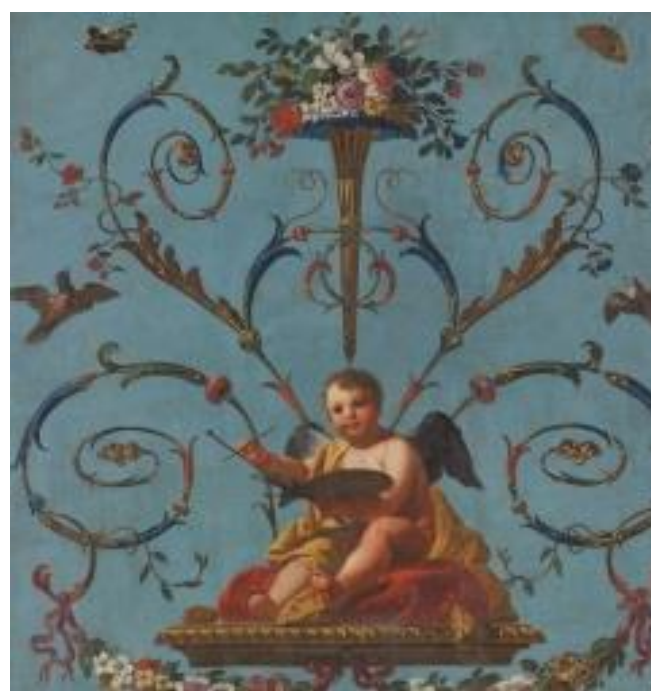

Fig.3.23 Alegoría de la pintura. José c Castillo. Gabinete de la princesa de Astu del palacio del Pardo.

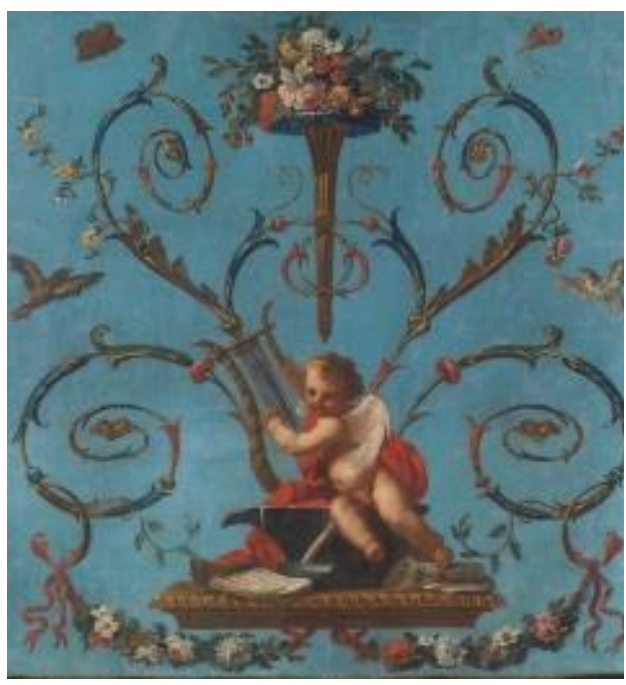

Fig.3.24 Alegoría de la música. José c Castillo. Gabinete de la princesa de Astu del palacio del Pardo.

Los cuatro amorcillos alados están situados en sendas peanas y dan un efecto ligero y armonioso a la vez, revelando el gusto del siglo XIX. Sobre ellos un medallón con una guirnalda de flores en su interior; y a su vez el medallón aparece flanqueado por lo que parecen dos musas. Las musas son las inspiradoras de las artes y aparecen aquí con vestiduras vaporosas, sandalias de cintas, los pechos al descubierto, y el cabello suelto.

${ }^{20}$ Imágenes publicadas en:

https://www.museodelprado.es/coleccion/obra-de-arte/alegoria-de-lapintura/9aed7935-c11b-4.3do-85f2-a4a13f6fd15e https://www.museodelprado.es/coleccion/obra-de-arte/alegoria-de-lamusica/1c6a1108-c7ab-412a-8e16-4eoad0193264_consulta realizada el 10 de marzo de 2019. 
Con origen en la mitología griega, las nueve musas de Apolo eran invocadas por los artistas para encontrar la inspiración, pero en la decoración de la bóveda aparecen dos en cada esquina, repitiéndose en las cuatro esquinas exactamente la misma representación, con el significado de la musa como inspiración como concepto, pero sin diferenciar entre ellas.

Las decoraciones de los paños hacen referencia a las actividades comerciales del marqués, pero son más complejas de interpretar. En dos de los paños hay un medallón sostenido por tres geniecillos que están sobre nubes y entre ellos una cinta decorativa. En los otros dos paños la composición decorativa es similar, pero en lugar de medallones tienen forma de escudos.

Tanto los dos medallones como los dos escudos tienen en su interior decoración en relieve que alude a las actividades económicas del marqués. En uno de los medallones aparece un farol (Fig. 3.25) y es en referencia a uno de los logros más importantes de José Campo para Valencia, la iluminación de las calles de la ciudad. La iluminación de las calles era necesaria porque cuando caía el sol la actividad de la ciudad se paraba, todo estaba a oscuras salvo algún farol de aceite y eso favorecía la inseguridad.

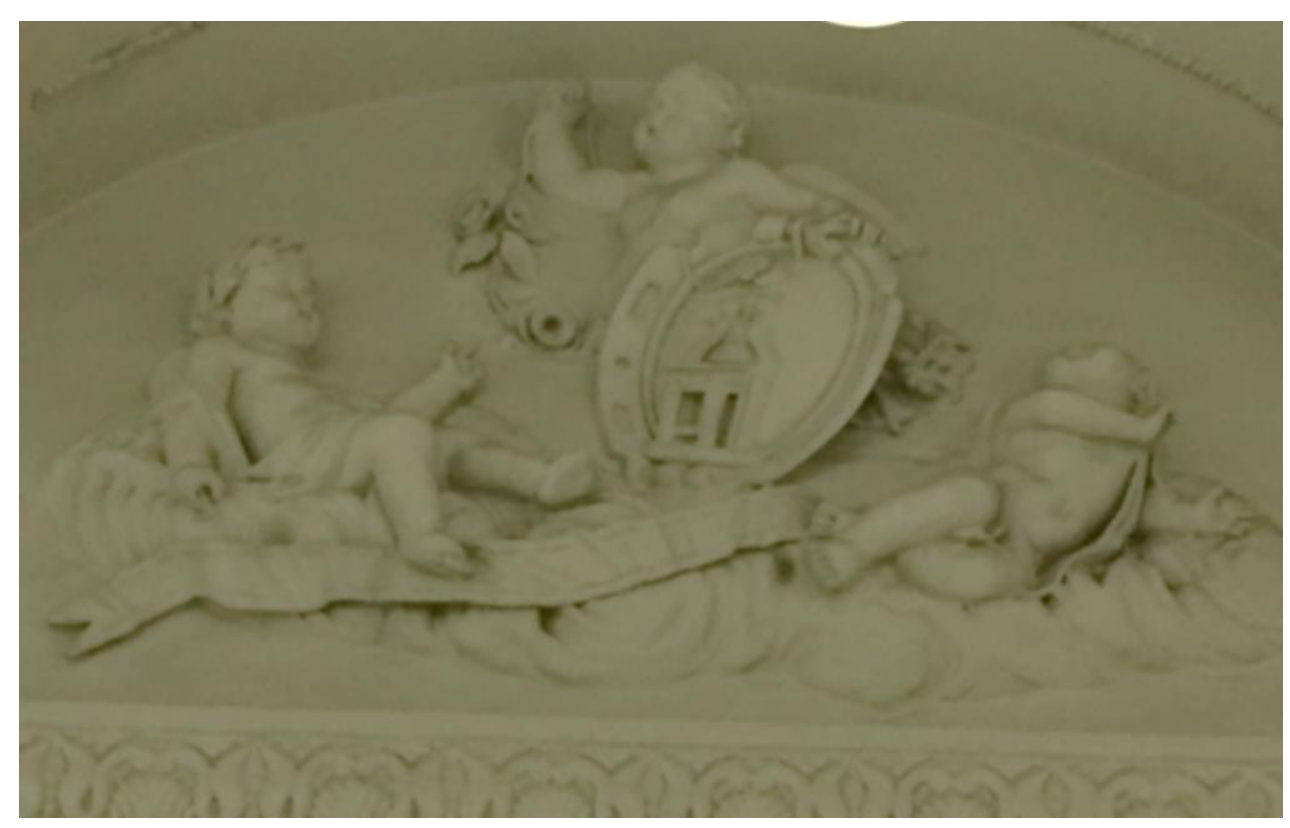

Fig. 3.25 La Iluminación. Fotografía de la autora. 
Otra de las representaciones (Fig. 3.26) podría ser alusiva a la fábrica de gas del marqués, porque en la imagen se ve un edificio con una chimenea de la que parece salir una llama, pero no lo podemos asegurar. En 1844 se inauguró la iluminación de gas de la Glorieta y con ello comenzó un gran negocio para Campo, porque creó la Sociedad de alumbrado de Gas, consiguió la concesión del ayuntamiento para el alumbrado y además era propietario de parte de la compañía de gas Lebón que se instaló en la ciudad, con la llegada de la iluminación de gas las calles cobraron vida y se volvieron más seguras.

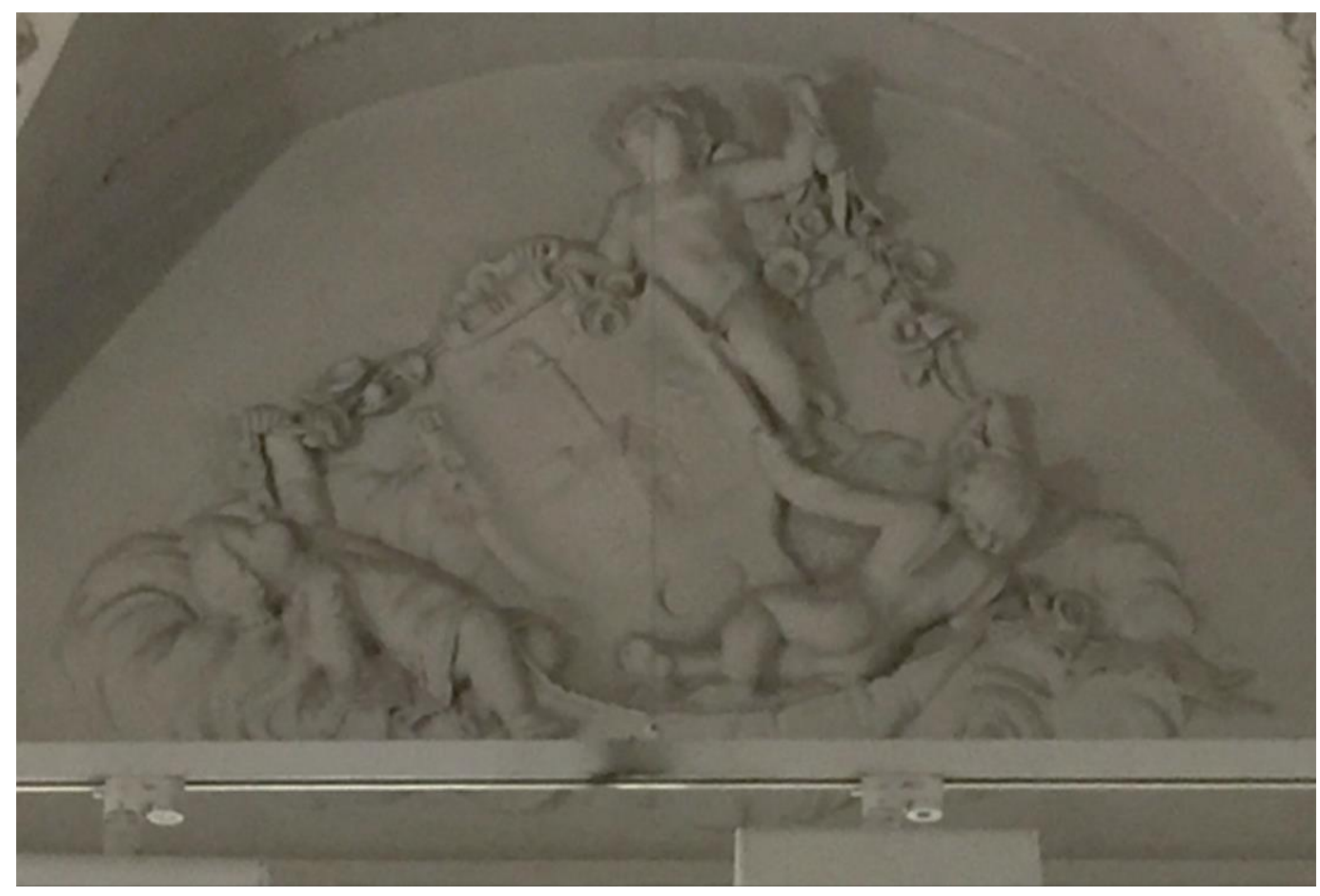

Fig.3.26 Posible representación de La Fábrica de Gas. Fotografía de la autora

Otro grupo de amorcillos (Fig. 3.27) parece estar representado la navegación porque sostienen un medallón que simula ser como una brújula con los puntos cardinales y podría se alusivo al negocio de los vapores del marqués, que contaba con una flota de 25 barcos para realizar el transporte de correo y mercancías entre España y Filipinas. 


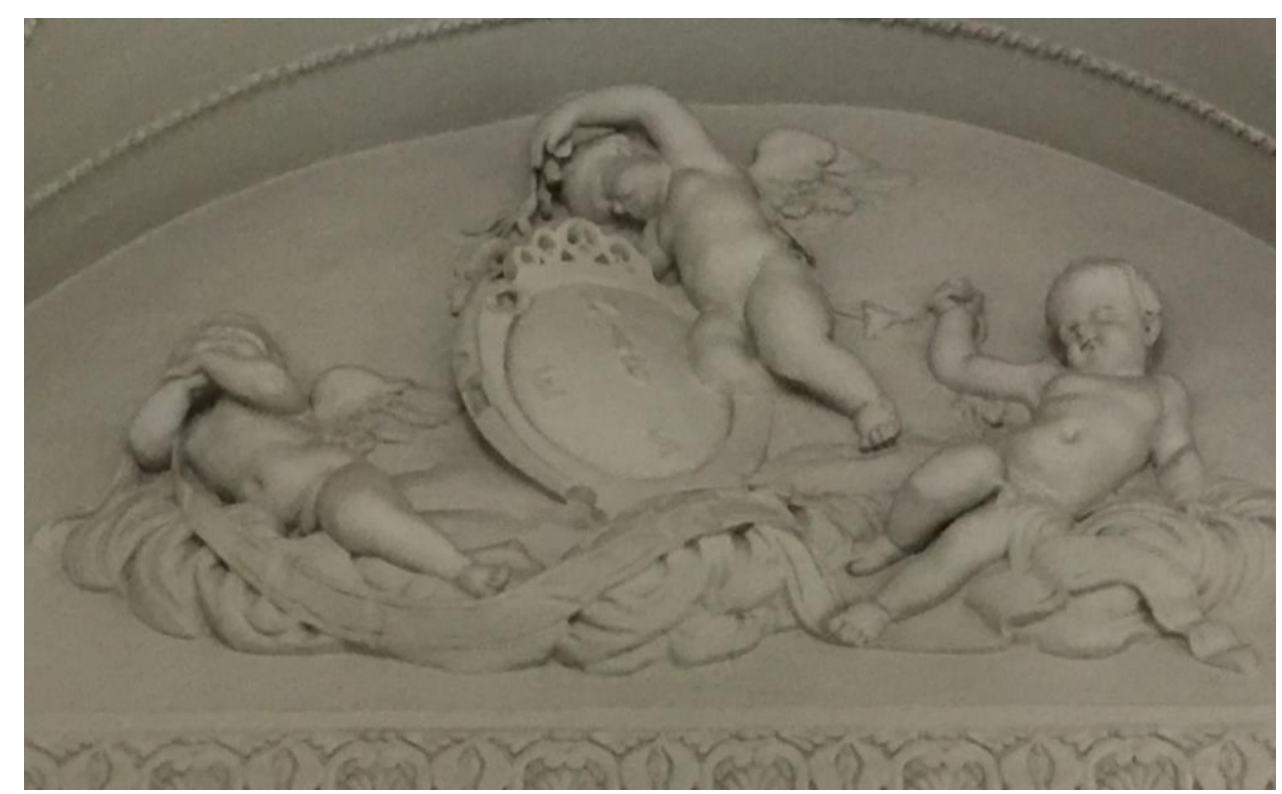

Fig. 3.27 Posible representación de La Navegación. Fotografía de la autora.

Y el último grupo de amorcillos (Fig. 3.28) podría está relacionado con el edificio del puerto de Valencia, cuya reforma impulsó como parte de su proyecto de mejorar y modernizar Valencia. Además, dado su negocio de vapores estaba muy interesado en habilitar el puerto y que fuera válido para el atraque de sus barcos.

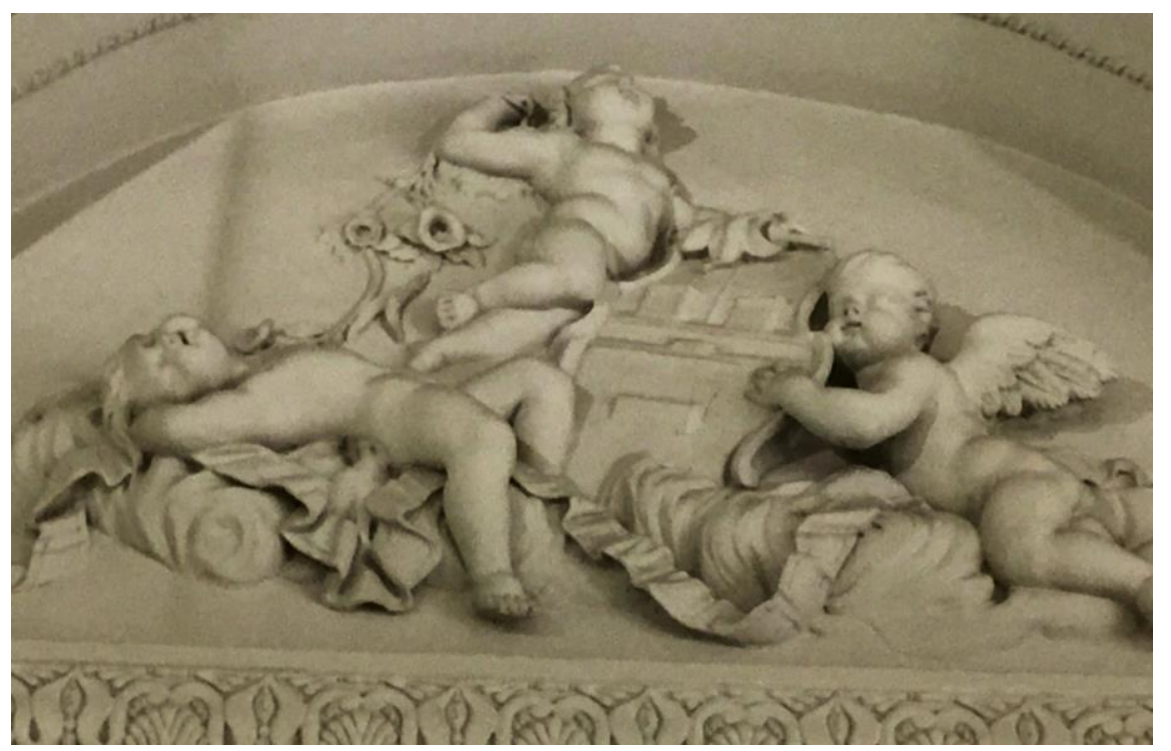

Fig. 3.28. Posible representación de El Puerto. Fotografía de la autora. 
Después de analizar el programa icnográfico de esta bóveda, nos preguntamos si fue idea del propio marqués o si hubo un artífice que le propuso la decoración. Pero conforme vamos conociendo la figura y la personalidad de José Campo, me inclinaría a decir que la decoración de los amorcillos y las personificaciones fueron idea suya. José Campo sabía muy bien lo que quería demostrar y dejar patente a los ojos del público. No era un hombre inculto sino un hombre ilustrado que también decidió, entre otras cosas el programa iconográfico de la fachada del segundo asilo que construyó, o el programa iconográfico de un altar con retablo en Torrijo del Campo, el pueblo de sus padres y que luego será estudiado en profundidad en otro capítulo de esta tesis. 


\section{2.- El palacio del paseo de Recoletos 14, Madrid}

Cuando en 1864 el General Narváez nombra a José Campo Senador del Reino, éste traslada su residencia definitiva a Madrid, donde se abre para él un nuevo periodo de proyectos económicos y empresariales; sin embargo, desde hacía varios años disponía de una residencia en la calle Fuencarral número 113, que ocupaba cuando debía ir a la capital por asuntos de política o negocios ${ }^{21}$.

Poco después José Campo fijó definitivamente su residencia en un palacete del Paseo de Recoletos, construido sobre un solar de unos $5.000 \mathrm{~m}^{2} \mathrm{y}$ perteneciente a uno de los barrios más exclusivos de la ciudad que se estaba reformando de acuerdo con el proyecto de alineación del arquitecto municipal Isidro Llanos, comenzado en 1835 y que formaba parte de un gran proyecto de reformas para convertir Madrid en una verdadera capital. Dicho proyecto provocará el nacimiento de nuevas manzanas y solares en las zonas del Paseo de la Castellana, Paseo de las Delicias, y el Paseo de Recoletos, llamado así por la anterior existencia del convento de los padres Recoletos y que fue derribado para ensanchar el paseo y construir palacios con jardines como el del marqués de Salamanca, el marqués de Remisa y el de la familia Calderón, que fue el que compró José Campo, justo al lado de la actual Biblioteca Nacional. El eje Recoletos-Castellana se convirtió en el más elegante de Madrid²2.

${ }^{21}$ Gaceta de los Caminos de hierro, 1862, año 7, n. ${ }^{\circ}$ 8, p. 162.

${ }^{22}$ NAVASCUÉS, Pedro. "Madrid, ciudad y arquitectura (1808-1898)". En: FERNÁNDEZ GARCÍA, Antonio (dir.). Historia de Madrid. Madrid: Editorial Complutense,1994, p. 401-439. 
El 24 de enero de 1866 Isabel II puso la primera piedra de la nueva Biblioteca Nacional, situada en el paseo de Recoletos (Fig. 3.29). Las obras se realizaron con mucha lentitud y, aunque se acabó en 1892 no fue abierta al público hasta 1896. La ceremonia de colocación de la primera piedra fue fotografiada y dibujada, y gracias a ello tenemos las primeras imágenes del palacio del sr. Campo, ya que su palacio estaba situado en el solar contiguo al de las obras 23 .

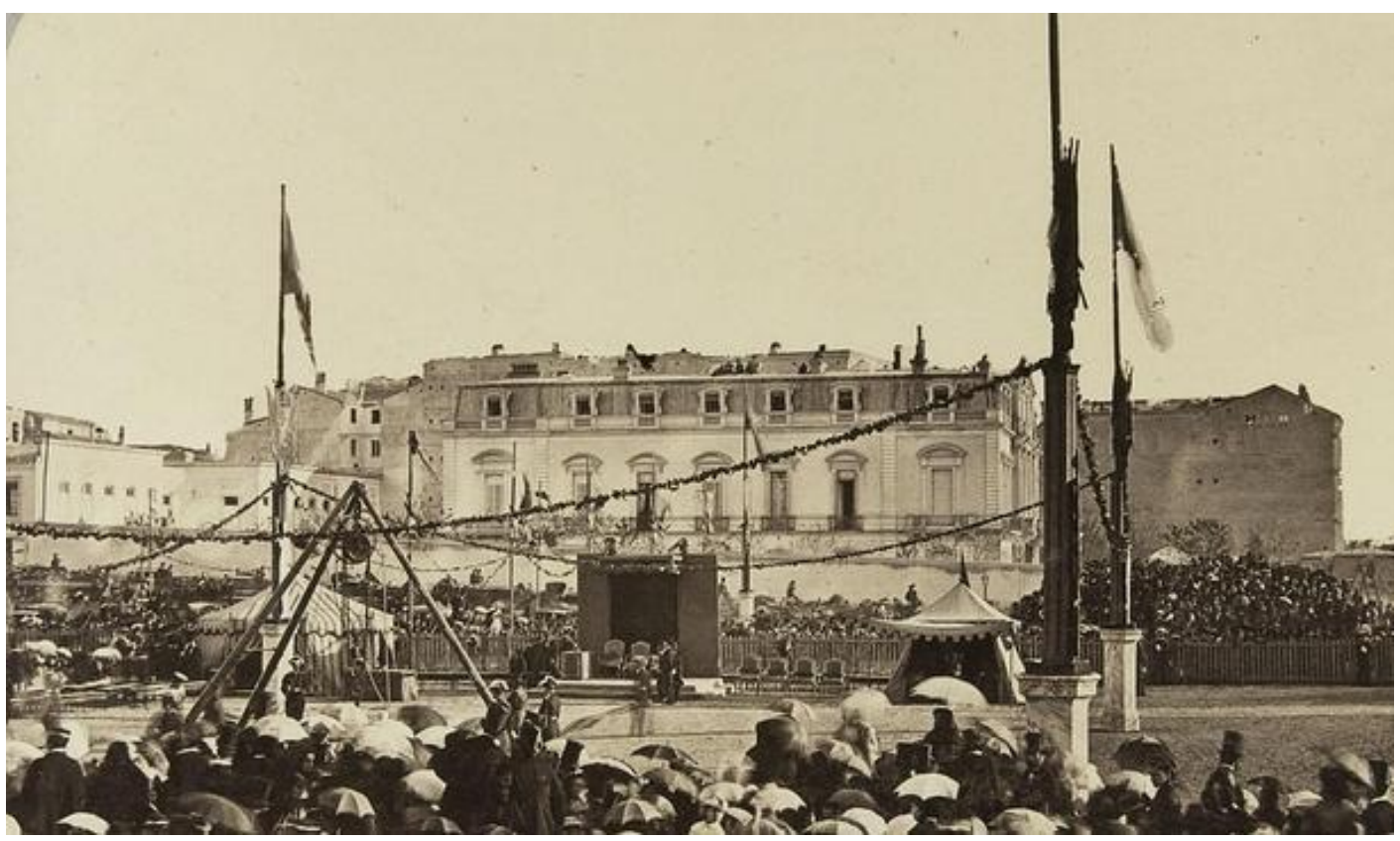

Fig. 3.29 Ceremonia de Colocación por la Reina Isabel II de la primera piedra de la Biblioteca Nacional. 24 de enero de 1886. La edificación de detrás es el palacio de José Campo.

Los grandes hombres de finanzas de la época de Isabel II tendrán casa en esta zona. Estos personajes pertenecen al grupo de capitalistas del momento, que desean vivir en casas de arquitectura noble, ricamente decoradas con obras de arte que muestran a los invitados en las grandes recepciones y cenas en las que se cierran importantes negocios 24 .

${ }^{23} \mathrm{http} / /$ www.bne.es/es/Micrositios/Exposiciones/BNE300/Exposicion/Seccion 4/Obra20.html?origen=galeria consultada el 20 de enero de 2017. 24 NAVASCUÉS, Pedro. Un Palacio Romántico, Madrid 1846-1858. Madrid: Ediciones el Viso, 1983, p. 42. 
Como dice Pedro Navascués: "entre el Madrid de Fernando VII y el de Alfonso XII, hay un largo puente que coincide con el Madrid de Isabel II, en el que la ciudad rompe su estrecho molde y se decide a cambiar de imagen, primero con la reforma de su casco antiguo y después ensayando la alternativa del Ensanche"25. Continúa diciendo que "el Madrid isabelino inició un modesto renacimiento urbano, de carácter burgués y progresista, que iba a ir acompañado de un renacimiento arquitectónico del mismo signo”26.

Lo curioso de esta circunstancia es que estas propiedades, ocupadas por la aristocracia surgida en parte del comercio, de los negocios y de la banca, eclipsan a las de la nobleza y aristocracia antigua, pero si bien ésta ha sostenido tres siglos sus casas, aquella en treinta años ha trasladado el dominio de más de dos docenas de las suyas. La explicación es que los nuevos ricos no tenían una situación económica o política estable en el tiempo y hubo casos como por ejemplo el del marqués de Salamanca o el del propio José Campo que provocaron sucesivos cambios en las propiedades: el primero tuvo que subastar varias veces parte de sus bienes y murió arruinado; y el segundo murió con tantas deudas que para poder pagarlas el palacio y todo su contenido se vendió.

La certificación del Registro de la Propiedad de Madrid de 21 de mayo de 1877 nos dice que José Campo, adquirió la propiedad mediante subasta pública a los herederos de Manuel Calderón y Molina por la cantidad de 9.878.564 reales (nueve millones ochocientos setenta y ocho mil quinientos sesenta y cuatro reales), y que la escritura de la venta se firmó en día 31 de octubre de 1864.

\footnotetext{
25NAVASCUÉS, Pedro. 1999, p. 40.

${ }^{26}$ NAVASCUÉS, Pedro. 1994, p. 414. 
Y la misma certificación nos dice que es una "Casa palacio aislada con jardín que la circunda y otras dependencias habitables, todo cerrado con un muro sito en esta Corte y su calle paseo de Recoletos por donde tiene su entrada principal”" 27.

Gracias al procedimiento de autorización de la venta de la casa por los herederos menores de edad del Sr. Calderón al Sr. Campo, podemos saber las dimensiones. La propiedad entera tenía una dimensión de 5750'86 metros cuadrados. La entrada principal estaba por el paseo de Recoletos y la fachada media 57'50 metros, la fachada de la calle Villanueva media 97'40 metros, la del sur medía 79'37 metros, y la de la calle del Cid, donde se situaban las oficinas de las empresas del marqués, media 65'25 metros. El palacio tenía una superficie de 1.286 '76 metros cuadrados sin contar ni pórtico ni escaleras exteriores. Las casas destinadas a cocheras y cuadras median 875 '6 metros cuadrados. El jardín con estufas, pabellones de portero, muros y verjas y otras dependencias tenía una superficie de 3.579'70 metros cuadrados ${ }^{28}$. Estas medidas nos permiten hacernos una idea de la magnitud de la vivienda y de los gastos y personal necesario para su perfecto mantenimiento.

Hoy en día el edificio no existe, pero podemos conocer su aspecto gracias a varias imágenes y dibujos. Uno de ellos es el grabado que publicó Fernández de los Ríos en su Guía de Madrid en 1876 (Fig. 3.30) en el que podemos ver el palacete, que era de estilo francés y rematado por una inconfundible mansarda; con un gran un jardín y rodeado por una valla con dos pabellones de portería en la entrada principal29.

${ }^{27}$ Certificación del Registrador de la Propiedad de Madrid sobre la posesión de una casa en el Paseo de Recoletos. Archivo del Senado de España. En: Expediente personal del senador Marqués de Campo, D. José Campo Pérez Arpa y Vela, por la provincia de Valencia y vitalicio (1864-1869), Legislatura 1877, carpetilla 03, rentas.

${ }^{28}$ AHPM, T. 28429, fols. 1004 y ss.

29 MARTÍNEZ DE LOS RÍOS, A. Guía de Madrid: manual del viajero y el forastero. Madrid: Ilustración Española y Americana, 1876, p. 721. 
Hacía contraste, por ejemplo, con el del palacio del marqués de Salamanca, de traza totalmente italianizante.

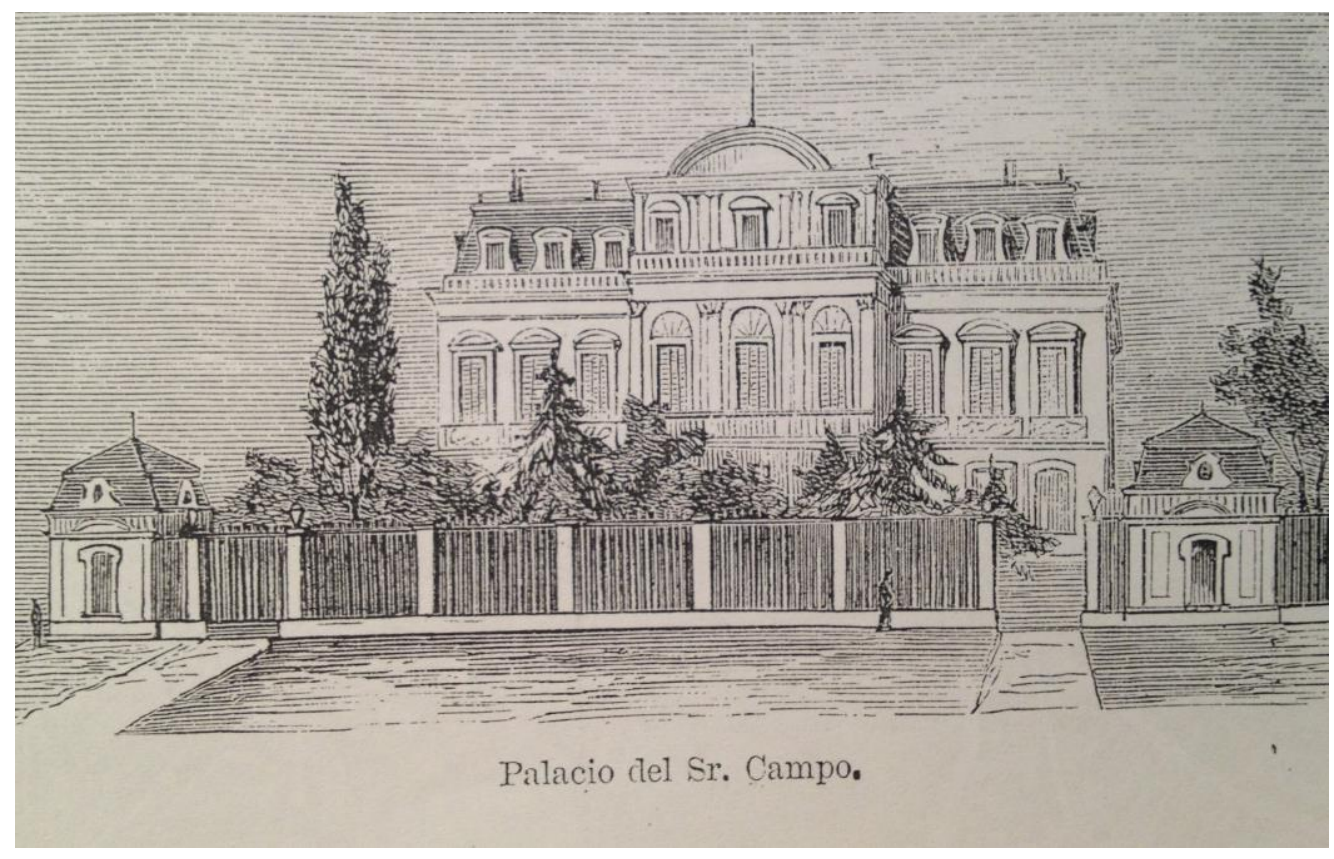

Fig. 3.3o Palacio del Sr. Campo. Imagen publicada en Guía de Madrid, 1876.

Otra imagen del palacio la encontramos en la revista La Ilustración Española y Americana con motivo de las bodas de Alfonso XII celebradas en 1878 (Fig. 3.31).

El marqués de Campo lo engalanó con una iluminación tan espectacular que se publicó un grabado del palacio iluminado y una crónica con la descripción. Era una iluminación elegante y variada, cuya instalación estuvo dirigida por el ingeniero Navarro Reverter (1844-1924), que resaltaba perfectamente todas las líneas arquitectónicas del edificio. 
Era la decoración más notable de toda la corte y causaba admiración a quienes la contemplaban ${ }^{30}$. No podemos olvidar en ningún momento que con este tipo de actuaciones José Campo alardeaba de su posición económica y social, pero a la vez promocionaba su propio negocio de iluminación.

Esta iluminación y otras similares que tuvieron lugar en el palacio de José Campo, serán objeto de análisis pormenorizado en otro capítulo de esta tesis.

Otra foto del palacio la encontramos en la obra Un palacio romántico (Fig. 3.32), de Pedro Navascués Palacios31.

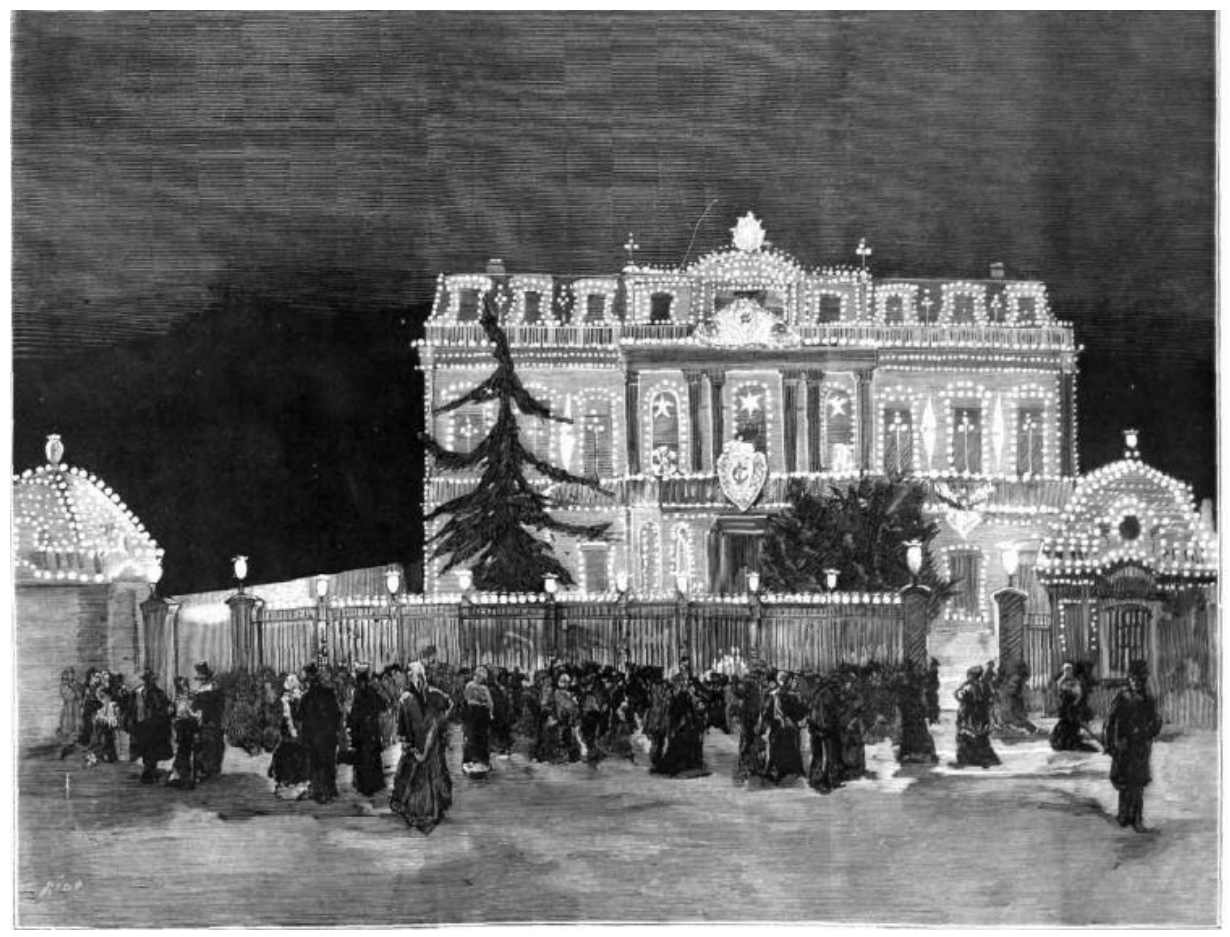

Fig. 3.31 Iluminación del palacio del Marqués de Campo durante las noches de fes reales (dibujo al natural por el señor Domec). Madrid. Imagen publicada en La Ilustración Española y Americana.

${ }^{30}$ La Ilustración Española y Americana, año XXII, núm. V, 8 de febrero de 1878, p. 90 y 94.

${ }^{31}$ NAVASCUÉS, Pedro. Un palacio romántico. Madrid 1846-1858. Madrid: Ediciones el Viso, 1983, p. 43. 


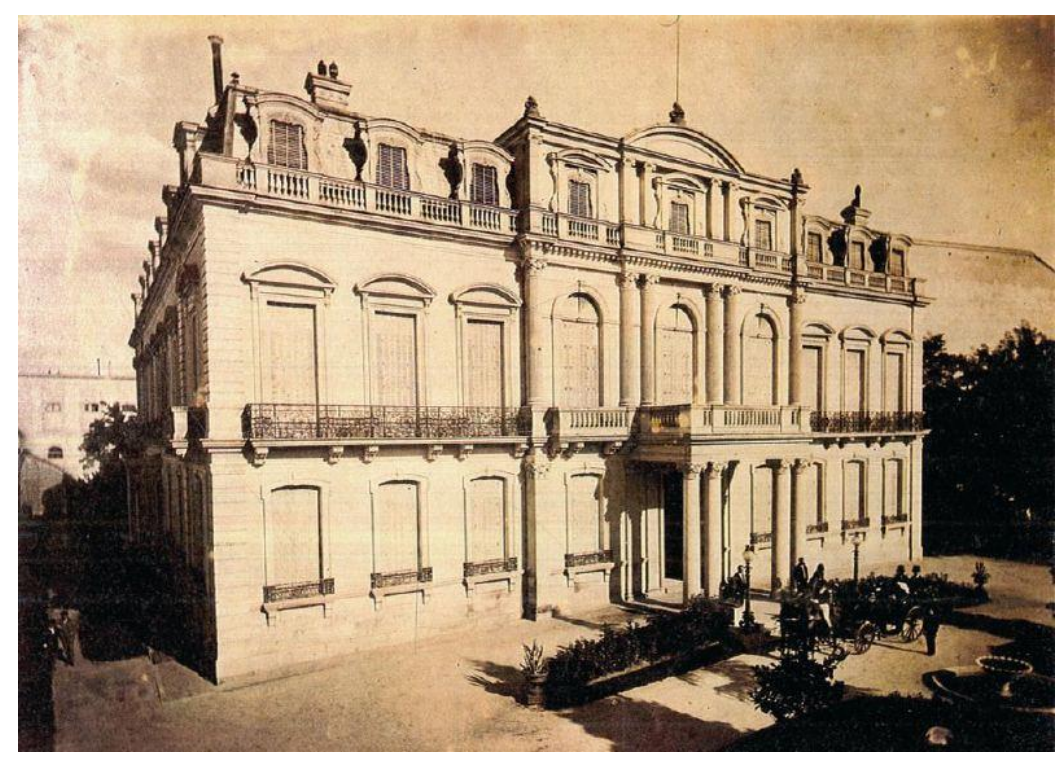

Fig. 3.32 Palacio del Marqués de Campo. Paseo Recoletos 14, Madrid. Foto publicada en Un palacio romántico.

Otra imagen de la que disponemos es la del plano a escala de 0,02 por metro, de la valla del palacio en el que se aprecian las casetas del portero y la riqueza de las verjas que rodeaban el recinto (Fig. 3.33). El dibujo se realizó por el arquitecto Manuel Seco Rodríguez ${ }^{2}$ cuando se solicitó la licencia de obras para la construcción del palacio en 1860.

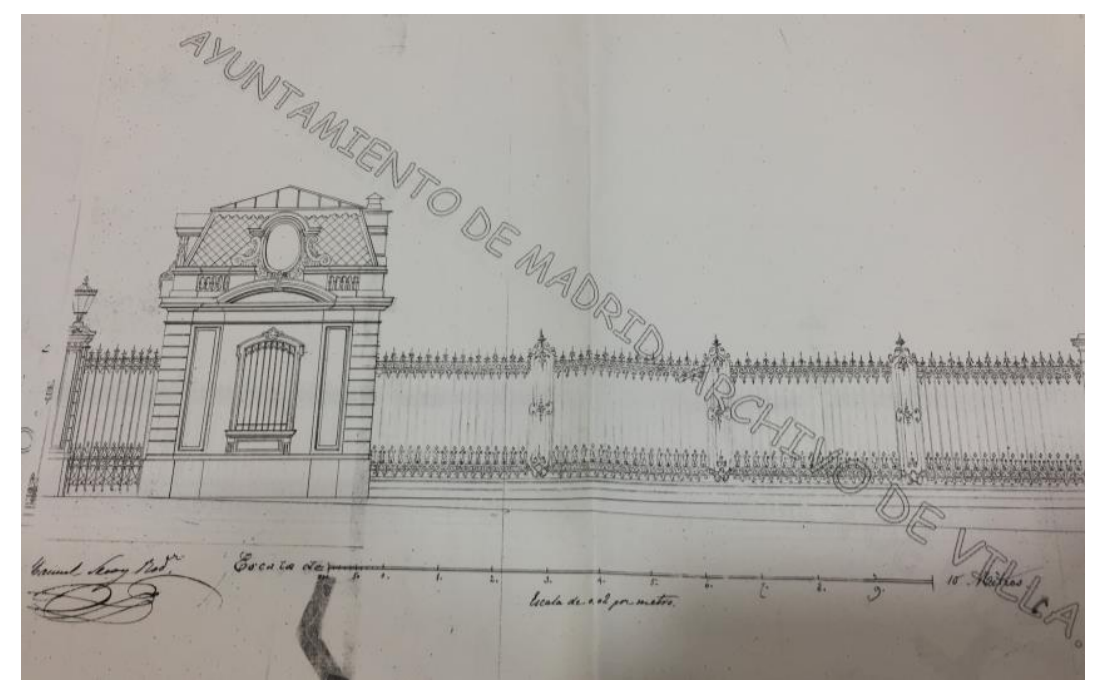

Fig. 3.33 Plano a escala de la verja y la caseta de portero. Manuel Seco Rodrígu€ Ayuntamiento de Madrid, Archivo de Villa.

$3^{2}$ Expediente instruido a solicitud de D. Carlos Manuel Calderón sobre edificación de una casa en los que fue la Huerta de Recoletos, Archivo de la Villa, Madrid, Negociado de obras, 1860, AVS 5-232-109 y 5-270-32. 
Fue construido durante el reinado de Isabel II por el arquitecto Juan Esteban Puerta.

Los dibujos publicados en Los palacetes de la Castellana33 reproducen la fachada principal y la lateral (Fig. 3.34), y se aprecia perfectamente la división en tres partes de la fachada principal, con un núcleo central con columnas y pilastras, que sobresale con una especie de porche que es la entrada principal de la casa y que sustenta un balcón. La planta principal tiene una balconada con balaustrada de piedra en el módulo central y de hierro forjado en los laterales.

El edificio se remata con una mansarda de pizarra con sus huecos correspondientes y sobre su parte central un frontón curvo. Además, podemos observar que los huecos, que tenían contraventanas de madera, son diferentes en cada planta, por ejemplo, los frontones de los huecos de la primera planta son curvos. Resalta el cortavientos de la fachada lateral, con una carpintería de tipo francés que posiblemente fuera colocado a posteriori.

Este tipo de construcciones solían seguir una misma línea y normalmente todas constaban de sótano para la cocina y almacenes, planta baja y dos pisos, cochera y bodega.

33 AGUILAR OLIVAR, Carlos; CASAS RAMOS, María Encarnación. Los palacetes de la Castellana. Madrid: Editorial fundación Cultural COAM, 1999. 

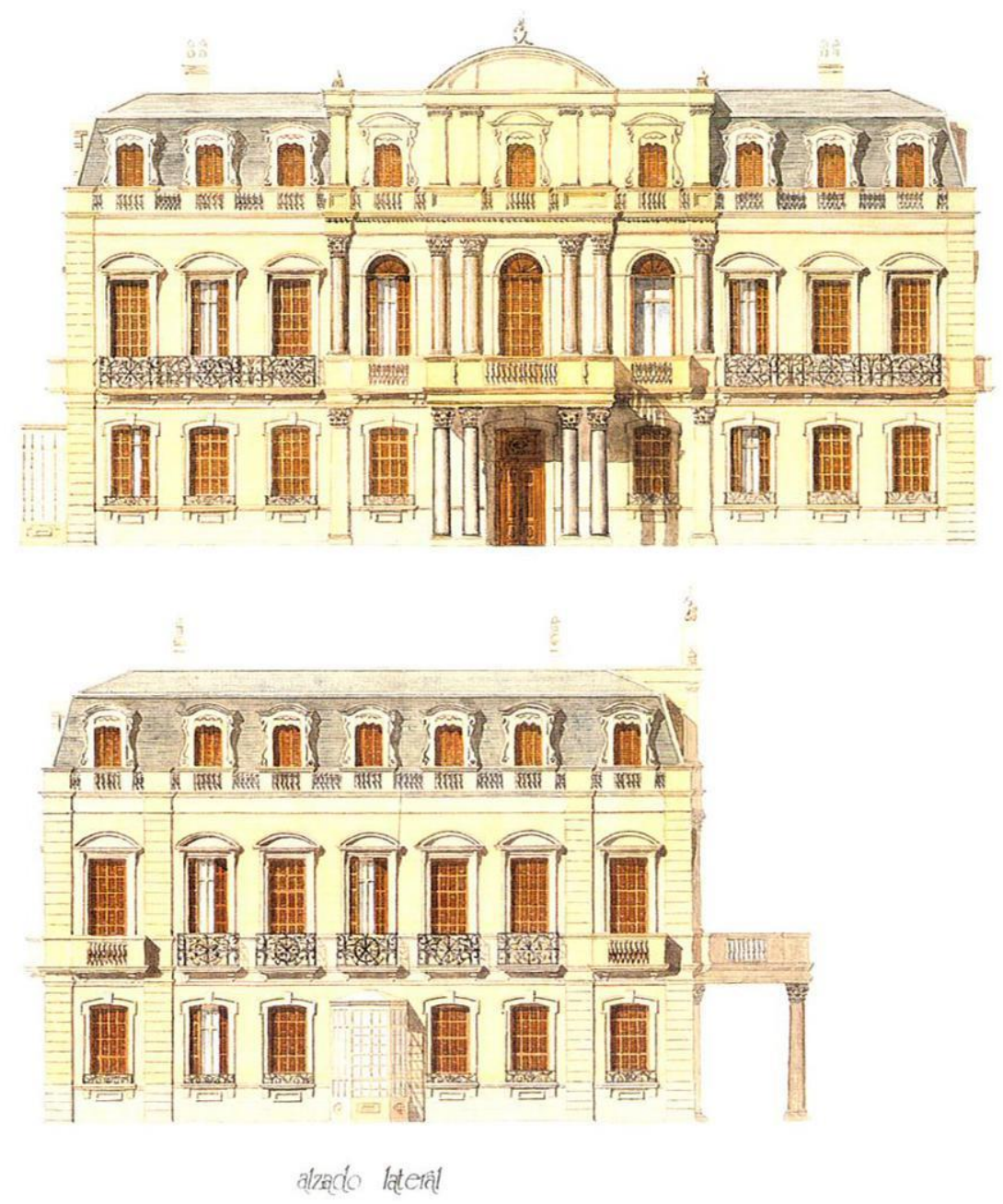

Fig. 3.34 Palacio del marqués de Campo.

Dibujo publicado en Los palacetes de la Castellana.

El magnífico palacio fue pasto de las llamas el día 3 de noviembre de 1869. Toda la información del suceso se puede encontrar en el legajo correspondiente del Archivo Histórico Nacional34. José Campo tenía asegurado el palacio con la compañía aseguradora El Fénix Español, y en el acta de reconociendo pericial de los daños sufridos podemos encontrar datos muy interesantes sobre el palacio.

${ }_{34}$ ES.28079.AHN/4.1.47.3//DIVERSOS-TITULOS_FAMILIAS,3769, N.20. 
El informe fue realizado por el arquitecto de Ayuntamiento de Madrid, Antonio Ruiz de Salces nombrado por la compañía aseguradora y el también arquitecto Francisco Jareño, nombrado por el propio José Campo. En el parte se dice que la causa del siniestro ha sido la aproximación involuntaria de una luz a las cortinas de la cama, de lo que se deduce que la cama del marqués tenía dosel.

El valor de los daños asciende a un total de 50.000 reales y en el informe de daños se habla de la sala de armas, del dormitorio, del tocador, de la antesala, de la galería y de las fachadas. El expediente nos da datos exactos de la medida de alguna de las instancias e incluso el nombre de quien realizó los trabajos de reparación de los daños. En la (Fig. 3.35) podemos ver un dibujo del estucado del techo y las medidas de la habitación.

- La sala de armas medía $9.62 \times 4.66$ x 4.84 metros de altura, el acceso era por una puerta de madera doble hoja, tenía el techo con tallas doradas y se conectaba también con el dormitorio.

- El dormitorio medía 4.77 x 4.57 x 4.84 metros de altura, el techo tenía adornos de cartón piedra en dorado; las ventanas tenían jambas de madera tallada y había una chimenea de mármol. Las ventanas de todas las estancias eran de hierro, con cristales de luna, que era una clase de cristal muy caro en esa época.

- El tocador tenía dos partes separadas entre sí por una puerta de doble hoja con cristales de luna; una parte medía 4.30 × 3.00 x 4.85 metros de altura con el techo pintado y las paredes empapeladas y la zona de lavabo y baño medía 2.95 x 3.00 x 4.85 metros de altura. El techo de estas estancias estaba pintado y los muros empapelados.

- La antesala medía 3.00 x 4.90 x 4.85 metros de altura y su techo estaba pintado. 
- La galería también sufrió daños y hubo que volverla a pintar toda; medía 73 metros de largo por 4.85 metros de altura y 3.25 metros de ancho, y tenía 23 huecos de ventanas de 3.50 metros de alto por 1.80 metros de ancho. Además, hubo que limpiar la fachada principal y una lateral y reparar varios huecos con sus jambas y repisas de piedra.

Los trabajos de pintura y dorado fueron realizados por M. Guibert, pintor y dorador con taller en la calle del Arenal número 4 de Madrid. Los trabajos de herrería de sustitución de persianas y cerraduras fueron realizados por Callejo; los trabajos de carpintería y cristalería por Laugan.

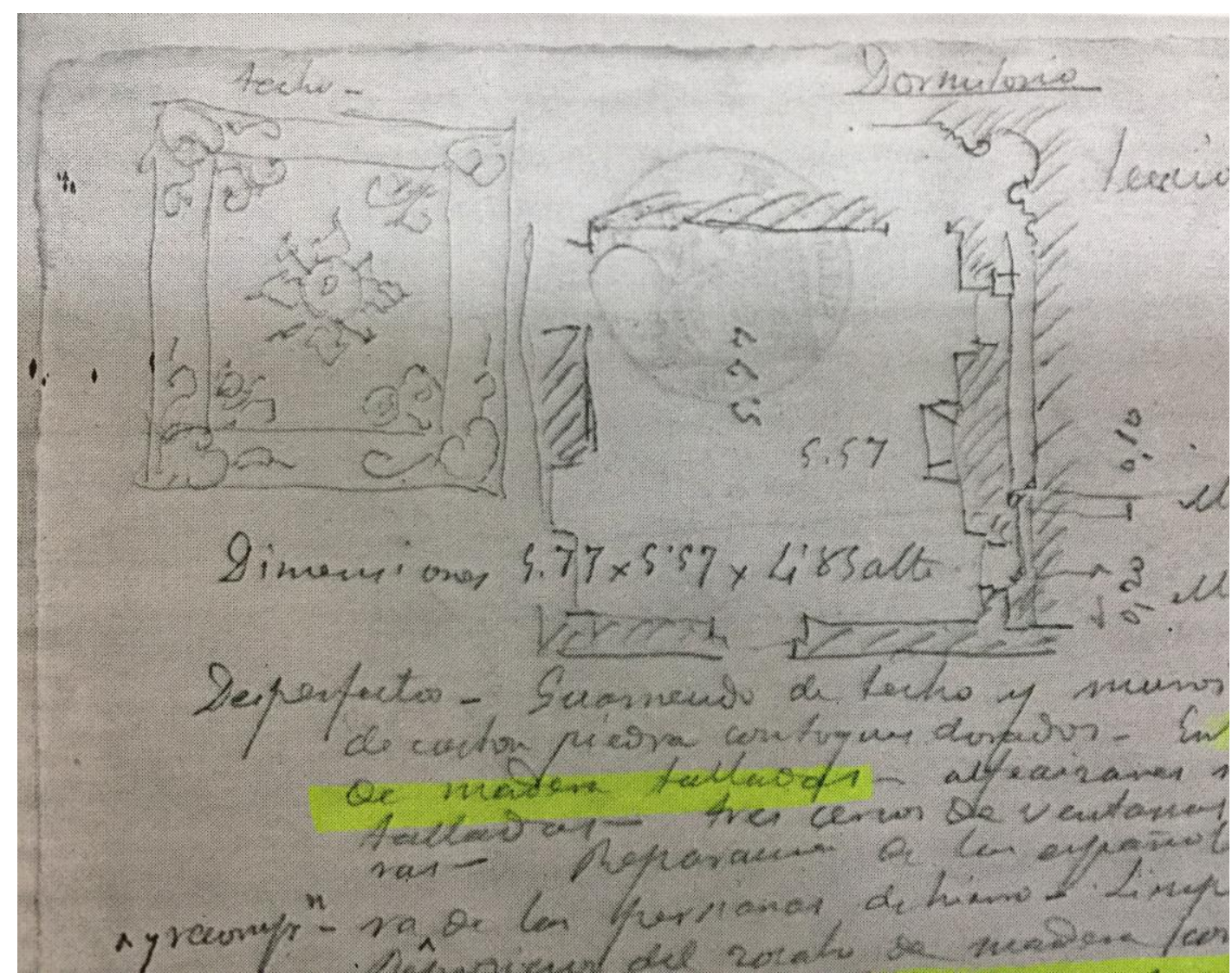

Fig. 3.35 Dibujo de la reparación de los daños del incendio.

Fotografía de la autora.

Por lo que hemos visto las estancias tenían dimensiones considerables, dignas de este tipo de construcciones de apariencia palaciega, donde la piedra y 
el ladrillo se mezclan en sus fachadas siguiendo muy de cerca el gusto francés como por ejemplo en el palacio del Duque de Uceda. Detalle curioso es que por sus mansardas negras se les denomina "casas de réquiem" dada la similitud de éstas con la tapa de un ataúd35. Una de las consecuencias del gusto por lo francés fue que los encargos para realizar estos edificios eran para los arquitectos del país vecino y los arquitectos madrileños veían cómo los proyectos se les escapaban de las manos.

Toda la "aristocracia nueva" surgida de la banca y del comercio, y de las armas y la política, quería un palacete en la zona del paseo de Castellana y alrededores; en opinión de Navascués: "La casa propia se convierte así en el primer soporte hacia fuera, hacia su entorno social y hacia dentro, en la organización de la vida doméstica sostiene la nueva conciencia de clase de este minoritario grupo que desde el dinero alcanzó títulos nobiliarios de nueva creación. Sus escudos, con coronas de marqueses, condes y vizcondes, tienden a aparecer con anómala insistencia en las fachadas de los edificios, en las verjas del jardín, grabados en los vidrios de las ventanas, tallados en las puertas, pintados en los techos, reproducidos en sus vajillas" ${ }^{36}$.

Podemos hacernos una idea del tamaño y distribución del palacio si leemos el inventario de bienes de dicho palacio realizado a la muerte de la primera esposa del marqués, Rosalía Rey37.

En la planta o piso principal había un antecomedor con un gran número de armarios y bufets de caoba para guardar todo el servicio de mesa. Un comedor principal con una gran mesa oblonga de 33 pies de cargo por 6 de ancho (es decir, más de diez metros de larga por 2 de ancha) para celebrar

\footnotetext{
35 NAVASCUÉS, Pedro. “Castellana: quién te ha visto y quién te ve”. Lápiz, 1985, n. ${ }^{\circ} 28$, p. $28-33$.

${ }^{6}$ NAVASCUÉS, Pedro. "Palacios madrileños del ochocientos". En: Casa de América, Rehabilitación del Palacio de Linares. Madrid: Editorial Electa, 1993, p. 23-28.

37 AHPM, T. 36643, fols. 7439 y ss.
} 
grandes banquetes; sillar de roble tallado, alfombras y cortinas de terciopelo, espejos de Venecia y grades arañas de iluminación. Junto al comedor había un salón verde y uno encarnado ricamente decorados, que daban paso al gran salón de baile, y a un salón de tapices, llamado así por la decoración que tenía, la cual como ya se ha dicho a propósito del palacio de Valencia, será objeto de capítulo aparte en esta tesis. Un boudoir o saloncito muy coqueto daba paso a un salón de juego con antesala, donde las señoras se divertían con juegos de todo tipo.

En esa misma planta estaban situados, un cuarto de dormir con su correspondiente antesala, una habitación dedicada a tocador de señoras, un gabinete contiguo y otro tocador, que seguro eran muy concurridos en las noches de baile en casa de los marqueses. Había también una galería, una capilla y una sacristía, además del despacho del marqués. A propósito de la capilla diremos que cuando este palacio fue construido por Carlos Calderón, realizó una gran obra en la capilla y de ello se hizo eco la prensa. En el ejemplar de Escenas Contemporáneas de 1863 podemos leer:

"Muy pronto quedará terminado completamente el precioso oratorio que el capitalista señor don Carlos Calderón ha construido en su palacio de Recoletos. El estilo bizantino con que está decorado, y el contener 35 cuadros pintados por el apreciable artista don Carlos Luis de Ribera, autor del techo del Congreso, hace que sea una obra monumental, dejando el señor Calderón grato recuerdo de su ilustración por las bellas artes, ejemplo que debiera hallar otros imitadores, rindiendo de esta manera tributo al gusto artístico y a la protección que se merecen los artistas españoles" 38 .

Y una vez pertenecía ya el palacio a José Campo, se celebró un baile que fue muy comentado en la prensa y la capilla del palacio fue otra vez objeto de admiración. El artículo decía así:

"Sólo una vez había interpretado la alta sociedad en los salones altos del palacio de Recoletos: cuando en abril de 1863 los inauguró tan dignamente su anterior propietario, hoy difunto, el senador del reino D. Carlos Calderón.

${ }^{38}$ Escenas Contemporáneas, Revista política, literaria y de ciencia, artes, comercio y agricultura, Tomo I, Madrid: 1863, p. 267. 
Yo, que me contaba en el número de las amigas de aquella apreciable y distinguida familia, no pude pisar los umbrales de su antigua morada sin un sentimiento de profunda tristeza. Un año ha todavía habitada aquella aquí. Alegre, feliz, tranquila; un año hace aún se celebraban fiestas y banquetes.

En ocho meses iqué cambio tan completo y tan radical! El Sr. Calderón murió a los pocos momentos de realizar el matrimonio de su hija; su desconsolada viuda ha ido a encerrarse en una de sus regias posesiones de Granda; el palacio ha pasado a poder de otro dueño, y en él, ahora como entonces, se dan suntuosas funciones. ¿no basta esta sencilla y elocuente narración para graduar el valor que debe darse a las pompas y vanidades de la tierra?

Muchos de los que asistíamos el viernes al baile de los Sres. Campo, consagrábamos tales recuerdos a lo pasado, y hacíamos paralelos semejantes entre él y lo presente: ¿̇era filosofía o sentimiento? Me complazco, juzgando por mí, que más bien lo segundo que lo primero.

Desechando estas fúnebres ideas, introduzcámonos en esa mansión soberbia, donde sólo reinan la alegría, la animación, el movimiento. Todo o casi todo se halla en el mismo estado que primitivamente: el jardín de invierno o patio árabe ostenta sus flores perfumadas, sus fuentes murmuradoras, sus pájaros parleros. Torrentes de luz se reflejan en las tranquilas aguas; esencias purísimas se escapan de las corolas entreabiertas de los rojos claveles y de las suaves violetas; los ecos de la armoniosa orquesta se confunden con el rumor de las conversaciones. En el salón principal polka y walsa toda la juventud madrileña; en los demás aposentos, en la bella e incomparable galería que circunda el patio bulle y circula una concurrencia inmensa, donde figuran las eminencias sociales y parlamentarias; las movilidades de la hermosura y el talento; los representantes de la alta banca y del comercio; todas las aristocracias, en una palabra.

Y ¿̇qué hay allí, qué objeto es aquel, a la par religioso y artístico, que los hombres lo contemplan con admiración, que las señoras se detienen a examinarlo, echando sobre los diamantes o las flores que ostentan en la cabeza sus diminutos y preciosos pañuelos de encaje? ¿por qué unos bajan la voz al entrar en aquel recinto, y por qué las otras doblaban la rodilla y se prosternan?

¡Ah! Es la capilla del palacio; es un prodigio del buen gusto; una maravilla del arte. En ella se ha conseguido lo que es muy difícil lograr que el lugar destinado al culto de nuestra religión conserve el carácter de grave e imponente austeridad que debe distinguirle, y que se combine con el lujo y la riqueza. Las pinturas y los cuadros recuerdan el estilo de los grandes artistas flamencos; las lámparas son 
dignas de una catedral; en fin, la arquitectura en general y en los detalles presenta severidad y grandeza" 39 .

Al leer estas dos reseñas de prensa sobre la capilla del palacio debemos destacar que, en la noticia sobre la inauguración de la capilla por Carlos Calderón en 1863, se dice que está adornada con cuadros de estilo bizantino pintados por Carlos Luis de Ribera y en la reseña sobre el baile de los Campo en 1865, se dice que en la capilla hay cuadros de estilo flamenco. Posiblemente al comprar José Campo el palacio a la muerte de Carlos Calderón, los cuadros de Carlos Luis de Ribera fueran retirados y José Campo compró nuevas obras para su decoración. Posiblemente, las obras de Teniers que exhibió en la Exposición universal de Barcelona, fueran esas pinturas flamencas que decoraban la capilla y que, según la periodista, fueron admiradas por los invitados al baile.

Como acabamos de ver, al igual que José Campo, el Sr. Calderón celebraba grandes bailes y banquetes de los que también daba buena cuenta la prensa. Uno de ellos se celebró el 12 de abril de 1863 y se narraba así:

"Un baile en el palacio del opulento banquero Sr. Calderón. ique riqueza, que variedad, que buen gusto en las toilettes de cuantas poblaban el sábado aquellos salones ...al poner el pie en ellos se creía uno trasportado a la región de los fantástico: todo allí era ideal, incomparable, magnífico! Desde la escalera de mármol blanco, iluminada a giorno y adornada con colosales espejos y jarrones llenos de perfumadas flores, empezaba una serie interminable de maravillas. El fausto de Oriente compitiendo con la elegancia moderna; la hermosura y la juventud eclipsando las infinitas bujías que iluminaban las estancias; los objetos de arte al lado de las mil bagatelas del lujo; obras maestras de la pintura junto a prodigios de tapicería; he aquí lo que desde luego se ofrecía a la vista del observador.

El palacio es bello y bien distribuido. En todo el centro, y admirablemente colocado se encuentra su jardín de invierno, o patio cubierto, en que crecen

39 La Época, 27/2/1865, p. 3. 
bosques de camelias gigantescas junto a pantas de los trópicos, entre murmuradoras fuentes y torrentes de luz...así era el lugar favorito de las damas, que fatigadas del baile, venía a respirar allí una atmosfera más pura y fresca...Dejémoslas, pues, objeto de la admiración de todos, y recorramos, mientras que no se baila, los diferentes salones, por donde circula una concurrencia brillantísima y tan considerable que no bajaría de mil personas"40.

Y como acabamos de ver unas líneas más arriba, en la descripción del baile de los señores Campo en 1865, se hace la misma referencia al jardín de invierno o patio árabe, con flores perfumadas, fuentes murmuradoras, pájaros parleros, estanques, y se enfatiza en la bella e incomparable galería que lo rodea todo.

Estas descripciones nos valen para hacernos una idea perfecta de cómo era el palacio y el tipo de actos que allí se celebraban. Y que una vez adquirido por José Campo continuaron celebrándose. En el palacio de recoletos se celebró la boda de su sobrina Concepción Moreno Campo con el Vizconde de Bétera, el bautizo del cuarto hijo de los señores Maicas, gran ayudante colaborador del marqués en todos sus negocios, el banquete de celebración de la expedición al canal de Panamá, que veremos en el capítulo correspondiente etc., pues el nivel económico y social de estos grandes hombres del siglo XIX exigía este tipo de demostraciones públicas de lujo y opulencia de vez en cuando ${ }^{41}$. También se celebraban veladas de teatro, como la comedia que según la prensa se representó antes de la Cuaresma ${ }^{2}$. Y es que el marqués, haciendo alarde una vez más de su poderío económico y de su interés por las artes, hizo construir dentro del palacio un pequeño teatro tal y como publicó la prensa "en el palacio

$4^{\circ}$ RASTIGNAC, Oscar de. Escenas Contemporáneas, Revista política, literaria y de ciencia, artes, comercio y agricultura, Tomo I, Madrid, 1863, p. 30 y 31.

${ }^{41}$ La Época, 19 /1/ 1886, p. 1.

La Ilustración Española y Americana, Año XXVI, NÚM. XLV, 8 de diciembre de 1882, p. 334.

La Época, 24 /5/ 1886, p. 1.

La Correspondencia de España, 10 /12/ 1875, p. 5 .

Las Provincias 1/3/ 1878, p..1.

El Imperial, $1 / 3 / 1878$, p. 3.

${ }^{42}$ La Gacetilla, 21 /3/ 1878, p. 3. 
que fue de Calderón, propiedad del señor Campo, se ha construido un teatrito para canto y verso" 43.

Siguiendo con la distribución del palacio en la planta baja estaban situadas las siguientes dependencias: la galería a la que nos acabamos de referir, la antesala y la sala de armas, la alcoba dormitorio del marqués, su tocador y su cuarto de baño. También se encontraba la biblioteca o salón de consejos, donde se celebraban reuniones de trabajo, su despacho nuevo, el comedor y una sala de billar. Como vemos todo lo necesario para el servicio del señor de la casa y para que, con sus socios o futuros contratistas, celebre reuniones de trabajo, comidas y pase ratos distendidos jugando al billar. Como ya hemos dicho antes, la biblioteca fue inaugurada en la fiesta que se celebró en el palacio en febrero de 1865, ello demuestra que hizo reformas en la que ya tenía el palacio, al mismo tiempo que revela el interés por la lectura del marqués, pues era un hombre culto y con muchos conocimientos.

También estaban en la misma planta los aposentos de la señora marquesa, su dormitorio, su tocador, una gran antesala y un salón chino donde tomar el té con amistades o familiares que vinieran a visitarla. La marquesa de Campo era una mujer devota y discreta que pasaba muchas horas rezando en sus habitaciones y colaboraba en las obras benéficas que requerían su presencia44.

En el piso segundo del palacio estaba la sección y habitaciones destinadas a la servidumbre femenina, y la sección y habitaciones destinadas a la

43 Noticia publicada en el periódico El Español en febrero de 1865, y que se cita en Madrid en sus Diarios, Tomo 3, 1876-1875, Seminario de Bibliografía y Filosofía hispánica de la Facultad de filosofía y Letras de Madrid, Madrid: Instituto de Estudios Madrileños, 1969, p. 167.

${ }^{4}$ Sabemos por el inventario de bienes que en sus habitaciones tenía muchos libros de oraciones, devocionarios, misales, rosarios, crucifijos, etc. AHPM, T 36643 , Fols. 7439 y ss. 
servidumbre masculina; el cuarto de la plancha, el cuarto ropero, y un cuarto de baño. En la época en la que José Campo habitaba el palacio tenía mucha servidumbre, pues la casa era enorme y para su mantenimiento y cuidado eran necesarias muchas personas, ello sin contar las necesarias para las noches de banquetes y bailes, ya que atender perfectamente a tan gran número de personas era un gran esfuerzo sobreañadido. Tenemos información de las personas que vivían en el palacio en el año 1878. El padrón de ese año sitúa en el palacio a 27 personas más el marqués, su esposa, dos jóvenes sobrinos y 24 criados, que se dividían de la siguiente manera: un cocinero francés y dos pinches de cocina, tres cocheros y cinco mozos de caballos, un portero, dos doncellas, tres sirvientas y cuatro sirvientes, un ayuda de cámara y un jefe de comedor. El palacio del marqués era el que más servicio tenía de todo el Ensanche Este de la capital45.

También había habitaciones que daban a la fachada principal destinadas a invitados, y un cuarto de la música. Una cocina pequeña, una grande y una despensa.

En los edificios que formaban parte del palacio pero que recaían en la calle Cid, estaban situados los despachos de los negocios del marqués: tabacos, vapores, ferrocarril, y varios despachos de letrados. Allí trabaja un gran número de personas, todas bajo el mando y supervisión del marqués, para sacar adelante cada una de sus empresas e iniciativas comerciales. En esa parte del palacio también estaban situadas las cocheras y las caballerizas. El periodista Mascarilla, cuando escribió sobre la muerte de José Campo hizo referencia al lujo y suntuosidad que había en este palacio de Recoletos, calificándolo de museo de obras de arte. La casa era un ejemplo de gusto, suntuosidad y riqueza, y tenía unos salones magníficos donde se celebraban grandes fiestas, un patio a la andaluza cubierto de cristal y un gran comedor donde se daban grandes

45 CARBALLO BARRAL, Borja. Los orígenes del Moderno Madrid: El Ensanche Este (1860-17878). Madrid: Universidad complutense de Madrid, 2015, p. 205. 
banquetes. Una de esas fiestas fue por la boda del rey Alfonso con Mercedes de Orleans, y otra con motivo de la expedición que el marqués mandó en el vapor Magallanes al istmo de Panamá ${ }^{6}$. Muchos de estos objetos y obras de arte de las que habla Mascarilla se expondrán, como luego veremos, en el pabellón del marqués en la Exposición de Universal de Barcelona de 1888 que será estudiado en otro capítulo de esta tesis, al igual que las obras de arte que había dentro del palacio.

Vamos a reproducir a continuación uno de esos magníficos bailes que se dieron en el palacio Campo durante la vida del marqués y que fue memorable por llegar casi a dos mil el número de invitados. La prensa se hizo eco de él y lo describió así:

"Anoche tuvo lugar en los magníficos salones del rico capitalista Sr. D. José Campo una brillante soiree, a la que asistió lo más selecto de la sociedad y grandeza de Madrid. A las diez y media de la noche, el paseo de Recoletos empezó a estar invadido por infinidad de carruajes conduciendo a los convidados, que todos ellos se apresuraban a tomar parte en tan extraordinaria fiesta. El señor D. Luis Mayans, en unión de la señora de la casa, doña Rosalía, recibieron a los convidados con la amabilidad y delicadeza que les caracteriza; aceptando esta honra el Sr. Mayans, por hallarse ausente el esposo de dicha señora. Ésta lucía un elegantísimo y en extremo sencillo traje, compuesto de falda blanca con túnica de terciopelo verde guarnecida caprichosamente con plumas de este último color. Un rico collar de perlas blancas rodeaba su cuello, y una magnífica mariposa de brillantes que ostentaba en su prendido dicha señora, completaba su toilette.

Una brillante orquesta y coros del teatro Real, dirigida por el Sr. Skocdopole, hacía resonar sus armoniosos ecos en los salones del palacio de Recoletos, entretanto que nuestras bellas damas se disponían para el baile.

Asistieron a tan animada fiesta, su alteza real la infanta doña Isabel, los señores príncipes de Pioglas, señoras duquesas, condesas y baronesas siguientes: de Fernandina, de Castro-Enriquez, de Fernan-Nuñez, de Baena, de Gor, de Malpica, de Villaseca, de Guad-el-Jelú, de Remisa, de Ortega, de Patilla, de Campo-Alange, de Toreno, de Torrejon, de Suporunda, de San Luis, de la Regalía, de Avendaño, de Osma, de Sclifani, de Montefuerte, de Torrepando, de Pezaela, de Santa

46 “El Marques de Campo". La Época, n. ${ }^{\circ}$ 13.288, de 20 /8/ 1889, p. 1. Citado en ALMELA Y VIVES, 1989, p. 76. 
Coloma, de Vistahermosa, de Tamames, de Medinaceli, de los Castillejos, viuda del Salar, de Uceda, de Camarasa, de Sástago, de Zaldivar, de Mayans, de Fuentes, de Molías, de Alcudia, de Sotomayor, de Casa-Córdoba, de Coello, de Santa Marta, de la Vera, de Guadalcázar y otras infinitas señoras cuyos nombres no podemos recordar, pidiéndolas perdón por la infidelidad de nuestra memoria. En los personajes más notables se encontraban: todo el Cuerpo diplomático; el Consejo de ministros, menos el señor duque de Valencia, el Sr. Armero y el Sr. Arrazola; el gobernador de Madrid, el capitán general Sr. Gasset, los señores Ulloa, Cánovas del Castillo, Salaverría, duque de Sexto, Coello, Ochoa, Gándara, y su señora, D. Antonio y D. Francisco de los Ríos Rosas, Sres. Marfori, Bañuelos, Ezpeleta, Ovieco, Cueto, Calonge, Llórenle (D. Alejandro), Norzagaray, Udaeta, D. Claudio Moyano, Javalquinto y su señora. Olivan, barón de Cortes, Lassala y señora, Beltran de Lis, Mollinedo y Weisweller, D. Enrique O'Donnell, la mayor parte de los directores de los ramos de administración, don Miguel Tenorio y otra infinidad de personas, cuya relación sería interminable por llegar a la respetable suma de dos mil.

A las once de la noche se abrieron las puertas del salón del buffet, donde a los convidados se les sirvió con profusión suculentos y exquisitos manjares. El salón del té también estuvo animado toda la noche. Por último, la magnífica biblioteca del Sr. Campo, que se estrenó anoche, sirvió para salón de fumar.

Se tocaron y cantaron escogidas piezas bailables y arias de las mejores óperas, ejecutadas todas por los profesores del teatro Real.

La reunión terminó a las seis de la mañana. El cotillón fue dirigido por el Sr. Caro y la señorita de Cortes, que tanto gusto han demostrado en las altas reuniones para la dirección de estos bailes.

Describir el gusto y amabilidad de los señores de la casa, sería hacer una ofensa a su proverbial galantería y todos se dieron la enhorabuena por las deliciosas horas que habían pasado en aquella esplendida morada"47.

A la muerte de José Campo, el palacio siguió siendo objeto de la prensa, en La Época del 24 de setiembre de 1889 se publicó: “Anuncia un periódico como posible que el palacio del marqués de Campo, del paseo de Recoletos, lo

${ }^{47}$ La Correspondencia de España, 26/2/1865, p. 2. 
adquiera el Banco Hispano Colonial de Barcelona, para sus oficinas y las del Ferrocarril de Almansa, Valencia y Tarragona"48.

Pero el palacio fue adquirido por Josefa Manzanedo e Intentas, hija del marqués de Santoña y II marquesa de Manzanedo. La prensa dio noticia de su nueva inquilina publicando en junio de 1892 la noticia de que la marquesa de Manzanedo se trasladaba desde el antiguo palacio de los duques de Bedmar al del marqués de Campo en el paseo de Recoletos 49.

La marquesa disfrutó mucho celebrando fiestas y bailes en el palacio y siempre que era objeto de noticia en la prensa se aludía a que su palacio había sido antes del Sr. Calderón y luego del marqués de Campo.

Por ejemplo, en La última moda de abril de 1894 se publicó:

"La marquesa de Manzanedo, ha obsequiado con un gran banquete a la duquesa inglesa de Mánchester, y hubo después recepción a la que acudieron unas doscientas personas, abriéndose por primera vez desde que la marquesa habita, los salones grandes del hotel que fue de los Calderón y del marqués de Campo" 50 .

En La última moda se publicó en otra ocasión:

“Continúa la animación en el Madrid aristocrático. Durante la última semana se ha bailado en el palacio de la marquesa de Manzanedo y en la embajada de Alemania. La hija y heredera del opulento banquero duque de Santoña, ocupa el precioso palacio del paseo de Recoletos, que hizo construir el Sr. Calderón, y que fue después morada durante muchos años del marqués de Campo, quien dio en él suntuosas fiestas" ${ }^{1}$.

\footnotetext{
${ }^{48}$ La Época, 24 /9/ 1889, p. 3.

49 Época, 20 /6/ 1892, p. 1.

$5^{\circ}$ La última moda, 8 /4/ 1894, p. 6.

${ }^{51}$ La última moda 22 /4/ 1894, p. 6.

Otro baile en la misma publicación el 26/5/ 1894, p. 6. 
En enero de 1898, se publicó en La Época un reportaje sobre los palacios de Madrid y se volvió a hacer referencia a que el palacio de la marquesa de Manzanedo fue del sr. Calderón y del marqués de Campo52.

En La Época del mes de febrero de 1899, en pleno Carnaval se publicó que "la duquesa de Manzanedo ha construido en el palacio que antes era del marqués de Campo, una tribuna para que sus amigos vean el desfile de carnaval" 53.

Sin embargo, pasados unos años, y por problemas de una deuda con Hacienda de los herederos de José Campo, el palacio tuvo que ser subastado.

El Día publicó el 2 de noviembre de 1899 lo siguiente:

"Mañana a las diez se celebrará en la tenencia alcaldía del distrito de Buenavista la subasta del palacio del marqués de Campo, sito en el paseo de Recoletos. Parece que se vende por un precio muy módico, dado el valor del inmueble"54.

Y en el ejemplar del mismo periódico del día siguiente se publicó:

SUBASTA DEL PALACIO DEL MARQUÉS DE CAMPO. "En la tesorería de la alcaldía del distrito de Buenavista se ha verificado esta mañana la subasta del palacio del marqués de Campo, como consecuencia del procedimiento de apremio por deuda a la Hacienda, por el impuesto de derechos reales de transmisión de bienes. La referida finca estaba valorada en 750.000 pesetas, admitiéndose posturas desde 500.000 .

Los postores han sido cinco y después de algún incidente ha sido adjudicado el expresado palacio del marqués de Campo por 751.100 pesetas a D. Miguel Prieto, quien antes había manifestado que era para transmitir a otra tercera persona.

${ }^{2}$ La Época, 20 /1/ 1898, p. 1.

${ }^{53}$ La Época,14 /2/ 1899, p. 3.

${ }^{54}$ El Día, 2 /11/ 1899, p. 2.

El Correo Español, 4 /11/ 1899, p. 4.

El día, 4 /11/ 1899, p. 2.

El Globo, 4 /11/ 1899, p. 2. 
Con ese motivo protestaron algunos de los postores restantes, por entender que estas clases de subasta no podía hacerse postura alguna en dichas condiciones.

Para el caso de que el delegado de Hacienda declare nulo el derecho del sr. Prieto, reclamó que se le adjudique la finca como mejor postor D. Octavio Campo, que había ofrecido la suma de 751.000 pesetas" 55 .

En ese momento comenzó un pleito por la subasta que fue objeto de recursos y de juicio contencioso administrativo que la prensa también reflejós6.

Incluso la subasta de su palacio fue objeto de polémica, igual que lo fue su vida, siempre en boca de todos gracias en parte a la prensa de la época, que hacía público hasta el más mínimo detalle de la vida de los que eran los hombres y mujeres del momento, ya fuera por motivos políticos, económicos o sociales. 


\section{3.- El castillo de Viñuelas en el monte de El Pardo, Madrid}

En 1870 José Campo adquirió el bosque de Viñuelas, en el monte de El Pardo, Madrid.

La propiedad, fue fundada por Felipe IV como cazadero real, perteneció en 1697 a la marquesa de Mejorada quien, de manos del tracista mayor José Moreno, convirtió la antigua fortaleza que estaba en ruinas en un castillopalacio, donde era recibido Felipe $\mathrm{V}$ para disfrutar de su afición a la caza.

Fernando VI se enamoró del soto de Viñuelas y lo compró en 1751 para incorporarlo al Real sitio de El Pardo. Desde ese momento se realizaron mejoras en la finca, el castillo y los torreones fueron restaurados, se edificaron nuevos pabellones y caballerizas, varias casas para los guardas, se construyeron puentes sobre arroyos y se cercaron los $40 \mathrm{Km}$ de perímetro. Monarcas como Carlos III, Carlos VI, Fernando VII e Isabel II cuidaron y disfrutaron de la propiedad, convirtiéndose el cazadero preferido de los Austrias en el de elección de la Casa de Borbón 57.

En 1851, las obras del canal de Isabel II para llevar agua a Madrid atravesaron toda la finca y dejaron huella en ella además de la servidumbre del Camino de la Dirección, que pasa por dentro. Pero mayor huella dejó en la propiedad la revolución de 1868, que supuso la creación de la Dirección General del patrimonio que fue de la Corona para la administración de la Propiedades Reales, y en 1869 se aprobó una ley de desvinculación y venta de los bienes de patrimonio Real destinados al uso de los monarcas. Se publicó así en abril de 1870 un boletín oficial de venta de bienes nacionales y se ofrecía en pública subasta la dehesa, monte y castillo de Viñuelas. La adquisición el día 3 de junio

${ }^{77}$ SÁNCHEZ DOMINGO, José Ramón. Viñuelas. Crónica de un castillo. Madrid: Lamparanza S.A., 1999, p. 41-45. 
de 1870 por parte de José Campo fue en dicha subasta por medio de su mandatario Eulogio Manuel Mejía, y pagó el precio de unos ocho millones de reales.

En la descripción que se hacía de la finca se declaraba que el edificio, llamado castillo, y sus cuatro torreones estaba en situación ruinosa, que en la planta segunda del edificio había habitaciones, tabiques, techos y suelos sin terminar. Los pabellones adyacentes y parte del muro de la finca también estaban en estado ruinoso y el uso que en ese momento se le daba era el de aprovechamiento de la caza, y el uso de la leña para el carbón58 ${ }^{8}$, (Fig. 3.36).

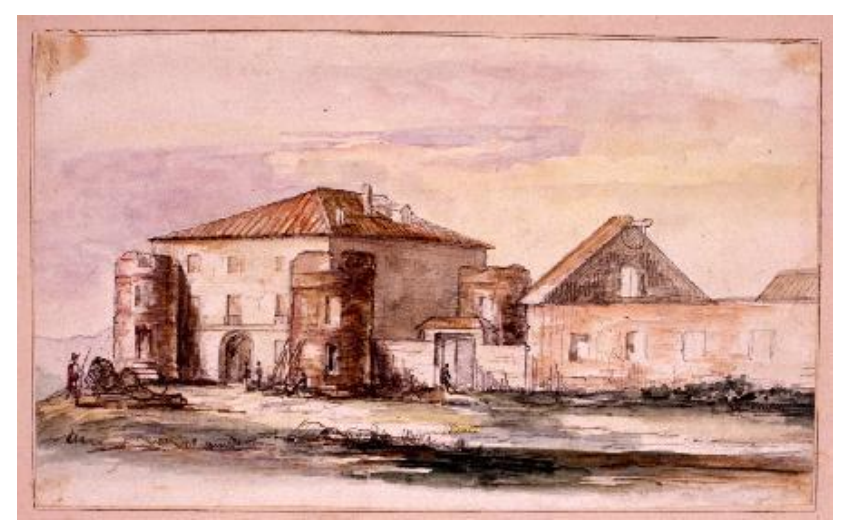

Fig. 3.36 Vista del castillo a mediados del siglo XIX, antes de las reformas que determinaron su actual aspecto 59 .

Gracias a esa descripción sabemos que cuando José Campo adquirió el soto de Viñuelas su estado era deplorable y él, a la vez que comenzó a realizar las obras necesarias para repararlo todo, siguió aprovechando la finca para subastar la caza y la leña ${ }^{60}$. Mandó convertir el ruinoso castillo en un palacio señorial que utilizó para solaz y recreo. Los torreones del castillo fueron reconstruidos y rematados por almenas; el interior del castillo-palacio fue restaurado y decorado con toda clase de lujos, esplendidos muebles y obras de

${ }^{8}$ SÁNCHEZ DOMINGO, José Ramón. 1999, p. 55.

59 Dibujo sobre cartulina, realizado por Valentín Carderera y Solano, (1796-1880).

Museo Lázaro Galdeano, Madrid, Archivo CERES: COLECCIONES EN RED.

6o Diario Oficial de Avisos de Madrid, 14/12/1870. p. 1.

La Época, 18/8/1871, p. 3., La Época, 10/8/1872, p. 3 
arte, de las que ahora hablaremos, con el fin de convertirlo en la majestuosa mansión de un potentado, donde poder recibir a invitados y agasajarlos con esplendidos banquetes, fiestas y cacerías. Algunos de los trabajos de decoración interior fueron realizados por el pintor escenógrafo y familiar suyo, José Vicente Pérez Vela ${ }^{61}$.

El contorno del castillo se arregló con jardines y paseos que se adornaron en estatuas, se reconstruyeron las casas adyacentes para guardeses y trabajadores de la finca, se hizo una capilla, unas nuevas caballerizas y mandó construir grandes pajareras para disfrutar de aves exóticas para deleite de los visitantes e invitados a las conocidas cacerías del señor. Campo.

De esas cacerías y fiestas se hacían eco las diferentes publicaciones de la época dando noticia de los nombres de los ilustres invitados y la duración de las mismas 62 .

El día 12 de diciembre de 1871 La Época daba cuenta de la siguiente noticia:

"En la semana última ha habido grandes fiestas en el castillo de Viñuelas. El viernes se inauguró la capilla que había sido bendecida pocos días antes, y se celebró en aquella magnifica posesión, por la familia de su propietario el Sr. Campo, el día del santo de su sobrina, la bella señorita doña Concepción Moreno. El sábado y domingo hubo grandes cacerías, a las que acudieron diestros cazadores y amigos del sr. Campo. Los convidados hacen los mayores elogios de

${ }^{61}$ PINEDO, Carmen; MAS, Elvira. Inédito. 2003.

${ }^{62}$ Diario Oficial de Avisos de Madrid, 25/10/1876, p. 3.

Diario Oficial de Avisos de Madrid, 20/11/1876, p.3.

Diario Oficial de Avisos de Madrid, 28/7/1878, p. 3. p. 2.

La Correspondencia de España, 9/3/1879, p. 3.

La Época, 12/11/1879, p. 3.

La Iberia, 13/11/1879, p. 3.

La Discusión, 15/11/1879, p. 3. 
la suntuosa hospitalidad que han recibido en el castillo, restaurado artísticamente por su nuevo poseedor, y amueblado con gran lujo, así como de la distracción que ofrece a los cazadores el bosque, de $40 \mathrm{~km}$ de circunferencia, en cuyo centro de levanta el castillo, al que sus cuatro torres dan el aspecto de residencia feudal 63 .

Los que tenían la suerte de ser invitados a Viñuelas alababan no sólo la excelente caza, sino también la espléndida hospitalidad y la deliciosa mansión, que igualaba en lujo y magnificencia con el más suntuoso palacio de Madrid64.

Otra noticia sobre fiestas y cacerías decía así:

"Esta tarde ha salido el marqués de Campo para su magnífica posesión y palacio de Viñuelas, acompañado de los Sres. Danvila, barón de Cortes, Higuera, Fernández Flores, y otros invitados a una de sus esplendidas cacerías con que dicho banquero acostumbra a obsequiar a sus amigos"65.

José Campo era hombre de grandes gestos y detalles y ejemplo de ello es que las invitaciones a estas cacerías se realizaban por medio de elegantes tarjetas en las que aparecía una magnifica litografía de la vista del castillo y el bosque 66 .

Para conocer con más precisión cómo era la propiedad acudimos a la certificación del Registrador de la Propiedad de Colmenar Viejo, expedida en 1877 para asegurar la capacidad económica del marqués para ejercer como senador vitalicio y podemos conocer perfectamente como era la propiedad y las edificaciones que contenía. La propiedad estaba situada en el monte titulado Viñuelas, sito en el término de El Pardo, procedente de Patrimonio y arrendado al Conde de las Patillas. La propiedad se halla cerrada por una tapia de piedra,

${ }^{63}$ La Época, 12/12/1871, p. 3.

${ }^{64}$ La Época, 15/9/1872, p.3.

La Correspondencia de España, 9/11/1874, p. 1.

La Correspondencia de España, 15/2/1877. P. 3.

${ }^{65}$ Diario Oficial de Avisos de Madrid, 28/7/1878, p. 3 .

${ }^{66}$ La Época, 12/11/1879, p. 3. 
tiene una dimensión de más de 3.350 hectáreas y cuenta con tierra de cultivo, pastos y bosque. En el perímetro de la propiedad hay siete casas para los guardas; y en el centro de la finca una para los condueños, con habitaciones también para los guardas.

La vivienda principal se denomina Castillo y comprende una superficie de casi seis mil metros cuadrados. La casa tiene cuatro torreones y consta de planta baja, piso principal, segundo y buhardilla. La planta baja está distribuida en habitaciones para los guardas, portal, caja de escaleras, oratorio y otras dependencias; la planta principal también está distribuida en salas, alcobas, dormitorios, comedor con chimenea francesa y cocina con su escusado; en la planta segunda hay varias habitaciones y una parte de estas se halla sin terminar las obras de tabiques y techos. Adyacentes a este edificio hay tres pabellones destinados a cuadras, cocheras y habitaciones para los criados, pero el estado es bastante ruinoso. Hay además varias casas con habitaciones para los guardas 67.

Podemos conocer el interior del castillo-palacio, la decoración, el lujo y las obras de arte que contenía, gracias descripciones que se hacían en publicaciones del momento, y con más precisión gracias al inventario de la propiedad realizado en 1889 a la muerte de la primera esposa de José Campo ${ }^{68}$

\footnotetext{
${ }^{67}$ Certificado del Registrador de la Propiedad del Partido de Colmenar Viejo sobre la posesión del Bosque de Viñuelas en este partido, comprado al Estado y satisfechos los plazos de pago. En: Archivo del Senado de España. Expediente personal del senador Marqués de Campo, D. José Campo Pérez Arpa y Vela, por la provincia de Valencia y vitalicio (1864-1869), Legislatura 1877, carpetilla 03, rentas.

68 Las fuentes se encuentran en el Archivo Histórico de Protocolos de Madrid, en especial el protocolo 36.638, referido al inventario de bienes del Marqués realizado en 18889 tras la muerte de su primera esposa.
} 
Por ejemplo, en un reportaje de la publicación Día de Moda del mes septiembre de 1880 podemos leer una descripción de la finca y la gran cantidad de empleados que trabajan en ella, pero lo que a nosotros nos interesa sobre todo la descripción del interior del castillo.

"Y en medio de todo, como vigilante atalaya que domina el extenso señorío, se levanta el castillo con sus cuatro torres almenadas y aspilleradas, con sus ventanas ojivales y sus muros de piedra. Sólo falta el foso y el rastrillo para que la ilusión sea completa. Dentro todo el confort y el lujo del siglo XIX.

El salón principal, si es que puede llamarse así, donde tantos salones hay, está cubierto de antiquísimos tapices y dos valiosos cuadros de Rubens y Scheneider, representando escenas de caza. Sus muebles son de ébano con delicadas incrustaciones de marfil, y luce dos panoplias de costosas e históricas armas. La sala de baile es espaciosa y elegante; el salón árabe es una joya imitativa de la Alhambra de Granada, con divanes persas y una alfombra formada de pieles de tigre.

La cámara de la marquesa, que da paso a un camarín cubierto de tapices flamencos, es esplendida, y en ella se han unido al lujo francés las infinitas comodidades del at home inglés.

El comedor con su bella chimenea dinamarquesa de porcelana; su magnífica lámpara de bronce, formada con atributos de caza; el despacho, el gabinete de lectura, la capilla, todo se halla alhajado con igual suntuosidad y buen gusto y por doquiera se ve el ojo experto del hombre que sabe vivir y que vive bien.

Uno de los torreones encierra una suave y bien alfombrada escalera que da paso a varios cuartos destinados a los huéspedes, dispuestos siempre para recibirlos.

El más atildado cazador encontrará en ellos cuanto pueda necesitar para su toilette, sin que le falte la chaisse longue, tan aclimatada ya en España, y tan necesaria para la siesta durante las horas del estío. Viñuelas es un edén para los cazadores. Díganlo si no el ilustre duque de la Torre, el marqués de Ahumada, el barón de Cortes y tantos otros como han visitado aquella espléndida morada. 
Dígalo sino el que estas líneas escribe, que sólo pide al cielo ser desterrado a Viñuelas"69.

$\mathrm{Si}$ acudimos al inventario citado vemos que se corresponde perfectamente con lo que se publicaba en las revistas. En el exterior del castillo para recibir a los visitantes había una figura de Diana Cazadora con un ciervo, de hierro fundido sobre una peana de piedra, y también dos figuras de leones alados de hierro fundido también sobre sendas peanas de piedra (Figs. 3.37 y 3.38) Se conserva una imagen de las mismas en una publicación de $1899^{70}$.

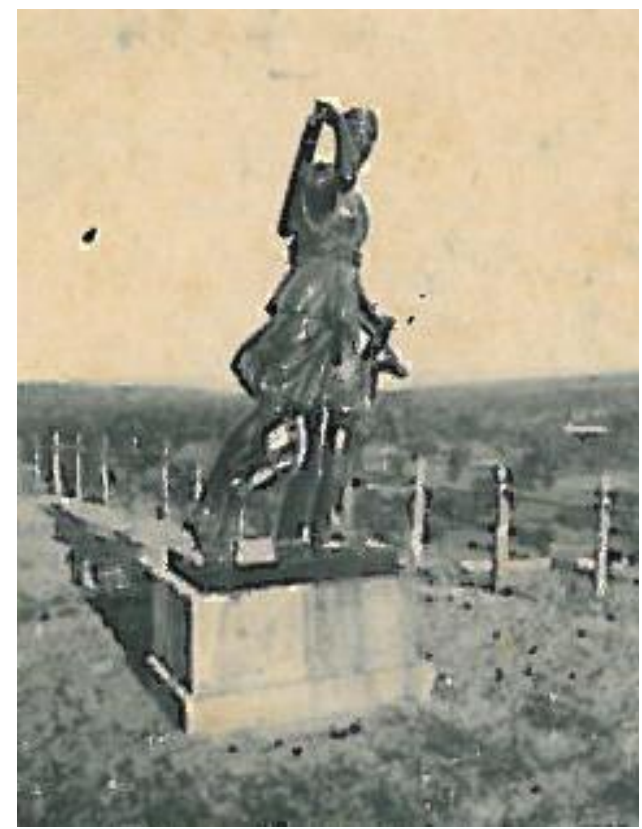

Fig. 3.37 Castillo de Viñuelas. Diana Cazadora.

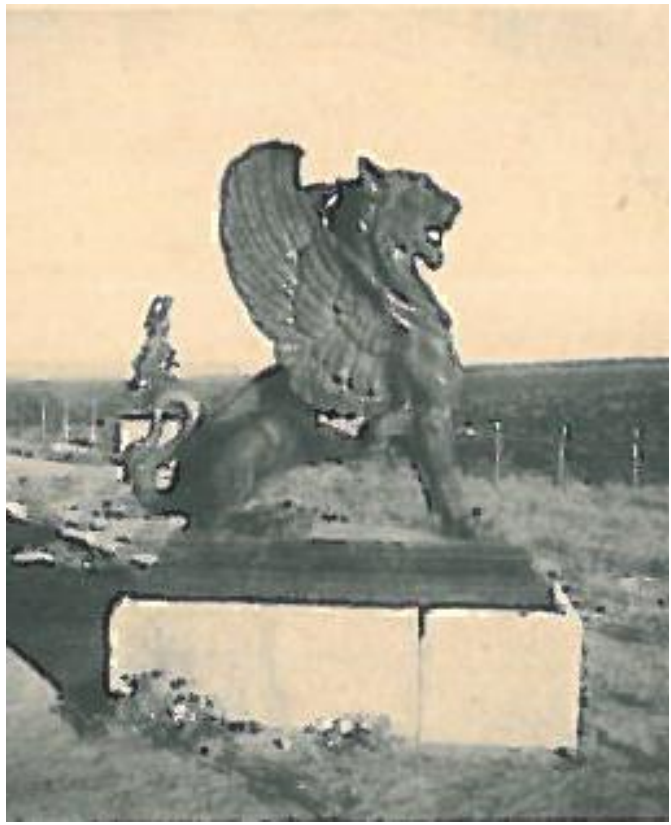

Fig. 3.38 Castillo de Viñuelas. León alado.

Una vez dentro, en el inventario se demuestra que el palacio tenía un gran número de habitaciones, al menos 12, para invitados con chimeneas de mármol, adornadas con relojes de mármol con figuras de bronce, muebles de gran calidad como camas de palosanto con las mejores colchas y edredones, candelabros de bronce, espejos de Venecia, alfombras, etc., para el disfrute de amigos y familiares. Así mismo vemos reflejadas en el inventario grandes

${ }^{69}$ FRANQUELO, "Viñuelas". Día de moda, 1880, año 1, núm. 34, p. 7.

70 UHAGON DE GUARDAMINO, Francisco. Viñuelas. Madrid: Fototipia de Hauser y Menet, 1899, p. 3. 
cantidades de ropa de cama, toallas, manteles y de menaje de mesa como copas, cubiertos, vajillas, juegos de café, y demás elementos necesarios para dar fiestas y banquetes a decenas de personas, como por ejemplo la que henos referido antes con motivo de la inauguración de la capilla y el santo de su sobrina.

Continuando con el inventario, podemos destacar que en las estancias comunes había toda clase de objetos de lujo, panoplias de armas, animales disecados, bandejas de plata antigua grabadas, jarrones de porcelana de varios tamaños y estilos, alfombras de muy buena calidad, sofás y sillones tapizados en ricas telas, cortinajes de damasco, biombos chinos con pinturas de paisajes, etc.

En el salón de tertulia había cuatro tapices de tema bíblico; en la antesala de la marquesa también aparecen en el inventario los tapices de estilo flamenco a los que se refería el artículo, y en el salón de armas había dos tapices más con bosques y figuras de estilo Renacimiento. En el salón árabe había una alfombra de piel de pantera.

En cuanto a los cuadros, en el inventario se especifica el autor de algunos y otros no: en una sala cercana a la terraza había un cuadro representando dos cabras firmado por Felipe Parra; en el despacho del marqués había 20 cuadros representado palacios, casas y bosques; en el salón encarnado ocho cuadros con marco dorado con retratos del marqués y miembros de su familia. En la capilla un cuadro en lienzo representado la coronación de la Virgen. En una de las salas del piso principal había un lienzo representando una Virgen con el Niño en los brazos y varios ángeles. En el salón de armas había dos cuadros grandes en lienzo representando cacerías antiguas, con perros y lanzas, que deben ser el de Rubens y el de Schenider que nombra la revista. 
Podemos hacernos una idea de la decoración de este castillo acudiendo a otras dos imágenes (Figs. 3.39 y 3.40) ${ }^{71}$ que se publicaron en el libro de F. Uhagon en 1899 y que, aunque pertenecen a la decoración del nuevo propietario del castillo en esa fecha, vemos que el aspecto se parece mucho a la que había en época del señor Campo según las descripciones y el inventario que hemos visto. Los tapices, los muebles con incrustaciones de marfil, cuadros, jarrones y armas bien pudieran ser los mismos adquiridos junto con la propiedad cuando fue vendida por José Recur, hijo de la segunda esposa del marqués a quien le correspondió en herencia a su muerte en marzo de 1889.

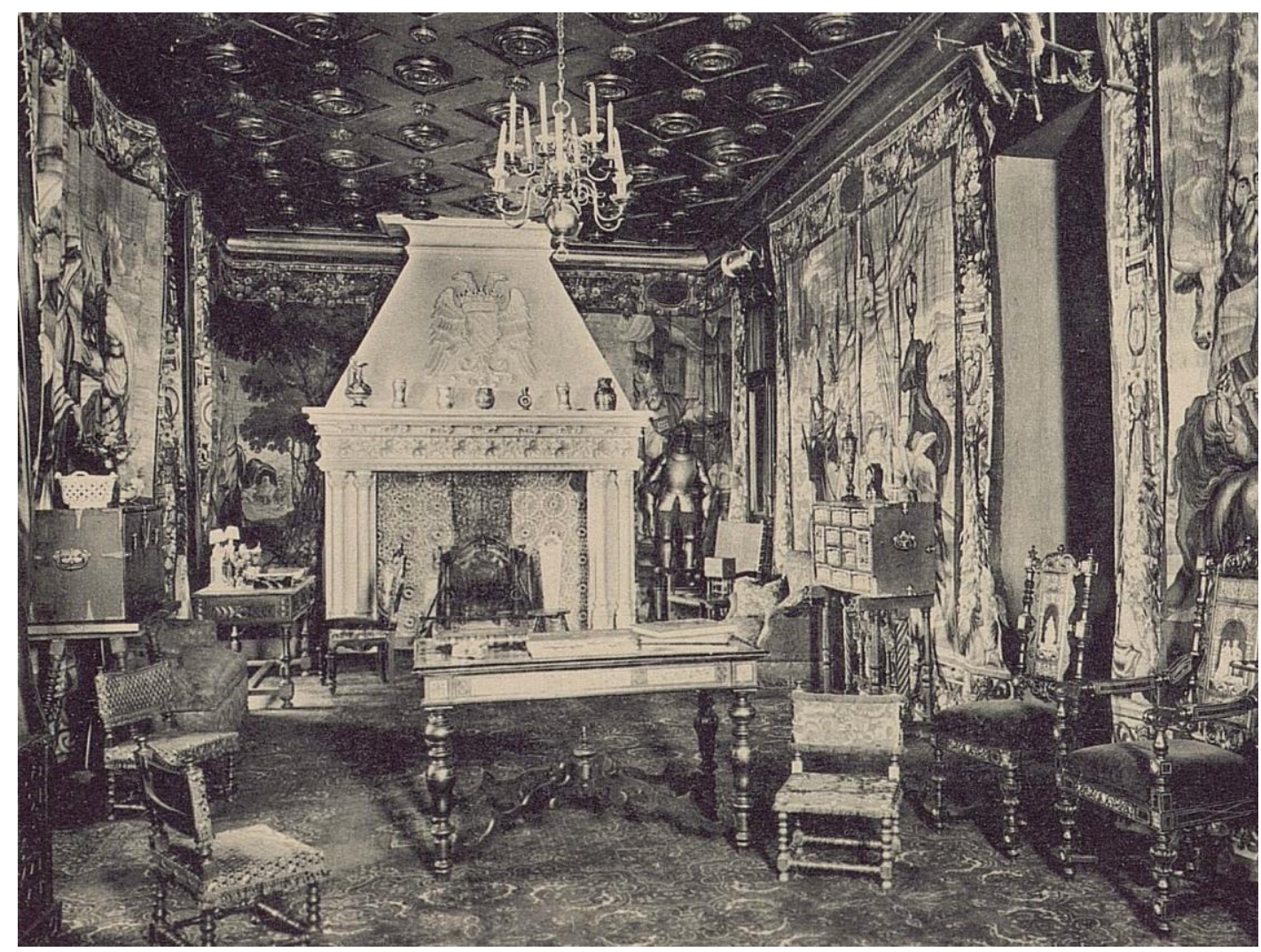

Fig. 3.39 Castillo de Viñuelas. Salón de tertulia.

${ }^{71}$ Imágenes publicadas en SÁNCHEZ DOMINGO, José Ramón. Viñuelas. Crónica de un castillo. Madrid: Lamparanza S.A., 1999. 


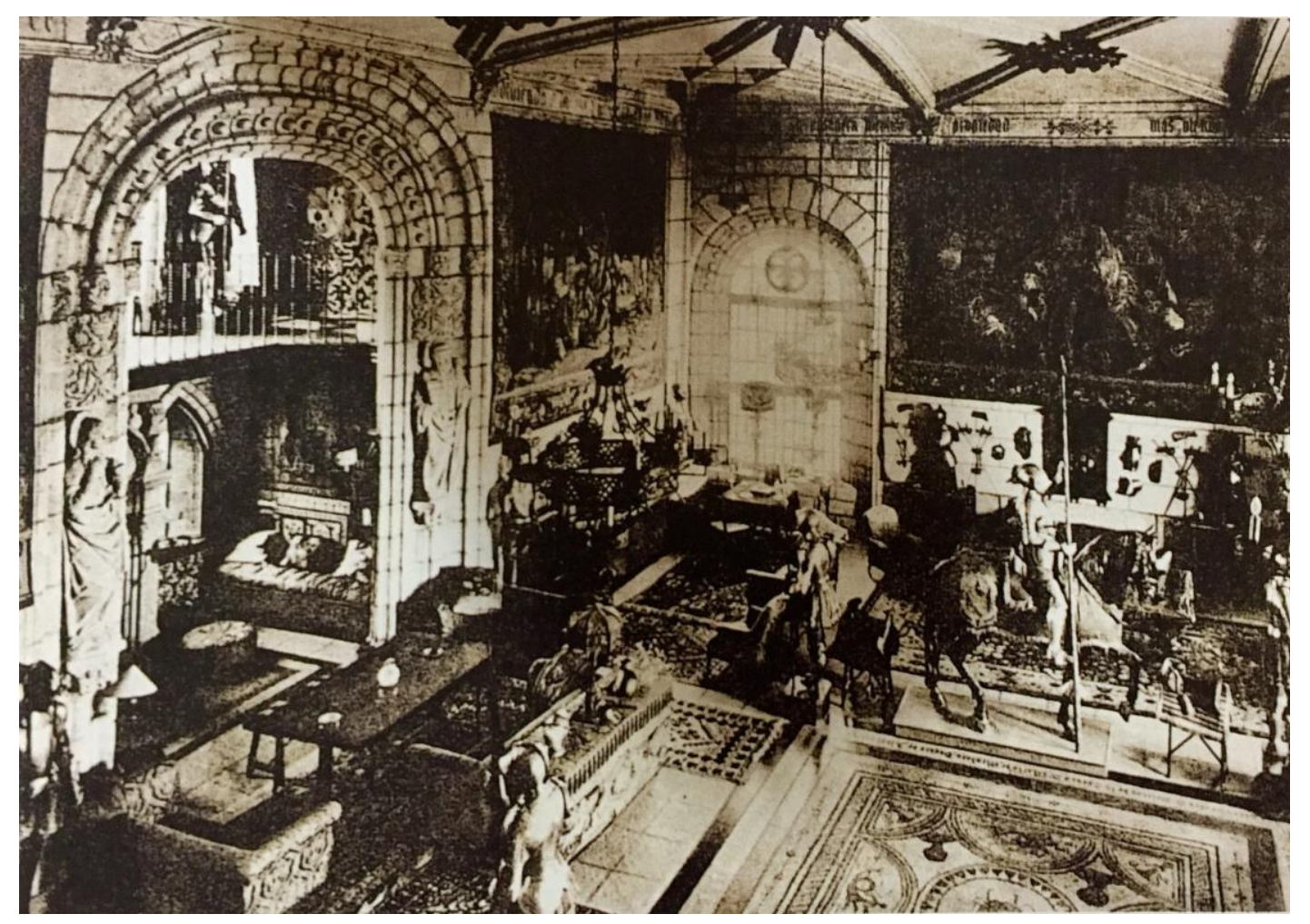

Fig. 3.40 Castillo de Viñuelas. Sala de armas.

El antiguo castillo de Viñuelas, convertido gracias a José Campo en un palacio señorial, no fue sólo un contenedor de obras de arte y objetos de lujo, sino también una vez más, un testigo mudo de la historia que se desarrolló en sus muros. Fue de opinión general que en las cacerías que organizó el Sr. Campo se habló mucho de política y se disparó poco pues, según las publicaciones del momento, allí se fraguó la subida al trono de Alfonso XII el diciembre de $1874^{72}$.

En diferentes publicaciones podemos leer los nombres de los políticos invitados a esas cacerías, desde 1871 a 1874, como el general Quesada, el marqués de Campo Sagrado, el barón de Cortes, Emilio Cánovas del Castillo, el marqués de Penifareig y de San José, don Nicolás María Rivero, etc. 73; y hacia 1882 también se rumoreó acerca de las maniobras políticas que se fraguaron en dichas cacerías a las que asistieron personajes como el duque de la Torre,

\footnotetext{
${ }^{2}$ ALMELA Y VIVES, Francisco. 1989, p. 77.

${ }^{73}$ La Época, 15/09/1872, p. 3.

La Correspondencia de España, 9/11/1874, p. 1.
} 
Castelar, Martos, Cánovas del Castillo, Romero Robledo, el marqués de la Conquista, Leopoldo Serrano, el señor. Silvela y también el resto de jefes de los partidos políticos 74 . No podemos olvidar que el primer título nobiliario que otorgó el rey Alfonso XII fue el de marqués a D. José Campo por su ayuda económica y su apoyo para subir al trono.

Como ya hemos dicho, una vez muerto el marqués, la propiedad fue heredada por su viuda, Luisa Solá, y luego pasó al hijo de ésta, José Recur, quien poco después la vendió al Marqués de Santillana volviendo así a sus legítimos dueños.

La compra y reparación del soto y el castillo de Viñuelas fue uno de los grandes logros personales de José Campo. Supuso ponerse al mismo nivel de la realeza con su propio castillo y cazadero en el que dar placer a su familia e invitados y demostrar su elevada posición social y su gran riqueza. Los invitados alababan el lujo y esplendor del palacio, así como la hospitalidad de su dueño, y volvían de las visitas maravillados. Campo trabajó sin descanso para demostrar a todo el mundo que su fortuna y su posición se la había ganado a pulso, y nadie puso nunca en duda su influencia en la política y la sociedad del momento. Viñuelas, junto con los palacios de Madrid y Valencia y la villa de verano en Arcachon, de la que ahora hablaremos, formaron un escaparate perfecto para demostrar su poder.

${ }^{74}$ El Liberal, 11/10/1882, p. 3.

La Correspondencia de España, 6/10/1882, p. 3.

El Día, 10/10/1882, p. 3. 


\section{4.- La residencia de verano en Arcachon, Burdeos (Francia)}

Arcachon, población situada en la costa del océano Atlántico y cerca de la ciudad de Burdeos, fue un centro de vacaciones con fines terapéuticos muy famoso en el siglo XIX; su clima suave, el aire del mar y los bosques de pinos se recomendaban para los enfermos de tuberculosis. Se construyeron numerosas villas, algunas de ellas en la misma orilla del mar, de diferentes estilos y cada una tuvo su particular historia. Desgraciadamente con el paso de los años muchas han sido sustituidas por modernos edificios de apartamentos.

José Campo adquirió una villa de vacaciones el 23 de marzo de 1880, que había pertenecido al Conde de La Combe y se le conocía con el nombre de "Chalet-rouge", aunque luego se le llamó "Villa Campo". Estaba situada en el número 55 del boulevard de l’Océan (Fig. 3.41).

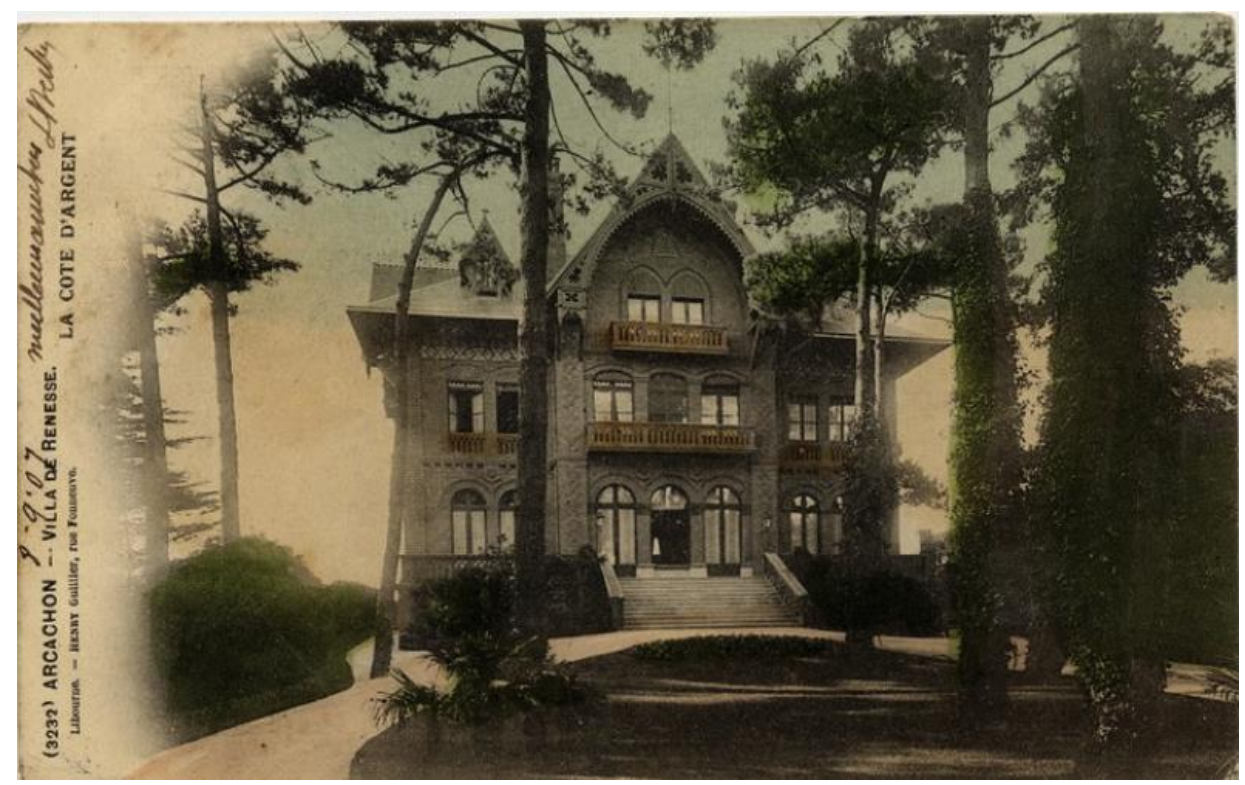

Fig. 3. 41 "Villa Campo" Vista hacia el camino. Arcachon. Francia

En agosto de 1880, durante la visita de la reina Isabel II a Arcachon, se alojó en la "Villa Carmen", pero José Campo puso a su disposición su villa, 176 
situada en la misma playa, para que la usara como acceso al mar. Cuentan las crónicas que cada mañana la reina acudía a esta villa, en aquellos momentos bastante asilada del resto de edificaciones, y se bañaba a solas 75 .

Tras la muerte de José Campo, fue vendida en 1898 a la condesa de Renesse, una viuda muy rica del norte de Francia que se enamoró del pretendiente al trono albanés, refugiado en España. Fue demolida en 1977. La villa no era exactamente lo que podría considerarse una casa de vacaciones. Las diversas salas y estancias estaban decoradas con toda clase de lujo y el aspecto era casi el de un palacio. (Figs. 3.42 y 3.43 ) ${ }^{76}$.

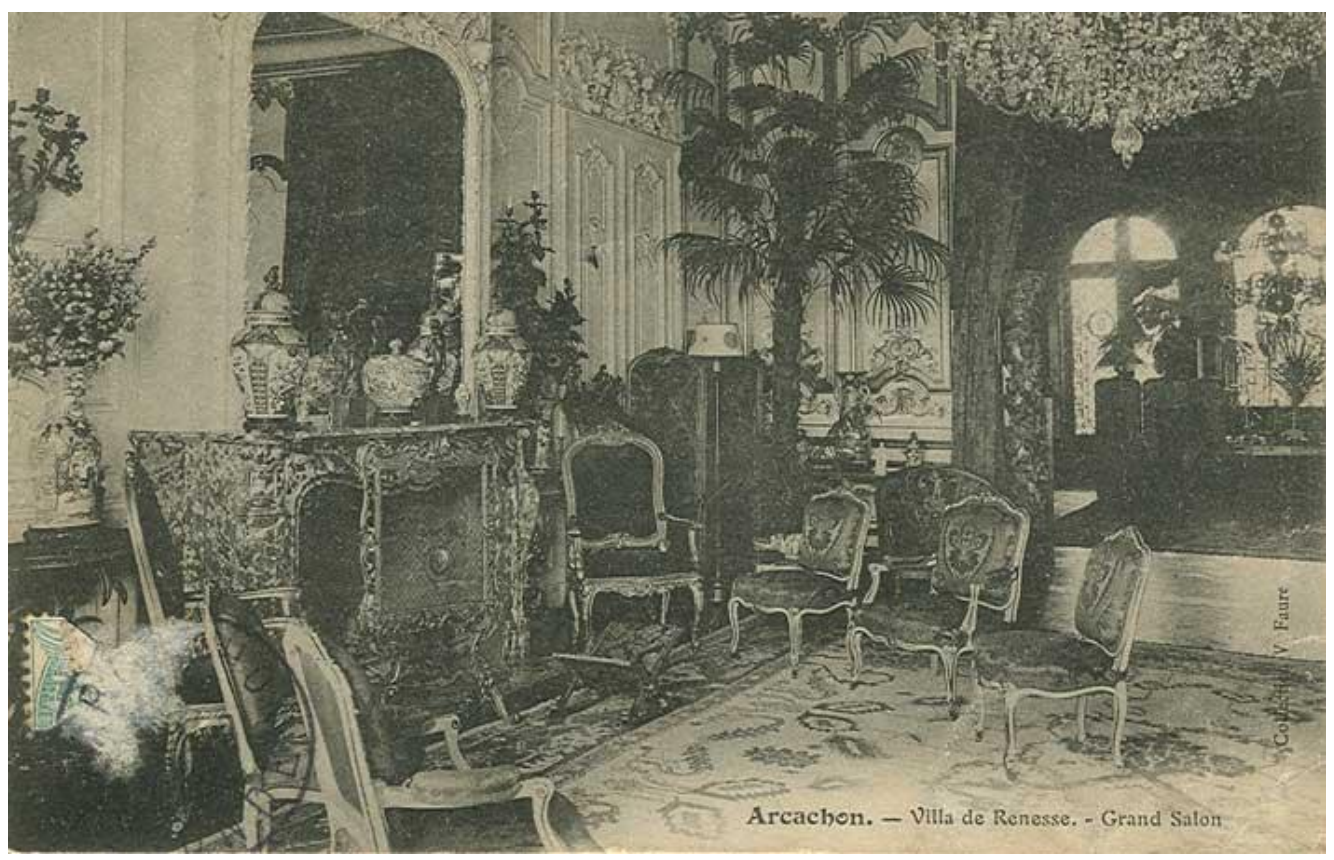

Fig. 3.42. "Villa Renesse". Gran salón. Arcachon. Francia

75 Isabelle II séjourne à Arcachon: http://shaa.fr/articles.php?Ing=fr\&pg=229 consultado el día 11 de junio de 2013.

${ }^{76}$ Imágenes en: www.arcachon-nostalgie.com/ consultada el día 11 de junio de 2013. 


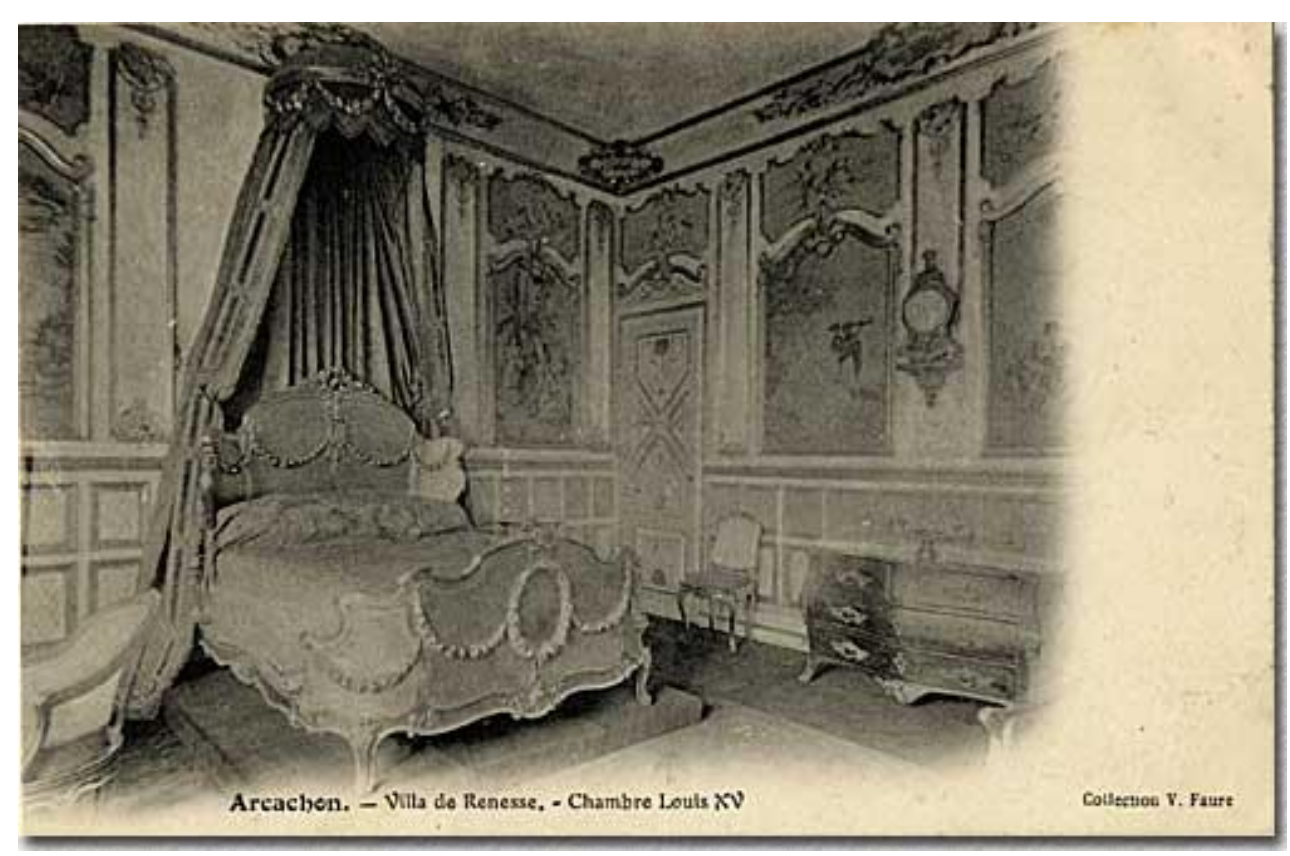

Fig. 3.43 "Villa Renesse". Habitación Luis XV. Arcachon. Francia.

Mediante estas imágenes podemos hacernos perfectamente una idea de la decoración suntuosa y lujosa que debía tener la villa en tiempos del marqués, pues era costumbre vender las propiedades amuebladas. No sería nada raro que la cama que aparece en la imagen fuera la de la propia marquesa de Campo o que en esas mismas sillas del gran salón se hubiera sentado la reina Isabel II. 


\section{Capítulo iv}

EL MARQUÉS DE CAMPO COMO PROMOTOR DE ARTE EFÍMERO

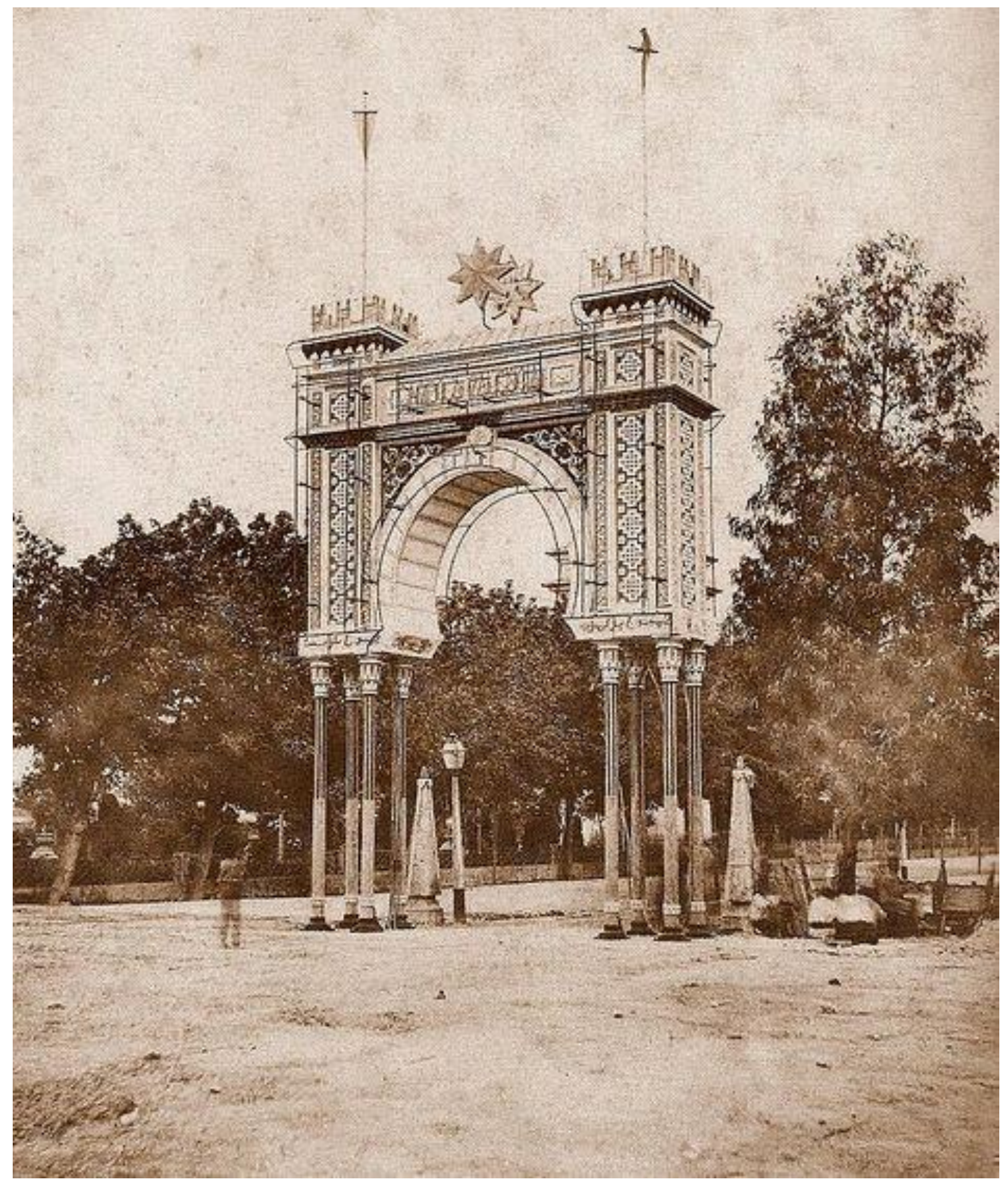





\section{Capítulo iv}

\section{EL MARQUÉS DE CAMPO COMO PROMOTOR DE ARTE EFÍMERO}

El análisis de la fiesta como manifestación jovial y conmemorativa de un pueblo, que en nuestro país ha gozado de gran tradición durante siglos y ha dado lugar a celebraciones religiosas, oficiales, profanas y populares, pone de manifiesto la integración entre la sociedad y el poder a través de factores sociales, económicos, culturales y políticos.

Estas fiestas no sólo se celebraban en España sino en el resto de Europa, donde se llevaban a cabo todo tipo de festejos en diferentes ocasiones en los que la población participaba en mayor o menor medida, siendo un buen ejemplo de ello Italia. Matrimonios, nacimientos y funerales reales, subidas al trono y otras fiestas religiosas o profanas de carácter público producían como consecuencia todo tipo de manifestaciones artísticas. 
Retratos, pendones en fachadas, estandartes, decoraciones florales, escenarios de espectáculos realizados en cartón piedra, monumentos, arcos de triunfo, carros triunfales para desfiles o cabalgatas, etc., siendo la mayoría de carácter efímero, realizados ex profeso para la ocasión y destruidos después¹.

Como dice Víctor Mínguez: "los festejos del XIX devienen de las celebraciones y fastos que ya se hacían en el siglo XVI y en cada época han sido reflejo de las corrientes artísticas que se han plasmado en decoraciones, arquitecturas efímeras, carros de desfile, engalanamiento e iluminación de fachadas, etc., para engalanar la ciudad que está de fiesta o de luto, según sea el motivo de celebración o duelo, pero, sea uno u otro la causa, siempre hay motivo para la propaganda de riqueza y poder que se hace y que casi siempre están relacionadas con la monarquía” ${ }^{2}$.

${ }^{1}$ Sobre el arte efímero ver:

ALBA PAGÁN, Ester. "El arte efímero y los artistas valencianos en la primera mitad del siglo XIX: de la fiesta barroca a la fiesta político-patriota (1802-1833)" en Cuadernos de arte e iconografía, Tomo 8, n. ${ }^{0}$ 16, Madrid: Fundación Universitaria Española, 1999, pp. 493-530.

GARCÍA SÁNCHEZ, Laura. "La fiesta como ejemplo de manifestación plástica y lúdica: Breve recorrido por un arte efímero valenciano a principios del siglo XIX" en Primer Congreso de Historia del Arte Valenciano. Mayo 1992. Valencia: Actas, Generalitat Valenciana, 1992, pp. 475-480.

MÍNGUEZ CORNELLES, Víctor; GONZÁLEZ TORNEL, Pablo; RODRÍGUEZ MOYA, Inmaculada. La fiesta barroca. El Reino de Valencia (1599-1802). Castellón: Universitat Jaume I, Servei de Comunicació i Publicacions, 2010.

PEDRAZA MARTÍNEZ, Pilar. Barroco efimero en Valencia. Valencia: Ayuntamiento de Valencia. 1982.

Sobre la fiesta en Europa ver entre otros:

MÍNGUEZ CORNELLES, Víctor. La fiesta áurea durante el reinado de Carlos II. El esplendor del barroco efimero. Alcañiz; Ars \& Renovatio, CEAR, 2019.

${ }^{2}$ MÍNGUEZ CORNELLES, Víctor. "El festejo valenciano deciochesco: arquitecturas, esculturas y decoraciones efímeras". En: Saitabi, Revista de la Facultad de Geografía e historia. Valencia: Universidad de Valencia, 1987, p. 255-256. 
Los burgueses enriquecidos, los nobles y las instituciones más relevantes de las ciudades del siglo XIX, como por ejemplo casinos, ateneos, gremios, estamentos militares, ayuntamientos e iglesias, no dudan en realizar toda una serie de festejos que normalmente duran entre tres y cinco días para participar del acontecimiento, que se celebra en Madrid normalmente, pero que nos es óbice para festejarlo en todas las ciudades de España.

En el caso de una celebración local, esté relacionada o no con la monarquía, ocurre lo mismo; se organiza una comisión de fiestas y un comité de personas con influencias y poder en la ciudad organiza los festejos. Por medio de ayudas, donaciones y suscripción pública, se reúne el dinero para llevar a cabo todos los actos y las obras necesarias para el engalanamiento de la ciudad y el disfrute del pueblo. En el caso de Valencia, cuando se celebró la boda de la reina Isabel II, el segundo centenario de la colocación de la Virgen de los Desamparados en la Basílica o el IV centenario de la canonización de san Vicente Ferrer, se nombraron comisiones que decidieron y organizaron todos los festejos3. Como dice Ester Alba: "la celebración de estas fiestas centenarias venía acompañada de importantes acontecimientos artísticos. Por ejemplo, coincidiendo con la celebración del segundo centenario de la instalación de la imagen de la Virgen de los Desamparados en la Basílica, se celebró una exposición regional que incluyó una sala de bellas artes"4.

\footnotetext{
3 Esto lo vemos reflejado en la crónica correspondiente a cada uno de estos festejos:

BOIX, Vicente. Relación de las fiestas reales con que la ciudad de Valencia solemnizó el enlace de S.M. la reina $D^{a}$ Isabel II con Francisco de Asís de Borbón, y el de la infanta María Luisa Fernanda con el Duque de Montpensier. Valencia: Ayuntamiento de Valencia, 1846.

BOIX, Vicente. Fiestas que se celebraron en el siglo IV de la canonización de San Vicente Ferrer en Valencia. Valencia: Imprenta de José Rius, 1855.

BOIX, Vicente. Memoria Histórica de las fiestas celebradas en Valencia con motivo del $2^{\circ}$ centenar de Nuestra Señora de los Inocentes Mártires y Desamparados, en el mes de mayo de 1867. Valencia: Ayuntamiento de Valencia, 1867.

4 ALBA PAGÁN, Ester. "El arte efímero y los artistas valencianos en la primera mitad del siglo XIX: de la fiesta barroca a la fiesta político-patriota (1802-1833)" en Cuadernos de arte e iconografía, Tomo 8, n. ${ }^{0}$ 16, Madrid: Fundación Universitaria Española, 1999, p. 493 y 394.
} 
Según dice Laura García: la celebración de fiesta era una inofensiva válvula de escape para la población, que estaba bajo el poder absoluto y no podía descontrolarse 5 . Las condiciones de vida del pueblo eran muy duras independientemente del periodo al que nos refiramos, y por lo menos durante las fiestas, parecía que la luz, el color y los adornos alegraban un poco el espíritu y hacían olvidar un poco el hambre y la enfermedad. Si bien es cierto, normalmente en las fiestas laicas y religiosas siempre había una partida económica destinada a caridad y se repartían alimentos y limosnas a los pobres.

De la misma manera en cada una de esas celebraciones se premiaban a las instituciones, gremios, particulares e iglesias que destacaban por la laboriosidad y la belleza del adorno realizado para la ocasión.

Vamos a ver ahora alguna de esas manifestaciones festivas en las que participó el marqués de Campo, ya fuera construyendo arcos efímeros o iluminando las fachadas de sus palacios y por las cuales también recibió premios.

5 GARCÍA SÁNCHEZ, Laura. "La fiesta como ejemplo de manifestación plástica y lúdica: Breve recorrido por un arte efímero valenciano a principios del siglo XIX" en Primer Congreso de Historia del Arte Valenciano. Mayo 1992. Valencia: Actas, Generalitat Valenciana, 1992, p. 475. 


\section{1.- Arco para la Feria de Julio de Valencia de 1871}

La Feria de Julio de Valencia se celebró por primera vez durante los días 21 al 26 de julio de 1871 Fue promovida por varios concejales del Ayuntamiento para evitar que la ciudad quedara vacía con motivo del verano y así promover la actividad comercial. Como era normal que por las fiestas de san Jaime y santa Ana se celebraran corridas de toros, se pensó en celebrar más festejos que atrajeran a ciudadanos y visitantes de fuera antes de que el mes de agosto paralizara la vida económica de la ciudad6.

La feria se planeó bajo el gusto de la burguesía, se montaron pabellones para distracción de las clases elevadas, se celebraron desfiles históricoalegóricos, certámenes literarios, corridas de toros, certámenes de bandas de música y, a partir de 1891, la famosa batalla de flores que ya se celebraba en poblaciones como Niza y Cannes. La burguesía deseó que el pueblo participara, pero demostrando al mismo tiempo su superioridad, su interés cultural, su prestigio y su poder económico.

Se decidió instalar la feria en los terrenos de la Alameda, entre los puentes del Real y del Mar, que servían de acceso al recinto; la entrada se puso cerca de la Fuente de las Cuatro Estaciones y allí se colocó un gran arco de entrada que corrió a cargo de José Campo. Pero esa no fue su única aportación a la feria.

Cuando de estableció el lugar de emplazamiento el problema era la iluminación, no sólo por el coste de las obras sino por el breve plazo de tiempo del que se disponía para hacerlas.

${ }^{6}$ MARTÍNEZ, Pilar; GASCÓ, Paco; CERVELLA, A. "La Feria de Julio y sus accesos". Revista Valenciana de Estudios Históricos, 2016, Vol.3, n. ${ }^{0} 5$. 
Pero eso no fue problema para José Campo quien, por medio de su Compañía, no dudó en utilizar presos de la cárcel de las Torres de Serranos y posteriormente otra mano de obra, y consiguió acabar los trabajos en un mes, exactamente para el día 21 de julio, fecha de la inauguración de la feria, y la instalación de luz fue perfecta. Lo que en un primer momento parecía un imposible fue realizado gracias al talante y carácter del señor. Campo, para quien según se decía, "la palabra imposible esté borrada de su diccionario"7.

Centrándonos ya en el arco efímero que mandó construir Campo (Fig. 4.1), éste fue colocado a la entrada de la feria y se mantuvo en ese mismo lugar hasta 1888 , cuando fue sustituido por otro arco construido con motivo de la visita a la ciudad de Alfonso XIII y su madre, la reina regente María Cristina ${ }^{8}$.

7MARTÍNEZ, Pilar; GASCÓ, Paco. "La iluminación de la primera Feria". En: La Feria Desconocida. http://verumvalentia.blogspot.com/2018/07/43-la-feria-desconocida-6la.html visto en línea el 10 de julio de 2019.

${ }^{8}$ Sobe el arte efímero en Valencia ver: GARCÍA SÁNCHEZ, Laura. "La fiesta como ejemplo de manifestación plástica y lúdica: Breve recorrido por un arte efímero valenciano a principios del siglo XIX" en Primer Congreso de Historia del Arte Valenciano. Mayo 1992. Valencia: Actas, Generalitat Valenciana, 1992, p. 475-480.

ALBA PAGÁN, Ester. "El arte efímero y los artistas valencianos en la primera mitad del siglo XIX: de la fiesta barroca a la fiesta político-patriota (1802-1833) en Cuadernos de arte e iconografía, Tomo 8, n. ${ }^{\circ}$ 16, Madrid: Fundación Universitaria Española, 1999, p. 493-530. 


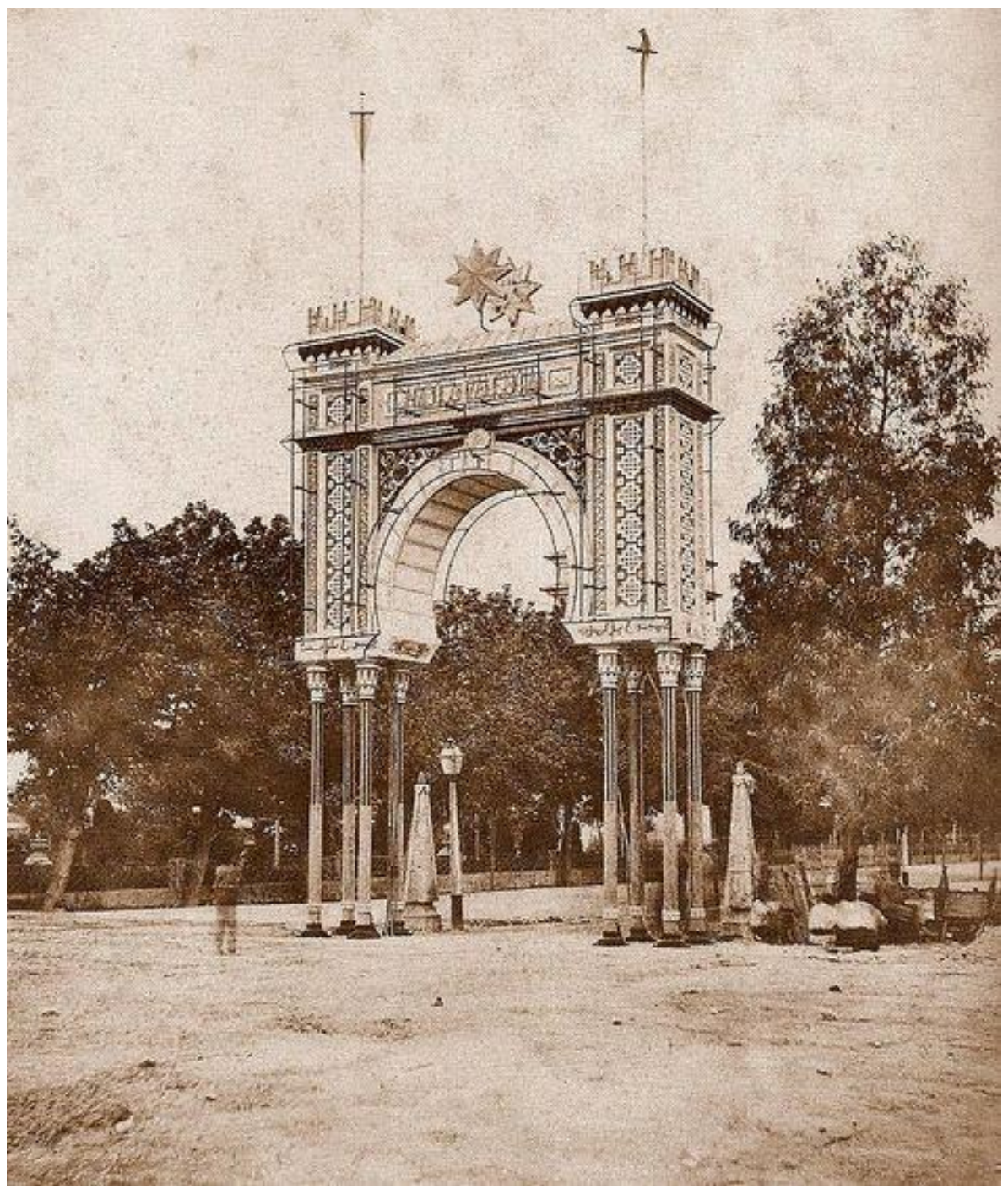

Fig.4.1 Arco de José Campo para la entrada de la Feria de Julio de 1871. Valencia. Imagen de la Biblioteca Valenciana

El arco mandado construir por José Campo fue objeto de admiración y fue descrito en varias publicaciones de la época, no sólo por su belleza sino por ser una demostración más del poder de la clase burguesa y concretamente de su promotor. Durante su mandato de alcalde de Valencia y posteriormente, Campo realizó múltiples reformas y mejoras para su ciudad natal, como ya hemos referido en otras partes de esta tesis, y la población lo tenía en gran estima. Este arco ayudó aún más a poner de relieve su poder económico, su prestigio y su posición social, incrementado desde su traslado a Madrid para ejercer su cargo de Senador. 
El arco fue diseñado por el ingeniero del ferrocarril Antonio Revenga y su ayudante Latorre. Fue pintado por Vicente Pérez Vela y José Flores Vela, escenógrafos y parientes del señor. Campo y la iluminación del mismo fue a cargo del ingeniero Francisco de Paula Rojas ingeniero de la fábrica de gas propiedad de Campo'.

La prensa del momento se hizo eco de la construcción del arco y se escribieron maravillas sobre él10. El arco recreó el estilo árabe, se realizó en un momento en el que se estudia el arte clásico y los motivos antiguos y se realizan mezclas y revivals para complacer a los clientes, en su mayoría burgueses, que querían demostrar su cultura y conocimiento del arte. En este caso el artista se decantó por emular un arco del patio de los Arrayanes de la Alhambra de Granada; lo exótico también estaba de moda y a José Campo le gustaba lo oriental; muestra de ello es que en su palacio de Valencia y en su castillo de Viñuelas había salas decoradas en ese estilo.

El arco en su totalidad medía unos 12 metros altura por siete de ancho y estaba sustentado por ocho columnas delgadas y estriadas de seis metros de altura más o menos, rematadas con capiteles octogonales. Todo el arco estaba decorado con dibujos y arabescos de vivos colores que resaltaban todavía más su aire oriental. La iluminación era un verdadero prodigio realizado por Francisco de Paula Rojas, y estaba formada por casi ocho mil luces que resplandecían por la noche en la feria. Las luces seguían las líneas principales del arco, los zócalos, la herradura, las pilastras, las cornisas y los torreones.

9 PINEDO, Carmen; MAS, Elvira. Dos artistas valencianos del siglo XIX: José Vicente Pérez Vela y José Flores Vela. La familia artística del Marqués de Campo. Inédito. Valencia, 2003.

${ }^{10}$ Las Provincias, 27/7/1871. 
Sobre el arco había seis estrellas, dos de ellas radiadas, dos compuestas por triángulos y las otras dos formadas por innumerables perlas de cristal tallado, todas ellas estaban iluminadas en su interior y provistas de reflectores. Todas estas luces estaban conectadas a tuberías de gas a las que se accedía por escaleras dada la altura del arco.

Como afirmó la prensa, para realizar el gran enrejado de tuberías de latón para poner más de siete mil salidas de gas, fue necesario subdividir el trabajo entre varias empresas valencianas: Ferré e hijos, Mestres y Japies, Ciervo y compañía, y otras que realizaron parte de la cerrajería. Pero todas las dificultades se vencieron y el arco lució cada noche de la feria y se decía que el terreno que lo iluminaba parecía alumbrado por el sol.

A su vez el arco tenía en su parte superior una dedicatoria; "Campo a Valencia”. No cabe duda de la intención de Campo de dejar constancia del amor que siempre tuvo por su ciudad natal y a la que tantas veces benefició con sus iniciativas, pero no olvidemos tampoco que cada una de esas iniciativas también le ayudó a enriquecerse un poco más. 


\section{2.- Arco Triunfal para la entrada de Alfonso XII en Madrid en 1875}

El historiador del arte Juan Chiva a propósito de las entradas de la casa de Austria en Madrid, dice que: "Las entradas reales son una de las ceremonias de la Edad Moderna que más relación guarda con el momento clave de la transmisión del poder, ya que se trata del ritual mediante el cual un nuevo monarca accede al trono de forma magnánima y frente al pueblo, su primera gran entrada triunfal como rey. Las entradas triunfales son un tipo de ceremonia donde un personaje de gran importancia ingresa en una ciudad, para lo que todo el aparato ceremonial y artístico de la misma se vuelca al servicio del lujo y el engalanamiento, alcanzando el arte efímero gran importancia y difusión y siendo su forma más exitosa el arco triunfal"11.

También dice Chiva en su estudio de los arcos de triunfo de Nueva España que: "Los arcos triunfales son una de las producciones culturales y artísticas más indisolublemente ligada al poder, a la iconografía del mismo y a su muestra triunfante frente a la sociedad. Ya en el mundo romano se levantaron cientos de arcos de triunfo en honor a emperadores o gestas militares, tanto en Roma como en los lugares más alejados del centro de poder imperial, costumbre que se retomará durante el siglo XVIII para adornar las grandes capitales europeas, como París, Londres, Madrid o Berlín. Pero también se levantan arcos con materiales perecederos, vinculados al mundo festivo, y más en concreto a la ceremonia de entrada triunfal. Se trata de la misma tipología arquitectónica, en el primer caso permanente y en el segundo efímera, que arranca en ambos casos del mundo ceremonial de la República romana"12.

Y continúa diciendo que: "de entre todos los elementos formales y arquitectónicos que van a poblar la fiesta durante la Edad Moderna, destaca por

${ }^{11}$ CHIVA BELTRÁN, Juan. Triunfos de la Casa de Austria: estradas reales en la corte de Madrid. Potestas, 2011, n. ${ }^{\circ}$ 4, p. 212.

${ }^{12}$ CHIVA BELTRÁN, Juan. "Arcos efímeros mexicanos. De la herencia hispana al nacionalismo artístico". En: SEMATA, ciencias humanas y sociales, 2012, p. 193 y 194. 
su relevancia y simbolismo el arco de triunfo. Esta estructura efímera, en forma de portada, con al menos un vano principal y recubierta de decoraciones, se va a convertir en la gran protagonista de las entradas triunfales en los siglos modernos"13.

En el siglo XIX se siguen realizando estradas triunfales de los monarcas en las ciudades y para ello se iluminan, se engalanan y se realizan construcciones de arcos efímeros. Con motivo de la llegada del rey Alfonso XII a Madrid, la ciudad se vistió de gala para recibir al recién nombrado monarca con los mejores festejos. Se organizaron numerosos actos de recepción, desfiles, bailes, fuegos de artificio nocturnos, se erigieron arcos de triunfo efímeros y se engalanaron e iluminaron fachadas de edificios oficiales y particulares, pero el que nos interesa es el arco efímero exento que mandó levantar José Campo.

A estas alturas de tesis es indudable el fervor que sentía José Campo por la monarquía y el interés y empeño que puso para que el hijo de Isabel II fuera nombrado rey de España y acabar con el problema carlista. Desde el principio sus actuaciones políticas fueron encaminadas a promover la vuelta de la monarquía, como ya vimos por ejemplo al hablar de sus cacerías de contenido político que organizaba en su catillo de Viñuelas. Y no olvidemos que uno de los primeros títulos nobiliarios que dio su majestad Alfonso XII al subir al trono fue el de marqués de Campo.

Para demostrar su patriotismo, su fervor monárquico y de paso su posición política, económica y social, José Campo mandó construir en el paseo de Recoletos, delante de su palacio, un arco efímero (Fig. 4.2) idéntico al que

13CHIVA BELTRÁN Juan. 2012, p. 195.

Ver también MÍNGUEZ CORNELLES, Víctor. "Arte, espectáculo y poder en la fiesta novohispana”. En:PÉREZ MARTÍNEZ, H. (ed.). México en fiesta. México: El Colegio de Michoacán, Secretaría de Turismo, 1998, pp. 315-329. 
había construido para la feria de julio de Valencia en 1871 y que ya hemos analizado.

En esta ocasión el arco fue diseñado y construido en Valencia por los mismos artistas e ingenieros a los que nos hemos referido páginas atrás, y llevado a Madrid para ser acabado de montar, en medio del paseo de Recoletos, por el ingeniero Julián García ${ }^{14}$.

Al igual que pasó con el arco de Valencia, la prensa madrileña y nacional se hizo eco de todos los preparativos de actos, celebraciones, adornos y construcciones que se llevaron a cabo con motivo de la llegada del rey, y el arco iluminado de Campo y la iluminación a gas de su palacio fueron objeto de muchos cometarios que no hacían sino elogiarlo y alabarlo por su belleza y novedad.
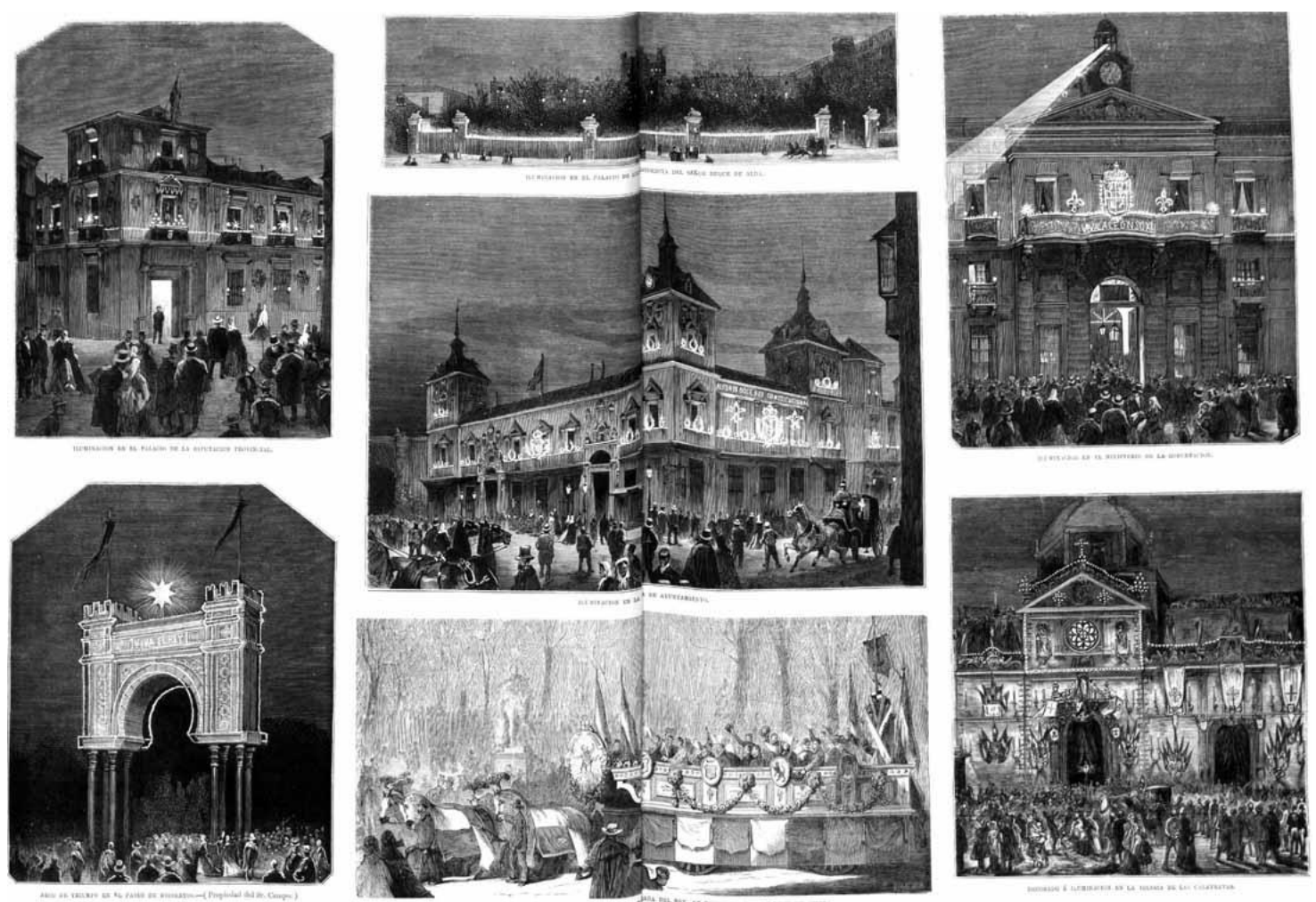

Fig. 4.2 Arco de José Campo y fachadas engalanadas para la entrada de Alfonso XII en Madrid 1875. Imagen publicada en La Ilustración Española y Americana.

${ }^{14}$ La Época, 13/1/ 1875, p.2. 
La entrada del rey se realizó el 14 de enero de 1875, y el arco del paseo de Recoletos fue traído desde Valencia y montado a toda prisa sólo un par de días antes del evento. Sabemos este dato porque en el diario La Época del día 13 de enero se publicó que el carruaje de la duquesa de Noblejas tuvo un percance por culpa de la zanja que mandó hacer José Campo en el paseo de Recoletos, para emplazar el arco y que no tenía faroles para alertar del peligro ${ }^{15}$.

En La Correspondencia de España del día 14 de enero se publicó que llamarán la atención la iluminación y el arco árabe que ha levantado en el paseo de recoletos José Campo, y se hace una breve descripción del mismo. El periodista lo describió como un arco de estilo árabe, sostenido por cuatro esbeltas columnitas a cada costado, imitando mármol negro y rematado por dos cornisas y dos torrecillas almenadas sobre las cuales pendían dos banderas.

Dijo que medía más de 11 metros de alto, por 6 de ancho y 1'5 de espesor, por lo que podemos decir que en diseño y tamaño era casi idéntico al de la feria de julio de Valencia, tal y como se observa en las imágenes que acompañamos y que son casi exactas a las del arco de Valencia de páginas anteriores.

Continua la descripción del arco (Fig. 4.3) ${ }^{16}$ diciendo que el arco central es de medio punto prolongado y el muro va pintado de colores imitando los alicatados arabescos y con inscripciones árabes. El alumbrado de gas que sigue las líneas del arco formado otro sobrepuesto, ostenta entre las dos cornisas, y a uno y otro lado, dos soles de luces y en los costados dos estrellas formadas por pequeños prismas de cristal que multiplican los destellos de la luz hasta el infinito $^{17}$.

Sobre los huecos de los arcos, a uno y a otro lado, cubre la cornisa inferior un letrero de gas que dice "VIVA EL REY" (este dato es una prueba más

${ }^{15}$ La Época, 13 /1/ 1875, p. 3.

${ }^{16}$ Imagen publicada en El periódico para todos, enero de 1875.

${ }^{17}$ La Correspondencia de España de la mañana, 14 /1/ 1875, p. 6. 
de que este arco es igual al de Valencia, pero allí el letrero decía "Campo a Valencia"). No olvidemos que el paseo de Recoletos formaba parte del itinerario que iba a hacer el rey en su entrada a la ciudad y por ello iba a ser contemplado por el mismo Alfonso XII ${ }^{18}$.

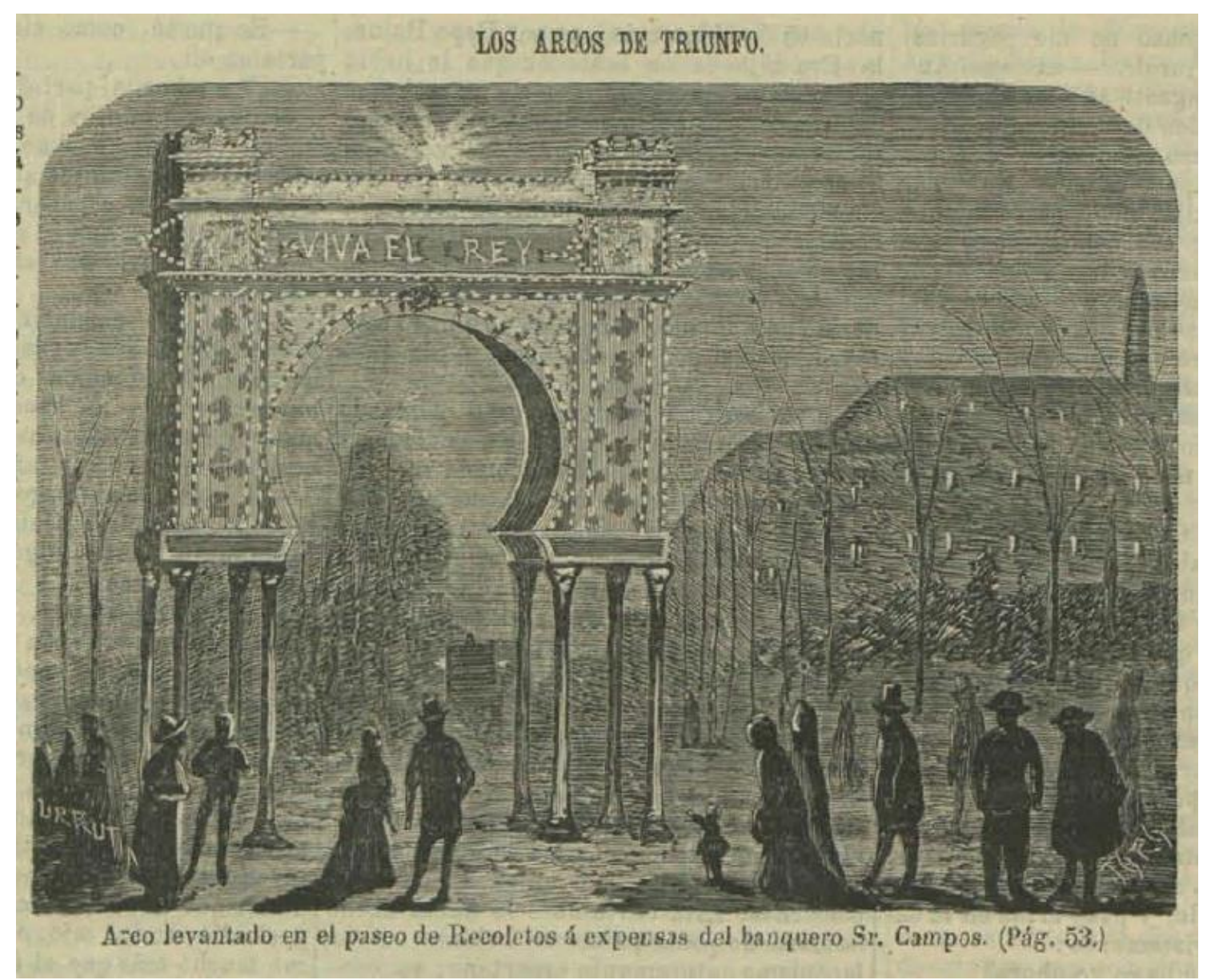

Fig. 4.3 Imagen del arco árabe de José Campo. Paseo de Recoletos, Madrid. 1875.

En El periódico para todos hay un amplio reportaje sobre los arcos de triunfo y demás decoraciones que vistieron de gala la ciudad y encontramos, la imagen que vemos arriba y referencias a su magnificencia. Se reproduce a continuación el fragmento de la mejor descripción del arco que se hizo en su momento.

${ }^{18}$ El Imparcial, 15 /1/ 1875, p. 2. 
"El arco árabe del Sr. Campo, visto de noche desde la fuente de Cibeles, y desde la gran avenida de carruajes del paseo de Recoletos, presentaba la perspectiva más elegante y preciosa que puede concebirse. Este arco, como puede verse en el dibujo, es de un solo cuerpo y se encuentra sostenido por columnitas, no imitando al hierro fundido negro, como se ha dicho por algunos, sino al lapislázuli, a que tan aficionados eran los sarracenos. El arco central es parecido al de la mezquita de Córdoba, y presenta en sus dos frentes toda la gala, toda la elegancia y toda la belleza del acicalado de aquellos delicados maestros de la arquitectura mudéjar. En los costados de cada frente arrancan torrecillas chatas almenadas, de manera que no puede pedirse pensamiento más acabado ni más gracioso. Sobre el colorido de la parte decorativa se ha superpuesto en todas sus líneas principales y en sus formas más esbeltas y sobresalientes, una tubería de gas; de modo que de noche el arco se convierte en una construcción de llamas del efecto más maravilloso. En fuego, y en la parte central, se lee el letrero de Viva el Rey; coronando todo el arco un prisma en forma de estrella que reproduce las luces hasta el infinito"19.

En otra descripción del mismo arco se dice que se nota la ligereza, elegancia, gallardía y primor de la arquitectura morisca ${ }^{20}$, ya que ese estilo estaba de moda en el momento y se adecuaba al gusto de la clase burguesa.

Con la construcción de este arco y la iluminación de su palacio, Campo quiso demostrar su ideal político y su adhesión y lealtad a la corona, y a su vez competir con otras construcciones y adornos. Podemos citar por ejemplo el arco de la calle Alcalá, de aspecto romano y costeado por la Asociación para el socorro de heridos del ejército; el arco de madera, tela y pintura de la plaza de la Armería, costeado por el Círculo Alfonsino; el carro de obreros y artesanos que siguió a la comitiva real hasta el palacio, y las diferentes iluminaciones de edificios como el Ayuntamiento, la Diputación Provincial, el ministerio de la

${ }^{19}$ El periódico para todos, núm.4, enero de 1875, p. 53.

${ }^{20}$ La ilustración española y americana, año XIX, núm., IV, 30 enero 1875, p. 6. 
Gobernación, la Iglesia de Calatrava y el palacio de Liria en cuyas fachadas había colgaduras de terciopelo, banderas, retratos de S.M. el rey, luces muy variadas de gas, escudos de armas reales, ramos de flores, etc. todo ello para engalanar el recorrido que iba a realizar el rey al entrar triunfante a la ciudad ${ }^{21}$. No será esta la última vez que Campo engalane su palacio del paseo de Recoletos por festejos relacionados con Alfonso XII.

Ya convertido en marqués de Campo, las batallas ganadas por el ejército de su majestad y los dos enlaces reales harán que el palacio se engalane y se ilumine de nuevo y que todo Madrid pueda admirarlo. No hay que olvidar que, con motivo de celebraciones relacionadas con la monarquía como bodas, nacimientos, entierros y entradas triunfales, entre otras, la ciudad y el país entero se sumía en una semana o más de celebraciones con toda clase actos como desfiles, conciertos, misas en acción de gracias, etc., y el engalanamiento de la ciudad era una parte muy importante de esas celebraciones en las que se implicaba el pueblo en la medida de sus posibilidades, para dar más relevancia a los actos. Por ello, parte de la fiesta era la admiración de esas decoraciones efímeras de arcos y fachadas iluminadas durante los paseos nocturnos de las noches de fiesta.

${ }^{21}$ La ilustración española y americana, año XIX, núm., III, 15 enero 1875, p. 3. 


\section{3.- Carro triunfal "El Progreso" para la Feria de Julio de 1888 y 1889}

Los carros triunfales o para desfiles eran muy utilizados en las fiestas del barroco y gozaban de tradición en España en desfiles y cabalgatas conmemorativas. Los carros eran verdaderas obras de arte cuya riqueza y esplendor dependía del gremio, asociación de personas, entidad pública o particular que lo sufragaba.

Para su realización se contrataba a carpinteros, escultores y pintores que llevaban a cabo en breve plazo de tiempo unas obras verdaderamente espectaculares y que lucían en las procesiones y desfiles. Ejemplos de carros triunfales en Valencia tenemos desde muchos siglos antes del que nos ocupa, puesto que podríamos ponerlo en relación con las Rocas o carros que, según Boix, desfilaban en la procesión del Corpus de Valencia desde 1413 "con objeto de celebrar la venida a Valencia del rey D. Fernando I de Aragón, encargando las obras a Juan Oliver, artista ingenioso y de gran reputación en aquella época”22.

$\mathrm{Y}$ carros triunfales en celebraciones profanas ya hubo en Valencia desde el siglo XVI, que han sido estudiados por Pilar Pedraza y más recientemente por Víctor Mínguez, Inmaculada Rodríguez y Pablo González²3.

\footnotetext{
${ }^{22}$ BOIX, Vicente. Fiestas Reales. Descripción de la cabalgata y de la procesión del Corpus. Valencia: Imp. De la Regeneración Tipográfica de Ignacio Boix, 1858. pp. 6-7. Para el tema de las rocas del Corpus ver también: MÍNGUEZ CORNELLES, Víctor. "Las rocas del Corpus valenciano: fuentes grabadas y tradición artesanal”. En: Lecturas de Historia del Arte. Vitoria: Ephialte, 4, 1994, pp. 248-254.

23 PEDRAZA MARTÍNEZ, Pilar. Barroco efímero en Valencia. Valencia: Ayuntamiento de Valencia, 1982.

MÍNGUEZ CORNELLES, Víctor; GONZÁLEZ TORNEL, Pablo; RODRÍGUEZ MOYA, Inmaculada. La fiesta barroca. El Reino de Valencia (1599-1802), Castellón: Universitat Jaume I, Servei de Comunicació i Publicacions, 2010.
} 
Hemos hecho antes referencia a que en 1871 se creó en Valencia la Feria de Julio para promover el comercio y la economía de la ciudad en la época estival y en esos días se celebraban bailes, espectáculos, conciertos, festejos taurinos, teatro, etc., y poco a poco se añadieron más festejos como por ejemplo una cabalgata que ponía fin a la feria y que se celebraba el último día, y para la cual el marqués de Campo hizo construir un carro triunfal que llevó por nombre El Progreso.

Podemos poner este carro triunfal en conexión con los carros triunfales y efímeros que se habían realizado en la ciudad años antes con motivo de la celebración del IV centenario de la canonización de San Vicente Ferrer. En esa celebración, tal y como relata Boix, el ayuntamiento asumió el coste de la realización de una roca nueva, que se le puso por nombre Valencia por ser una alegoría de la ciudad. Dicha roca fue realizada Luis Téllez, profesor de la Academia de Bellas Artes de san Carlos, pintor del ayuntamiento y director de la sociedad de artistas valencianos ${ }^{24}$. Además de esa roca, la asociación de valencianos que se constituyó para la celebración de la fiesta, asumió el coste de la construcción de cuatro carros triunfales que fueron realizados por el pintor José Vicente Pérez y por el carpintero Miguel Santamaría25.

José Vicente Pérez Vela era un famoso pintor y escenógrafo, académico de mérito de san Carlos, familiar del marqués de Campo por parte de su madre, que realizó las decoraciones de su palacio de Valencia y su castillo de Viñuelas, junto con su hermanastro José Flores Vela ${ }^{26}$.

\footnotetext{
${ }^{24}$ BOIX, Vicente. 1858 , p. 61.

25 BOIX, Vicente. 1858, p. 66.

${ }^{26}$ Sobre José Vicente Pérez Vela y José Flores Vela ver: PINEDO HERRERO, Carmen; MAS ZURITA, Elvira. Dos artistas valencianos del XIX: los escenógrafos José Vicente Pérez Vela y José Flores Vela, (inédito) Valencia: 2003.
} 
Pero en este momento nos interesa resaltar que José Vicente Pérez Vela también realizó la decoración de varias fachadas como la del Gobierno Político, con un templete de estilo jónico, en las fiestas celebradas en 1846 con motivo de las celebraciones por las bodas de Isabel II y su hermana Luisa Fernanda. Destacar que cuando se llevaron a cabo estas celebraciones José Campo era el acalde de la ciudad, y bajo su dirección se engalanó e iluminó la ciudad, y las celebraciones incluyeron fuegos artificiales y juegos náuticos en el cauce del río Turia $^{27}$.

Los cuatro carros que ejecutó José Vicente Pérez Vela en 1858 fueron diseñados por un miembro de la asociación de valencianos; y también realizo la decoración de las fachadas de la Iglesia de san Esteban, que conserva la pila donde san Vicente recibió el bautismo ${ }^{28}$.

Reproducimos las imágenes de los cuatro carros que han llegado hasta nuestros días gracias a la Crónica de Vicente Boix (Figs. 4.4, 4.5, 4.6 y 4.7).

De los cuatro carros, el primero representaba a Valencia; el segundo la religión católica y las virtudes teologales; el tercero la fundación por san Vicente del colegio imperial de huérfanos y el asilo de pobres párvulos, que se inauguró en esos días gracias a la caridad valenciana del siglo XIX; y el cuarto carro representaba las Cortes de 1412 que se celebraron en Caspe, donde san Vicente Ferrer concilió las encontradas opiniones de los representantes de la corona de Aragón, con motivo de la sucesión al trono, vacante por fallecimiento del rey Don Martín, proclamando rey a Fernando I de Antequera ${ }^{29}$.

${ }_{27}$ BOIX, Vicente. Relación de las fiestas reales con que la ciudad de Valencia solemnizó el enlace de S.M. la reina $D^{a}$ Isabel II con Francisco de Asís de Borbón, y el de la infanta María Luisa Fernanda con el Duque de Montpensier. Valencia: Ayuntamiento de Valencia, 1846, p. 13, 19, 40, y 73.

${ }^{28}$ BOIX, Vicente, 1858 , p. 30 y 57.

${ }^{29}$ BOIX, Vicente, 1858. p. $61-64$. 


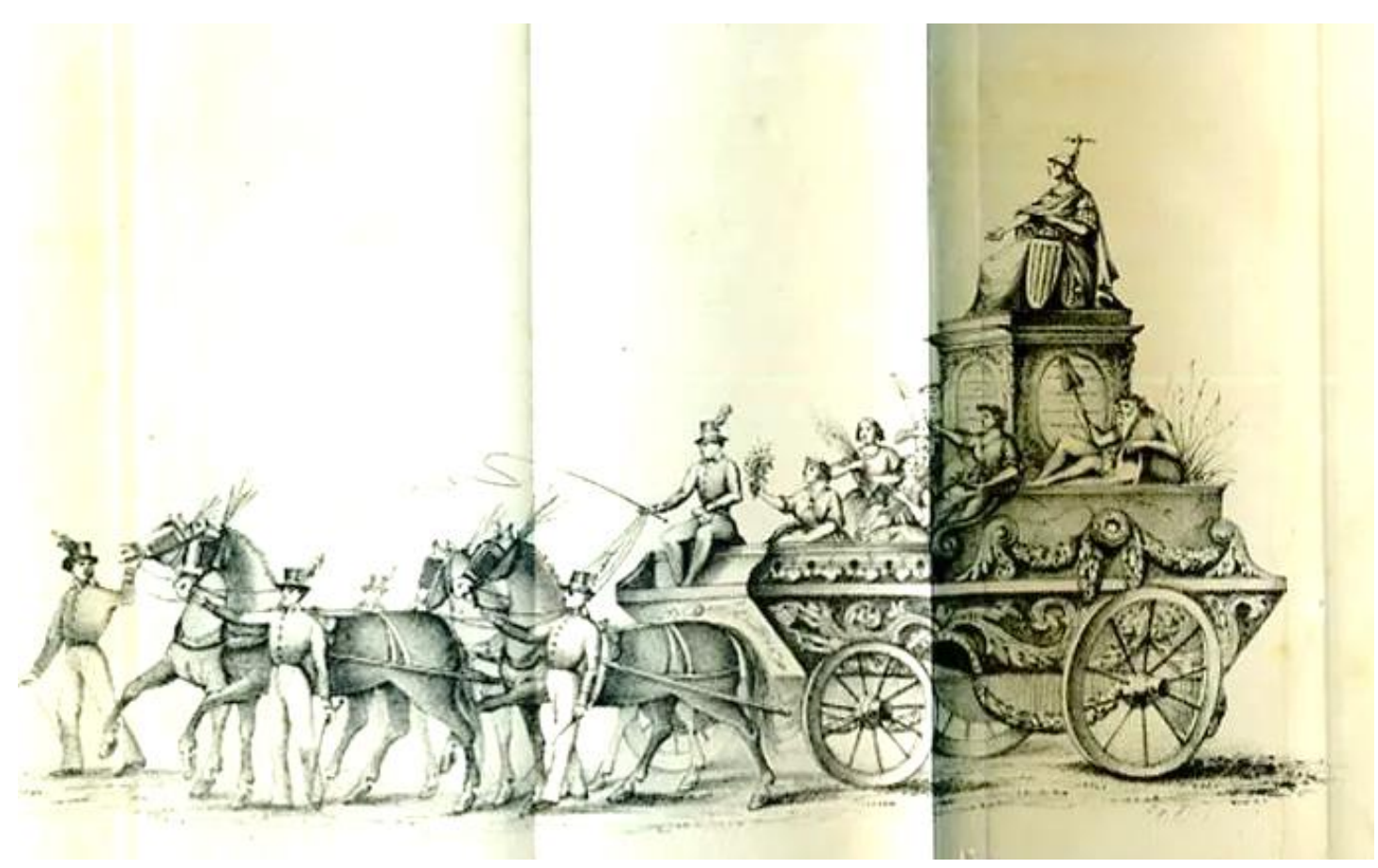

Fig. 4.4 Carro que representa a Valencia. Imagen publicada por Boix.1858

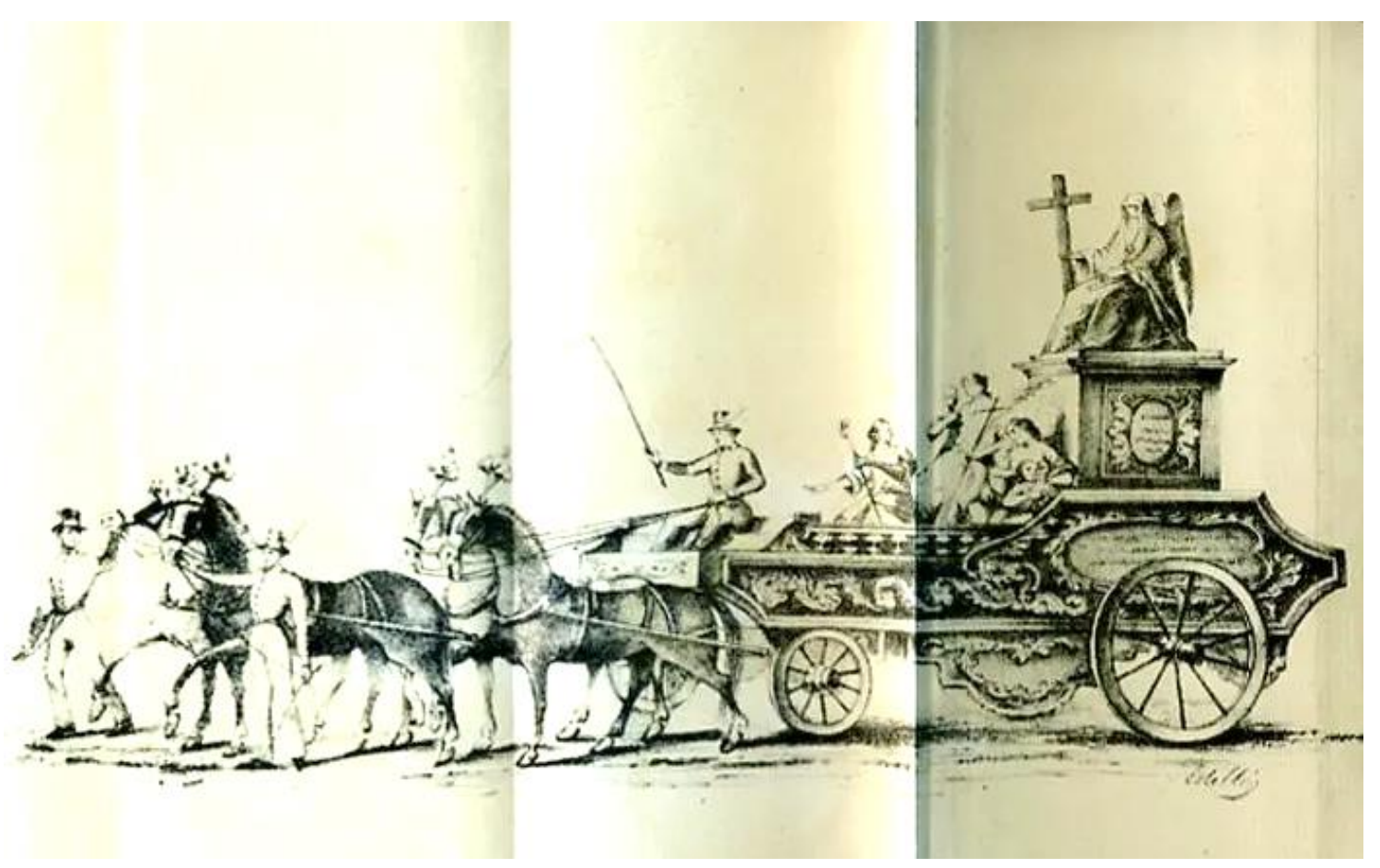

Fig. 4.5 Carro que representa la religión católica y las virtudes teologales. Imagen publicada por Boix. 1858. 


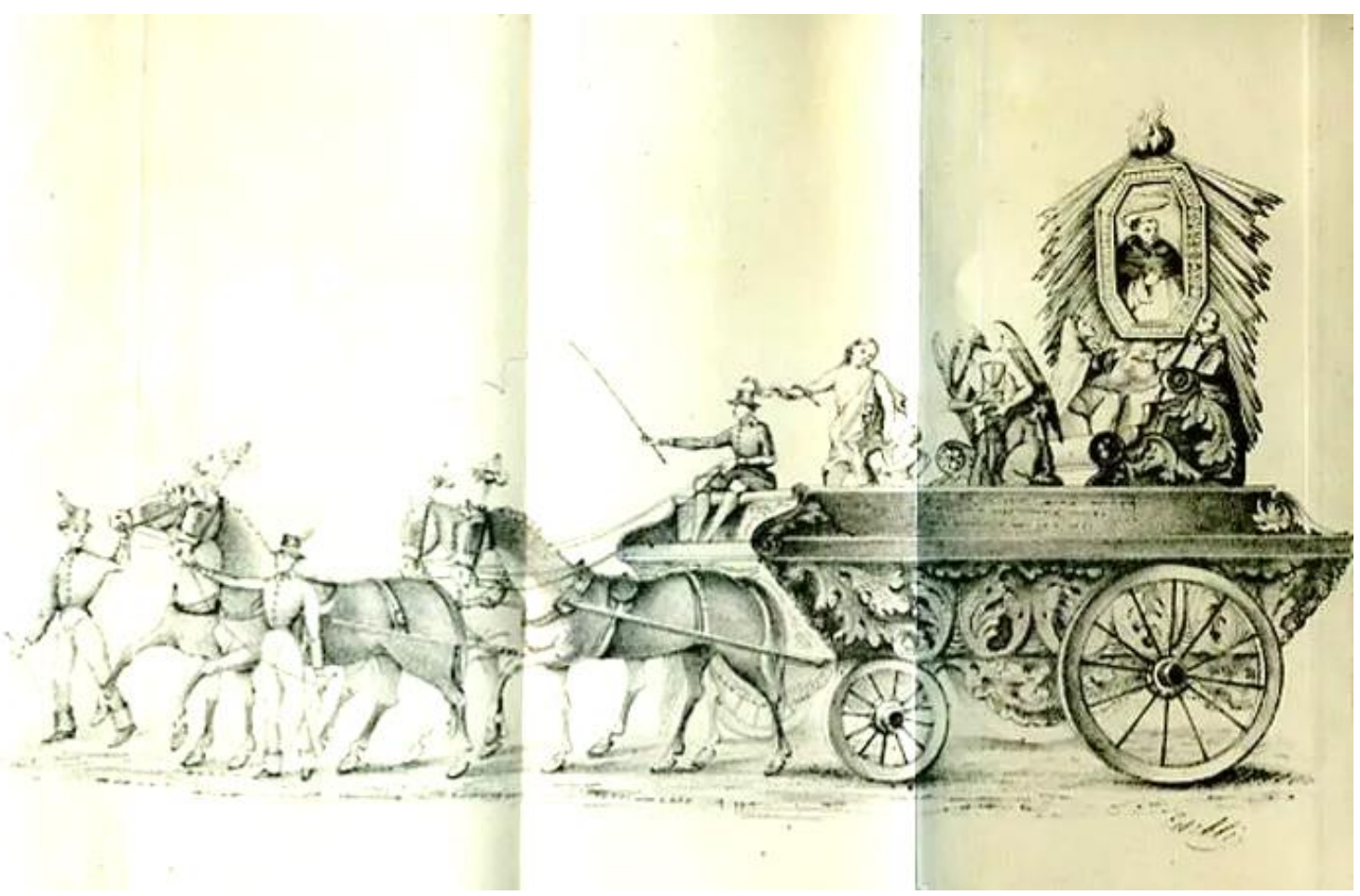

Fig. 4.6 Carro que representa la fundación del Colegio Imperial de huérfanos de san Vicente. Imagen publicada por Boix. 1858.

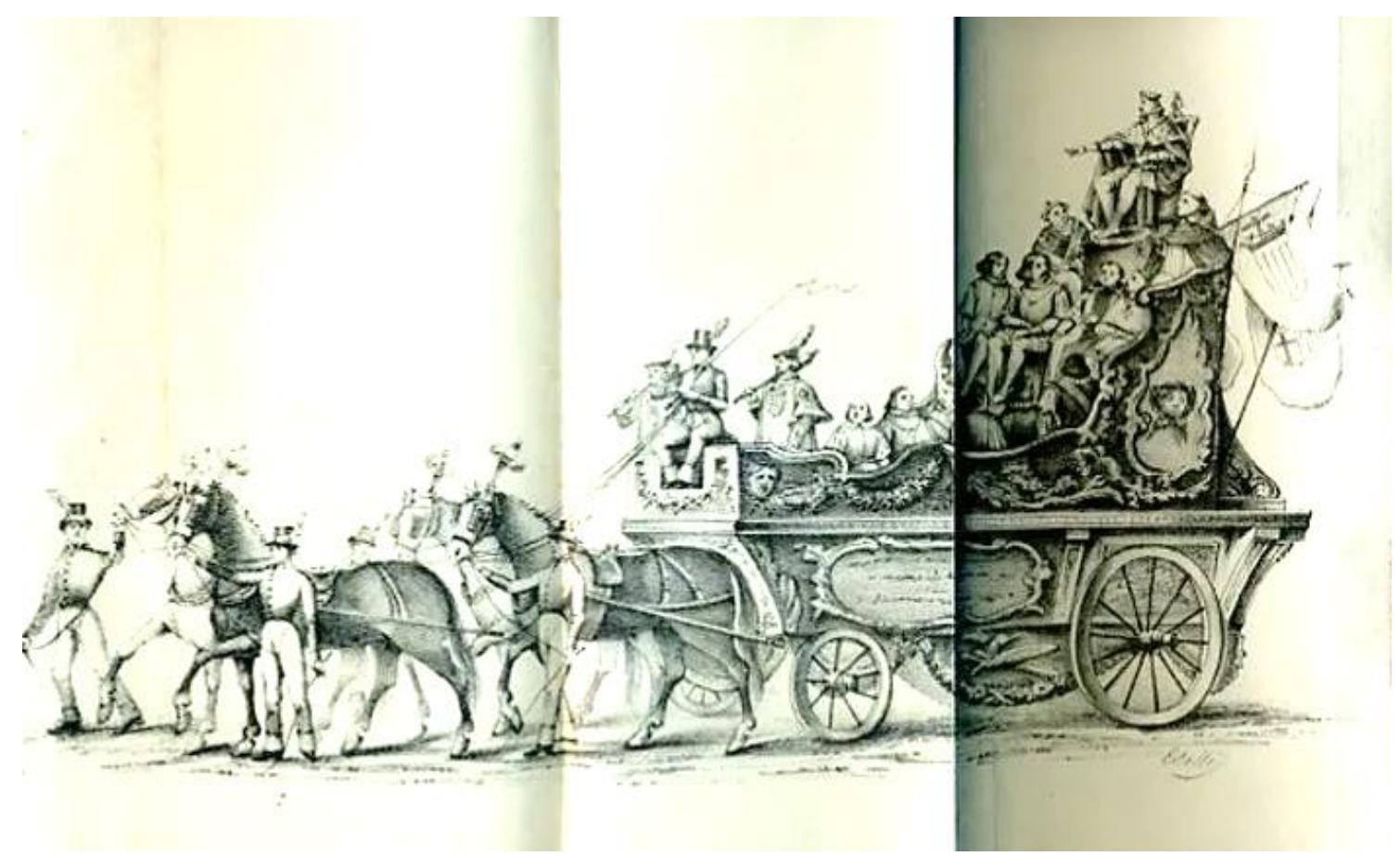

Fig. 4.7 Carro que representa las Cortes de 1412 en Caspe. Imagen publicada por Boix. 1858. 
Estas ilustraciones que acabamos de ver nos pueden ayudar a hacernos una idea de cómo debió ser el carro triunfal y efímero que hizo construir el marqués de Campo a su familiar Vicente Pérez Vela, para la cabalgata de 1888.

En la cabalgata de la feria de julio que realizaba cada año desfilaban diferentes carrozas y carros decorados con flores, guirnaldas, figuras y otros símbolos. El carro se llamaba El Progreso, y es que conociendo a estas alturas el carácter trabajador y emprendedor del marqués, no es de extrañar que fuera ese el nombre porque en definitiva desde su juventud uno de sus grandes empeños fue que su ciudad natal progresara. Mejoró las instalaciones de agua y gas, iluminó las calles, las empedró para evitar el barro y los charcos continuos, reformó el puerto, trajo el ferrocarril, es decir, procuró para su Valencia natal todo aquello que la pudiera igualar con otras ciudades europeas del momento que se estaban modernizando.

Es una pena que no se conserve ninguna imagen del carro, pero la descripción detallada del carro El Progreso del marqués que participó en la cabalgata del día 31 de julio de 1888, la encontramos en un bando publicado con fecha del día anterior por el alcalde D. Pedro Fuster y secretario accidental D. T. García Valdivieso.

A dicho bando pertenecen los siguientes párrafos:

"Carro de El Progreso (costeado por el marqués de Campo). Representa un buque de los de su empresa; está tomado del vapor Magallanes, tiene seis metros de longitud y ha sido construido de una manera sólida a la par de artística por dos maestros de calafatería del Grao.

En la popa del buque, construido náuticamente con todo su velamen y aparejos, está el escudo del marqués de Campo; en la proa el Asilo de párvulos que dicho señor ha fundado en Valencia, y encima del tímpano hay una columna sostenida por una amazona que representa la luz eléctrica; colocada a un lado hay otra amazona representando la luz del gas y dando la mano a la primera para demostrar que ambas aborrecen la oscuridad. 
En la cubierta del buque se ven los gasómetros, que tiene por remate una matrona representando el Progreso. Colocada a la parte de estribor hay una máquina del ferro-carril, de un metro de longitud próximamente y a babor están representadas las aguas potables con el Comercio, las Artes y la Industria, resultado un conjunto tan artístico como soberbio. Gran banda de dulzaineros y tabaleros. Banda de música. Banda de trompetas de caballerías"3o.

El carro tuvo tanto éxito y gustó tanto al público que, al año siguiente, el 30 de julio de 1889 se publicó un bando haciendo saber:

"que el éxito obtenido el año anterior por la Cabalgata o manifestación denominada Del Progreso, ha hecho indispensable que figure en el programa del actual, mayormente cuando por imprevistos accidentes no pudo la generalidad del vecindario apreciar los detalles del festejo”.

La reseña de la mencionada carroza se hacía en los mismos términos a los copiados 31 .

Es decir, que el carro efímero del marqués participó como mínimo en dos ocasiones en la cabalgata final de la feria de julio de Valencia; pero teniendo en cuenta que José Campo murió en agosto de ese mismo año, se puede deducir que el carro ya no se exhibió más y por ello ya no hay más noticias sobre el mismo.

$3^{\circ}$ Estos datos referentes al bando del día 30 de julio de 1888 se encuentran en el Dosier Marqués de Campo 1. Carro Feria de la Biblioteca Valenciana.

${ }^{31}$ Dosier Marqués de Campo 1. Carro Feria de la Biblioteca Valenciana. 


\section{4.- Templete para la Exposición Regional de Valencia de 1883}

En esta ocasión la construcción efímera es un templete para la Exposición Regional de agricultura, industria y artes de Valencia de 1883 celebrada en los Jardines del Real (fig. 4.8).

José Campo participó en dicha feria para promocionar su compañía de gas, que estaba situada en la zona de la Glorieta desde 1843 y que llevaba el suministro a las zonas de la ciudad donde se estaba instalando el alumbrado público a gas. Como ya hemos dicho anteriormente su compañía fue la encargada de realizar las obras de alumbrado para que fuera posible la realización de la feria de julio de 1871. Dicha compañía la mantuvo durante toda su vida, pero el suministro de gas a la ciudad lo compartió con la compañía de gas Lebón desde 1872. 


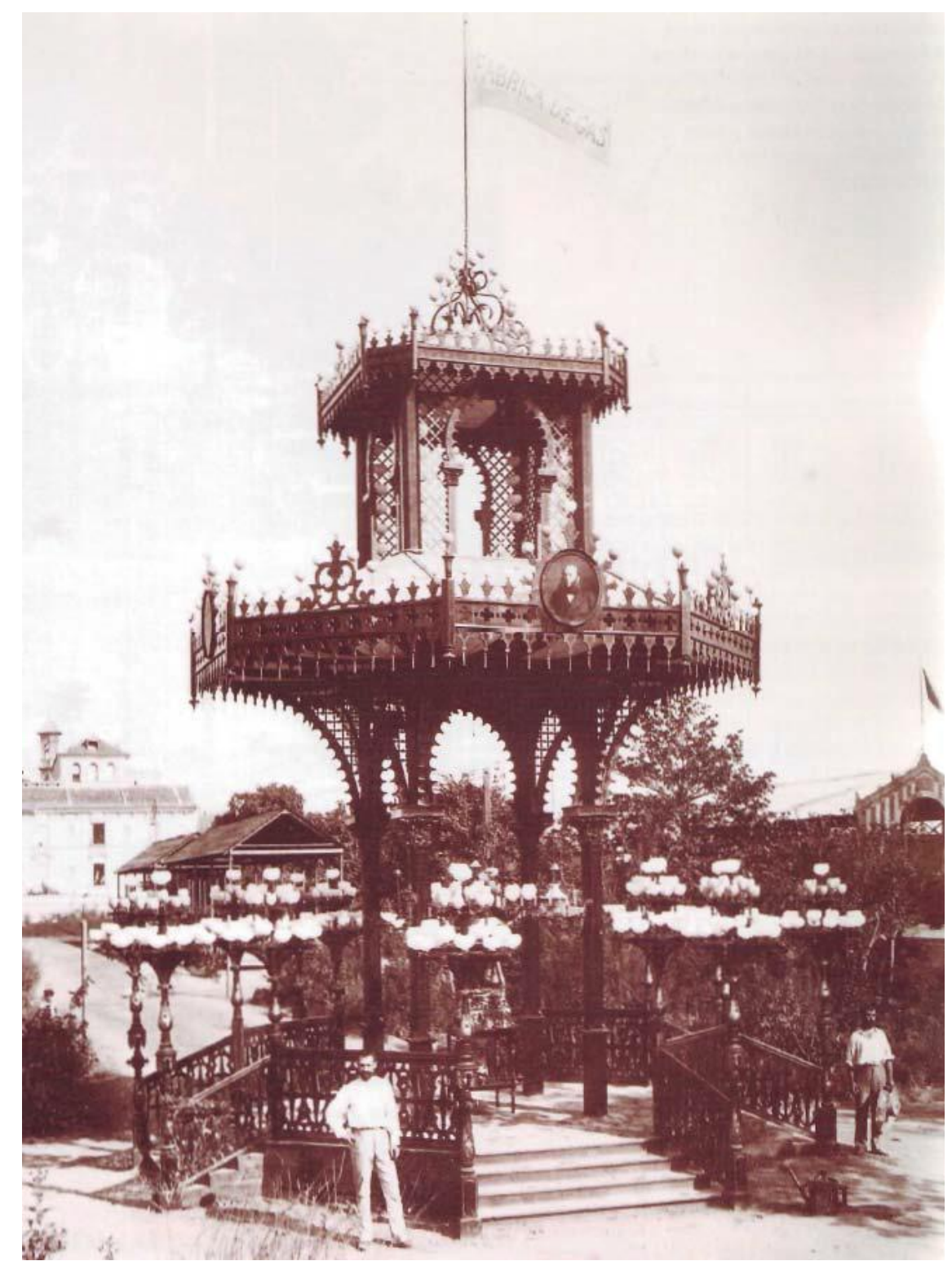

Fig. 4.8 Instalación de la fábrica de gas del marqués de Campo en la Exposición de 1883. Imagen del archivo del Ateneo de Valencia. 2009.

El templete es una construcción efímera de planta octogonal, con una plataforma rodeada de barandillas realizadas en madera con unas decoraciones historiadas y a la que se accede por escaleras en cuatro de sus lados. 
En el centro de la plataforma se alzan cuatro columnas de base cuadrada que soportan un remate de inspiración árabe con una especie de mirador de forma cuadrada en el que se exhiben unas ricas celosías y unas cresterías muy recargadas que aparecen rematadas por bolas de luz para que por la noche luzcan y le den al templete un aspecto de joya.

A su vez en las barandillas de los escalones hay una gran cantidad de farolas con incontables luces. Como veremos más adelante, la iluminación de sus palacios era una de las actividades más remarcables de José Campo, que mantuvo siempre una gran relación con las compañías de lámparas inglesas y nunca reparó en gastos para alumbras sus construcciones, arcos, etc.

Hay que destacar que en la parte alta del templete se observa un retrato de forma oval del marqués que es uno de los que hemos estudiado en el capítulo de esta tesis dedicado a sus retratos. Es exactamente el realizado por José Struch que ya hemos analizado en otro capítulo de esta tesis.

En La Ilustración Española y Americana (Fig. 4.9) podemos leer: "es un precioso templete árabe, profesamente iluminado en las primeras horas de la noche, que se levanta enfrente del pabellón de Bellas Artes. La fábrica tiene establecidos en el local de la Exposición hasta 180 aparatos de cinco mecheros cada uno, encerrados en globos de cristal blanco y los cuales forman un conjunto de 900 luces, sin contar las de las instalaciones particulares"32.

${ }^{32}$ La Ilustración Española y Americana, año XXVII, 30 de agosto de 1883, NÚM. XXXII, p. 115 . 


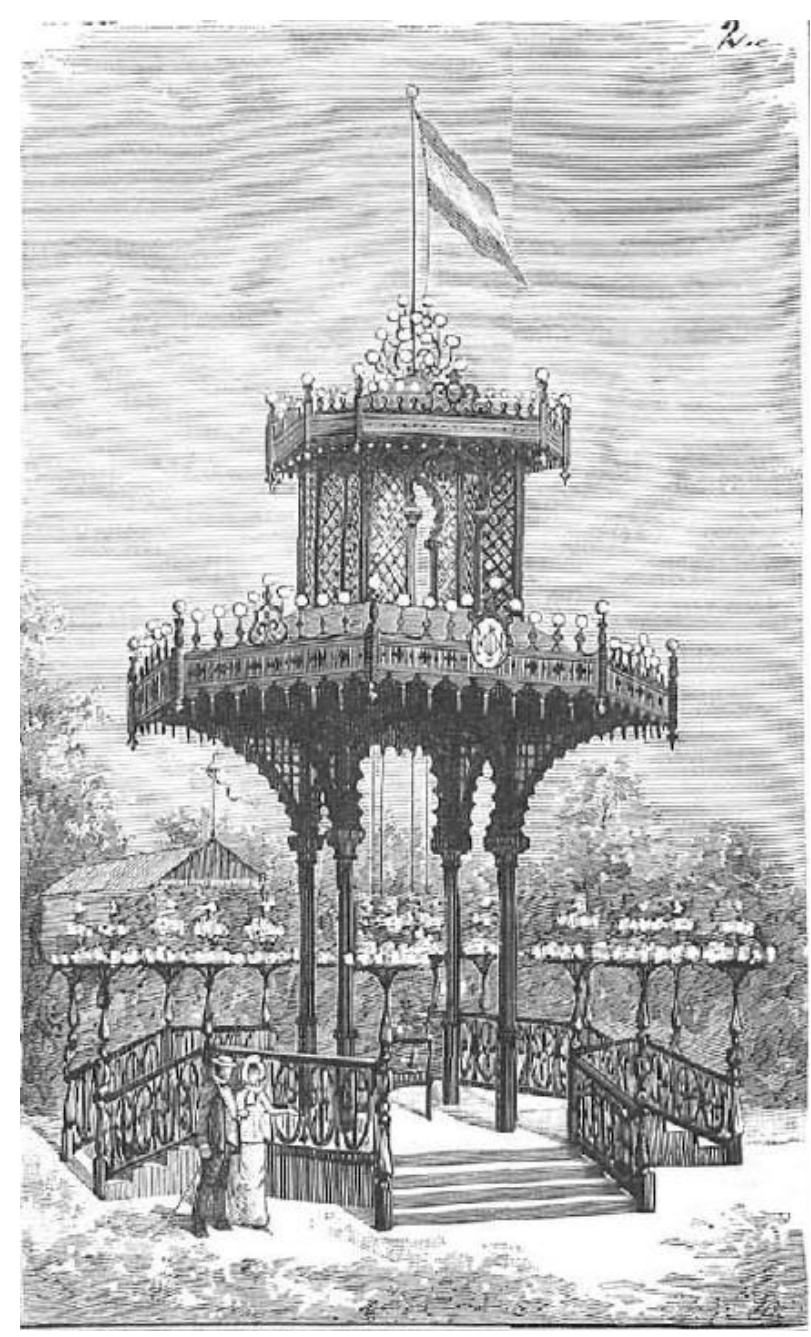

Fig.4.9 Instalación del Marqués de Campo. Exposición Regional 1883. Imagen publicada en La Ilustración Española y Americana, 30 de agosto de 1883.

Al igual que los arcos efímeros que hemos visto, el templete pudo ser diseñado por Antonio Revenga, quien ya diseño el arco de la feria de 1871; y la iluminación debió correr a cargo del ingeniero Francisco de Paula Rojas, ingeniero de la fábrica de gas del marqués, pero como en otras ocasiones, bajo la supervisión de Navarro Reverter.

El templete de la compañía de gas causó tal sensación en los visitantes que el jurado de la exposición le entregó el mayor premio, que era el Gran Diploma de Honor. 


\section{5.- Iluminaciones efimeras de su palacio de Madrid}

Como dicen Víctor Mínguez e Inmaculada Rodríguez: "En las celebraciones públicas en la cultura renacentista y barroca, y expresamente en la monarquía hispánica, tuvieron mucha trascendencia las iluminaciones nocturnas y los fuegos de artificio en calles y plazas de las ciudades, e interiores de templos y palacios. Las crónicas y relaciones festivas hablan de miles de luces de cera, en sus múltiples foras; velas, candelabros, arañas, lámparas, globos, etc., que inundaban catafalcos, altares, y demás estructuras y decoraciones efímeras, así como los áticos, murallas, campanarios y torres, suponiendo un gasto formidable" 33 .

Las luminarias barrocas en Valencia es una de las manifestaciones festivas barrocas que han sido estudiadas por Pilar Pedraza quien establece que las fiestas eran una manifestación adecuada para transmitir determinada ideología al pueblo y dice: " el pueblo las acogía con alborozo y pasmo, y en su fuero interno el hombre de la calle pensaba que tales cosas, casi mágicas, emanaban de un poder que, ejercitado sobre otro tipo de cosas, podría, en cuanto se lo propusiera, remediar la triste situación por la que se atravesaba" 34; y Víctor Mínguez, dice que "el barroco festivo tuvo su esplendor en todos los territorios del impero en el reinado de Carlos II, y se celebraban espectáculos urbanos basados en la apariencia y el ilusionismo"35. Está claro que la intención de quien ejercía el poder, era la de maravillar y subyugar al pueblo mostrándoles, con este tipo de iluminaciones y otras actividades, quien era quien tenía el mando y el poder.

33 MÍNGUEZ CORNELLES, Víctor; RODRÍGUEZ MOYA, Inmaculada. "Un imperio iluminado por el sol y cien mil luminarias". En: Visiones de un Imperio en Fiesta, Madrid: Fundación Carlos de Amberes, 2016, pp. 11 y 12.

34PEDRAZA MARTÍNEZ, Pilar. Barroco efímero en Valencia. Valencia: Ayuntamiento de Valencia, 1982, p. 21.

35 MÍNGUEZ CORNELLES, Víctor.” La fiesta áurea durante el reinado de Carlos II. El esplendor del barroco efímero". En: Ars \& Renovatio. Alcañiz: Centro de Estudios de arte del Renacimiento. 2019, p. 431. 
Hemos de tener en cuenta que la llegada de la iluminación a gas a las ciudades se produce en el siglo XIX, momento en el que la nueva burguesía desea ocupar el lugar de la realeza y la nobleza y con un gran poder económico, participan de esas celebraciones que se dan en las ciudades más importantes de España, tanto en las celebraciones laicas como en las religiosas, los burgueses y los gremios y algunas instituciones engalanan las fachadas de sus palacios y sedes, construyen arcos efímeros como ya hemos visto y participan de todo tipo de actividades para que la fiesta sea un verdadero festival para la ciudad y para el pueblo, mostrando a su vez, como ya se ha dicho, que quien maneja la economía y realiza tales actos es quien ostenta el poder. Por ejemplo, el hecho de que las ciudades no estuvieran iluminadas por la noche hasta que llegó el gas, hizo que la noche fuera el momento perfecto para malas acciones y tropelías, sin embargo, en las noches de fiesta las iluminaciones y los fuegos artificiales daban vida a la oscuridad. El hecho de que con los años en las ciudades existieran iluminaciones públicas, no fue impedimento para seguir adornando las fachadas, los arcos efímeros y demás adornos con miles de luces como hizo el marqués de Campo en sus palacios de Madrid y Valencia en varias ocasiones con motivos de celebraciones laicas y religiosas como ahora veremos.

Como una herencia cultural, fuegos artificiales y calles iluminadas en fiestas es hoy día una realidad en muchas ciudades y pueblos de España, la noche iluminada tiene algo de mágico; algo poderoso se logra venciendo la oscuridad. 


\section{1.- Iluminación por la entrada de Alfonso XII en Madrid en 1875}

En La Correspondencia de España ${ }^{6}$, además de la descripción del arco, que ya hemos analizado, podemos leer:

"La iluminación del palacio ostenta sobre el pórtico una fuente rebosando hilos de luz de sus tazas. En el piso segundo una gran estrella coronada de vidrios de colores. En los balcones de fachas a uno y otro lado figuran una pirámide y unas macetas cuyas ramas se adornan con hojas de lucecitas de gas".

En una reseña de unos días más tarde se dice37:

"La asombrosa iluminación del palacio del marqués de Campo lucirá todavía con más esplendor, cuando se enciendan algunos aparatos que no brillaron anoche".

No es de extrañar que en ocasiones fallaran los complicados mecanismos de la luz y que algunas noches las iluminaciones no lucieran completas.

\section{2.- Iluminación por la entrada de Alfonso XII vencedor en 1876}

El 20 de marzo de 1876, el rey Alfonso XII entró en Madrid con las tropas vencedoras tras acabar con las ultimas revueltas carlistas. En La Época 38 podemos leer:

"Entre las iluminaciones del mejor gusto que se preparan”..."no será menos notable la iluminación del palacio del marqués de Campo. Una línea

\footnotetext{
${ }^{36}$ La Correspondencia de España, 14 /1/ 1875, p. 3.

${ }^{37}$ La Correspondencia de España, 25 /1/ 1875, p. 2.

${ }^{38}$ La Época, 12 /3/ 1876, p. 3. 
de gas recorrerá en enverjado del parque con mecheros de diez luces en cada columnata. Las jambas de los balcones de fachada, la repisa y el ático estarán asimismo alumbradas por líneas de lucecitas. En el centro se destacará un gran escudo, que con sus pequeños prismas de cristal de colores reflejaran millares de luces, y por último sobre el ático se verá también una inscripción alegórica que aún no ha sido enviada de Valencia”.

En El Imparcial 39 podemos leer la breve descripción de la iluminación del palacio de Campo de un periodista que se denomina Un Lunático y que se expresa en estos términos:

"La del palacio del marqués de Campo es propia de la habitación de un hombre acaudalado, y del mejor gusto.

Balcones y ventanas están encerrados en marcos hechos con blancas bombas de cristal, dentro de las cuales palpita la luz del gas. El palacio parece un aderezo de perlas.

Llamadme, si queréis, hombre apegado a la tradición, pero os confieso que nada encuentro tan encantador como una iluminación de farolillos de colores. Que combinaciones tan lindas, que aspectos más vistosos, que espléndidos en el color, que diversidad de dibujos, tonos y reflejos iesto sí que seduce, entretiene y maravilla. iSi queréis ver una muestra de este género, mirad la Iglesia de las Calatravas, en la calle Alcalá!”

Está claro que hay gustos y opiniones para todos y en este caso la iluminación del palacio de Campo no es del agrado del comentarista, que la encuentra demasiado novedosa y excesiva. Por su comentario deja claro que la iluminación refleja el potencial económico del dueño del palacio y su gusto, que choca con lo tradicional y deja clara la intención del marqués de destacar y ser objeto de admiración.

Una magnifica descripción de la iluminación del palacio (Fig. 4.10) la encontramos en el diario La Época40:

${ }^{39}$ EL Imparcial, 21 /3/ 1876, p. 2. 
"A mayor número ascendía la iluminación de la casa del marqués de Campo, ya citada, y cuyo gusto era exquisito. La verja que da al paseo de Recoletos y los dos pabellones laterales los iluminaban líneas de globos blancos y racimos de luces, también encerradas en globos. En la fachada del palacio se recorrían todas las líneas arquitectónicas con globos blancos, formando nueve arcos, del centro de los cuales colgaban elegantes jardineras adornadas con flores e iluminadas. En el arco central de medio punto se leían en una cinta de luces la siguiente inscripción: iViva el Rey!. La cornisa superior tenía también sus líneas de globos, y los tres arcos del segundo piso del cuerpo principal se iluminaban del mismo modo, apoyando sobre la balaustrada en el del medio un sol elíptico en cuyo centro se leía la palabra "paz". Terminaba el conjunto de la fachada una magnífica estrella de cristales blancos tallados iluminada por detrás.

El principal adorno era un soberbio escudo de cristales tallados de colores, terminado por una corona de marqués y con las iniciales J. C. Entrelazadas en el centro. A los lados figuraban dos trofeos simbolizando la agricultura, la industria, las artes, el comercio y la marina. Más de dos juegos imitando surtidores de aguas y en el piso superior dos elegantes pirámides. El número de luces que constituían tan admirable iluminación asciende, según cálculo aproximado a 5.00o. Es de notar que todo, excepto el escudo que procede de Londres, se ha construido en los talleres de la fábrica de gas de Valencia, lo cual honra a la industria nacional.

En la puerta de la izquierda la inscripción “Al ejército" y en la de la derecha "A la marina”. La gruta, cascada y ría estaban iluminadas formando arcos de luces. En el interior del jardín de invierno se veía un aparato revestido de hojas de palma con 300 luces. La torre y la casa rústica colindantes tenían luces en las cornisas, arcos y ventanas. La parte alta del edificio llevaba el cuerno de la abundancia de varios tonos, con luces de colores, de gas. En los balcones los letreros de "Paz, Orden, Trabajo". Se veían también aparatos simulando palomas y dos preciosas estrellas, debajo de las cuales se leía el siguiente lema: “Alfonso XII el pacificador”. Pero esta hermosa iluminación no pudo lucir por haberse roto uno de los aparatos principales"

${ }^{40}$ La Época, 21/3/1876, p. 2. 
Esta magnífica y detallada descripción de la iluminación y la publicación del grabado nos dan una valiosísima información. Primero para descubrir algunos detalles de la arquitectura de la fachada del palacio y sus características (que ya hemos estudiado en otro capítulo de esta tesis). Segundo para darnos cuenta de que la iluminación utilizada con símbolos, escudos, frases etc., no es una iluminación al azar, sino que lleva detrás todo un programa icnográfico con un significado y un mensaje que su propietario quiere transmitir a quien lo contempla. Las alusiones al rey en letreros de "viva el rey el Alfonso XII el pacificador" demuestran su total adhesión al monarca a quien considera el portador de la paz y viene a confirmar la teoría de que Campo participó y financió parte de las actividades necesarias para la vuelta al trono de Alfonso XII, (no olvidemos las cacerías "políticas" llevadas a cabo en Viñuelas y a las que ya nos hemos referido en otro capítulo de esta tesis). Por otro lado, el escudo de cristales tallado terminado en una corona de marqués y con las iniciales J. C. es muy importante porque supone el anuncio a todo el mundo del reciente nombramiento de Campo como marqués (hecho que tuvo lugar días después de la vuelta a Madrid del rey en enero de 1875). Para el hijo de un humilde comerciante de Torrijo del Campo, llegar a marqués es el culmen de sus ambiciones y de sus aspiraciones sociales y su comportamiento debe reflejar tal categoría, en todo momento y lugar, incluso con la luz de su palacio debe demostrar a todos su rango y posición.

El uso por parte de Campo de trofeos o alegorías con referencia a la Industria, el Comercio, las Artes y la Marina es normal, pues ya encontramos esas decoraciones en la fachada y el interior de su palacio de Valencia y con las que hace referencia a sus actividades comerciales, sus negocios de navegación, sus industrias de gas, y como no, a su interés por las artes, que es el tema aglutinador de esta tesis.

También la referencia en la iluminación al Ejército y a la Marina, es por su agradecimiento en la participación los enfrentamientos con los carlistas y que por fin han conseguido la paz para España. La iluminación es toda una declaración de principios e intenciones que deja en evidencia su poder 
económico y su categoría social anunciado a los cuatro vientos su título de marqués.

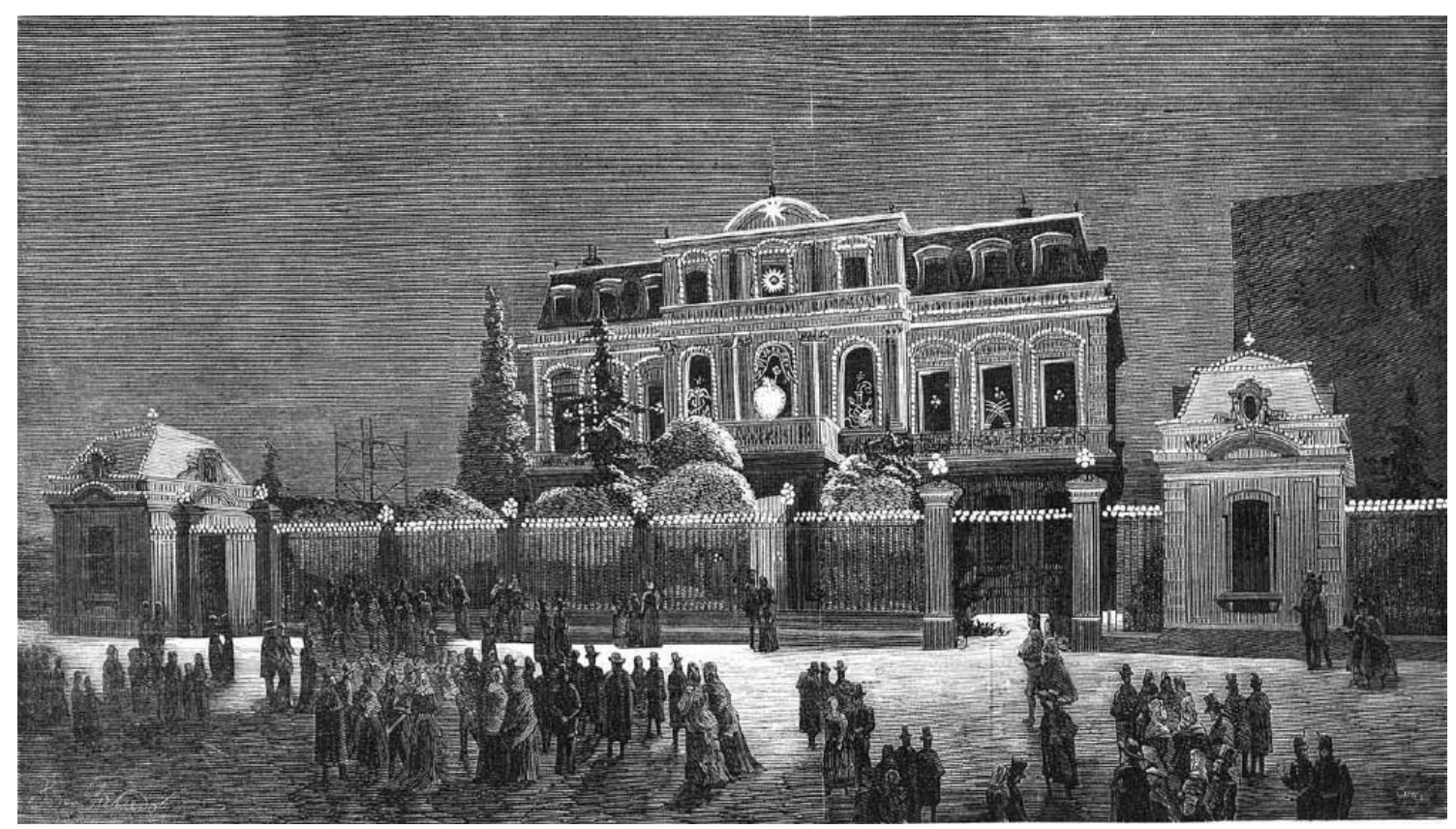

Fig. 4.10 Iluminación del palacio del Excmo. Marqués de Campo en Recoletos Imagen publicada en La Ilustración Española y Americana el 30 /3/ 1876.

Además, vemos en la parte izquierda del grabado (Fig. 4.10) unos andamios. Pertenecen a las obras de la nueva Biblioteca Nacional, situada justo al lado del palacio de Campo, que comenzaron el día 21 de abril de 1866. Su majestad Isabel II colocó la primera piedra en una ceremonia a la que ya hemos hecho referencia en otro capítulo de esta tesis. Las obras se demoraron durante varios años hasta su finalización en 1892 y por eso el dibujante, siendo lo más fiel posible a la realidad que sus ojos contemplaron, ha dejado constancia de las obras y ello nos lleva a apreciar el dibujo en todo su detalle para apreciar la belleza y esplendor de la iluminación del palacio.

No hay duda de que el sistema utilizado era novedoso en Madrid, pues eran conocidos los contactos y acuerdos económicos del marqués con las empresas de luz de Londres y en varias ocasiones las iluminaciones provenían del Reino Unido, como en el caso de la feria de julio de Valencia de 1871, ya comentado anteriormente. Sin embargo, la pieza que más llama la atención en 
las dos reseñas es el escudo del marqués. Era una pieza grandiosa y espectacular y que fue realizada en Valencia por su propia empresa de gas, (no olvidemos que Campo promovió y construyó el alumbrado público de gas de Valencia), por lo tanto, no fue más que cuestión de dinero poner a los operarios a trabajar en la iluminación del palacio para poder exhibir una vez más su poder y dejar al público asombrado.

Durante los días que duraron los festejos por la vuelta a Madrid de un Alfonso XII vencedor y pacificador se siguieron escribiendo reseñas de los diferentes actos y celebraciones y diariamente se hacían referencia en la prensa a las iluminaciones que cada noche admiraba el público que llenaba las calles y paseos de la capital 41 .

\section{3.- Iluminación por la boda real de Alfonso XII con} María de las Mercedes en 1878

La boda de Alfonso XII con su prima doña María de las Mercedes de Orleans y Borbón fue otra ocasión para celebrar grandes fiestas en todo el país, pero sobre todo en Madrid, donde se celebró el enlace el día 23 de enero de 1878 en la Basílica de Atocha. Una vez más se adornaron calles y plazas y se iluminaron los principales edificios de la capital, a los que se unieron las grandes casas y palacios de nobles y burgueses que demostraban así su adhesión al monarca.

Como es normal la prensa se hizo eco de esos adornos e iluminaciones efímeras que no sobrevivieron tras las celebraciones pero que cumplieron a la perfección su función de agasajo a los reyes y demostración pública del estatus social y económico de quien las costea.

${ }^{41}$ La Correspondencia de España, 22/3/ 1876, p. 1.

La Ilustración Española y Americana, año XX, núm. XII, 30 de marzo de 1876, p. 214. 
Fue tan importante la iluminación del palacio de José Campo que el día de antes de la inauguración ya se publicó en prensa que se habían hecho pruebas para que todo estuviera perfecto el día de la boda y que se esperaba que dicha iluminación fuera una de las que más llamasen la atención ${ }^{42}$.

Las expectativas se cumplieron y la iluminación causó verdadera sensación. En el periódico La Época leemos lo siguiente:

"La iluminación del marqués de Campo merece capítulo aparte.

La riqueza y el buen gusto en armonía daban al palacio de Recoletos el aspecto ideal. Cerraban la verja del jardín filas de globos elípticos de cristal blanco tallado, coronadas por unos sombreretes chinescos. Domina esta fila una serie de bolas de grandes dimensiones, de cristal opale, terminados por una corona de marqués y ostentando los blasones de las provincias de España, primorosamente pintados de colores. A ambos lados de la verja hay dos casetas bordadas de pequeños globos de cristal, de colores variados y terminadas por unas cúpulas, cuyos remates son grandes globos con el escudo de armas del marqués de Campo. Calculamos en 4.500 luces de esta primera línea cuyo efecto es admirable. La frontera presenta un golpe de vista deslumbrador y fantástico. Todos los resaltos del edificio y todas sus líneas arquitectónicas, cornisas, balcones, ventanas y medios puntos estaban recorridas por líneas de elegantísimos globos en forma de tulipanes, de colores pálidos, azul, rosa y verde, cuya combinación es muy artística.

En los balcones principales sobresalían esbeltos candelabros de rojo y oro, terminados en racimos de caprichosos globos, y había además las grandes piezas siguientes, todas formadas con perlas de cristal tallado de colores vivos. Un gran escudo en forma de corazón, fondo blanco y las iniciales J. C. entrelazadas, con una corona de marqués encima. A ambos lados atributos del comercio, la navegación y la industria. Sobre las barandillas de los balcones de cada uno de los cuerpos laterales lucía una

42 El pabellón Nacional, 23 /1/ 1878, p. 3. 
colosal guirnalda de hojas de laurel, de cuyo centro pendía un magnífico medallón con las iniciales A. B. a la derecha y M. O. a la izquierda.

En la cornisa que separa el primero del segundo piso, descansa un gran juego, también de pedrería de cristal compuesto de tres óvalos entrelazados con ramas de roble y laurel, y coronado en el centro con una diadema real. En éste campean las letras A. M. entrelazadas; en el de la derecha se veían las lises de la casa de Borbón y en el de la izquierda la brisura y las lises de los Orleans. Esta pieza ceñida por una ondulante cinta de colores nacionales, es calificada de combinación magistral. Termina el edificio en un arco iluminado, y sobre él, como si estuviera suspendida en los aires, brilla una estrella con cambiantes de luz y de preciosos colores que se distingue desde grandes distancias...Sólo en las iluminaciones extrajeras entre otras las de los Campos Elíseos de París, en la época del imperio, hemos visto cosa semejante a la del marqués de Campo...Pasear en Recoletos...bajo miles de luces coloreadas en los farolillos, parece uno hallarse en el propio Venecia"43. (Fig. 4.11)

${ }^{43}$ La Época, 24 /1/1878, p 3. Podemos leer una reseña casi idéntica a la transcrita En La Ilustración Española y Americana del 8 de febrero de 1878. 


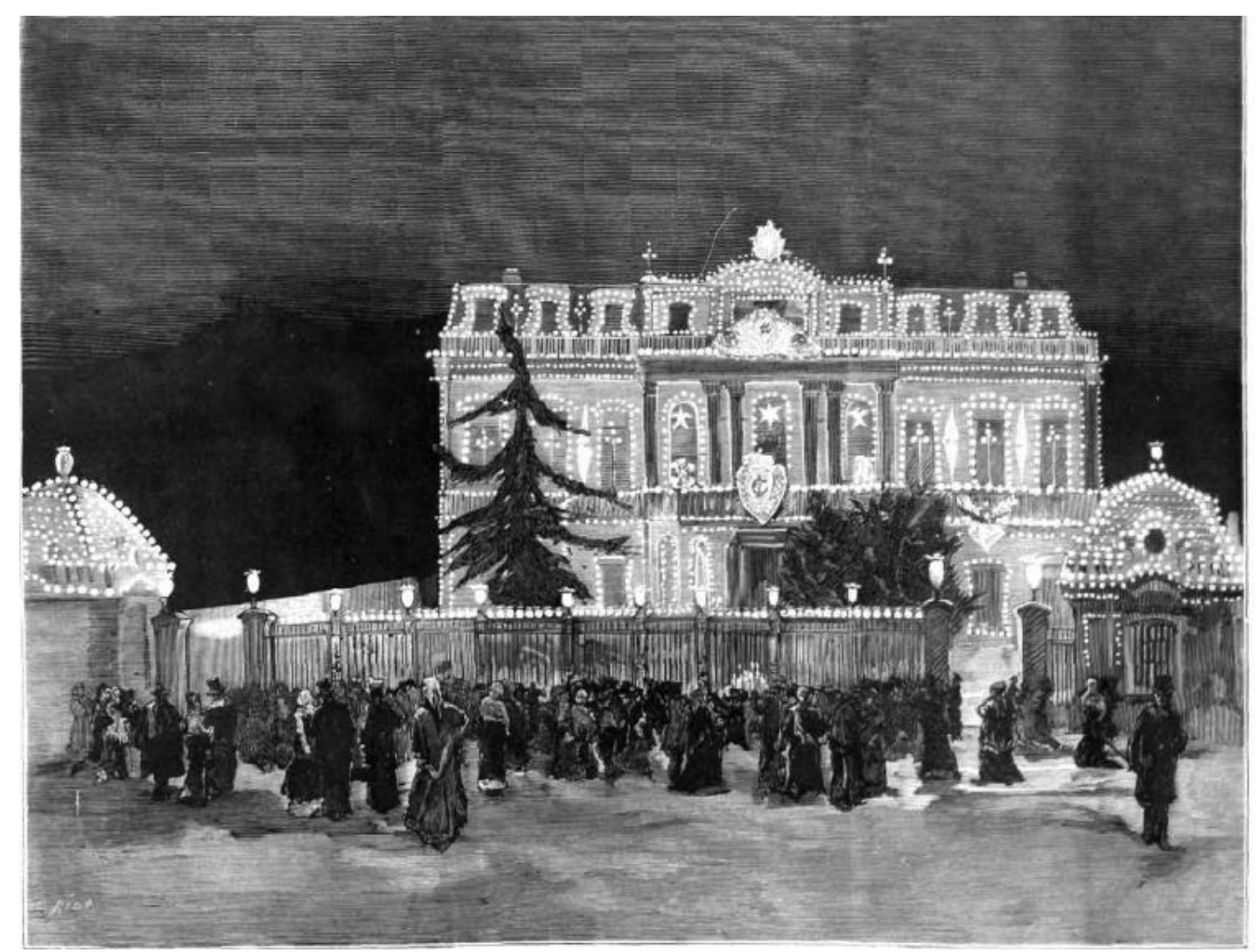

Fig. 4.11 Madrid: Iluminación del palacio del Marqués de Campo.

Imagen publicada en La Ilustración Española y Americana 8 de febrero de 1878.

Las principales iluminaciones de la ciudad fueron visitadas por sus majestades la noche del 24 de enero, acompañados por el gobernador civil de Madrid, el señor conde de Heredia-Spínola, precedidos de cuatro batidores del escuadrón real y detrás la correspondiente escolta. Destaca la prensa que una de las iluminaciones visitadas es la del paseo de Recoletos, obviamente la del marqués de Campo entre otras, que brillaban de una manera admirable 44 .

La gran iluminación del marqués, fabricada en Valencia, que dejó a todo el público sorprendido por su belleza sufrió algún percance y una de las noches no pudo lucir en todo su esplendor, tal y como refleja la prensa: "La asombrosa

44 La Época, 27 /1/ 1878, p. 3. 
iluminación del palacio del marqués de Campo lucirá todavía con más esplendor, cuando se enciendan algunos aparatos que no brillaron anoche"45.

Dos reseñas idénticas sobre la iluminación y mucho más descriptivas aún que las anteriores encontramos en los diarios La Época y La Iberia del 23 de enero de 1878. Se reproduce integro el de La Iberia. 46

"Las iluminaciones que tendrán lugar durante tres noches consecutivas, son las siguientes: ...Respecto al palacio del marqués de Campo, situado en el paseo de Recoletos, es difícil describir su iluminación por lo extraordinario de su efecto y lo variado de sus combinaciones.

La fachada del palacio es una mezcla armónica de luces, colores, globos, cristales tallados y juegos diversos, prodigados con arte y distribuidos con singular gusto. Las líneas principales del edificio, los contornos de ventanas, balcones y cornisas, y la cubierta, todo está festoneado de unos elegantísimos globos de formas prolongadas, con toques dorados y otros opales semejando gruesas arracadas de perlas. En el saliente central hay un escudo grande en forma de corazón, con las iniciales del marqués de Campo entrelazadas, y terminadas por una corona de marqués. Esta pieza es de cristales tallados y de un efecto precioso. En los balcones de los lados se ostentan dos aparatos de cristal tallado, compuesto de colosales grupos de hojas de laurel, y colgando del centro dos medallones ovalados, como de un metro de altura en uno de los cuales se destacan, como rubíes sobre diamantes, las iniciales del rey don Alfonso de Borbón y de doña Mercedes de Orleans.

Sobre el fondo de los balcones laterales se destacan seis candelabros de bronce y grana, con un coronamiento de grandes aparatos con globos grabados en caprichosos juegos. En los tres balcones del centro brillan dos grandes flores de lis y una estrella. Los símbolos de las artes y la navegación completan esta primera línea. Sobre la cornisa del primer cuerpo y en el centro se ve un grandísimo grupo de tres óvalos enlazados por ramas de laurel y graciosamente ceñido por una cinta con los colores nacionales. El

45 La Correspondencia de España, 25 /1/ 1878, p. 2.

${ }^{46}$ La Iberia, 23 de enero de 1878, p. 2.

La Época, 23 de enero de 1878, p. 3. 
óvalo central, de grandes dimensiones, tiene un marco de relieve, y sobre fondo de plata brillan las letras A.M. de azul y rojo. Los escudos laterales contienen las armas de las casas de Borbón y de Orleans. El todo queda perfectamente acabado por una corona real. Este grandioso aparato es una obra maestra de gusto y perfecta construcción.

Sobre el arco que termina el palacio, y separada de modo que domina largas distancias, como si estuviera suspendida por cables invisibles, centellea una estrella de colores cuyos destellos deslumbran por lo vivos. Las casetas y la verja están bordadas de globos y con los escudos de las provincias de España pintados a la perfección sobre grandes piezas opales. El número de luces es incalculable, porque en cada uno de los aparatos hay millares de ellas en corto espacio reunidas. El de globos es más fácil de apreciar, y creemos que pasarán de 5000. Pero estas cifras no dan remota idea de lo notable de la combinación, de los juegos, del efecto fantástico de esta decoración nocturna.

Cubierto el ramaje de la verja por una hilera de bombas de luces de gas, ya dentro del jardín todos sus montículos y macizos aparecen resplandecientes de luz.

En el edificio todas sus líneas arquitectónicas están reproducidas por bombas de cristal de varios colores. Entre los huecos del piso bajo, flores de lis; entre los del principal, lindas figuras cuadrilongas imitando piedras preciosas; entre los del segundo, grandes candelabros. También los hay en los huecos mismos del principal airosos y esbeltos.

Dos medallones en la planta baja del palacio contienen, como formados por piedras de valor las iniciales del rey A.B. en un lado, y las de la reina M.O. en el otro.

En el centro del balcón principal otro vistoso y gran medallón con las del señor marqués J.C. y unas palmas o laureles a ambos lados de un efecto primoroso.

En el piso segundo otro precioso efecto: un gran medallón de diamantes con las iniciales de los augustos desposados en rubíes; a sus lados flores de esmeraldas y topacios y medallones, donde sobre campos azules y verdes se ven las lises en brillantes de las casas de Borbón y Orleans, y todo ello entrelazado por unas bellas flores de esmeralda y topacio. Todo ello 
rematado por una corona de rubíes, y en fin, sobre todo el edificio una gran maceta en cada extremo del mismo con bombas de radiante luz, y en el centro una elegante y vistosa estrella de rubíes y diamantes.

La iluminación del antiguo palacio de Calderón, hoy de los marqueses de Campo, ha de ser de las más admiradas y celebradas.

Traídos sus principales aparatos de Inglaterra y algunos de Valencia, se calcula su coste en unos doce o catorce mil duros. Su colocación y dirección ha corrido a cargo del señor Navarro Reverter".

Este tipo de comentarios en la prensa da una idea de la importancia del marqués en la vida social de Madrid, ya que cualquier cosa relacionada con él era digna de mención. El mero hecho de publicar si una noche alguna de las luces de su palacio no se encendió, o si la iluminación había tenido un gran coste, o si había sido hecha en Londres o en España, etc., nos lleva a darnos cuenta del escrutinio al que estaba sometido, no sólo en sus aportaciones a los festejos sino en todas sus actividades económicas y políticas, por ello encontramos tanta información en la prensa, cosa que intuyo, agradaba mucho al marqués, puesto que como buen burgués ascendido a noble su intención no era precisamente pasar desapercibido en ninguno de sus actos.

\section{4.- Iluminación por la boda real de Alfonso XII con María Cristina en 1879}

Una breve descripción de la iluminación del palacio la encontramos en la Crónica de los Festejos Reales celebrados con motivo del regio enlace de su majestad el rey Alfonso XII con la Archiduquesa de Austria. La boda se celebró el 29 de noviembre de 1879. En esa crónica se recogen todos los preparativos y festejos realizados con motivos de la boda y no podían faltar las iluminaciones 
de toda la ciudad. Describe los edificios oficiales y luego pasa a hablar de los particulares como el palacio de Campo, y dice así:

"La iluminación de particulares ha sido tan general como espontánea hasta en los barrios más apartados del centro, y merecen mención especial la del palacio del marqués de Campo, consistente en un precioso escudo formado con diminutas luces de colores de un efecto admirable, y en el adorno con bombas blancas de siluetas de los pabellones, y verja que constituyen el frente de aquel edificio" 47.

Idéntica descripción encontramos en varios artículos de prensa ${ }^{48}$. El palacio de Campo se iluminó y adornó de manera especial en otras ocasiones como por ejemplo cuando se celebró la boda de su sobrina Concepción Moreno Campo con el Vizconde de Bétera; cuando se celebró el bautizo de un sobrino suyo; o cuando se celebró un banquete por el gran éxito de la expedición a las obras del canal de Panamá que él mismo costeó y a la que envió su vapor Magallanes, y que desarrollaremos en otro capítulo de esta tesis.

\footnotetext{
${ }_{47}$ Crónica de los festejos reales celebrados con motivo del regio enlace de S. M. el rey don Alfonso XII con su A.R. la archiduquesa de Austria Doña María Cristina en 29 de noviembre de 1879 por Leopoldo Vázquez Rodríguez. Madrid: imprenta de Editorial Rubiños, 1880, p. 47 y ss.

${ }^{48}$ La Época, 30/11/1879, p. 2 


\section{6.- Iluminaciones efimeras de su palacio de Valencia}

\section{1.- Iluminación por el centenario de la Virgen de los Desamparados en 1867}

En 1867 se celebró en Valencia el segundo centenario de la coronación de la imagen de la Virgen de los Desamparados, patrona de la ciudad. Fueron unas fiestas muy importantes y su descripción con todo lujo de detalle la encontramos en la Memoria Histórica de las fiestas celebradas en Valencia con motivo del $2^{o}$ centenar de Nuestra Señora de los Inocentes Mártires y Desamparados, obra del cronista de la ciudad Vicente Boix ${ }^{49}$.

Las fiestas se celebraron desde el día 12 al 19 de mayo y fueron organizadas por una comisión formada por el alcalde y otros hombres importantes e influyentes de la ciudad como José Campo. Se celebraron multitud de actos y también se llevó a cabo el engalanamiento de la ciudad e iluminación de edificios, como era habitual en este tipo acontecimientos.

Para esta ocasión José Campo, además de realizar una donación de 300 trajes para los alumnos de su asilo de párvulos $5^{50}$ y unos exámenes y reparto de premios ${ }^{1}$, mandó a sus ingenieros llevar a cabo los trabajos necesarios para iluminar su palacio de la plaza del Arzobispo y resultó ser una de las mejores iluminaciones de la ciudad.

\footnotetext{
49 BOIX, Vicente. Memoria Histórica de las fiestas celebradas en Valencia con motivo del $2^{\circ}$ centenar de Nuestra Señora de los Inocentes Mártires y Desamparados, en el mes de mayo de 1867, Valencia: Ayuntamiento de Valencia, 1867.

50 BOIX, Vicente. 1867, p. 44.

${ }^{51}$ BOIX, Vicente. 1867, p.181-182. El reparto de premios al que se ha hecho referencia está ampliamente estudiado en el capítulo de esta tesis dedicado a José Benlliure y que dio origen al cuadro que el pintor realizó para José Campo.
} 
La obra de Vicente Boix la describe de esta manera:

"En la plaza del Arzobispo de espaldas a un obelisco costeado por el gremio de tintoreros, se alzaba rico y ostentoso el palacio del Excmo. Sr. D. José Campo, que tenía un aparato para iluminación de gas, de punta de diamante, desconocido en Valencia: de noche fue admirable el efecto de esta esplendida y hermosa iluminación como veremos" 52 .

El cronista, maravillado por su novedad, belleza y originalidad, describe dicha iluminación en el capítulo dedicado al paseo de noche por las calles y plazas de la ciudad, donde enumera todas la luces y adornos que pueden verse cada noche por el público que recorre las calles en fiesta y en el que destaca el palacio de Campo:

"Terminaremos este paseo fijándonos en la iluminación del palacio del Sr. Campo, porque sin duda era la más notable por la novedad y por el gusto. Vióse por primera vez en España este sistema de iluminación, llamado en Londres, donde recientemente se ha inventado, de diamante, porque presenta el aspecto de colosales placas de brillantes que se iluminan con una luz interior. Grandes placas de cristal, minuciosa y artísticamente tallado, producen este resultado, colocando detrás luces de gas, cuyos rayos concentra una plancha metálica. Los aparatos que se admiraban en los balcones, eran en el del centro un óvalo con la cifra de María, sobre campo de diamante, circundada por una ancha faja de brillantísimos topacios; y en el de los lados dos estrellas, figurando también diamantes. Nada más bello que el brillo de la luz en aquellas placas de fuego, que afectaban todos los suaves fulgores de las piedras preciosas. El Sr. Campo dio otra prueba más de su buen gusto.

El viento impidió con frecuencia que tanta iluminación fuera tan esplendente como era de desear, y como lo fue en la noche del día 11, en que se vio toda y en todas partes por completo. Pero fueron tantas las luces que profusamente alumbraban la ciudad, que las noches eran deliciosas, magnificas, poéticas, que atraían a las calles una muchedumbre que las

52 BOIX, Vicente. 1867, p. 92. 
obstruía, confundiéndose todas las clases, luciendo el gusto en los trajes, reinando la más cordial y pacífica alegría” 53 .

Este tipo de iluminación fue una novedad en la ciudad que Campo hizo posible por sus relaciones comerciales con Inglaterra y sobre todo por su deseo de llamar la atención con algo novedoso que sorprendiera a todos sin importar su coste. En esas fechas Campo es senador vitalicio y vive en Madrid, por lo que su palacete de Valencia está deshabitado, pero eso no es obstáculo para llevar a cabo una iluminación que deje a todos maravillados por su novedad y su riqueza. Ilumina su palacio para demostrar una vez más su capacidad económica y su posición social, e incluso para competir con las demás iluminaciones de la ciudad, puesto que hay premios, y él resultó agraciado con el tercer puesto para la categoría de casa particular, ganando el segundo el palacio del marqués de Dos Aguas, con el que no tenía muy buena relación54.

\section{2.- Iluminación por la visita del Rey Alfonso XII en 1875}

La llegada en barco del Rey Alfonso XII a Valencia el día 12 de enero de 1875 fue todo un acontecimiento para la ciudad, que se vistió con sus mejores galas y organizó todo tipo de actos y celebraciones para tal acontecimiento. Una vez más la ciudad, y como no el palacio de José Campo, se iluminó por las noches de fiesta y la prensa se hizo eco de ello.

El Imparcial del 14 de enero de 1875 dice:

"Difícilmente podrá verse en Valencia una iluminación más completa que la que ofrecían anoche las calles de la capital. No se veía a oscura ni un balcón, ni una ventana, aun en los barrios más apartados. Todos los edificios públicos estaban

\footnotetext{
53 BOIX, Vicente. 1867, p. 104-105.
}

54 BOIX, Vicente. 1867, p. 209. 
perfectamente decorados, ostentado muchos de ellos el retrato de S.M. en medio de caprichosos juegos de luces. Los cuarteles, especialmente el de artillería, eran los que con mayor gusto estaban adornados. Muchas casas particulares ostentaban también brillantes iluminaciones distinguiéndose entre ellas la de los Sres. Campo, la del marqués de Dos Aguas"... "La multitud invadía todas las calles, haciendo sumamente difícil el tránsito por el centro de la población" 55 .

Como acabamos de ver una vez más la iluminación de Campo está en competición con la del palacio marqués de Dos Aguas. Ya se ha comentado antes que las reformas de ambos palacios se hicieron próximas en el tiempo y que intervinieron casi los mismos artistas en las ricas decoraciones de techos y paredes.

Tras las celebraciones el rey continuó viaje en tren hacia Madrid donde, ya hemos visto, le esperaba el arco de triunfo y el palacio iluminado de José Campo.

\section{3.- Iluminación por la visita de la Reina regente María Cristina, Alfonso XIII y las infantas en 1888}

El día 6 de junio de 1888 llegó a Valencia su majestad la reina regente María Cristina, su hijo Alfonso XIII y las dos infantas. La visita fue todo un acontecimiento social para la ciudad y produjo un gran regocijo. Se engalanaron las calles y se alzaron 6 arcos triunfales para adornar el trayecto por donde iba a pasar la comitiva real.

${ }_{55}$ El Imparcial, 14 /1/ 1875, p. 2. 
Uno de esos arcos era de estilo mozárabe y muy parecido a los levantados años antes por el marqués en la entrada de la feria de muestras de Valencia y en frente de su palacio de Madrid para la celebración de la llegada a España de Alfonso XII como rey.

La reina regente y sus hijos fueron recibidos en la estación de tren con suelta de palomas, pétalos de rosas, versos y demás felicitaciones; al salir de la estación comenzó una marcha triunfal por las calles de toda la ciudad que estaban engalanadas y llenas de público. Visitaron la catedral y la basílica de la Virgen de los Desamparados, al salir pasaron por la plaza de la Almoina donde se encuentra el palacio arzobispal y el del marqués, engalanado e iluminado para tal ocasión.

Campo puso mucho interés en la iluminación de su palacio porque según relata la prensa, estaba previsto que sus majestades se alojaran en su palacio, pero finalmente se hospedaron en la Capitanía General. Este dato lo recoge la prensa: "parece que S. M. la reina, cuando visite Valencia no se hospedará en el palacio del marqués de Campo, sino en la capitanía general"56.

La prensa recoge con detalle todos los actos que se realizaron en honor de sus majestades y destaca las iluminaciones y animaciones de las calles por la noche. En La Dinastía se nombran como las más espectaculares, las iluminaciones del palacio del marqués de dos Aguas y la del palacio del marqués de Campo57.

${ }^{56}$ La Unión Católica, 1 /5/ 1888, p. 3.

${ }_{57}$ La Dinastía, 8 /6/ 1888, p. 6. 


\section{4.- Otras iluminaciones en Valencia con ocasión de otras celebraciones}

Toda festividad era excusa para engalanar el palacio del marqués y así, hacer notar su interés por seguir participando en la vida de la su ciudad natal desde su residencia de Madrid.

En noviembre de 1884 su santidad León XIII nombró al obispo Antolín Monescillo, Cardenal y Arzobispo de Valencia, y para celebrar su llegada el palacio del marqués fue iluminado según se narra en el periódico madrileño $L a$ Unión ${ }^{8}$. Había una brillante iluminación en el palacio del marqués de Campo y en otros edificios particulares y públicos. Cualquier festividad o acontecimiento era aprovechado para iluminar el palacio, pero en este caso, si tenemos en cuenta la privilegiada situación del palacio de Campo el plena plaza del palacio arzobispal, entendemos perfectamente que sus iluminaciones sean siempre parte de las celebraciones ya que, esa plaza junto con la de la catedral, en la que se encontraba la llamada Casa de la Ciudad, equivalente al actual ayuntamiento, había constituido desde siglos atrás el centro de poder político y religioso de la ciudad, y por ello el interés en afianzar su situación en un espacio de poder.

Otra ocasión de iluminación fue la festividad del Corpus de 1885, que desde siglos atrás se celebraba en la ciudad con grandes procesiones y demás actos en los que participaba la ciudadanía y que conllevaba la decoración de plazas y fachadas.

${ }^{58}$ La Unión, 19 /12/ 1884, p. 2. 
Como en ocasiones anteriores las actividades del marqués también se reflejan en la prensa y en La Correspondencia de España podemos leer lo siguiente: "Gran número de casas del contorno de la Catedral lucían vistosas iluminaciones. El Palacio del señor marqués de Campo se distinguía por el lujo y buen gusto con que estaba iluminado, ofreciendo un golpe de vista brillantísimo" 59 .

En este capítulo hemos visto cómo el marqués de Campo tuvo una relación muy activa con la creación del arte efímero que promovió, pero en realidad lo que dejó en cada una de sus actuaciones fue su propia huella.

${ }^{59}$ La Correspondencia de España, 6 /6/ 1885, p 1. 



\section{Capítulov}

EL MARQUÉS DE CAMPO COMO PROMOTOR Y MECENAS DE ARTISTAS
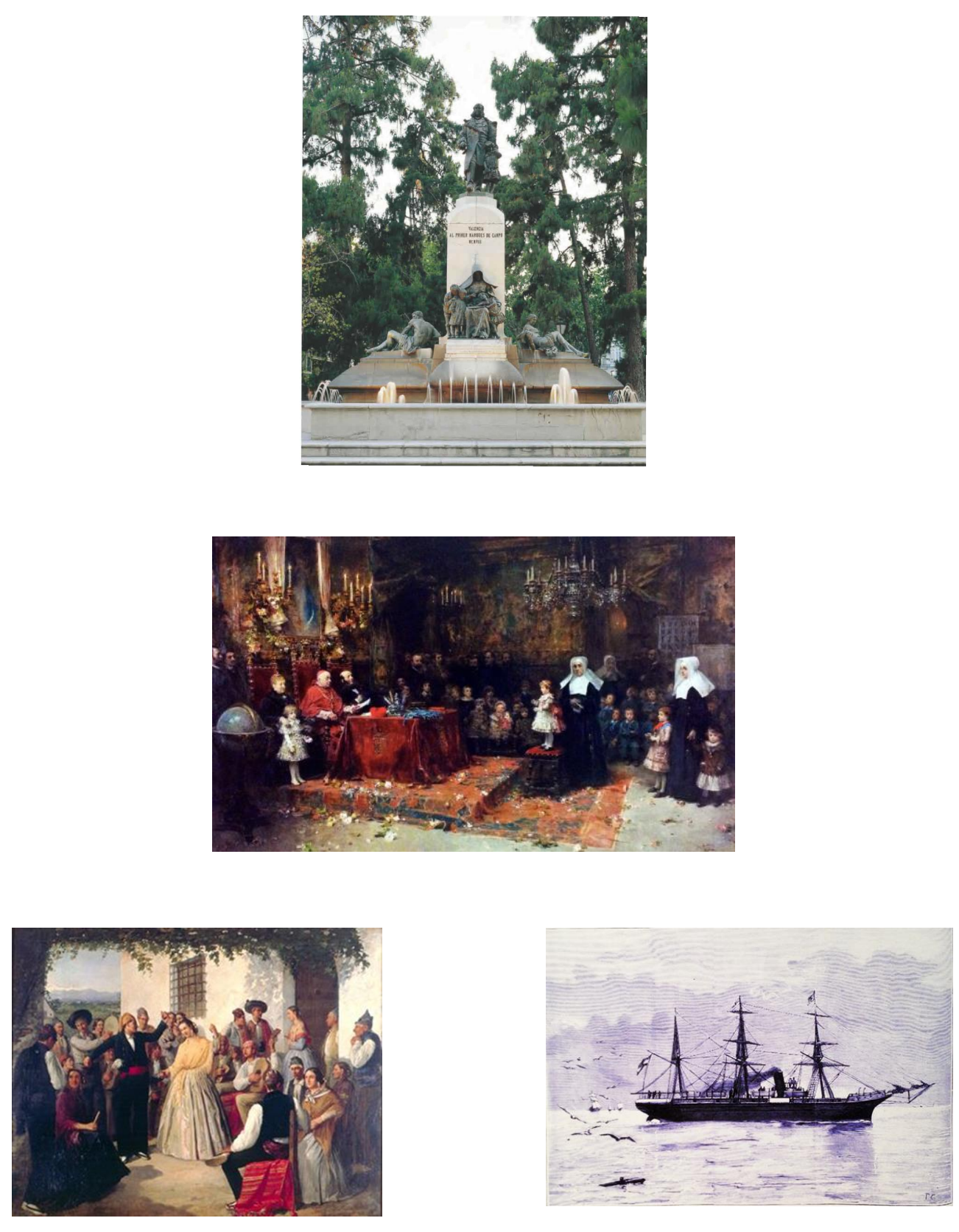



\section{Capítulov}

\section{EL MARQUÉS DE CAMPO COMO PROMOTOR Y MECENAS DE ARTISTAS 1}

Según el diccionario de la Real Academia, mecenas significa persona que patrocina las letras o las artes. Y según el mismo diccionario, mecenazgo es la protección o ayuda dispensadas a una actividad cultural, artística o científica² ${ }^{2}$

Este significado no es nuevo, desde la antigüedad ha habido mecenas y se ha ejercido el mecenazgo. Pero el mecenazgo se puede ejercer de muchas formas, según Peter Burke, en La Italia del Renacimiento, un mecenas podía acoger en su casa al artista y mantenerlo mientras trabajaba para él o bien encargarle obras en un momento puntual, con el propósito de favorecer su carrera; pero a su vez el artista podía ejecutar obras con la intención de

\footnotetext{
${ }^{1}$ Parte de este capítulo fue objeto de una comunicación en el Congreso de mecenazgo y coleccionismo celebrado en la Universidad de Sevilla en 2017.

MORANT GIMENO, Ana María. "Un mecenas desconocido de la España decimonónica: el marqués de Campo (1814-1889)" en Coleccionismo, mecenazgo y mercado artístico en España e Iberoamérica, Sevilla: Universidad de Sevilla, 2017.

${ }^{2}$ DRAE edición 2020 https://dle.rae.es/mecenas consultado en línea el 10 de julio de 2020.
} 
venderlas, lo cual era muy arriesgado, pero de ese modo se fue creando el mercado del arte 3 .

A lo largo de la historia ha habido mecenas de todo tipo: el Papa, la Iglesia, los gremios, las familias importantes como por ejemplo los Medici, los reyes y los nobles, que con diferentes motivaciones han protegido o ejercido el mecenazgo de artistas de todo tipo; y en el siglo XIX, con el nacimiento y desarrollo de la burguesía, ésta entra a formar parte de ese selecto grupo que ejerce el mecenazgo por placer, piedad, prestigio, orgullo, competencia u honor. En opinión de Fernández Arenas: "se trata de financiar algo para la propia exaltación, prestigio y gloria personal y familiar"4.

Haskell dice que "los patronos engloban a los mecenas del Renacimiento, a los estamentos de poder -Iglesia, Rey y corporaciones-, a las asociaciones, a los marchands y a los nuevos mecenas (instituciones, bancos, cajas de ahorro, empresas nacionales y multinacionales, fundaciones y, en última instancia, los particulares)"5.

En el mecenas hay también una cierta sensibilidad ante las formas artísticas y demuestra aprecio ante la obra de alguien, adquiriéndola y colaborando de este modo al pleno ejercicio de su actividad. Se le presupone pues, un propósito: promover, financiar, comprar, coleccionar, y para ello ha de ser alguien con poder político, espiritual o económico.

3 BURKE, Peter. El Renacimiento italiano. Cultura y sociedad en Italia. Madrid: Alianza, 2001, p. 99.

4 FERNÁNDEZ ARENAS, José. Las claves del Renacimiento. Barcelona: Ariel, 1986, pp. 13-14.

5 HASKELL, Francis. Patronos y pintores. Madrid: Catedra, 1988. 
Pero en el siglo XIX, la Iglesia y las órdenes religiosas ya nos son lo que eran antes, la monarquía está debilitada, la nobleza está en una situación decadente y, por los cambios socio-políticos, es la burguesía la que entra en el mercado del arte aplicando sus leyes de mercado. Sin embargo, no faltan burgueses con grandes fortunas que ejercerán el mecenazgo "a la antigua", manteniendo a artistas y promocionando sus carreas, al margen de las compras de obras de arte que realizan porque les gustan determinados artistas, quienes se limitan en ocasiones a satisfacer los deseos de estos aficionados a las bellas artes, convirtiendo así al arte en mera mercancía. Pedro Madrazo ya dijo en 1844 que: "el artista es un trabajador que vende los productos del alma"6.

Hemos visto que José Campo pasó de joven comerciante a político y hombre de negocios con una gran influencia en la sociedad del momento, y parte de ese acenso social conllevó a que, como buen burgués, se convirtiera en promotor y cliente actuando en dos ámbitos distintos: en el lugar donde estaba establecido y ejercía su actividad, Madrid y en relación a su lugar de origen, Valencia.

Normalmente la progresión económica del burgués lo llevaba a colaborar y promover todo aquello que mejorara las condiciones de vida de los más desfavorecidos, como obras arquitectónicas o reformas urbanísticas, que transmitían su ascenso y promoción personal y su estatus económico. El burgués no ejercía un mecenazgo de las artes entendido como en la Edad Media; en el ámbito de la arquitectura actuaba la mayor parte de las veces como promotor y no como cliente; ya que casi siempre encargaba la obra, aunque en ocasiones adquiría un edificio acabado por ser emblemático o para reformarlo y adaptarlo a su gusto, de manera que reflejara su estatus.

\footnotetext{
${ }^{6}$ MADRAZO, Pedro. "Bellas Artes. Su estado actual en la capital de España. Pintura. Exposición del Liceo”. El Laberinto, 1844, año 1, n. ${ }^{0}$ 15, p. 107.
} 
Como dice Joaquín Yarza: "la promoción arquitectónica está siempre ligada a la fama personal, el prestigio social, la rentabilidad política, la exaltación de la estirpe o la superación del estatus"7

Cuando un burgués encargaba un edificio quería proyectar su imagen y su posición económica desahogada, aunque en ocasiones también tenía aspiraciones estéticas, que no tenían por qué coincidir con el gusto del momento. Normalmente detrás de estos proyectos había un arquitecto de renombre, que daba aún más categoría al promotor, convirtiéndose la obra en un certificado del nuevo estatus adquirido y de su categoría social. Esto podemos verlo sobre todo en la vivienda y otras construcciones privadas como la tumba, y también en obras de destino público como escuelas, hospitales, asilos, capillas, etc., que solían construirse en la ciudad de origen para proyectar el afán de progreso y mejora de las condiciones de vida.

En el caso de obras pictóricas el comportamiento del burgués era diferente y éstos realizaban encargos directos a los artistas, como por ejemplo un retrato; a veces compraban obras de determinado autor por preferencia personal; en ocasiones les unía una relación de amistad o de otro tipo con un familiar de algún artista al que favorecían comprando sus obras; y en el caso de artistas extranjeros lo que imperaba era la preferencia del gusto y el interés de posesión para exhibición ante amigos y conocidos que acuden a recepciones para demostrar su categoría social. Las obras de arte, igual que ocurre en la actualidad, daban prestigio a su poseedor y cuanto más caras eran mejor cumplían su cometido.

7 YARZA LUACES, Joaquín. "Clientes, promotores y mecenas en el are medieval hispano”. En: Patronos, Promotores, Mecenas y Clientes. Actas del VII Congreso CEHA, Murcia: Universidad de Murcia 1988, p. 40. 
José Campo encaja perfectamente en la figura del burgués mecenas que acabamos de ver y ejerció una gran actividad de mecenazgo y promoción artística.

Fue mecenas y protector de pintores, escultores y arquitectos; y encargó y compró numerosas obras de arte de todo tipo. Esculturas, pinturas, tapices, armaduras, joyas, y todo tipo de objetos de decoración adornaban las estancias de sus cuatro residencias, que ya hemos visto y dejaban asombrados a los visitantes, invitados a bailes, cacerías, etc.

Algunos casos de promoción y mecenazgo del marqués son dignos de destacar y por ello vamos a adentrarnos un poco en ellos.

\section{1.- Promotor y mecenas de la familia Benlliure}

La familia Benlliure, conocida por ser una gran saga de artistas, tuvo una relación muy especial con José Campo.

El patriarca de la familia fue Juan Antonio Benlliure y Tomás (18321906), pintor y decorador que se casó con Ángela Gil Camps (1829-1907) y tuvieron cuatro hijos: Blas (1852-1936) pintor y decorador; José (1855-1937) pintor; Juan Antonio (1860-1930) pintor y Mariano (1862-1947) escultor. Tanto José como Mariano fueron alumnos de la escuela del primer Asilo que construyó José Campo en 1862, tal y como se lee en una de las cartas que el Marqués le envió en 1883 a Mariano $^{8}$, con quien mantuvo correspondencia a raíz de varios encargos.

${ }^{8}$ ACMB No C4CAM-oo8 de fecha 12-11-1883. 
La familia Benlliure era una familia muy humilde y la necesidad económica hizo que fueran alumnos del asilo. Mariano de pequeñito hacía las delicias de las monjas realizando figuritas de cera en las que ya demostraba su gran talento para la escultura.

Durante toda su vida José Campo benefició la carrera profesional de los tres hermanos Benlliure y encargó y compró obras a los tres: pinturas a José y a Juan Antonio, y esculturas a Mariano, quien además hizo el monumento en homenaje a Campo que hoy luce en la plaza Cánovas de Valencia.

\section{2.- Promotor y mecenas de José Benlliure}

José Campo compró varias obras de José Benlliure para adornar las paredes de sus residencias, pues era un artista del momento que cada vez ganaba más fama y el marqués deseaba, deleitar y asombrar a los amigos y visitas, y a la vez promocionar el trabajo de un artista valenciano, como hizo en otras ocasiones y luego veremos.

En las paredes de su palacio de Madrid colgaban obras firmadas por José Benlliure como por ejemplo: La bodega de una posada y soldados, Una gira de campo con majos y majas, gitanos, Una corrida de toros, y más obras que luego serán analizadas en la parte de esta tesis dedicada al marqués de Campo como coleccionista. Estas obras aparecen reflejadas en el inventario de bienes 9 realizado a la muerte de la primera esposa de José Campo, Rosalía Rey en enero de 1889 y se exhibieron en la Exposición Universal de Barcelona de $1888^{10}$.

\footnotetext{
9 AHPM, Tomo 36643 , fols. 7439 y ss.

${ }^{10}$ Anónimo. Exposición Universal de Barcelona. Catálogo de la instalación del Excmo. Señor Marqués de Campo. Barcelona, 1888.
} 
Dentro de las numerosas obras de José Benlliure que tenía el marqués, una de ellas merece especial atención porque fue un encargo muy especial. Le encargó un cuadro de grandes dimensiones para el salón principal del segundo asilo de párvulos que construyó en 1882 y del que ya hemos hablado en otro capítulo de esta tesis. Pero el acto que el marqués quería conmemorar en el cuadro era una entrega de premios a las niñas que recibían enseñanza en el primer asilo celebrada el día 17 de mayo de 1867.

El encargo era de tal magnitud que fue noticia en la prensa ${ }^{11} \mathrm{e}$ hizo necesaria una correspondencia fluida entre el pintor y Campo para ponerse de acuerdo con los detalles del cuadro.

En la Revista de Valencia de 1880 podemos leer lo siguiente: "Y ya que he citado á un valenciano opulento y me ocupo de los hermanos Benlliure, ahí va una noticia, algo nebulosa, porque no estoy autorizado para aclararla más. Un hijo de Valencia, que posee envidiable fortuna y un título nobiliario, va a levantar en las inmediaciones del paseo de la Glorieta un monumental Asilo para niños pobres, y le ha encargado á José Benlliure un lienzo de grandes dimensiones, destinado á perpetuar en uno de los departamentos de la nueva casa de caridad el recuerdo de quien invirtió sus riquezas en tan laudable obra" 12 .

El cuadro (Fig. 5.1), que hoy se conserva en la fundación Asilo Marqués de Campo, es de grandes dimensiones 1'85 x 3'o3 m. y la escena es de una sensibilidad extraordinaria. A la izquierda del cuadro podemos ver sentados tras una mesa al marqués y al Cardenal-Arzobispo de Valencia D. Antolín Monescillo; a su lado podemos ver a la marquesa de Campo, Rosalía Rey, que coge de los hombros a su hijo adoptivo Luis M. a Bruna; a la derecha del cuadro y en primer plano una niña subida a un taburete que, bajo la mirada tierna de

${ }^{11}$ La Ilustración Española y Americana, año XXX, núm. XXXIX, 22 de octubre de 1886, p. 2 y 9.

${ }^{12}$ A. Q.: Revista de Valencia, Valencia, 1880, p. 137. 
una monja, está recitando algo. La escena es contemplada por un gran número de asistentes, entre los que hay varios niños y niñas y un grupo de hombres adultos entre los que aparece autorretratado el propio José Benlliure y otros personajes conocidos amigos suyos como el pintor Francisco Pradilla, José Villegas, Mateo Silvela, Antonio Muñoz Degrain, José Echena, Juan Luna Novicio y Juan José Puerto; en el rostro de una monja está retratada la esposa del pintor, M. ${ }^{a}$ Ortiz $^{13}$.

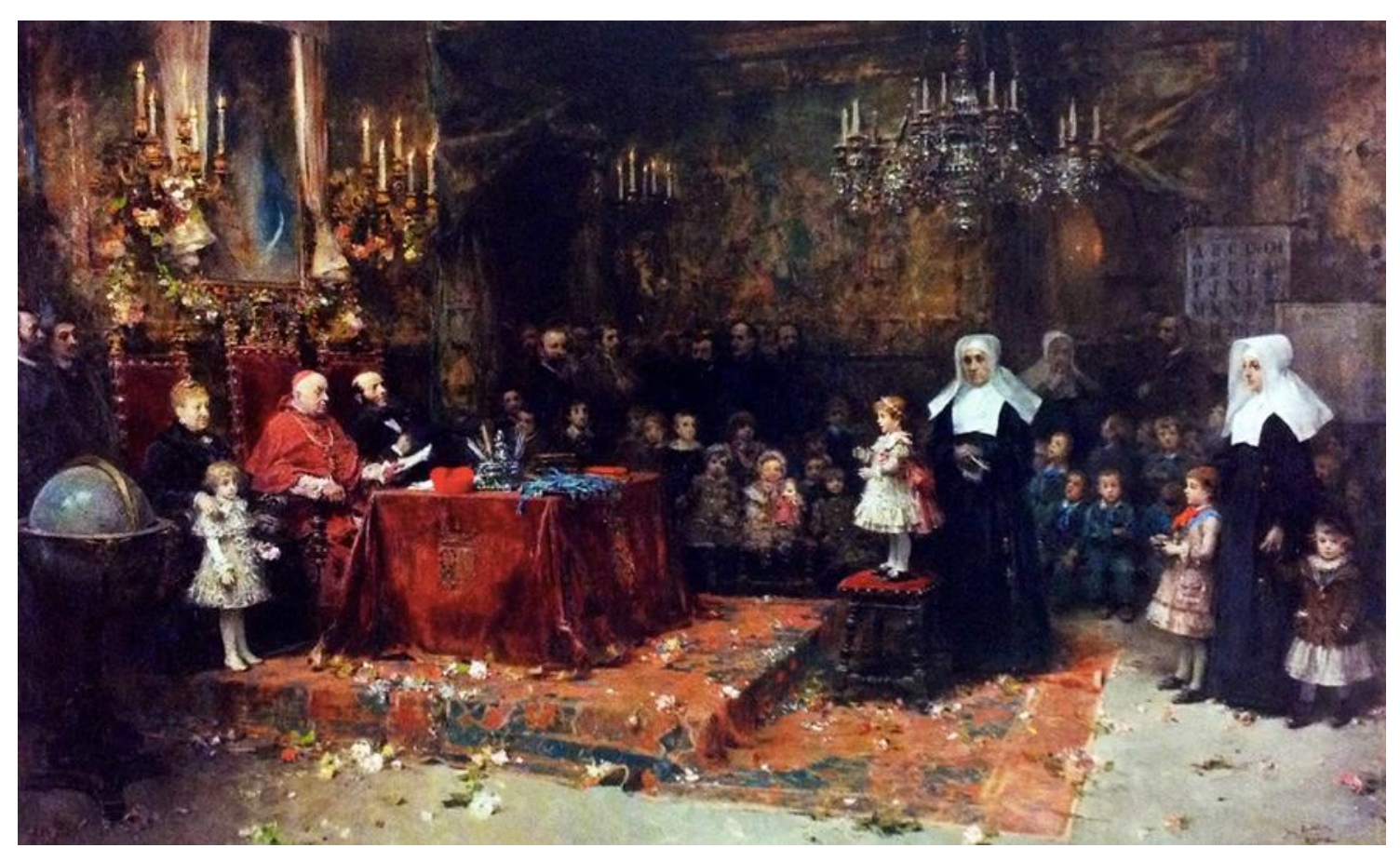

Fig. 5.1 Distribución de premios en el Asilo del Marqués de Campo. José Benlliure. (1881-1886). Óleo sobre lienzo. Fundación Marqués de Campo.

Este cuadro, refleja exactamente lo que aconteció en dicho acto, tal y como podemos leer en la crónica de Vicente Boix escrita con motivo de la celebración del segundo centenario de la coronación de la Virgen de los Desamparados ${ }^{14}$. El primer asilo de párvulos había sido construido en 1863 y, en 1867 con motivo de la celebración mencionada, se celebraron en la ciudad muchos actos de tipo religioso, festivos y de caridad con los más pobres.

\footnotetext{
13 VIDAL CORELLA, Vicente: Los Benlliure y su época, Valencia, 1977, p. 91-92.

${ }^{14}$ BOIX, Vicente. Memoria histórica de las fiestas celebradas en Valencia con motivo del $2^{\circ}$ centenar de Nuestra Señora de los inocente mártires y Desamparados en el mes de mayo de 1867. Valencia: Imprenta Salvador Martínez, 1867.
} 
Por ese motivo José Campo regaló trajes nuevos a todos los niños del asilo, un total de 300, se celebraron unos exámenes extraordinarios y luego una entrega de premios.

En la página 44 de la crónica de Boix se hace referencia a los trajes nuevos para los alumnos, y en la página 181 dice exactamente:

"El día 17 en la escuela del párvulos de José Campo se celebró un acto solemne y tierno, como todos los que tiene que ver con la infancia. Se realizaron en el asilo unos exámenes extraordinarios a niños y niñas, que reciben en él educación gratuita........el acto se verificó en la sala de la escuela, adornada con ramos de flores y dispuesta por las Hijas de la Caridad.....Ocupaba la presidencia el concejal presidente de la Comisión Municipal de Instrucción primaria, a cuya derecha estaba la Excma. Señora doña Rosalía Rey de Campo, y D. Antonio Quilis en representación de la Comisión de escuelas de párvulos de la Sociedad de Amigos del País; y a la izquierda D. Juan Reig García en representación del Sr. Campo y D. Vicente López, secretario de la Asociación Benéfica Domiciliaria. Algunas señoras y varios convidados asistían al acto.

Los párvulos ocupaban el graderío de la escuela, y bajo la dirección de las religiosas fueron examinados de los ejercicios que constituyen su enseñanza, interpolando sencillos himnos que cantaron con acierto. Todos los concurrentes pudieron admirar la extensión de los conocimientos de aquellos pobres pequeñuelos que, en doctrina cristiana, aritmética, sistema decimal, geografía, nociones de geometría, historia civil, y religiosa, y otros varios ramos, dieron notables muestras de aprovechamiento.

Terminado el examen general, el Sr. Presidente leyó un sentido y breve discurso...

A continuación, el Sr. Reig manifestó el encargo de expresar el sentimiento del patricio de no haber podido asistir al acto pero que se hallaba allí la persona a quien había entregado su corazón, su esposa ....

Unos sentidos versos en agradecimiento pronunció una tierna niña y se procedió a la distribución de los premios, que consistían en medallas y dos lindas coronas. El niño y la niña agraciados con ellas, dieron las gracias. 
Las personas invitadas subieron luego a las habitaciones superiores donde se les sirvió un elegante refresco. Los párvulos fueron socorridos con una abundante comida. El asilo de Campo es un gran monumento del esplendido capitalista”.

Tras leer este trozo de la crónica no cabe duda de que este acto es el que José Campo quería reflejar en el encargo, pero la realización de la obra fue ardua y este encargo fue uno de los más exigentes que José Benlliure tuvo en su carrera y tras acabarlo decidió no volver a admitir proyectos tan grandes, pues tenía mucha clientela y no podía satisfacer todas las peticiones. Las grandes dimensiones de la obra exaltaban la generosidad y magnificencia del benefactor. En opinión de la Dra. Bonet, no se conoce otro ejemplo en la obra de José Benlliure en el que el objeto del contrato fuera la exaltación y gloria de un evento o de una persona ${ }^{15}$.

Cuando José Campo eligió a José Benlliure para este trabajo, éste estaba viviendo en Roma, trabajando en su taller de la vía Margutta número 33, Campo y Benlliure mantuvieron correspondencia para ponerse a de acuerdo en los detalles por la lectura de la correspondencia sabemos que el proyecto del pintor no era exactamente como el cuadro final (Fig. 5.2).

Posiblemente el Sr. Campo le envió la crónica y el artista se hizo una idea y de ahí el boceto que envió al mecenas, que no se parece al resultado final. El proyecto de Benlliure era una escena diferente pues lo que presenciaba el Marqués y su familia desde detrás de la mesa era a un niño con un puntero en la mano delante de un mapa explicando algo, y no aparecía tampoco el grupo de hombres contemplando la escena.

15 BONET, Victoria. José Benlliure Gil (1855-1937) El oficio de pintor. Valencia: Ayuntamiento de Valencia, 1998. 
Pero en una carta de fecha 12 de noviembre de $1883^{16}$, José Campo escribió al pintor, le dijo que estaba de acuerdo con parte del boceto, le dio instrucciones para incluirse a él mismo y al arzobispo de Valencia en la escena, eliminando a otros que sí habían estado presentes y así reflejar exactamente el momento en el que la niña premiada con la corona de flores da las gracias a los presentes.

Este interés del marqués en que la obra sea realizada acorde a su gusto está en la línea de lo que los artistas de la época debían hacer en muchas ocasiones; someter sus ideas y proyectos al gusto de quien paga el encargo, accediendo de buen o mal grado a las peticiones del cliente.

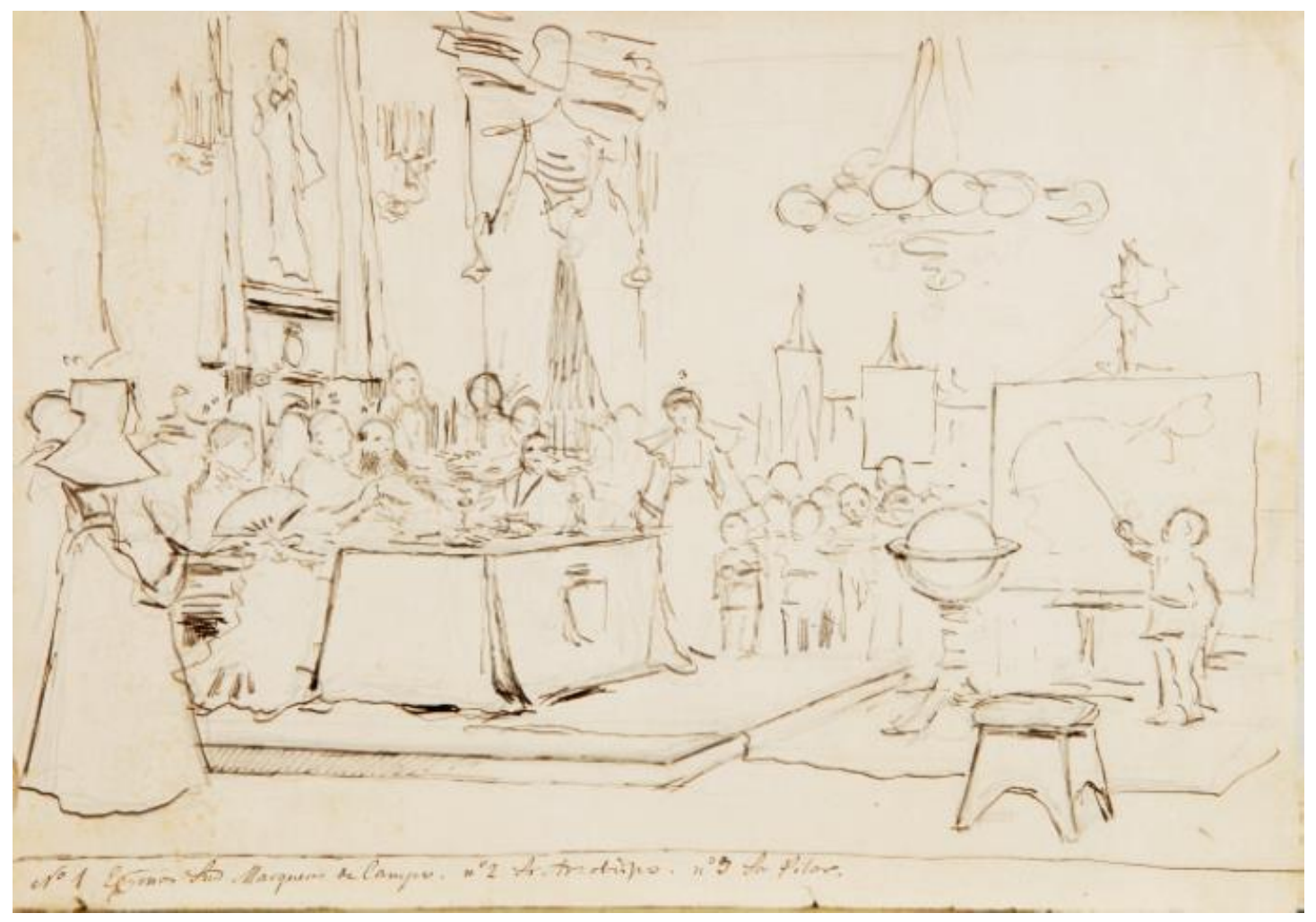

Fig. 5.2 Distribución de premios en el Asilo del Marqués de Campo. José Benlliure. Boceto $\mathrm{n}^{0}{ }_{1}$. Casa Museo Benlliure.

${ }^{16}$ ACMB (Archivo Casa Museo Benlliure) No C4CAM-oo8 de fecha 12-11-1883. 
Por otro lado en los años 1881, 1882 y siguientes José Benlliure estaba como ya hemos dicho en Roma, pero no sabemos quién lo mantenía, sin embargo en el periódico El Imparcial de mayo de 1881, en un artículo sobre la Exposición de Bellas Artes, en relación a la marcha de buenos pintores españoles a París y Roma donde son más valorados, podemos leer: "Hace poco, a un joven pintor, Benlliure, se le han hecho proposiciones ventajosas: pintar dos años para una especia de Celestina del arte por 30.000 duros. Los dioses de la pintura nos abandonan y hacen bien"17

Posiblemente esa proposición de pintar dos años fuera de José Campo y el encargo recibido fuera el cuadro de la entrega de premios al que nos hemos referido. En las cartas entre el marqués y el pintor se habla de la cantidad de 6.00o pesetas como precio del encargo, pero luego el precio cambió a 20.000 pesetas, hecho que enfadó bastante al marqués y que pagó por medio de un banquero de Roma amigo suyo, Antonio Cesari ${ }^{18}$.

Benlliure tardó mucho en acabar el cuadro y José Campo se lo reclamó varias veces incluso a través de su hermano Mariano, mediante carta de fecha 26 de septiembre de 1885, con quien se escribía en relación al monumento que el Ayuntamiento de Valencia quería erigir en su honor ${ }^{19}$. Finalmente lo acabó en octubre de 1886.

Hoy en día el cuadro permanece embalado en plástico blanco, junto con las cuatro piezas del marco, en la tribuna del primer piso de la capilla del asilo de la calle de la Corona. Participó en una exposición hace unos años y nuca más se ha vuelto a colgar.

${ }^{17}$ Los Lunes del Imparcial, 17 /5/ 1881, p. 1.

${ }^{18}$ ACMB No C4CAM-009-1 de fecha 11-12-1883.

${ }_{19}$ ACMB No $\mathrm{C}_{31 \mathrm{CAM}-005}$ de fecha 26-9-1885. 


\section{3.- Promotor y mecenas de Juan Antonio Benlliure}

José Campo también fue mecenas de Juan Antonio Benlliure, a quien compró y encargó numerosas obras de temática variada; alguna de esas obras, que colgaban de las paredes de su palacio de Recoletos, fueron expuestas en su pabellón de la Exposición Universal de Barcelona de 1888. Allí se pudieron ver obras como por ejemplo Una niña, Soldados antiguos, Frailes leyendo, Plaza de toros, etc. ${ }^{20}$ Unos de los encargos más importantes que le hizo el marqués fue un cuadro sobre unos soldados riñendo en una taberna y que fue noticia en la Revista de Valencia de $1880^{21}$.

En la publicación podemos leer:

"Decía antes que la familia Benlliure es una familia de artistas, y lo demuestra bien el que figura ya honrosamente al lado de los nombres de José y de Mariano el de su hermano Juan Antonio, que se dedica á la pintura. Estos días le ha comprado un acaudalado marqués, paisano nuestro, una tabla en la que aparece el interior de una taberna, en donde varios soldados de los tercios españoles, sobrexcitados por sus repetidas libaciones, promueven acalorada disputa y vienen á las manos, repartiéndose sendos linternazos. Vuélcase la mesa, ruedan los sombreros de los contendientes, y el roto jarro derrama sobre las baldosas el encendido zumo de las uvas, mientras los compañeros, que fueron ajenos á la cuestión, echan mano á las espadas para imponerse con su actitud á los revoltosos y devolver la paz á los acalorados ánimos.

Hay energía en el grupo, propiedad en las actitudes, buen color y, sobre todo, seguridad en el toque. Juan Antonio Benlliure hará fortuna, si persevera en el trabajo con el entusiasmo que hoy le domina".

También fue noticia la misma obra en el Diccionario Biográfico de Artistas Valencianos ${ }^{22}$.

${ }^{20}$ Anónimo. Exposición Universal de Barcelona. Catálogo de la instalación del Excmo. Señor Marqués de Campo. Barcelona: A. López Robert Impresor, 1888.

${ }^{21}$ A. Q. Revista de Valencia, Valencia, 1880, p. 137.

22 BARÓN DE ALCAHALÍ. Diccionario Biográfico de Artistas Valencianos. Valencia: Imprenta Federico Doménech, 1897, p. 63. 


\section{4.- Promotor y mecenas de Mariano Benlliure}

Pero el gran protegido de la familia fue sin duda Mariano Benlliure (1862-1947). El marqués y el escultor se apreciaron mutuamente en vida e intentó favorecerle y ayudarle para que pudiera desarrollar su arte. Esa relación era pública y notable.

En el periódico La Correspondencia de España se publicó durante los días 6, 7, 8 y 9 de marzo de 1917 un largo reportaje sobre Marino Benlliure, dentro de una sección titulada Cómo viven los valencianos en Madrid, y el artista habló de toda su vida en general23.

El reportaje reproduce literalmente las palabras del artista y en referencia a su relación con el marqués de Campo dijo:

"El marqués de Campo fue uno de mis mayores protectores. Me quería entrañablemente. En Madrid, por la época en que presenté en la Exposición El monaguillo, me hizo varios encargos y me los pagó muy bien. Invitábame muchos días a comer y almorzar con sus amigos Martos y Navarro Reverter. Fue cuando me encargaron el monumento al marqués. Me pagaban por mensualidades a 10.000 francos. Así viví un año gastando a tutiplén, como quien vive de renta. Me lo gasté todo.

$\mathrm{Al}$ año de comenzada la obra murió el pobre marqués. Si vive medio año más, resuelvo mi problema. Me había prometido facilitarme medios para hacerme independiente y poder trabajar sin agobio alguno. Su protección extendíase a la familia. También hizo a mi hermano Pepe varios encargos. Entre ellos un cuadro de un reparto de premios que está en el asilo de Valencia, donde por cierto figura el marqués. Le compró también uno de aquellos cuadros de asuntos de brujas que hacía Pepe por aquella fecha. Y

23 MARTÍN CABALLERO. "Cómo viven los valencianos en Madrid". La Correspondencia de España, 8 /3/1917, p. 1. 
recuerdo que un día el marqués, que estaba enfadado me decía: Mi casa es el cuadro de brujas de tu hermano Pepe.

Por las noches todos salen de aquí cargados de cosas por las ventanas. Desaparece todo... Pero, aunque yo no me puedo mover, un día probaré que todavía soy un león....

Cuando me marché en uno de mis viajes a Roma, tuvo el marqués, cuyo recuerdo guardaré siempre venerándole, el siguiente rasgo conmigo. Estuve a despedirme, y me preguntó: ¿llevas dinero? Para el viaje, si, le contesté; pero nada más que para eso. Pues toma. Y extendió un cheque de un talonario por valor de 15000 pesetas que cobré en las oficinas de su casa. Cuando me despedí, me dijo: "vete a escape, si quieres cobrar, pues si me arrepiento diré por teléfono que no te paguen”. De esa manera quiso pagarme, sin duda, una cabeza suya y otra de la marquesa, que había hecho recientemente y que no llegaron a fundirse”

Las obras de la familia a las que se refiere Mariano están reflejadas en el inventario realizado a la muerte de la primera esposa del marqués y además algunas fueron exhibidas en el pabellón de la feria de Barcelona de 1888. Citemos como ejemplo dos bustos del marqués y su esposa que nunca se llegaron a fundir en bronce ${ }^{24}$; deben ser los mismos que aparecen en el inventario de bienes del palacio de Madrid descritos como dos bustos de barro cocido del marqués y la marquesa difunta sobre pedestales de madera ${ }^{25}$. En el mismo inventario se reflejan otras obras que sin bien no aparecen atribuidas a ningún autor, por el tema y demás características podrían apuntar a Mariano como autor, como por ejemplo un busto de mármol del marqués, una escultura de mármol blanco "el niño Pepito acostado" (se estaría refiriendo al hijo adoptivo del marqués), una estatua ecuestre de Alfonso XII en bronce, dos grupos de ninfas de bronce plateados con pedestal de piedra y ónix, y varias esculturas de diverso tamaño y temática de bronce y mármol en el palacio de Valencia y en el castillo de Viñuelas.

24 MARTÍN CABALLERO. “Cómo viven los valencianos en Madrid”. Madrid: 1971. ${ }^{25}$ Archivo Histórico de Protocolos de Madrid, núm. 36.638, referido al inventario de bienes realizado a la muerte de su primera esposa en 1889 . 
Además de las obras que realizó, Mariano fue el escultor elegido para realizar el monumento que el Ayuntamiento de Valencia quiso hacerle a José Campo para agradecer la modernización de la ciudad (Fig. 5.3). Como ya se ha dicho, las calles se empedraron, las aguas se canalizaron, se instalaron las primeras fuentes públicas, se instaló el alumbrado público a gas en las calles, etc., y de ahí el calificativo de modernizador de la ciudad.

El monumento al marqués de Campo fue uno de los que más tardó en inaugurarse de los que se han realizado en Valencia y estuvo envuelto en mucha polémica. En enero de 1885 el ayuntamiento acordó realizar el monumento y se lo comunicó por carta al marqués, quien contestó muy emocionado y agradecido ${ }^{26}$, pero el marqués no lo vio acabado con vida, ya que las figuras fueron colocadas finalmente en 1909.

José Campo recibió la noticia con mucha satisfacción y estaba muy interesado en su realización, por lo que decidió establecer correspondencia con el escultor para hacerle algunas peticiones sobre el mismo.

En carta de fecha 16 de julio de 1885 el marqués le dice que va a dar orden a un empleado suyo en Roma para que le facilite a Mariano la cantidad que éste crea necesario para ir atendiendo los gastos del monumento. Le dice además que le gustaría que Mariano hiciese un cálculo aproximado del coste total del trabajo 27.

\footnotetext{
${ }^{26}$ La carta dirigida al marqués de Campo por el Ayuntamiento de Valencia el día 23 de enero de 1885 y la contestación del marqués de fecha 25 de enero de 1885, aparecen publicadas en ALMELA I VIVES, Francisco. 1989, p. 11 y ss.

${ }^{27} \mathrm{ACMB} \mathrm{N}^{\circ} \mathrm{C}_{31} \mathrm{CAM} 003$ de fecha $16-4-1885$.

248
} 
El marqués estuvo preocupado por el coste del monumento y por su emplazamiento desde el primer momento, porque él sabía que era una gran obra, que iba a ser costosa y no confiaba mucho en que el Ayuntamiento pudiera conseguir el dinero suficiente para costearlo.

En carta de fecha 24 de julio de 1885 el marqués le escribe a Mariano desde Arcachón y le dice que ha recibido su carta dando a conocer el presupuesto de 30.000 pesetas sin contar los honorarios como escultor, el embalaje de las estatuas, el transporte, los derechos de aduana, la colocación sobre un pedestal, etc ${ }^{28}$.

José Campo, que está muy orgulloso del homenaje que le va a hacer la ciudad, se toma la libertad, por la amistad que le une con el artista de sugerirle la idea de que dos de las estatuas del monumento representen en sus facciones a los dos únicos seres queridos que le quedan de familia, su mujer y su hijo adoptivo, y que pudiera ser su esposa la madre de la Caridad que aparece al pie del centro y que el rostro de su hijo adoptivo fuera el de cualquiera de los niños inmediatos.

A su vez el marqués está dispuesto a aceptar el precio de 150.000 pesetas que ha solicitado Mariano y como tiene dudas de la cantidad que pueda recaudarse en unas suscripciones públicas que se han abierto en el Ateneo Mercantil y en el Ateneo Obrero de Valencia, él mismo comienza a abonar cantidades para que el artista pueda continuar el trabajo.

${ }^{28}$ ACMB. No ${ }^{\circ} 31 \mathrm{CAM}-004$ de fecha 24-7-1885. 
El marqués le comenta a Mariano, como una muestra más de la confianza que se tienen, que en realidad el monumento está destinado a una plaza que ni siquiera está construida, que los terrenos ni siquiera están expropiados, que incluso se han de construir aceras, y que no confía mucho en que el Ayuntamiento lo consiga.

En carta de fecha 26 de septiembre de 1885 el marqués acusa el recibo de la foto del boceto y muestra su acuerdo con todo 29 . De paso le pregunta por el encargo del cuadro del asilo que le hizo a José porque hace meses que le prometió acabarlo y no lo ha hecho. Como los dos hermanos estaban en Roma trabajando el marqués aprovechó la carta para ver si Mariano le llamaba la atención a José sobre el retraso de la obra a la que antes nos hemos referido.

${ }^{29}$ ACMB. No C31CAM-005 de fecha 26-9-1885. 


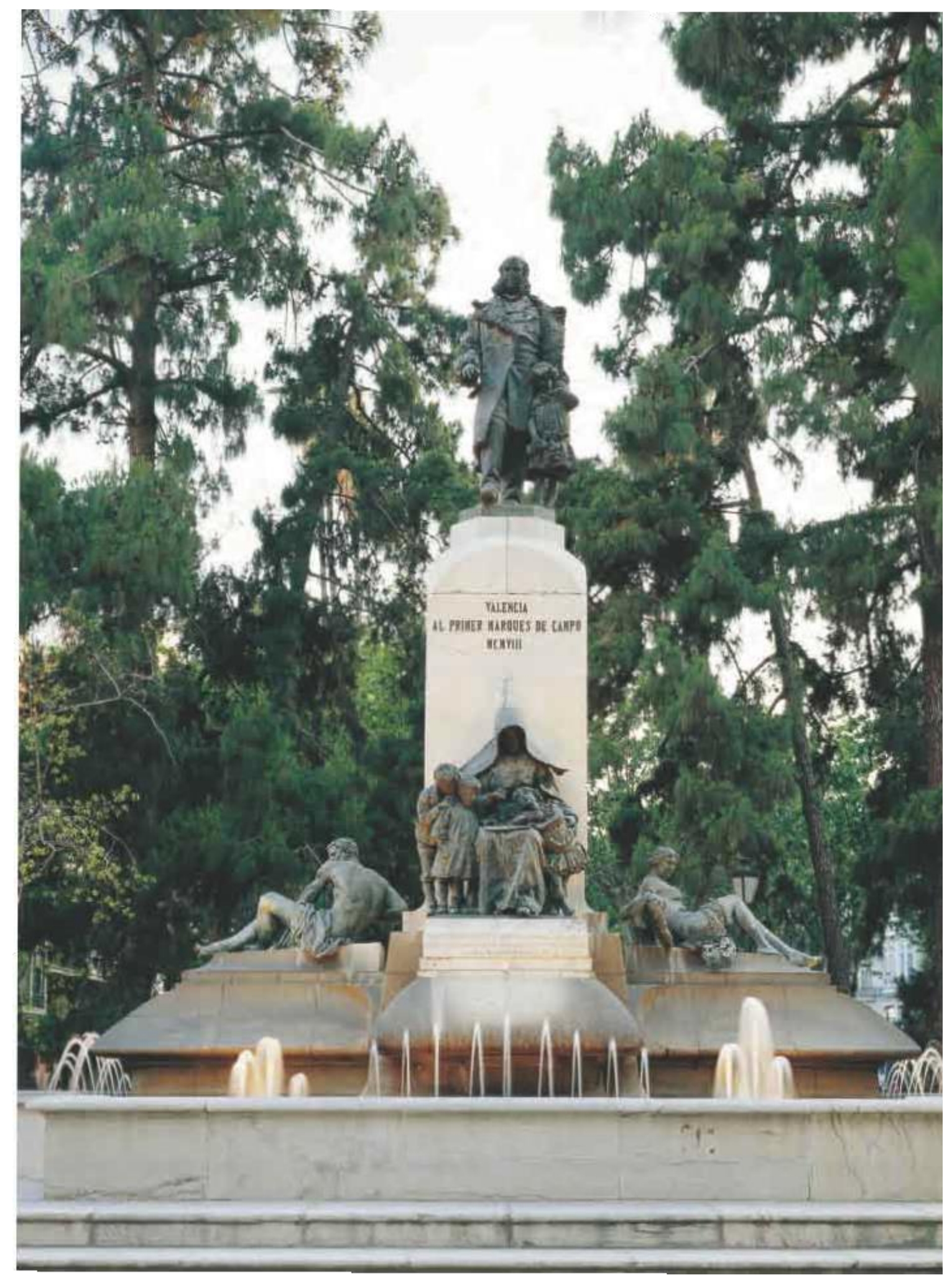

Fig 5.3 Monumento a José Campo. Mariano Benlliure. 1885.

Fotografía de la autora. 
A su vez el marqués está muy interesado en la realización de su escultura, pero como no confía en su éxito, él mismo va a sufragarla y por ello en su testamento dejó una partida especial para que se pagara al artista. Una vez gastada esa cantidad, el Ayuntamiento acordó pagar el coste restante para acabarla y la figura del marqués fue colocada primero sin pedestal en la plaza de San Francisco, delante del actual Ayuntamiento, para luego ser trasladada definitivamente en 1929 al lugar que ahora ocupa en la plaza Cánovas del Castillo de Valencia.

Todas las esculturas que forman el monumento son de una calidad exquisita y algunas de ellas, como por ejemplo las que representan el Ferrocarril y la Navegación (Fig. 5.4 y 5.5), fueron premiadas en la Exposición Nacional de $1890^{30}$ y en la de Munich de 1894. El monumento estaba dedicado a la caridad, la industria y el comercio, y a rendir homenaje al benefactor de la ciudad; y así vemos en las diferentes figuras de Benlliure representadas las mejoras que realizó: el Gas (Fig. 5.6) por haber realizado la instalación para el alumbrado público y luego para las casas; la Navegación por la reforma del puerto de Valencia; el Ferrocarril, cuya construcción promovió y materializó, y la Caridad (Fig. 5.7) por la generosidad manifiesta en la creación y el sostenimiento de los dos asilos de párvulos que llevaban su nombre.

\footnotetext{
${ }^{30} \mathrm{El}$ proceso de creación y realización de ese monumento estuvo acompañado de mucha polémica y dificultades. Para más información ver entre otros:

FERRER OLMOS, Vicente. Monumentos a valencianos ilustres en la ciudad de Valencia. Valencia, 1987, p. 61-63.

GIL, Rafael; PALACIOS, Carmen. El ornato urbano. La escultura pública en Valencia. Valencia: Ayuntamiento de Valencia, 2000.

MONTOLIU, Violeta. "El Monumento al Marqués de Campo". En: Monumentos Conmemorativos de Valencia: Memoria esculpida de una ciudad: 1875-1936. Valencia: Real Academia de Cultura Valenciana, p. 79-84.

REYERO, Carlos. La escultura conmemorativa en España. La edad de oro del monumento público, 1820-1914. Madrid: Cuadernos de arte cátedra, 1999.
} 
En la (Fig. 5.9) vemos en detalle el retrato del marqués y se observa el perfecto parecido en sus rasgos y actitud que consiguió el gran Mariano Benlliure. Bien vestido con abrigo de cuello de piel, con el pie hacia adelante demostrando su carácter y actitud hacia las cosas, afrontarlas y seguir pase lo que pase. Para él no había nunca obstáculos como hemos podido apreciar ya a estas alturas de la tesis. La interpretación icnográfica del a imagen son lleva a decir que la niña que lo acompaña representa a su ciudad natal, Valencia, a la que siempre demostró fidelidad y cariño.

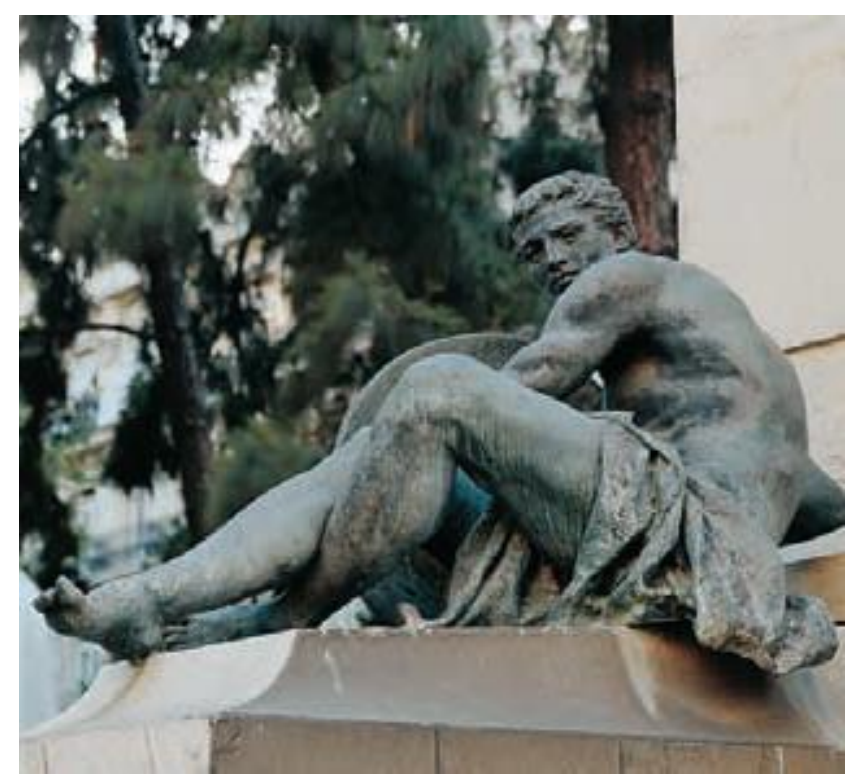

Fig. 5.4 El Ferrocarril. Mariano Benlliure. 1885. Fotografía de la autora.

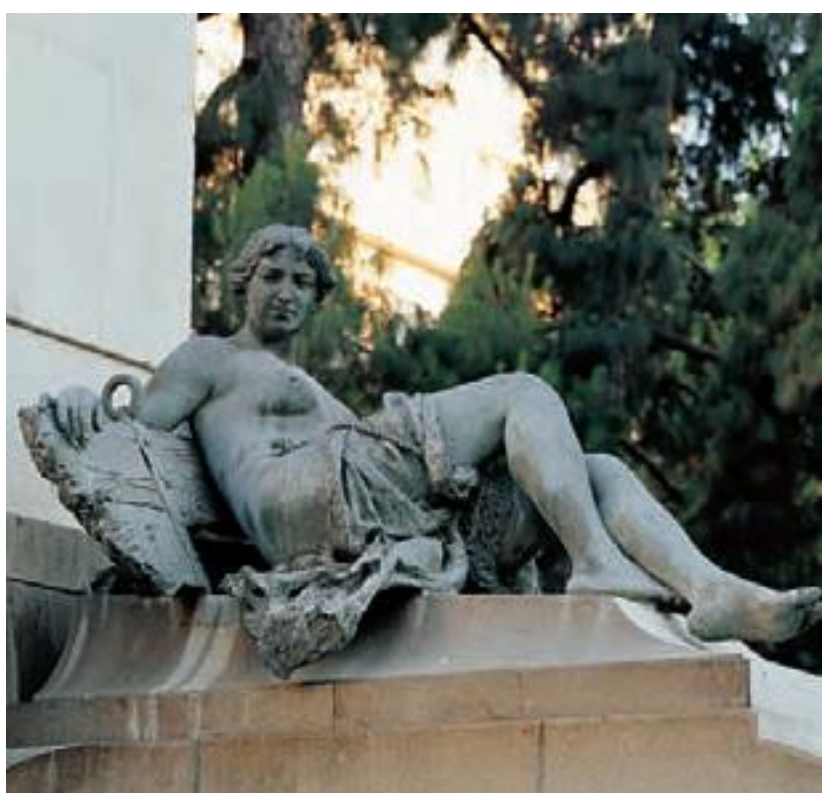

Fig. 5.5 La Navegación. Mariano Benlliure.1885. Fotografía de la autora. 


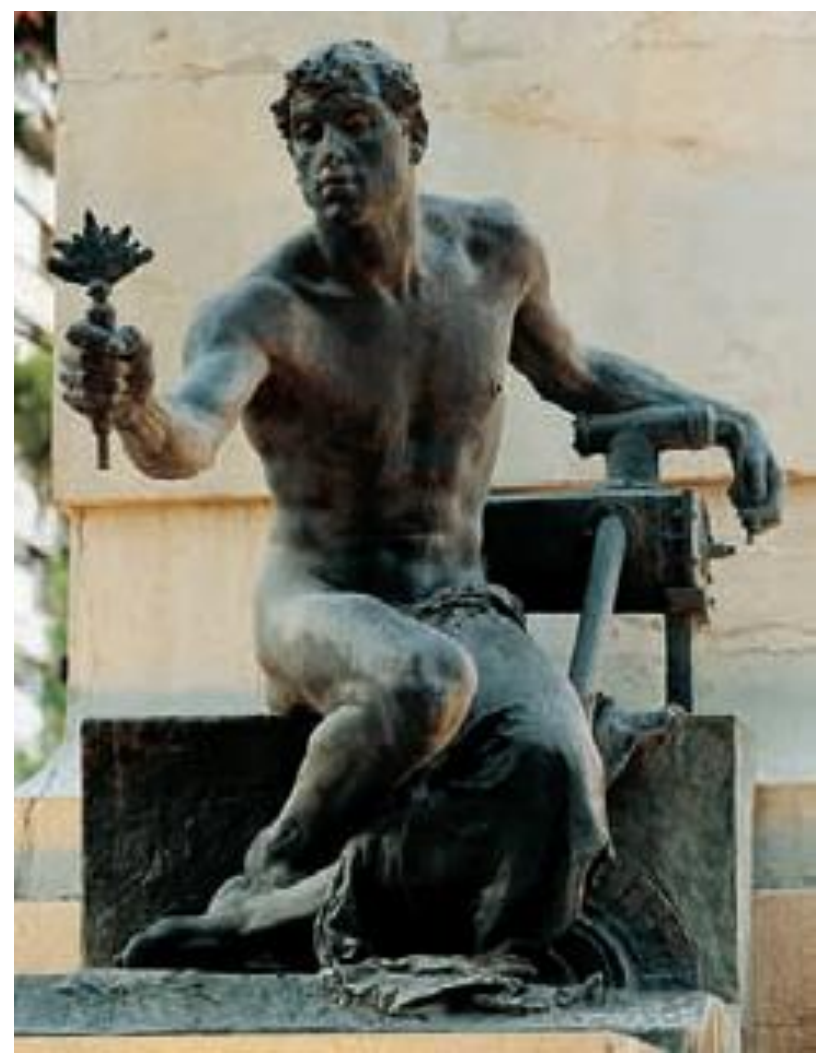

Fig. 5.6 El Gas. Mariano Benlliure.1885. Fotografía de la autora.

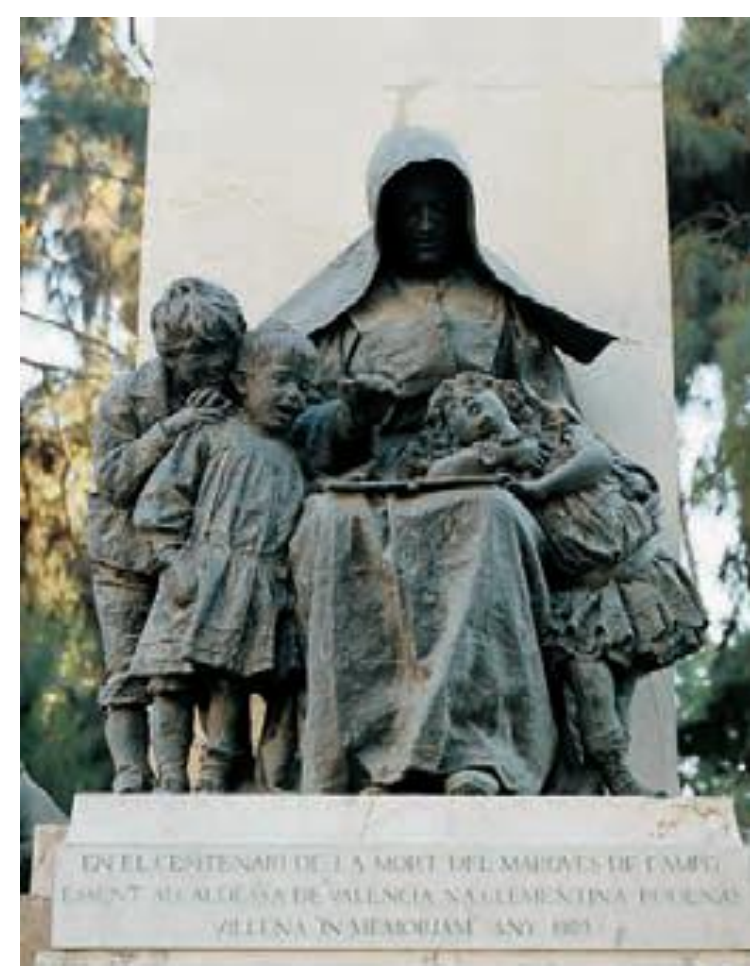

Fig. 5.7 La Caridad. Mariano Benlliure. 1885. Fotografía de la autora.

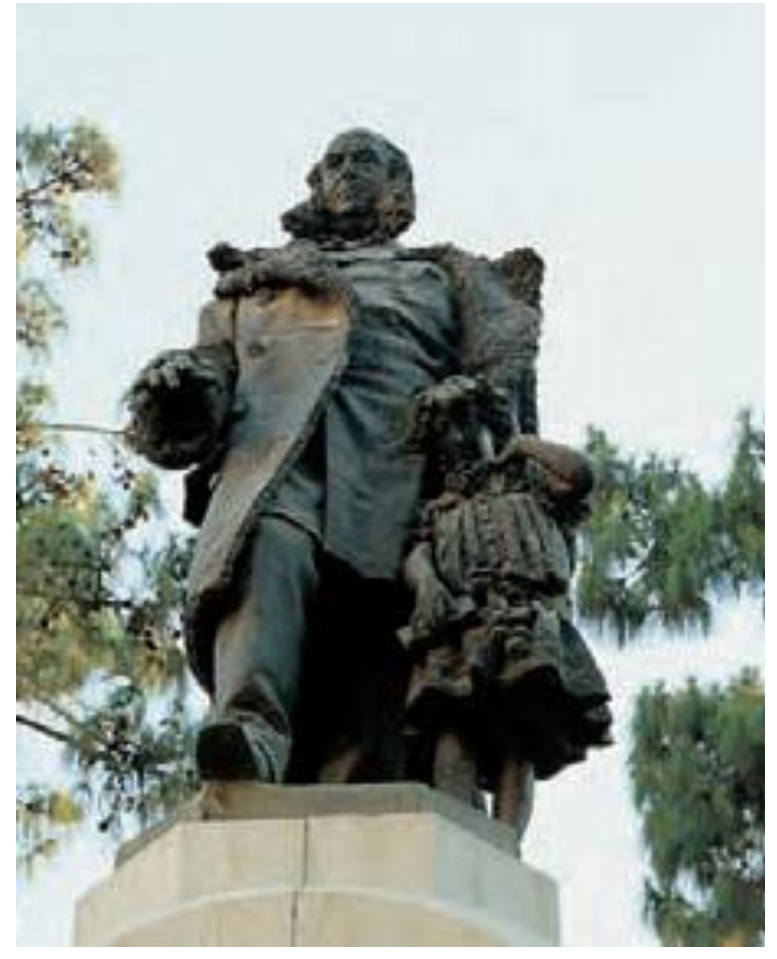

Fig.5.8 José Campo. Mariano Benlliure. 1885. Fotografía de la autora. 
La realización de las figuras y su instalación final no estuvo exenta de problemas que se reflejaron en la prensa del momento.

En La Correspondencia de España ${ }^{3^{1}}$ leemos referido a noticas de Valencia: "se ha recibido en esta ciudad y se ha depositado en el palacio del marqués de Campo el grupo que representa La Caridad, obra del escultor Mariano Benlliure y que ha de formar parte del proyectado monumento".

Es decir, que el grupo de la Caridad permaneció almacenada en el palacio de Valencia.

El grupo del marqués estuvo durante varios en Roma, en los talleres de Aquiles Crescendi donde se fundieron sin poder pagar el precio para poder sacarlo de allí hasta que Benlliure solicitó al ayuntamiento de Valencia que pagara lo debido para poder trasladarla a Valencia, pero fueron llevadas a su palacio de Recoletos y permanecieron en el palacio de Madrid embargadas por el impago del impuesto de sucesiones por el sucesor del marqués, hasta que en 1905 Navarro Reverter medió para que la nueva dueña del palacio de Recoletos, la marquesa de Manzanero accediera a la entrega de las figuras para su traslado a Valencia. Dichas figuras aparecen en el inventario realizado tras la muerte del marqués y se describe como una estatua del Excelentísimo Señor Marqués de Campo, con su pedestal y figuras alegóricas que componen un grandioso monumento, fundido en bronce, obra del escultor don Mariano Benlliure, cuyo importe asciende a 160.000 pesetas $^{32}$.

${ }^{31}$ La Correspondencia de España, 24/3/ 1889, p. 1.

${ }^{2}$ Testamentaria de José Campo Pérez, marqués de Campo, protocolizada el día 18 de agosto de 1891, por el notario Luis González Martínez. Tomo 37092. 
Como podemos observar el proceso para su realización y montaje fue complicado y elegir su ubicación también, pero hoy en día la figura del marqués, desde lo alto del pedestal sigue recordando a la ciudad lo que hizo por ella.

De lo expuesto se puede deducir sin duda que la relación de José Campo con José, Juan Antonio y Mariano Benlliure es un ejemplo claro de mecenazgo burgués y a su vez deja evidencia del interés del marqués por los artistas de su tierra, de los que ahora veremos más ejemplos, que estaban encauzando sus carreras dentro y fuera de España. 


\section{5.-Mecenas de otros artistas}

Los burgueses del siglo XIX emulaban el mecenazgo de los reyes y príncipes; eran clientes y mecenas, e invertían grandes cantidades de dinero en promocionar la carrera de un artista en particular o bien compraban y encargaban obras de varios artistas para que así aumentara su clientela33.

Aunque, como acabamos de ver, el caso más llamativo de mecenazgo del marqués de Campo sea el de varios miembros de la familia Benlliure, el marqués fue mecenas y promotor de la carrera de artistas de todas las disciplinas.

Fue promotor y mecenas de arquitectos como Jaime Bethy y José Camaña Laymon, a los que ya hemos estudiado en el capítulo referente a la construcción de los dos asilos para niños que José Campo construyó para paliar la pobreza infantil de su Valencia natal.

En la construcción y decoración de estos dos asilos intervinieron muchos artistas que también hemos visto ya y que vieron su carrera favorecida porque, el hecho de intervenir en las obras de aquellos edificios que fueron tan comentados por la prensa y tan aplaudidos por la opinión general, hizo que sus encargos aumentaran. Es el caso por ejemplo de: Vicente Ríos, Damián Pastor y Micó (1845-1904), Luis Gilabert (1848-1930), Antonio Yerro, José Aixa (18401920), Bondía, Manuel Chambó (1848-...) y Vicente Pellicer, entre otros.

\footnotetext{
33 Sobre mecenazgo ver: MORANT GIMENO, Ana María. "Un mecenas desconocido de la España decimonónica: el marqués de Campo (1814-1889)”. En: Coleccionismo, mecenazgo y mercado artístico en España e Iberoamérica. Sevilla: Universidad de Sevilla, 2017.

DELGADO BEDMAR, José Domingo et al. Patronos, promotores, mecenas y clientes. Actas del CEHA 1988, Murcia: Universiada de Murcia, 1992.
} 
José Campo promocionó los trabajos del arquitecto Manuel Ferrando Mora, quien reformó su palacio de Valencia en 1857. Por otra parte, artistas de la talla de Rafael Montesinos Ramiro (1811-1874), Plácido Francés (1834-1902) o el reconocido escenógrafo José Gallel (1825-...), le decoraron los techos de las estancias de dicho palacio de Valencia. José Vicente Flores Vela, otro pintor, escenógrafo y dedicado a la decoración de interiores, que casualmente era pariente del marqués, le decoró también varias estancias del palacio de Valencia y del castillo de Viñuelas 34 .

José Vicente Flores Vela también intervino junto con otros artistas en otros trabajos para el marqués, como por ejemplo el arco de la feria de julio de 1870, el arco para la entrada de Alfonso XII en Madrid en 1875, y el carro del Progreso de la feria de Valencia, trabajos todos ellos estudiados en otro capítulo de esta tesis.

A lo largo de su vida José Campo promocionó y ejerció el mecenazgo de pintores como por ejemplo Rafael Monleón (1843-1900). Éste era hijo del prestigioso arquitecto municipal Sebastián Monleón (1815-1878), constructor de la plaza de toros de Valencia y con quien José Campo tenía amistad al haber sufragado parte de las obras para poder finalizar la construcción y el alumbrado de dicha plaza.

José Campo fue propietario a partir de 1880 de una flota de 25 barcos "Vapores Marqués de Campo" con la que daba servicio de correos y transporte a la colonia española en Filipinas, en una línea que cruzaba el canal de Suez. Con este negocio desplazó al naviero Larrinaga y empezó a enemistarse con Antonio López, primer marqués de Comillas y propietario de otra gran flota de vapores.

34 PINEDO HERRERO, Carmen; MAS ZURITA, Elvira. Dos artistas valencianos del siglo XIX: José Vicente Pérez Vela y José Flores Vela. La familia artística del Marqués de Campo. Inédito. 2003. 
El negocio empezó su declive con la muerte de López y la venta de parte de la flota de vapores del marqués de Campo a la compañía Trasatlántica en 1884, pero siguió funcionando en parte hasta su muerte en 1889 .

Antes de finalizar su aventura como naviero, el marqués de Campo encargó a Rafael Monleón, pintor e hijo de su amigo y arquitecto Sebastián Monleón, 25 marinas de los vapores de su flamante naviera. El encargo parecía hecho a la medida del pintor, ya que Rafael Monleón fue piloto náutico antes de ser alumno de Carlos de Haes y Rafael Montesinos, desde su juventud se dedicó en exclusiva a la pintura de marinas, y fue nombrado pintor del almirantazgo y del Museo Naval. Por tanto, era el candidato perfecto para realizar esas obras para el Marqués.

El pintor realizó el encargo y las obras se hallaban colgadas en las paredes de sus despachos del palacio del paseo de Recoletos35. Las obras fueron expuestas en el pabellón del marqués en la Exposición Universal de Barcelona de 1888, y así en el catálogo correspondiente al pabellón del marqués, aparecen enumeradas las marinas con los nombres de los barcos: Manila, Magallanes, Venezuela, León XIII, Viñuelas, Valencia, Madrid, Panamá, Barcelona, Ebro, España, etc. ${ }^{36}$, como vemos son nombres con significado para el marqués; su castillo, su ciudad, su patria, etc.

Rafael Monleón llegó a ser un pintor de gran prestigio en materia de pintura de barcos y realizó varias obras sobre el puerto de Valencia. En el inventario de los bienes del marqués, en el palacio de Recoletos aparecen reflejadas las 25 marinas que se valoraron en 7.464 pesetas y un lienzo del

\footnotetext{
35 Archivo Histórico de Protocolos de Madrid, núm. 36.638, referido al inventario de bienes realizado a la muerte de su primera esposa en 1889 .

${ }^{36}$ ANÓNIMO. Exposición Universal de Barcelona. Catálogo de la instalación del Excmo. Señor Marqués de Campo. Barcelona: A. López Robert impresor, 1888. p.9-11.
} 
mismo artista con una marina que representa el puerto de Valencia, un vapor y varias lanchas que se valoró en 500 pesetas.

José Campo también fue mecenas del pintor Salvador Martínez Cubells (1845-1914), pues en sus inicios como pintor, el Marqués le compró sus primeras obras: La visita del Novio y El Baile (Fig. 5.9), perteneciente hoy a la colección Bancaja37.

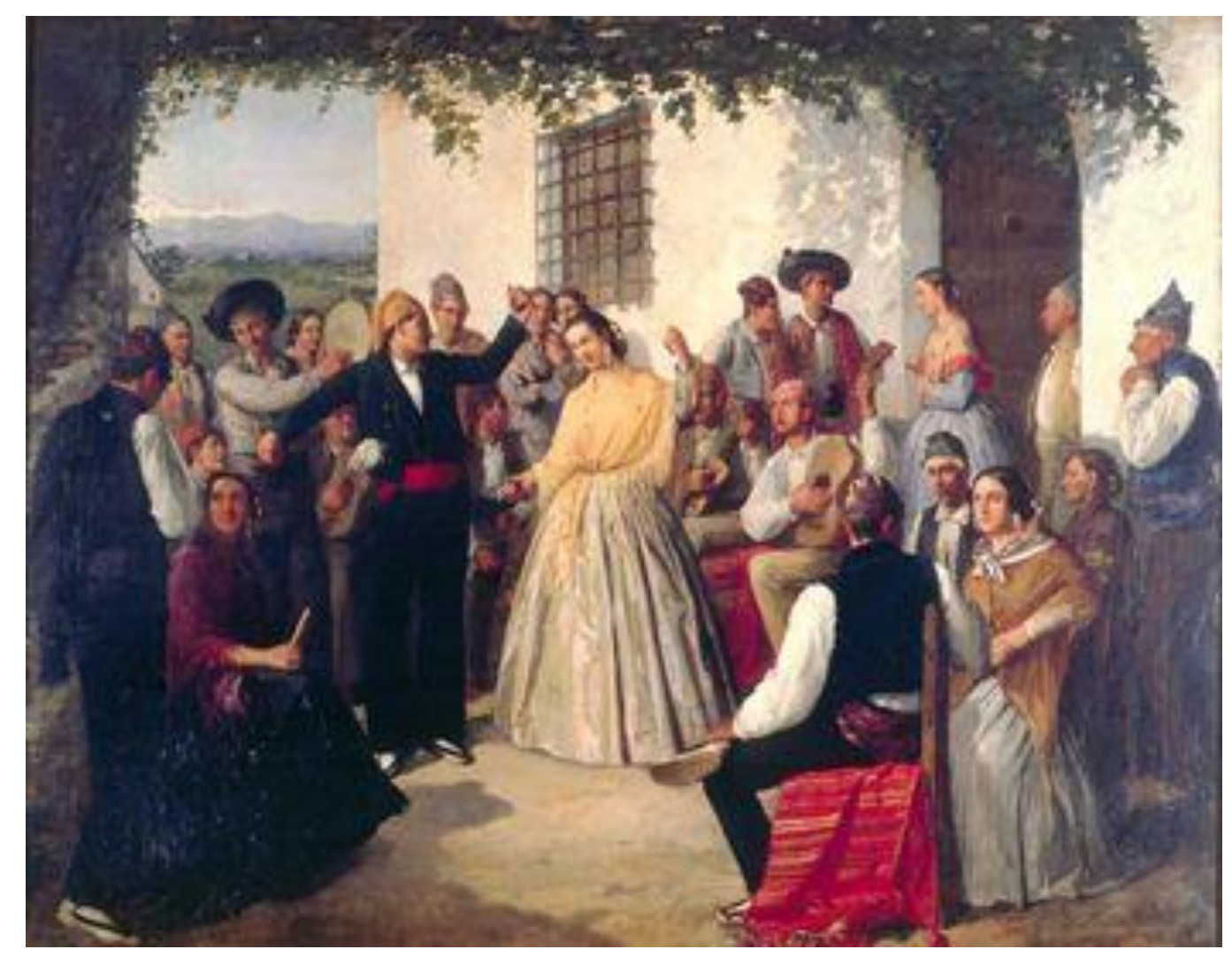

Fig.5.9, El Baile, Salvador Martínez Cubells, 1864, Imagen de la Fundación Bancaja.

Otro ejemplo claro de promoción artística gracias al marqués es el caso del dibujante Tomás Campuzano y Aguirre (1857-1934) al que se le dedica un capítulo entero en esta tesis.

37 TRAMOYERES BLASCO, Luis. "Salvador Martínez Cubells" en Archivo de Arte Valenciano, $1915, \mathrm{n}^{\mathrm{o}} 1, \mathrm{p} .37$. 


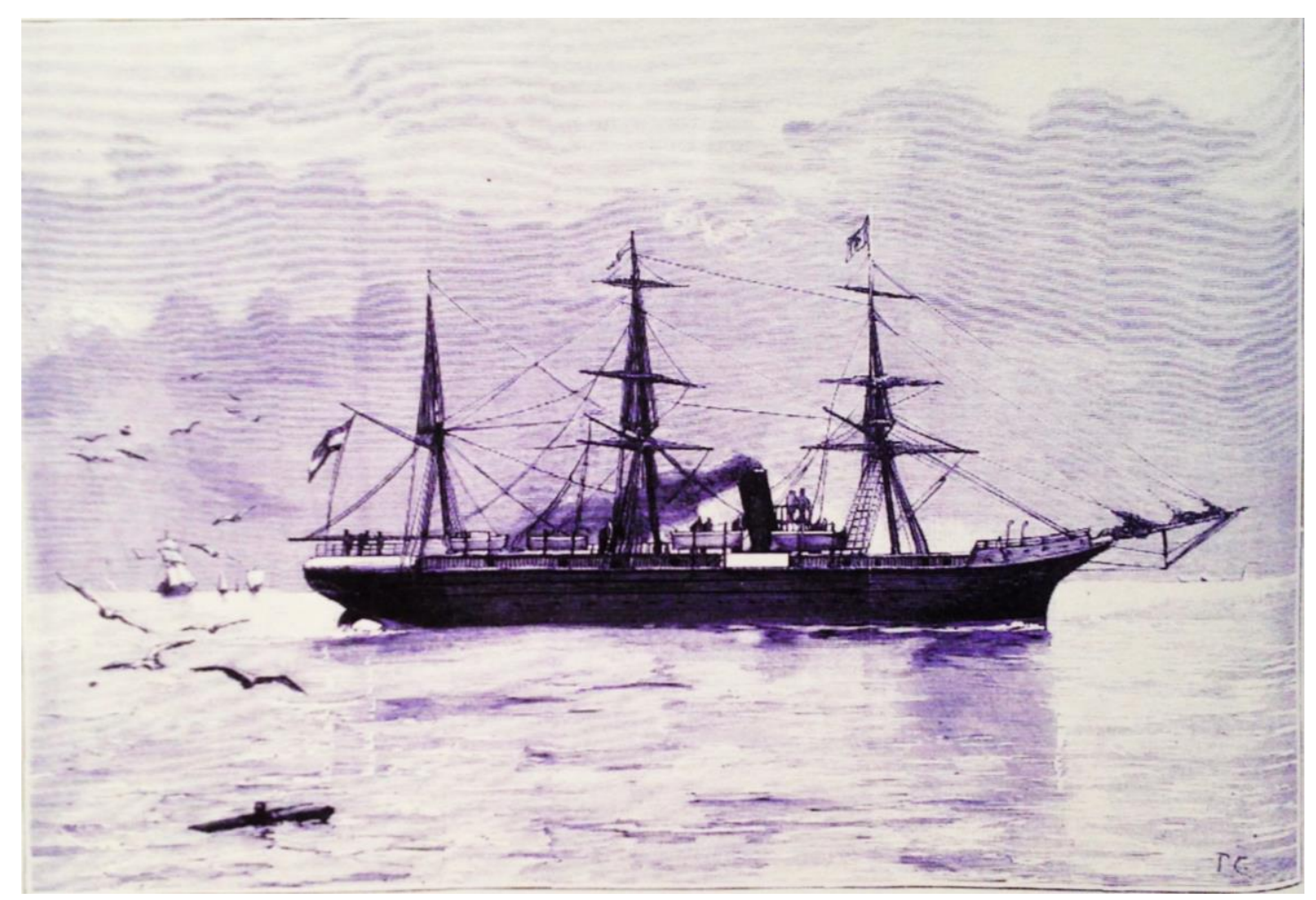

Fig.5.10. Vapor Magallanes. Grabado de Tomás Campuzano. 1886.. Publicado en La Ilustración Española y Americana

El marqués de Campo también fue mecenas de escritores, como es el caso de Manuel Vázquez Taboada, que le presentó una novela para que el marqués sufragara los gastos de publicación. De este hecho se hizo eco la prensa: "El joven novelista don Manuel Vásquez Taboada ha dedicado y presentado estos días su novela de costumbres titulada El Mundo de Madrid al conocido banquero Sr. Don José Campo”38.

En los certámenes de los Juegos Florales que se celebraban anualmente en Valencia, José Campo pagaba una cantidad de dinero para premiar al poeta o escritor que eligiera el jurado en cada una de las disciplinas del concurso. 
No olvidemos que su esposa Rosalía era mecenas del escritor José Zorrilla, al que mantenía con una cantidad periódica de dinero, como ya hemos comentado anteriormente.

El burgués interesado en el arte se convierte en cliente o en mecenas y en el caso del marqués de Campo fueron las dos cosas. Por una parte, era un gran comprador de obras de arte como ya hemos visto por la gran colección que tenía en sus residencias, sobre todo de pinturas y esculturas, y por otro lado favoreció económicamente a otros artistas de otras disciplinas para impulsar su carrera.

Pero todo ello sin olvidar en ningún momento que ser mecenas da individualismo y prestigio social, y que desde hace siglos ha habido una conexión entre el mecenazgo y el prestigio social de quien protege y paga; una vez más las artes unidas al poder y al estatus social, que en el caso del marqués de Campo siempre van de la mano. 


\section{Capítulovi}

EL MARQUÉS DE CAMPO COLECCIONISTA DE OBRAS DE ARTE
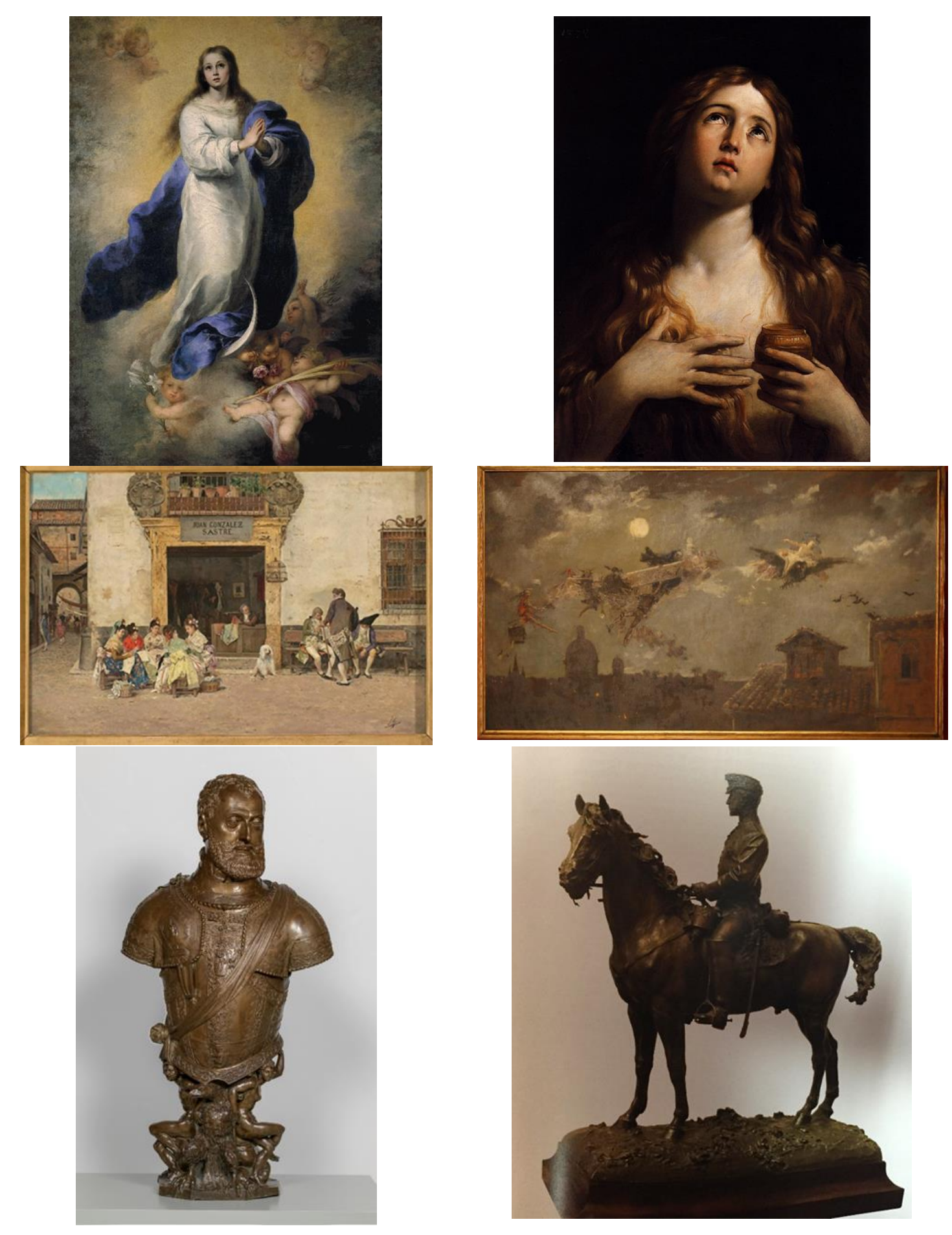



\section{Capítulovi}

\section{EL MARQUÉS DE CAMPO COLECCIONISTA DE OBRAS DE ARTE 1}

El origen del coleccionismo, como dice Fernando Checa en su obra $\mathrm{El}$ coleccionismo en España, hay que buscarlo fuera de nuestras fronteras ${ }^{2}$, y Schlosser lo sitúa fuera del mundo occidental, en los ajuares funerarios y en los tesoros que se depositaban en templos griegos de la antigüedad3. El coleccionismo de una forma $\mathrm{u}$ otra, ya sean pinturas, objetos de la naturaleza, objetos exóticos, medallas, esculturas, insectos o cualquier otra cosa, ha sido desde siempre una pasión de reyes, eruditos, nobles, etc., y como ejemplos podemos pensar en personajes tan importantes como Constantino, Napoleón, Carlos V, Felipe II, y así toda la realeza española y también la nobleza que a lo

\footnotetext{
${ }^{1}$ Parte de este capítulo fue objeto de una publicación en la revista Materia.

MORANT GIMENO, Ana María. "Un coleccionista desconocido en la corte de Alfonso XII: el marqués de Campo (1814-1889)". Materia, Revista Internacional de Arte, n. ${ }^{\circ} 9$. Barcelona: Departamento de Historia del Arte, Universidad de Barcelona, 2015, p. 115127.

2 CHECA CREMADES, Fernando; MORAN TURINA, Miguel. El coleccionismo en España. De la cámara de las maravillas a la galería de pinturas. Madrid: ensayos de arte Cátedra, 1985, p. 15 .

3 SCHLOSSER, Julius von. Las cámaras artísticas y maravillosas del renacimiento tardío. Madrid: Akal Universitaria, 1988, p. 9.
} 
largo de los siglos ha manifestado interés por atesorar para disfrute propio o como elemento de prestigio y de ostentación 4 , toda una serie de objetos de naturaleza profana y religiosa.

Semejante a lo que pasaba con las colecciones reales, las colecciones de nobles y las de los burgueses, que se formaron sobre todo en el siglo XIX, tenían una parte importante de pinturas y, entre ellas había de tema profano y de tema religioso5. En el caso de la colección del marqués de Campo, típico ejemplo de colección creada en el XIX gracias al poder económico, nos vamos a encontrar pinturas de tema religioso de artistas como Murillo o Guido Reni, y pinturas de tema profano de artistas como Paul de Vos, Teniers, etc., que reflejan el afán coleccionista. Y por otra parte pinturas de artistas de la época en la que vive el marqués. Artistas que están empezando su carrera y a quienes desea promocionar y ahí es donde se une la intención coleccionista con la intención de mecenas. Sin olvidar por supuesto la galería de retratos de toda colección y que también observaremos en el caso del marqués, pues en todas sus residencias abundan las fotografías y pinturas de él y de los demás miembros de su familia.

Checa dice que ya en el siglo XVII la nobleza valora el coleccionismo de obras de arte como algo esencial 6 , y es que la nobleza siempre ha querido imitar a la realeza y cuando llega el siglo XIX, también hace lo mismo la nueva burguesía que emerge con mucho capital para gastar en obras de arte, pero sin la preparación intelectual y el gusto para tener un criterio de selección, salvo, claro está, alguna excepción.

\footnotetext{
${ }_{4}^{4}$ CHECA CREMADES, Fernando; MORAN TURINA, Miguel. 1985, p. 213 y 214.

${ }_{5}$ CHECA CREMADES, Fernando; MORAN TURINA, Miguel. 1985, p. 58 y 59.

${ }^{6}$ CHECA CREMADES, Fernando; MORAN TURINA, Miguel. 1985, p. 183. 
Las artes se convierten en una forma de mostrar el poder, ya sea económico, religioso o personal7. La función del arte va cambiando y el monarca, el clero y la nobleza dejan paso al coleccionista del siglo XIX, que casi siempre es un amateur que busca y reúne con gran esfuerzo económico las más variadas piezas a través de ventas y subastas, y experimenta un placer comparable al de los conquistadores que regresaban con el botín de guerra para mostrar el poder militar y la superioridad cultural ${ }^{8}$. Aquí entra ya en escena la figura del burgués enriquecido y, en ocasiones también ennoblecido, que desea emular ese comportamiento y comienza a coleccionar obras de arte, sobre todo pinturas y esculturas, obras religiosas y obras profanas como en cualquier colección de arte, obras de maestros antiguos, obras de primera calidad y otras obras de artistas del momento a través de encargos promocionales o adquiridas en subastas o en exposiciones de bellas artes, que se convierten en escaparates para que los artistas se promocionen y para que las medallas y premios signifiquen el ascenso rápido del galardonado y aumenten los encargos y el valor de sus obras; sin olvidar el papel de la crítica, que puede ensalzar o acabar con la carrera de un artista rápidamente.

Como las obras de arte son un valor al alza, desde la Ilustración, los bienes artísticos comenzaron a ser protegidos por las Academias de Bellas Artes, de Historia, e incluso por las Sociedades Económicas de Amigos del País, formadas por expertos9. Si embargo en el siglo XIX tomó impulso el mercado del arte derivado del auge de las exposiciones, de las subastas y ventas de obras de colecciones particulares; de la vuelta a España de obras objeto de desamortización, etc., y aparece la figura del marchante, que actúa como asesor del interesado en invertir grandes cantidades en obras de arte. Ejemplo de ello

\footnotetext{
7 ANTIGÜEDAD DEL CASTILLO-OLIVARES, María Dolores (dir.). Colecciones, expolio, museos y mercado artístico en España en los siglos XVIII y XIX. Madrid: Editorial Universitaria Ramón Areces, 2011, p. 13.

8 ANTIGÜEDAD DEL CASTILLO-OLIVARES, María Dolores (dir.). 2011, p. 14.

9 ANTIGÜEDAD DEL CASTILLO-OLIVARES, María Dolores (dir.). 2011, p. 23.
} 
es el caso de los miembros de la familia Madrazo o extranjeros como Lebrum o Bucharan que vinieron a España en busca de negocio ${ }^{10}$.

Así de este modo van formando las colecciones los nobles y burgueses que ocupan los palacetes de la Castellana y Recoletos, levantados por los nuevos ricos y que según Begoña Torres "son burgueses enriquecidos de repente que no entienden una palabra de arte ni les importa"11; como por ejemplo el marqués de Salamanca que compró y vendió su colección varias veces a la par que su fortuna subía y bajaba; y otros burgueses que veían cómo sus negocios triunfaban o fracasaban según los vaivenes políticos característicos de esos años que influían enormemente en la economía y en las inversiones.

A la par de las colecciones privadas existen las colecciones públicas en los museos, que visitan sobre todo alumnos de la Academia para aprender dibujo o copiar y en ocasiones algún experto o algún amateur que se interesa por el arte. Por eso al mismo tiempo algunos coleccionistas privados comienzan a abrir al público sus colecciones privadas; y sus casas y palacios son objeto de visita de amigos y aficionados para admirar el tesoro artístico, orgullo de su propietario. Cada vez aumenta más el interés por el arte español en el extranjero, sobre todo obras de grandes artistas de renombre que en su mayoría se encontraban en iglesias y conventos y que fueron objeto de la desamortización y vendidas fuera de España ${ }^{12}$.

${ }^{10}$ ANTIGÜEDAD DEL CASTILLO-OLIVARES, María Dolores (dir.). 2011, p. 33. GONZÁLEZ, Carlos; MARTí, Montserrat (dir.). El mundo de los Madrazo, Catálogo de exposición. Madrid: Consejería de cultura y deporte de la Comunidad de Madrid, 2007. ${ }^{11}$ TORRES, Begoña. Guía del Museo del Romanticismo. Madrid: Ministerio de Cultura y Deporte, Secretaría General Técnica, Subdirección General de Atención al Ciudadano, Documentación y Publicaciones, 2018. ${ }^{12}$ TORMO, Elías. Las iglesias del antiguo Madrid. Madrid: N. A. Edición, 1985. 
Algunas pasaron a formar parte de los museos de algunas ciudades, pero el expolio fue un hecho al cual contribuyeron los franceses, las compras de marchantes, los coleccionistas privados ingleses y franceses y las subastas celebradas a partir de 1840, que fueron aprovechadas por personajes como por ejemplo Sir William Stirling Maxwell que reunió una enorme colección de artistas españoles como Murillo, Velázquez, Goya, e incluso escribió incluso varios libros sobre arte español.

A la vez que en Madrid está dándose la situación que hemos descrito, en Valencia también se estaban formando colecciones privadas, y es que la burguesía del siglo XIX, como dice Rafael Gil, "recogió las tradiciones de la antigua aristocracia: fundó hospitales, edificó asilos, construyó palacios, accedió al mundo del coleccionismo, compró pinturas, grabados, bronces y mármoles acumuló joyas, piezas de orfebrería, obras maestras de la cerámica, y acumuló sus tesoros en castillos y palacetes"13. Parece que el autor haya descrito a José Campo porque ése fue exactamente su comportamiento como ya hemos visto a lo largo de esta tesis y ahora veremos respecto a su actividad como coleccionista.

El coleccionismo de la nobleza y de la burguesía en Valencia siguió las mismas pautas que en toda España: priman las pinturas, las de tema religioso junto con las de tema profanos, y las de grandes artistas junto con las de artistas del momento que ya tienen cierto renombre, como es el caso de los hermanos Benlliure y otros que destacaban por ganar medallas en las exposiciones.

${ }_{13}$ GIL SALINAS, Rafael. Arte y coleccionismo privado en Valencia del siglo XVIII a nuestros días. Valencia: Alfonso el Magnánimo, 1994, p. 28 y 29. 
Rafael Gil distingue en Valencia, entre grandes coleccionistas históricos como la iglesia y la nobleza, como por ejemplo el patriarca Ribera ${ }^{14} \mathrm{o}$ el marqués de Dos Aguas; y los coleccionistas vinculados con el comercio y la pujante industria. La expansión de la agricultura, el crecimiento de las manufacturas o industrias artesanas, y la generación del comercio exterior, hace que los beneficiados por este tipo de economía, tengan como afición adquirir cuadros, grabados y esculturas. $\mathrm{Y}$ a su vez esto va significando la decadencia de las familias nobles que habían formado su patrimonio y sus colecciones de generación en generación ${ }^{15}$.

Dentro de las colecciones del siglo XIX podemos distinguir las formadas por amateurs, de gasto elevado y que buscan piezas raras o renombradas; las formadas por curiosos, que coleccionan lo que está de moda sin gusto, pero con interés por aquello que nadie tiene; y la colección del experto, que tiene conocimiento histórico, intuición, gusto y conocimiento práctico, y adquiere obras con criterio y por un motivo determinado.

Como ahora veremos, el caso de José Campo es el de un amante del arte, con educación suficientemente exquisita para saber apreciar la calidad y la importancia de las obras que adquiere o encarga, y con un afán de poseer piezas de artistas importantes como Murillo, Teniers o Guido Reni, sin olvidar las obras que adquiere en las exposiciones de Bellas Artes que visita asiduamente y las exposiciones permanentes como la del Sr. Bosch. El deseo de mostrar o exhibir también forma parte del coleccionista, y puede ser uno de los principales motivos de sus compras y en el caso de José Campo lo veremos en el capítulo siguiente cuando analicemos su participación en la Exposición Universal de Barcelona de 1888.

14 BENITO DOMÉNECH, Fernando. Pinturas y pintores en el Real Colegio Del Corpus Christi. Valencia: Imprenta de Federico Doménech, 1980.

15 GIL SALINAS, Rafael. 1994, p. 80. 
$\mathrm{Y}$ ahora vamos a analizar las colecciones del marqués de Campo y su comportamiento como coleccionista, aunque la tarea no va a ser nada fácil, porque durante los años que he estudiado la documentación relacionada con la colección de obras de arte que el marqués tenía en cada una de sus residencias, he podido comprobar que en José Campo no vamos a encontrar una actitud o un comportamiento comparable al de otros coleccionistas como el marqués de Salamanca, el marqués de Remisa o Lázaro Galdiano, quienes dedicaron parte de su vida a reunir, entre otros objetos, una colección de pinturas de grandes maestros y de cuyas compras y transacciones se conserva documentación.

En este caso no existe documentación de las compras, excepto alguna notica de prensa. No tenemos facturas, no tenemos documentos que lo relacionen con un determinado marchante, etc., pero no hay duda de que José Campo era un burgués enriquecido gracias a la política y los negocios y ennoblecido gracias a Alfonso XII, que gastaba mucho dinero en obras de arte para decorar sus residencias, promocionar la carrera de los autores de dichas obras, exhibirlas ante invitados, amistades y hacer ostentación de su poder económico y su posición social; sin que podamos olvidar su exhibición pública de algunas de esas obras, como colección en sí misma, en su pabellón de la Exposición Universal de Barcelona de 1888, donde se dijo que los objetos expuestos que "no sólo honrarían al mejor gabinete de coleccionista, sino que darían importancia al salón más suntuoso ${ }^{16 ”}$.

En el periódico El Día, se publicó una de las muchas compras realizada por el marqués en una almoneda que se instaló en Madrid en los salones del palacio de los condes de Altamira, en calle de la Flor: "No se puede reprimir un sentimiento de tristeza cuando se penetra en aquellas estancias. Todo lo que hay allí, a pesar de su belleza, a pesar de su valor y de su mérito tiene la melancolía de la felicidad pasada, de la majestad caída.

${ }^{16}$ La Ilustración Española y Americana, año XXXII, núm. XXVII, 22 de julio de 1888, p. 469 y 479. 
Ved esos dos magníficos jarrones colocados a los lados del ancho balcón de la última sala; la luz hace brillar dulcemente el claro azul del fondo, se alzan esbeltos sobre su artística y dorada peana, y un pincel maravilloso parece que ha pintado sus flores y sus figuras. Son una obra admirable da Sajonia. Luis Felipe, el rey de unos cuantos años, se los regaló a Balzac, una celebridad imperecedera. Desde el Palacio Real fueron al despacho del novelista como tributo pagado a la majestad del talento por la majestad de la cuna. Qué dichas y qué triunfos simbolizaron. A qué catástrofes de pueblos, de dinastías y de familias han sobrevivido. Luis Felipe murió en el destierro. Balzac en la ruina. De venta en venta han llegado los jarrones, salvados por su mérito artístico, a exponerse en los salones alquilados de un noble antiguo. De allí los sacará el dinero de un noble moderno; los compra el marqués de Campo para adornar su palacio del paseo de Recoletos"17.

Debemos dejar claro desde este momento que lo que desde ahora vamos a denominar "colección de arte del marqués de Campo" está formada no sólo por cuadros, sino por todas las pinturas, esculturas, relieves, muebles, relojes, tapices, jarrones, objetos de plata, armas, esmaltes, marfiles, repujados, grabados, textiles y otros objetos suntuarios que decoraban sus distintas residencias. Y es intención de este capítulo ofrecer un panorama general del contenido de esta colección, para lo que vamos a analizar en profundidad las piezas que poseía en cada una de sus casas e intentar arrojar un poco de luz sobre su origen y adquisición. Para ello nos vamos a basar sobre todo en el inventario de los bienes de los marqueses realizado a la muerte de su primera esposa Rosalía ${ }^{18}$, y de las noticias de prensa.

La colección del marqués de Campo es la colección de un nuevo noble, formada por autores contemporáneos de los que habla la prensa y a los que quiere favorecer en su carrera; no son obras heredadas de los antepasados.

\footnotetext{
${ }^{17}$ El Día, 18/11/1882, p. 1.

${ }^{18}$ AHPM Tomo 36643, fols. 7439 y ss. 
El crecimiento de la burguesía desplazó a la nobleza a un papel secundario, y derivado de ello, las obras de arte empezaron a ser parte de la decoración de las casas de muchos burgueses adinerados y no sólo un elemento exclusivo de las casas nobiliarias. Y uno de los motivos fue la creación de exposiciones permanentes como la del Bosch y las exposiciones de Bellas Artes que proliferaron cada vez más y que permitían la compra o el encargo de nuevas obras para los que tenían buena posición económica. La burguesía impulsa las colecciones en época de Isabel II y la nueva nobleza sigue la misma pauta, un ejemplo claro es nuestro protagonista, quien cada vez intenta aumentar sus posesiones, palacios, castillos, etc., y con ello sus colecciones.

No podemos obviar el hecho de que una de las actividades del coleccionista es la colocación de cada nuevo objeto adquirido en el lugar destinado para él, un lugar nuevo en el que antes no estaba, y ello está lleno de simbología, porque lo puede situar en un lugar donde lo vea el visitante o lo puede sustraer a la mirada de extraños y ser sólo para su disfrute personal privado. A veces incluso una habitación de la casa o palacio se dedicaba exclusivamente a la exhibición de obras y se le denominaba galería. Así que, en el caso de José Campo, veremos que algunos objetos están en sus habitaciones privadas, otros en su despacho, y otros en los salones y comedores de libre acceso a los invitados a sus casas para que fueran admirados y alabados. 


\section{1.- La colección del palacio de Valencia}

El palacio de la plaza del Arzobispo de Valencia, ya ha sido analizado como inmueble en otro capítulo de esta tesis y ahora nos vamos a centrar en los objetos de arte que lo decoraban y que lo convertían en uno de los más ricos de la ciudad, sólo comparable en riqueza y ostentación al del marqués de Dos Aguas.

Hay que tener en cuenta que cuando José Campo se marchó a vivir a Madrid en 1864, el palacio de Valencia se quedó amueblado, pero ya no con objetos de gran valor puesto que su vivienda principal estaba en Madrid, y por ello al analizar el inventario de este palacio nos damos perfecta cuanta de ello.

En la planta baja destacaba el patio de armas, núcleo de la edificación originaria del siglo XVII, que ya hemos descrito, y el despacho del señor marqués. En este despacho, donde realizaba sus negocios, había una decoración sobria, pero a la vez elegante. La habitación estaba cubierta por una alfombra, había varios sillones y divanes ricamente tapizados, cortinas de terciopelo azul, y destacaban: un reloj de tres esferas sobre la chimenea, un armario con libros para demostrar que era un hombre culto e ilustrado, un busto tallado de su padre Gabriel Campo con repisa de roble, tres retratos en fotografía de miembros de la familia, y un cuadro de San Pedro "estilo Greco". No hay duda de que la referencia a su padre en el despacho era para recordar sus orígenes comerciales y junto con las fotografías de la familia, dar una idea de hombre de moral y principios basados en la familia. El San Pedro, cuyo autor desconocemos, ayudaba a dar imagen de hombre creyente y con palabra. 
Para acceder a la primera planta había una escalera principal y en ella una imagen de la Purísima de mármol con pedestal de madera, cuyo autor desconocemos, y una fuente de mármol de carrara. Al pie de la escalera había unos sitiales góticos de talla cuyo origen se desconoce.

En la primera planta estaban las estancias principales del palacio, cada sala o habitación se encontraba destinado a una función y ésta determinaba la ornamentación, la decoración mural, los complementos y el mobiliario. El palacio de José Campo seguía estas reglas.

En lo que se denominaba la galería, había nueve bustos de mármol con pedestales, pero en el inventario no describe de quién son los rostros de los bustos ni los autores; había también un grupo de composición de bronce sin descripción, un grupo de bronce representando una corrida de caballos sobre un pedestal de madera pulimentada, un piano de palosanto francés sobre el que había un reloj de mármol, y 31 cuadros pintados al óleo de diferentes tamaños. Flaco favor nos hace el autor del inventario con esa somera descripción que nos deja en blanco sin saber ni la temática de los cuadros, ni los autores ni los tamaños, pero como vamos a ver a lo largo de este capítulo, era la tónica general, lo que no es obstáculo para darnos cuenta de la enorme colección de arte de todo tipo que tenía el marqués, pero nos deja sin información de autorías que pudiera proporcionarnos pistas para poder localizar las obras en la actualidad.

La llamada sala de cuadros tenía, tal y como describe el inventario, 75 cuadros pintados al óleo, de varias dimensiones que valora en 6.500 pesetas. Quien realizó el inventario nos deja otra vez sin información, pero dada la cifra de obras, se advierte la intención del marqués de adquirir gran cantidad de cuadros. Hay veces que una colección de pintura se considera como tal a partir de 35 o 50 cuadros y en este caso sólo en dos habitaciones ya hay 106 cuadros. 
En las habitaciones del marqués, formadas por la sala dormitorio, la toilette, el ropero y el cuarto de baño; había todo un mobiliario de palosanto, y destaca un cuadro al óleo de la Virgen, que estaba colocado en una mesa sobre una peana de madera dorada, llama la atención que no estuviera el cuadro colgado en la pared.

En las habitaciones de la marquesa, formadas por tocador, toilette, saladormitorio y salón, había una cama imperial de palosanto y toda una serie de muebles de las mejores calidades y algunos tapizados en las más ricas telas. Había un cuadro de su hija Josefa de cuerpo entero con marco dorado (ya hemos dicho antes que este cuadro se encuentra hoy en el asilo). Las habitaciones de la marquesa estaban alfombradas, las paredes tapizadas y las cortinas del terciopelo más caro del momento. Todo lujo era poco.

En la antesala del comedor había 13 cuadros pintados al óleo valorados en 1.710 pesetas. Una vez más ni temática ni autores.

En el comedor había un biombo de madera negra con adornos dorados, chino, que estaban muy de moda en esa época. Un reloj sobre piedra negra y dos figuras de bronce valoradas en 800 pesetas; dos figuras grandes de bronce; tres floreros de porcelana, dos floreros de cristal con pie de bronce, dos candelabros grandes de bronce con una figura cada uno sosteniendo un canasto, valorados en 1.00o pesetas. La valoración de las piezas da idea de su importancia, pero con tan escasos datos no podemos decir mucho más.

En el salón Chinesco para tomar café destacaremos dos esculturas tamaño natural representando un chino y una china valorados en 1.000 pesetas; un servicio de café para 36 personas de porcelana china y tres figuras de porcelana del Japón, de primera, refiriéndose el tasador a la calidad, claro está. 
Del salón de fumar destacar 8 cuadros al óleo valorados en 1,750 pesetas. Del salón de billar destacar dos jarros grades de porcelana del Japón situados sobre la chimenea. De la Sala de armas destacar dos panoplias de acero en la pared y cuatro armaduras de hombre completas valoradas en 3.900 pesetas.

En el gran salón de baile destacar los espejos con marco dorado, que eran piezas muy caras.

En el salón de compañía había una chimenea de mármol sobre la que reposaba un reloj con un grupo de figuras de bronce y una bola blanca encima. Como veremos a lo largo de este capítulo, los relojes de mármol, de bronce y otros materiales con figuras y adornos es uno de los objetos que más se repite en el inventario.

En el oratorio del palacio había una virgen del Pilar de plata, una imagen de san José en el altar, un crucifijo de plata; y en la sacristía un crucifijo de plata con la Dolorosa, una reliquia de un clavo de la Cruz (se desconoce su autenticidad y su paradero), dos medallones con la cabeza del Salvador y de la Virgen.

En las habitaciones del piso alto había 10 cuadritos rectangulares, tres cuadros ovalados y dos redondos; en otra habitación 5 cuadros de litografía; en otro cuarto 4 cuadros y un cuadro al óleo representado un pontífice; y en otro cuarto un reloj dorado con bola de cristal y pie de nogal, "del imperio", dos jarrones de porcelana franceses y una escribanía de plata. 
Así pues, podemos resumir que en Valencia tenía 152 cuadros, bustos de mármol, varias esculturas de bronce, figuras de porcelana, armaduras y relojes con decoración em bronce. Además de imágenes religiosas, lo que ya nos permite hacernos una idea del alcanzase y envergadura de la colección.

No podemos acabar esta parte dedicada a la colección de arte del palacio de Valencia sin hacer referencia a un cuadro que no consta en el inventario pero que, según la familia del arquitecto José Camaña Laymon, le fue regalado al arquitecto por el marqués en agradecimiento al finalizar las obras del segundo asilo de niños en $1883^{19}$.

La obra en cuestión es un cuadro de San Dionisio, obra de Jerónimo Jacinto de Espinosa, que esta doctoranda ha tenido la oportunidad de visitar en el domicilio de los descendientes del arquitecto y que ha podido estudiar y fotografiar. (Fig. 6.1).

\footnotetext{
${ }^{19}$ Según refieren los descendientes del arquitecto José Camaña Laymón. 278
} 


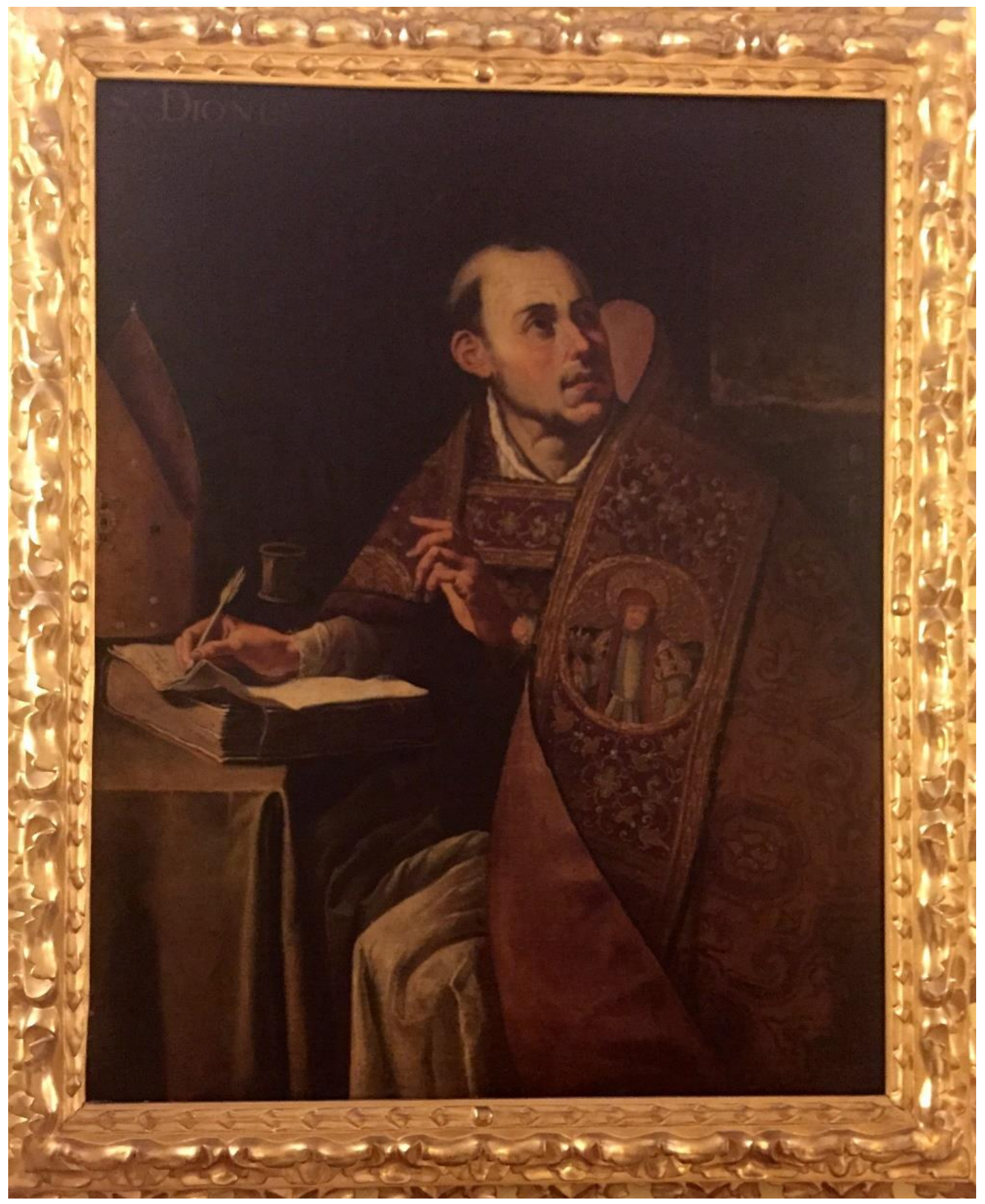

Fig.6.1. San Dionisio. Jerónimo Jacinto de Espinosa. Fotografía de la autora

Desconocemos cómo llegó a manos del marqués esta obra, pero parece factible que con motivo de la ley de desamortización de 1835 pudiera ser parte del gran conjunto de obras de arte que, pertenecientes a conventos y monasterios, se dispersaron con motivo de la desafectación. 
La pintura al óleo sobre lienzo representa a san Dionisio, santo de gran devoción en Valencia, sentado delante de una mesa, en escorzo, mirando una visión mientras escribe una carta encima de un libro. Aparece ataviado con una capa pluvial bordada y un medallón también bordado con una representación de San Sebastián con vestiduras medievales y con tres flechas en la mano²0. Sobre la mesa reposa la mitra, pues san Dionisio fue obispo de París.

Gerónimo Jacinto de Espinosa fue un pintor barroco especializado en temática casi exclusivamente religiosa, evangélica y hagiográfica ${ }^{21}$. Su paleta es de un color tostado y caliente, la iluminación tenebrista y la insistencia en el dibujo de manos y rostros que en esta obra podemos apreciar perfectamente.

Este tipo de pinturas de santos formaba parte del programa iconográfico del concilio de Trento para aumentar la devoción de los fieles, ya que se hace uso de temas tradicionales de la iconografía cristiana basados en la Biblia, en los textos apócrifos, o en relatos de vidas de santos para conmover los sentimientos del fiel y por ello el artista utiliza todo tipo de recursos para provocar la respuesta de un pensamiento piadoso.

La obra pudo en su día ocupar una de las muchas salas que tenía el palacio del marqués de la plaza del Arzobispo ${ }^{22}$, pero dudamos que cumpliera la función de persuasión y devoción para la que fue creada. Más bien ocuparía un lugar de preferencia en la decoración del palacio y se lo regaló al joven arquitecto como muestra de su aprecio.

${ }^{20}$ En lugar de representar a san Sebastián semidesnudo y atravesado por las flechas, aquí aparece vestido y con las flechas en la mano; forma de representarlo que se popularizó en la Corona de Aragón en el siglo XV.

${ }^{21}$ PÉREZ SÁNCHEZ, Alfonso. Jerónimo Jacinto de Espinosa (160o-1667). Valencia: Consorcio de Museos de la Generalitat Valenciana, 2002, pp. 37 y 39.

22 MORANT, Ana María. "El segundo centenario de un mecenas y coleccionista valenciano: el marqués de Campo (1814-1889)”. Debats, 2015, n. ${ }^{\circ}$ 125, pp. 96-105. 


\section{2.- La colección del palacio de Madrid}

Ya se ha dicho en páginas anteriores que cuando José Campo llega a Madrid se establece en el palacio del paseo de Recoletos que había sido de la familia Calderón.

Y es dentro de este palacio del paseo de Recoletos, donde guarda y exhibe ante amigos e invitados a cenas y recepciones la mayor parte de sus obras de arte, tal y como se refleja en las publicaciones del momento. Las obras eran adquiridas unas veces directamente por él mismo y otras veces las adquiría con las casas que compraba. Es el caso del palacete de Recoletos, y del chalet de Arcachón que compró amueblados.

Es obvio que dentro de la casa de Recoletos debía de haber un rico mobiliario y una exquisita decoración, pues el propietario, que era senador como José Campo, pertenecía a una acaudalada familia de Granada y poseía entre otras cosas la finca de El Carmen de los Mártires, dentro del recinto de la Alhambra de Granada y no olvidemos que, dentro del precio de compra, casi un millón de pesetas fue por el mobiliario de la vivienda.

El palacio del paseo de Recoletos 14 fue descrito en la prensa del momento como un verdadero museo de arte. El periodista Mascarilla, cuando escribió sobre la muerte de José Campo, hizo referencia al lujo y suntuosidad que había en este palacio calificándolo de museo de obras de arte.

El periodista dice textualmente: "Su palacio de Recoletos es un museo de obras de arte. Nada le parecía bastante caro ni suficientemente bueno. Así consiguió que su casa fuera un ejemplo de gusto y un prodigio de suntuosidad y belleza. 
Allá, en aquellos salones, en aquel patio a la andaluza, con cubierta de cristal y bellas plantas (debidas a la afición de su anterior propietario Don Carlos Calderón), se celebró el 26 de febrero de 1878 la gran fiesta con la que los Marqueses de Campo quisieron sumarse a la alegría con que toda España celebró el casamiento del rey don Alfonso con su augusta prima doña Mercedes de Orleans. En el comedor del palacio se celebraron famosos banquetes: uno hace pocos años para solemnizar el viaje del vapor Magallanes, perteneciente a la flota del Marqués y que llevó a bordo la comisión española que fue a visitar las obras del Canal de Panamá. En aquel banquete, honrado con la presencia de muchos políticos importantes, brindaron Martos, Navarro Rodríguez y alguno otros"23.

Como era normal en este tipo de grandes construcciones, cada una de las habitaciones del palacio estaba destinada a un uso concreto y la decoración, los complementos y el mobiliario estaba en consonancia con ese uso. La decoración tenía como factores determinantes el poder adquisitivo y el gusto del propietario. El poder económico era necesario para poder adquirir los artículos de lujo propios de la condición social alcanzada por la burguesía. La suntuosidad se convirtió en el parámetro regulador de un status social que en cierto modo pretendía asimilar las buenas maneras y el gusto refinado distintivos de la nobleza.

Enumerar habitación por habitación todos los objetos de decoración que había en el palacio de Recoletos supondría otra tesis doctoral con la reproducción del inventario completo, así que en este capítulo vamos a reproducir los objetos más destacables, con la misma numeración y descripción que aparece en el inventario, para continuar conociendo y admirando la colección de arte del marqués:

${ }^{23}$ La Época, n. ${ }^{\text {o } 13.288, ~} 20$ de agosto de 1889, p. 1. "El Marqués de Campo". Citado en ALMELA Y VIVES, Francisco. El Marqués de Campo, Capdavanter de la burguesia valenciana (1814-1889). Valencia: Ajuntament de València, 1989, p. 76. 
298: dos figuras de bronce del Imperio con pie de cristal.

311: un grupo de bronce "la caza del ciervo".

312: dos grandes tibores de China como de dos varas de altura.

315: dos estatuas de composición de dos varas de altura, sobre pedestales de roble tallado.

317: un reloj de mármol negro y dos candelabros de bronce para siete bujías.

323: tres grandes caballetes para retratos, de roble, con toques dorados y coronas de marqués.

331: dos grupos de ninfas de bronce plateados, con pedestal de piedra ónix.

333: cuatro jarrones de porcelana de Sèvres sostenido candelabros para ocho bujías cada uno.

346: un biombo de seis hojas cubierto de seda encarnada y con bordados blancos japoneses.

350: dos bustos de mármol blanco con columnas de mármol jaspeado, representado al señor marqués y a la señora marquesa difunta.

375: dos copas de ágata blancas y bronce dorado.

386: un grupo de porcelana figurando cuatro angelitos llevando en hombros un canasto de flores.

387: un grupo de biscuit, un page sosteniendo una Chocha.

388: un grupo de porcelana, una doncella con su palomita y copa para dulces o flores.

389: un velador de mármol, tablero de ajedrez y pie de bronce, mosaico en malaquita, mármol sanguíneo, lapislázuli y marfil.

395: dos figuras de China representado a Ruth y Esther.

422: un tapiz oriental "La Magicciene" como de tres metros de alto y cerca de dos de ancho, con marco de madera negra.

428: veinticuatro marinas de Monleón, representado diferentes barcos de la flota del señor marqués, marco dorado.

429: un cuadro pequeño al óleo sobre tabla representando unos labradores valencianos, firmado Benlliure.

430: un cuadro pequeño oleografía sobre tabla, apaisado, representado varios personajes mitológicos, de autor desconocido. 
431: un cuadro pequeño sobre tabla, representado un torero y una maja por María Mathichy.

432: un cuadro sobre lienzo representado un artesano dando de comer a varios niños, sin firmar.

433: un cuadro sobre lienzo, al óleo, sin firma, representado a una jauría y un cazador a caballo.

434: un cuadro sobre lienzo representado un artesano y dos criaturas en una cocina.

435: un cuadro lienzo, marina, firmado Monleón, representado el puerto de Valencia, un vapor y varias lanchas.

436: un cuadro lienzo, gran tamaño, representando una gira y baile campestre, por P. Francés.

437: un cuadro sobre lienzo representando un café con varias majas por el Espagnoleto.

438: un cuadro sobre tabla representando un baile campestre, firmado Paresu.

439: dos cuadros pequeños sobre tabla representado músicos ambulantes.

440: un cuadro pequeño apaisado de Agrasot, sobre tabla, representando una sastrería de la Edad Media.

441: dos cuadros ovalados sobre lienzo, personajes de capricho.

442: un cuadro sobre tabla representando un lago, dedicado al excelentísimo señor marqués de Campo.

443: un cuadro pequeño de lienzo, representando un embarcadero de un lago en un paseo o jardín, sin firma.

444: un cuadro tamaño mediano, sobre lienzo, representando un pastor recitando ante varios personajes; de Hispaleto.

445: un cuadro pequeño apaisado sobre lienzo, sin firma, representando una cantina.

446: un cuadro gran tamaño retrato de Van Dyk y otro personaje.

447: un cuadro pequeño sobre lienzo representando una patinadora, por Lamberti.

448: un cuadro pequeño apaisado, tabla, representando una escena de sociedad principios de siglo. El minué, por Benlliure. 
449: un cuadro sobre lienzo, representando una joven en un jardín por Lamberti.

450: un cuadro sobre lienzo, representando un incroyable por Bernard.

451: un cuadro sobre lienzo, representando dos pastores con dos ovejas, sin firma.

452: un cuadro sobre lienzo, representando un incroyable por Bernard.

453: un cuadro sobre tabla, pequeño, representando una riña de soldados antiguos, por Juan Antonio Benlliure.

454: un cuadro sobre lienzo, representando tres soldados de la Edad Media, por Barbudo.

455: un cuadro pequeño sobre tabla, representando un fraile y varios soldados antiguos, por D. Muñoz.

456: un cuadro gran tamaño sobre lienzo, representando un campo de batalla luego de una acción, por Benlliure.

457: un cuadro pequeño sobre tabla, representando un árabe tendido sobre una alfombra, por Barbudo.

458: dos bodegones ovalados sobre lienzo, firmados Parra.

482: un retrato al óleo, tamaño natural, medio cuerpo, marco dorado, representando a la señora marquesa difunta; en el marco corona de marqués.

483: un retrato tamaño natural, medio cuerpo, al óleo, representando a $D$. Gabriel Campo, padre del señor marqués, marco dorado.

484: un retrato al óleo tamaño natural, medio cuerpo, de la señora madre del marqués.

486: una pandereta pintada.

487: un retrato fotografía, busto de D. Gabriel Campo y Pérez, con marco de terciopelo y madera dorada.

488: un retrato fotografía representando el niño Pepito en paños menores.

516: un cuadro lienzo, representando a Santiago, sin firma.

517: un cuadro pequeño sobre tabla, representando la cena de un fraile, por Muñoz.

518: un cuadro sobre tabla, firma que no se entiende.

519: un cuadro sobre lienzo, bodegón de frutas, sin firma. 
520: un cuadro tabla, representando la plaza de la Virgen de Valencia iluminada.

521: un cuadro tabla, paisaje, representando un río.

522: un cuadro mosaico de piedras, representando un templo derruido.

523: un cuadro sobre lienzo, representando una escena amorosa en el campo, por Bernard.

524: un cuadro sobre tabla, un viejo y una joven por Antony Perez.

525: un cuadro sobre tabla representando una visita, Edad Media, por J. Parra.

526: un cuadro tamaño regular, bodegón aves muertas.

527: dos cuadros sobre lienzo, representando escenas del campo.

537: cuatro cuadros dorados con grabados.

556: un cuadro acuarela, retrato del señor marqués y alegorías, con marco de maderas de ébano y caoba, con iniciales M.C. y corona de marqués.

557: un cuadro sobre lienzo al óleo, una manola a medio cuerpo, copia de Alarcón, firmado por Soria.

558: un cuadro de gran tamaño, al óleo sobre lienzo, sin marco, representando caza muerta y una figura.

561: un cuadro sin marco, al óleo, sobre lienzo, representando el castillo de Viñuelas, firmado J. Castellote y Villafruela.

579: un Virgen de la Purísima, trono de nubes.

583: un cuadro pequeño de santa Rosalía de Pérez.

596: una imagen de talla de la Virgen de las Mercedes.

652: dos cuadros al óleo, costumbres valencianas.

653: un cuadro, Concepción de Murillo, marco dorado.

654: tres cuadros más pequeños diferentes, maco dorado, escuelas Bizantina, Tiziano y Flamenca.

655: un cuadro pequeño de Teniers, Bizantina.

656: un cuadro sobre tabla que representa la Virgen, marco dorado. Escuela Sevillana.

658: un cuadro esmalte representa el Monte Calvario.

661: un busto de biscuit del señor marqués.

662: un busto de bronce de Carlos V.

665: dos fotografías de la familia litografiadas. 
666: una fotografía, retrato del señor marqués, en óvalo dorado con corona. 684: doce cuadros grabados copias del Vaticano.

687: un cuadro pintado al óleo, representado una orgía, de Teniers, un metro de ancho por $80 \mathrm{~cm}$ de alto.

703: dos bustos de mármol blanco, con sus pedestales de mármol jaspeado, representando a D. Alfonso XII y D. ${ }^{a}$ María Cristina.

704: un busto de mármol blanco representando al señor marqués.

717: seis cuadros con trabajos caligráficos.

718: un cuadro lienzo marco dorado, representando el busto de una niña, firmado A. B. Gil.

719: un cuadro paleta, sobre fondo de terciopelo rojo con marco dorado, por Antonio Benlliure y Gil.

720: un centro de mesa de cuatro cuerpos plateados y dorados con alegorías, fabricado por la Fábrica de Gas de Valencia.

722: una bandeja de plata rebujada.

726: una estatua de mármol de Carrara, representando a Silvia, con pedestal giratorio de mármol, por Ernesto Floulé.

756: un marco damasquinado con incrustaciones de oro y plata, sobre fondo de terciopelo verde, con retrato del señor marqués.

757: un cuadro lienzo al óleo, costumbres valencianas.

774: tres cuadros acuarelas representando el palacio del señor marqués en Madrid.

803: tres cuadritos marfil de alto relieve.

804: una bandeja de metal Cristofle.

805: dos cuadros al óleo, San José, escuela sevillana y una cabeza de Baco.

806: dos grabados representando San José y el retrato del General Prim.

815: un mueble antiguo incrustado de marfil. Árabe.

826: dos figuras y un grupo de mármol.

828: una estatua ecuestre de D. Alfonso XII. Bronce.

838: una peana con busto de Hércules, de mármol blanco.

842: dos cuadros al óleo, marco dorado, representando niños y flores.

846: diez y siete cuadros al óleo, representado diferentes asuntos y de distintos autores. 
854: un alto relieve en mármol, con marco de nogal tallado, embutido en la pared.

862: un busto en bronce, sobre la chimenea, representando al señor marqués.

867: una cajita de madera con relieves de marfil, objeto de arte.

868: un jarrón de bronce con relieves de marfil, objeto de arte.

878: tres cuadros tapices con marco de madera tallada.

886: un armario biblioteca de tres cuerpos bajos, con puertas de cristal, conteniendo bastantes volúmenes.

887: un jarrón y dos grupos, caballos y negros, de bronce.

912: un reloj estatua de bronce.

916: un gran lienzo figurando cacería, con magnífico marco de nogal tallado.

917: dos acuarelas: una representando el interior de una iglesia, de Araujo, y otra representando un viejo, de Villodas.

943: dos bodegones al óleo sobre lienzo, firmados Parra.

944: dos grandes cuadros sobre lienzo, representando floreros.

945: dos cuadros al óleo sobre lienzo, con marco dorado, representando: uno pordioseros, y otro, músicos ambulantes; se tienen por originales de Teniers.

946: un cuadro al óleo sobre lienzo, busto de una mujer, capricho, firmado A. B. Gil.

947: un paisaje pequeño, borregos, firmado Morben.

948: un paisaje firmado A. Cánovas.

949: dos cuadros grandes al óleo, marcos dorados, paisaje y ganado, por E. Deprales.

950: un cuadro al óleo, paisaje Riberas del Tíber.

951: un cuadro al óleo, sin marco, caza del jabalí.

956: dos estatuas de bronce con sus pedestales.

964: dos flamencos en bronce.

1000: un reloj de chimenea de mármol azul y dos ángeles de adorno, bronce dorado.

1001: dos jarrones grandes de porcelana de Sevres, modernos, con figuras pintadas.

1066: dos cajas de palosanto para juego del Enano Amarillo. 
1069: dos bustos de barro cocido representando, uno al señor marqués y uno a la señora marquesa.

1072: un reloj de sobremesa antiguo, de bronce, madera y cristal.

1073: una escultura de mármol blanco representando al Niño Pepito acostado.

1075: una gran copa de porcelana de Sajonia, con adornos de bronce y miniaturas.

1077: tres cajas pequeñas de maderas filipinas, trabajadas y caladas.

1079: dos floreros pequeños de bronce y esmalte.

1080: un florero de porcelana blanca y rosas de relieve.

1081: un florero pequeño con cinco niños jugando a la gallina ciega.

1085: cuatro figuras representando a Las cuatro estaciones.

1086: un grupo de biscuit, con peana de mármol, y fanal de cristal, representando Las tres Gracias.

1087: un grupo de porcelana de Sajonia, representando una lección, formado por cuatro figuras.

1088: dos altos relieves pequeños, con colores, marcos de madera, porcelana y bronce. Del Retiro.

1089: un velador de porcelana bronce y madera, con miniaturas de Luis XIV, vestido de corte y alrededor retratos miniaturas de las damas de la corte, con escudo real.

1090: un piano vertical de Erard.

1091: dos cuadros al óleo sobre lienzo, sin marco, representando dos jarrones de flores, firmado $\mathrm{H}$. Bonat.

1092: un cuadro al óleo sobre lienzo, apaisado, marco dorado, representando un reto por el juego, firmado Barbudo.

1093: dos cuadros en cobre, paisajes, parecen flamencos.

1094: un cuadro con el retrato del señor marqués hecho a pluma a Torrielly, con marco negro.

1095: un cuadro al óleo sobre lienzo, marco dorado, representando la bodega de una posada y soldados, firmado por J. A. Benlliure.

1096: un cuadro tabla representando una gira de campo, majos y majas, por $\mathrm{J}$. Benlliure. 
1097: un cuadro tabla, Teniers, un baile campestre, mar y paisaje, con marco de madera negra.

1098: un cuadro tabla, marco dorado, representando gitanos, firmado J. Benlliure.

1099: un cuadro tabla, marco dorado, representando un bazar moruno, firmado Barbudo.

1100: un cuadro lienzo al óleo, marco dorado, representando una corrida de toros, firmado J. Benlliure.

1101: un cuadro tabla, marco dorado, representando el interior de una casa de campo y una mujer aseando a un niño, por Richart.

1102: un cuadro tabla, marco dorado, representando dos soldados y dos aragoneses, por M. Alcázar.

1103: un cuadro tabla, marco dorado, apaisado representando frailes, leyendo en la biblioteca del convento, por J. Benlliure.

1104: un cuadro tabla, representando una fuente pública, un soldado y una aguadora por Barbudo.

1105: un cuadro tabla, marco dorado, representando una aparición, firmado J. Benlliure.

1106: dos cuadros pequeños, tabla, representando un caballero y una señora, estilo Velázquez.

1107: dos cuadros grandes al óleo, lienzo, representando países nevados, parecen alemanes.

1108: dos cuadros lienzo, al óleo, sin marco, con flores.

1109: un cuadro tabla, marco dorado, representando un lacayo, por C. Pla.

1110: un cuadro tabla, marco dorado, representando dos soldados en traje de campaña al amor de la lumbre, por C. Pla.

1111: un cuadro tabla, marco dorado, representando las verjas de una posesión, dos caballos y un soldado, firmado L. Franco.

1112: un cuadro tabla, marco dorado, estudio de un pintor, por Barbudo.

1113: un cuadro tabla, marco dorado, representando una joven jugando con un gato, por Francés.

1114: dos cuadros al óleo, sobre tabla, representando vistas de Venecia, por Benlliure. 
1115: un cuadro lienzo, marco dorado, representando visita en un jardín, por Giménez Martín.

1116: un cuadro lienzo, representando lección de lectura, por C. Pla.

1117: un cuadro lienzo al óleo, marco dorado, representando soldados $y$ manolas por Giménez Martín.

1118: un cuadro tabla al óleo, representando un busto de la Virgen con el Niño al brazo.

1125: seis tapices japoneses.

1138: dos tapices bordados en sedas de colores, con dos grandes figuras chinas.

1144: un reloj de piedra, ónix y bronce.

1147: diez y siete bibelots de porcelana china, marfil y hueso.

1249: una estatua de mármol de Carrara representando una Venus.

1288: una Virgen, escultura de madera, con manto de plata bordado de oro, que representa Nuestra Señora de los Desamparados, con su base repisa de nubes y fanal de cristal para cubrir dicha imagen.

1301: cinco bajos relieves de barro cocido.

1369: dos cuadros al óleo de vapores.

1384: un cuadro al óleo asunto de vapores.

1401: un cuadro al óleo y sedas, vapor Magallanes.

1431: un cuadro de madera, representando al señor marqués de Campo.

En el palacio había al menos 175 cuadros entre paisajes, bodegones, escenas de caza, retratos, escenas populares, caballos, marinas, pintura religiosa, etc. Y los autores también son muy diferentes, pues había obras de José Benlliure, José Parra, Plácido Francés, Pablo de Vos, Murillo, Juan Antonio Benlliure, Luis Franco, Espagnoleto, Domingo Muñoz, Cecilio Plá, Araujo, Villodas, Miguel Sánchez Barbudo, Joaquín Agrasot, Rafael Monleón, Giménez Martínez, etc., y como ya hemos dicho algunos de esos cuadros fueron exhibidos en el pabellón del marqués de la Exposición Universal de Barcelona de 1888, del que se habla en otro capítulo de esta tesis y fueron apreciados por el público y alabados en prensa, calificando al marqués de coleccionista. 
El marqués tenía al menos 12 obras de la familia Benlliure. Ya he hablado de la relación que mantuvo con la familia de artistas en otro capítulo de esta tesis, y no ponemos en duda que el trabajo de los hermanos le gustaba.

Sobre las noticias que conocemos acerca de la compra de alguna de las obras que hemos descrito, en realidad con pocas. En relación a un cuadro de Benlliure la publicación Revista de Valencia publicó que:

"un acaudalado marqués paisano nuestro le ha comprado una tabla en la que aparece el interior de una taberna, en donde varios soldados de los tercios españoles, sobrexcitados por sus repetidas libaciones, promueven acalorada disputa y vienen a las manos, repartiéndose sendos linternazos. Vuélcase la mesa, ruedan los sombreros de los contendientes, y el roto jarro derrama sobre las baldosas el encendido zumo de las uvas, mientras los compañeros, que fueron ajenos a la cuestión, echan mano a las espadas para imponerse con su actitud a los revoltosos y devolver la paz a los acalorados ánimos. Hay energía en el grupo, propiedad en las actitudes, buen color y, sobre todo, seguridad en el toque. Juan Antonio Benlliure hará fortuna si persevera en el trabajo con el entusiasmo que hoy le domina". Y la noticia continúa comentando que "el mismo personaje va a levantar un asilo para niños y le ha encargado a José Benlliure un lienzo de grandes dimensiones para el edificio"24

Este cuadro de Juan Antonio Benlliure es el que aparece descrito como una Riña de soldados antiguos, firmado por Juan Antonio Benlliure en el catálogo de Barcelona y en el inventario con el número 1095: La bodega de una posada y soldados.

De este artista tenía más obras, como por ejemplo el Busto de una niña, una Escena de frailes leyendo y unaPpaleta pintada, obras todas que fueron expuestas en Barcelona.

${ }_{24}^{24}$ A. Q. Revista de Valencia, Valencia, 1880. P. 37 
De José Benlliure había un óleo de unos labradores valencianos, otro de un campo de batalla luego de una acción, otro una escena de sociedad, y muchos otros, pero descritos tan someramente que se hace difícil localizarlos en la actualidad, aunque la investigación sigue su curso y no se acaba en esta tesis.

Entre los bodegones descritos destacan dos bodegones ovalados, un bodegón de aves muertas y dos bodegones firmados todos ellos por J. Parra y que se pudieron admirar también en la Exposición de Barcelona. Respecto a este tipo de obras hay que destacar el papel decorativo que tenían en los hogares de la burguesía. Teodoro Llorente en su obra Memorias de un sesentón decía al hablar de la decoración de las casas: "era la época de los papeles pintados. A excepción de los dormitorios, la cocina y los pasillos, todo iba empapelado, La moda imponía siempre el cromo, con su buen marco de madera. La mayoría de las veces representaba un bodegón. No todos podían tener la suerte de adquirir un Parra”. Refiriéndose a José Felipe Parra Piquer (1824-1864) afamado pintor de bodegones y flores 25 .

La relación de José Campo con el marqués de Salamanca y el marqués de Remisa, reconocidos coleccionistas, pudo influir en sus actuaciones como coleccionista, de las que encontramos noticia en la publicación Madrid en sus diarios. Allí se refleja por ejemplo que el 11 de mayo de 1875 el Marqués visitó junto con su majestad el rey Alfonso XII la exposición permanente de bellas artes de la Platería Martínez. En esa visita el rey compró un cuadro y el marqués una escultura y un relieve de José Vilches, que había sido el escultor de cámara de Isabel II ${ }^{26}$. La Correspondencia de España reseñó el mismo hecho publicando lo siguiente: “...el señor marqués de Campo ha comprado una estatua y

${ }^{25}$ LLORENTE, Teodoro. Memorias de un sesentón. De mi Valencia de otro tiempo, 3 Vols. Valencia: Doménech, 2001. Citado en RIDAURA, Concha. Vida cotidiana y Confort en la Valencia burguesa (1850-1900). Valencia: Generalitat Valenciana, 2006, p. 151. ${ }^{26}$ Madrid en sus Diarios, tomo 3, p. 206. 
relieve en mármol del reputado escultor Sr. Vilches. La exposición del Sr. Bosch está demostrando cada día más el acierto que presidió a su instalación”27

Si miramos el inventario, el relieve puede ser el número 854: un alto relieve en mármol, con marco de nogal tallado, embutido en la pared; y la escultura puede ser la 1249: una estatua de mármol de Carrara representando una Venus.

En otra ocasión El Globo publicó: “el señor marqués de Campo ha adquirido en 30.000 francos una de las mejores estatuas de mármol que figuran en el pabellón de Italia. Traslado al Sr. Pérez de san Millán, para que averigüe si el opulento banquero, propietario y capitalista la compró a nombres suyo o a nombre de los hermanos Profeci, sus factores en Valencia. Aguardamos impacientes que traigan a Viñuelas tan hermosa estatua, para que algún notable revistero haga de ella una magnifica descripción”28.

Sabemos también que compró los primeros cuadros del pintor Salvador Martínez Cubells: El Baile, perteneciente hoy a la colección Bancaja, y La visita del Novio 29 .

El número 1111 del inventario es un cuadro tabla, marco dorado, representando las verjas de una posesión, dos caballos y un soldado, firmado L. Franco; era un pintor muy reputado por la pintura de caballos, premiado en las exposiciones nacionales y a quien el rey Alfonso XII había encargado algunas obras 30 .

${ }_{27}^{2}$ La Correspondencia de España, 11 /5/ 1875, p. 4.

${ }^{28}$ EL Globo. Diario Ilustrado, 14 /8/ 1878, p 4.

29 TRAMOYERES BLASCO, Luis. "Salvador Martínez Cubells". Archivo de Arte Valenciano, $1915, \mathrm{n}^{\mathrm{0}} 1$, Valencia, p. 37.

${ }^{30}$ Revista de Valencia, 1881, p. 36. 
Y dentro de los múltiples bustos de diversos materiales que había en el palacio, uno de ello podría ser del escultor Tomás Cardona y Abelló, pues en $L a$ Dinastía se publicó: "el escultor tortosino, don Tomás Cardona, ha ganado en el certamen de «Lo Rat Penat», de Valencia, el premio ofrecido al mejor busto retrato del señor marqués de Campo" 31

Los dos bustos de barro cocido de los marqueses que aparecen en el número 1069 del inventario ya hemos dicho en el capítulo correspondiente que podrían ser los que hizo y no puedo terminar Mariano Benlliure.

No podemos acabar de hablar sobre las obras del palacio sin nombrar una pintura de una Inmaculada de Murillo que estaba en el despacho del marqués. En aquellos años se celebraban continuamente subastas de grandes obras de colecciones privadas como las que realizó el marqués de Salamanca y en esas subastas se vendían obras como la comentada. El precio que se pagaba por esas obras no hubiera sido un problema para el marqués, y si en la exposición de Barcelona la prensa y el público nunca puso en duda la autenticidad de la obra, no somos nosotros quien para ponerla ahora en entredicho. A estas alturas el capítulo nos permitimos hacer una pequeña reflexión sobre la presencia de un cuadro de una Inmaculada de Murillo en el despacho del marqués: según se desprende de la documentación del inventario de su herencia32, el marqués de Campo tenía en su despacho del palacio del paseo de Recoletos de Madrid un cuadro de una Inmaculada Concepción de Murillo. El cuadro fue expuesto, junto con otras obras de su colección, en su pabellón de la Exposición Universal de Barcelona de 1888, tal y como reflejan las publicaciones de la época, que alaban la calidad y excepcionalidad de las obras que expuso para deleite de los visitantes33.

\footnotetext{
${ }^{31}$ La Dinastía, 25 /7/ 1889, p. 2.

${ }^{2}$ Archivo Histórico de Protocolos de Madrid, en especial el protocolo 36.638, referido al inventario de bienes realizado tras la muerte de la primera esposa del Marqués en 1889.

33 Sobre la exhibición de las pinturas del marqués de Campo en la Exposición de Barcelona ver: Diario oficial de avisos de Madrid, año CXXX, núm. 6o, de 18 /9/ 1888.
} 
En el siglo XVII, la imagen de la Inmaculada Concepción se convierte en la representación más popular de la Virgen en España pues, aunque estaba muy arraigada la creencia de que María estaba libre de la mancha del pecado original desde el momento de su concepción, el dogma no se proclamó hasta el siglo XIX, cuando en 1854 el Papa Pío IX emitió la bula Ineffabilis Deus; sin embargo, esta doctrina fue aceptada y apoyada en España con especial fervor desde principios del siglo XVII (fig. 6.2).

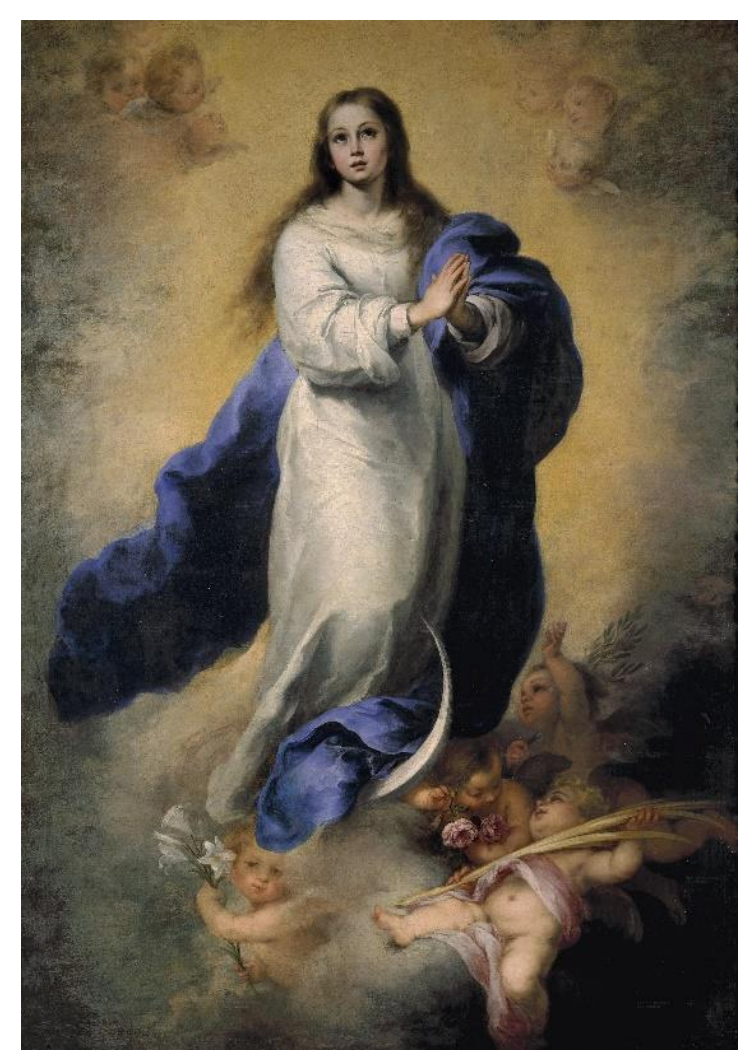

Fig.6.2. La Inmaculada Concepción. Murillo

La prescripción para su iconografía había sido codificada por Pacheco en su Arte de la Pintura, pero su tipología estaba ya establecida desde mediados del siglo anterior 34 y se emprendió una especie de cruzada de la defensa mariana a través del arte contra la Reforma protestante. La Virgen se convierte en protectora de la Iglesia, madre y auxiliadora de los que la honran, y ese fervor creciente en la Virgen se tradujo en la plástica.

34AYALA, Nina. Del Greco a Murillo. La pintura española del siglo de oro, 1556-17oo. Madrid: Alianza, 1991, p. 91. 
Autores como el Greco, Zurbarán, Pacheco, Roelas, Velázquez, Ribera, Valdés y Espinosa, realizaron representaciones del tema de la Inmaculada. Como hemos dicho, había un tipo icnográfico ya determinado que en el caso de las obras de Murillo varía poco. Normalmente se representa a la Virgen de figura completa, rara vez de medio cuerpo, sobre la media luna, derecha o inclinada sobre el globo terrestre, rodeada de ángeles con palmas o con flores y vestida con túnica blanca y manto flotante de un color azul purísimo35.

Deducimos pues que la que poseía el marqués y presidía su despacho, seguiría esta tipología. Pero no podemos olvidar que, en el siglo XIX la manera de ver el arte barroco ha cambiado y el fin para el que se crearon este tipo de obras ya no se corresponde con la mera función de objeto de decoración sino también de demostración del poder y prestigio que las obras maestras dan a su propietario.

Cada vez que alguien entrara en su despacho para cerrar algún negocio y viera la obra maestra en la pared, no dejaría de pensar en la grandeza de la obra y en el poder económico y social de su propietario. Era un modo de sobrecoger al contrincante.

Sin embargo, aunque el marqués se caracterizó por demostrar su religiosidad construyendo capillas en sus residencias y por expresar públicamente su catolicismo, como todo buen burgués adinerado, tenía una especie de doble moral y una vida amorosa fuera del matrimonio, por lo que dudamos que La Inmaculada de Murillo presidiera su despacho para actuar de Madre Auxiliadora y pedir su consejo y protección a la hora de tomar decisiones en negocios importantes, pues pocos escrúpulos tenía cuando de negocios se trataba; sino que La Inmaculada de Murillo se convierte en el siglo XIX en un objeto que cualquier noble o comerciante enriquecido quería poseer, que daba

35 ABBAD, Francisco. Las Inmaculadas de Murillo. Barcelona: Ed. Juventud, S.A., 1948. 
estatus a su dueño y maravillaba al visitante, igual que pasó en la Exposición Universal de Barcelona cuando la exhibió en su pabellón y la prensa del momento se hizo eco de ello.

El cuerpo de María Inmaculada, que en el arte Barroco es la Madre Protectora, la Madre Auxiliadora, la Prudencia y el Templo de la Sabiduría, pasa en el siglo XIX, sin dejar de ser un objeto religioso per se, a ser objeto material valorado por el prestigio de su artífice.

Para finalizar con las obras más importantes del palacio mencionaré cuatro tapices de Teniers, dos cuadros del mismo autor, dos cuadros de cacería de Pablo de Vos y un bronce de Carlos V de Pompeo Leoni. Estas obras sin duda debieron causar admiración por su importancia, a quienes visitaron el palacio y la Exposición de Barcelona, pero actualmente su paradero es desconocido y teniendo en cuenta que a la muerte del marqués hubo de celebrarse una almoneda para saldar deudas, entendemos que cayeron en manos de coleccionistas particulares y es imposible localizarlas.

El bronce de Carlos $V$ también aparece en el inventario con el número 662, pero no se dice su autor, sin embargo, en el catálogo de la Exposición de Barcelona se dice que es de Pompeo Leoni, famoso escultor por haber realizado entre otras obras, unos bustos de Carlos V que fueron muy apreciados por el público Respecto a los cuadros de Paul de vos, en el inventario se nombra con el número 916: "un gran lienzo figurando una cacería con un magnífico marco de nogal tallado", y con el numero 951: un "cuadro al óleo de la caza de un jabalí". Entiendo que estas dos obras son las dos obras de Paul de Vos que exhibió en Barcelona.

Podemos entender que el encargado de hacer el inventario no fuera experto en arte y ante el ingente trabajo de inventariar hasta el más mínimo 
bien del patrimonio de los marqueses, hubiera momentos en los que las descripciones no fueran exactas, pero se echan en falta más detalles que nos hubieran ayudado enormemente en la localización de las obras. (hemos de tener en cuenta que el inventario completo tiene más de 700 folios y miles y miles de objetos catalogados).

En esta parte del capítulo vamos a aportar algunas imágenes de obras que serían muy parecidas o similares a las que el marqués tendría en su palacio y que hemos visto en el inventario. Pero no podemos asegurar que sean esas, puesto que la mayoría seguro que se encuentran en colecciones particulares y ha sido imposible obtener datos de su adquisición. Coinciden en el autor y en la descripción del tema, pero no podemos saber si con esas exactamente; así que valga esta pequeña muestra para hacerse una idea del interior del palacio de Recoletos.

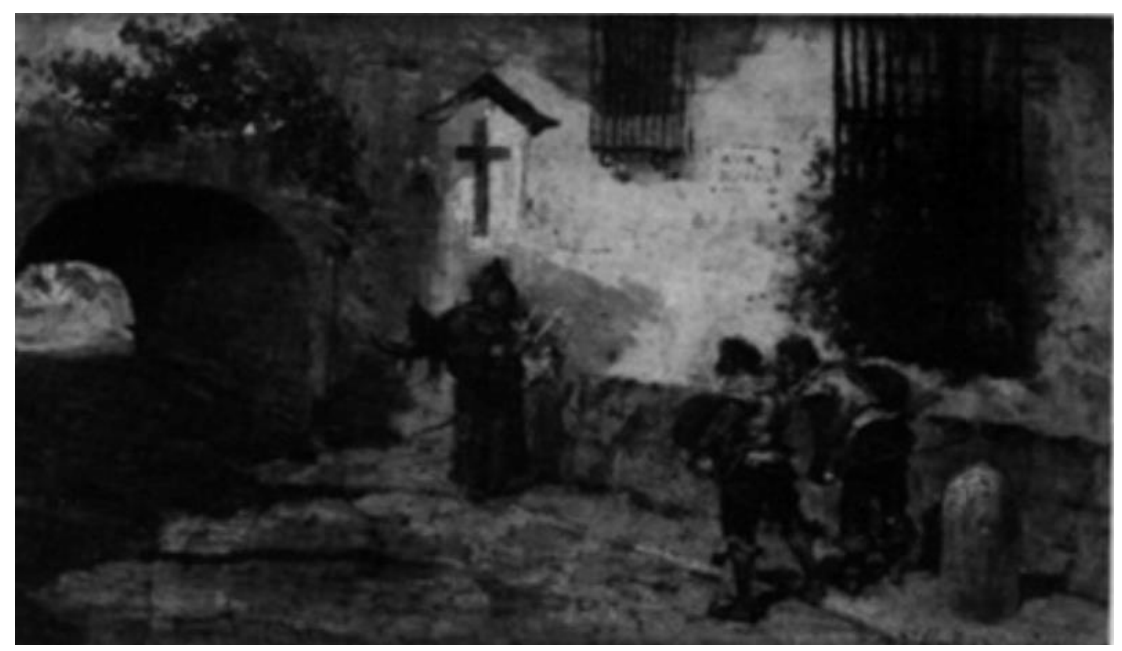

Fig. 6.3.- Obra similar a la inventariada con el número 455: un cuadro pequeño sobre tabla, representando un fraile y varios soldados antiguos, por D. Muñoz ${ }^{36}$.

36 Imagen publicada en: http://www.artnet.com/artists/domingo-mu\%C3\%B1oz-ycuesta/figures-by-a-monastery-5i liD86WrlNiAweNeEwBA2 


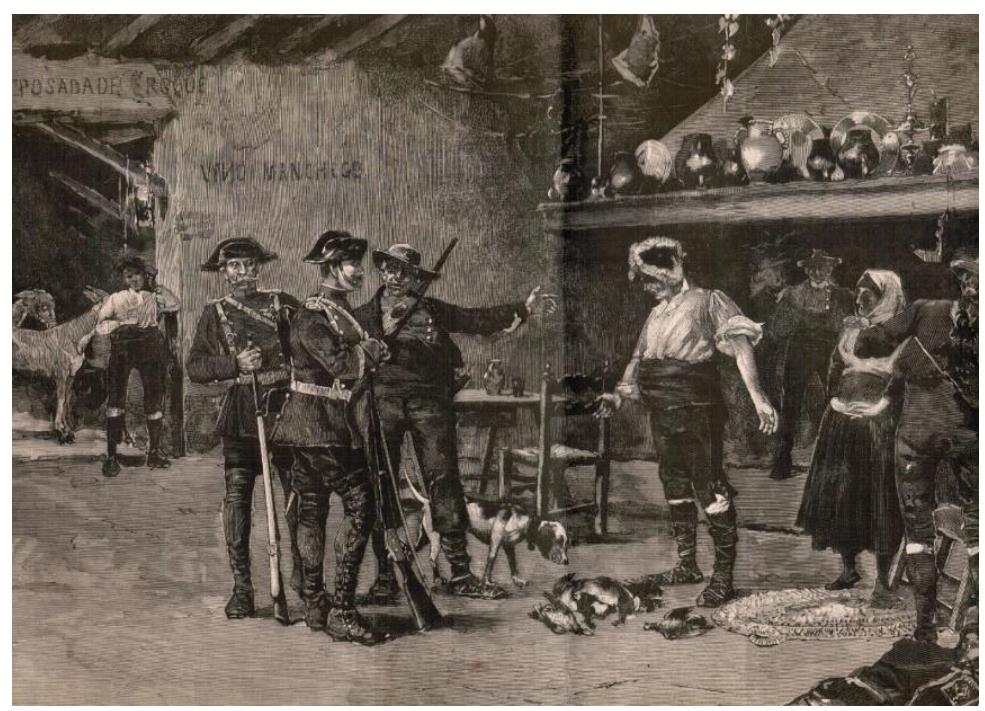

Fig. 6.4.-Obra similar a la inventariada con el número 1102: un cuadro tabla, marco dorado, representando dos soldados y dos aragoneses, por M. Alcázar37.

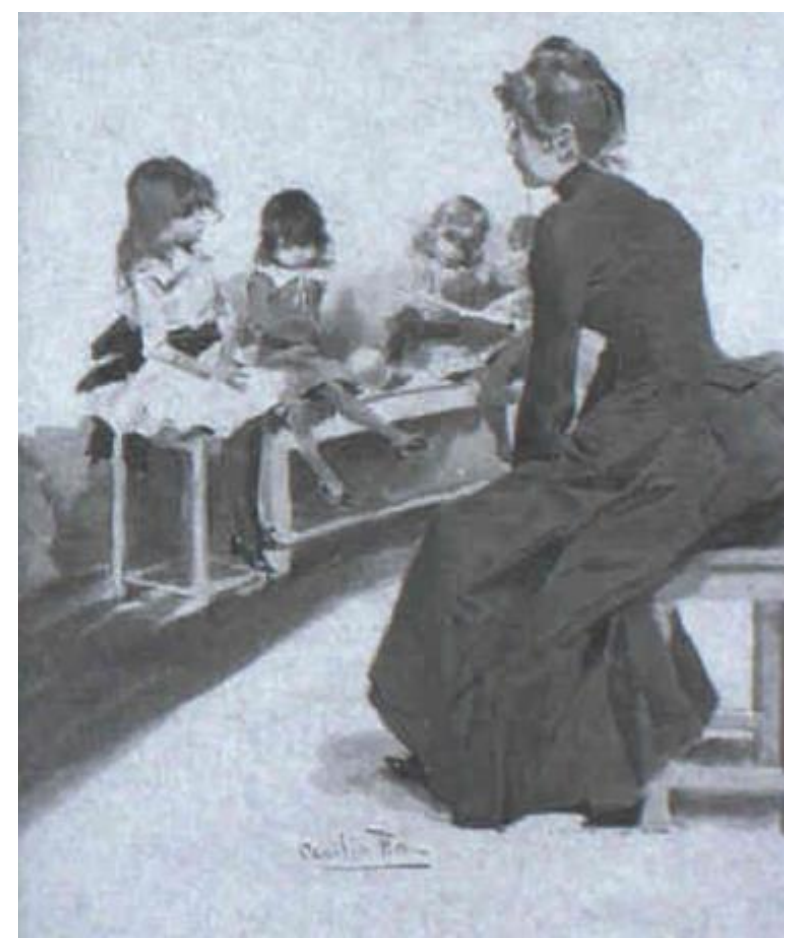

Fig. 6.5.- Obra similar a la inventariada con el número 1116: un cuadro lienzo, representando lección de lectura, por C. $\mathrm{Pla}^{38}$.

37 Imagen publicada en: http://wm1640482.web-maker.es/BIOGRAF-AS-DEPINTORES-A/Manuel-Alcazar-Ruiz/mobile/

${ }^{38}$ Imagen publicada en: http://www.artnet.com/artists/cecilio-pl\%C $3 \% \mathrm{~A} 1 / 9$ 


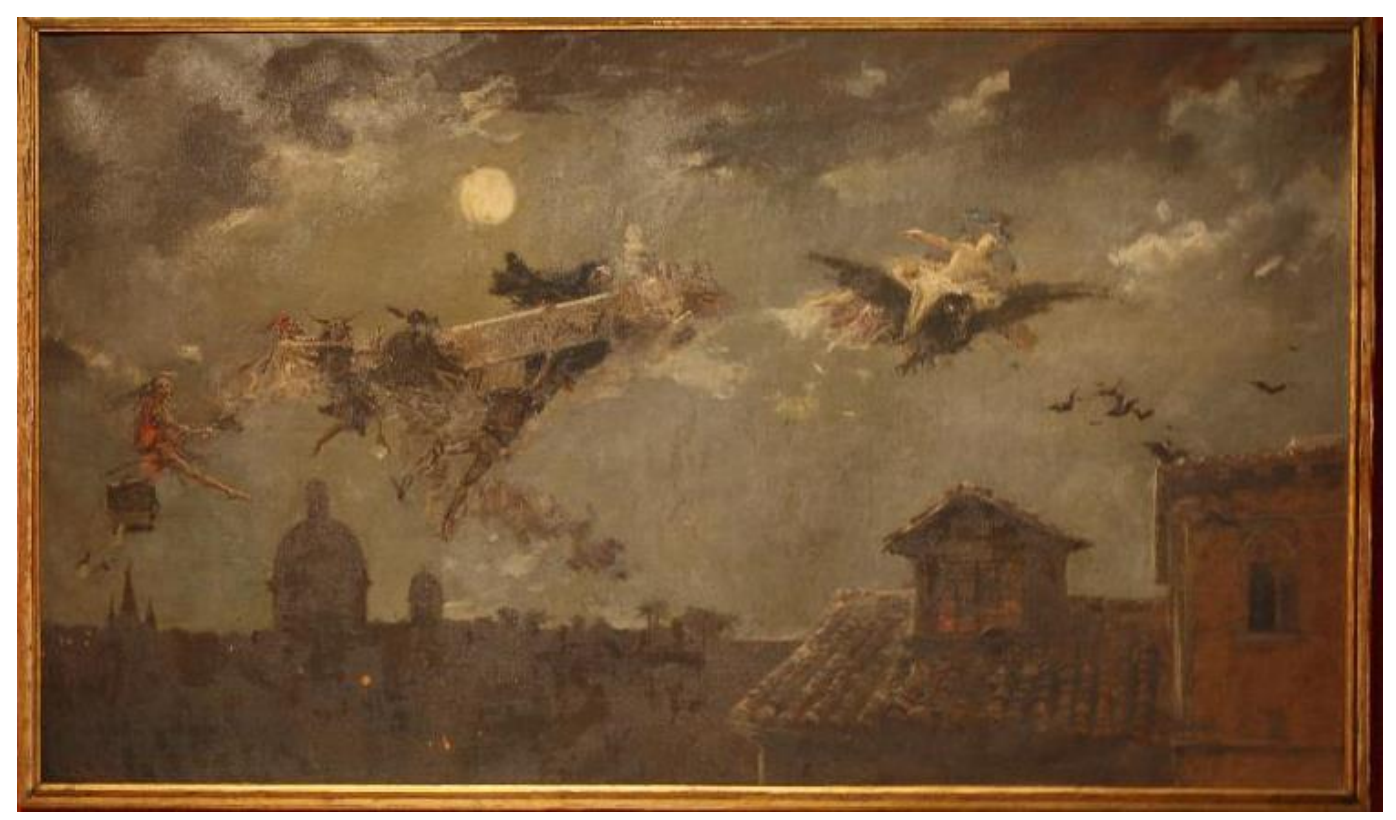

Fig. 6.6.- Un cuadro de Brujas de J. Benlliure 39 .

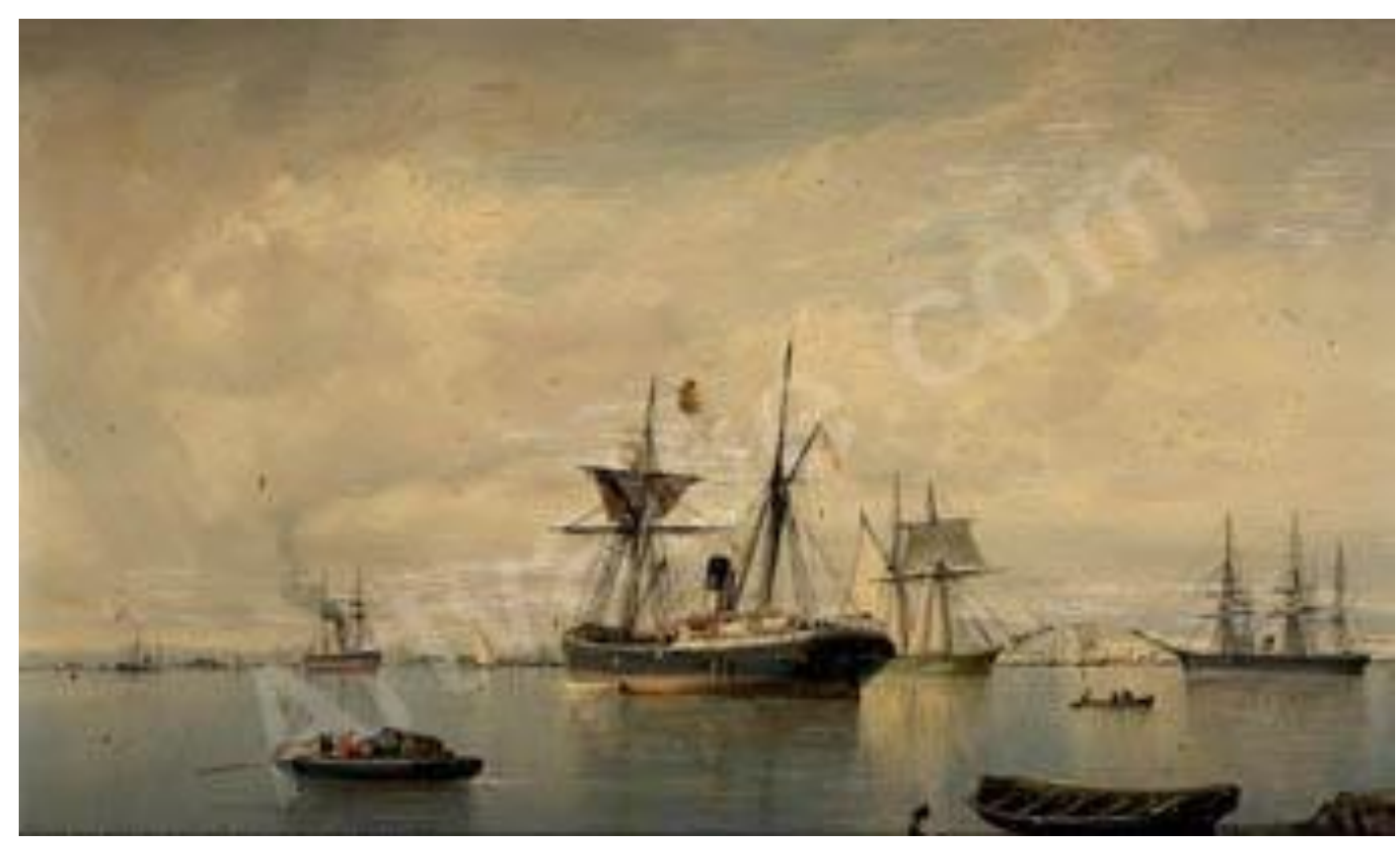

Fig. 6.7.- Obra similar a la inventariada con el número

435: un cuadro lienzo, marina, firmado Monleón, representando

El puerto de Valencia, un vapor y varias lanchas.

39 A este cuadro se hace referencia en el capítulo dedicado al mecenazgo de la familia Benlliure en el que se reproduce una frase del propio marques diciendo que en su casa pasa como en el cuadro, que la gente por la noche se lleva cosas por las ventanas. 


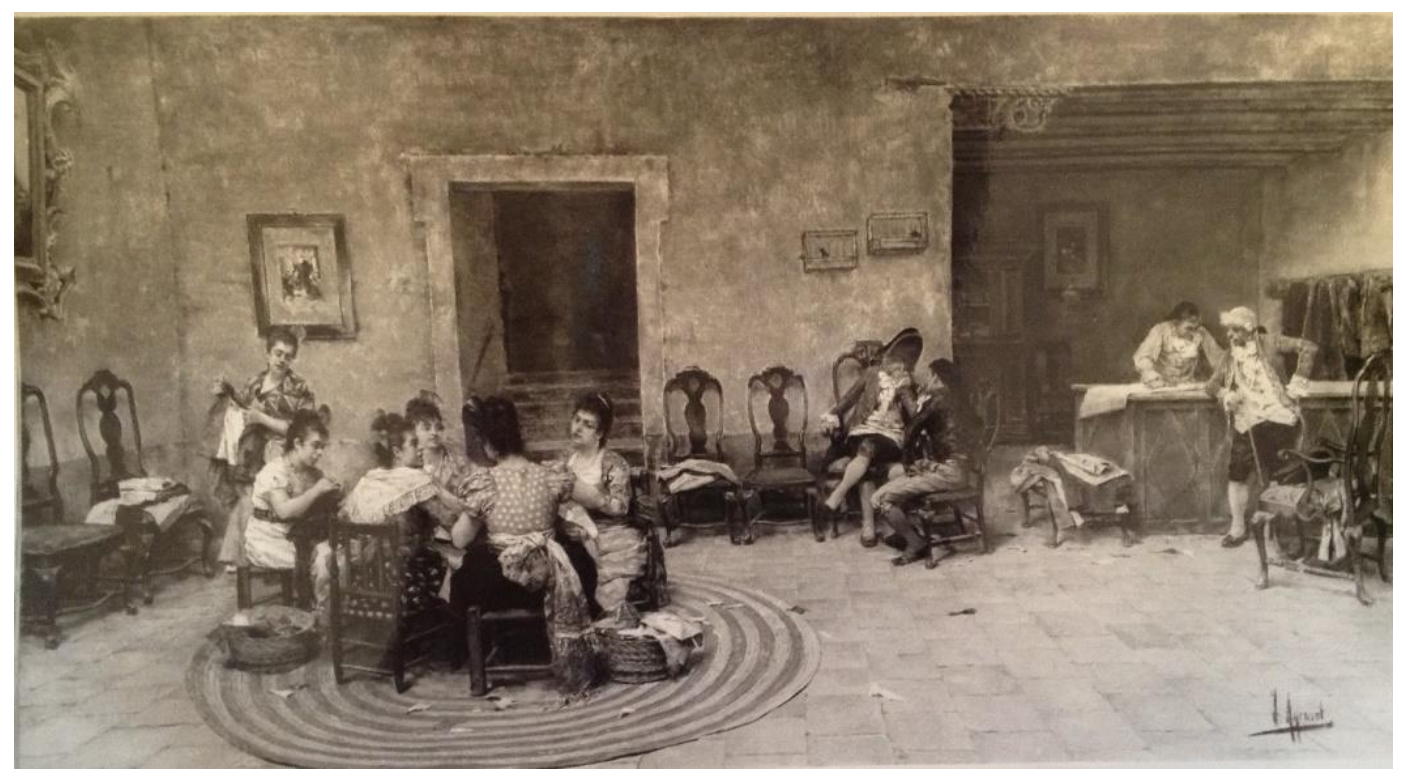

Fig. 6.8.- Obra similar a la inventariada con el número 440: un cuadro pequeño apaisado de Agrasot, sobre tabla, representando Una sastrería de la Edad Media40.

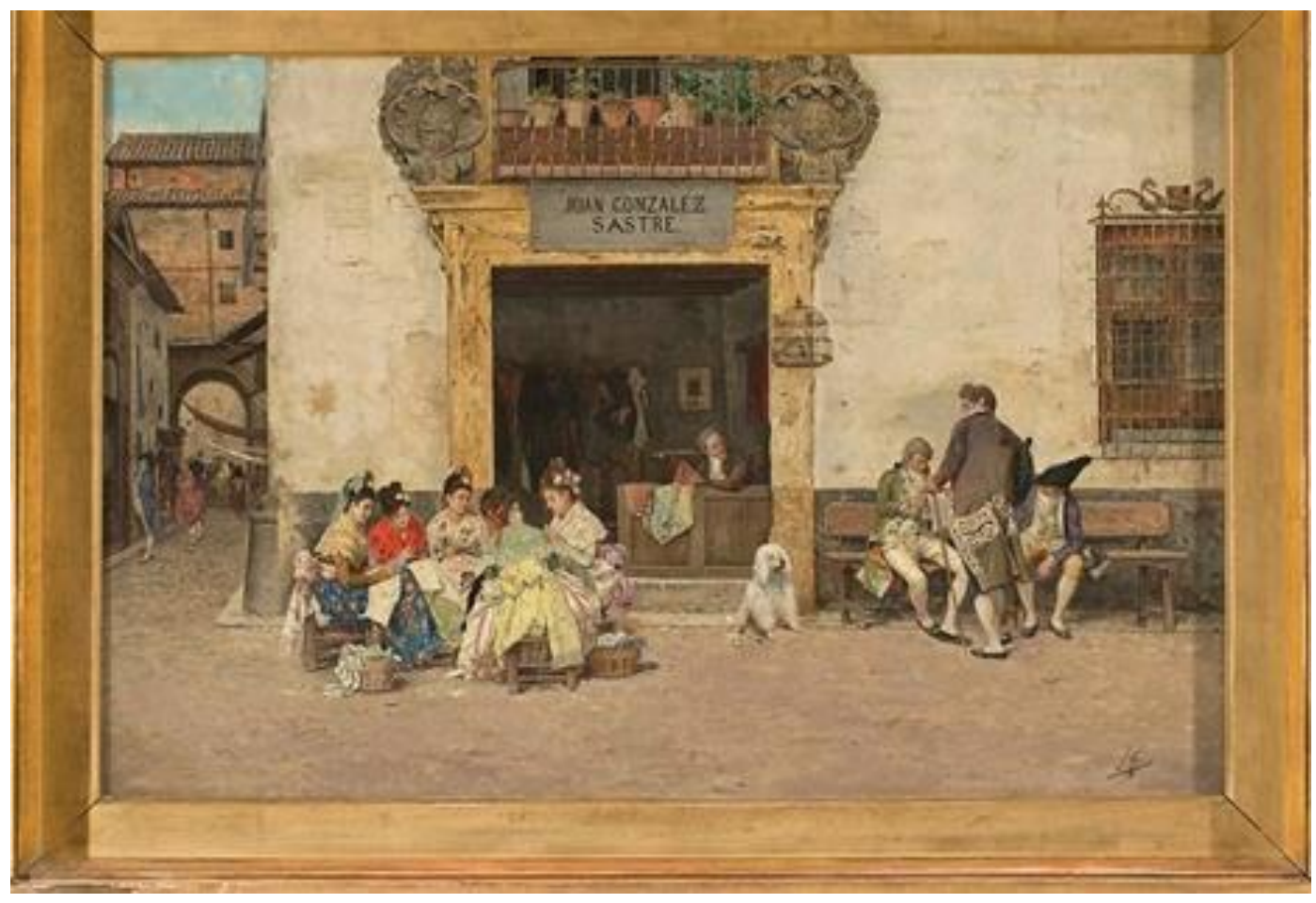

Fig. 6.9.- Obra similar a la inventariada con el número 440: un cuadro pequeño apaisado de Agrasot, sobre tabla, representando Una sastrería de la Edad Media ${ }^{41}$.

${ }^{40}$ Imagen perteneciente a la colección de fotos Huguet.

41 Imagen publicada en:http://www.artnet.com/artists/joaqu\%C3\%ADn-agrasot-yjuan/sastrer\%C3\%ADa-YaoO8UQPUTWWuzoSFZc1VA2 


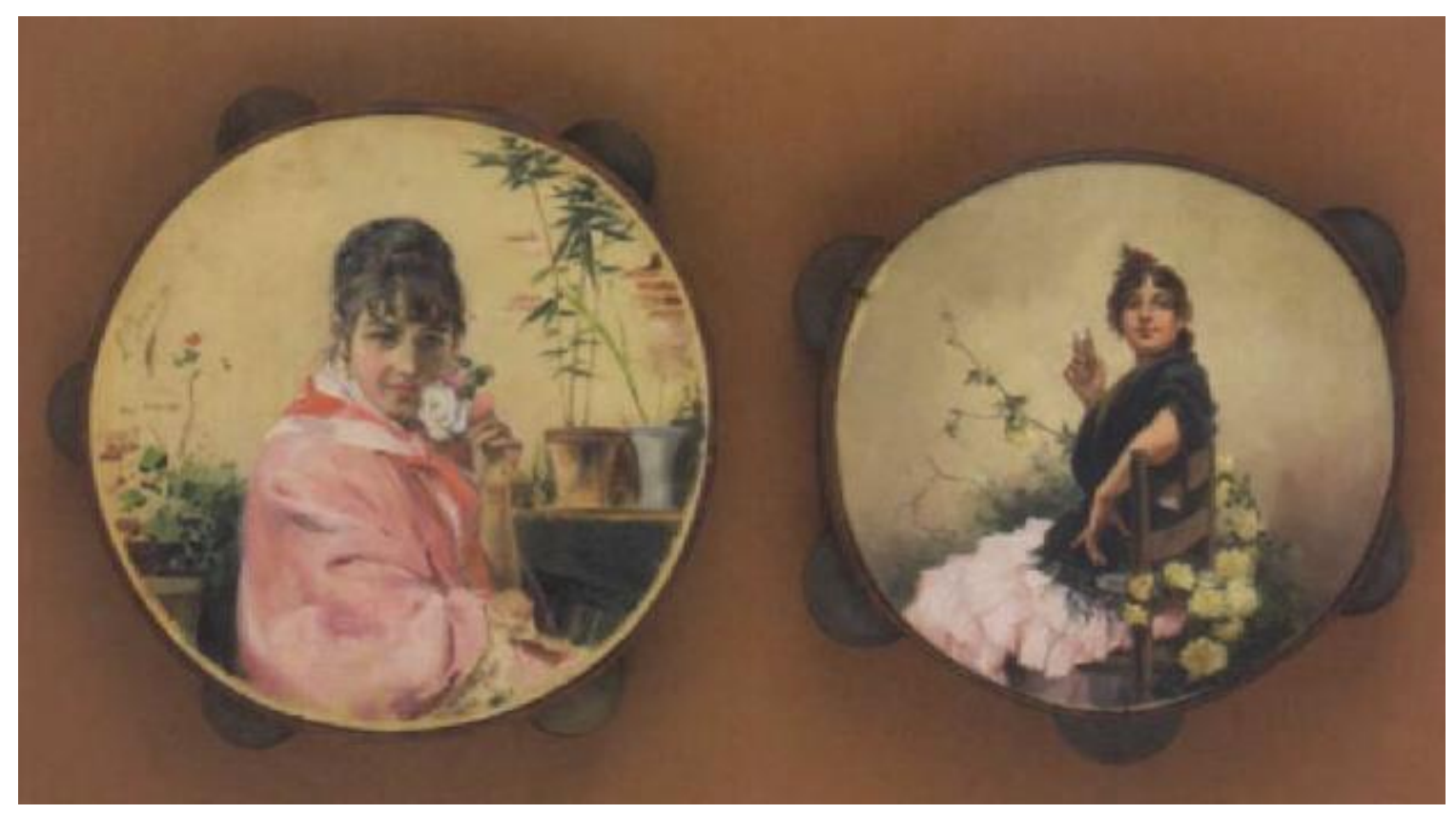

Fig. 6.10.- Dos obras similares a la inventariada con el número 486: una pandereta pintada42.
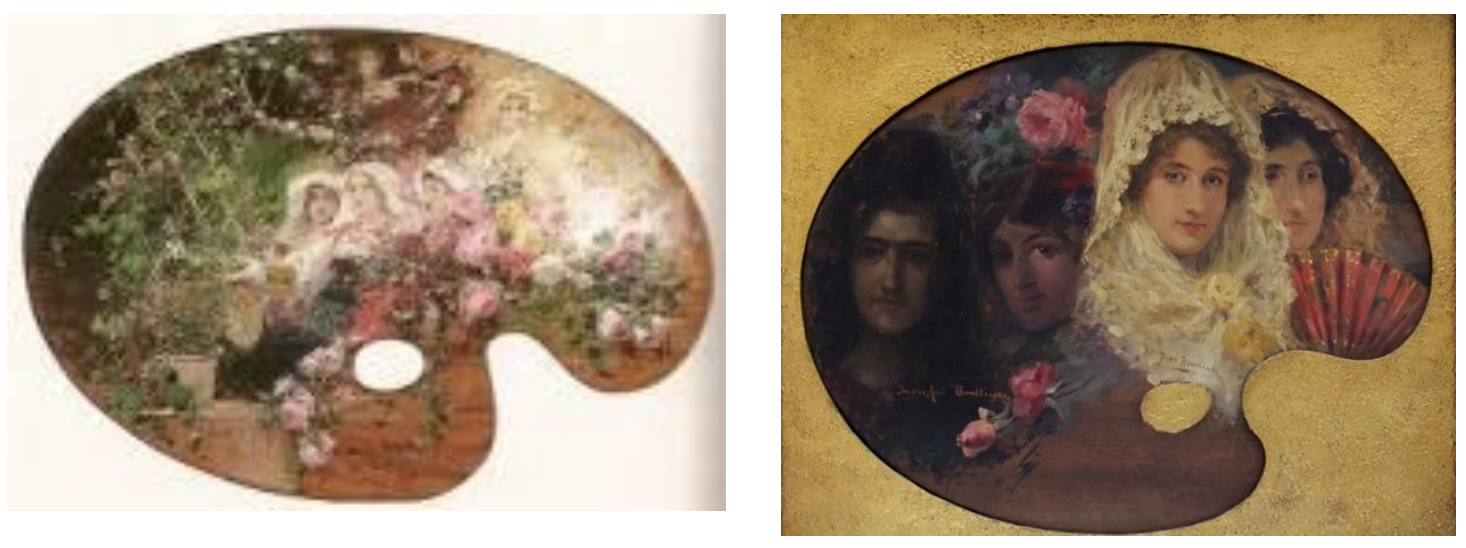

Fig. 6.11.- Dos obras similares a la inventariada con el número 719: un cuadro paleta, sobre fondo de terciopelo rojo con marco dorado, por Antonio Benlliure y Gil43.

42 Imagen publicada en: http://www.artnet.com/artists/luis-lluis-franco-salinas/ 43 Imagen publicada en: https://www.pinterest.es/pin/35346227073845.5661/ 


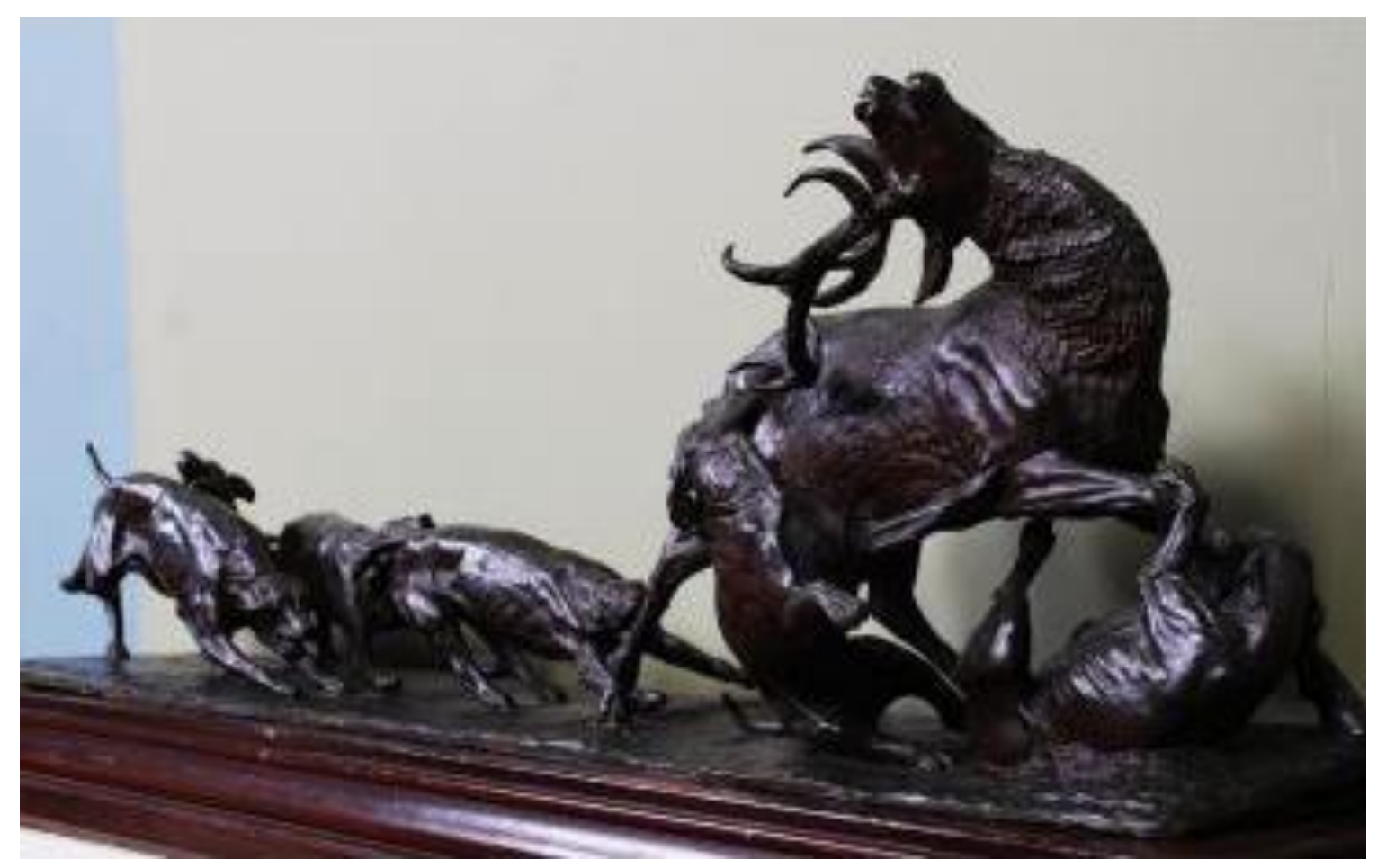

Fig. 6.12.- Obra similar a la inventariada con el número 311: un grupo de bronce "La caza del ciervo" 44.

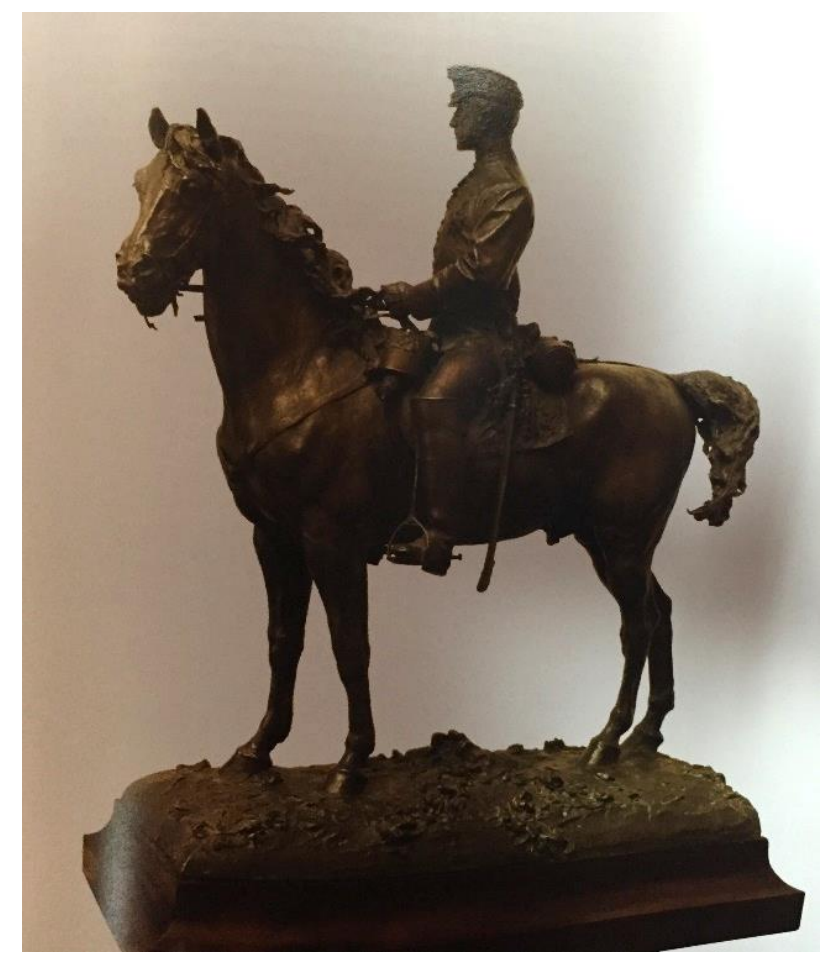

Fig. 6.13.- Obra similar a la inventariada con el número 828: una estatua ecuestre de D. Alfonso XII. Bronce ${ }^{45}$.

44 Imagen publicada en: https://www.wikiwand.com/es/Christopher Fratin 


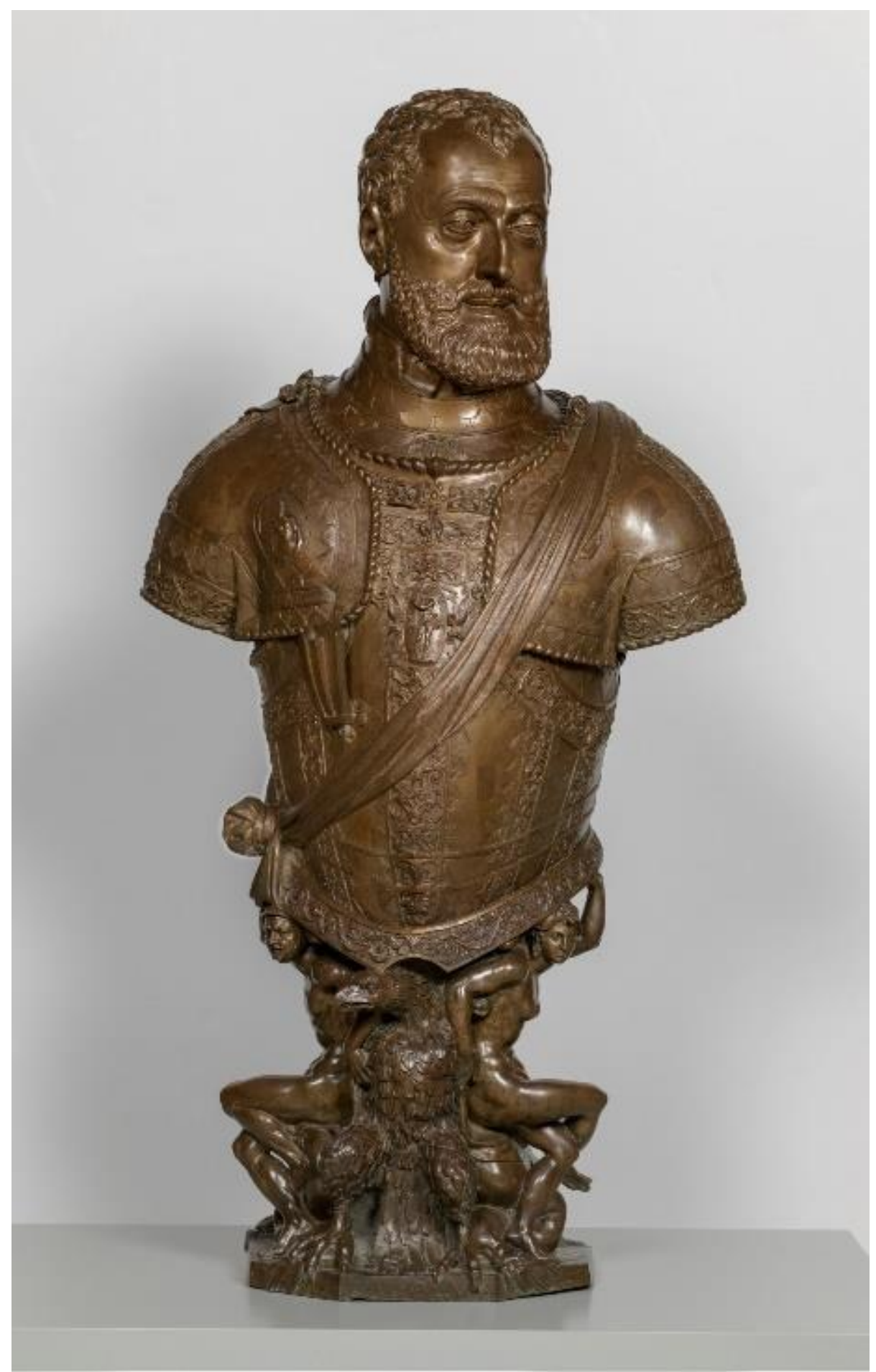

Fig. 6.14.- Obra similar a la inventariada con el número

662: un busto de bronce de Carlos $V^{46}$.

45 Esta figura corresponde a una obra de Mariano Benlliure, y la que poseía el marqués bien podía ser una como ésta.

46 Imagen publicada en: https://www.museodelprado.es/coleccion/obra-dearte/carlos-v/1dccf209-6c2c-42d7-b6dd-e3ff2b75c4cb Este busto es de Pompeo Leoni, 


\section{3.- La colección del Castillo de Viñuelas}

Ya se ha explicado en esta tesis que José Campo adquirió el día 3 de junio de 1870 el bosque de Viñuelas, en el monte de El Pardo, Madrid. La adquisición fue en una subasta por medio de un mandatario, y pagó el precio de unos ocho millones de reales. La propiedad, fundada por Felipe IV como cazadero real, estaba hipotecada y pertenecía al Estado, a Patrimonio.

Sabemos por las publicaciones de la época que José Campo reformó y redecoró el castillo en 1870, realizando algunos trabajos el pintor escenógrafo y familiar suyo, José Vicente Pérez Vela.

El periodista Franquelo cuenta en Día de Moda47:

"que el castillo de ventanas ojivales y torres almenadas, estaba decorado interiormente con muy buen gusto y con toda clase de objetos lujosos. El salón principal estaba cubierto de tapices, y había dos valiosos cuadros de Rubens y de Scheneider (1559-1657) representado escenas de caza. Los muebles eran de ébano con delicadas incrustaciones de marfil, y había varias panoplias con armas históricas. Contaba con una sala de billar y un salón árabe que imitaba a la Alhambra de Granada que tenía divanes persas y una alfombra de piel de tigre.

La cámara de la marquesa, que daba paso a un camarín lleno de tapices flamencos, era espléndida. El comedor tenía una bella chimenea dinamarquesa de porcelana y una magnífica lámpara de bronce formada con atributos de caza. El despacho, el gabinete de lectura, la capilla, y el resto de las dependencias estaban decoradas con suntuosidad y buen gusto. Allí el marqués organizaba grandes fiestas y cacerías, y los invitados eran muy bien recibidos; se dice que en esas cacerías de

y aunque en el inventario no se refleja el autor, en el catálogo de la Exposición de Barcelona de 1888, se dijo expresamente que el busto de Carlos V era de Pompeo Leoni. ${ }_{47}$ Día de Moda, 27 /9/ 1880, p 7. 
disparaba poco y se conspiraba mucho, y hay anécdotas que refieren que allí se fraguó la subida al trono de Alfonso XII”

Si estudiamos detenidamente el inventario al que ya nos hemos referido de 1888, vemos que en el castillo de Viñuelas había, entre otro,s los siguientes objetos de arte:

1515: un cuadro al óleo que representa dos cabras, firmado F. Parra.

1521: una bandeja de plata antigua con un caballo y un jinete.

1529: reloj de mármol con dos figuras, dos ciervos y candelabros de metal.

1537: 20 cuadros de palacios, casas y bosques.

1538: un cuadro retrato del Sr. marqués.

1539: un cuadro retrato del marquesito.

1540: un cuadro retrato de D. José Maicas Niño.

1548: una figura de perro de bronce.

1557: un piano chapeado figurando mosaico de maderas, con sus candelabros.

1563: 8 cuadros, marcos dorados, ovalados, retratos del Sr. marqués y su familia.

1577: un armario joyero, chapeado de ébano y concha, con pinturas finas, interiores, en bronce.

1582: 4 tapices con figuras Asuntos de la Biblia.

1586: un armario de roble tallado para el tabaco.

1599: 19 libros grandes encuadernados, 18 pequeños, un libro devocionario, 20 libros en rústica.

1607: un busto de metal bronceado del señor marqués.

1067: un biombo chino con pinturas de paisajes y perros.

1630: un árbol de centro de mesa, con cuatro candelabros de quita y pon, cuatro flores con cuatro platos de cristal y metal blanco y cuatro pies de metal blanco con cuatro platos de cristal.

1820: un cuadro pintado en lienzo representado la Coronación de la Virgen.

1953: 3 tapices con figuras y alzapaños de cordón de seda azul y dos abrazaderas de bronce.

1958: un armario de caoba de dos cuerpos y tres departamentos. 
1960: un biombo chino con países y figuras finas.

1970: un reloj de bronce con figuras, caballo y jinete.

1987: un cuadro al óleo representado una Virgen con el Niño en los brazos y varios ángeles.

1991: un reloj de mármol con una garza de bronce.

1996: un armario de palosanto y entrecalles de palo-rosa, interior de maple.

2040: dos jarrones de porcelana, color rosa y flores, con tapaderas figurando piñas.

2052: dos tapices con bosques y figuras y franja de terciopelo morado, estilo Renacimiento.

2055: dos cuadros grandes en lienzo, representado cacerías antiguas con peros y lanzas.

2056: un reloj de música, de metal dorado, guarnecido de terciopelo morado.

2058: dos espejos ochavados de cristal de Venecia tallados.

2060: una panoplia compuesta de un casco, tres lanzas, dos espadas, dos martillos y dos dagas.

2061: una panoplia compuesta de casco, pechera, tres lanzas, dos espadas, dos hachas, dos martillos y dos manoplas.

2079: un reloj de mármol con una figura de un caballo de bronce.

2102: un reloj de mármol con una figura de un perro de bronce.

2470: una figura Diana Cazadora, con un ciervo, de hierro fundido y peana de piedra.

2471: dos leones alados de hierro fundido y peanas de piedra.

De la documentación estudiada comprobamos que los comentarios de la prensa son ciertos. La decoración de todas las estancias era exquisita, con grandes chimeneas con adornos en bronce, relojes de sobremesa de mármol con figuras también de bronce, diferentes cuadros con retratos de la familia del marqués, etc. Había un busto del marqués, un biombo chino y un centro de mesa muy historiado que era un adorno de mesa habitual en las grandes casas donde se celebraban banquetes y solían ser decorados a su vez con flores o con comida. 
En la capilla, además de crucifijos y todos los elementos necesarios para la celebración de la Santa Misa, había un lienzo de La Coronación de la Virgen del cual se desconoce su autor.

En los diferentes salones había panoplias con armas, tapices con escenas de bosques y figuras que cubrían las paredes y de los que habla el periodista antes mencionado; también había dos cuadros grandes al óleo con escenas de cacerías antiguas con perros y lanzas sin nombre de autor en la documentación estudiada pero que deben ser el de Rubens y el de Scheneider que nombra Franquelo; sin embargo el catálogo de la Exposición de Barcelona nombra dos bastidores de cacerías de Paul de Vos, pero esos cuadros eran del palacio del paseo de Recoletos, como ya hemos comentado. También había cuatro tapices con figuras y asuntos de la Biblia, y otros cuadros entre los que destacamos un óleo con unas cabras firmado por J. Parra y uno de la Virgen con el Niño.

En la explanada que daba entrada al pórtico del castillo había una escultura de Diana cazadora con un ciervo, que nos recuerda a la Diana de Versalles que se conserva en el museo del Louvre y dos Leones alados, que podrían recordar a quimeras; todos ellos de hierro fundido situados sobre peanas de piedra (Figs. 6.15 y 6.16). Reproducimos en este punto las figuras del exterior por ser las únicas que de verdad coinciden con las descritas y que aparecieron publicadas en un libro sobre Viñuelas de Francisco Uhagon al que ya nos hemos referido en otro capítulo de esta tesis. 


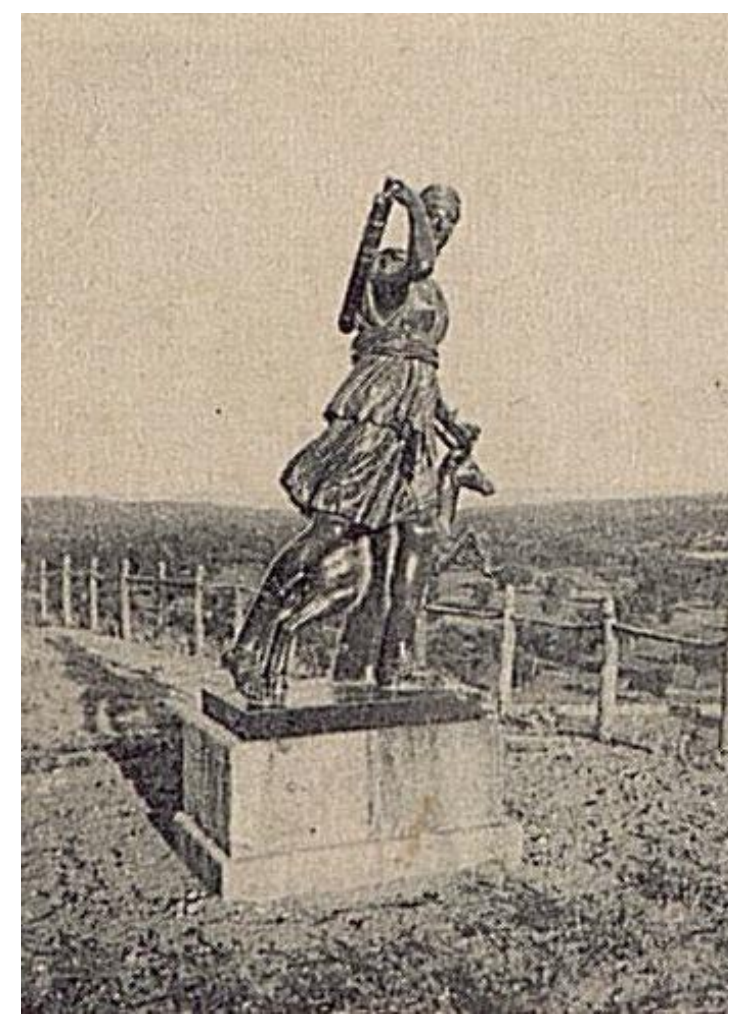

Fig. 6.15 Diana Cazadora. Viñuelas ${ }^{48}$

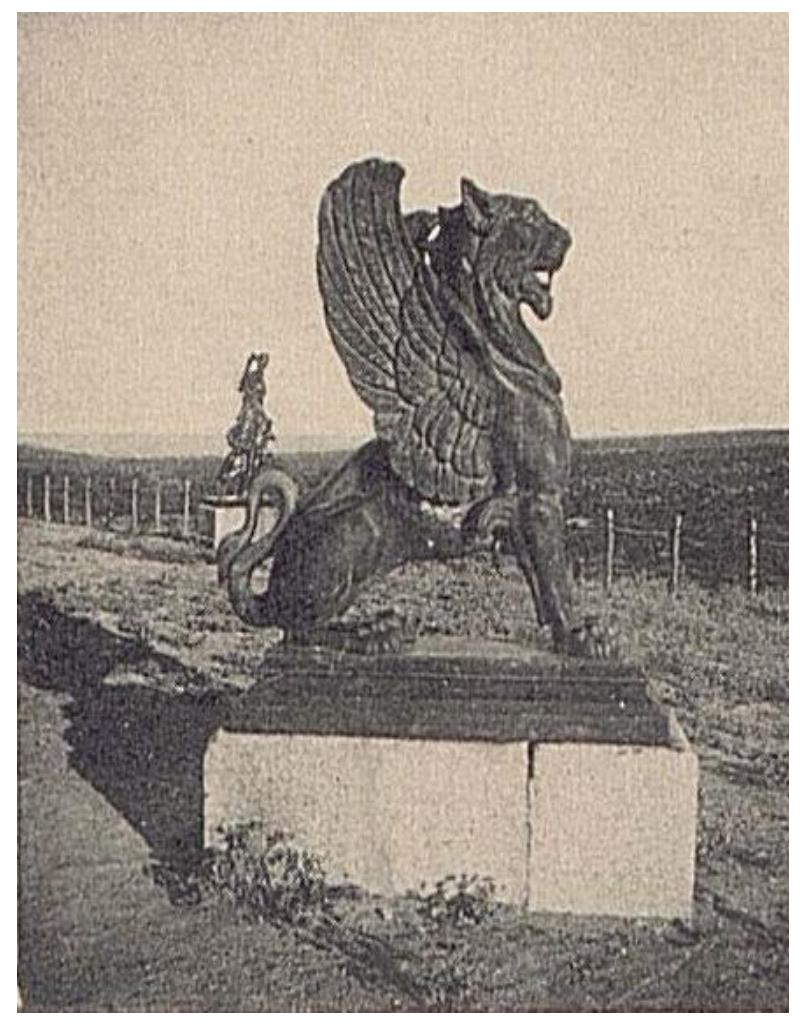

Fig.6.16 León alado. Viñuelas ${ }^{49}$

Queda patente una vez más el interés del marqués por los objetos de arte y por su voluntad de rodearse de todo tipo de lujo en sus residencias; máxime en esta, donde eran habituales las invitaciones a personajes de la vida política madrileña y de la nobleza para cacerías y fiestas. José Campo se rodeaba de este tipo de objetos para reforzar más aun su imagen de poder.

\footnotetext{
${ }^{48}$ Imagen publicada en UHAGON DE GUARDAMINO, Francisco. Viñuelas. Madrid: 1899. ${ }^{49}$ Imagen publicada en UHAGON DE GUARDAMINO, Francisco. Viñuelas. Madrid: 1899.
} 


\section{4.- La colección de la villa de Arcachon. Francia}

De la adquisición y características de la villa ya se ha hablado en el capítulo tercerode esta tesis. En este punto nos vamos a centrar una vez más en los objetos de arte que decoraban la villa y que aparecen en el inventario referido y además en la escritura de compraventa de la villa, ya que se compró amueblada y que en parte coinciden. Las posteriores adquisiciones del marqués completaron la decoración y convirtieron la Villa Campo en un lugar de solaz y descanso de la ajetreada vida de Madrid.

Todo el mobiliario era de época, estilo Luis XV de un gusto exquisito.

Las alfombras de ricos dibujos y colores cubrían parte de las salas.

Los objetos de arte más destacados según el inventario ya mencionado son:

3497: una mesa de billar de madera negra, con funda de dril, firmada por Duran.

3450: una mesa de roble con columnas salomónicas.

3502: dos jardineras de laca china.

3503: dos candelabros dorados y plateados estilo Luis XV.

3505: dos vasijas con tapadera y pies de madera, japonesas.

3506: una gran copa del Japón, con pie de madera.

3508: un aparador de madera negra, tallado y el interior de roble.

3510: dos tibores de porcelana del Japón, medianos.

3511: un relicario chino, de bronce tallado y dorado, con un santo y un ídolo en bronce.

3516: dos caballos en bronce, de Marly.

3519: un reloj de péndulo, holandés, con caja de madera tallada con embutidos e incrustaciones de madera y movimiento marítimo.

3522: un gran tibor de porcelana del Japón, dorado y encarnado.

3523: dos tibores de porcelana china.

3524: dos leones de porcelana.

3525: una figura de un holandés de porcelana.

3530: dos pájaros de piedra rojos. 
3587: un gran tibor de porcelana.

3538: dos tibores de porcelana china, alto relieve azul.

3540: dos figuras de tierra cocida, de Sevilla.

3543: dos tibores en verde manzana, grandes, de porcelana del Japón.

3544: una estatua pequeña de pasta italiana.

3559: dos grandes vasijas de bronce, con zócalo de mármol vede.

3560: una quimera de bronce viejo con base de mármol.

3561: dos estatuas de bronce viejo con base de mármol.

3564: un gran espejo con marco de metal. Luis XVIII.

3573: un piano vertical de madera negra, de Erard.

3574: un musiquero torneado.

3577: un gran tazón de porcelana del Japón con pie de madera negra.

3580: un tapiz persa con fleco.

3581: un gran tibor Japón, alto relieve, con pie de madera negra.

3582: dos pies para lámpara de porcelana del Japón.

3586: un bronce, primer ejemplar de Merie.

3587: una caja de palosanto antigua, con incrustaciones de nácar.

3588: una caja antigua de laca de Pekín, maqueada.

3596: cuatro abanicos valencianos y dos chinos.

3597: diez tomos de libros, algunos en francés.

3598: diez y siete tomos de novelas británicas.

3604: un reloj con peana estilo Luis XIV.

3607: una tortuga de bronce.

3608: un sapo de bronce.

3609: una figura de una mujer china en bronce.

3610: una figura de mujer en bronce y base de pierda ónix.

3611: un arca persa, cincelada de bronce y cobre.

3612: dos botellas tulipán de Bohemia.

3615: una mesa giratoria con cajones y secretos, estilo Luis XVI, e incrustaciones de maderas.

3620: un florero Nuremberg.

3626: dos candelabros estilo Luis XVI, dorados a fuego.

3628: una estatua pequeña con un collar, de tierra cocida, cerámica. 
3628: un espejo de luna de Venecia, Renacimiento, marco de bronce dorado, filigrana.

3631: una figura italiana, Pierrot.

3633: un cuadro pequeño, al pastel, asunto familia.

3642: dos vasijas de porcelana de Sajonia.

3644: un par de morillos esfinges de bronce dorado.

3651: trece tomos "Cartas de Madame de Savigné".

3656: una mesa pequeña, Versalles, madera dorada, cubierta de terciopelo morado y franja gobelina.

3658: dos estatuas pequeñas de bronce estilo Luis XIV, con pie de mármol rojo sanguino.

3663: un bronce La Prynne de Pradier.

3674: un escritorio estilo pompeyano, italiano, del siglo XVI, con fondo tallado y columnas de alabastro, con puertas incrustadas en maderas antiguas.

3683: una pequeña estatua representado una Diosa de Saba de la pagoda de Delhy con su correspondiente pedestal de piedra jaspe.

3692: un esmalte de Bernard Mayer, con marco de madera negra sobre un templete dorado y tallado.

3697: un retrato de Santa Teresa al óleo.

3697: un retrato de San Jerónimo de Tiziano, con marco dorado. al óleo.

3702: una papelera holandesa de dos cuerpos, con recortes de metal blanco e incrustaciones.

3705: un bajo relieve italiano del siglo XVI con marco de ébano.

3709: una pintura italiana, con marco de bronce.

3711: un bajo relieve de Vasari.

3715: una papelera con incrustaciones de marfil, calada de Florencia.

3716: dos figuras de barro cocido Ruy Blas.

3717: un reloj de sobremesa, Luis XIII y caja de ébano.

3718: un medallón de mármol con marco de madera de Gustavo Adolphe Desiré Crauck.

3725: un grupo de biscuit de Fauno y Bacante, de Sèvres.

3726: un plato del Japón esmaltado. 
3728: un cuadro al óleo, representado La Magdalena, firmado por Guido Reni, con marco dorado.

3731: una Virgen Aux petits de Bergame.

3747: una cuchara de Enrique II en plata antigua, con blasones de grandeza.

3757: un bajo relieve de mármol, cupido, Italia.

3826: un elefante de bronce con pie de mármol.

3910: un secreter de palo-rosa, Luis XVI.

3916: un reloj de sobre mesa. Miniatura de marfil, estilo Luis XVI.

3930: un tríptico estilo bizantino, Santa Lucía y Santa Catalina.

4014: una Virgen del Pilar de plata.

4203: un crucifijo de marfil, tamaño mediano. 
Como no hemos podido localizar las piezas originales que pertenecieron a José Campo, vamos a mostrar unas cuantas imágenes de obras similares, como hemos hecho antes, para podernos hacer una idea de su belleza.

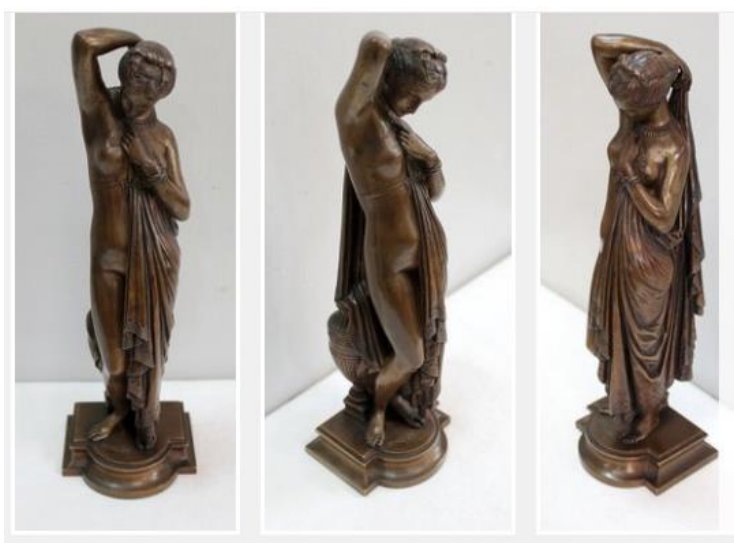

Fig. 6.17.- 3658: La Prynne de Pradier5o.

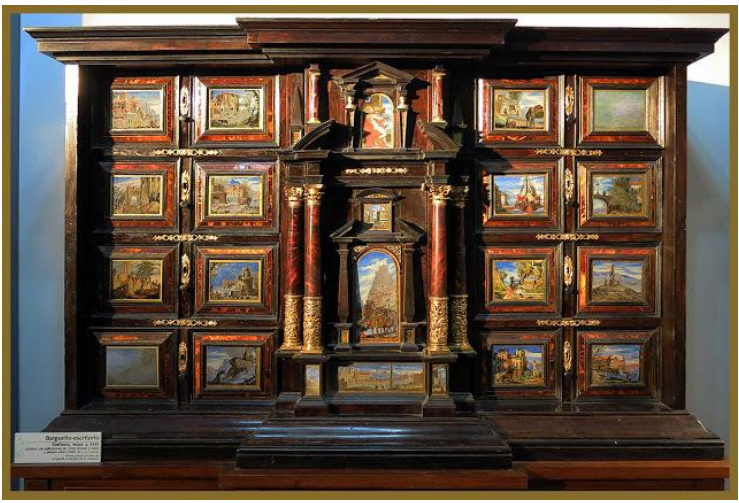

Fig. 6.19.- 3674: Escritorio estilo pompeyano ${ }^{52}$.

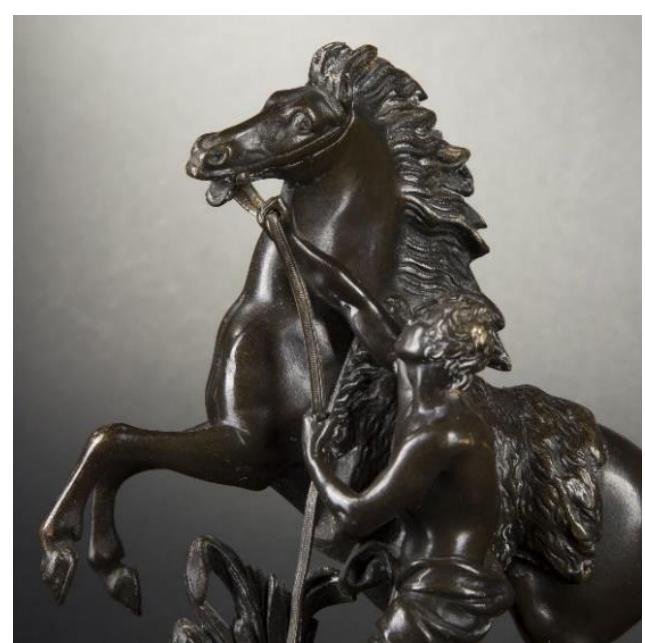

Fig. 6.18.- 3596: Caballo de bronce de Marly51.

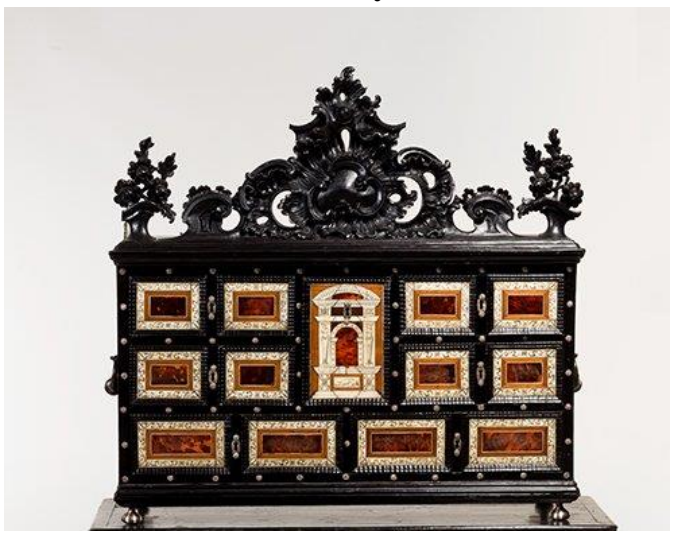

Fig. 6.20.- 3715: Papelera florentina con marfil53.

50 Imagen publicada en: https://www.pamono.es/escultura-phryne-de-bronce-dejames-pradier-para-susse-freres-decada-de-1840 consultada el 14 de enero de 2018.

${ }^{51}$ Imagen publicada en: https://es.expertissim.com/segun-guillaume-coustou-marlycaballo-bronce-12204687 consultada el 14 de enero de 2018.

${ }^{2}$ Imagen publicada en: http://domuspucelae.blogspot.com/2018/04/theatrumescritorio-el-prestigio-traves.html consultada el 14 de enero de 2018.

53 Imagen publicada en: https://arsmagazine.com/una-papelera-florentina-de-ff-s-xviisobresale-en-la-licitacion-de-ansorena/ consultada el 14 de enero de 2018. 


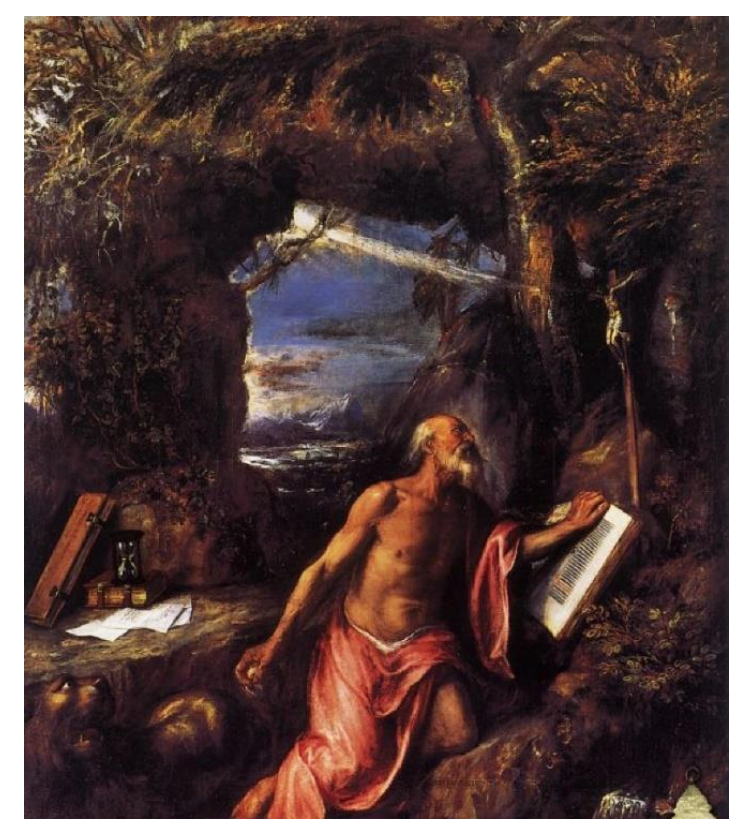

Fig. 6.21.- Obra similar a la inventariada con el número 3697: San Jerónimo, 1575, Tiziano54.

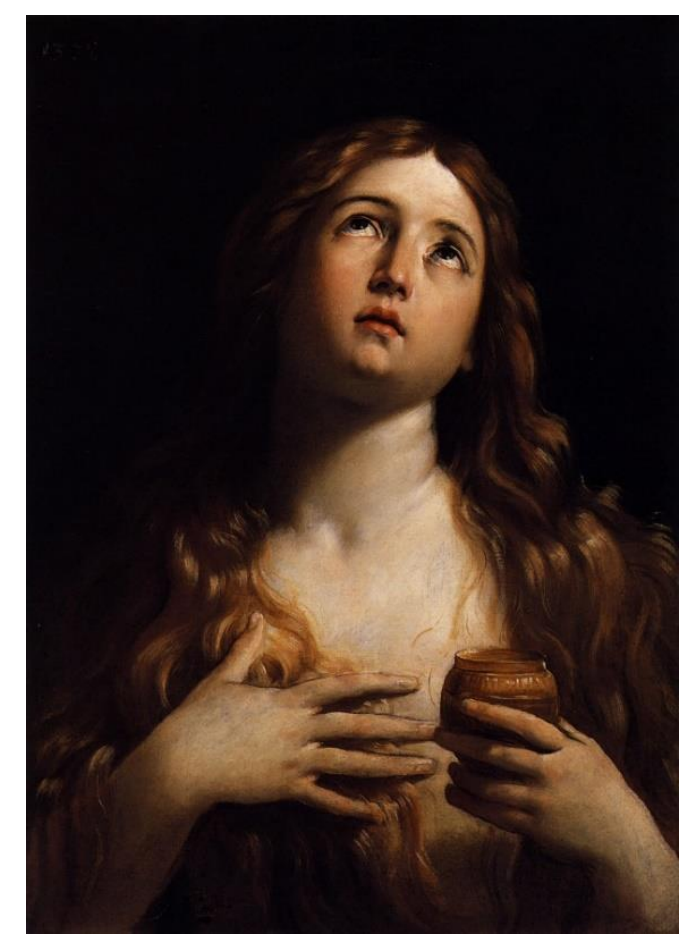

Fig. 6.22.- Obra similar a la inventariada con el número 3728: Magdalena penitente, 1616, Guido Reni55.

54 Imagen publicada en: https://www.artehistoria.com/es/obra/san-jer\%C3\%B3nimo$\underline{26}$ consultada el 13 de marzo de 2017.

55 Imagen publicada en: https://es.wahooart.com/@@/8XY62Y-Reni-Guido-(LeGuide)-mar\%C3\%ADa-Magdalena consultada el 13 de marzo de 2017. 
La villa no era exactamente lo que podría considerarse una casa de vacaciones "normal". Las diversas salas y estancias estaban decoradas con toda clase de lujo y el aspecto era casi el de un palacio. Destacamos en la decoración de la casa: un piano vertical de madera negra de Erard, un esmalte con marco de madera sobre un templete dorado y tallado obra de Bernard Mayer, un óleo de Santa Teresa, otro de San Jerónino obra de Tiziano y otro óleo representando a la Magdalena firmado por Guido Reni. Un bajo relieve italiano del siglo XVI con marco de ébano, un medallón de mármol blanco con marco de madera negra de Gustave Adolphe Désiré Crauk, dos esculturas de caballos de Marly realizados en bronce por Guillaume Coustou y una esultura en bronce de $L a$ Prynne de Pradier.

Llama la atención la presencia en una villa de vacaciones de dos cuadros como la Magdalena o el San Jerónimo, dos santos penitentes, arrepentidos, cuyo mensaje no cuadraría mucho con unas vacaciones en la playa.

María Magdalena fue otro de los temas que popularizó Trento para mostrar de manera didáctica, en pinturas y sermones la doctrina de la iglesia acerca de los sacramentos como medio de salvación eterna. Con este tipo de obra, representado a una Magdalena penitente arrepentida de la vida licenciosa que había llevado hasta que unió su vida a la de Jesús, se pretendía que el espectador meditara en el sacramento de la penitencia, cuestionado por la reforma protestante. El arrepentimiento de la Magdalena debía ser objeto de meditación por el fiel, y debía ser el ejemplo a seguir para, a través del mismo, llevar un camino de purgación de pecados como paso previo a la comunión y a la santificación del alma. 
Sin embargo, en el siglo XIX, un cuadro de La Magdalena colgado en una pared de una villa de veraneo de un burgués dedicado a los grandes negocios, no parece que tenga la misión de hacerle reflexionar sobre el sacramento de la penitencia, sobre todo porque en vacaciones el marqués y sus invitados se entregaban a los placeres del buen comer y a las grandes fiestas que eran comentadas por la sociedad del momento.

José Campo, aunque católico, no era un devoto al uso. Sí lo era sin embargo su primera esposa, Rosalía Rey, quien tenía en sus habitaciones reclinatorios, devocionarios, crucifijos y rosarios para rezar íntimamente, pero no creemos que el cuadro de la Magdalena, ni el de san Jerónimo cumplieran su función de convertir y persuadir a la señora marquesa, sino que eran un elemento más de la exuberante decoración de la villa que dejaba impresionados a los invitados.

Tras la muerte de José Campo, la villa fue vendida en 1898 a la condesa de Renesse, una viuda muy rica del norte de Francia que se enamoró del pretendiente al trono albanés, refugiado en España. Fue demolida en 1977.

Como hemos podido ver a lo largo del capítulo, en la colección de pintura del marqués se aprecia una predilección por artistas contemporáneos y sobre todo de tierras valencianas; para promocionar su trabajo; sin que falten grandes nombres como Murillo, Teniers o Paul de Vos. Así mismo tiene obras de artistas españoles que estaban triunfando en las exposiciones de pintura y escultura.

El marqués no se preocupó nunca de dejar testimonio de sus transacciones ni de documentar la procedencia de las obras que adquirió, y desconocemos qué lo motivaba a la hora de comprar cuadros y bustos y demás objetos. 
La colección era fruto de varios factores: era un signo de distinción, era un modo de asimilarse a los círculos sociales más elevados y a la vez era también consecuencia de su pasión por el arte. Conociendo los orígenes humildes de José Campo y su familia, no podemos sino sorprendernos de ver la gran transformación que sufrió a lo largo de los años y sobre todo cuando fue nombrado marqués, momento en que vio cumplidas sus ansias de reconocimiento social. 



\section{Capítulo vil}

LA EXPOSICIÓN UNIVERSAL DE BARCELONA DE 1888 Y LA COLECCIÓN DE ARTE DEL MARQUÉS DE CAMPO

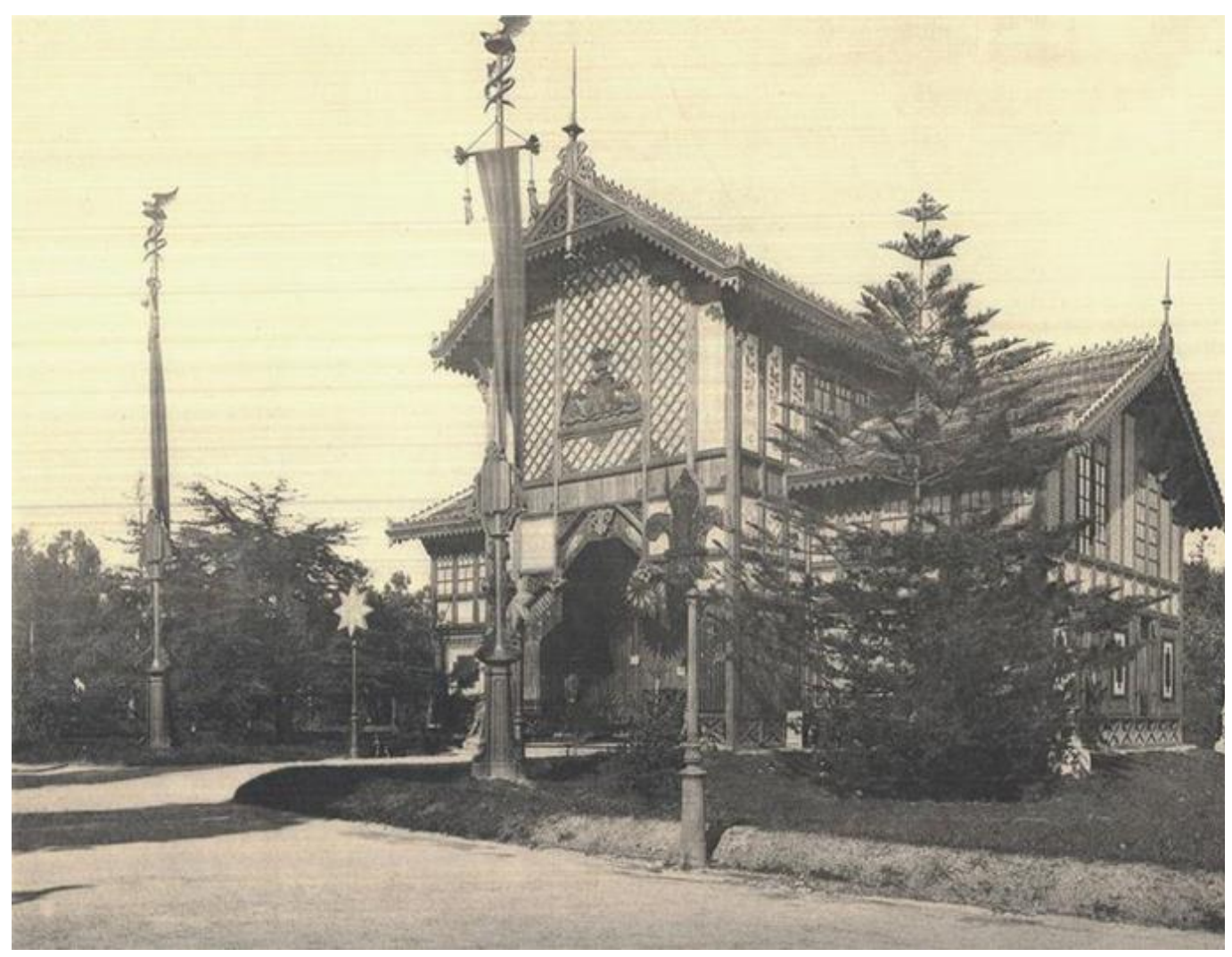





\section{Capítulo viI}

\section{LA EXPOSICIÓN UNIVERSAL DE BARCELONA DE 1888 Y LA COLECCIÓN DE ARTE DEL MARQUÉS DE CAMPO}

Como se ha comentado antes, parte de la colección de obras del marqués de Campo fue objeto de exhibición en su pabellón, aunque algunos llaman "chalet" de la Exposición Universal de Barcelona celebrada en 1888, y fue un acontecimiento tan importante para el marqués, desde el punto de vista de un coleccionista de arte, que meceré ser tratado en un capítulo entero en esta tesis.

Las Exposiciones Universales se originaron como consecuencia de las exposiciones nacionales industriales que comenzaron a celebrarse en Francia en el siglo XIX. Otros países comenzaron también a celebrar exposiciones nacionales, y en 1851 se celebró la primera Exposición Universal en Londres, en el Cristal Palace de Hyde Park, bajo el título "Gran Exposición de los trabajos de la industria de todas las naciones”.

En estas exposiciones se mostraban los avances de las industrias y la tecnología de los países participantes, y eran acontecimientos que movían muchos capitales para su organización; provocaban un flujo de visitantes que además supuso el comienzo de un tipo de turismo interesado en este tipo de 
eventos para buscar nuevos productos para sus empresas; supusieron además un aumento de las relaciones internacionales entre los países participantes y provocaron, en ocasiones, la construcción de iconos arquitectónicos, algunos de los cuales siguen hoy en día en pie. Por ejemplo, la exposición de Londres de 1851 supuso la construcción del Cristal Palace de Hyde Park por Joseph Paxton (18031865); la de París de 1889 supuso la construcción de la torre Eiffel por el ingeniero Gustave Eiffel (1832-1923), etc.

Las Exposiciones Universales provocaron además la producción de un gran número de publicaciones en forma de guías, catálogos, postales, y otro tipo de obras con comentarios o críticas, además de toda la cobertura de la prensa antes, durante y después de la celebración¹.

Según Aimone y Olmo, "la presencia de España en las exposiciones universales decimonónicas, y en algunas posteriores, ha sido interpretada por algunos historiadores como el resultado de una necesidad u obligación institucional, más que el producto de un interés real por diseñar y aplicar un verdadero proyecto expositivo"2. Pero según Sánchez Gómez en realidad lo que buscaba España con la participación en las exposiciones era dar a conocer sus productos y sus artistas, aunque es verdad que el Estado no se implicó del mismo

\footnotetext{
${ }^{1}$ Sobre las Exposiciones Universales en general hay pocas publicaciones especializadas; para consulta ver: GREENHALGH, Paul. Ephemeral Vistas: The Expositions Universelles, Great Exhibitions and Worl's fair 1851-1939. Manchester: manchester University Press, 1988.

CHANDLER, Arthur. The Paris Exposition Universelle of 1878. Consultado en línea el 1 de marzo de 2020 http://www.arthurchandler.com/new-pageparis-1878-exposition Sobre la Exposición Universal de Barcelona, además de las publicaciones citadas en este capítulo ver: GARCÍA LLANSÓ, Antonio. La primera Exposición Universal española. Barcelona: Imprenta Luis Tasso Serra, 1888.

GRAU, Ramon. (dir.). Exposición Universal de Barcelona. Catálogo de la Sección Oficial del Gobierno. Barcelona: López Robert, 1888.

SERRATE, José maría (ed.). Estudios sobre la Exposición Universal de Barcelona, 1888. Barcelona: Establecimiento tipográfico del diario mercantil, 1888.

${ }^{2}$ AIMONE, L.; OLMO, C. Les Expositions universelles,1851-19oo, París: Belin, 1993, p. 87. 
modo en todas en las que ha participado 3 , por ejemplo en el caso de la de París de 1878 sí que lo hizo, pero en el caso de la de Barcelona 1888 no, y por ello fue un proyecto de la ciudad.

La exposición Universal de Barcelona de 1888, fue un intento de poner en valor la industria y las empresas españolas y por su puesto las de los demás países que participaron en ella. A lo largo del siglo XIX se celebraron varias exposiciones universales en diversas ciudades de Europa y eso era bueno para el comercio, la industria y las transacciones económicas. La de Barcelona supuso la modernización y reforma de la ciudad para ponerla a punto para el gran acontecimiento que reunió a miles de personas para admirar los adelantos y exhibiciones de cada uno de los países y por supuesto de las empresas españolas participantes.

El marqués de Campo no dudó en participar en ella para promocionar todos sus negocios relacionados con el ferrocarril, la compañía de vapores, la fábrica de gas, la iluminación, el tabaco, etc., pero en su pabellón el marqués llegó más allá y exhibió no sólo locomotoras o faroles de gas, sino piezas relacionadas con los dos asilos para niños que había construido en Valencia y que ya han sido objeto de estudio en esta tesis, y también piezas de arte que formaban parte de la decoración de sus residencias y que formaban parte de la gran colección de obras de arte que ya hemos estudiado anteriormente. De esa manera conseguía aumentar su promoción internacional y a la vez mostrar su personalidad a través de la exhibición de algunas de sus posesiones más preciadas y que ahora veremos.

\footnotetext{
3 SÁNCHEZ GÓMEZ, Luis ángel. Glorias efímeras: España en la Exposición Universal de París de 1878.

https://eprints.ucm.es/id/eprint/14589/1/Glorias ef\%C3\%ADmeras.pdf consultado en línea el 1 de marzo de 2020.
} 
La Exposición Universal de Barcelona fue todo un acontecimiento social. Desde varios meses antes, la prensa de la época ya se hacía eco de todas las obras que se estaban llevando a cabo para la realización del evento; y se publicó, por ejemplo, que se iba a realizar una guía ilustrada en castellano y en francés que contendría unos 200 grabados artísticos4.

En abril se publicaron todos los festejos que iban a tener lugar en la inauguración y durante la duración de la exposición y algunas de las pinturas que se iban a exponer en el Palacio de Bellas Artes, con nombres como Tamburini, Barrau, Cusi, Llovera, Fabres, Galofre, Alarcón, Marqués, y otros5.

De la Exposición se publicaron varia guías y folletos, pero sólo una era la oficial de dicha exposición; La guía Ilustrada, que se publicó para uso del visitante y que contiene el plano general del recinto (Fig.7.1 y 7.2). En la leyenda podemos observar que el número 41 designa la instalación del Excmo. Marqués de Campo $^{6}$ (Figs. 7.3 y 7.4).

${ }^{4}$ Las Provincias. Diario de Valencia, viernes $1 / 3 / 1888$, portada.

${ }^{5}$ Las Provincias. Diario de Valencia, viernes 27/4/1888, portada.

6VALERO DE TORNOS, Juan. Guía ilustrada de la Exposición Universal de Barcelona 1888, Barcelona: Editorial G. De Grau, 1888. 


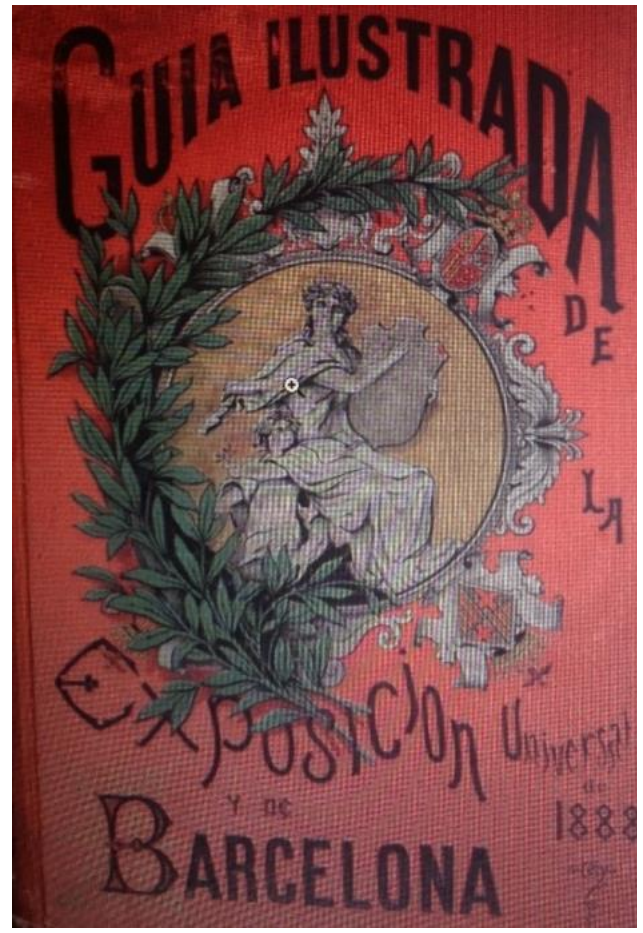

Fig. 7.1 Portada de la Guía Ilustrada dı Exposición Universal de Barcelona $18 \varepsilon$

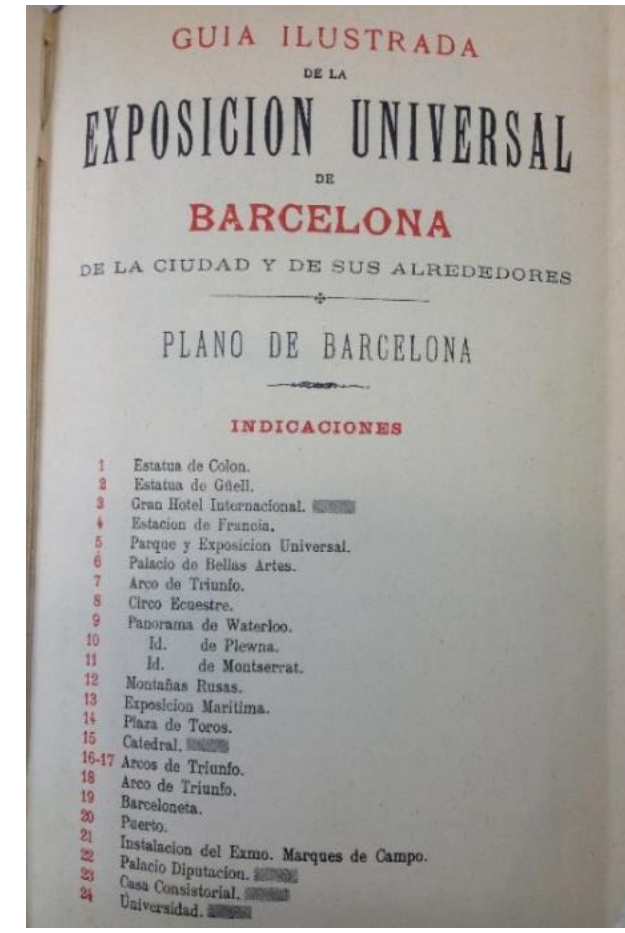

Fig. 7.2 Índice de la Guía Ilustrada d Exposición Universal de Barcelona 18

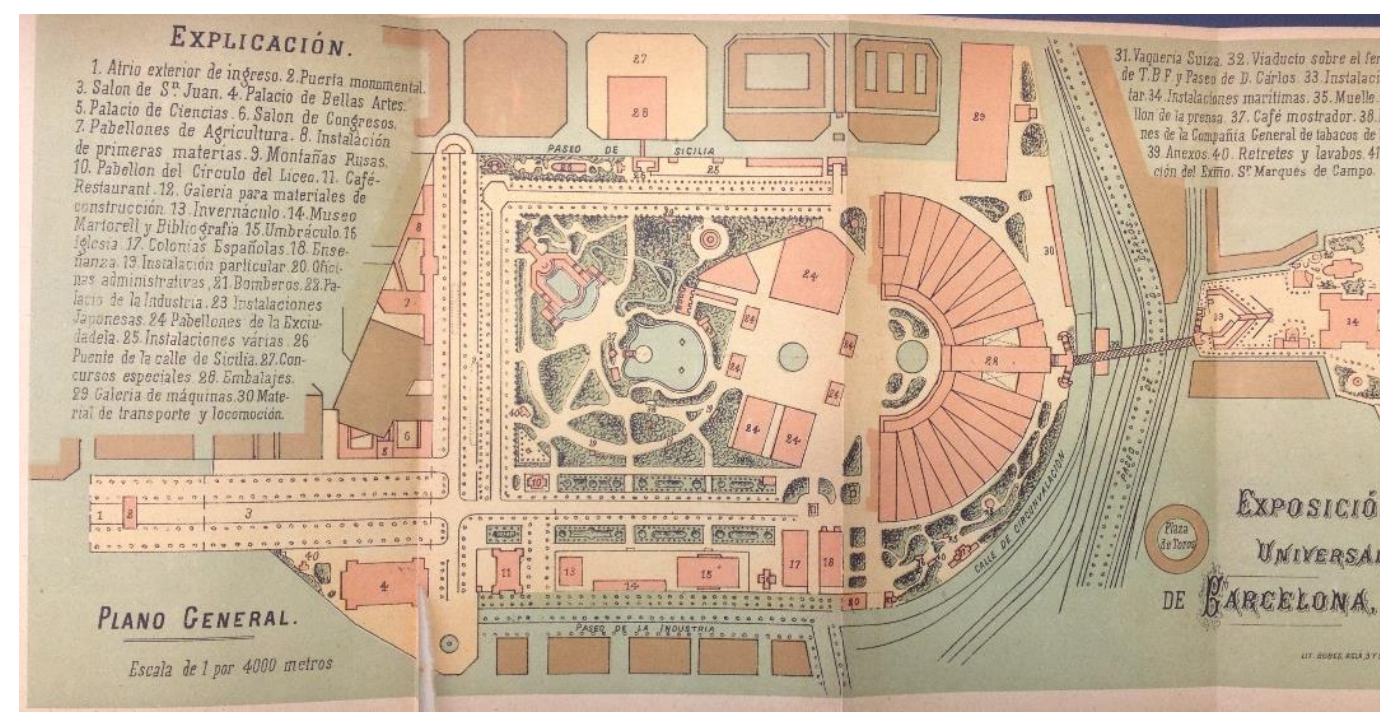

Fig. 7.3 Plano de las instalaciones de la Exposición Universal de Barcelona de 1888.Guía Oficial Ilustrada. 


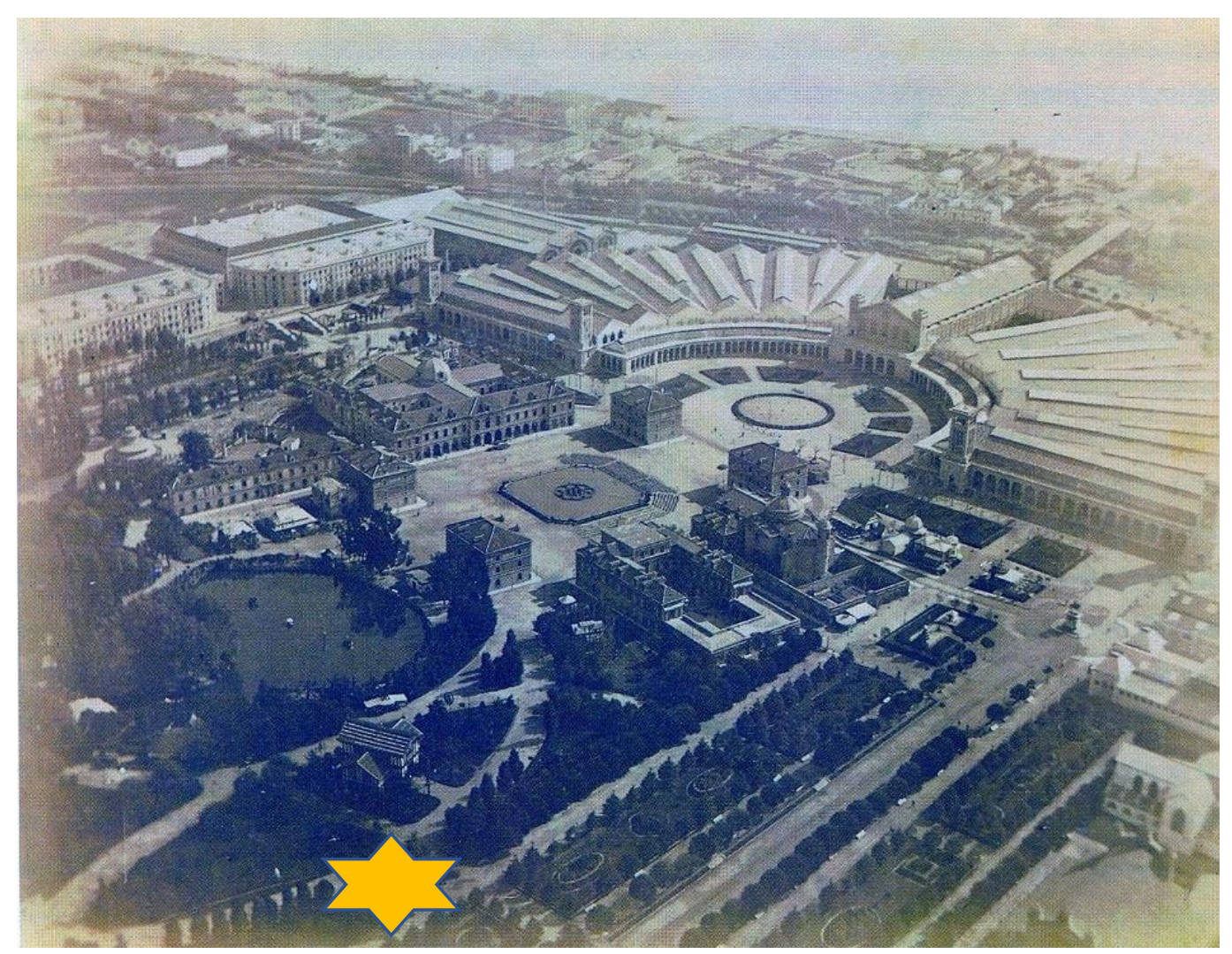

Fig. 7.4 Exposición Universal de Barcelona 1888.

Vista aérea del pabellón del marqués de $\mathrm{Campo}^{7}$

José Campo tuvo una implicación muy directa en la organización de la Exposición, y en la construcción y diseño del pabellón (Fig.7.5).

En La Dinastía en el mes de abril de 1888 se dice: "El marqués de Campo concurre también a la Exposición de Barcelona, y ha encargado a los industriales valencianos la formación de memoria, planos y presupuestos del proyecto de instalación. Ofrecerá este elegante aspecto: en la fachada y parte superior destacan el busto y escudo de armas del marqués; y el edificio, construido de ladrillo, maderas y cristales, y coronado por elegante cúpula, afectará la figura de un rectángulo con pórtico saliente" 8 .

7 Imagen publicada en https://archivo.fundaciomascort.com/inventari/vistaaerea-de-la-exposicion-universal-de-barcelona-de-1888-desde-el-globo-el-

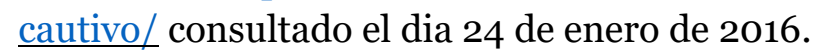

${ }^{8}$ La Dinastía, $6 / 4 / 1888$, p.2 
En otro ejemplar del mismo periódico del mes mayo de 1888 se dice:

“El Excmo. señor Marqués de Campo está construyendo en el interior de la Exposición un magnífico pabellón dividido en tres departamentos. En el del centro se expondrá la primera locomotora que vino á España y algunos modelos de embarcaciones. En las dos habitaciones laterales, ricamente decoradas y amuebladas, se exponen valiosos objetos artísticos. Las paredes de una de las dos piezas estarán cubiertas con «velours» de Génova y amueblada la misma con doce sillas de «peluche» combinándose los colores granate y oro. En la otra habitación, también tapizada de. «velours» de Génova, se colocará una magnífica sillería, estilo del renacimiento, de raso; en esta estancia se combinarán los colores verde y oro. El decorado de la parte exterior consistirá en mosaicos venecianos y azulejos. Los señores Pons y Ribas son los encargados de la dirección de los trabajos que deben ejecutarse para el decorado interior de dicho pabellón que está destinado a llamar poderosamente la atención de las personas que lo visiten tanto por el lujo como por la sencillez y buen gusto con que está proyectado" 9 .

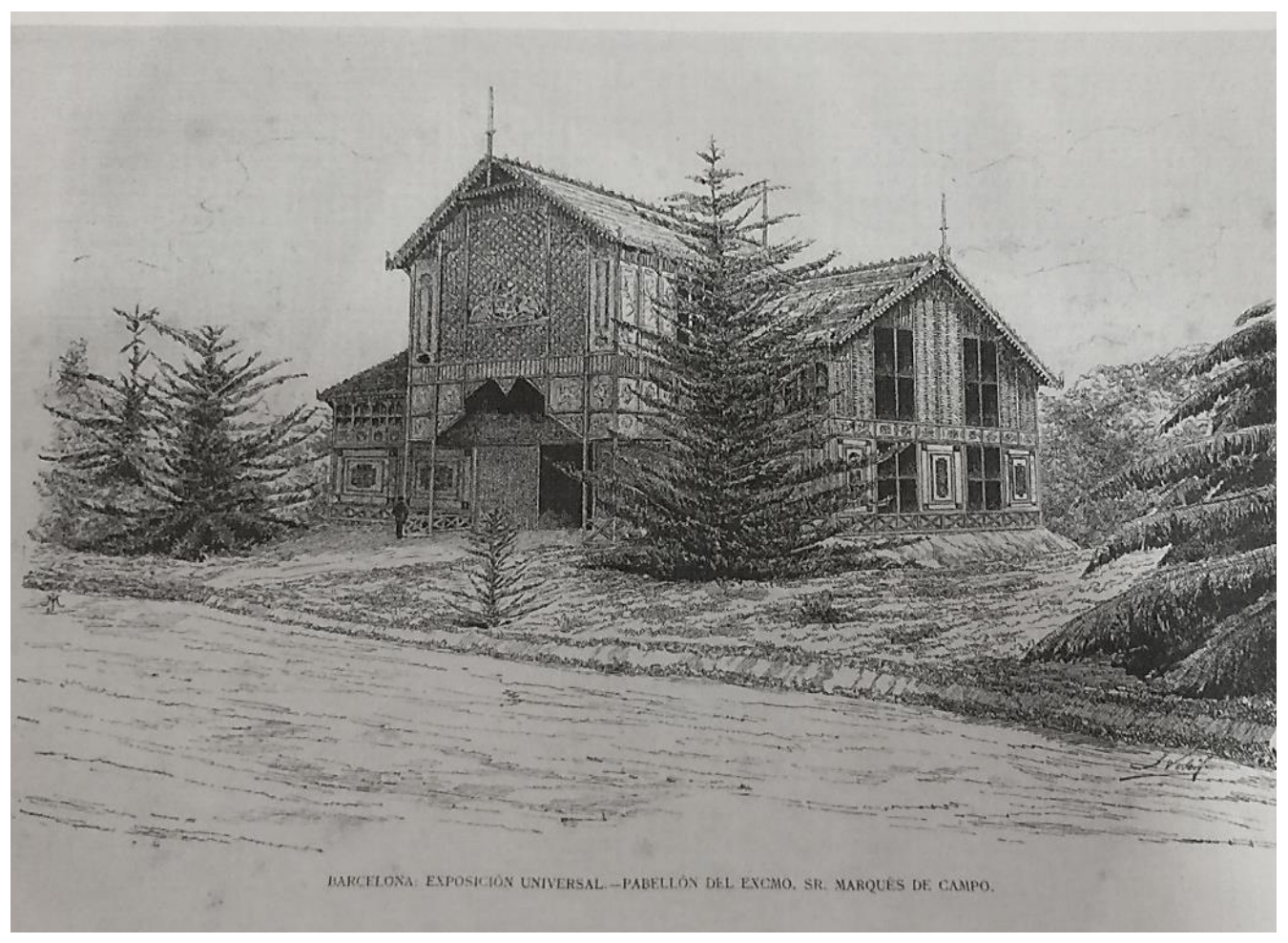

Fig.7.5. Pabellón del marqués de Campo. Exposición Universal de Barcelone Imagen publicada en La ilustración, 22 de julio de 1888.

${ }^{9}$ La Dinastía, 11 /5/ 1888, p. 2. 
La Exposición fue inaugurada el día 20 de mayo de 1888 y finalizó el 9 de diciembre de ese mismo año.

De la ceremonia de la inauguración del chalet del marqués se destacan estas palabras de las que varios diarios se hicieron eco ${ }^{10}$ :

"Barcelona: Con asistencia de unos 300 invitados se ha verificado la inauguración del chalet, que el marqués de Campo ha levantado en la Exposición. En el chalet se exhiben preciosos objetos de arte. Con motivo de la inauguración se ha celebrado un Iunch. El marqués de Campo, ha ofrecido regalar su pabellón al Ayuntamiento de Barcelona. Han brindado por el marqués de Campo, elogiando sus empresas, el comisario regio y los señores Settier, Planas, Jaunar y López, director de la Revista de la Beneficencia. Al acto han concurrido elegantes damas y el alcalde Sr. Rius y Taulet”.

La inauguración también fue publicada, entre otros, por el periódico La Dinastía en septiembre de 1888 en la que, además de esta ceremonia, se narra también la descripción del pabellón:

"Conforme habíamos anunciado oportunamente, en la tarde de ayer tuvo lugar la inauguración del magnífico chalet que el marqués de Campo ha construido en los jardines de la Exposición, junto al pabellón donde se fabrican tabacos filipinos.

A la hora anunciada presentóse el alcalde señor Rius y Taulet, quien felicitó al señor marqués en nombre de la Junta directiva de la Exposición.

Haremos gracia a nuestros lectores de la descripción de los numerosísimos y valiosos objetos que en la instalación que nos ocupa figuran, pues resultaría tarea sobrado prolija. Sólo enumeraremos de paso las secciones en que aquella se divide, que son cinco, por el orden siguiente: Fábrica de gas de Valencia, de la cual se encargó el señor Marqués en 1844; Sociedad de ferrocarriles de Almansa a Valencia y Tarragona, fundada por dicho señor en 1851, - en cuya sección figuran hermosas fotografías de la línea de Almansa, estación de Valencia y líneas del Grao, Tarragona y Denia;- Flota de vapores, o sea vistas de los vapores correo a

${ }^{10}$ La Unión Católica, 15 /9/ 1888, p. 2 
Filipinas. cuyo servicio se adjudicó al señor Marqués en enero de 1880; Asilo de párvulos, fundado en Valencia por el propio señor en 1863 y, por último, objetos artísticos, procedentes del palacio que en Madrid posee el ilustre patricio valenciano, y entre los cuales figuran gran número de primorosísimos tapices, retratos al óleo y al carbón, bustos en bronce y en mármol, cajas y jarros de marfil, etc., etc. Después que los invitados se hubieron hecho cargo de los objetos expuestos, sirvióseles un lunch en un pabellón que se improvisó junto al chalet, ocupando lugar preferente el ilustre expositor, que tenía enfrente a los Excelentísimos señores don Francisco de P. Rius y Taulet y don Manuel Duran y Bas.

Llegada la hora de los brindis, iniciólos el señor alcalde, quien encareció los servicios que el señor marqués de Campo había prestado a España, protegiendo al desvalido, desarrollando la industria y fomentando el comercio. Añadió que, si otras pruebas no existieran, bastaría el interés que dicho señor habla demostrado por la obra más grande que ha emprendido España en el presente siglo, la Exposición Universal, para que se le considerara como uno de los más entusiastas amantes del progreso. (Aplausos.)

Terminó el señor Rius y Taulet dando las gracias al señor marqués de Campo por haber hecho donación a Barcelona del chalet cuya inauguración acababa de verificarse, y brindando por dicho señor.

El señor Siquier, de Valencia, brindó por los catalanes, a cuyo genio emprendedor atribuyó la realización de la Exposición Universal.

El señor Jaumar brindó por el marqués de Campo, a quien consideró como uno de los representantes del progreso humano.

Por fin, el distinguido director de la Revista. de Beneficencia, de Madrid, cuyo nombre sentimos no recordar, elogió al señor marqués por haber fundado en Valencia un asilo de párvulos, demostrando que no estaba reñida la opulencia con la caridad.

A este punto y con haber dado el señor marqués las más expresivas gracias a los concurrentes-que eran muchos, figurando entre ellos distinguidas damas-por haber correspondido a su invitación, se dio por terminado el acto.

Al subir el señor marqués al coche, la música del Asilo Naval ejecutó la «Marcha de los Infantes.» 
Olvidábamos consignar que la banda municipal amenizó el acto, ejecutando varias piezas con el acierto de costumbre"11.

Así pues, no hay duda de que la intervención del marqués en la Exposición Universal causó sensación por el pabellón, por su contenido y por todos los actos que se celebraron relacionados con él.

El pabellón fue objeto de muchas visitas y no sólo del público en general sino de personajes ilustres como por ejemplo el rey de Portugal. De esta visita la prensa publicó:

"El señor marqués de Campo, que fue el primero en asociarse al brillante certamen universal de Barcelona construyendo un espléndido chalet, donde se exhiben las manifestaciones de sus grandes y múltiples empresas, ha tenido la satisfacción de recibir anoche el siguiente despacho telegráfico del alcalde de dicha ciudad: S. M. el rey de Portugal se ha dignado honrar hoy con su visita el magnífico pabellón en que tiene V. E. hechas sus ricas e interesantes instalaciones, y felicito por ello con entusiasmo á V. E.-Rius y Taulet”12.

También recibió la visita de unos obreros de Valencia:

"Con motivo de haber visitado la Exposición de Barcelona una comisión de 27 obreros valencianos, el señor marqués de Campo ha recibido el siguiente telegrama de nuestro amigo el Sr. Peris Mencheta: "Obreros valencianos visitado Exposición, debido al apoyo del Ayuntamiento de Valencia y a la generosidad de V. E., facilitándoles medios para el viaje, le felicitan por mi conducto por su magnífica instalación, honra de la región valenciana, y piden a Dios guarde muchos años la vida de V. E. para bien de la patria,- Mencheta” 13.

\footnotetext{
${ }^{11}$ La Dinastía, 15 /9/ 1888, p. 2.

${ }^{12}$ La Correspondencia de España, 12 /10/ 1888, p. 2.

${ }^{13}$ La Correspondencia 16 /10/ 1888, p. 2. 
Según cuenta el Anecdotario Histórico Español, el marqués de Campo contribuyó en esas mismas fechas a la realización de la estatua de Colón, pero para no igualar al rey, que había donado para la obra la cantidad de 20.000 reales, él donó la cantidad de 19.999'50 reales ${ }^{14}$. La estatua se realizó a iniciativa del catalán Antonio Fojas que había vivido muchos años en América, y el costo de la misma superó con creces el presupuesto inicial.

En relación a la participación del marqués de Campo en la Exposición, contamos con dos fuentes que nos ofrecen noticias de la instalación del marqués y su contenido: la prensa, que dio cuenta de casi todas sus actuaciones en relación con su pabellón, y en especial La Ilustración Española y Americana y el catálogo de la instalación del marqués que describe con exactitud su contenido.

En el ejemplar de La Ilustración Española y Americana de fecha 22 de julio de 1888 se publicó un grabado (Fig. 7.6) ${ }^{15}$ que nos muestra el Pabellón del Marqués de Campo en la Exposición, con una descripción del exterior y de su interior ${ }^{16}$.

${ }^{14}$ OLMEDO DE CERDÁ, María Fernanda. Anecdotario histórico español. Valencia: Carena Editors, 2004, p. 125.

${ }^{15}$ Imagen publicada en La Ilustración Española y Americana, 22 de julio de 1888.

${ }^{16}$ La Ilustración Española y Americana, año XXXII, núm. XXVII, 22 de julio de 1888 p. 469 y 479. 


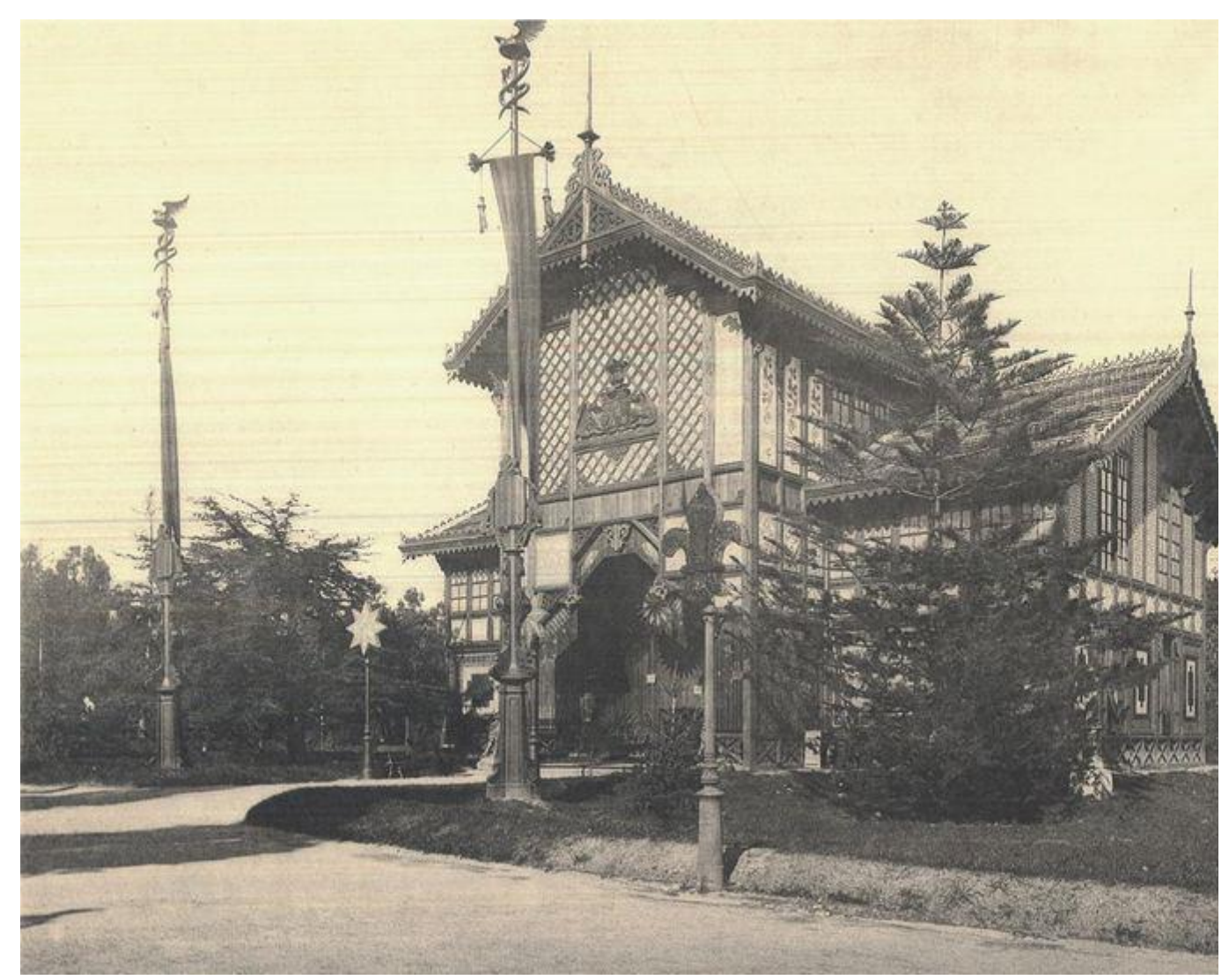

Fig. 7.6 Instalacion del marqués de Campo en la Exposición Universal de Barcelona de 1888. Imagen publicada en La Ilustracion Española y America

El pabellón era un grandioso y elegantísimo "chalet" decorado con cresterías de madera y mosaico de la fábrica de Nolla y Sagrera según diseño de Joaquín Ribera ${ }^{17}$. Este diseñador fue galardonado con la medalla de plata en esta

17 Nolla y Sagrera era una prestigiosa casa de fabricación de pavimentos de cerámica creada por Miguel Nolla y Bruixet durante la segunda mitad del siglo XIX. Su factoría supuso una interesante experiencia tecnológica y ornamental, e impuso un sistema de producción impactante para la época. Realizaron trabajos para Napoleón y Eugenia, para la Reina de España y también para países como Rusia y América.

Para más información ver:

BARBERÁ NOLLA, Rita. "Evocación de la fábrica de mosaicos de Nolla". En: Meliana, Bodas de oro de la Cooperativa Eléctrica 1923-1973, Meliana: Cooperativa eléctrica de Meliana, 1973.

RIDAURA, Concha. Vida y confort en la Valencia burguesa (1850-190o). Valencia: Generalidad Valenciana, 2006.

ROIG CONDOMINA, Vicente. La Real Sociedad Económica de Amigos del País de valencia como promotora de las bellas artes: el ejemplo de las exposiciones del siglo XIX en Anales 1999-2000, Valencia 2001-vol II, p. 929. 
exposición por la dirección del proyecto del pabellón del marqués de Campo ${ }^{18}$. Al parecer el diseño fue presentado como proyecto en un boceto de una acuarela sobre azulejos de 100 x $150 \mathrm{~cm}$.

La decoración interior con muebles de cedro y tapices de Génova corrió a cargo de Pons y Ribas, una prestigiosa casa de muebles de Barcelona, presentado el mobiliario un aspecto severo a la par que elegante y rico.

El artículo de La Ilustración Española y Americana continúa diciendo:

"el señor Campo expone todos los productos de su ferrocarril y su fábrica de gas de Valencia, notables marinas del célebre pintor Rafael Monleón que reproducen fielmente los veinticuatro vapores del marqués, varios cuadros de Murillo, Theniers y Goya; riquísimos y notables tapices antiguos; una magnífica colección de bandejas de plata repujada; varias arquillas de marfil de imponderable valor artístico, y otros objetos que demuestran la riqueza y preciosidad que ha debido el marqués atesorar en su palacio de Madrid.

Merece consignarse que en dicha colección se ve también la primera locomotora que funcionó en 1853 en el ferrocarril del señor Campo, modelos de buques de su flota, armas antiguas, fotografías de las mejores obras que él ha construido, los aparatos más notables que se construyen en su fábrica de gas y que por su ejecución sostiene victoriosa competencia con los del extranjero; labores de los albergados en su suntuoso Asilo, etc... El pabellón del Excmo. Sr. marqués de Campo, figura por su grandiosidad y magnificencia y por los múltiples objetos de arte e industriales que en ella se exhiben, entre las mejores instalaciones de nuestro certamen, no cediendo a ninguna importancia.

La Ilustración se complace en tributar al señor Campo sus más sinceros plácemes por el notabilísimo contingente que ha aportado a nuestra Exposición y que contribuye grandemente a la mayor importancia de la misma.

${ }^{18}$ FELIU, Joan. Dinero azul cobalto: el negocio americano de la cerámica en la provincia de Castellón en el siglo XIX, Castellón: Universitat Jaume I de Castelló, 2005, p. 142. 
Ojalá en España hubiese resonado tan patrióticamente en los oídos de todos los que podían haber contribuido al mayor lustre de la nación en nuestro certamen del trabajo y de la paz, como en los del Sr. Campo, el eco de la primera Exposición Universal celebrado da en nuestra patria"19.

Una vez finalizada la exposición, el marqués cedió las instalaciones a la ciudad para que fueran usada como biblioteca, pero con el paso del tiempo el pabellón entró en estado de ruina y fue derrumbado. De hecho, en la prensa se hicieron eco de la desaparición por ejemplo de unas estatuas que estaban a la entrada del pabellón y de las que nada más se supo ${ }^{20}$.

Antes de entrar en contenido no podemos dejar de mencionar que el pabellón fue objeto de una iluminación extraordinaria y de ello también se hizo eco la prensa. No podemos olvidar todas esas iluminaciones de sus palacios que hemos visto en otro capítulo de esta tesis y en el caso del pabellón no iba a ser diferente.

La prensa dijo: "El del Marqués de Campo reluce decorado exteriormente con azulejos. Así, el hierro, la madera pintada o sólo barnizada, las mayólicas, las telas de colores, se combinan al infinito y producen un conjunto cuyos tonos gratos y brillantes contrastan o armonizan con la vegetación”21.

"Hay en nuestra Exposición algo más mágico que la fuente: tal es la iluminación del pabellón del marqués de Campo. Os la describiré en otro número. Entretanto,

${ }^{19}$ La Ilustración Española y Americana, año XXXII, núm. XXVII, 22 de julio de 1888 p. 469 y 479.

${ }^{20}$ ZABALA, Fernanda. 125 valencianos en la historia. Valencia: Carrera editors, 2002 , p. 57.

La Monarquía, 9 /11/ 1888, p. 2.

La Dinastía, 7 /7/ 1890, p. 3.

${ }^{21}$ La Ilustración Artística, 12 /11/ 1888, p. 2. 
figuraos el carro de la Aurora derramando toda su lluvia de oro y rosa en un jardín paradisíaco, y tendréis idea aproximada de esta espléndida iluminación” ${ }^{22}$.

Vamos a hora ver el contenido del pabellón del Sr. Campo tal y como se describe en el folleto explicativo de la instalación que publicó la propia organización de la Exposición. Reproducimos a continuación varias imágenes del mismo (Figs. 7.7, 7.8, 7.9, 7.10, y 7.11)23.
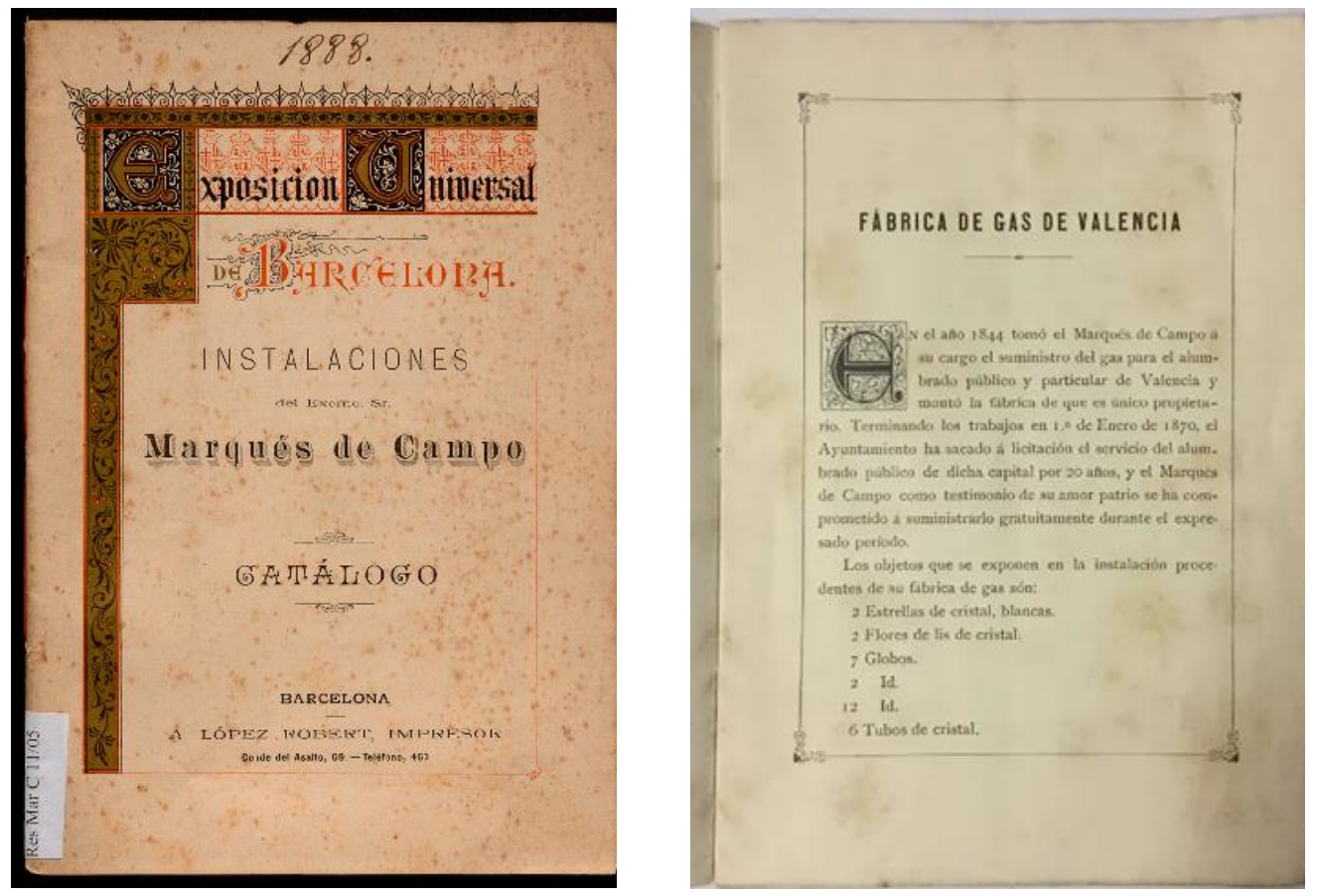

${ }^{22}$ El Camarada, 29 /9/ 1888, p. 5.

${ }_{23}$ ANÓNIMO. Exposición Universal de Barcelona. Catálogo de la instalación del Excmo. Señor Marqués de Campo. Barcelona: A. López Robert Impresor, 1888. 

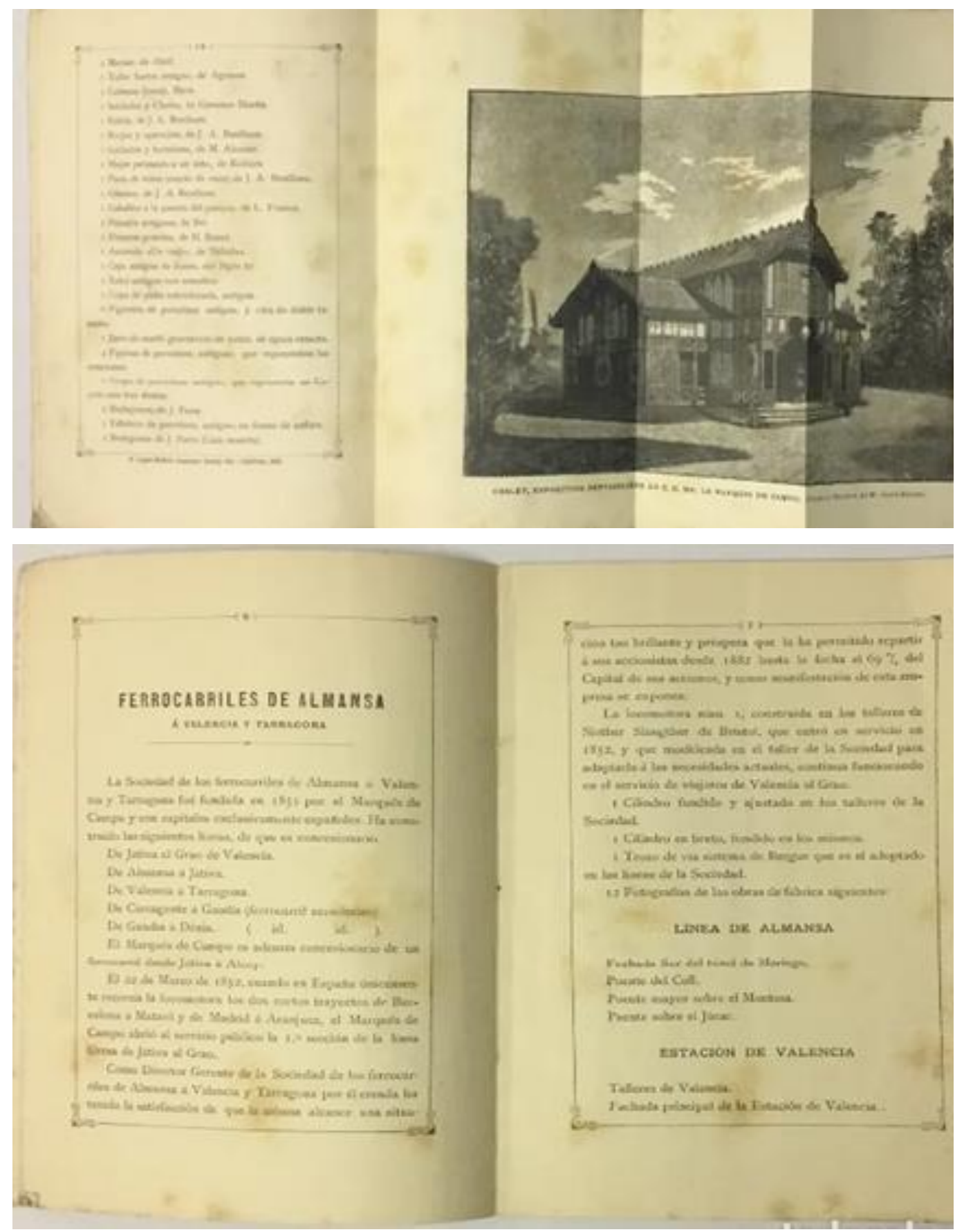


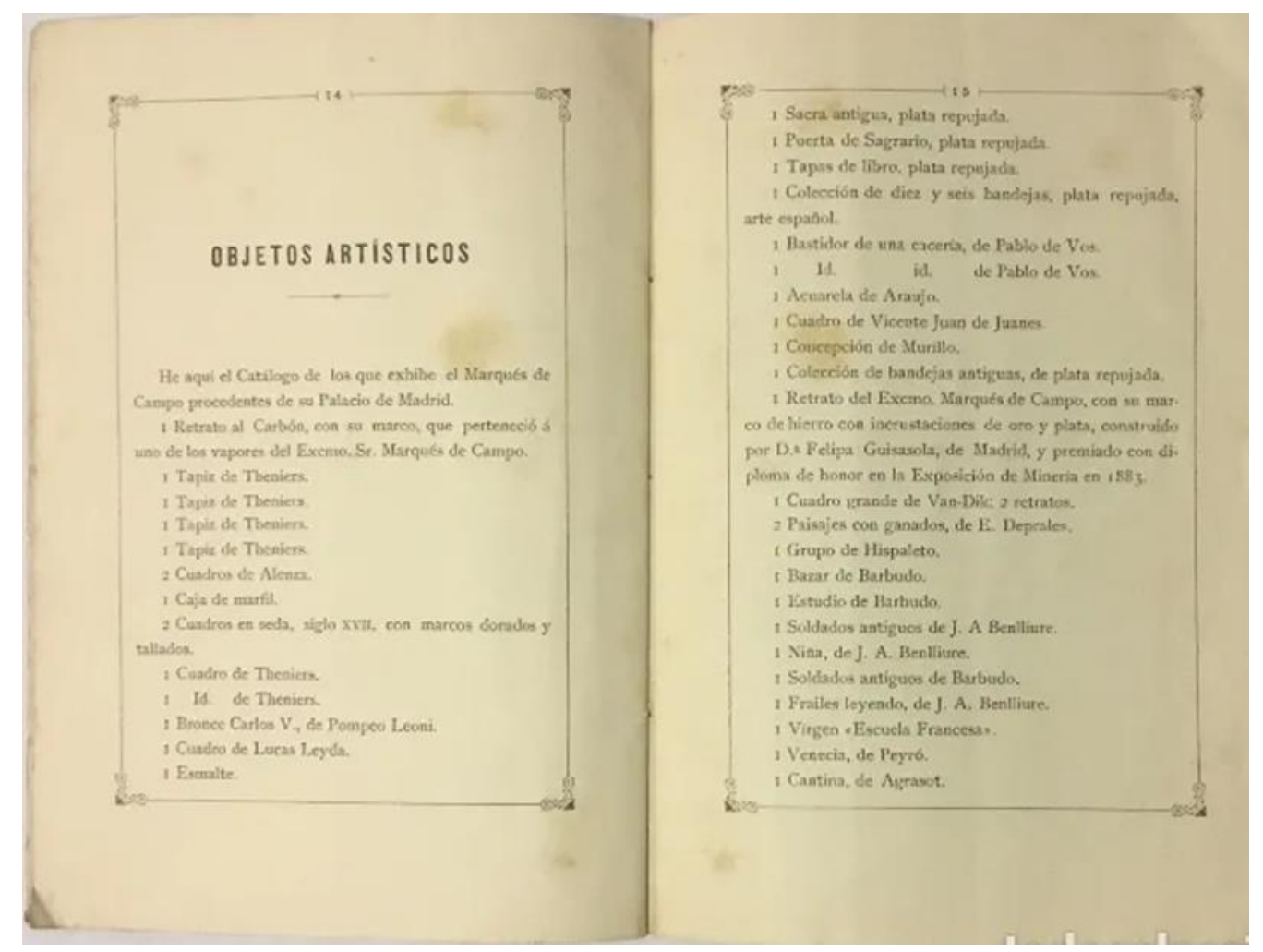

Figs. 7.7, 7.8, 7.9, 7,10 y 7, 11. Catálogo de las instalaciones del marqués de Campo en la Exposición universal de Barcelona 1888.

Biblioteca Nacional de Cataluña.

El catálogo separa los productos expuestos según su procedencia y describe los objetos expuestos por el siguiente orden, pero en este caso vamos a hacer hincapié sobre todo en las obras de arte:

A) De la Fábrica de Gas de Valencia expuso toda una serie de tubos de cristal, globos de cristal, lámparas, candeleros, lámparas góticas para aceite, faroles de metal, etc., que eran una novedad en ese momento y que seguro también tenían interés artístico por el diseño, pues eran piezas novedosas y muy caras, utilizadas para dar luz y decorar las casas de los más adinerados y por tanto debían ser objetos lujosos.

B) De la Línea de Ferrocarriles de Almansa a Valencia y Tarragona expuso la locomotora número I, fabricada en Bristol y que entró en servicio en 1852 y fotografías de las diferentes obras en las líneas férreas como puentes y fachadas de estaciones. Desconocemos el autor de esas fotografías, pero 
conociendo el carácter del marqués, no sería raro que fueran obra de los más prestigiosos fotógrafos del momento. También expuso fotografías de la línea del Grao, la línea de Denia y la estación de Valencia.

C) De la Flota de Vapores expuso 24 cuadros que son marinas del Rafael Monleón representando los 25 vapores de su flota; con nombres como Manila, Venezuela, Caridad, Julieta, Romeo, Reina Mercedes, San Agustín, España, etc.

D) Del Asilo de Párvulos expuso los planos, fotografías y varios bordados, entre ellos un manto de la Virgen de los Desamparados bordado en oro.

E) Y por último los objetos artísticos procedentes de su palacio del paseo de Recoletos de Madrid entre los que había:

Un retrato al carbón, con su marco, que perteneció a uno de los vapores del Excmo. Sr. marqués de Campo

Cuatro tapices de Theniers

Dos cuadros de Leonardo Alenza

Dos cuadros en seda, del siglo XVIII, con marcos dorados y tallados.

Un cuadro de Teniers.

Un cuadro de Teniers 24

Un bronce de Calos V de Pompeo Leoni

Un cuadro de Lucas Leyda

Un Esmalte

Una sacra antigua de plata repujada

Una puerta de Sagrario de plata repujada

Unas tapas de libro, plata repujada

Colección de 16 bandejas de plata repujada, arte español

Dos bastidores de cacerías de Pablo de Vos

Una acuarela de Araujo

Un cuadro de Vicente Juan de Juanes

Concepción de Murillo

\footnotetext{
${ }^{24}$ No es un error de repetición. En el catalogo de la exposición se publicó así: cuadro de Teniers; y a renglón seguido cuadro de Teniers. Y en realidad en el inventario de sus bienes aparecen dos cuadros de Teniers. Número de inventario 655 y 687 .
} 
Retrato del Excmo. Marqués de campo, con su marco de hierro con incrustaciones de oro y plata, construido por $D^{a}$ Felisa Guisasola, de Madrid, y premiado con diploma de honor en la Exposición de Minería de 1883

Un cuadro grande de Van Dyck; dos retratos.

Dos paisajes con ganado de E. Deprales

Un grupo de Hispaleto

Un bazar de Barbudo

Estudio de Barbudo

Un cuadro de J. A. Benlliure, soldados antiguos

Niña, de J. A. Benlliure

Virgen de "Escuela francesa"

Venecia, de Peyró

Cantina, de Agrasot

Marina, de Abril

Taller de sastre antiguo, de Agrasot

Cabezas (locos), Mark

Soldados y chulas, de Giménez Martín

Paleta de J. A. Benlliure

Brujas y aparición, de J. A. Benlliure

Soldados y hortelana, de M. Alcázar

Mujer peinando a un niño, de Richart

Plaza de toros (suerte de vara) de J. A. Benlliure

Gitanos, de J. A. Benlliure

Caballos a la puerta del parque, de L. Franco

Dos paisajes antiguos de Bri

Dos floreras grandes de H. Bonat

Una acuarela "un viejo" de Villodas

Una caja antigua de hueso, del siglo $X V$

Un reloj antiguo con esmaltes

Una copa de plata sobredorada, antigua

Seis figuritas de porcelana antigua y otra de doble tamaño

Un jarro de marfil guarnecido de metal, de época remota 
Cuatro figuras de porcelana, antiguas, que representan las estaciones Grupo de porcelana, antiguo, que representa un Cupido con tres damas Dos bodegones de J. Parra

Un pebetero de porcelana, antiguo, en forma de ánfora

Dos bodegones de J. Parra (Caza muerta)

Viendo el tipo de obras que expuso el marqués en 1888, no cabe ninguna duda de que José Campo era amante del arte y se rodeaba de buenos ejemplos que le gustaba exhibir. Aparecen obras de primera clase cuya autenticidad no se pone en duda en ningún momento, e incluso algunas de ellas pertenecían a pintores del ámbito valenciano como Rafael Monleón, Agrasot, Juan Antonio y José Benlliure, o el pintor Peyró, que en esos momentos estaban triunfando es las exposiciones nacionales y que fueron adquiriendo gran fama.

Por el momento alguna de esas obras está sin localizar y desconocemos también si fueron encargos o el marqués las adquirió directa o indirectamente por consejo de algún marchante o por voluntad propia, o si fue en alguna subasta, etc.

Todas estas obras, y muchísima más, aparecen reflejadas en el inventario de los bienes de los marqueses realizado a la muerte de Rosalía Rey, su primera esposa, en enero de 1889. Todos los cuadros, tapices, esculturas, y demás objetos aparecen distribuidos por las diferentes habitaciones y salones de sus residencias ${ }^{25}$. Todas estas obras y las demás que formaban la colección del marqués de Campo será analizada en profundidad en el capítulo correspondiente de esta tesis.

${ }^{25}$ AHPM, T36643, fols. 7439 y ss. 
No podemos olvidar que, a mediados del siglo XIX, estamos en una época en que la burguesía necesita imitar a la nobleza y a la aristocracia copiando su modo de vida, sus gustos y sus formas de comportarse, y entre ellos está el poseer una colección de arte y exhibirla en los palacetes urbanos o villas de recreo ante invitados y futuros socios de negocios; era una forma muy convincente de demostrar que se confirmaba la posición social y económica.

José Campo desplegó en la Exposición de Barcelona su patriotismo dejando constancia de los adelantos de sus compañías y a la vez la imagen de burgués ilustrado y culto. Es importante saber que su pabellón estaba en la parte de la exposición dedicada a la industria, no en la dedicada a las artes, pero no hay duda de que su riquísima decoración debió causar el asombro de quien lo visitó, aunque para ser sinceros más asombro debía causar visitar su palacio de Madrid, pues las obras que expuso en Barcelona solo fue una pequeña parte de su colección.

Su pabellón ganó varios premios de medalla de oro. Una por la iluminación ya que era esplendida y muy decorada. ${ }^{26}$ Otra medalla de oro fue por la platería; por la buena colección de bandejas y un magnífico marco de aceros incrustado de oro y plata ${ }^{27}$. Y el tercer premio también medalla de oro en la sección de Bellas Artes por un magnifico cofre de marfil, varias bandejas repujadas de plata, esmaltes, un tapiz y más cubiertas de plata repujadas y labradas ${ }^{28}$. Como se puede comprobar, esas piezas aparecen en el catálogo de la exposición que hemos visto y también en el testamento antes referido.

${ }^{26}$ LACAL, Saturnino. Libro de honor: apuntes para la historia de la Exposición Universal de Barcelona, premios concedidos y dictámenes que los productos expuestos merecieron del jurado. Tip. De Fidel Giró, Barcelona,1889, p. 149.

27 LACAL, Saturnino. 1889, p. 156.

${ }^{28}$ LACAL, Saturnino. 1889, p. 240. 
Como ya se ha dicho a lo largo de esta tesis, las obras de arte que fueron expuestas en Barcelona y el resto de su colección están en paradero desconocido, pero una vez finalizada esta tesis, es mi intención continuar esta investigación para poder localizar el mayor número de obras posibles que pertenecieron a la colección del marqués, para demostrar con más fuerza todavía que, si bien sus actividades económicas y políticas fueron el centro de su vida, también se dedicó ampliamente a actividades filantrópicas, benéficas, de promoción y mecenazgo artístico y como no al coleccionismo, constituyendo un claro ejemplo de promotor artístico de la España del siglo XIX.

Y para acabar el capítulo reproducimos con exactitud un comentarioresumen sobre la instalación del marqués de Campo escrita en el libro de Honor por Saturnino Lacal, que nos hace ver más claro todavía la impresión que causó el marqués en la Exposición ${ }^{29}$.

"El marqués de Campo

Ya no existe el ilustre patricio que ostentaba ese título desde que se restauró la dinastía en la persona augusta de Alfonso XII. Bajó a la tumba en 19 de agosto último, cuando a pesar de sus 75 años de edad, no esperaban aquel repentino accidente los que mejor conocían la enérgica naturaleza del acaudalado valenciano.

No hemos de enumerar nosotros los eminentes servicios que aquella poderosa inteligencia prestó a la industria nacional, ni lo que su espíritu emprendedor contribuyó al buen nombre de España en las apartadas regiones de ambos hemisferios que su grandiosa flota visitó con el pabellón de España. Pero precisamente porque ya no existe, nos consideramos con más libertad y más en la obligación de anotar el último de los rasgos brillantes de su historia, porque él se relaciona con la Exposición Universal de esta Ciudad.

La Comisión ejecutiva pidió al marqués de Campo que cooperara al brillo del Certamen; y el marqués de Campo, nunca sordo ante los casos de honra

29 LACAL, Saturnino, 1889, p. 73 y 74. 
nacional, hizo construir entre el lago y el paseo de los tilos un precioso Chalet de cedro con artísticos mosaicos. Según algunos que tiene motivos para saberlo, su costo total no bajó de 40,000 duros.

En su interior estableció el opulento banquero un verdadero museo que, siendo suntuosa ostentación de las artes decorativas por el mérito de muchos objetos, era a la vez, por la significación de otros, la síntesis de las principales empresas mercantiles e industriales que había llevado a feliz término.

Así, procedentes de su fábrica de gas en Valencia, expuso: estrellas, flores, globos, coronas y cien otras piezas de cristal blanco y de colore; mil diversos modelos de lámparas y otros aparatos de alumbrado en metales varios; el plano de la fábrica y las vistas de la misma.

Representando la Sociedad de los ferrocarriles de Almansa a Valencia y Tarragona, veíanse 12 grades fotografías de las obras de fábrica más notables en aquella línea; otras de la estación y los talleres de la Sociedad en Valencia; dos cilindros fundidos y ajustados en dichos talleres; y la locomotora número uno que construida por la casa Hother Slangther de Bristol, adquirióla el marqués de Campo para abrir el 22 de marzo de 1852 la $1^{\text {a }}$ Sección de la línea férrea de Játiva al Grao. Entonces la locomotora en España, únicamente recorría los dos cortos trayectos de Barcelona a Mataró y de Madrid a Aranjuez. Hoy aquella veterana de la tracción a vapor, ha sido rejuvenecida en los talleres de la Compañía y sigue funcionando en el servicio de viajeros de Valencia al Grao.

Desde el 30 de enero de 1880 en que se adjudicó al marqués de Campo la conducción del correo a Filipinas, consagróse a fomentar los intereses marítimocomerciales de España en los principales mercados del mundo, organizando líneas de navegación por Europa, Asia, América y Oceanía. Sin auxilio del Estado estableció la primera línea de vapores españoles al Pacífico; y a sus expensas envió en el Magallanes una lúcida Comisión científica, cuando en marzo de 1886, herido su orgullo patrio por no haber sido invitada España a la inauguración de las obras en el Canal de Panamá, resolvió que la gloriosa bandera había de tremolar dignamente en aquellos mares por ella descubiertos. 
Como manifestación de sus empresas navieras, expuso 24 primorosas marinas de Monleón que representan los 25 vapores de la flota que llegó a formar bajo la bandera española.

Del Asilo de niños fundado por el marqués en 1883 y desarrollado de una manera grandiosa en 1884, exhíbense planos, fotografías y valiosos bordados en blanco, en sedas y en oro, descollando entre estos un estandarte y un manto para la Virgen de los Desamparados.

Finalmente, de su palacio en Madrid, hizo traer el marqués de Campo multitud de joyas artísticas como tapices y cuadros de Teniers, cuadros de Lucas Leyda, de Juan de Juanes, de Murillo, de Van Dyk, de Barbudo, de Benlliure, de Peyró, de Agrasot, de Villodas, de L. Franco y de otros muchos; porcelanas, esmaltes y marfiles antiguos; bronces de Pompeo Leoni; y entre oros objetos que será prolijo enumera, dos magníficas y numerosas colecciones de bandejas antiguas de plata repujada.

El marqués vino a Barcelona para la inauguración de su Chalet; invitó a lo más selecto de la Sociedad barcelonesa y cuando al final un lunch, servido con la esplendidez que es fácil presumir, se levantó para brindar por la Exposición que se estaba celebrando, manifestó que recibiría honor especial si esta industriosa Ciudad quería aceptar como suyo aquel modesto pabellón. El Sr. Ríus y Taulet, en un sentido discurso, aplaudió el afán con que aquel venerable anciano había querido contribuir al éxito del Certamen; y en nombre de Barcelona, por esto y por su galante donativo, le dio un abrazo de gratitud.

Poco tiempo después el Sr. Alcalde telegrafiaba al marqués:

"Este ayuntamiento, en sesión de hoy, ha declarado a V.E. hijo adoptivo de esta ciudad, que recordará siempre con gratitud el interés que ha inspirado a V.E. y los importantes servicios que V.E. le ha prestado. Reciba V.E. por le acuerdo con que este Municipio acaba de honrarle mi más sentida y entusiasta felicitación. Ríus y Taulet.”

El señor marqués de Campo, contestó en los siguientes términos:

"Excmo. Sr. Marqués de Olérdola, alcalde de Barcelona: con emoción profunda he leído el lisonjero telegrama de V.E. en que se sirve trasmitirme el 
acuerdo de ese ilustre Ayuntamiento, declarándome hijo adoptivo de la gran ciudad de Barcelona. No encuentro palabras con qué expresar mi intensa y viva gratitud por tan inmerecida cuanto honrosa merced, y embargado por este sentimiento, que jamás podrá borrarse de mi alma, me complazco en reiterar a V.E, a la digna corporación que preside y al noble y laborioso pueblo que ha realizado el primer certamen universal de nuestro país, las más sinceras protestas de mi reconocimiento profundo, de mi admiración y de mi entusiasmo por sus brillantes éxitos. M. de Campo.” 



\section{Capítulo vii}

LA CONSTRUCCIÓN DE UN ALTAR EN LA IGLESIA DE TORRIJO DEL CAMPO, TERUEL, A EXPENSAS DEL MARQUÉS DE CAMIPO. ANÁLISIS ICONOGRÁFICO

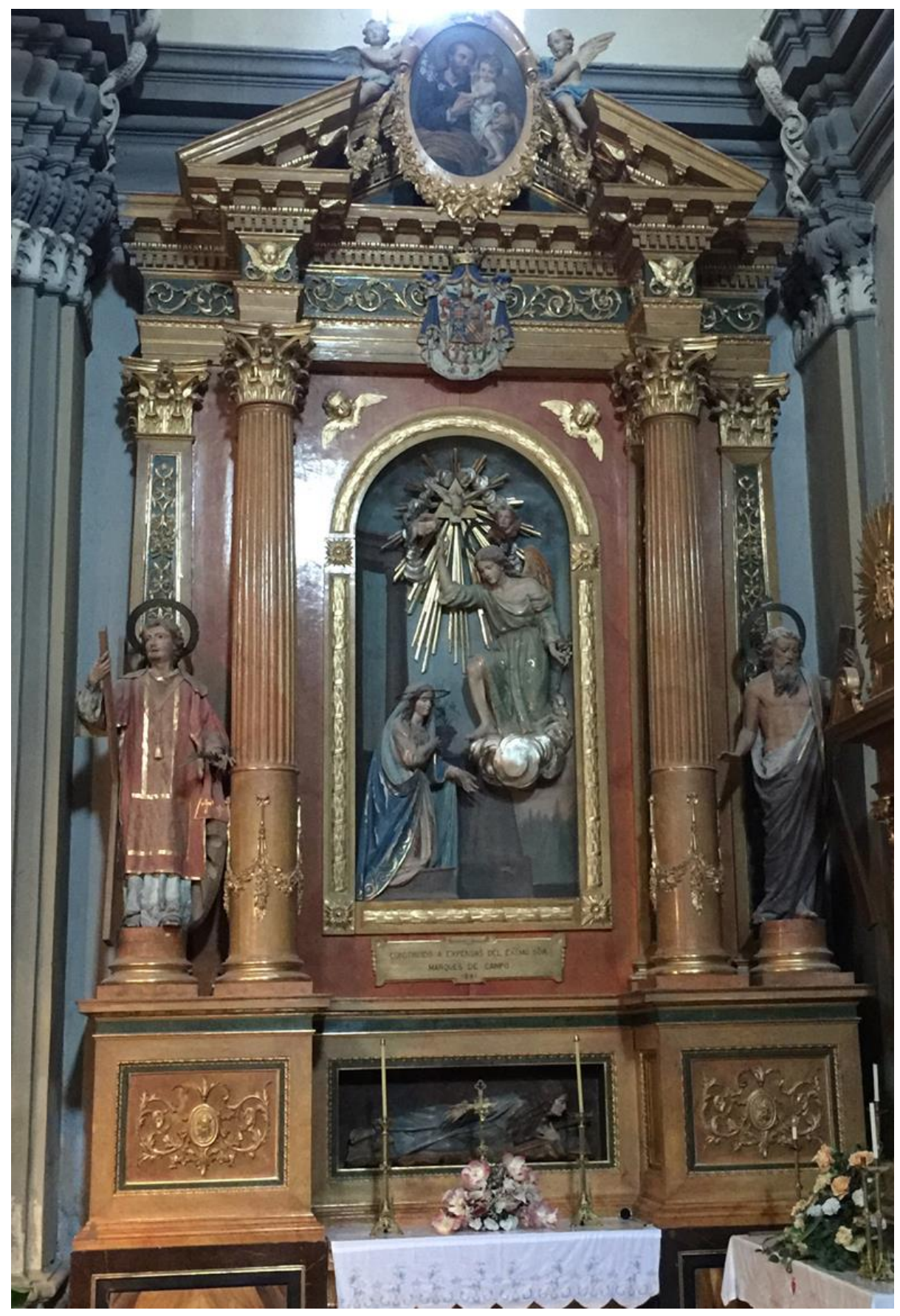





\section{Capítulo viII}

\section{LA CONSTRUCCIÓN DE UN ALTAR EN LA IGLESIA DE TORRIJO DEL CAMPO, TERUEL, A EXPENSAS DEL MARQUÉS DE CAMPO. ANÁLISIS ICONOGRÁFICO}

José Campo era hijo de Gabriel Campo Arpa, un comerciante natural de Torrijo del Campo, un pequeño pueblo de la provincia de Teruel. En 1881, cuando su posición política, económica y social era inmejorable, el marqués quiso realizar otras de sus iniciativas para dejar huella de su importancia y así ensalzar la memoria de sus antepasados, construyendo un altar en la iglesia de Torrijo del Campo y demostrando así que el apellido de la familia Campo había llegado lejos ${ }^{1}$.

En el pueblo de sus antepasados está la iglesia de san Pedro, de estilo barroco (Fig. 8.1). Consta de tres naves de cuatro tramos separadas por pilares cruciformes que sostienen bóvedas de medio cañón con lunetos; en el tercer tramo hay una cúpula sobre pechinas, y la cabecera del templo es plana prolongando la nave central. Destaca en la iglesia una torre de cinco cuerpos y decoración barroca de tradición mudéjar que es la más alta de la comarca.

\footnotetext{
${ }^{1}$ Recordemos que en esta tesis se ha hecho referencia anteriormente al cambio que el propio José Campo solicitó en su partida de nacimiento para eliminar el pasado humilde de su padre pasando de constar como vendedor de salsas en el mercado a constar como hombre dedicado al comercio.
} 


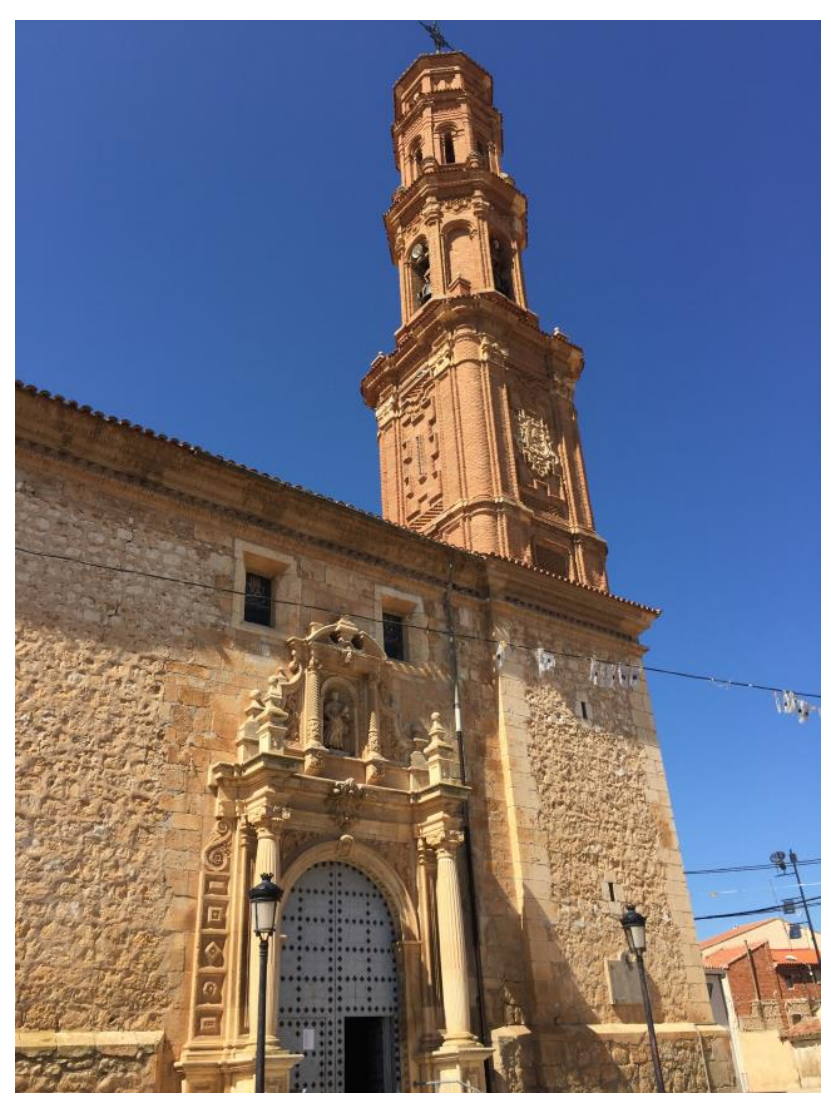

Fig. 8.1 Iglesia de san Pedro. Torrijo del Campo, Teruel. Fotografía de la autora

En su interior la decoración es barroca y en el primer tramo de la nave derecha, adosado a la pared encontramos hoy en día un altar con retablo mandado construir por José Campo en 1881 (fig.8.2).

No se nos puede escapar el hecho de que construir un altar con un retablo dentro de una iglesia era una posibilidad limitada sólo a unos pocos; sólo gremios, cofradías y personalidades muy importantes llevaban a cabo este tipo de obras, pues eran muy costosas, necesitaban un mantenimiento y conllevaban importantes donaciones a la iglesia. Pero esto no supuso un obstáculo para Campo, quien mandó traer el retablo desde Valencia a Torrijo del Campo en carro desmontado por piezas ${ }^{2}$.

\footnotetext{
${ }^{2}$ Según relato del actual archivero de Torrijo del Campo, D. Mariano López Serrano. 


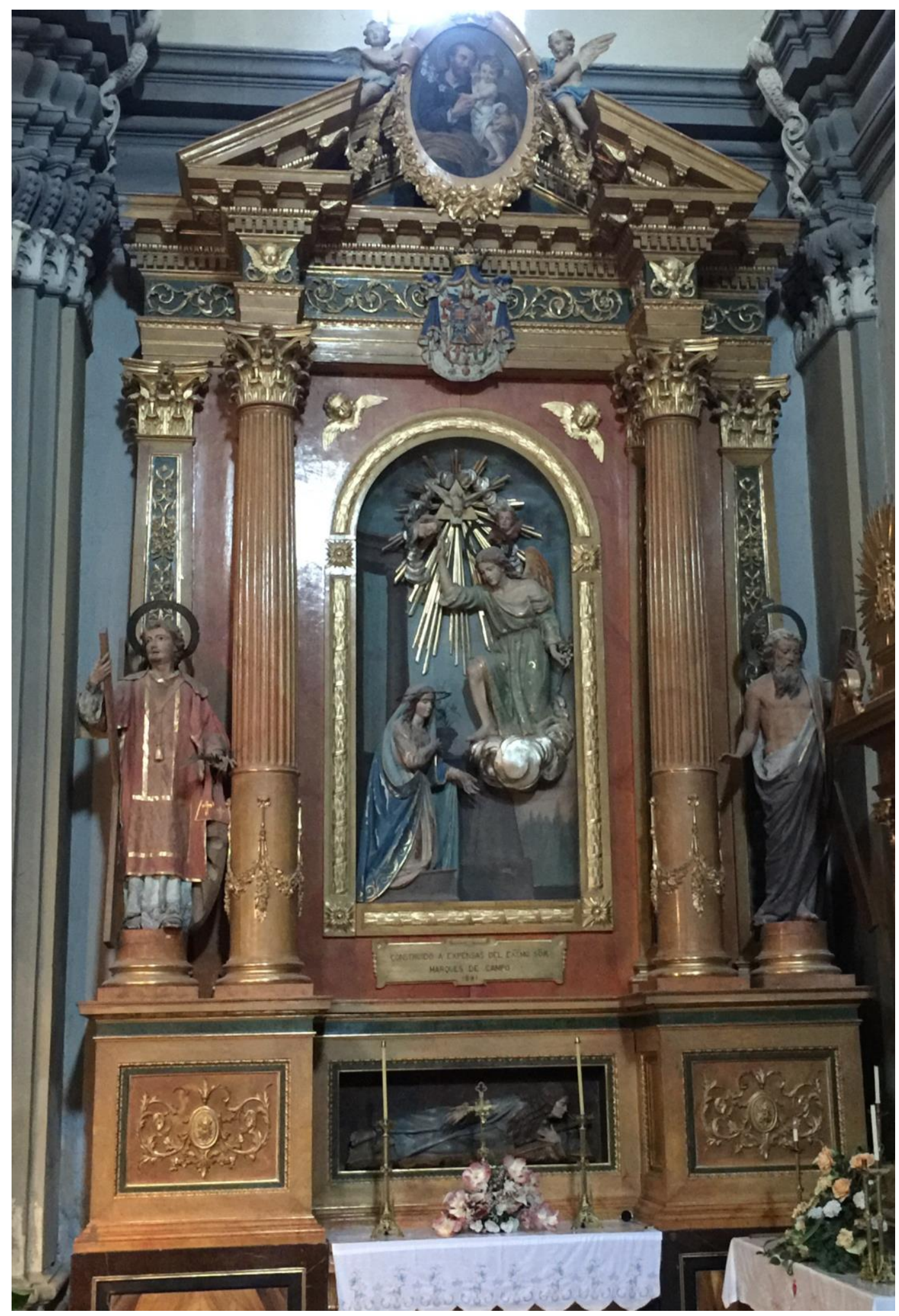

Fig.8.2. Altar y retablo construido a expensas del marqués de Campo. Iglesia de san Pedro, Torrijo del Campo. Teruel. Fotografía de la autora. 
Un altar con retablo es un objeto de devoción y contemplación religiosa, pero también fomenta la contemplación de la obra de arte que es por sí misma, independientemente del lugar en que se encuentre. En este caso es en una nave de una iglesia y refleja además el gusto de la persona que lo encarga y la clara intención de proclamar su devoción a la vez que su capacidad económica y que posee la cultura necesaria para ordenar una iconografía con una intención concreta como es el caso de este altar y retablo que ahora analizaremos, pues hay representaciones de los santos con los nombres de los miembros de la familia Campo y eso no ocurre al azar.

El altar y el retablo son de estilo neoclásico, de moda en esos momentos por los estudios que realizan los artistas, quienes recuperan los ideales griegos y romanos como muestra de buen gusto, éxito e inteligencia, que es exactamente la intención del marqués al realizar esta obra. El retablo podemos dividirlo en tres partes tanto verticalmente como horizontalmente, y aun pueda parecer poco habitual, para entender mejor la estructura y el mensaje de su iconografía, vamos a realizar el análisis de arriba a abajo 
En la parte superior del retablo o ático (Fig.8.3) hay un frontón triangular en cuyo centro esta situada, sustentadas por dos angelitos, una pintura de forma oval, de San José con el Niño3, aquí ya tenemos la primera alusión al promotor de la obra, de nombre José. En el centro del friso, decorado con roleos, está situado el escudo de armas del marqués, otra alusión al promotor para que nadie olvide quién es el que ha pagado la obra y distinguir a su familia del resto del pueblo que los vio nacer.

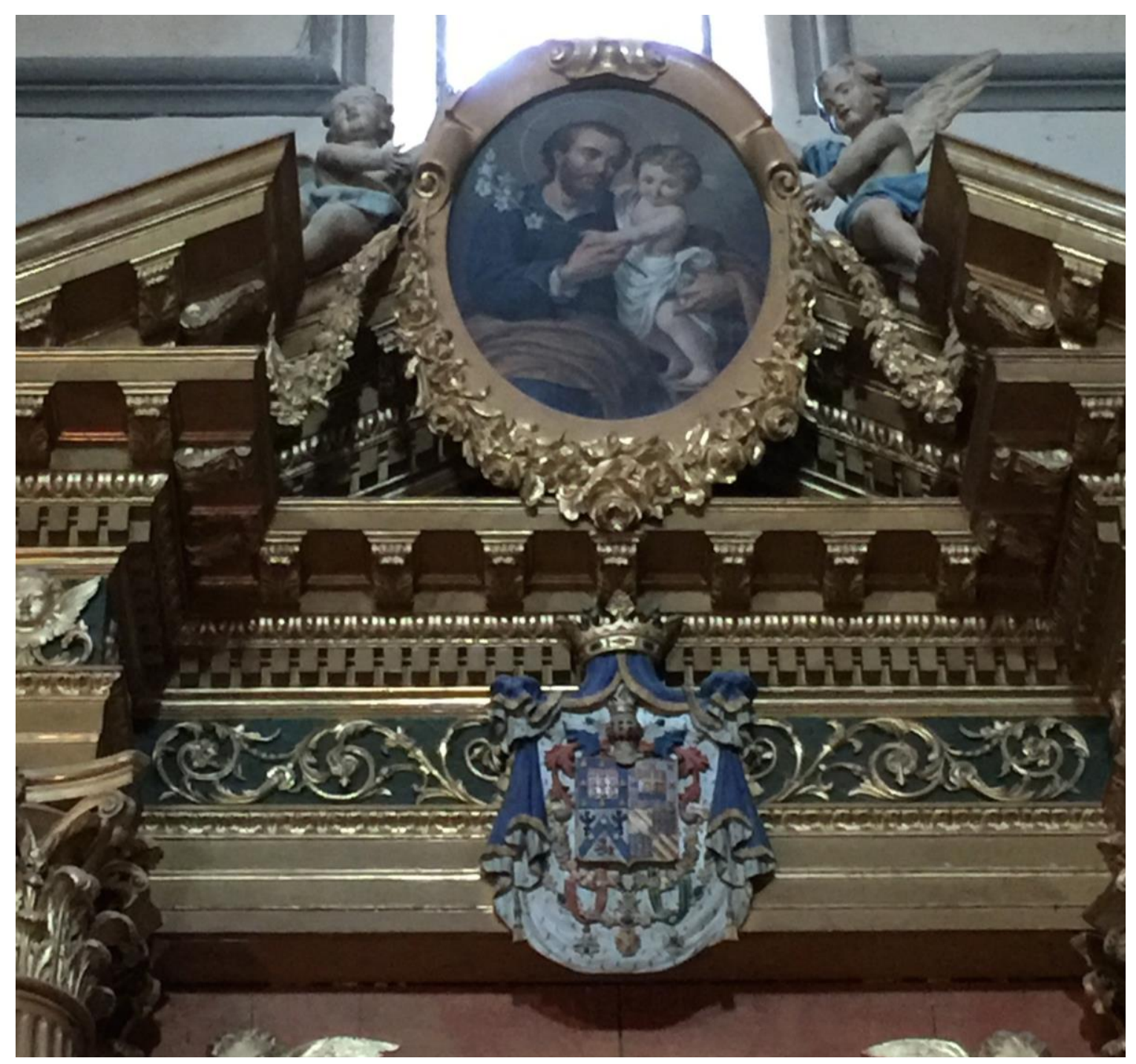

Fig.8.3 Parte superior del retablo. Imagen de san José y escudo de armas del marqués. Iglesia de san Pedro, Torrijo del Campo, Teruel. Fotografía de la autora.

3 Para la iconografía de san José ver GIORGI, Rosa. Santos. Barcelona, Electa, 2005, p. 184-194. 
En la parte o calle central del retablo hay una hornacina de madera con marco decorado con hojas, en cuyo interior hay un altorrelieve de la Anunciación4 (Fig. 8.4). En él aparece el arcángel Gabriel portando una azucena en la mano dando la buena nueva a la Virgen María quien, arrodillada sobre un escalón y con expresión calmada, extiende sus manos hacia arriba aceptando la voluntad de Dios. El fondo de la escena está realizado en pintura simulando arquitecturas de estilo renacentista donde se aprecia un muro y una columna con arquitrabe. En este caso la referencia a la familia es a su padre, de nombre Gabriel como el arcángel.

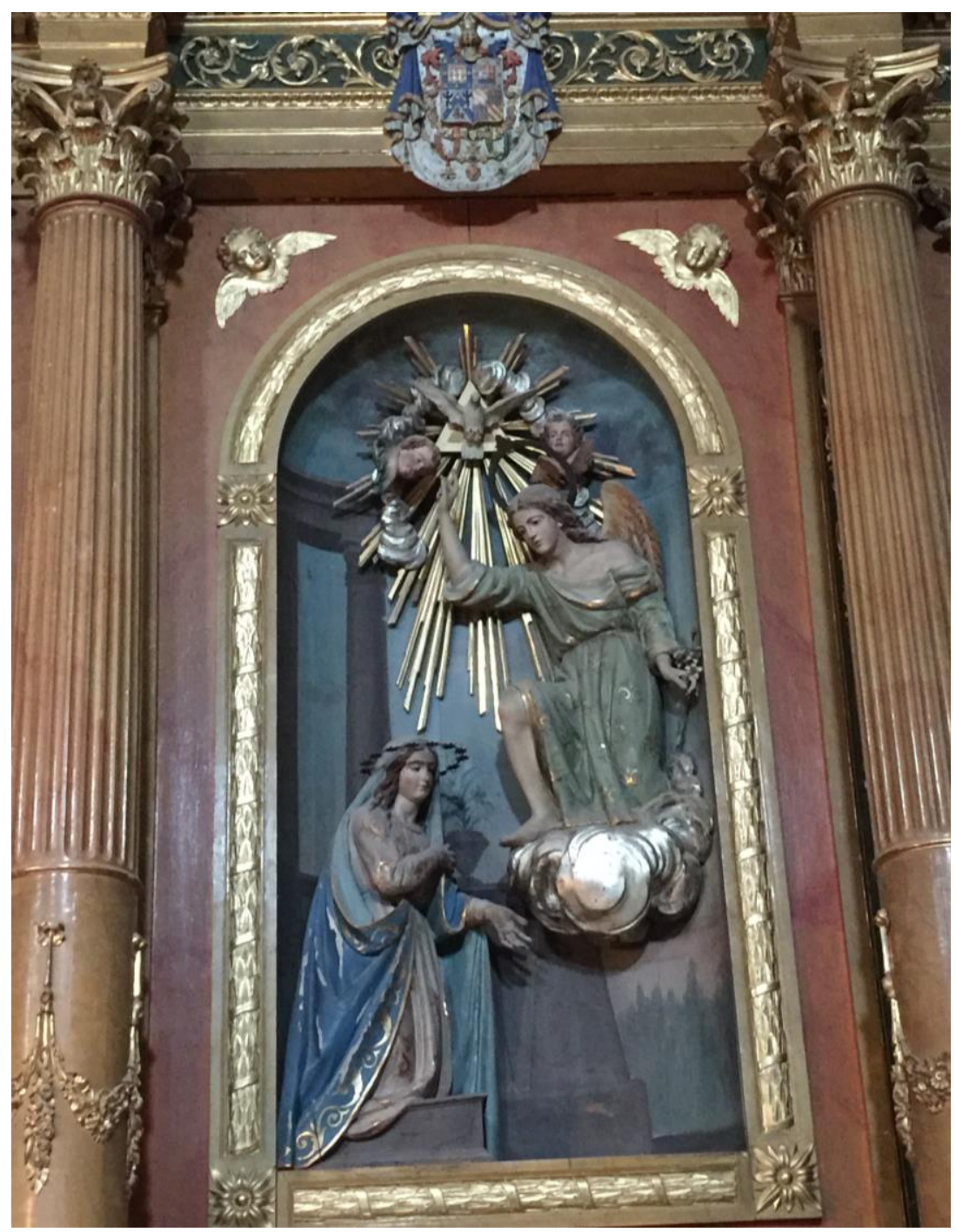

Fig.8.4 Hornacina central del retablo. La Anunciación. Fotografía de la autora.

4 La Anunciación aparece en la Biblia en: Lucas 1 (26-38).

Para la iconografía del Arcángel Gabriel ver GIORGI, Rosa. Santos. Barcelona, Electa, 2005, p.142-145. 
En la parte inferior del retablo, lo que sería el banco o predela, hay una urna rectangular con una imagen de santa Rosalía recostada sobre una roca, vestida con una túnica azul, el cabello suelto y venerando un crucifijo que lleva en su mano5 (Fig. 8.5).

Esta santa venerada en Palermo, Italia, aparece también en la portada del asilo que el Sr. Campo mandó construir en Valencia y del que ya hemos hablado; en este caso la referencia es en honor a su primera esposa Rosalía, de origen francés, quien siempre se mantuvo en un segundo plano dejando todo el protagonismo a su esposo y que falleció en enero de 1889.

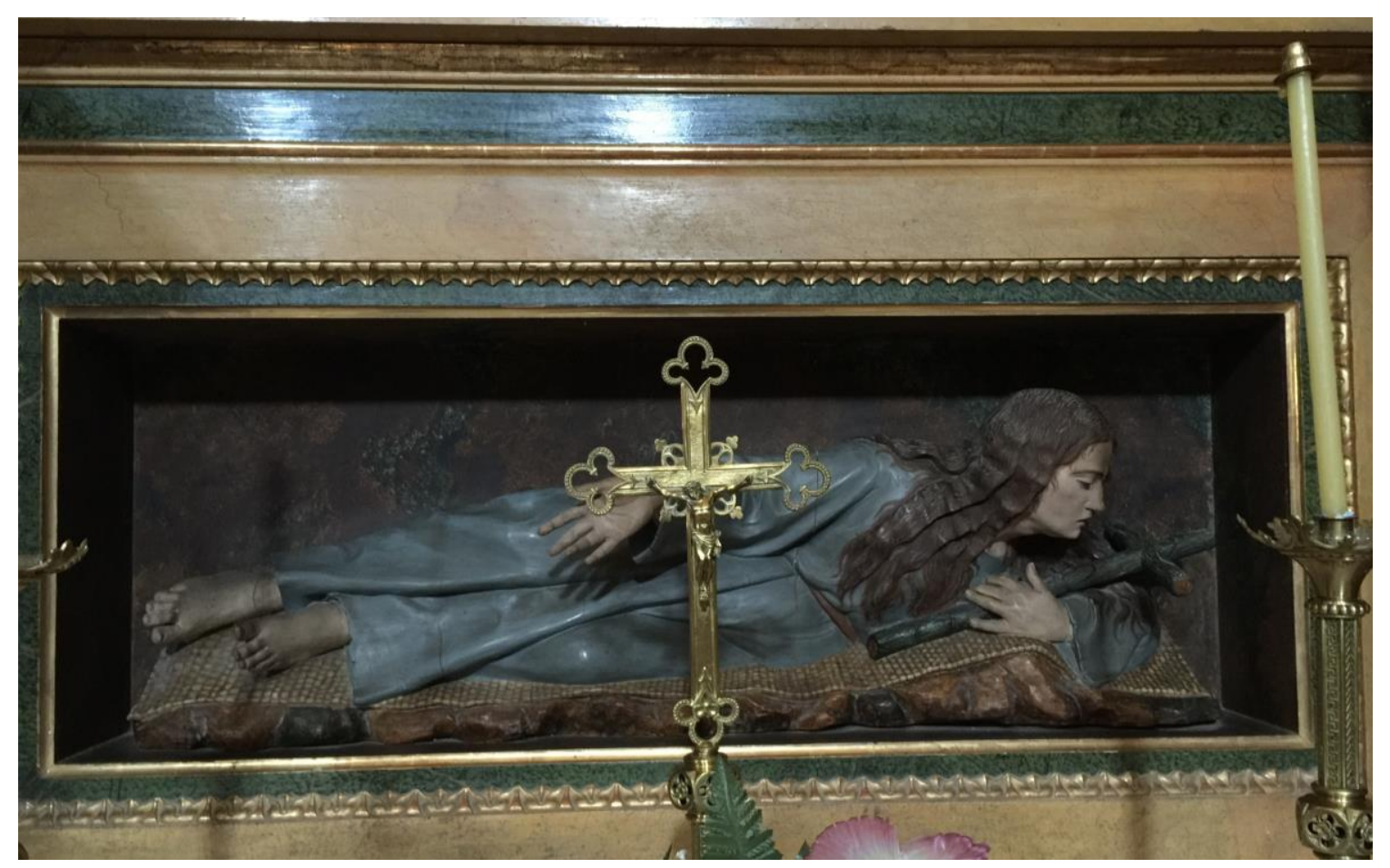

Fig.8.5 Urna del banco del retablo. Santa Rosalía de Palermo.

Fotografía de la autora.

5 Para la iconografía de santa Rosalía ver GIORGI, Rosa. Santos. Barcelona, Electa, 2005 , p. 318. 
Bajo la hornacina de la Anunciación y por encima de la urna con santa Rosalía hay una inscripción rectangular en la que se lee: "CONSTRUIDO A EXPENSAS DEL EXCMO. SR. MARQUÉS DE CAMPO 1881” (fig. 8.6); para que no haya duda alguna de quién está detrás de esta obra que destaca sobre el resto de la decoración de la iglesia, mucho más antigua y en muy mal estado de conservación.

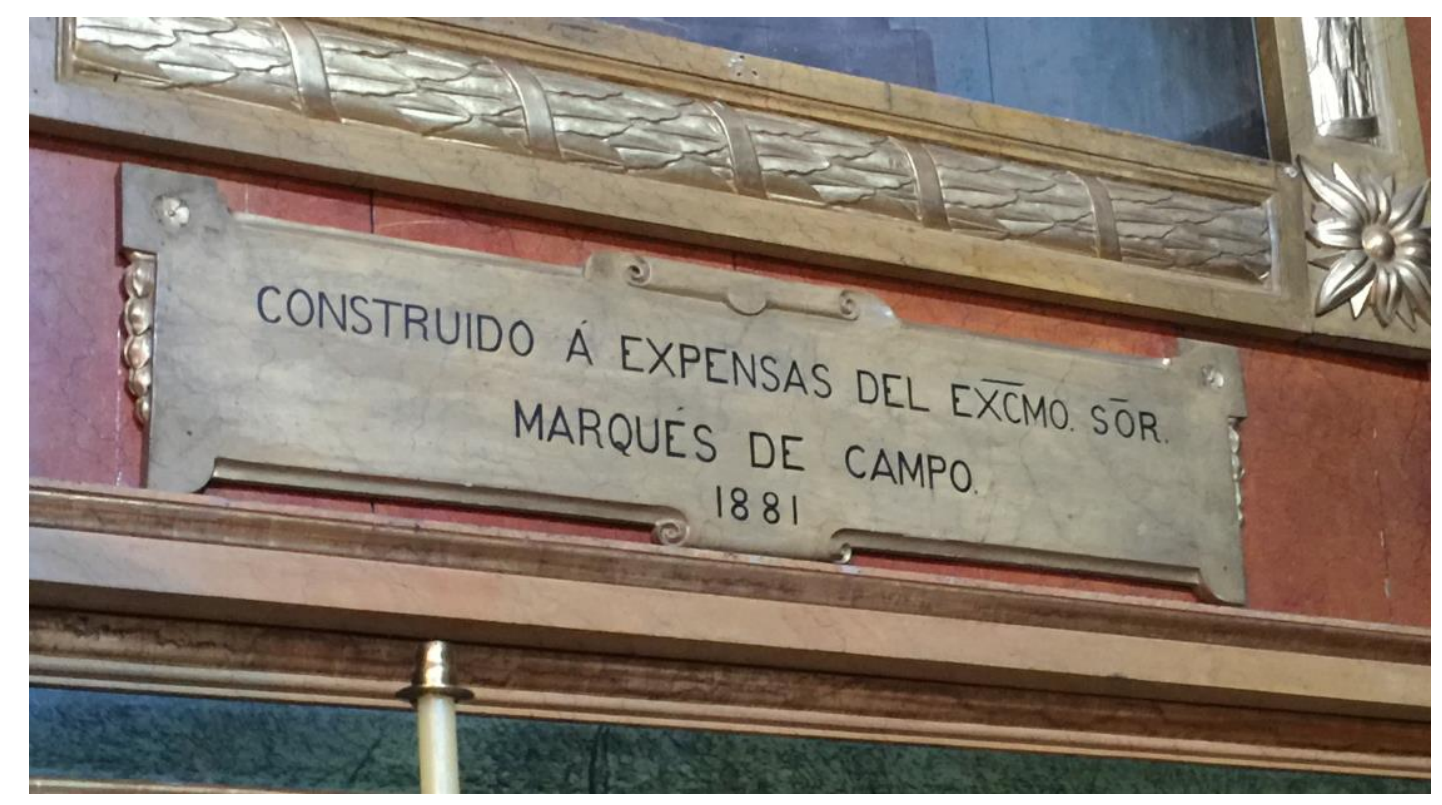

Fig.8.6. Altar y retablo del marqués de Campo, Detalle. Iglesia de San Pedro, Torrijo del Campo, Teruel. Fotografía de la autora.

$\mathrm{El}$ altar y el retablo forman un conjunto armonioso y proporcionado, y completa su decoración con dos columnas de fuste estriado y capitel corintio para mantener el frontón y en parte servir de entrecalles; y con dos pilastras con decoraciones a candelieri adosadas al fondo.

Delante de las pilastras y al lado de las columnas, en lo que serían las calles laterales, hay sendas figuras de santos: en la calle de la izquierda está san 
Vicente Mártir ${ }^{6}$ por ser el patrón de la ciudad de Valencia y porque su madre se llamaba Vicenta; y en la calle de la derecha está san Andrés7, en honor a su abuelo paterno originario también de Torrijo del Campo (Figs. 8.7 y 8.8).

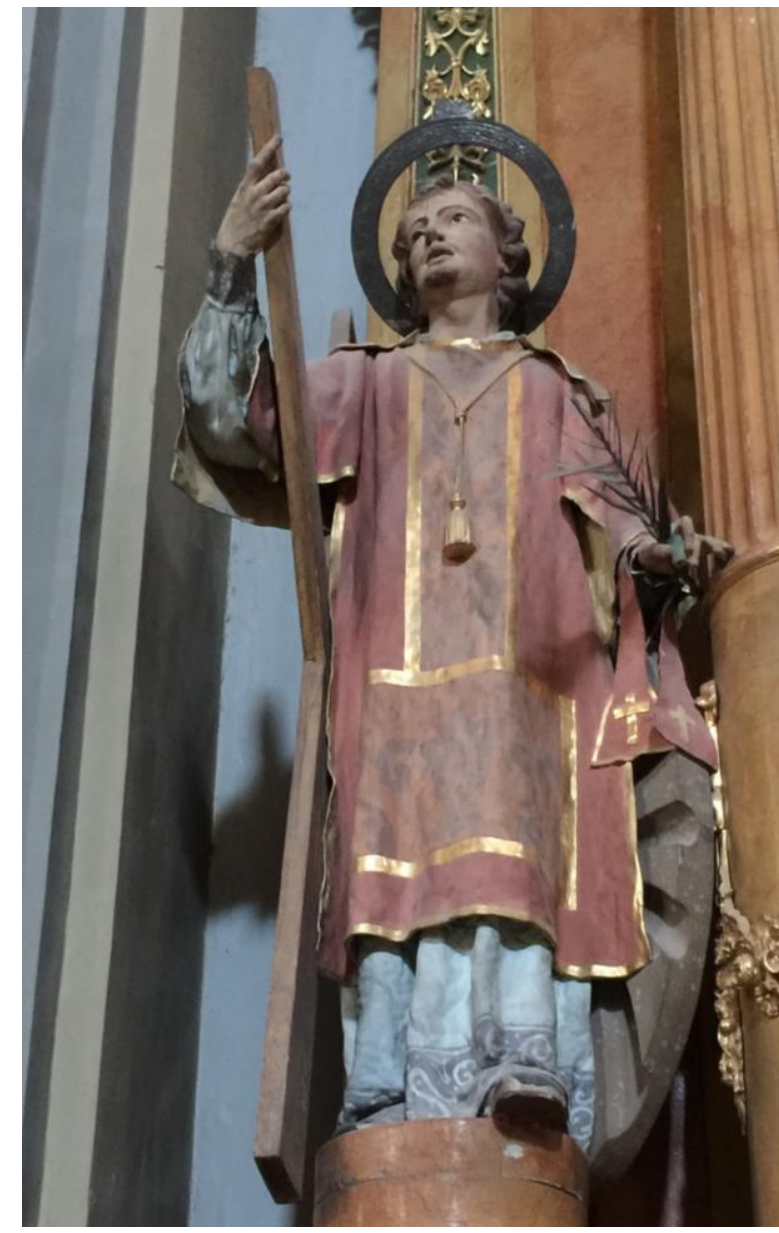

Fig.8.7 San Vicente Mártir. Imagen de la autora

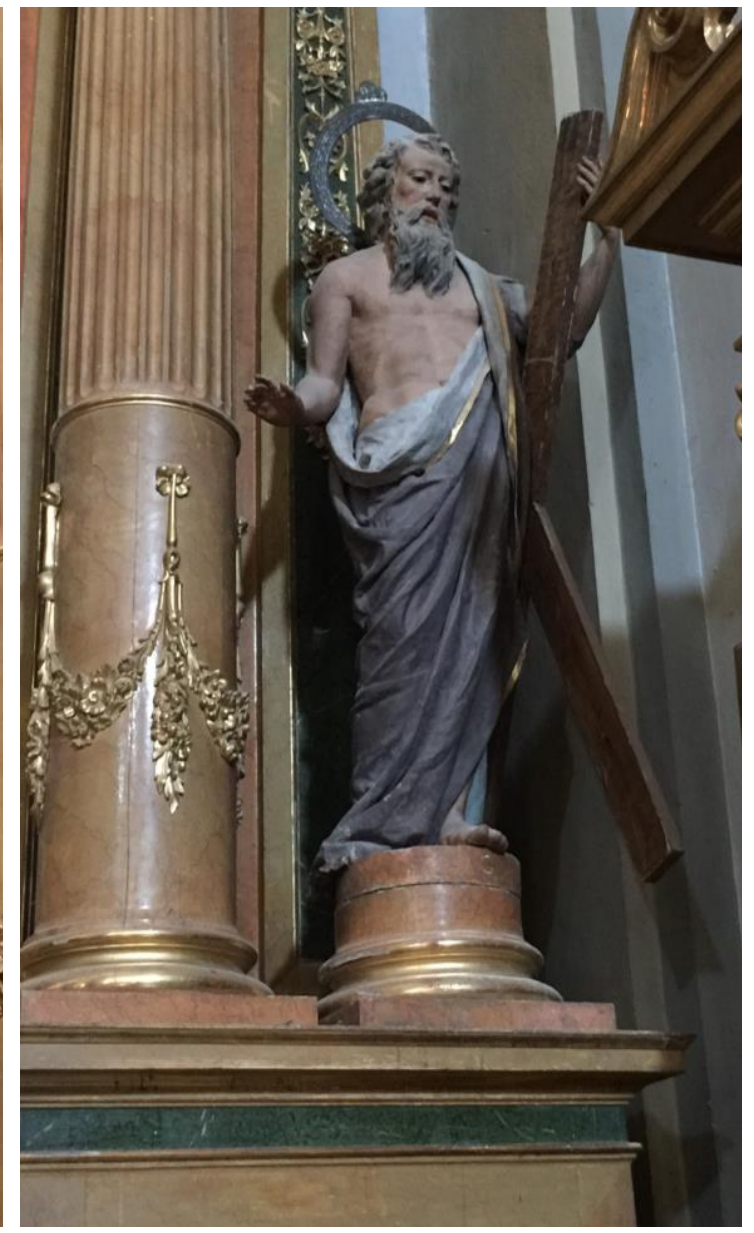

Fig. 8.8 San Andrés.

Imagen de la autora

Como hemos visto, el altar y el retablo del marqués para la iglesia de Torrijo del Campo es en su conjunto una obra costosa, hecha a mano, por encargo y con contrato, y que integra técnica pictórica, escultórica y formas arquitectónicas con un resultado espectacular. Fue necesario un conjunto de

\footnotetext{
${ }^{6}$ Para la iconografía de san Vicente Mártir ver MATEU IBARS, María Dolores. Iconografía de san Vicente Mártir, Tomo I. Pintura. Valencia, Institución Alfonso el Magnánimo, 1990.

7 Para la iconografía de san Andrés ver GIORGI, Rosa. Santos. Barcelona, Electa, 2005, p. 33
} 
artistas para realizarlo, empezando por un buen diseño, un buen carpintero para su estructura y el montaje, un escultor y un pintor decorador. Desconocemos en verdad el nombre de todos ellos, pero si tenemos en cuenta los artistas que en otras ocasiones han realizado trabajo para el Sr. Campo, podemos aventurarnos a decir que el diseño pudo ser de su ingeniero Antonio Revenga, quien ya había diseñado los arcos efímeros de Valencia y Madrid.

Las esculturas pudieron ser obra del mismo escultor que realizó las del asilo de Valencia, y la decoración pictórica pudo realizarla José Flores Vela y Vicente Pérez Vela, escenógrafos y familiares suyos a los que ya nos hemos referido en esta tesis 8 .

Si bien en siglos anteriores la nobleza y la iglesia han sido los defensores de las artes en general y quienes han realizado este tipo de obras por su coste y envergadura, conforme crece y evoluciona la clase burguesa esto cambia radicalmente y todo burgués adinerado y con posición política quiere emular sus acciones y hacer obras que perduren en el tiempo y dejen memoria de su paso por este mundo; por ello Campo construye este altar y retablo, para que las gentes de Torrijo del Campo admiraran su prosperidad y su riqueza, pero también para que hoy sigamos hablando de él.

\footnotetext{
${ }^{8}$ Según testimonio del archivero de Torrijo del Campo, D. Mariano López Serano, no hay ningún documento ni información sobre los autores del altar ni del retablo.
} 


\section{EL ESCUDO DE ARMAS DEL MARQUÉS DE CAMPO: SU COMPOSICIÓN HERÁLDICA}

Tras ver la espléndida representación del escuro de armas del marqués que hay en el centro superior del retablo, no podemos sino aprovechar esta ocasión para identificar e interpretarlo.

Para ello me he basado en un trabajo de José Antonio Vivar del Riego, para poder entender el interesante y a la vez complicado mundo de la heráldica, y además en la consulta de varios libros y diccionarios sobre heráldica9. Esta imagen será analizada junto con el escudo del cuadro de Simarro del capítulo 1 de esta tesis y el escudo de la fachada del asilo del capítulo 2 (aunque en este caso es escudo es muy pequeño, los colores no coinciden y las figuras no se aprecian) Así pues en las formas y figuras nos basaremos en el de la fachada del asilo y en el del retablo; y en los colores, por supuesto en del de madera del retablo.

9 VIVAR DEL RIEGO, José Antonio. "Taller de heráldica. Cómo diseñar y describir un escudo”. En: GALENDE DÍAZ, Juan Carlos (coord.). De Sellos y Blasones: miscelánea científica, Madrid: Universidad Complutense de Madrid, 2012.

CADENAS Y VICENT, Vicente de. Diccionario heráldico. $3^{\text {a }}$ edición, Madrid: Editorial Hidalguía, 1983.

COSTA Y TURELL, Modesto. Tratado completo de la ciencia del blasón, o sea, código heráldico-histórico, $2^{\mathrm{a}}$ edición, Madrid: Librería española, 1858.

GARCÍA CARRAFFA, Alberto. Ciencia Heráldica o del Blasón, según el método de los más insignes tratadistas, Madrid: Imprenta de Antonio Marzo, 1919.

MESSÍA DE LA CERDA Y PITA, Luis. Heráldica española: el diseño heráldico. $2^{\mathrm{a}}$ edición, Madrid: Aldaba Ediciones, 1998.

PARDO DE GUEVARA, Eduardo. Manual de Heráldica Española. $1^{\text {a }}$ edición, Madrid: Aldaba Ediciones, 1987.

PIFERRER, Francisco. Tratado de heráldica y blasón, adornado con láminas, Madrid: El Libro de Oro, 1858. 


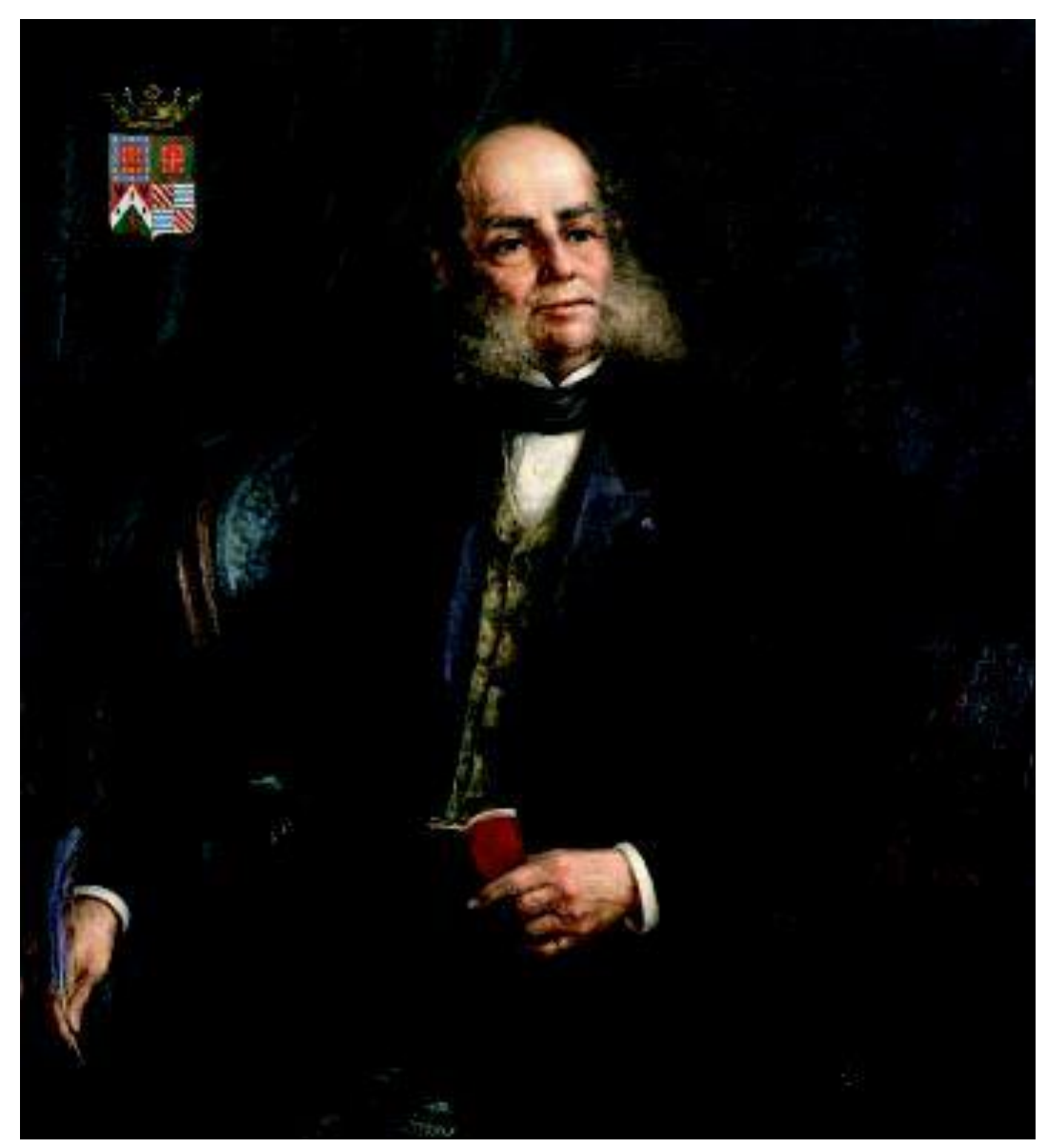

Fig.8.9 El marqués de Campo. Manuel Moreno Simarro 1964, Fundación Bancaja

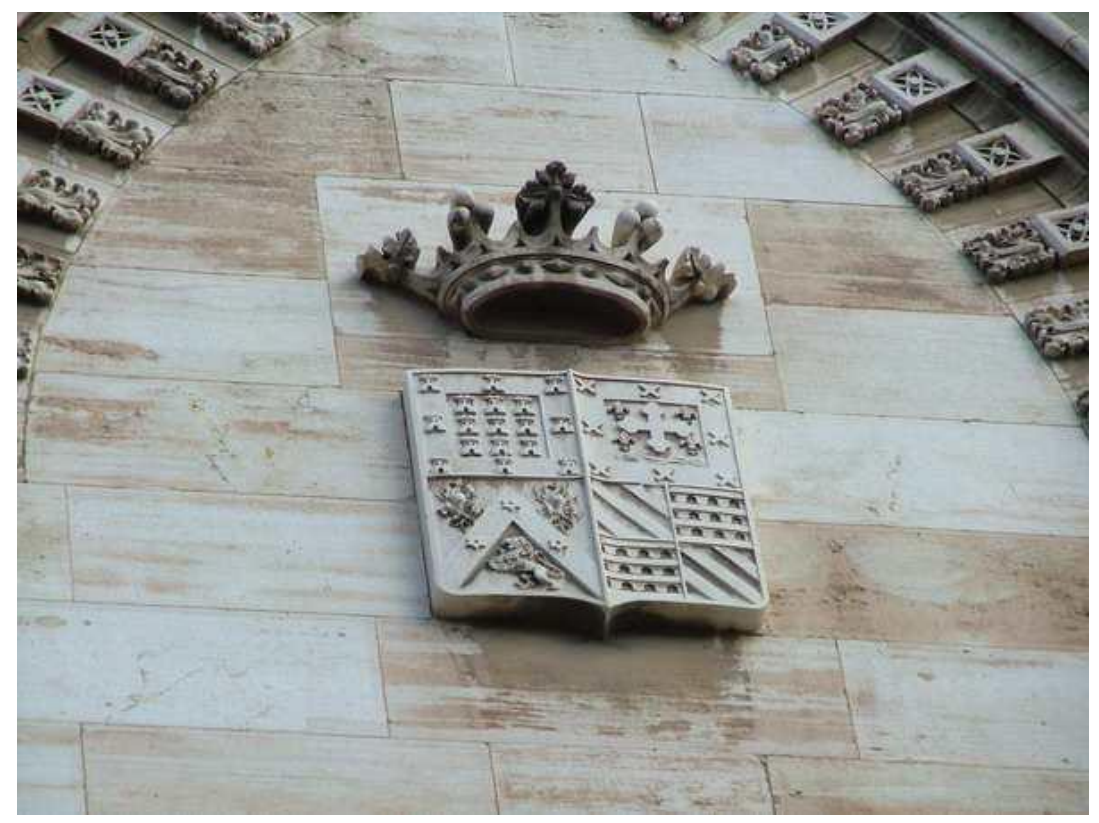

Fig.8.10 Escudo de armas del marqués de Campo. Fachada del asilo. Valencia 
Comenzaré el análisis diciendo que el escudo de armas del marqués de Campo tiene forma o boca española ${ }^{10}$, y como vemos en cualquiera de las imágenes, está dividido en cuatro cuarteles, es decir es un escudo cuartelado en cruz, y el cuarto de la punta siniestra está dividido también en cuatro.

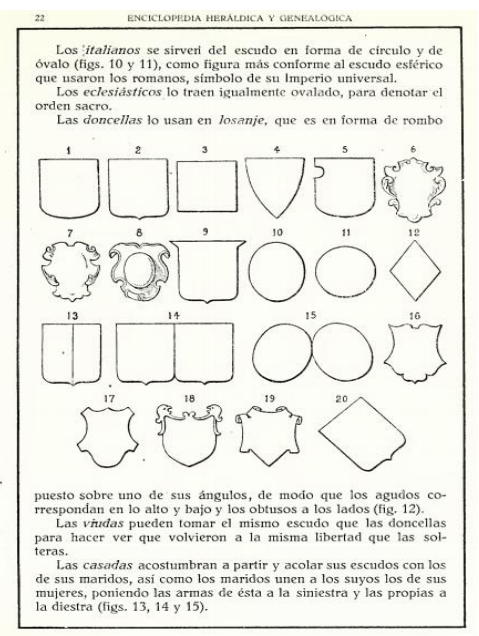

Fig.8.11 Formas de los escudos. El del marqués es el n. ${ }^{\circ}$ 2, forma española. Imagen de la Enciclopedia Heráldica y Genealogía de García Carraffa 1919.

La distribución en cuarteles permite representar en los cuatro cuartos ascendientes. En los dos de la diestra la familia paterna y en los dos de la siniestra la familia materna. Este tipo de división nació en la heráldica española, en la cancillería del rey castellano Fernando III, debido a la necesidad de representar en paridad la unión de los reinos de Castilla y León ${ }^{11}$. La diestra o siniestra se tiene en cuenta según la posición de quien porta el escudo y no la visión del que tiene enfrente.

10 GARCÍA CARRAFFA, Alberto, Enciclopedia Heráldica y genealogía HispanoAmericana. Tomo I, Ciencia Heráldica o del Blasón, Madrid: Imprenta de Antonio Marzo, 1919, p. 22.

${ }^{11}$ VIVAR DEL RIEGO, José Antonio. "Taller de heráldica. Cómo diseñar y describir un escudo”. En: GALENDE DÍAZ, Juan Carlos (coord.). De Sellos y Blasones: miscelánea científica, Madrid: Universidad Complutense de Madrid, 2012. P. 431 


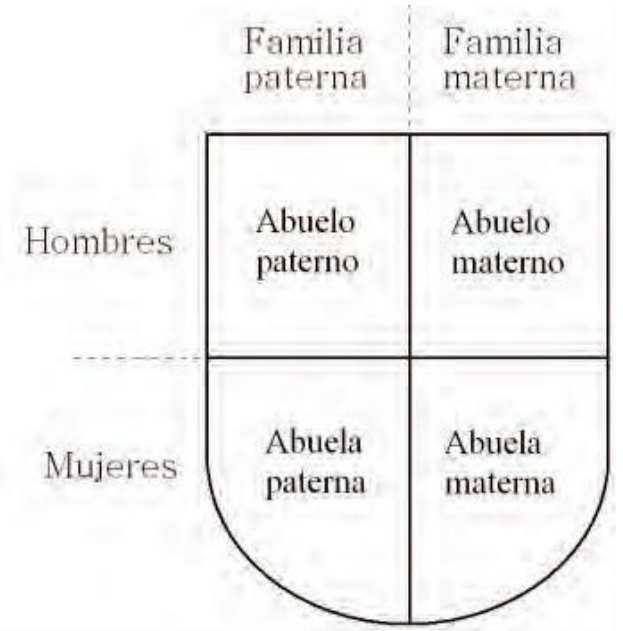

Fig.8.12 Configuración habitual para un escudo de cuatro costados.

En el caso del escudo del marqués el cuarto jefe de siniestra representa al apellido Campo, y sobre un campo de plata hay nueve torres gules con una bordura azur con ocho torres iguales.

El cuarto de punta de siniestra representa el apellido Arpa y sobre campo de plata hay un cabrio o chebrón azur con tres rosetas o estrellas de varias puntas agujereadas. Bajo el cabrio una figura de un león rampante sobre campo sinople y sobre el cabrio dos arpas personificadas.

El cuarto jefe de diestra representa el apellido Pérez, y sobre campo de plata hay una cruz amarilla trilobulada con cuatro flores de lis, rodeado todo con una bordura de aspas o armiños.

El cuarto de punta de diestra aparece a su vez cuarteado y representa al apellido Vela. En dos de los cuartos aparecen campos de plata atravesados por tres bandas de gules y en los otros dos, franjas de ondas en plata y azur. 


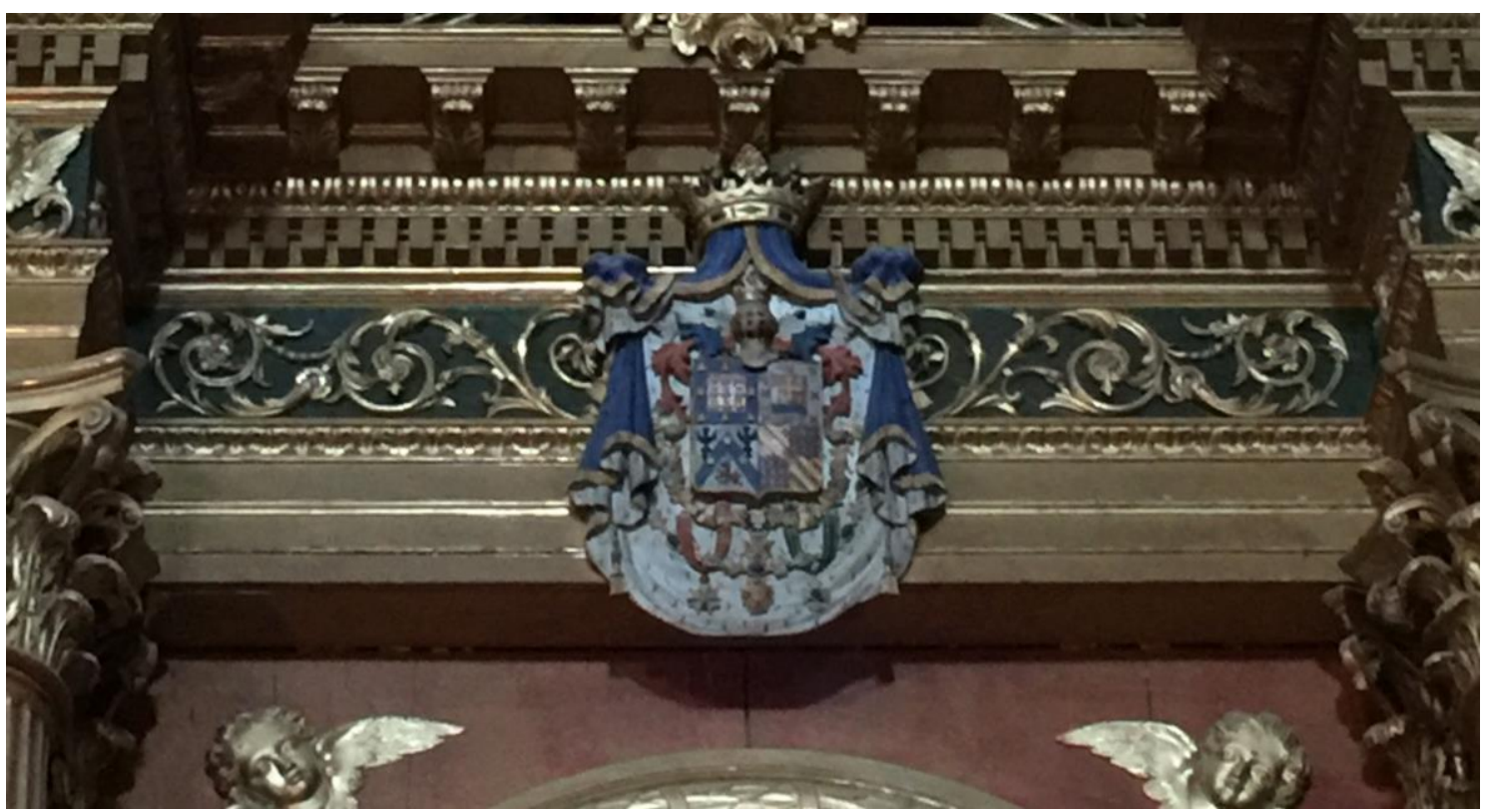

Fig.8.13 Escudo de armas del marqués de Campo. Iglesia de san Pedro.

Torrijo del Campo. Teruel. Fotografia de la autora.

Vamos a ver ahora las decoraciones exteriores del escudo que son muy importantes porque lo caracterizan y suelen ordenarse con arreglo al gusto o a la costumbre más que por unas normas establecidas como para con el interior, a excepción de coronas, bonetes $\mathrm{u}$ otros timbres ${ }^{12}$.

Con el paso del tiempo fueron añadiéndose nuevos elementos, bien caracterizadores (símbolos de órdenes, lemas y divisas, etc.), bien ornamentales (lambrequines, tenantes, banderas genéricas, panoplias pretendidamente simbólicas, etc.). Si el barroco mostró composiciones heráldicas enmarcadas con un aparato que sobrepasaba en ampulosidad el contenido del propio escudo, hasta el siglo XIX hay una tendencia hacia composiciones recargadas que pretenden resaltar la grandeza del personaje amontonando mantos, cordeles, coronas variadas, collares de órdenes, palmas, cimeras y cuantos elementos pudieran encontrarse en los tratados al uso, ordenados con criterios a

${ }^{12}$ VIVAR DEL RIEGO, José Antonio. "Taller de heráldica. Cómo diseñar y describir un escudo”. En: GALENDE DÍAZ, Juan Carlos (coord.). De Sellos y Blasones: miscelánea científica, Madrid: Universidad Complutense de Madrid, 2012, p. 463. 
veces discutibles (Fig. 8.15) ${ }^{13}$. En la actualidad no se frecuentan tales excesos: predomina el uso del escudo sencillo sin abuso de elementos exteriores o, al menos guardando un equilibrio entre el escudo y su panoplia' ${ }^{14}$.

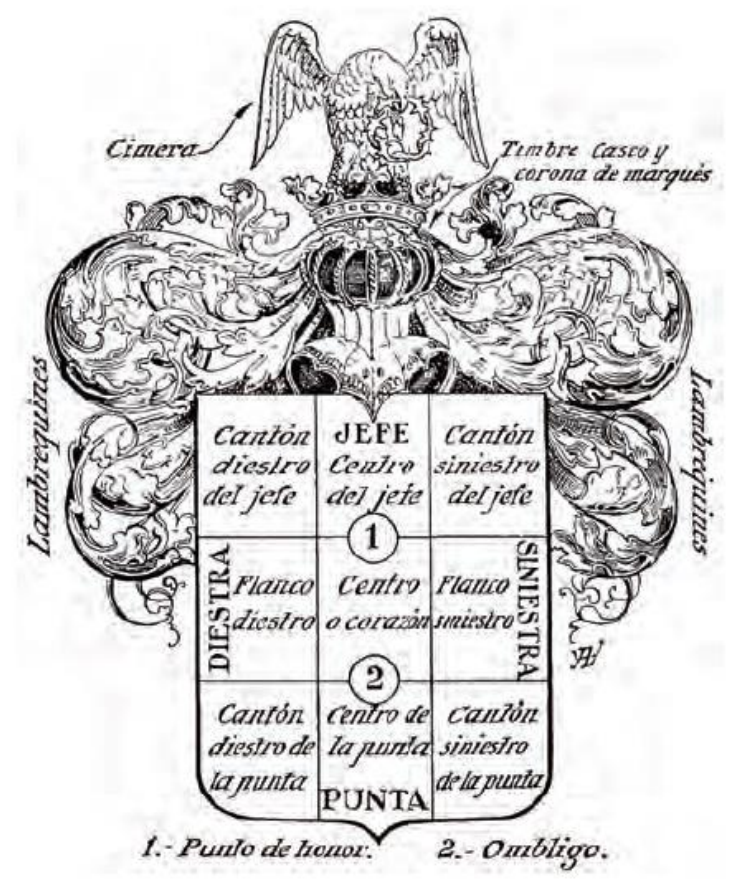

Fig.8.14 Partes y adornos exteriores de un escudo de armas

El timbre del escudo del marqués de Campo lo forma la corona de marqués, que según los tratados de heráldica como el del marqués de Avilés en su obra Ciencia Heroyca de $1725^{15}$, está decorada con cuatro florones y cuatro ramos de tres perlas cada uno.

${ }^{13}$ Imagen del libro CASANTE, Ignacio. Heráldica General y fuentes de las armas en España, Barcelona 1956, publicada en VIVAR DEL RIEGO, José Antonio. 2012, p. 419. 14 VIVAR DEL RIEGO, José Antonio. 2012. P. 464.

${ }^{15} \mathrm{Me}$ refiero a la obra de AVILÉS, José. Ciencia Heroyca; reducida a las leyes heráldicas del blasón, Tomo I, Barcelona: Imprenta de Juan Piferrer, 1725. 
Como es miembro de la nobleza se ha colocado también bajo la corona un manto o pabellón de color azur y armiño, sobre el que resalta el yelmo con rejas en la visera. Los mantos y pabellones se asocian con la realeza y la más alta nobleza ${ }^{16}$.

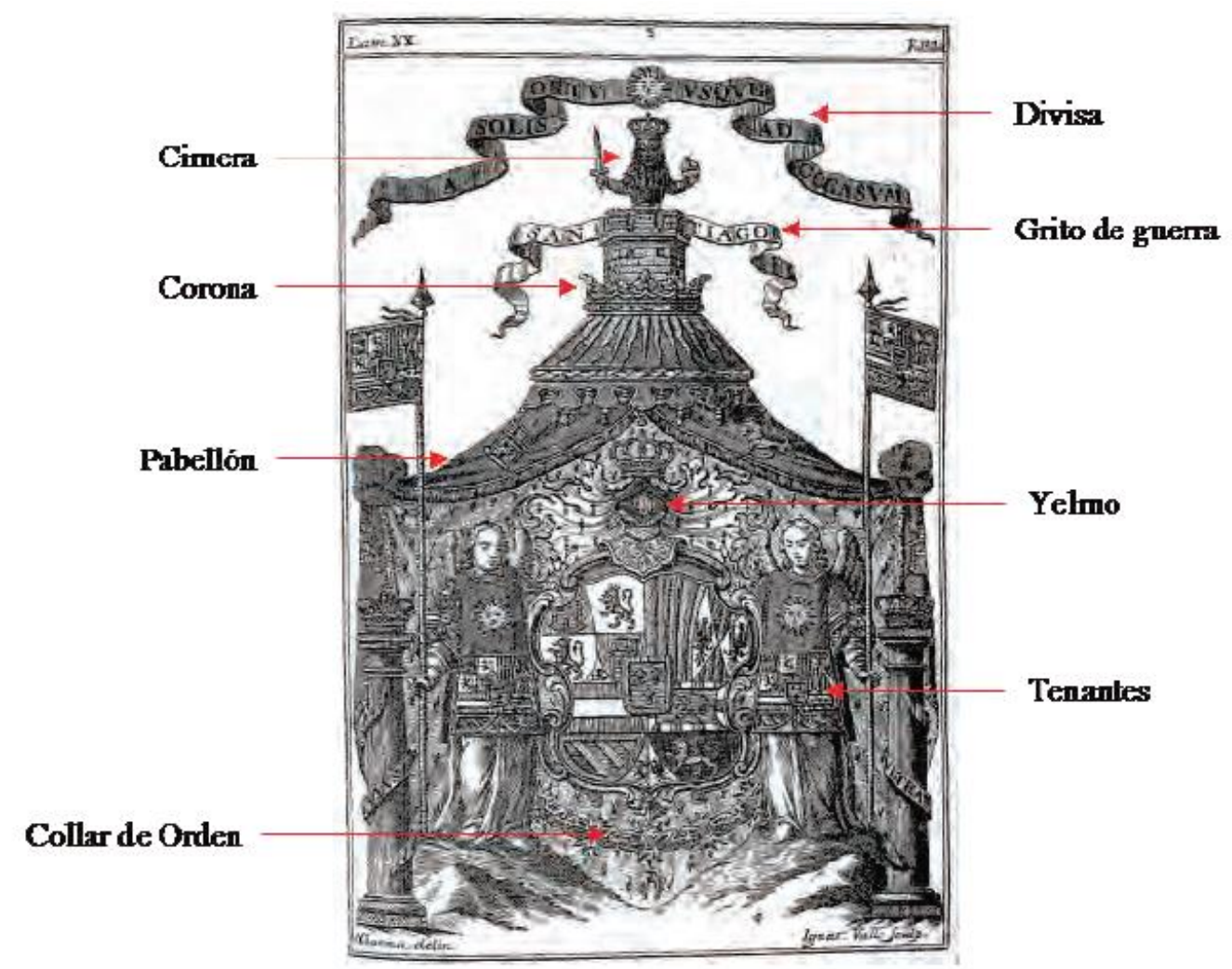

Fig.8.15 Imagen con los nombres de los adornos exteriores de un escudo de $\operatorname{armas}^{17}$

El escudo está rodeado por lambrequines, que es un adorno que parte del timbre en forma de jirones de tela o elementos vegetales de diseño libre, pero para su realización se tiene en cuenta el color y el metal que predomina en el escudo y en este caso son de color gules y azur.

Bajo es escudo se colocan las insignias de dignidad, que en el caso del marqués fueron varias y vemos algunas de ellas representadas en el escudo, aunque la calidad de la fotografía no ofrezca mucho detalle.

${ }^{16}$ VIVAR DEL RIEGO, José Antonio. 2012. p. 468.

${ }^{17}$ Imagen del libro GARMA, Francisco Xavier. Adarga catalana, Barcelona, 1753. 
José Campo fue Senador Vitalicio del Reino; Gentil hombre de la Cámara de s. M. con ejercicio; Gran Cruz de la Real y distinguida Orden Española de Carlos III; Gran Cruz de Isabel la Católica; Gran Cruz del Mérito Naval; Presidente Honorario y Socio de Mérito de varias corporaciones de Madrid. Fue también Oficial de la Legión de Honor de Francia; Comendador de la Orden Real del Gran Ducado de los Países Bajos, etc.

En el escudo se alcanza a ver la Gran Cruz de Carlos III, la Gran Cruz de Isabel la Católica, y la Gran Cruz del Mérito Naval que cuelgan con las cintas de los colores correspondientes.

Mi intención ha sido realizar un simple análisis del escudo de armas del marqués, que me ha permitido adentrarme un poco el mundo de la heráldica y me ha parecido apasionante, a la vez que reconozco que es toda una ciencia en la que seguro volveré a introducirme. 


\title{
Capítulo ix
}

\author{
LA EXPEDICIÓN DEL MARQUÉS DE CAMPO A LAS
} OBRAS DEL CANAL DE PANAMÁ EN 1886
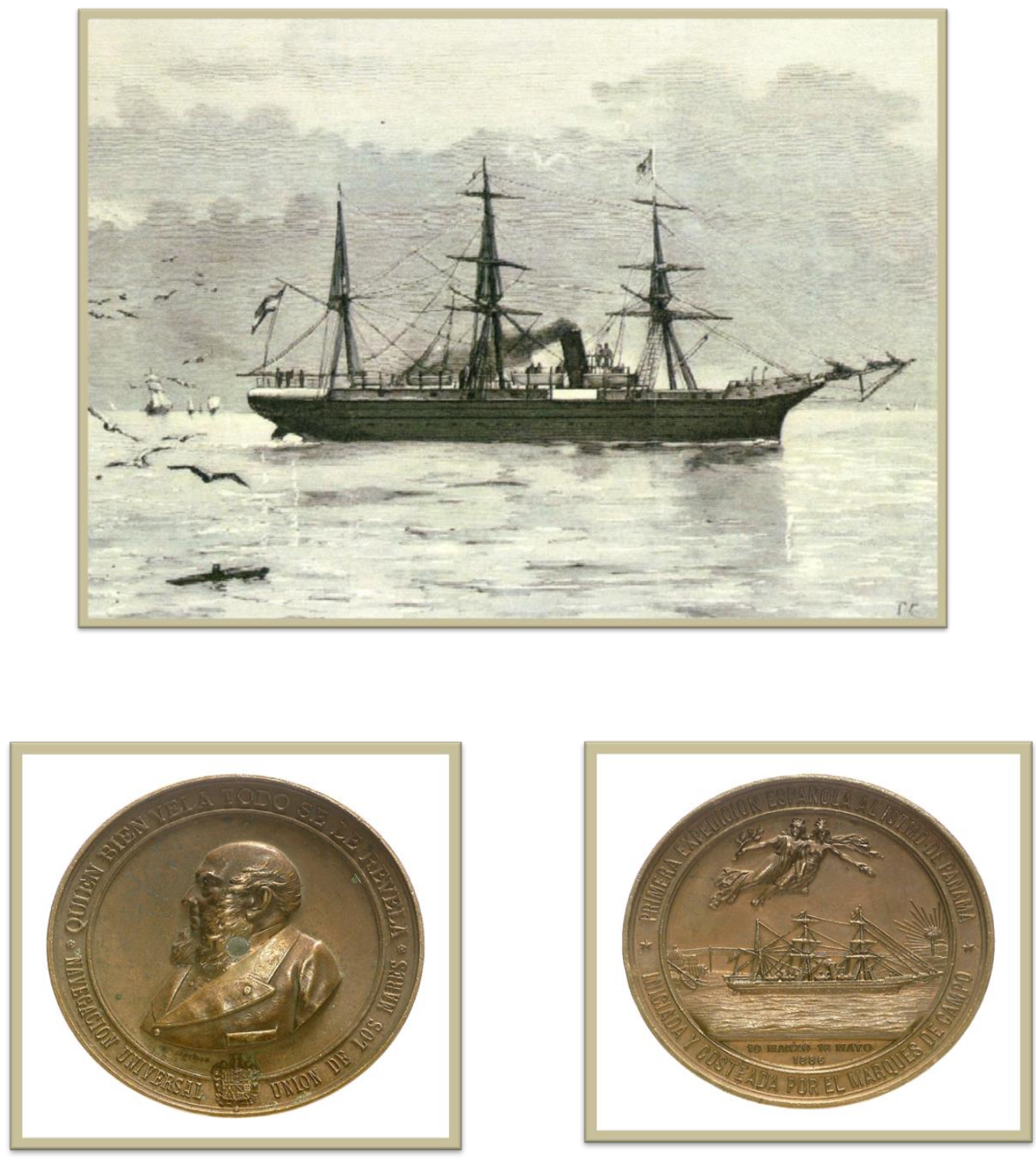



\section{Capítulo ix}

\section{LA EXPEDICIÓN DEL MARQUÉS DE CAMPO A LAS OBRAS DEL CANAL DE PANAMÁ EN 1886'}

\section{1.- José Campo y el origen de la expedición al canal de Panamá}

Como ya se ha visto en otros capítulos de esta tesis, José Campo fue uno de los personajes más influyentes en la vida social y política de Valencia y Madrid en el siglo XIX. Su participación en nombre de España en la realización de las obras del canal de Panamá fue otra de sus grandes acciones en pro de su querida patria.

${ }^{1}$ Parte de este capítulo formó parte de una comunicación presentada en el congreso del CEHA 2014 celebrado en Toledo. MORANT GIMENO, Ana María. "El conocimiento de otros mundos a través de la literatura de viajes: crónicas y dibujos de las obras del Canal de Panamá en 1886”. En: Actas del Congreso Nacional del CEHA 2014, Toledo: 2014. 
Las obras del canal de Panamá habían comenzado en 1882 bajo el control y dirección del vizconde Ferdinand Lesseps (1805-1894) y cuando el marqués de Campo conoció la noticia de que Lesseps iba a realizar una visita a las obras del Canal, no se tomó a bien que no fuera invitado ningún representante del gobierno español. Para él era una ofensa a nuestro país. La compañía francesa había invitado a visitar las obras a representaciones de los gobiernos de Gran Bretaña, Francia, Alemania, Holanda y Estados Unidos, así como a la Cámara de Comercio de Barcelona. Olvidó invitar a las demás Cámaras y al Gobierno español, y José Campo, a su costa y riesgo, organizó el viaje poniendo a disposición del Gobierno y las Cámaras su mejor buque, el Magallanes, mediante carta enviada a la Presidencia del Consejo de Ministros el día 27 de enero de $1886^{2}$.

El Presidente Sagasta (1825-1903), rechazó en principio el ofrecimiento al no estar invitada España oficialmente, pero al final se halló una fórmula de compromiso, formándose una comisión mixta con la aprobación del ministro de Marina, Beránger, integrada por jefes y oficiales de la Armada, altos funcionarios del Ministerio de Estado, representaciones de la Cámara de Comercio y del Ministerio de Fomento. La presidía el brigadier de la Armada Eliseo Sanchiz y Basadre.

Lesseps, como es sabido, tenía grandes relaciones con la alta sociedad barcelonesa desde sus tiempos de cónsul de Francia en la Ciudad Condal y todas las invitaciones eran, en el fondo, interesadas en busca de refuerzos financieros para la aventura de la construcción del canal.

${ }^{2}$ SANCHIZ y BASADRE, Eliseo. Una visita a las obras del Canal de Panamá. Madrid: Imprenta de F. Maroto y Hermano, 1886, p. 161.

372 
El marqués de Campo, gran patriota y hombre de ideas claras y fijas, decidió enviar una expedición, corriendo con todos los gastos, para que España tuviera presencia en lo que él calificó como “...grandiosa obra. gloria de nuestra época...”3. En opinión del periodista Francisco Peris Mencheta, José Campo era uno de los mayores accionistas de la Compañía del Canal Interoceánico y tuvo un arranque de generoso y levantado patriotismo ofreciendo al gobierno de España la mejor de sus naves para llevar hasta el lugar una comisión que estudiara las obras. En el prólogo de su crónica se refleja muy bien el carácter del marqués: "Pensarlo y hacerlo, fue para el Marqués de Campo, obra de pocos momentos. Y la empresa no era pequeña. Pero es el de Campo un hombre de un temple tal, que las dificultades lo agigantan, y que sólo goza en vencer y dominar aquello que a los demás parece imposible o irrealizable"4. A su vez, el propio marqués despidió con estas palabras a la Comisión: "iHay que dejar bien sentado el pabellón español! Mi caja está abierta para que así suceda. No reparen en gastos”5.

Y así el día 10 de marzo de 1886 zarpaba desde el puerto de Vigo el vapor Magallanes (Fig. 9.1), con una comisión a bordo dispuesta a realizar una misión en beneficio de los intereses españoles en el canal y sobre todo en representación de su amada patria, sentimiento que compartían la comisión y el marqués. El viaje duró dos meses y ocho días e hicieron escala en las ciudades de Tenerife, San Juan de Puerto Rico, La Habana y la ciudad de Colón, regresando a Santander habiendo cumplido un buen papel comercial y diplomático.

3 Carta del Marqués de Campo al Presidente del Consejo de ministros de 27 de enero de 1886 en SANCHIZ y BASADRE, Eliseo. Una visita a las obras del Canal de Panamá. Madrid: Imprenta de F. Maroto y Hermano, 1886, p. 162.

4 PERIS MENCHETA, Francisco. De Madrid a Panamá. Crónica de la Expedición enviada por el Excmo. Sr. Marqués de Campo. Madrid: Antonio de San Martín Editor, 1886, p. 9.

5 PERIS MENCHETA, Francisco. 1886, p. 16.. 
Para celebrar el éxito de la expedición, el marqués hizo acuñar en oro, plata y cobre, una medalla conmemorativa de la expedición con su busto reproducido en el anverso bajo el lema "Quien bien vela todo se le revela", y el vapor Magallanes bajo dos figuras que representaban a Europa y América cogidas de la mano en el reverso. Imagen que veremos más adelante.

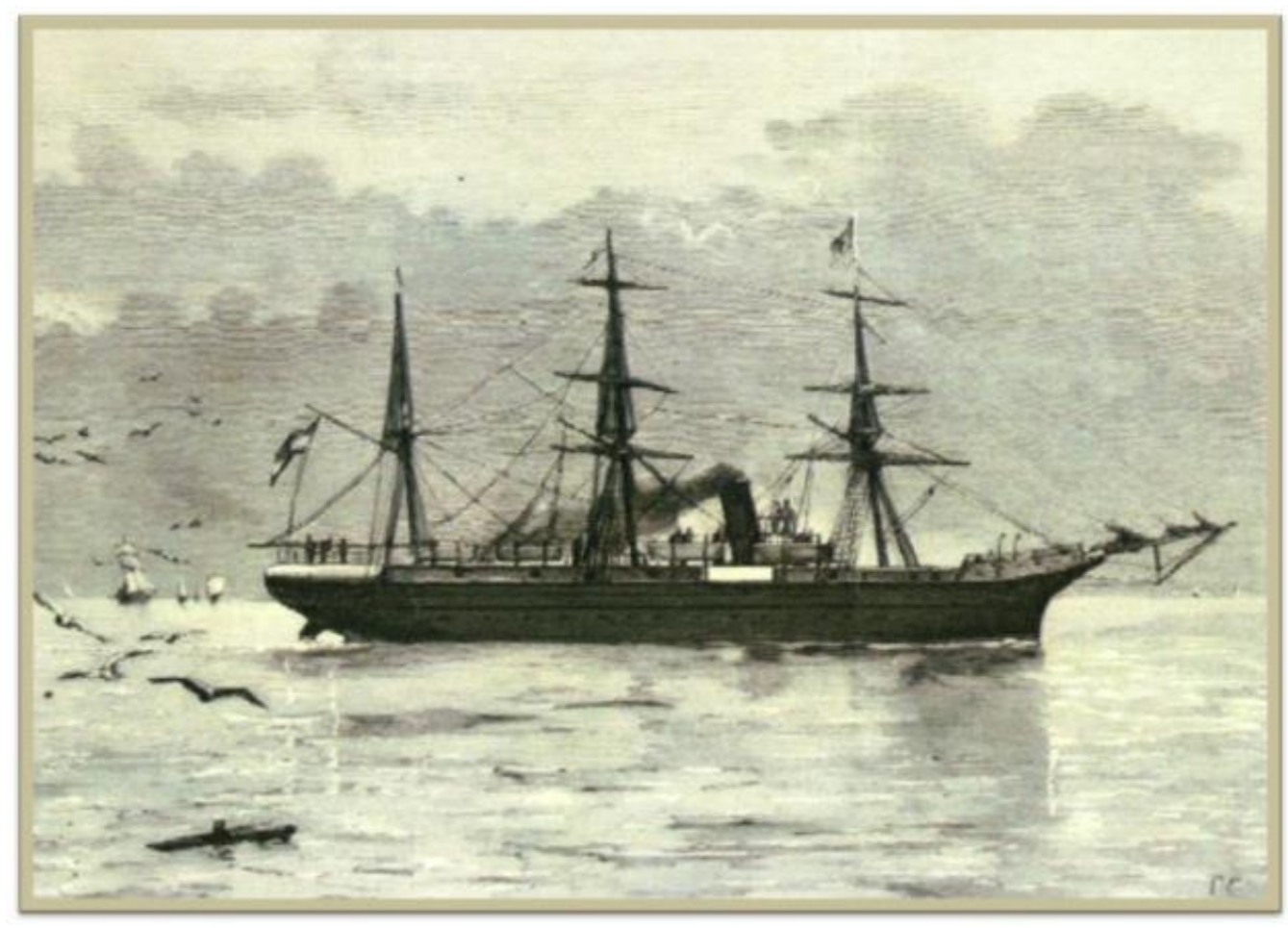

Fig. 9.1 Vapor Magallanes. Tomas Campuzano.

Imagen publicada en La Ilustración Española y Americana 1886. 


\section{2.- Las crónicas de la expedición a las obras del canal de Panamá}

De la expedición se escribieron dos crónicas: La "oficial" del brigadier Eliseo Sanchiz y Basadre y la del periodista Francisco Peris Mencheta. (Figs. 9.2 y 9.3) Las dos crónicas relatan el viaje en primera persona, describen las ciudades y pueblos donde hicieron escala y reflejan el modo de vida de los habitantes de cada país. Describen las visitas que realizaron y los grandes banquetes y fiestas a las que fueron invitados y en los que no faltaron los brindis con champagne en honor al marqués de Campo y su gran obra. Sin embargo, aunque en esencia cuentan lo mismo, cada uno de los autores lo ve desde su punto de vista y hace hincapié en aspectos distintos según sus ideas e inquietudes. Las mayores diferencias las encontramos a la hora de describir los lugares por donde pasaron y lo que vieron. Peris Mencheta describe la ciudad de Vigo, desde donde parte el Magallanes, y también Santa Cruz de Tenerife, San Juan de Puerto Rico, y La Habana, donde hicieron escala antes de llegar a la ciudad de Colón, lugar desde donde realizaron las visitas a la ciudad de Panamá y a las obras del canal. Por el contrario, Eliseo Sanchiz sólo describe un poco la Habana y la ciudad de Colón, mientras que hace una descripción meticulosa de las obras del canal y demás detalles relacionados sobre todo con aspectos técnicos y políticos del viaje. La diferente profesión de los cronistas, reportero uno y brigadier el otro, y la diferencia de carácter, de puntos de vista y del modo de vivir el viaje, se refleja en lo que cada uno de ellos narra y la doble visión enriquece mucho más nuestro conocimiento de los hechos. 


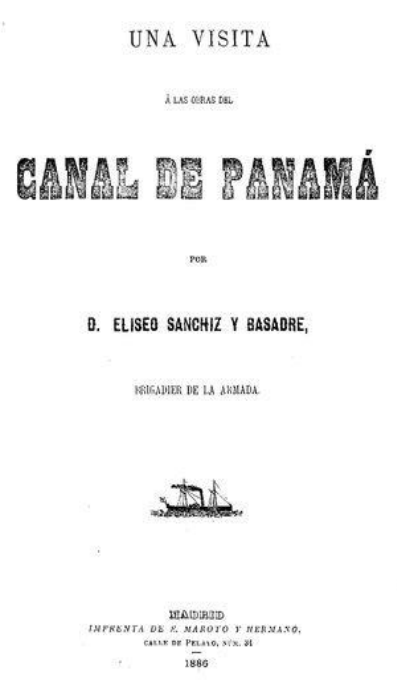

Fig. 9.2 Portada de la Crónica del Sr. Eliseo Sanchiz y Basadre

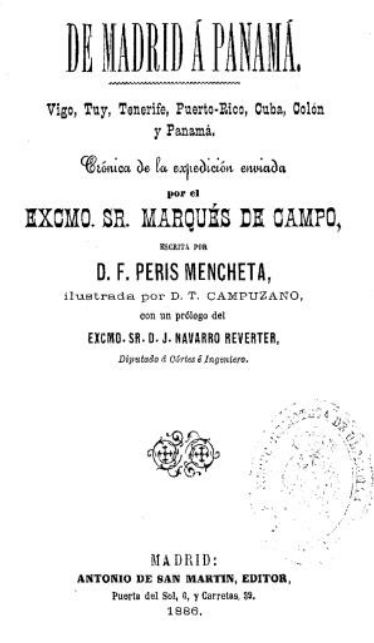

Fig.9.3 Portada de la Crónica del Sr. Peris Mencheta.

Eliseo Sanchiz y Basadre (1825-1902) era un brigadier de la armada que fue nombrado presidente de la comisión, por José María Beránger, Ministro de Marina en el gobierno de Sagasta, a petición del marqués de Campo mediante carta de fecha 5 de febrero de $1886^{6}$. El interés del brigadier en la expedición radicaba en servir a su país y al marqués de Campo, y por ello le ofrece su "diario", como él lo llama, que ha escrito a vuela pluma y en su mayor parte en la mar7.

La crónica de Eliseo. Sanchiz es considerada como la crónica “oficial” del viaje, escrita por un miembro de la Armada, para dar cuenta al marqués de todo lo acontecido en el viaje pero desde un punto de vista objetivo, sin cometarios adicionales que no sean relativos a cuestiones técnicas y sin juicios de valor.

${ }^{6}$ Carta del Marqués de Campo al General D. José María Beránger de 5 de febrero de 1886 en SANCHIZ y BASADRE, Eliseo. Una visita a las obras del Canal de Panamá. Madrid: Imprenta de F. Maroto y Hermano, 1886. 175.

7 SANCHIZ y BASADRE. Eliseo. 1886, prólogo.

376 
Utiliza un tono neutro, un estilo de escritura muy correcto y un lenguaje exquisito. No describe las ciudades ni los lugares que ven, pero si todas las actividades y visitas que realizaron y las tomas de contacto y reuniones con personalidades políticas y comerciales relacionadas con las obras del canal y con negocios del propio marqués de Campo, acompañándolo todo de un apéndice documental muy extenso. Al regreso de la expedición, E. Sanchiz y Basadre fue ascendido hasta llegar a General de Marina.

El autor de la otra crónica, Francisco Peris Mencheta (1844-1916) fue el precursor del reporterismo en España. De joven fue cantero y colaboró con varios periódicos de su ciudad, donde alguno de sus artículos le valió el exilio a Francia. Trabajó en El Diario Mercantil y luego para Las Provincias en 1874, donde actuó como corresponsal de guerra en la campaña carlista. Su buen hacer le llevó a trabajar en La Correspondencia de España y se convirtió en el primer reportero de su época. Fue el informador de los viajes de Alfonso XII y Alfonso XIII, y también Diputado y Senador Vitalicio. Por su fama y su relación con Alfonso XII fue elegido por el marqués para escribir la crónica del viaje pues el marqués era uno de los más fervientes seguidores del monarca, en cuya subida al trono tuvo mucho que ver como ya hemos visto a lo largo de esta tesis.

La crónica de Peris Mencheta contiene descripciones costumbristas, pero sin olvidar los aspectos técnicos de las obras que visitan. Su obra no es sólo un diario de viaje, sino un documento sobre la sociedad colonial e internacional de 1866. Hace observaciones de todo tipo: describe los paisajes y ciudades, valora las jerarquías e inclinaciones políticas de la sociedad colombiana, describe las obras del canal, relata con detalle el recibimiento y agasajo que les dispensan allá donde van, escribe los ecos de sociedad de La Habana, y aprovecha también sus escritos para criticar a modo de denuncia las deficiencias de la administración ultramarina. Todo ello sirve de marco para situar en el contexto histórico e ideológico el sentido del patriotismo del marqués de Campo, 
incluyendo anécdotas como la intención del marqués, años antes, de comprar Gibraltar mediante una suscripción nacional.

En las descripciones de las ciudades y pueblos que visitan demuestra su gusto por los edificios de estilo academicista que se habían construido en ciudades como La Habana en tiempos de Isabel II. Rechaza todo aquello que tiene aires barrocos, calificándolo de Churrigueresco y de poco gusto estético, y alaba todos los edificios, ya sean teatros, grandes casas o edificios oficiales que tengan rasgos de decoración clásica, tildándolos de elegantes. Compara las casas elegantes del Cerro de la Habana y del Paseo de Carlos III con los palacetes que se han construido en el Paseo de la Castellana de Madrid y el Teatro de Tacón con el Teatro Real de Madrid. Critica la catedral de La Habana y sólo destaca de ella la lápida que señala dónde están las cenizas de Cristóbal Colon. Nombra algunas estatuas públicas como la de mármol de Isabel II que estaba en el paseo de Carlos III de la Habana y hoy en día está en el Museo de Cárdenas, o la estatua de Ponce de León situada en San Juan de Puerto Rico, de la que dice que no guarda proporción el tamaño de la base con el de la estatua.

No hay duda de que estas dos obras entran dentro del género de la literatura de viajes y sus descripciones son valiosas para la Historia del Arte, pero no podemos olvidar además que la crónica de Peris Mencheta fue ilustrada por el dibujante Tomás Campuzano y Aguirre, del que hablaremos en el capitulo siguiente. 


\section{3.- La medalla conmemorativa de la expedición a las obras del canal de Panamá. Interpretación iconográfica}

La expedición del Canal de Panamá de 1886 trajo como consecuencia otra actividad de promoción artística; José Campo hizo acuñar una medalla conmemorativa en oro, plata y bronce (Figs. 9.4 y 9.5). El diseño de la misma recayó en el escultor catalán Eusebio Arnau (1863-1933), y la realizó la empresa Castells, con despacho en la calle Colón y talleres en la calle de los Escudellers, de Barcelona ${ }^{8}$. La medalla de bronce dorado pesa 153 gramos, mide $63 \mathrm{~mm}$ de diámetro y tiene $5 \mathrm{~mm}$ de grosor.

En el anverso de la medalla está el busto del marqués de perfil, con las leyendas siguientes en el exergo: "QUIEN BIEN VELA TODO SE LE REVELA” y "NAVEGACIÓN UNIVERSAL UNIÓN DE LOS MARES” interrumpidas por el escudo de armas del Marqués.

En el reverso el vapor Magallanes, en el acto de llegar a la desembocadura del canal interoceánico, y los genios de Europa y América unidos por las manos, con el olivo de la paz y la corona del triunfo. Bajo se leen las fechas de 10 de marzo y 15 de mayo de 1886, fechas de salida y regreso del buque. En el exergo se leen las leyendas: "PRIMERA EXPEDICIÓN ESPAÑOLA AL ISTMO DE PANAMÁ. SINGLADA Y COSTEADA POR EL MARQUÉS DE CAMPO”.

8 Sobre la medalla ver:

CRUSAFONT, Miquel. Medalles conmemoratives dels Països Catalans i de la Corona Catalano-aragonesa (s. $X V-X X$ ), Barcelona: Sociedad Catalana d'estudis numismàtics, Institut d'estudis catalans, 2006, p. 444.

MARÍN, Ma Isabel. L'obra medallística de l'escultor Eusebi Arnau, Barcelona: Sociedad Catalana d'estudis numismàtics, Institut d'estudis catalans, 2005, p. 99. 


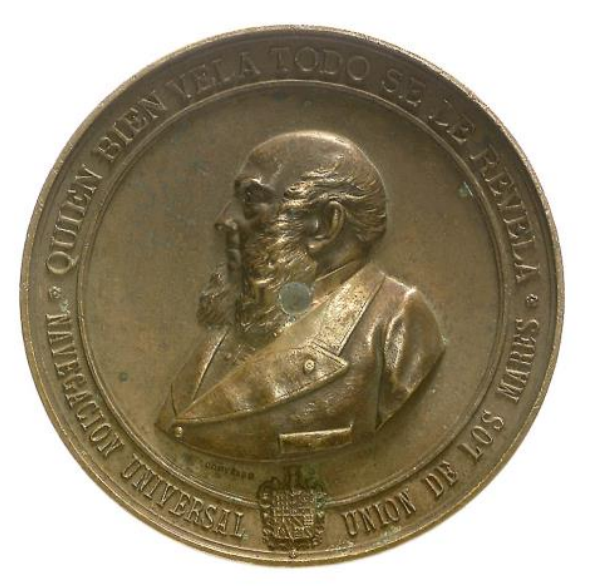

Fig. 9.4 Medalla conmemorativa de la expedición al canal de Panamá. 1886. Anverso. Imagen del Museo del Prado.

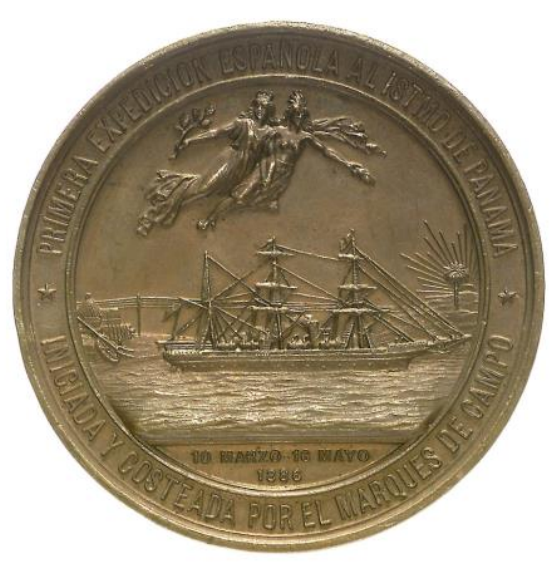

Fig. 9.5 Medalla conmemorativa de la expedición al canal de Panamá. 1886. Reverso. Imagen del Museo del Prado.

He realizado el estudio de las leyendas y la iconografía de esta medalla y he descubierto que la leyenda "quien bien vela todo se le revela" corresponde a un proverbio cuya glosa encontramos en El libro de los proverbios glosados de Sebastián de Horozco y que nos remite al Rey Jaime I en el momento de la conquista de Valencia en el siglo XIII9.

Según cuenta el maestro Pere Antón, en su Crónica de España y de Aragón, en el segundo libro, en el capítulo 37, en la hoja 103, estando el rey don Jaime en el Real sobre Valencia, teniendo cercada la ciudad y a su rey Zaen, más hacia por maña que por fuerza y dijo que a quien bien vela todo se le revela. $\mathrm{Y}$ se deduce que, como consecuencia de esto, el rey tomó por divisa el murciélago, que duerme colgado de los pies, y tiene naturaleza de ir de noche. Y por tanto el refrán dice "a quien bien vela todo se le revela” y el murciélago es símbolo de los que con diligencia mañosamente negocian.

9 HOROZCO, Sebastián de. El libro de los proverbios glosados I (1570-1580), Kassel: Edition Reichenberger, 1994, p. 89 y 315. 
Mi interpretación es que José Campo eligió este proverbio por el modo en que se desarrollaron los acontecimientos que provocaron la expedición; cuando el conde de Lesseps, antiguo cónsul de Francia en Barcelona, convocó a los diferentes países para ir a inspeccionar las obras, no invitó a España y cuando se enteró el marqués decidió ofrecer al gobierno mandar una expedición a su costa, pues en su opinión no era posible que España, que había cristianizado esa tierra y había dejado españoles enterrados en ella, no formara parte de tan gran empresa. Era una manera de expresar que hay que estar pendiente de todo, y velar por todo para que el resultado sea bueno.

En relación a la iconografía del reverso, las figuras de los genios de Europa y América nos remiten necesariamente a la Iconología de Cesare Ripa.

La imagen de Europa y de América acuñadas por Cesare Ripa fueron el estereotipo fielmente seguido por pintores, grabadores, escultores y editores y se reprodujo en Europa y en todo el mundo, pero las aquí representadas difieren un poco en los atributos

\section{Respecto de Europa Ripa Dice:}

"Europa es una mujer muy ricamente vestida con un atuendo regio de numerosos colores. Lleva una corona en la cabeza, apareciendo sentada entre dos cornucopias que se cruzan, una de ellas repleta de toda suerte frutos, trigo, maíz, panizo, arroz y similares, y la otra lleva uvas blancas y negras, sosteniendo un hermosísimo templo con la diestra y señalando con el índice de la siniestra muchos reinos y cetros, guirnaldas y coronas, así como otras cosas semejantes. Además, junto a ella se ha de poner un caballo, con escudos, trofeos y muchas clases de armas, pintándose también un libro y sobre él una lechuza, con muy diversos instrumentos musicales, una escuadra, unos cinceles y una paleta de las que suelen utilizar los pintores, con colores y pinceles" ${ }^{10}$.

${ }_{10}$ RIPA, Cesare. Iconología (Tomo II). Madrid: Ediciones Akal, 1996, p. 102 y 103. 
Sin embargo, aquí el genio de Europa aparece vestida con una túnica vaporosa y portando una corona en la cabeza; y en su mano derecha sostiene una rama de olivo representado la paz.

\section{Respecto de América Ripa Dice:}

"América es una mujer desnuda y de color oscuro, mezclado con el amarillo. Será fiera de rostro y ha de llevar un velo jaspeado de diversos colores que le cae de los hombros cruzándole todo el cuerpo, hasta cubrirle enteramente las vergüenzas. Sus cabellos han de parecer revueltos y enardecidos, poniéndosele alrededor de todo su cuerpo un bello y artificioso ornamento, todo él hecho de plumas de muy diversos colores. Con la mano izquierda ha de sostener un arco, y una flecha con la diestra, poniéndosele al costado una bolsa o carcaj bien provista de flechas, así como bajo sus pies una cabeza humana traspasada por alguna de las saetas que digo. En tierra y al otro lado se pintará algún lagarto o un caimán de desmesurado tamaño"11.

El genio de América aparece en la medalla diferente de la definición de Ripa. Si que lleva el torso desnudo, pero no está sobre ningún caimán ni tampoco pisa una cabeza de humano; lleva en la cabeza un adorno de plumas y en su mano izquierda una corona del triunfo.

En la medalla se ve además el vapor Magallanes, orgullo de la flota del marqués, llegando a la desembocadura del canal interoceánico, y se ven además al fondo unos postes de tendido de telecomunicaciones, a la derecha unos cerros y una palmera tras la que se oculta el sol y a la izquierda unos útiles de labranza una rueda de carro, unas cajas y lo que parece una choza. En mi opinión todos ellos pueden interpretarse como atributos de la industria, la agricultura y el comercio, que se verían muy beneficiados de la realización del canal.

${ }^{11}$ RIPA, Cesare. Iconología (Tomo II). Madrid: Ediciones Akal, 1996, p. 108 y 109. 


\section{4.- La celebración del éxito de la expedición al canal de Panamá: el banquete del marqués de Campo visto por la prensa}

No podemos acabar este capítulo sin reproducir letra por letra un reportaje del periódico La Época de fecha 24 de mayo de 1886, en el que se cuenta con todo detalle el gran banquete que tuvo lugar en el palacio del marqués para celebrar el éxito de la expedición ${ }^{12}$.

"En la suntuosa residencia que el banquero valenciano tiene en el paseo de Recoletos verificóse anoche el banquete con que aquél obsequiaba a los expedicionarios del vapor Magallanes.

Asistieron a la comida las dieciocho personas -marinos, ingenieros, militares, artistas, escritores -que formaban parte de la expedición, asistieron también los presidentes de ambas Cámaras, señores Marques de la Habana y Martos, el Ministro de la Marina Beranger, el ingeniero y escritor, Sr. Navarro Reverter, y en representación de la prensa Alfredo Escobar.

No hubo más señoras en la mesa que la Marquesa de Campo y la señorita Sánchez Toca.

Fueron recibidos los invitados al festín en el salón y el gabinete de la Marquesa; ambos recientemente decorados. Los que conocen el palacio del Marqués de Campo, saben que es uno de los que más riquezas atesoran en Madrid. A pesar de ello, llamaban la atención y admiraban las dos estancias referidas.

El salón está exornado con molduras y relieves do oro viejo, de cuyo color es la rica, peluche de los muros.

${ }^{12}$ La Época, 24/5/1886, p. 1 y 2. 
El efecto es severo, magnífico y muy nuevo. Completa la magnificencia de su conjunto la cantidad de hermosísimas pinturas modernas que contiene. El gabinete es genuinamente chino; telas, muebles, accesorios, todo procede del Celeste Imperio y todo es de un lujo que nunca mejor pudo calificarse de oriental.

El zócalo de lacas de colores, las porcelanas legítimas del pueblo que las inventó, los cortinajes recamados de pájaros y flores bórdalos con brillantes sedas, daban carácter completamente chinesco al precioso gabinete que no se cansaban en contemplar y ponderar los concurrentes.

A las ocho entraron en el comedor el anfitrión y los comensales. El comedor simula un gran invernadero de plantas y flores. En los grandes aparadores rebosaba, si así puedo decirse, los objetos de plata repujada; y del propio metal macizo, artísticamente cincelado, eran las grandes piezas que componían el centro de mesa.

La comida fue digna del comedor: manjares escogidos y delicados, vinos exquisitos; léase si no la lista de unos y otros.

\section{Potages}

Connommé imperial.

Bigque d'ecrevisses

\section{Hors d'oeuvres}

Timbal purcé truffes en macaroni

\section{Relevés}

Saumon á la Mongolitflere.

Longe de veau á l'escarlatte,

Punch a la Tomaine

\section{Roin}

Galantine de volaille á la gelee

Poule dinde.

Salade ruase

\section{Legumes}

Asperges en branches sauce mouseline

\section{Entremets}

Gateau millefeuilles

Walewaky au café 


\author{
Vinos \\ Jerez, Chateau Laffite, \\ Champagne Frappé, Oporto
}

$\mathrm{Al}$ destaparse el Champagne empezaron, como es de rigor, los brindis.

Pero antes de dar cuenta de ellos, es oportuno recordar el objeto y carácter del acontecimiento quo los motivaba. España no fue invitada a examinar los trabajos del canal de Panamá.

El Gobierno español deseó, según era de presumir, hacerse representar en aquellos mares, y el Marqués de Campo, anticipándose a sus deseos puso a disposición del Gobierno y de la comisión que éste nombrase un vapor de su flota, el Magallanes, ofreciéndose además a costear los gastos todos de esta expedición.

Tan espléndido arranque dio por resultado el viaje del que ya tiene noticia todo el mundo.

El Marqués de Campo no ha querido que España, la nación de las empresas atrevidas y romancescas, descubridora de aquellas tierras, y única depositaría durante siglos de la civilización de Oriente, dejara de mostrar su conformidad y hasta su alegría por los proyectes matrimoniales que en aquellos mares se concertaban. El «coqueteo» del Atlántico y el Pacífico es tan antiguo como el descubrimiento de América; pero ni el Emperador Carlos V, aconsejado por el portugués Galvao, después de la llegada a Méjico de Cortés; ni la poderosa Inglaterra, animada por los consejos de Nelsson; ni Europa, aleccionada por la experiencia de Humboldt; ni en tiempos más próximos, Francia y los Estados Unidos, quisieron pagar los gastos de la boda.

Y ha sido preciso una fuerza mucho más poderosa que la de las naciones y la de los Reyes, la fuerza de la asociación de capitales, dirigida la por la ciencia de Lesseps y aguijoneada por el interés general, para remover los obstáculos que se oponían al indicado enlace. 
Es justo, pues, considerar al Marqués de Campo como el representante español más genuino de esa fuerza, que impulsa en nuestros días el progreso.

Una española, la Emperatriz Eugenia, inauguró la gran vía del Mediterráneo al Mar Rojo, y un español es el que ha hecho que nuestra patria haya estado ahora representada en el canal que unirá el Atlántico y el Pacifico.

iSingular coincidencia! No obstante, los siglos trascurridos y los gigantescos adelantos hechos por la ciencia, el canal se abre precisamente hoy por el punto que marcaron los descubridores españoles. Todo esto y aún máscomo es las ventajas que a la navegación y al comercio ha de reportar la apertura del istmo y cuanto con este acto se relacione-significaba la expedición a Panamá de los comisionados españoles a bordo del Magallanes y todo esto venía a la memoria al empezar los brindis del banquete de anoche. El primero que brindó fue, como era natural el Marqués de Campo, quien lo hizo por los presidentes del Senado y del Congreso y por el feliz regreso de los expedicionarios.

Replicó el Sr. Marqués de la Habana brindando por el Marqués de Campo, encareciendo la importancia de la expedición, haciendo notar la oportunidad do que haya ido España A los mismos lugares que descubrió y recordando los beneficios que el canal de Panamá, juntamente con el de Suez, reportarán al comercio.

El Sr. Martos, que es elocuente hasta en sus conversaciones privadas, lo había de ser, y mucho necesariamente, en un brindis. Dedicó éste en primer lugar, y como hombre galante, a la Marquesa de Campo. Luego, refiriéndose A los servicios prestados por el opulento banquero a su país. y señaladamente el de la expedición a Panamá dijo que, si en Francia se llama a Lesseps «el gran francés,» bien pudiera llamarse a Campo, aunque en más modesta esfera, «el gran español»

El Ministro de Marina coincidió en apreciaciones generales con los quo la precedieron en el uso de la palabra, y además habló del papel importante 
que en aquellos remotos mares le está reservado a nuestra marina de guerra.

El Sr. Sanchiz, brigadier de artillería jefe de la expedición, relató el entusiasmo con que ésta había sido acogida en todas partas, y espacialmente en la América Central donde veían flotar la bandera de sus antepasados. El periodista popular por excelencia, el tan activo repórter de La Correspondencia, Peris Mencheta, en suma, expresó con fácil y oportuna palabra el deseo de que el hijo del Marqués de Campo, reúna, cuando sea hombre, las cualidades de su padre y de los presentes en aquel instante.

$\mathrm{Al}$ celebrar luego las espaciales condiciones de inteligencia y laboriosidad del anfitrión, dijo (aludiendo al monumento que trabaja en Roma Benlliure, el escultor, para Valencia) que será de los pocos hombres que habrán visto erigírsele una estatua en vida.

A nombre de la prensa, y en representación de LA ÉPOCA, brindó el Sr. Escobar.

Cerró la serie de brindis D, Juan Navarro Reverter con viva elocuencia. Al manifestar que debía quedar un recuerdo tangible y que perpetuase la expedición de Panamá, le interrumpió el Marqués de Campo...

-Que traigan las fotografías que hay sobre mi mesa-dijo.

Quedóse suspenso Navarro Reverter y asimismo los demás.

Llegaron las fotografías: lo eran de dos modelos de medallas conmemorativas con el busto del Marqués y su lema: «quien vela, se le revela» por un lado, y dos figuras simbólicas de España y América abrazándose por el otro.

-Ya veis-exclamó Navarro Reverter, señalando al infatigable banqueromientras nosotros hablamos, él ejecuta.

Y este es, en efecto, el carácter determinante de la vida del Marqués de Campo, y lo que siempre le ha distinguido, cual brillantemente lo prueba la expedición a Panamá costeada por él: mientras los demás dicen, él hace”.

Fdo. Mascarillla. 



\section{Capítulox}

LA PROMOCIÓN ARTÍSTICA Y MECENAZGo DE TOMÁS CAMPUZANO Y AGUIRRE (1857-1934), AUTOR DE LOS DIBUJOS DE LA EXPEDICIÓN A LAS OBRAS DEL CANAL DE PANAMÁ

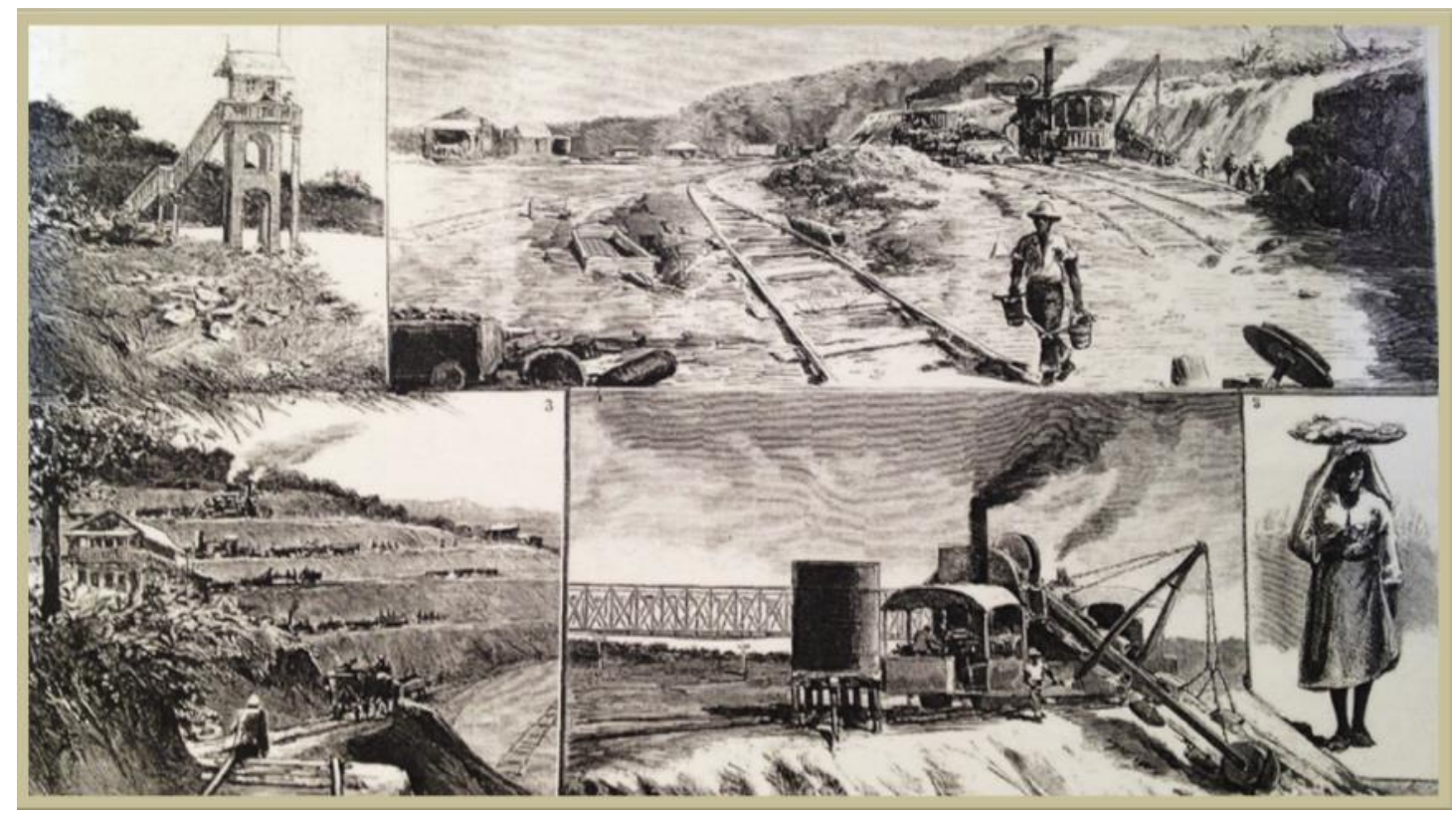





\section{Capítulox}

\section{LA PROMOCIÓN ARTÍSTICA Y MECENAZGo DE TOMÁS CAMPUZANO Y AGUIRRE (1857-1934), AUTOR DE LOS DIBUJOS DE LA EXPEDICIÓN A LAS OBRAS DEL CANAL DE PANAMÁ 1}

Una vez analizada en el capítulo anterior la expedían del marqués a las obras del canal de Panamá, vamos ahora ver el trabajo del dibujante tomas Campuzano y cómo influyó en su carrera profesional haber sido en dibujante de la expedición.

Desconocemos quién fue el responsable de elegir a Tomás Campuzano como artista encargado de ilustrar la expedición, pero no hay duda de que fue elegido por sus cualidades como dibujante de puertos y mares, y también por ser el dibujante oficial de la revista La Ilustración Española y Americana.

\footnotetext{
${ }^{1}$ Parte de este capítulo formó parte de una comunicación presentada en el congreso del CEHA 2014 celebrado en Toledo: MORANT GIMENO, Ana María. "El conocimiento de otros mundos a través de la literatura de viajes: crónicas y dibujos de las obras del Canal de Panamá en 1886". En: Actas del Congreso Nacional del CEHA 2014. Toledo: Universidad de Toledo, 2014.
} 
Tomás Campuzano y Aguirre², nació en Santander en 1857 estudió derecho en Madrid, compaginó sus estudios con clases en la Escuela Especial de Pintura, Escultura y Grabado de la capital, y expuso su primera obra en el Círculo de Bellas Artes en 1880. En 1884 tuvo relación con la Colonia Artística de Muros de Nalón, y recorrió las costas asturianas con dos de sus principales miembros, Casto Plasencia (1846-1890) y Alfredo Perea (1839-1895). Incansable viajero, recorrió Portugal y Galicia y realizó obras donde refleja la incesante actividad de los puertos provocada por la industrialización del norte de España, pero salvo alguna excepción, no pintó vapores o cargueros, sino barcos de vela o pequeñas embarcaciones de remos.

Fue alumno de Carlos de Haes (1826-1898) del que aprendió la visión de una naturaleza nostálgica, pero a la vez positiva y romántica, y pintó sus obras de modo que el progreso no la modificaba en exceso. Campuzano es considerado uno de los mejores difusores del paisaje moderno en España porque utilizó en su producción los argumentos idílicos de los plenairistas y captó a la perfección las preferencias del gusto burgués de la segunda mitad del siglo XIX y principios del siglo XX. Aunque es famoso por sus láminas al aguafuerte y sus obras sobre la sierra de Guadarrama, Campuzano es por mérito propio el pintor de los puertos y de los barcos. Pertenece a ese grupo de pintores fascinados por la riqueza visual de los puertos, los barcos y los viajes, en los que el mar y el barco son los principales protagonistas, pero también las gentes que viven de él, como los marineros y en ocasiones sus mujeres y familias.

Su observación del mar y de los barcos es directa, pero algunas de sus obras no son reproducción de ningún paisaje real, sino escenas compuestas con detalles tomados de aquí y de allá que dan a sus obras un aspecto verosímil pero improbable; son paisajes compuestos, montajes que acababa en su taller y donde en ocasiones el mar es un mero escenario de sus composiciones de barcos.

\footnotetext{
${ }^{2}$ Sobre Tomás Campuzano ver: SAZATORNIL RUIZ, Luis. Tomás Campuzano y Aguirre (1857-1934). Santander: Fundación Marcelino Botín, 2000.
} 
Vamos a analizar los dibujos que realizó Campuzano durante la Expedición a las obras del Canal de Panamá y que sirvieron para ilustrar los artículos que sobre la expedición escribió Eusebio Martínez Velasco en la revista " $L a$ Ilustración Española y Americana” y los dibujos que ilustraron la crónica de Peris Mencheta.

\section{1.- Grabados publicados por La Ilustración Española y Americana}

\section{1.- Vapor Magallanes}

El grabado fue publicado en el ejemplar de la revista del día 28 de febrero de 11863. (Fig. 10.1). El vapor Magallanes cuyo nombre recuerda al descubridor del paso entre el océano Atlántico y el Pacífico, era uno de los vapores de la Compañía de Vapores del Marqués de Campo, que cubría la línea de Filipinas.

Era un barco mixto de vela y vapor, con chimenea roja rematada en negro y contraseña blanca, cuadrada, con las iniciales MC enlazadas bajo una corona. Había sido construido en Clyde (Escocia) con materiales de primera calidad, tenía 98 metros de eslora y había sido hasta 1880 el famoso "China" de la compañía británica Cunard. Llevaba alojamiento para 150 pasajeros de primera clase y 753 de tercera y recorría 11 millas por hora y hasta 12 y media si le ayudaban las velas. Hasta 25 vapores llegó a tener el marqués para cubrir diferentes líneas de correos con las Antillas, el paso del estrecho de Magallanes y San Francisco, entre otras4.

\footnotetext{
3 La Ilustración Española y Americana, año XXX, núm. VIII, 28 de febrero de 1886 p. 130-132.

4 Para ampliar conocimiento sobre la flota del Marqués de Campo ver: GONZÁLEZ ECHEGARAY, Ramón. "La Flota insólita del Marqués de Campo". Revista general de Marina, núm. 196, 1979, p. 3-16.
} 
Esta obra entra dentro de lo que podríamos llamar "retrato de barcos" que deberíamos de distinguir, dentro de los temas marineros, de la "marina con barco". La distinción es evidente porque la embarcación es el elemento que condiciona la obra, siendo el mar mero escenario o pretexto para representar el verdadero objeto de la obra, el barco, que es retratado con todo lujo de detalles5. Este tipo de obras siempre se ha tenido en cuenta desde la perspectiva de la arquitectura naval, pero no debería ser así porque los elementos secundarios de estas obras no están dispuestos al azar, sino que son importantes a la hora de realizar una lectura detenida del cuadro, y que enriquecen el conjunto.

Estas obras se realizaban sobre todo para los propietarios de los barcos, que igual que encargaban retratos de miembros de la familia encargaban retratos de los barcos de su flota, orgullosos de mostrarlos en las dependencias de sus compañías navieras. El retrato de barcos fue muy valioso en el siglo XIX para documentar e ilustrar las publicaciones navales y otras historias con naufragios y batallas navales.

En el caso del marqués de Campo, como ya se ha comentado en esta tesis, encargó a Rafael Monleón (1843-1900), reputado pintor de barcos y creador de la escuela marinista valenciana del siglo XIX, una colección de retratos de sus 25 vapores que adornaban diferentes estancias de su palacio de Recoletos y que fueron expuestos en la Exposición Universal de Barcelona en 1888 en el pabellón del marqués.

\footnotetext{
5 Sobre el retrato de barcos ver: ARMENGAUD SHUPPISSER, M. "El retrato de barcos en el siglo XIX”. Revista de Historia Naval,1999, año 17, núm. 64, p. 119-126.
} 


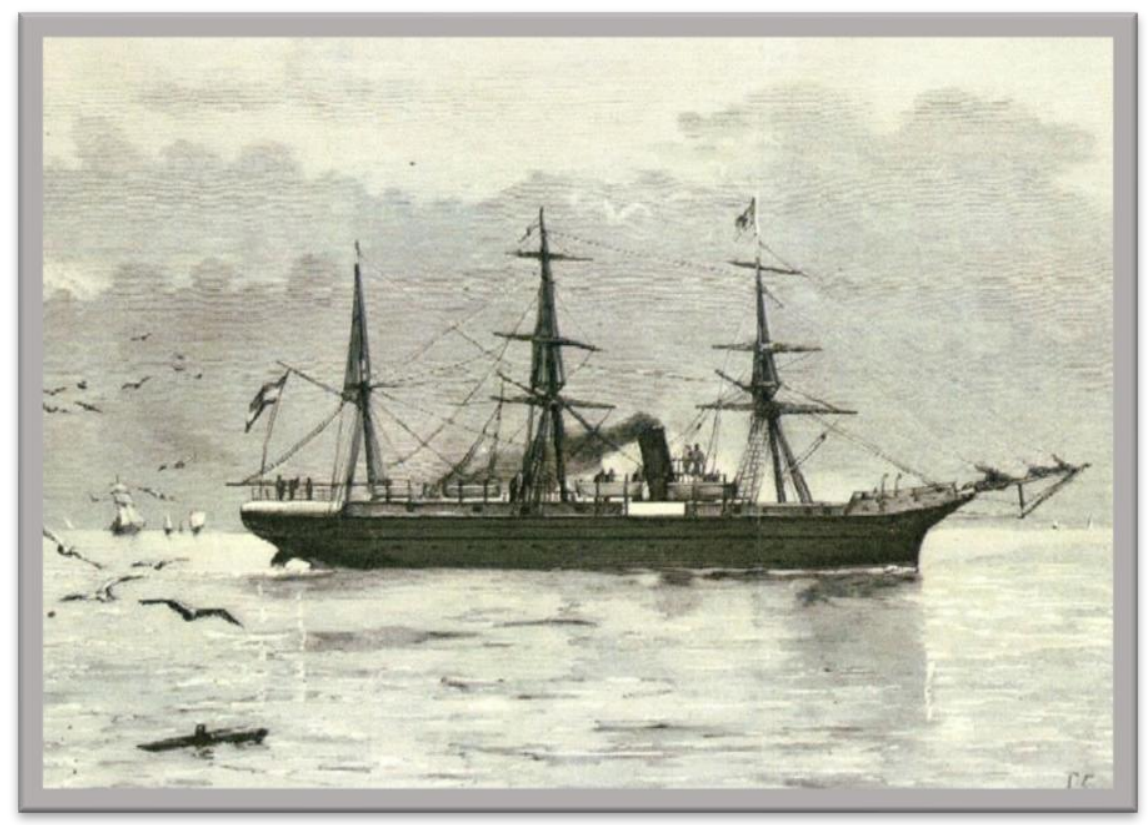

Fig. 10.1 Vapor Magallanes. Tomás Campuzano.

Imagen publicada en La Ilustración Española y Americana. 1886.

En el grabado publicado en La Ilustración Española y Americana vemos al vapor Magallanes que navega majestuoso sobre aguas tranquilas, en un tímido escorzo, con mucha precisión en los detalles, y un núcleo de gaviotas salpicando el mar.

Para entender el sentido de la obra en sí hay que tener en cuenta que el retrato de un barco revela información al espectador a través de sus detalles: por la bandera y la contraseña conocemos la nacionalidad y el propietario del barco, en este caso nacionalidad española y propiedad del marqués. Al ser un barco de vapor supone además una muestra del dominio del hombre sobre la embarcación y sobre el medio. Otro detalle a tener en cuenta en un retrato de barco es el casco, por el que los expertos en la materia pueden identificar el fabricante, de cuya categoría depende a su vez la del propietario, y en este caso no era para menos porque el Magallanes había sido el primer buque de hélice de la prestigiosa compañía británica Cunard. Y por último, la firma del pintor indica que se trata de un autor consagrado a la pintura de barcos, puertos y mares, en este caso Tomás Campuzano, no un capitán de barco amateur que pintaba un retrato de su barco por placer para poder admirarlo. 


\section{2.-Apuntes de viaje}

En fecha 22 de abril de 1886 se publicó un grabado titulado "Apuntes de viaje"6. En la publicación se califican como apuntes y se especifica que están tomados del natural, pero vemos muchos detalles y es una especie de collage de varios momentos del viaje. El embarque de la comisión en el Magallanes, las primeras impresiones del viaje, un rato de descanso en la toldilla de cubierta, donde unos charlan animadamente, otros contemplan el paisaje y otros leen, transmitiendo al espectador una sensación de calma y bienestar. También podemos ver una vista de una casa típica de Santa Cruz de Tenerife, con patio interior y un piso alto con balaustradas corridas de madera y los típicos plataneros; y una vista de la ciudad desde el muelle al momento de partir. La perspectiva del dibujo es muy buena y parecen talmente fotografías que recogen y congelan momentos del viaje (Fig. 10.2).

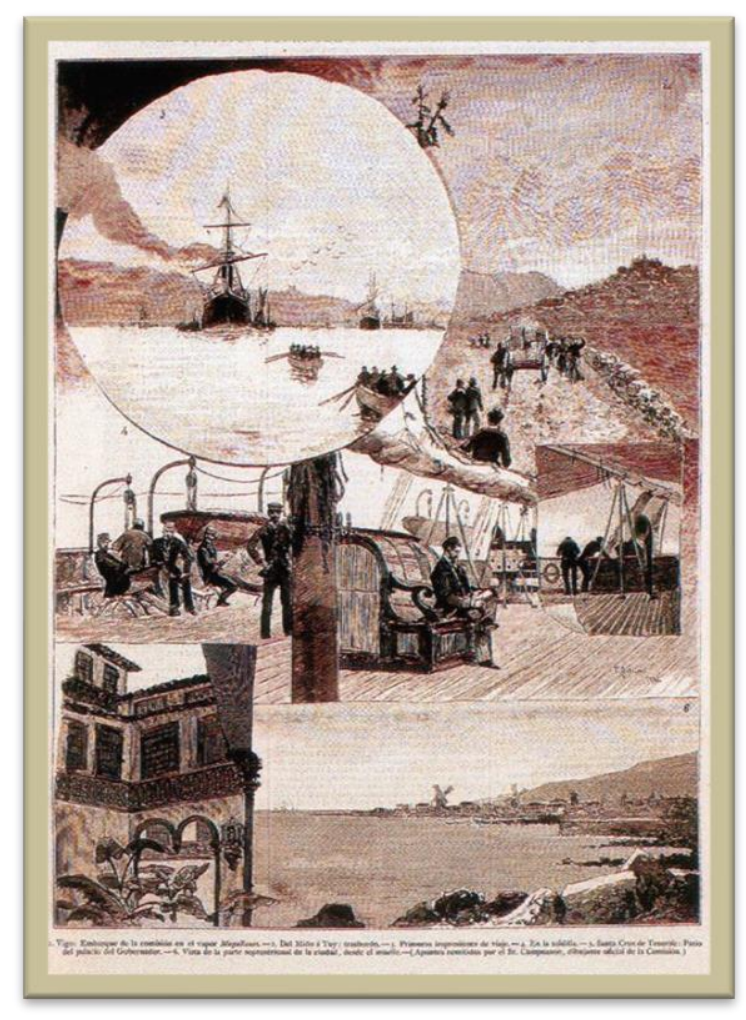

Fig. 10.2 Apuntes de Viaje

\footnotetext{
${ }^{6}$ La Ilustración Española y Americana, año XXX, núm. XV, 22 de abril de 1886 p. 243 y 252.
} 


\section{3- La desembocadura del canal en el Pacífico. El grupo de Colón y América}

Este grabado fue publicado en el ejemplar del día 8 de junio de 1886 En estas fechas la Comisión ya ha vuelto a Madrid y el dibujante sigue proporcionando ilustraciones a la revista para que Eusebio Martínez siga contando cómo se ha desarrollado el viaje. En este caso el artículo cuenta que la Comisión ya ha visitado las obras con éxito y que ha sido muy bien recibida por la compañía constructora7.

La estatua de Colón y América (Fig. 10.3), que Peris Mencheta describe en su crónica como Colón protegiendo a una india ${ }^{8}$, fue encargada por la Emperatriz Eugenia como regalo a Méjico para rememorar el genio de Cristóbal Colón; estaba realizada en bronce por el artista italiano Vincenzo Vela (1822-1891) durante su estancia como profesor en la Academia Albertina de Turín. Este artista es considerado como uno de los mejores autores de escultura realista a nivel mundial. El bronce se expuso en la exposición de París de 1867 y en 1870 salió para Colombia, pero diversos acontecimientos políticos impidieron la llegada a su destino y determinaron la colocación definitiva de la estatua en la ciudad de Colón, en un terraplén a orilla del Atlántico, enfrente de la entrada del canal, cerca del palacio de la compañía constructora, en una placeta con palmeras, plantas y árboles tropicales 9 . En la inauguración estuvieron Lesseps y el obispo de Costa Rica, y se pronunciaron discursos de agradecimiento a la emperatriz Eugenia que fueron muy aplaudidos por la enorme concurrencia al acto ${ }^{10}$.

\footnotetext{
${ }_{7}$ La Ilustración Española y Americana, año XXX, núm. XXI, 8 de junio de 1886 p.346, 347 y 357.

8 PERIS MENCHETA, Francisco. 1886, p. 133.

${ }_{9}^{9}$ Sobre esta estatua ver: SUSTO, Juan Antonio. "Concepción, Vida y Pasión de la estatua de Colón”, en Lotería, núm. 41, octubre,1944, p. 8-10.

${ }^{10}$ La Ilustración Española y Americana, año XXX, núm. XXI, 8 de junio de 1886, p. 347.
} 


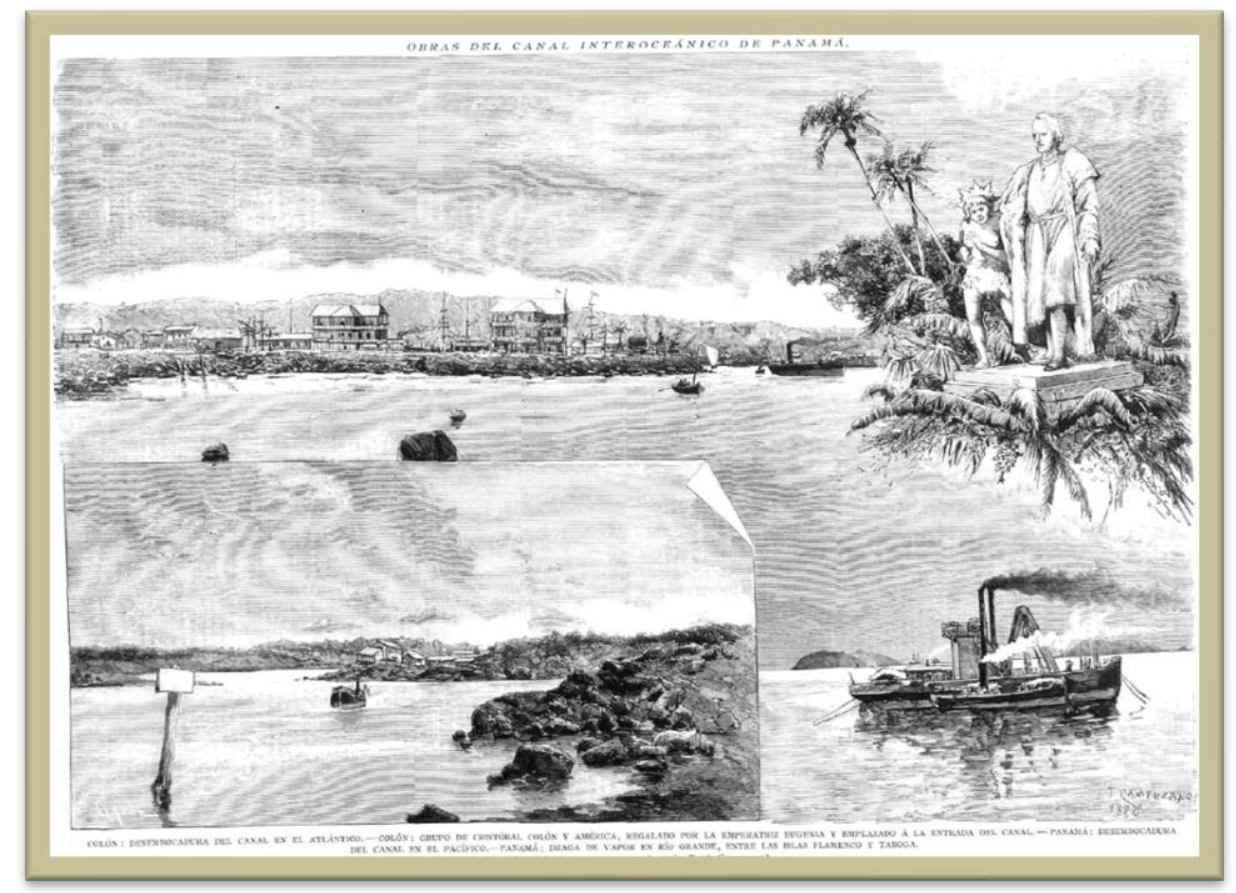

Fig. 10.3 La desembocadura del canal en el Pacífico.

El grupo de Colón y América.

La estatua, muy expresiva como todas las de Vincenzo Vela, representa a un Cristóbal Colón enérgico y corpulento con la mirada hacia el viejo mundo, la mano derecha extendida y la izquierda sobre la espalda de una joven indígena que representa a América. Como dice Carlos Reyero: "resulta también muy curioso que, mientras las representaciones escultóricas de Colón realizadas o destinadas a ser exhibidas en América tienden a concentrarse siempre en el navegante, y, por tanto, omiten al receptor indígena, las concebidas en Europa, por el contrario, colocan siempre en una posición sumisa a alguna india, lo que no sólo indica una superioridad colonialista, sino también un mensaje de evidente prepotencia paternalista masculina. En la Europa decimonónica, el indígena americano se presenta asociado a un mensaje de sumisión, bajo el yugo europeo, que responde a una superioridad intrínseca frente a cualesquiera otras razas y pueblos"11.

\footnotetext{
${ }^{11}$ REYERO, Carlos. "Pasivos, exóticos, vencidos, víctimas. El indígena americano en la cultura oficial española del siglo XIX”. Revista de Indias, 2004, vol. LXIV, núm. 232, p. 721-748, espec. p. 728.
} 
Peris Mencheta, como hemos dicho antes, dice en su crónica que la estatua representa a Colón protegiendo a una india, una apreciación sin duda motivada por la figura de la mujer semidesnuda con los pechos al aire y tapada a penas con una piel, que poco recuerda a las personalizaciones de América basadas en la icnografía de Ripa, quien la representa como una mujer semidesnuda y de color oscuro, con cabellos revueltos, que lleva una corona de plumas, un carcaj con flechas, un arco y está normalmente sentada sobre un caimán y con una calavera bajo sus pies ${ }^{12}$.

Actualmente la estatua está situada en el paseo centenario de la ciudad de Colón.

\section{4.- Secciones de las obras y vendedora de licores}

Este grabado, formado como el anterior por varias imágenes tomadas del natural y compuestas para su difusión a modo de collage, se publicó el día 22 de julio de 188613. Como ya hemos dicho, la Comisión ha vuelto en mayo, pero se siguen publicando noticias sobre la expedición, las obras y las duras condiciones en que se trabaja. Para ilustrarlas T. Campuzano hace una composición con instantáneas del viaje donde vemos parte de la maquinaria utilizada en las obras y que expresa cómo el hombre por medio de las máquinas domina el terreno reflejando a la vez la dureza de esos trabajos. (fig.10.4)

${ }^{12}$ RIPA, Cesare. Iconología (T. II). Madrid: Ediciones Akal, 1996 (1 ${ }^{\mathrm{a}}$ edición ilustrada Roma 1593), p. 108.

${ }^{13}$ La Ilustración Española y Americana, año XXX, núm. XXIII, 22 de junio de 1886, p. 387. 


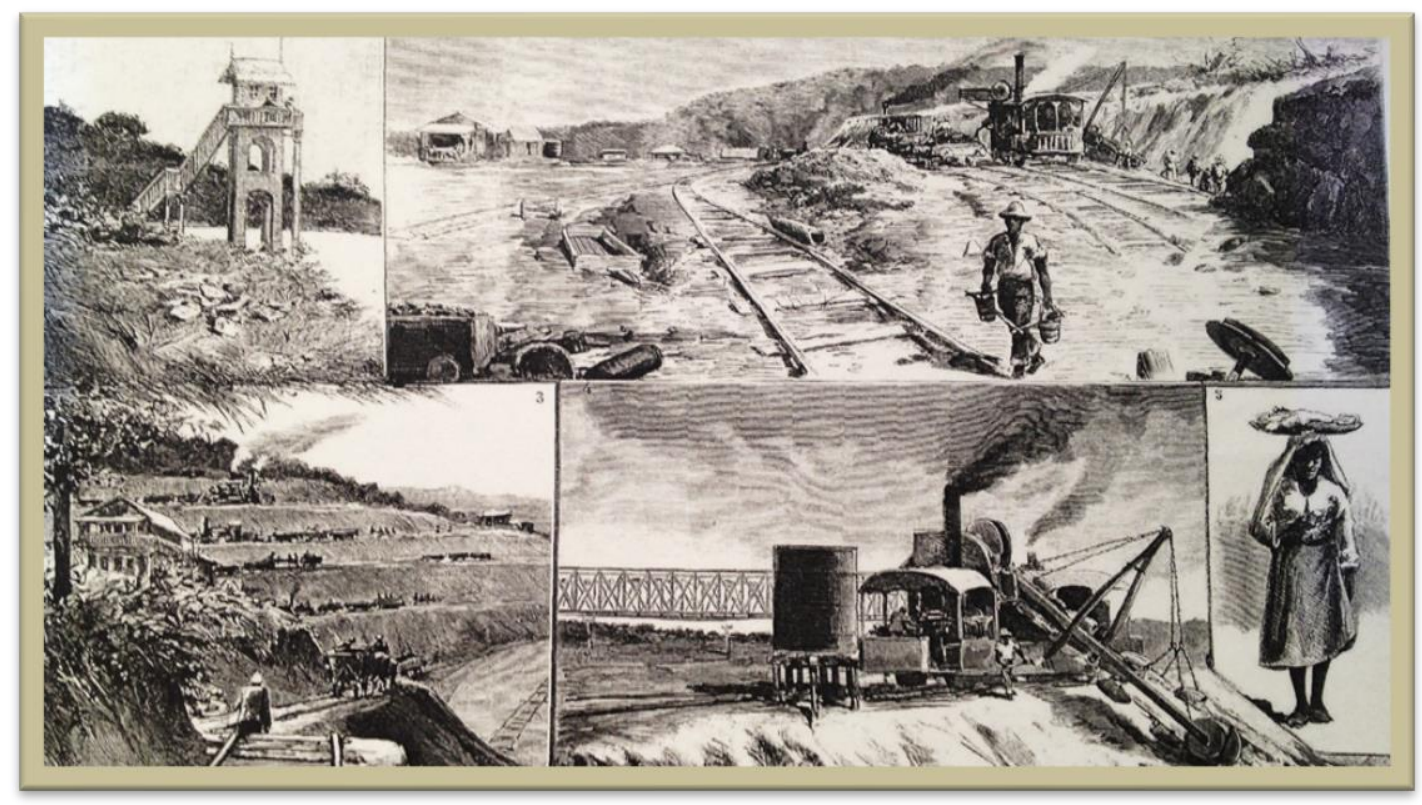

Fig. 10.4 Secciones de las obras y vendedora de licores.

De este conjunto de vistas destacamos la imagen de la vendedora de licores y que comenta el reportaje de Eusebio Martínez utilizando las notas que el propio artista ha facilitado. Campuzano dice: "el sueldo de los trabajadores sin especialidad es muy bajo y el de los que tienen especialidad depende de su destreza; pero bajo el clima ardiente y malsano del país, y sin agua potable, los infelices trabajadores tienen que pasar sus ahorros a las vendedoras de aguardiente, ginebra y licores, que circulan incesantemente por las secciones donde las brigadas de operarios son más numerosas"14. Peris Mencheta hace un comentario similar en su crónica y dice que hay mucha humedad y que la temperatura durante la mayor parte del año es de 36-37 grados centígrados a la sombra y hasta 46 grados centígrados al sol ${ }^{15}$.

14. La Ilustración Española y Americana, año XXX, núm. XXIII, 22 de junio de 1886, p. 379.

15 PERIS MENCHETA, Francisco. 1886, p. 154. 


\section{5.- Matachín. Lavanderas en el río Chagres}

Este grabado fue publicado junto en el anterior ${ }^{16}$. En esas fechas diferentes periódicos se hicieron eco de las noticias que llegaban sobre la imposibilidad de finalizar las obras en el plazo previsto por la falta de medios económicos y de maquinaria especializada, y por las numerosas muertes por fiebres de los trabajadores, poniéndose incluso en duda su efectiva realización por la magnitud del proyecto (fig. 10.5).

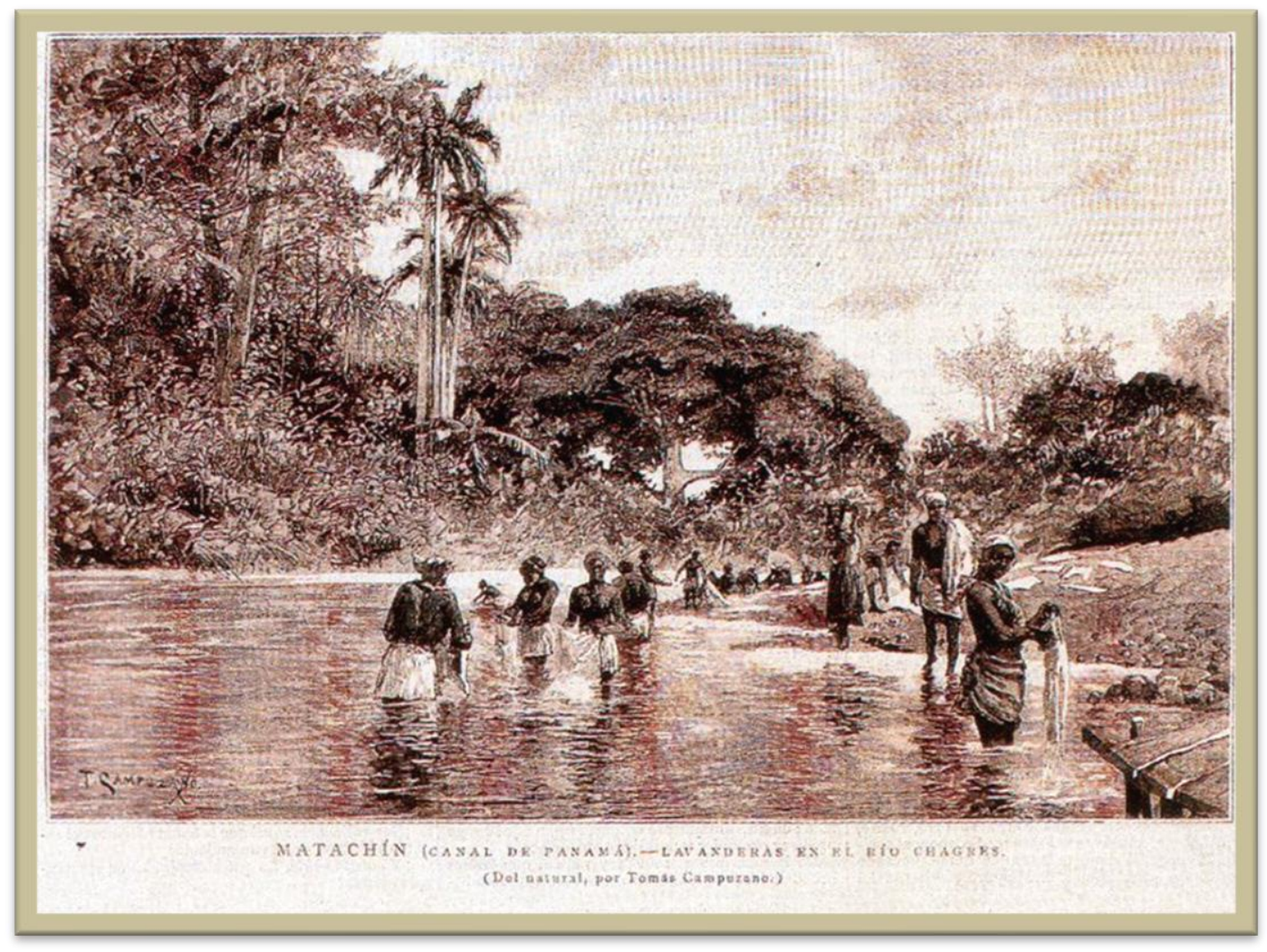

Fig. 10.5 Matachín. Lavanderas en el río Chagres.

${ }^{16}$ La Ilustración Española y Americana, año XXX, núm. XXIII, 22 de junio de 1886, p.388. 
El periodista Martínez Velasco, utilizando una vez más las notas descriptivas del autor, dice que Lavanderas en el río Chagres es una vista tomada del natural en un momento en el que numerosas lavanderas negras, metidas en el río, casi desnudas, se ocupan en la faena de su ingrato oficio ${ }^{17}$.

Esta escena, que tuvo lugar durante una de las visitas a las obras, se produjo en el río Chagres, que entra en el canal en su Km 45 y desemboca en el océano Atlántico. Causó tal impresión a todos que fue comentada en las dos crónicas.

La crónica de Peris Mencheta dice: "Al detenerse el tren contemplamos un bellísimo cuadro; a dos metros del empuje de la corriente que eleva las laguas a los depósitos para alimentar las calderas de las máquinas, está el lavadero de las negras. Quince o veinte de estas, casi desnudas, luchaban desesperadas para hacer más blanca la ropa que subido era el color de sus carnes. El contraste no podía ser más evidente..."18

La crónica de E. Sanchiz dice: “...bajamos al río Chagres en canoas y fuimos a desembarcar en las cercanías de Matachín, disfrutando de un paisaje encantador. En un frondoso y pintoresco remanso de este río había un grupo de mujeres de ébano lavando y bañándose, que fijó la atención de todos nosotros, y sobre todo la del artista Campuzano, que acompañaba a la expedición. Era un verdadero cuadro típico de belleza tropical digno de haberse fotografiado si hubiésemos tenido las cámaras a mano"19.

No sabemos cuánto tiempo contempló el pintor la escena, pero no sería mucho, sin embargo, el dibujante tuvo tiempo de plasmar la imagen con mucho detalle, destacando la exuberante vegetación de la zona y captando perfectamente el gesto de sorpresa de las mujeres que miran al espectador al verse sorprendidas en su trabajo.

${ }^{17}$ La Ilustración Española y Americana, año XXX, núm. XXIII, 22 de junio de 1886, p. 379.

${ }^{18}$ PERIS MENCHETA, Francisco, 1886, p. 139.

19 SANCHIZ y BASADRE, Eliseo, 1886, p. 71. 


\section{6. - Draga Slaven en el río Mindi}

Una vez más Tomás Campuzano hace el retrato de un barco; en este caso la draga americana Slaven y lo importante es la máquina y sus detalles, quedando el paisaje en segundo plano (Fig. 10.6). El grabado, tomado del natural, se publicó el día 8 de julio de $1886^{20}$.

Esta draga también se describe en las dos crónicas como la mejor del momento. E. Sanchiz la define como magnífica ${ }^{21}$. Sin embargo, Peris Mencheta se detiene un poco más y dice que es la única máquina que responde a la magnitud de las obras que se están realizando y explica que es una draga sistema Compound, de 300 caballos de fuerza que extrae cada hora 250 metros cúbicos de arena y fango ${ }^{22}$

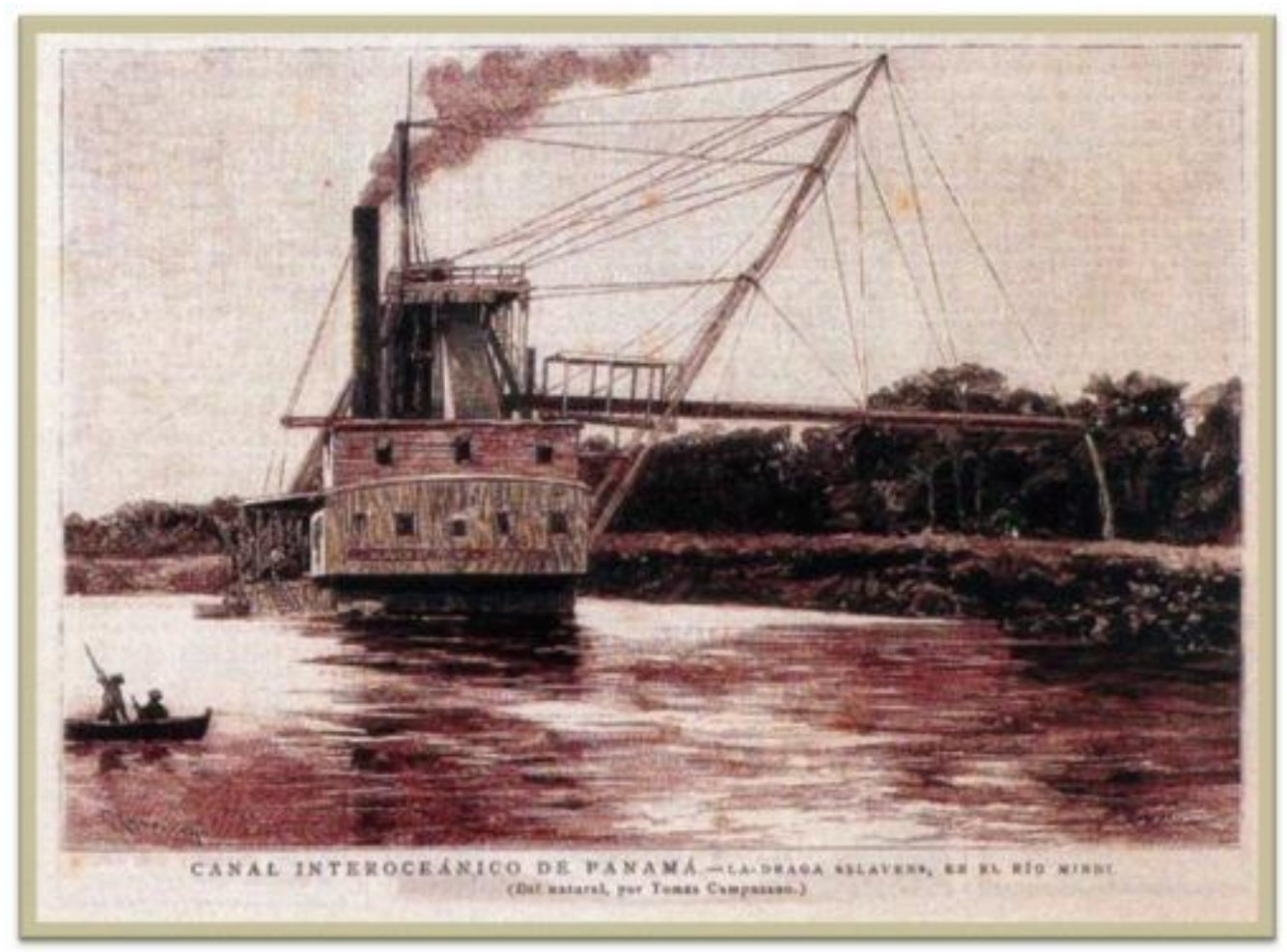

Fig.10.6 Draga Salven en el Río Mindi.

${ }^{20}$ La Ilustración Española y Americana, año XXX, núm. XXV, 8 de julio de 1886 p. 15. ${ }^{21}$ SANCHIZ y BASADRE. Eliseo, 1886, p. 83.

${ }^{22}$ PERIS MENCHETA, Francisco, 1886, p. 154. 
Eusebio Martínez menciona las dificultades que existen para poder llevar a cabo la realización de las obras, entre otras cosas, por los millones de metros cúbicos de tierra que hay que remover sin los medios adecuados. $\mathrm{Y}$ de nuevo adjunta a sus palabras las notas del artista explicando que “...parte del trabajo ha sido adjudicado a la sociedad Slaven y compañía de Nueva York. Dicha sociedad ha instalado algunas dragas de vapor y la mejor de ellas es la del dibujo, que parece una casa-fábrica flotante y arroja el barro extraído por medio de un tubo de hierro que se prolonga horizontalmente hasta la orilla del canal...". Dice además que ...”es económica como invento norte-americano, porque evita el gasto de transportar los materiales extraídos hasta la orilla”23..

El dibujo está hecho del natural, pero por la fecha de publicación, más de dos meses después de volver la expedición, estoy casi segura de que es el producto final acabado en su taller Madrid con origen en los distintos apuntes tomados durante el viaje.

${ }^{23}$ La Ilustración Española y Americana, año XXX, núm. XXV, 8 de julio de 1886, p.6. 


\section{2.- Ilustraciones de la crónica de Francisco Peris Mencheta}

\section{1.- El castillo del Morro y la entrada del Magallanes en el puerto de La Habana}

En este caso estamos ante una escena que parece real pero que nuestro dibujante no ha podido ver ya que en el mismo momento en el que el Magallanes entra en el puerto de La Habana él está a bordo del barco, por lo que esa visión del vapor acercándose al muelle no la pudo ver. Es un montaje que parece real. Como he comentado, su observación del mar y de los barcos es directa, pero algunas de sus obras no son reproducción de ningún paisaje real, sino escenas compuestas con detalles tomados de aquí y de allá que dan a sus obras un aspecto verosímil pero improbable; son paisajes compuestos, montajes que acaba en su taller. (Fig. 10.7).

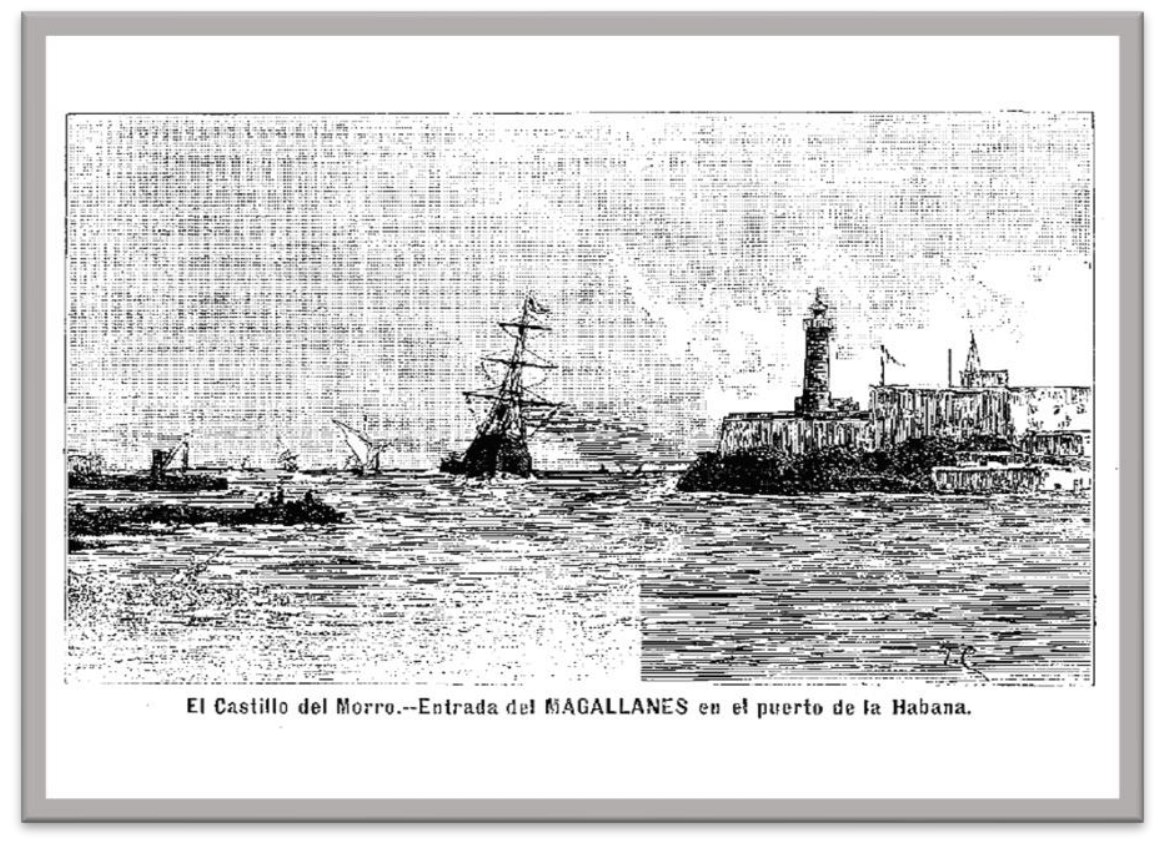

Fig. 10.7 El Castillo del Morro y la entrada del Magallanes en el puerto de La Habana. 
Peris Mencheta dice en su crónica ${ }^{24}$..."la bahía ofrece un bellísimo aspecto, a la izquierda el castillo del Morro y a la derecha el fuerte de la Punta"..., por lo que este es el momento de entrada y las palabras del reportero sitúan al dibujante dentro del barco pero Campuzano representa la escena vista desde fuera, por lo que sin duda tomó diferentes apuntes de escenas similares desde la orilla de la fortaleza de la Punta y luego sustituyó el barco por el Magallanes, consiguiendo una escena verosímil.

\section{2.- Una calle de Colón}

Según describe Peris Mencheta, la ciudad de Colón tiene un bello barrio francés que está aseado, con buenas construcciones y lindos jardines; pero los otros barrios son muy desagradables, de repugnante aspecto, por faltar toda medida de policía urbana. Las calles son auténticos barrizales donde las aguas fecales corren libremente y dice que las casas son de madera, al estilo americano, traídas de América del Norte y están levantadas sobre estacas y pilotes, para aislarlas un poco de la humedad y de la calle25.

Las palabras de Peris Mencheta las vemos en la ilustración de Campuzano (Fig. 10. 8), que refleja perfectamente la inmundicia en la que viven los habitantes de los barrios pobres de Colón y sobre todo los trabajadores de las obras. Observamos la pobreza de las casas, el poco aseo de sus ropas, el amontonamiento de las familias, y en mi opinión, el artista y el cronista tienen interés en destacarlo porque todo esto llama mucho la atención en un momento en el que crecen las preocupaciones higiénicas que están transformando el paisaje urbano de las ciudades. Es como una especie de reivindicación de las malas condiciones en las que viven los trabajadores de la obra más famosa del siglo.

\footnotetext{
${ }^{24}$ PERIS MENCHETA, Francisco, 1886, p. 95.

${ }_{25}$ PERIS MENCHETA, Francisco, 1886, p. 133. 
Vemos las construcciones en madera sobre pilotes para aislarlas de la humedad, y se transmite la pobreza y las malas condiciones de vida. No es una representación de un paisaje idílico ni con nostalgia, sino una especie de fotografía de la cruda realidad.

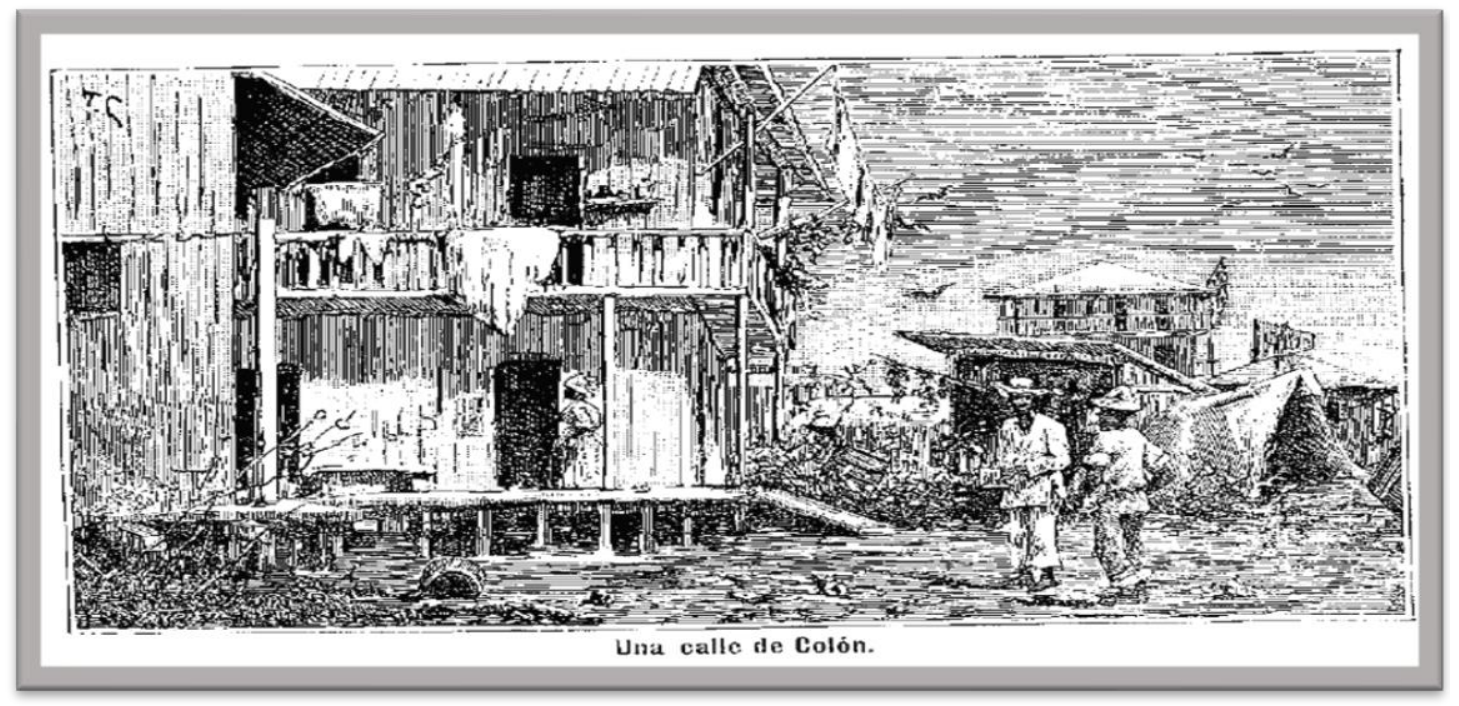

Fig. 10. 8 Una Calle de Colón

\section{3.- Punta de Panamá}

Las dos crónicas hablan del mal estado de los embarcaderos de Panamá, de la abundante vegetación que llega hasta la costa y de los materiales putrefactos que arrastra la marea y que huelen mal. Y Tomás Campuzano una vez más refleja las palabras en su dibujo; podemos ver los pilotes que hacen de muelle, unas embarcaciones pequeñas y unas edificaciones poco destacables (Fig. 10.9).

En este caso podríamos estar ante un dibujo sacado de una fotografía, pues ya hemos sabido que los miembros de la expedición llevaban cámaras fotográficas, pero dado que en todos los grabados de la revista La Ilustración Española y Americana se especificó que estaban tomados de apuntes del natural, nada nos puede indicar lo contrario en el caso de las ilustraciones de esta crónica. 
Sin embargo, como la obra se acabó de escribir el 1 de junio de 1886, bien pudo el dibujante retocar esos apuntes en su estudio y darles mayor definición y detalles.

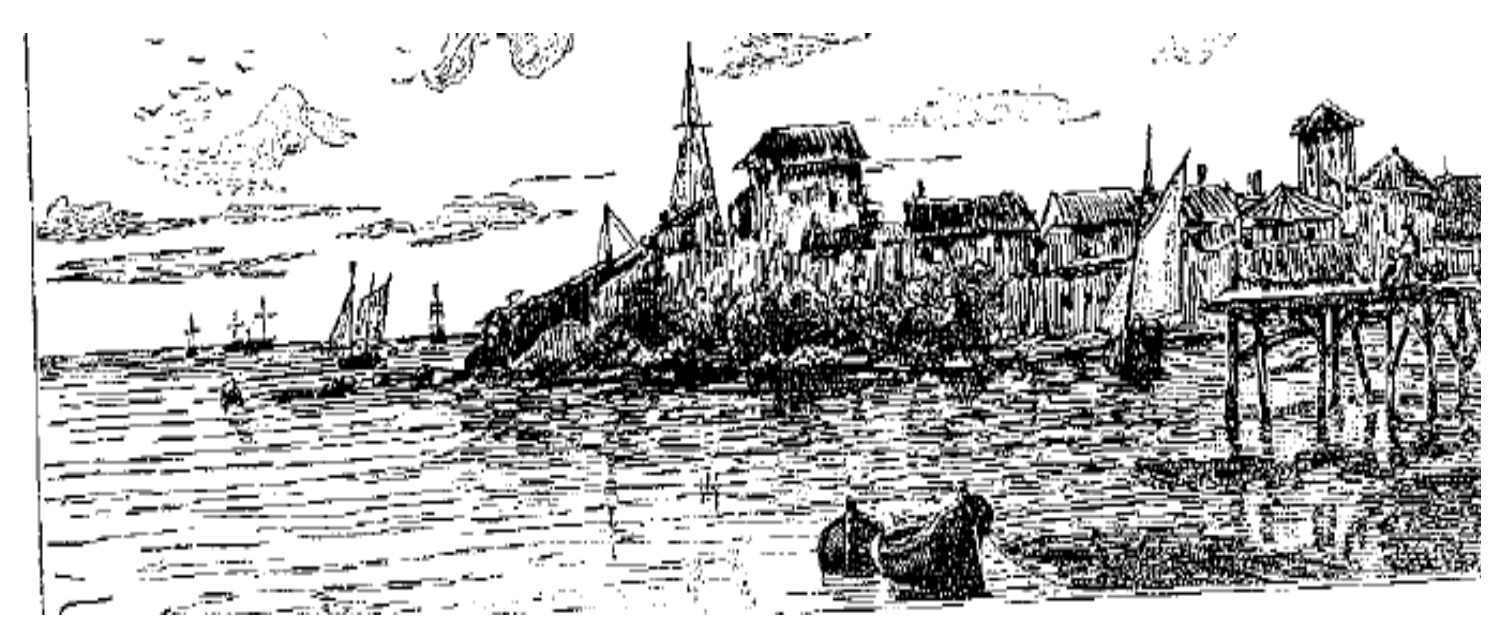

Fig. 10.9 Punta de Panamá.

\section{4.- Draga en el Pacífico}

La ilustración representa otra de las muchas dragas de vapor que trabajan en el canal y que remueven el fondo para sacar la arena y el fango. En este caso no es comparable a la anteriormente nombrada Slaven porque es necesaria una embarcación que lleve los materiales extraídos a la orilla, pero no por ello el dibujante deja de detallar la máquina, que como ya hemos dicho supone el dominio del hombre sobre el medio y era un aspecto muy importante que había que destacar para reforzar la idea positiva de poder realizar las obras con éxito.

Actualmente no disponemos de la imagen pero realizaremos las investigaciones necesarias para intentar localizarla. 


\section{5.- El rio Chagres en Matachín}

Esta ilustración es una imagen diferente pero muy similar a la escena de Las lavanderas en el río Chagres que hemos visto antes y que se publicó en $L a$ Ilustración Española y Americana (Fig. 10.5). Podemos deducir que durante el tiempo en que la expedición estuvo detenida en ese lugar, Campuzano tuvo posibilidad de tomar varios apuntes que le sirvieron para elaborar después las dos obras, que apreciadas en general reflejan el mismo lugar y el mismo momento, pero en detalle son distintas. No cabe duda de que el exotismo de la escena causó impresión a los miembros de la expedición. (fig. 10.10)

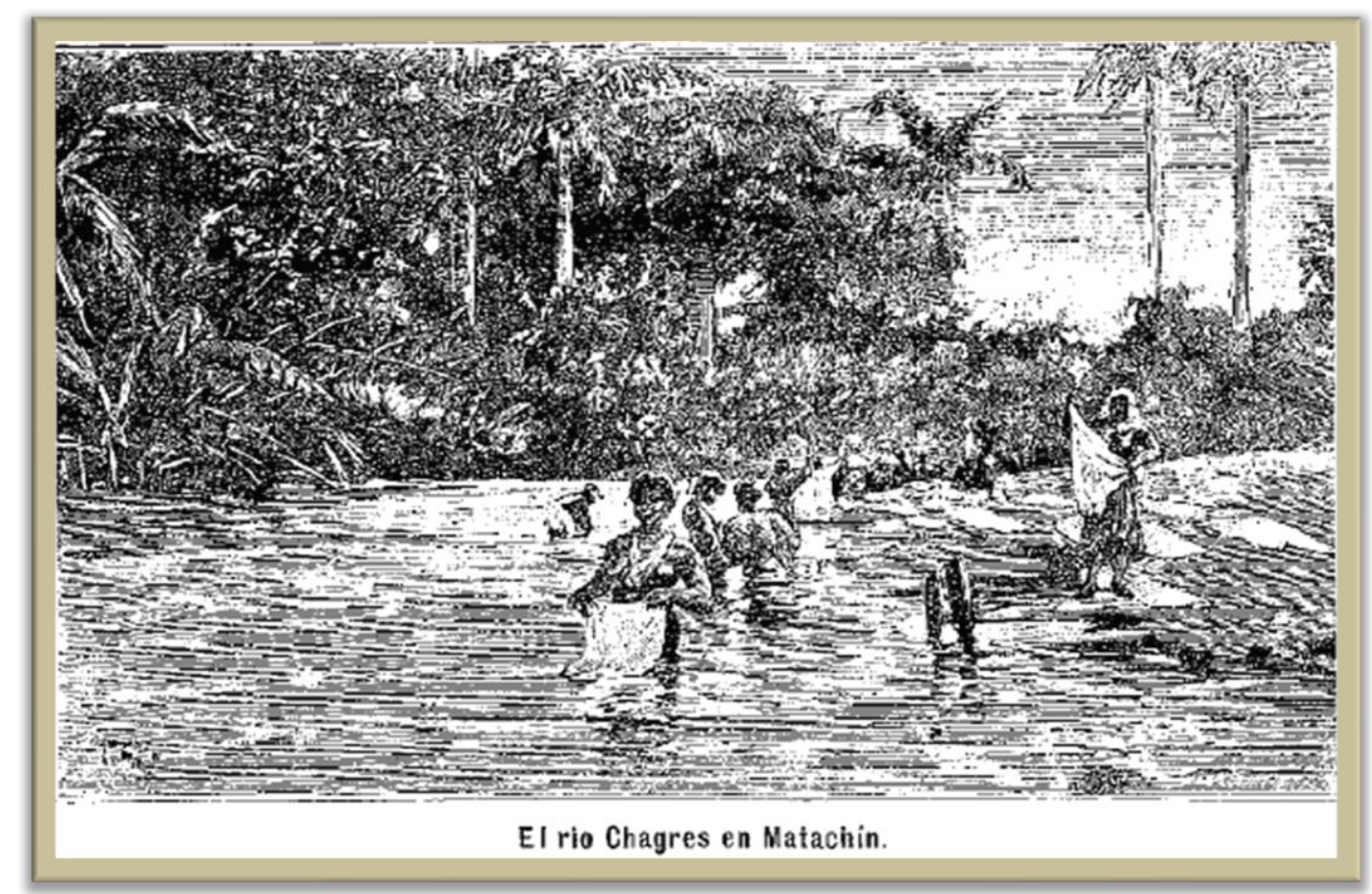

Fig. 10.10 El río Chagres en Matachín. 
De lo visto hasta ahora no hay duda de que Tomás Campuzano fue el dibujante perfecto para plasmar las impresiones del viaje a Panamá. Los apuntes realizados y luego publicados nos permiten hacernos una idea perfecta de los paisajes del lugar, las costumbres de los habitantes y las obras del canal, a la vez que nos dan idea del tipo de actividades que realizaron allí los miembros de la expedición.

Tomás Campuzano fue nuestros ojos y gracias a él participamos, con esos dibujos y las crónicas que los acompañaron, en el viaje. No hay duda de que supuso un antes y un después, pues para él una gran experiencia a la vez que promocionó su carrera como ya hemos visto, pero no nos olvidemos que todo ello fue posible, una vez más a José Campo, para quien la palabra “imposible”, no existía. 


\section{Capítulo Xi}

UN REGALO DEL MARQUÉS DE CAMPO AL GENERAL JOVELLAR EN 1875. INTERPRETACIÓN ICONOGRÁFICA

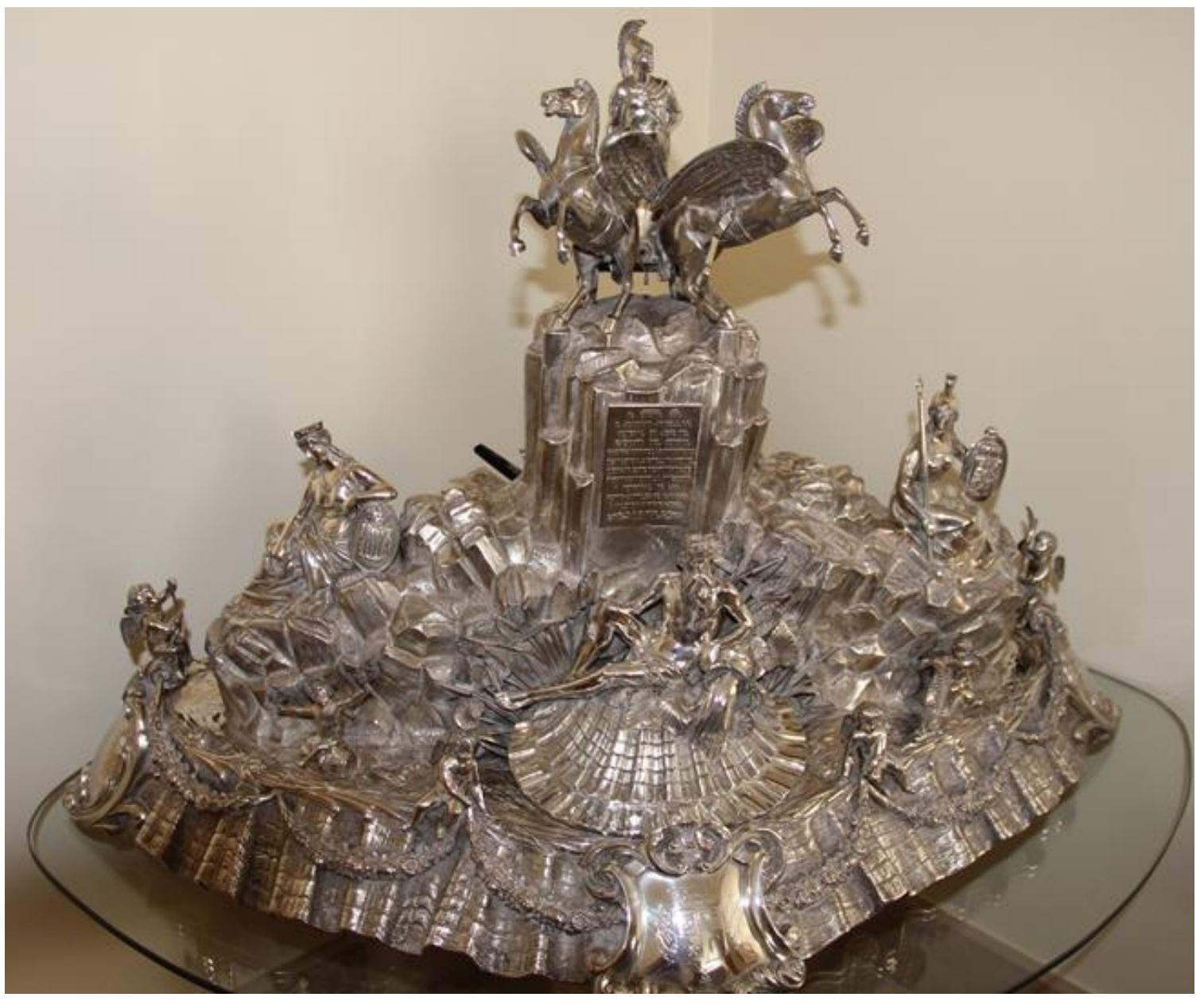





\section{Capítulo Xi}

\section{UN REGALO DEL MARQUÉS DE CAMPO AL GENERAL JOVELLAR EN 1875. INTERPRETACIÓN ICONOGRÁFICA}

En 1883 tuvo lugar en Madrid la Exposición Nacional de Minería y Artes Metalúrgicas, Cerámica, Cristalería y Aguas Minerales. Se celebró en el llamado entonces Campo Grande, una zona del Retiro de Madrid que se había mantenido silvestre hasta el reinado de Isabel II. El ingeniero de minas Enrique de Nouvión se hizo cargo del proyecto para acondicionar la zona y trazó un recinto cerrado con dos accesos, cuyo punto de referencia era el Pabellón Central, que fue obra de Ricardo Velázquez Bosco (1843-1923). Velázquez se inspiró para su construcción en el Crystal Palace de Londres y hoy el edificio es conocido con el nombre de Palacio de Velázquez en honor a su creador (Fig. 11.1).

\footnotetext{
${ }^{1}$ Parte de este capítulo formó parte de una comunicación presentada en el Congreso de Emblemática celebrado en Mallorca en diciembre de 2015.

MORANT GIMENO, Ana María. "Un regalo del marqués de Campo (1814-1889) al general Jovellar (1819-1892) en 1875: buscando una interpretación iconográfica”. En: BALLESTER, Blanca, BERNAT, Antonio, CULL, John (Eds.). Encrucijada de la palabra y la imagen simbólicas. Estudios de emblemática. Palma de Mallorca, Editorial Marcial Pons, 2018.
} 
Velázquez Bosco trabajó con el ingeniero Alberto de Palacio y Elissague (1856-1939). Palacio, que convirtió la forja industrial en artística, cursó sus estudios sobre carpintería de hierro en Francia y fue discípulo de Gustav Eiffel2; calculó toda la estructura del edificio y fue montado por el constructor del hierro Bernardo Asins y Serralta (1840-1897).

A raíz del éxito alcanzado por la Exposición Universal de Londres de 1851, la arquitectura de hierro y cristal comenzó a identificarse con los pabellones de muestras, donde se ensayarían las más avanzadas técnicas constructivas que después habrían de aplicarse en las demás edificaciones. Nacía así una nueva tipología de carácter en principio efímero, que reflejaba el triunfo del capitalismo y cuyos ejemplos se convertirían en hito del progreso, sin renunciar a expresar, mediante su composición arquitectónica, nuevas opciones estilísticas.

El exterior del palacio, muy bien conservado en la actualidad, muestra una gran nave central con bóveda de cañón y cuatro torreones en las esquinas, unidos por galerías. Las fachadas de fábrica de ladrillo en dos colores están decoradas con figuras escultóricas y cerámica (Figs. 11.2 y 11. 3). La armadura, la cubierta y los marcos de los huecos son de hierro, cinc y cristal. La preciosa azulejería de cerámica es obra de Daniel Zuloaga (1852-1921). Entre todos estos grandes artistas y profesionales crearon uno de los edificios más singulares de Madrid.

2 La biografía de Alberto Palacio Elissague se puede consultar en: http://dbe.rah.es/biografías/ consultado en línea el 12 de octubre de 2015. 


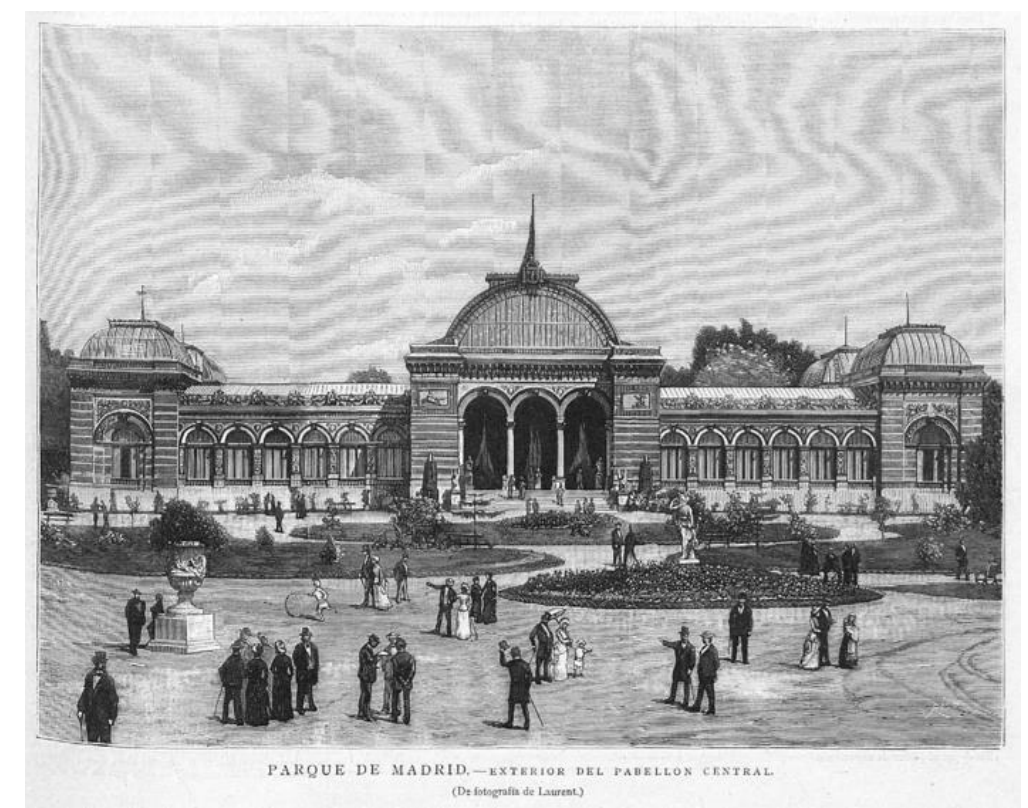

Fig. 11.1 Palacio Velázquez. La Ilustración Española y Americana, 1883.

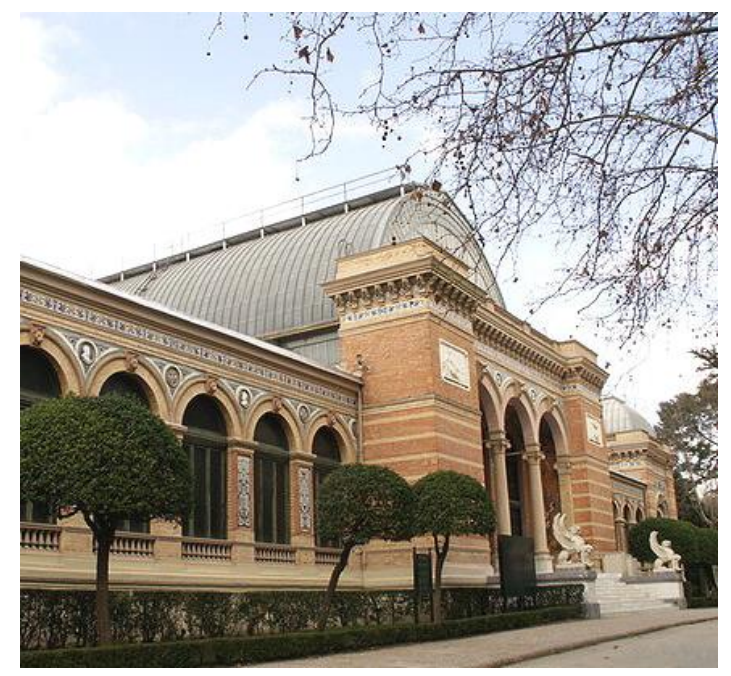

Fig.11.2 Palacio Velázquez. Madrid. Estado Actual3.

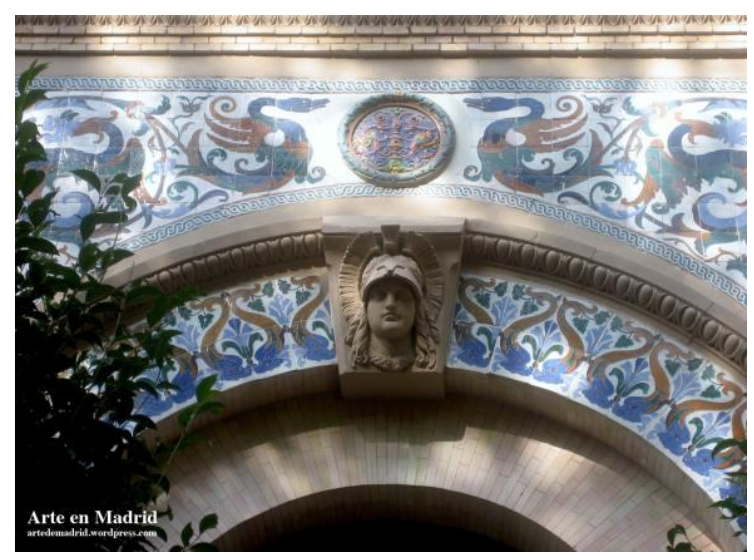

Fig.11.3 Palacio Velázquez. Pabellón Zuloaga. Madrid, Estado actual4.

\footnotetext{
3 Imagen publicada en:

https://www.madrid.es/portales/munimadrid/es/Inicio/Cultura-ocio-ydeporte/Cultura-y-ocio/Direcciones-y-telefonos/Palacio-deVelazquez/?vgnextfmt=default\&vgnextoid=a34f29ea9281c010VgnVCM100000ob205a oaRCRD\&vgnextchannel=76f3efff228fe410VgnVCM2000000c205a0aRCRD consultada en línea el 23 de abril de 2014.

${ }^{4}$ Imagen publicada en: https://artedemadrid.wordpress.com/2010/08/12/palacio-develazquezl, consultada el día 23 de abril de 2014.
} 
La exposición fue inaugurada el día 27 de mayo de 1883 por el rey Alfonso XII y el rey de Portugal Luis I de Saboya, quien casualmente se encontraba en Madrid de visita con su esposa y sus hijas5.

En esa exposición participó la platería "Espuñes e hijos" de Madrid, fundada hacia 1840 por Ramón Espuñes y Durán (hacia 1820-1884)6. Ramón Espuñes aprendió el oficio de platero en la famosa platería Martínez. Por su técnica y su estilo ganó fama muy pronto y en 1850 formó sociedad con otro platero llamado Ángel Marquina hasta 1867, fecha en la que Ramón Espuñes se asoció con su hermano Francisco y se convirtieron en proveedores de la Real Casa. El pequeño taller que tenían en el callejón de la Yedra pasó a ser una fábrica situada en la Ronda de Atocha, de donde salieron incontables piezas de gran valor y de gran nivel técnico y artístico.

Espuñes fabricaba piezas religiosas, pero sobre todo piezas civiles representativas de la platería romántica madrileña, copas conmemorativas, vajillas, etc., con recuerdos a estilos pasados como el barroco o el rococó, espejos, volutas, rocallas, etc., pero a la vez buscando nuevos diseños para una sociedad en constante cambio y evolución, en función de unos hechos históricos que la alteran profundamente.

En sus piezas se observa una influencia francesa que estaba muy de moda en ese momento, fue uno de los primeros en introducir la decoración llamada de "guilloché". Concurrió a la exposición de Zaragoza en 1868, donde ganó su primera medalla; también tuvo mucho éxito en la exposición Internacional de

\footnotetext{
5 La visita de la familia real de Portugal fue objeto de varias publicaciones en las que se daban los detalles de los festejos celebrados y se publicaban grabados como por ejemplo en La Ilustración Española y Americana de 30 de mayo de 1883.

${ }^{6}$ Para conocer la historia y el trabajo de la platería Espuñes ver: MARTIN, Fernando; SIERRA, Luis. 150 años Platería Espuñes. Madrid: Artes Gráficas Luis Pérez S.A., 1990.
} 
Viena de 1873, y en la nacional de Madrid de 1873 donde de nuevo volvió a obtener medalla de plata, igual que en la exposición de 1883 que es la que nos ocupa.

En dicha exposición exhibió muchas piezas, pero una de ellas destacó sobremanera y fue comentada por la prensa de la época.

En los diferentes artículos de prensa y revistas que se refirieron a la exposición, se hizo referencia a esta pieza en particular, que es el objeto de estudio en este capítulo y que es un centro de mesa de plata, repujado y cincelado, de unos $25 \mathrm{Kg}$ de peso que según la prensa de la época ... "representa hechos de armas acaecidos en la última guerra civil...”7

En otra noticia de prensa podemos leer: "Llaman la atención los primorosos objetos de plata que exponen los señores Espuñes e hijos, cuya casa ha ido incesantemente progresando en los cuarenta y tres años que cuenta de existencia. Demasiado conocidos son del público sus productos para que nos detengamos en elogiarlos. Entre los objetos expuestos se fija inmediatamente el observador en el que fue dedicado al general Jovellar en 1875 por las compañías de los ferrocarriles del Centro y Valencia, que representa una escarpada montaña, en cuyo vértice hay un carro triunfal, conduciendo al dios Marte, como alegoría de la guerra, y además varias otras figuras, que forman un bellísimo conjunto, realzado al propio tiempo que, por el mérito artístico, por el bellísimo color blanco mate de la plata...”"

Dicha pieza fue un regalo del marqués de Campo en nombre de la dirección y el personal de los Ferrocarriles de Almansa a Valencia y Tarragona al General Jovellar (1819-1892) por su participación en diversas batallas en la tercera guerra carlista que posibilitaron la liberación y pacificación de las

\footnotetext{
${ }^{7}$ La Ilustración Española y Americana 30 de mayo de 1883, p. 347.
}

${ }^{8}$ El Globo 3/6/1883, p. 2. 
provincias de Valencia, Castellón y Teruel y en las que se utilizó el tren como medio de transporte de las tropas y mercancías y cuya construcción había llevado a cabo José Campo dentro de la línea Almansa-Valencia-Tarragona9, (Figs. 11.4 y 11.5).

\footnotetext{
9 Para saber más sobre los negocios y la construcción del ferrocarril por José Campo ver:
}

HERNÁNDEZ, Telesforo. Ferrocarriles y capitalismo en el País Valenciano 1843-1879. Valencia: Ayuntamiento de Valencia, 1983.

HERNÁNDEZ, Telesforo. "Los negocios ultramarinos del Marqués de Campo en Cuba y Filipinas (1880-1886)” en HERNÁNDEZ, Telesforo (coord.). Los valencianos y América. Valencia: Generalitat Valenciana, 1992.

HERNÁNDEZ, Telesforo. "Tensions familiars i patrimoni: ventura i desventura de la fortuna acumulada pel marquès de Camp". En: Afers, fulls de recerca i pensament, Vol. VIII, La burguesia dels Països Catalans al segle XIX. 1993.

HERNÁNDEZ, Telesforo, “José Campo Pérez” en VIDAL, Juan (dir.). Cien Empresarios Valencianos. Madrid: Editorial Empresarial, 2005.

PONS, Anacleto; SERNA, Justo. La ciudad extensa. Valencia: Diputación de Valencia, 1992.

PONS, Anacleto; SERNA, Justo. Los triunfos del burgués. Estampas valencianas del Ochocientos. Valencia: Tirant lo Blanch, 2011.

MORANT GIMENO, Ana María et al, El Marqués de Campo, político, empresario y coleccionista de obras de arte. Valencia: Ayuntamiento de Valencia, 2015. 


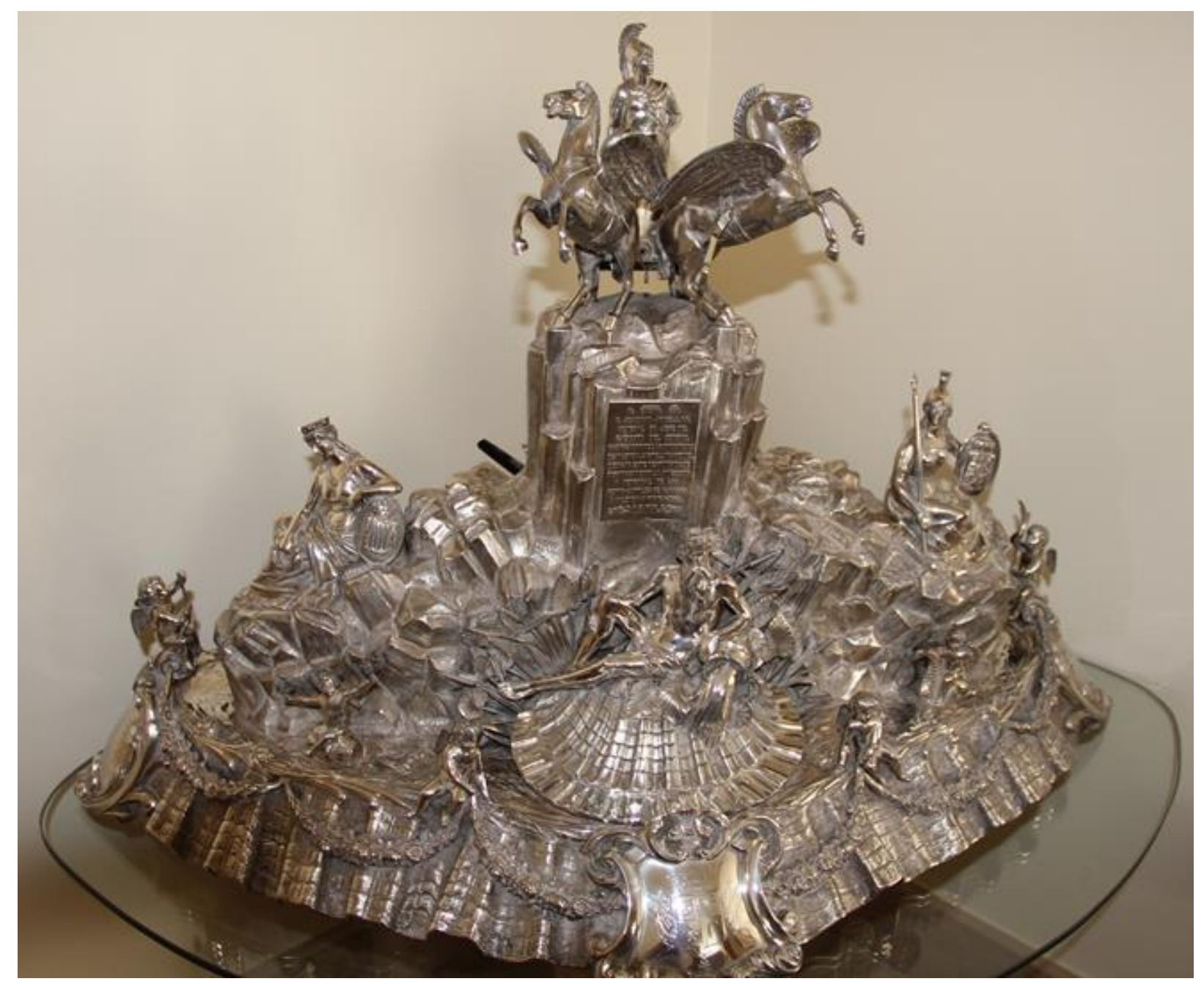

Fig. 11.4 Figura para el General Jovellar. Platería Espuñes e hijos. 1883. Colección particular. Fotografía de la autora. 


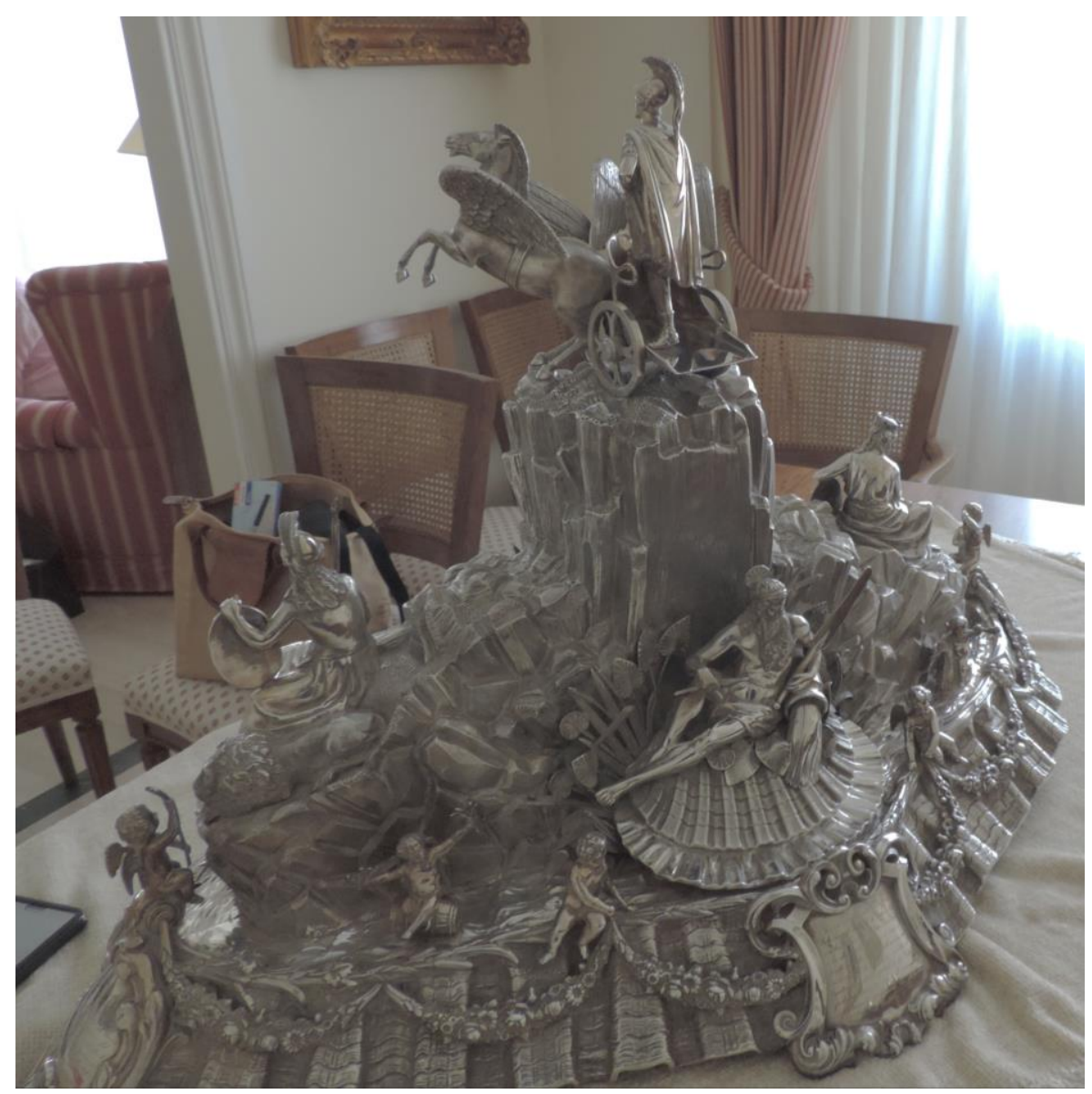

Fig. 11.5 Figura para el General Jovellar. Platería Espuñes e hijos. 1883. Colección particular. Foto de la autora.

Joaquín Jovellar y Soler nació en Palma de Mallorca el día 28 de diciembre de 1819. A los 16 años entró en el ejército recién comenzada la guerra carlista. Ascendió poco a poco en el escalafón militar hasta que en 1873 fue nombrado Capitán General y en 1874 General en Jefe del Ejército del Centro. Junto con el General Martínez Campos y el Brigadier Daban, proclamó en los campos de Sagunto la monarquía de Alfonso XII y la restauración de la dinastía legítima ${ }^{10}$.

${ }^{10}$ CASTRO GIRONA, Alberto. Jovellar. Madrid: Editorial Purcalla,1947. En este libro de la biografía del General Jovellar se describen con todo lujo de detalles sus hazañas en los diferentes campos de batalla en los que estuvo y sobre todo su actuación con el Ejército del Centro en el pronunciamiento de Sagunto. 
En 1875 fue nombrado Ministro de la Guerra, acompañó a Alfonso XII en la revista al ejército del norte y concurrió a los hechos de armas de levantamiento del bloqueo de pamplona y la ocupación del río Arga. Fue administrador de Cuba y Capitán General de las islas filipinas, Presidente del Consejo Supremo de Guerra y Marina y Senador del Reino y fue presidente del Consejo de ministros desde el 12/09/1875 al 2/12/1875. Alfonso XII le ofreció un título nobiliario de marqués, pero él lo rechazó (Fig. 11.6).

El General Jovellar obtuvo, entre otras, las siguientes condecoraciones: Gran Cruz de Isabel la católica 20/11/1865, Gran Cruz de San Hermenegildo 13/01/1869, Gran Cruz del mérito militar 1878, Gran Cruz de San Fernando, Collar de la Torre y la Espada, Gran Cruz de San Benito de Avis, de Portugal, Gran cruz de la Estrella polar de Suecia y Noruega.

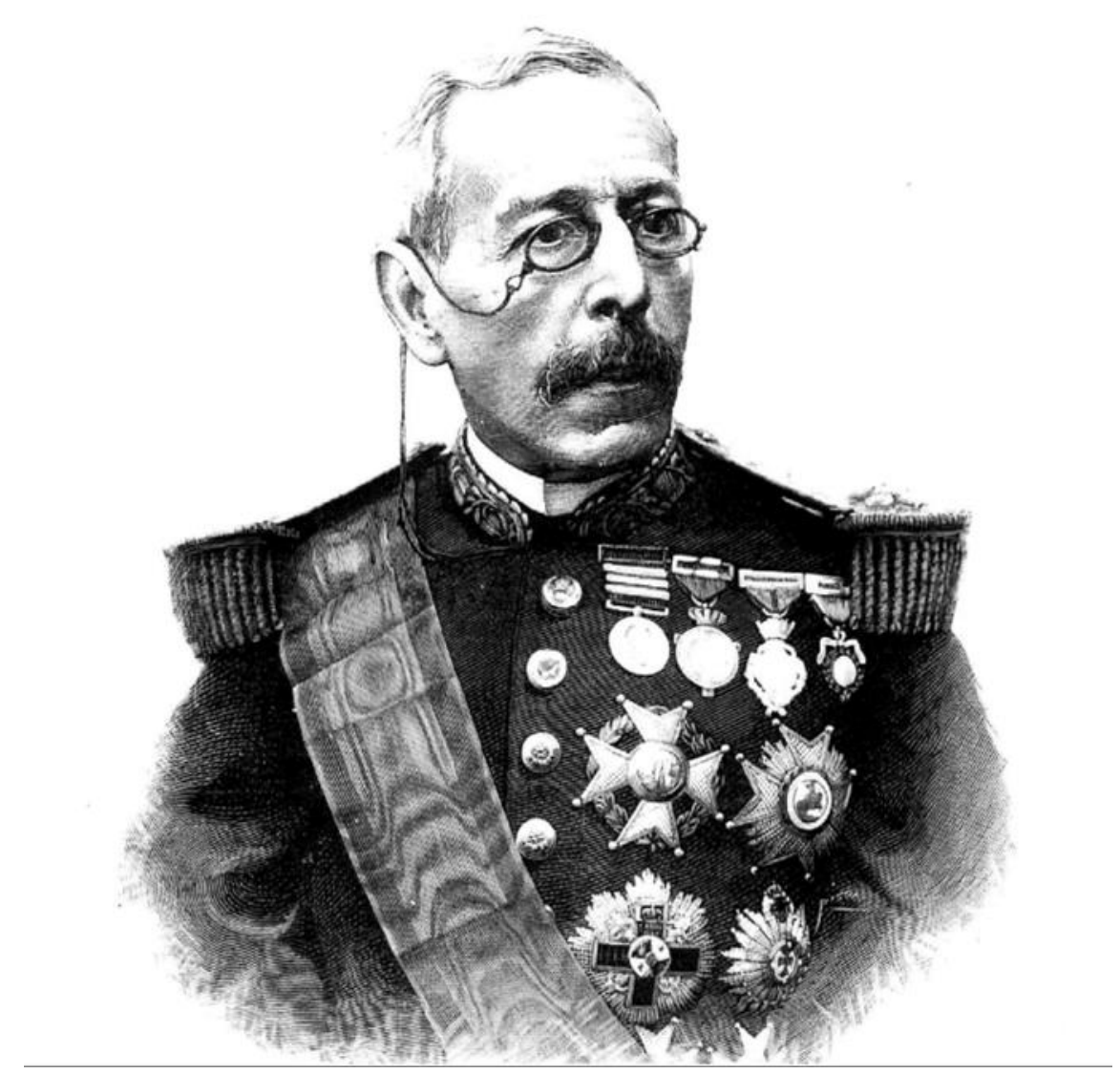

Fig.11.6 General Joaquín Jovellar y Soler. La Ilustración Española y Americana, 1982. 
La pieza de la platería Espuñes que se expuso y que José Campo regaló al General Jovellar tiene una placa en la parte delantera que die: «Al Excmo. Sr. D. Joaquín Jovellar, General en Jefe del Ejército Norte del Centro. Pacificador de las provincias de Valencia, Castellón y Teruel. Dedican este testimonio de reconocimiento, la Dirección y Personal de los ferrocarriles de Almansa a Valencia y Tarragona 1875». (Fig. 11.7).

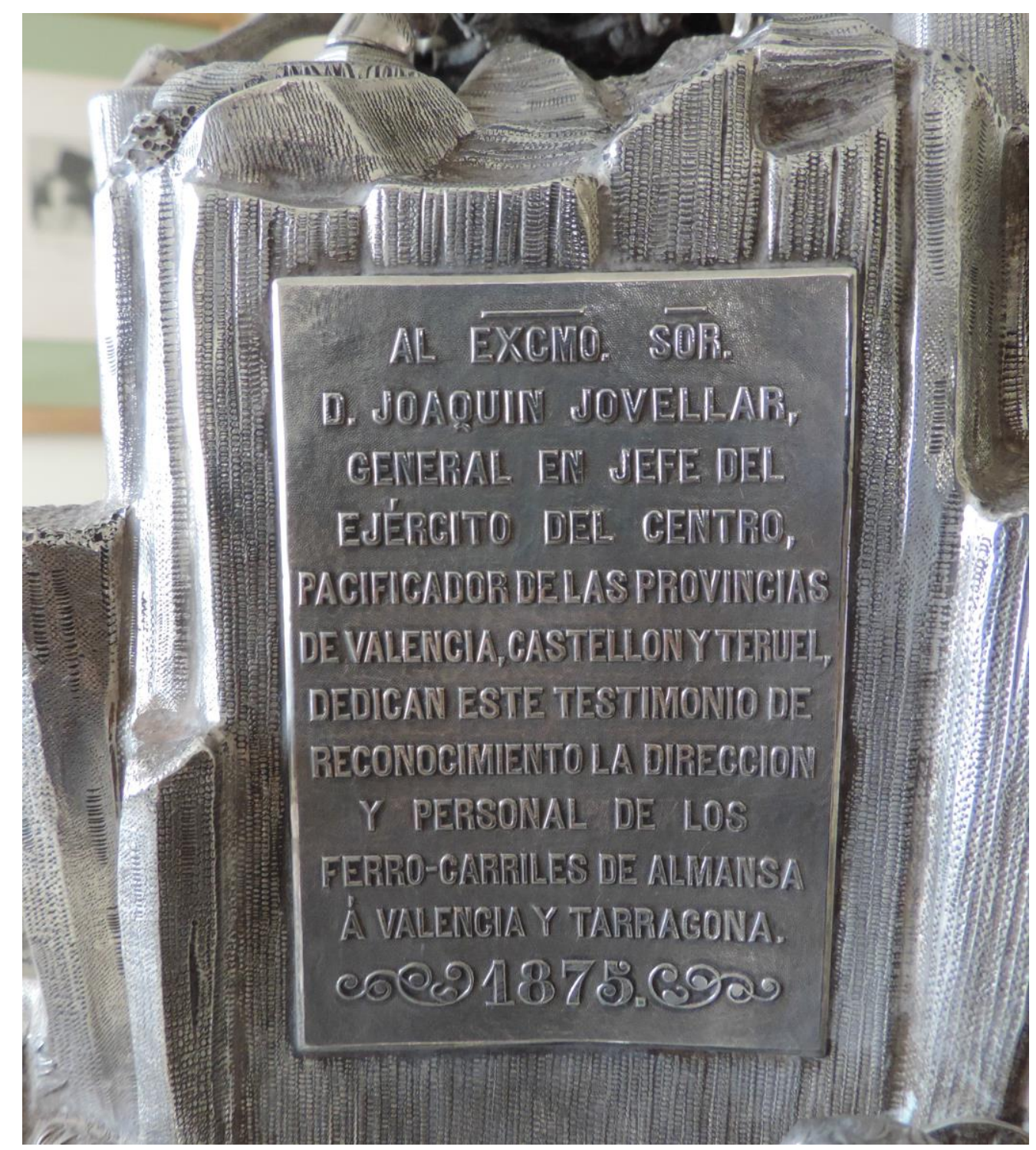

Fig.11.7 Figura para el General Jovellar. Platería Espuñes e hijos.1883. Vista trasera. Colección particular. Fotografía de la autora. 
La dedicatoria de agradecimiento es muy clara y ofrece la información completa que deja clara la intención del obsequio. Campo le agradece la pacificación de las provincias de Valencia, Castellón y Teruel. Zonas donde se resistía el ejército carlista. La declaración de la vuelta de la monarquía se hizo en Sagunto, y el presidente de la compañía del ferrocarril era un partidario muy interesado en el nombramiento de Alfonso XII como ya hemos visto a lo largo de esta tesis doctoral.

Pero en realidad el agradecimiento al general Jovellar es doble; por un lado, la pacificación hizo posible la vuelta de los Borbones al trono, y por otro lado, porque durante la guerra carlista la línea de ferrocarril Almansa-ValenciaTarragona sufrió muchos atentados. Los carlistas quemaron locomotoras, vagones, levantaron kilómetros de vías, aflojaron traviesas, destruyeron puentes, etc. por lo que José Campo, como presidente de la compañía, le agradece al General Jovellar su labor, ya que la pacificación de la zona supuso poder restablecer el tráfico de las vías y poder continuar con la explotación del negocio.

Durante el reinado de Isabel II España experimentó una notable modernización con la inauguración de las primeras líneas ferroviarias. La aparición del ferrocarril vendría a revolucionar los sistemas de transporte debido a su velocidad y a su capacidad de carga, y con ello se aceleró el desarrollo industrial y comercial. El tendido de la red ferroviaria sería el negocio más importante del siglo XIX en España. Supuso la creación de un mercado nacional integrado y una verdadera unificación e integración del territorio nacional. Este novedoso transporte, pieza clave de la revolución industrial, encontró en España en sus primeros años de existencia serias dificultades. El desconocimiento técnico, la difícil orografía peninsular, la falta de capital, y el atraso económico en general, fueron las primeras causas de este retraso. 
A José Campo se le adjudicó la construcción de la línea de ferrocarril Valencia-Tarragona en 1861. Resultó muy costosa y muy dificultosa su construcción por la necesidad de puentes y demás, y se inauguró en ocho etapas, la primera entre Valencia y Sagunto y la última el puente sobre el río Ebro en Tortosa el 21 de junio de $1868^{11}$.

Para su construcción tuvo que pedir créditos y necesitó inversores, que tenían que cobrar sus intereses, y la guerra y los atentados provocaron que no fuera continuo el funcionamiento de la línea. José Campo era el primer interesado en la pacificación de la zona y por ello le da las gracias al general con esta pieza exuberante y magnífica.

Una vez finalizada la guerra en esa zona, había que reconstruir la línea y reponer todas las locomotoras y vagones y demás material. El gobierno concedió ayudas para la reconstrucción de las vías, pero había que devolverlas en tres años y además los inversores debían cobrar sus intereses y el ferrocarril estuvo parado por problemas en múltiples ocasiones veces, por lo que el negocio era ruinoso para la compañía y para el propio José Campo ${ }^{12}$.

La pieza lleva también detrás y en los extremos de la base tres cartelas rodeadas por tornapuntas molduradas que contienen inscripciones referidas a las batallas que libró y ganó el general a lo largo de su vida y que la convierten en un documento histórico.

\footnotetext{
${ }^{11}$ ESTRELA, Juan Carlos. "José Campo Pérez, primer marqués de Campo". A Todo Vapor, 2003, n. ${ }^{\circ} 39$, p. 5 .

12 PERIS, J., Notas sobre los transportes militares por ferrocarril, en Castellón, en el entorno de la III ${ }^{a}$ guerra carlista. http://myslide.es/documents/45-notas-sobre-lostransportes-militares-por-ferrocarril-en-castellon-en-el-entorno-de-la-iii-a-guerracarlista.html consultado en línea el 7 de septiembre de 2015.
} 
La placa de la izquierda (Fig. 11.8) dice: "Llardecans. Bicenti. SieteAguas. Gandesa. Chiva. Linares. Arcos de la Cantera. Cati. Villar de Canes. Lucena. Alcora. Villar del Arzobispo. Morella. Madrid. Comargall. MonteEsquinza. Pamplona. Monlleo. Cantavieja y Seo de Urgel”.

La placa de la derecha (Fig. 11. 9) dice: "Campaña de África. Combates en los valles y alturas de los reductos al frente de Ceuta, 30 de noviembre, nueve, doce, quince, diez y seis, veinte, veintidós, veinticinco, veintinueve y treinta de diciembre de 1859. Valle y posiciones de los Castillejos. Alturas de la Condesa. Montenegro. Río Azmiz. Cabo Negro. Valle de Tetuán. Guad el Jelu. Tetuán. Sanisa. Wad-Ras”.

La placa del reverso de la figura dice: «El General Jovellar, salió a campaña desde Sagunto el día 13 de junio de 1875 y a los 20 días, el 3 de Julio, había huido a la otra parte del Ebro, el grueso del ejército carlista. El día 6 del mismo mes, se le rindió la fortaleza carlista de Cantavieja y el 19 capituló la del Collado, quedando con ello libre de enemigos y completamente pacificadas las Provincias de Valencia, Castellón y Teruel» ${ }^{13}$.

13 CASTRO GIRONA, Alberto. Jovellar. Madrid: Editorial Purcalla, 1947. 


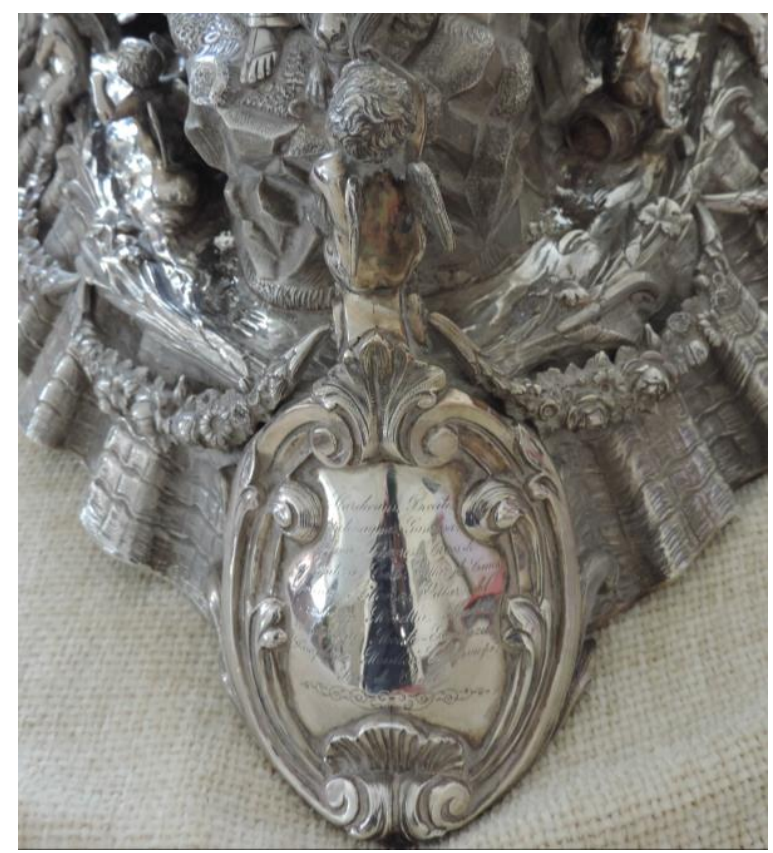

Fig. 11.8 Batallas ganadas por el General Jovellar en España. Fotografía de la autora.

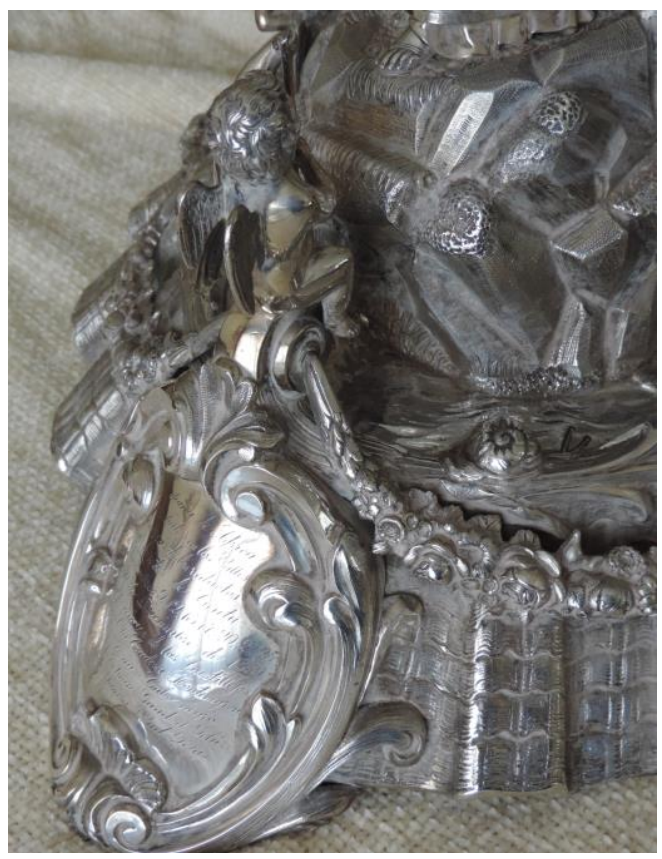

Fig. 11.9 Batallas ganadas por el General Jovellar en la Campaña de África. Fotografía de la autora.

Entrando ya de lleno en el estudio iconográfico de la pieza, ésta es de forma piramidal y simula una montaña escarpada sobre una base ovalada de 90 x $50 \mathrm{~cm}$ que representa el mar Mediterráneo. La escultura, que mide $60 \mathrm{~cm}$. de alto, está coronada por una biga de dos caballos alados rampantes conducidos por lo que parece un soldado romano, y en la base hay a ambos lados sendas figuras de mujeres sentadas con un escudo bajo el brazo y ataviadas con túnicas clásicas. Miden unos $15 \mathrm{~cm}$. de alto cada una y representan a España y a Valencia. En el frente de la pieza y en la parte de detrás hay sendas figuras de ancianos recostados con un cántaro bajo el brazo y abundante vegetación. Miden unos $20 \mathrm{~cm}$. de ancho cada uno y representan a los ríos Turia y Ebro.

En el centro de la parte delantera de la base hay una cartela de unos $7 \mathrm{~cm}$. de anchura por $8 \mathrm{~cm}$. de altura, con el escudo de armas del general Jovellar (Fig. 11.24) y que más adelante analizaremos.

La pieza es de estilo neobarroco, y semeja un triunfo. En época barroca (XVII-XVIII) también se hacían triunfos de mesa, que en ocasiones eran de 
materiales no perecederos, pero a veces también eran comestibles. Es como una fuente pública hecha en plata y recuerda a la fuente de los 4 ríos de Bernini, donde el agua y la roca basta son la base de las personificaciones y alegorías.

Las figuras están perfectamente acabadas, y la plata pulida de las carnes contrasta fuertemente con la rugosidad del resto de la pieza. Esto pone de manifiesto la gran maestría del artífice y la creatividad de su diseñador. El conjunto resulta de una gran belleza plástica y el juego de volúmenes está muy bien equilibrado.

\section{1.- Las figuras de la base y del remate:}

\section{1.- La personificación de Valencia (Fig. 11.10)}

Mirando la pieza de frente, al lado izquierdo hay una mujer sentada sobre unas rocas, con una corona mural en la cabeza, ataviada con vestiduras clásicas y sandalias y sosteniendo en su mano derecha una corona de laurel, símbolo del triunfo y reposando su brazo derecho en el escudo de la ciudad de Valencia ${ }^{14}$. Las rocas son símbolo de constancia, y la montaña se asocia con el coraje y la fidelidad puesta a prueba ${ }^{15}$.

${ }^{14}$ TERVATENT, Guy de. Atributos y símbolos en el arte profano. Diccionario de un lenguaje perdido. Barcelona: Ediciones del Serbal, 2002, p. 319

15 TERVATENT, Guy de. 2002, p. 447. 


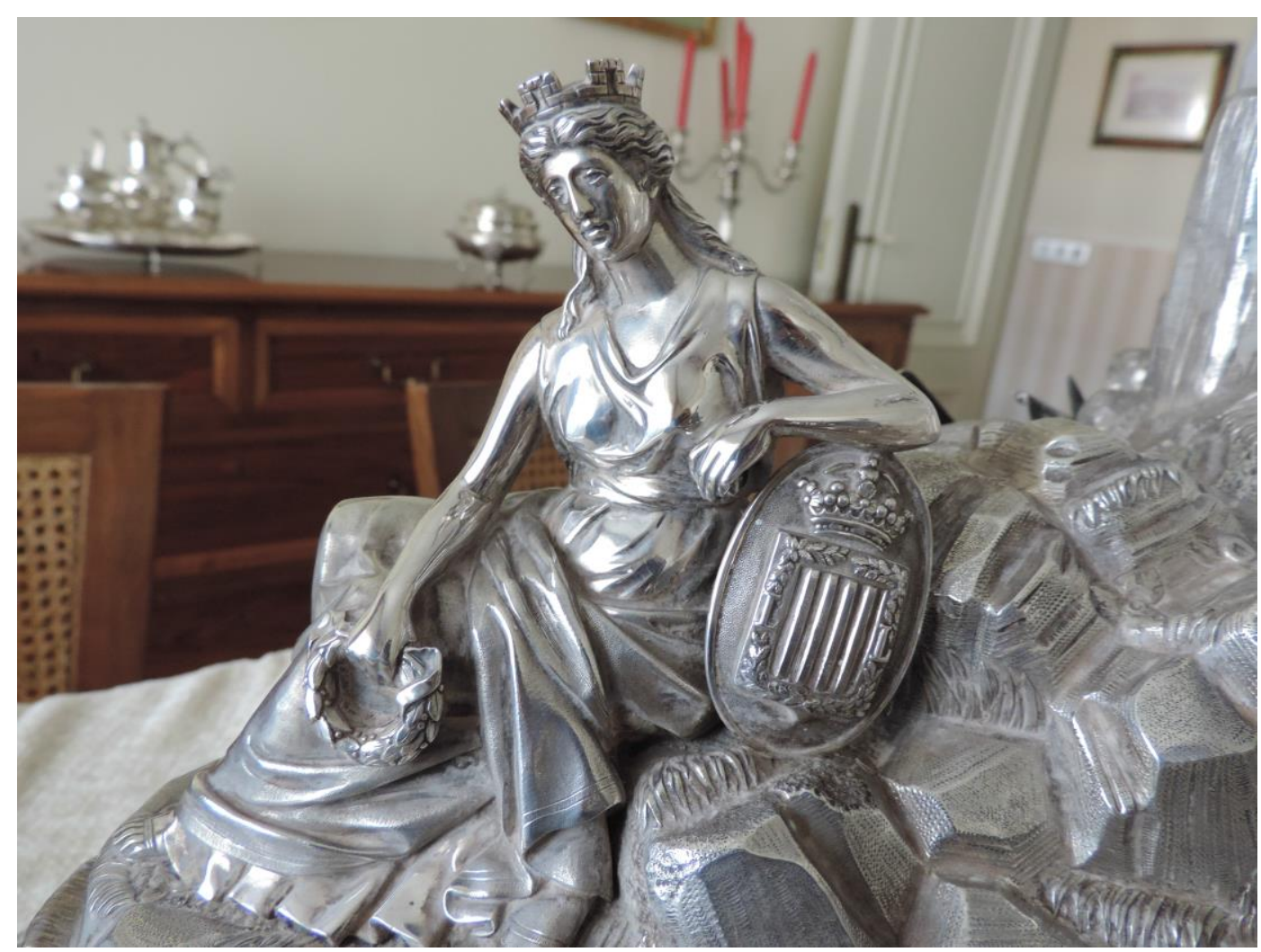

Fig. 11.10 Personificación de Valencia. Colección particular. Fotografía de la autora.

A finales del siglo XIX poco cambian las personificaciones de las ciudades, que se las representa, según era costumbre, en forma de matrona, generalmente sentada, vestida con túnica clásica o talar sujeta al talle con cinturón, y ceñida la cabeza con una corona de almenas o castilletes, símbolo de la ciudad ${ }^{16}$.

En el escudo que porta la mujer vemos la corona que otorgó Pedro IV a la ciudad por el apoyo en la guerra de los dos Pedros entre Castilla y Aragón (13561365). Pedro IV también reconocerá en esa guerra la lealtad de la ciudad en dos ocasiones que sufrió asedio y de ahí la "L” a cada lado del escudo.

16TERVATENT, Guy de. 2002, p. 137. 
El uso de las dos ramas de laurel en el escudo, lo concedió Fernando VII después de la guerra de la independencia de 1808, como símbolo de la defensa de la ciudad ante el general francés Moncey, que la tuvo cercada.

El murciélago que reposa sobre la corona crea controversia en los autores, pero parece ser que lo introdujo el rey Jaime I cuando conquistó Valencia porque esperando de noche el asalto a la ciudad, se dio cuenta de que esos animales no duermen de noche y dijo: «...a quien bien vela todo se le revela». Y de hecho es también el lema que José Campo hizo grabar en la medalla conmemorativa de la expedición que costeó para visitar las obras del canal de Panamá17, como ya hemos estudiado en el capítulo correspondiente.

El modelo en el que se basó el artista para la personificación de Valencia, podemos encontrarlo en la decoración del Salón de Conferencias o de «los pasos perdidos» del Congreso de los Diputados en Madrid (Fig. 11.11)18 inaugurado en 1872, tres años antes de la realización de la pieza estudiada. Dicha sala cuenta con una bóveda decorada por Vicente Camarón (1803-1864) con diversas alegorías: los cuatro Continentes, la Ley, la Justicia, la Religión y la Abundancia; en el perímetro inferior aparecen 28 medallones con los políticos más célebres del siglo XIX y sobre ellos 12 cuadros con alegorías de los reinos, provincias y ríos españoles realizadas entre otros por Francisco Aznar (1831-1911) e Isidoro Lozano (1826-1895) entre otros.

$Y$ es en esta decoración donde encontramos la misma idea de la mujer sentada, vestida a lo clásico, con la cabeza con corona mural, y apoyada sobre el escudo, como se puede observar en los casos de Canarias y de Córdoba (Fig. 11.12)

\footnotetext{
${ }_{17}$ MORANT GIMENO, ANA María. "El conocimiento de otros mundos a través de la literatura de viajes: crónicas y dibujos de las obras del Canal de panamá en 1886”. En: Actas del XX Congreso del CEHA. Toledo, Universidad Complutense, 2014. ${ }^{18}$ Las figuras 11.11 y 11.12 son imágenes publicadas en: https://www.congreso.es/es/cem/BienesInmuebles, consultada el día 10 de diciembre de 2014.
} 


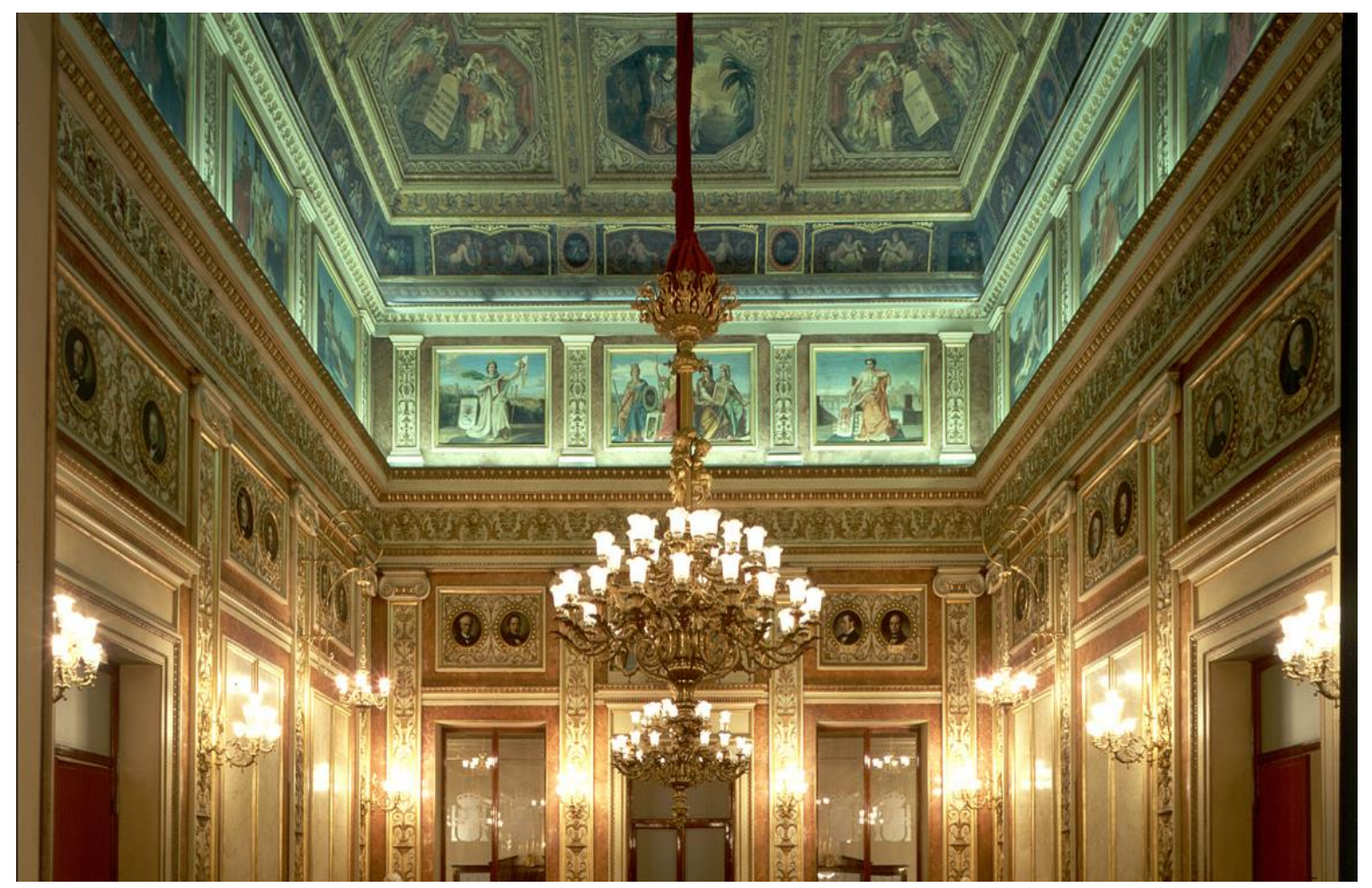

Fig. 11.11 Salón de conferencias o de los pasos perdidos.

Palacio de congresos, Madrid. 1872.

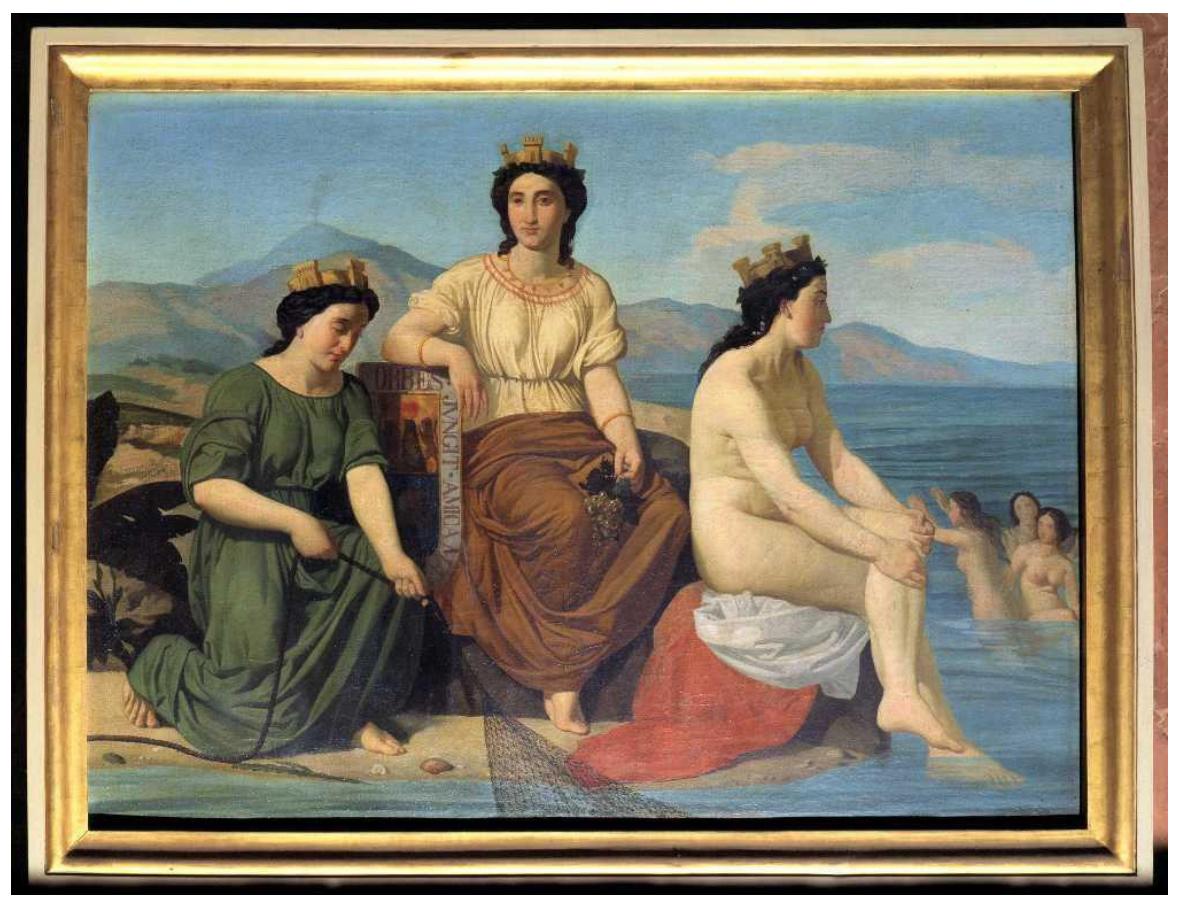

Fig.11.12 Personificación de las provincias españolas.

Salón de conferencias del Congreso. Madrid. 1872. 


\section{2.- La personificación de España (Fig. 11.13)}

Al lado derecho de la escultura aparece la personificación de España. Los artistas sacan los repertorios de la icnografía clásica, libresca o de modelos escultóricos y pictóricos, y cuanto más codificadas son, más eficaces y comprensibles resultan. A la patria se le ha representado en ocasiones como una matrona con gesto protector vestida con amplia túnica, pero en este caso España aparece personificada como Atenea, diosa griega de la sabiduría, la guerra y la estrategia.

Atenea ya se utilizaba para la personificación de España en época de Fernando VII, derivado de una herencia iconográfica antigua. La utilización de figuras humanas como personificación de ciudades y territorios cuenta con testimonios en la cultura egipcia del II milenio A.C. ${ }^{19}$.

Las alegorías tratan en definitiva de hacer visible los fundamentos del poder, y en este caso proporcionan el conocimiento y el significado que tienen las nuevas ideas políticas de quienes han conseguido devolver el trono a los Borbones. Las imágenes alegóricas fueron concebidas con la idea de crear opinión y, por lo tanto, de respaldar una forma de pensar ${ }^{20}$.

En este caso es una ocasión para conmemorar el fin de la guerra y es apropiado utilizar esta personificación de la diosa de la guerra y la estrategia,

${ }_{19}$ El tema de la personificación de España es tratado con gran detenimiento en: REYERO, Carlos. Monarquía y Romanticismo. El hechizo de la imagen regia, 18291873. Madrid: Siglo XXI, 2015.

REYERO, Carlos. Alegoría, nación y libertad. El olimpo constitucional de 1812. Madrid: Siglo XXI, 2010.

Sobre iconografía ver también: GARCÍA MAHÍQUES, Rafael. Iconología e iconografía, Vols. I y II. Valencia: Editorial Encuentro, 2008.

20 REYERO, Carlos. Alegoría, nación y libertad. El olimpo constitucional de 1812. Madrid: Siglo XXI, 2010, p. 5 y 18. 
porque con la guerra carlista se atacaba el poder legítimo que se reconocía en la continuación de la dinastía borbónica y que al final se impuso.

El hecho de que la personificación de España en época contemporánea sea dependiente de tradiciones anteriores puede relacionarse con la inexistencia de ruptura con el pasado monárquico con el que el discurso nacionalista español del siglo XIX se identificó casi siempre ${ }^{21}$.

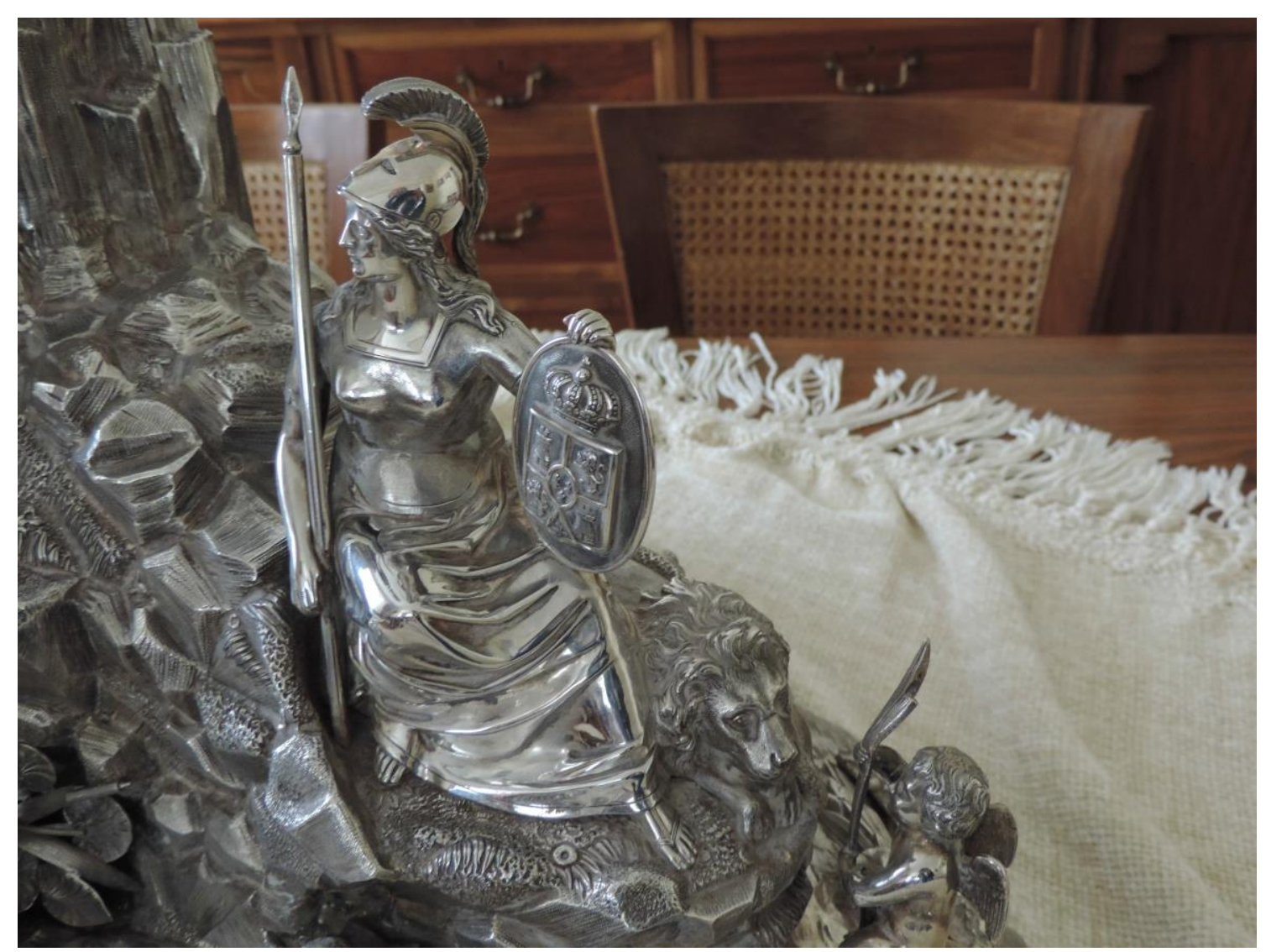

Fig. 11.13 Personificación de España. Colección particular. Fotografía de la autora.

La mujer sentada sobre un león, lleva el casco o yelmo, que suele llevar en la cabeza Atenea bien elevado sobre la frente para dejar ver su cara, suele estar adornado con grifos, cabezas de corderos, caballos y esfinges, en este caso con

${ }^{21}$ REYERO, Carlos. 2010, p. 10. 
un penacho de plumas. La égida, una coraza de piel de cabra que se decía le fue dada por Zeus, aquí es sustituida por una especie de cuerpo ajustado con escote cuadrado, que viste sobre una túnica clásica, que entronca con los valores clásicos, que permanecen.

El escudo redondo en cuyo centro aparece la cabeza de la Gorgona Medusa, aquí aparece sustituido por el escudo de España y lo sujeta con su mano izquierda. También lleva la habitual lanza que simboliza la autoridad de la libertad. La expresión general de la figura es meditabunda y seria, su cara tiene forma ovalada, su cabello abundante está peinado hacia atrás y cae por su espalda. La figura completa es majestuosa, en actitud quieta y reposada mostrándose como un valor o idea incontrovertible; está sentada sobre un león que representa al pueblo, símbolo utilizado también entre los reinados de Felipe V y Alfonso XIII. El león también se utilizó como atributo de la fortaleza, símbolo de la fuerza y del valor, es también el atributo de la justicia ${ }^{22}$.

Se pretende dar el mensaje de una soberanía intrínseca, que permanece más allá de los avatares de las circunstancias y de los cambios políticos que se producen.

El escudo de España de la figura es el de la época de Isabel II, cuartelado con los reinos de León y Castilla alternados, las armas del reino de Granada y en el centro las flores de lis de los Borbones. Encima la corona real. Es el mismo de la moneda de un escudo de 1862, y del sello de Isabel II. Este escudo se utilizó hasta la revolución de 1868 y retornó con la restauración de 1875, perduró hasta la segunda república y finalmente, sobrevivió desde 1938 hasta 198123. (Fig. 11.14, 11.15, 11.16 y 11.17).

\footnotetext{
22 TERVATENT, Guy de, 2002, p. 324-330.

23 REYERO, Carlos, 2010, p. 25.
} 


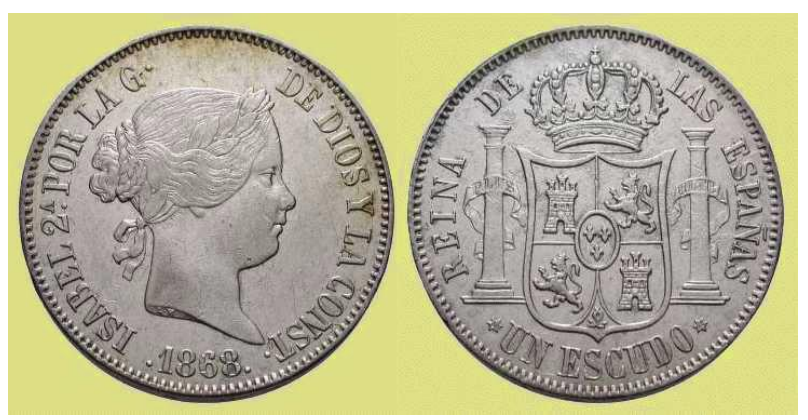

Fig. 11.14 Moneda de un escudo de 1862.

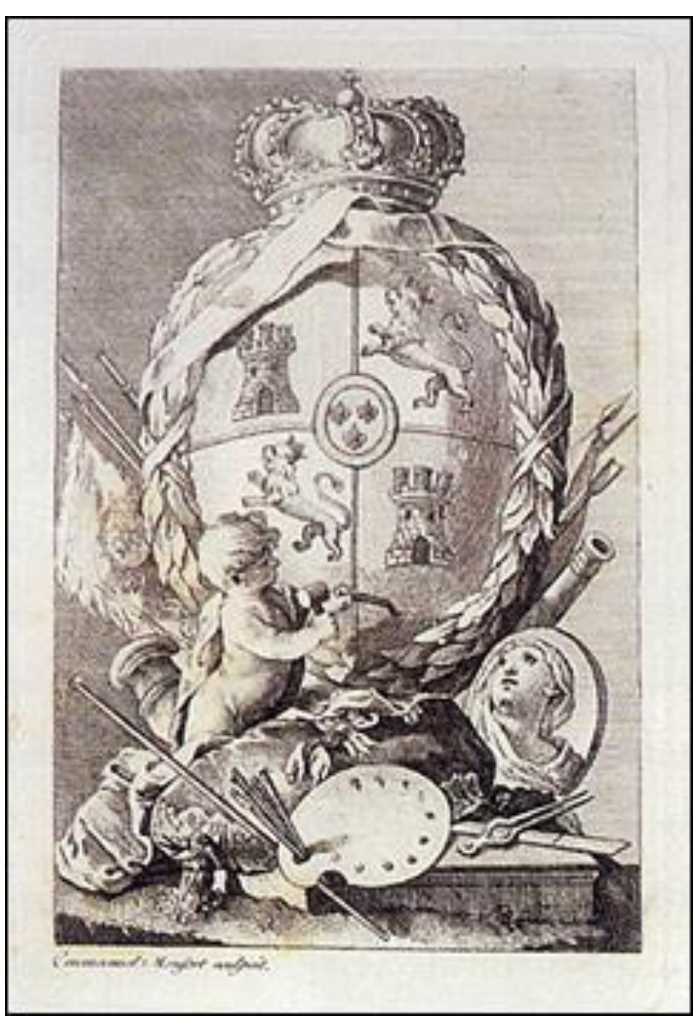

Fig. 11.16 Escudo real del siglo XVIII. Manuel Monfort.

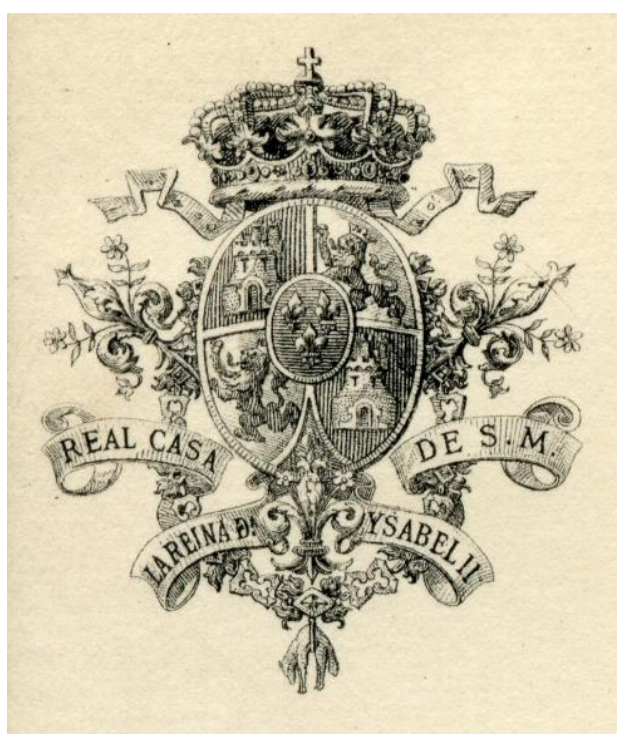

Fig. 11.15 Sello de Isabel II.
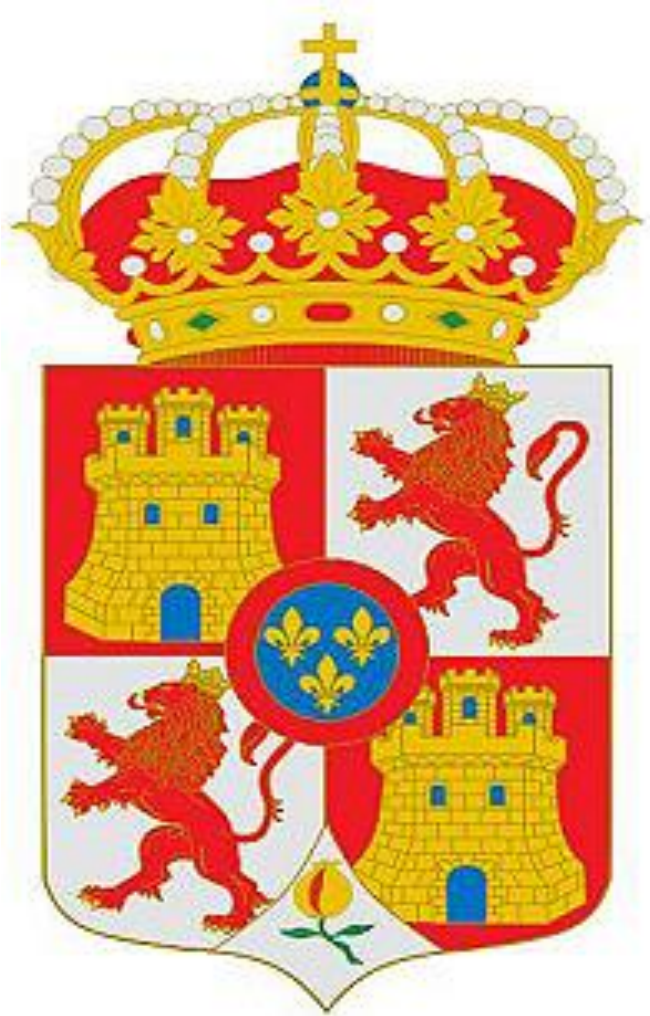

Fig. 11.17 Escudo de España en época de Isabel II. 


\section{3.- La personificación de los ríos Turia y Ebro (Fig. 11.18 y 11.} 19)

En el frente de la pieza aparece el río Turia personificado en una figura de un aciano recostado sobre un cántaro del que mana el agua. Es una personificación al modo de la antigüedad como dice Hall24. En esta pieza el río representado es el Turia, porque pasa por la ciudad de Valencia y por ser el lugar del que parte la vía de ferrocarril de Valencia a Tarragona. La zona que liberó el General Jovellar.

En la parte trasera, la otra figura de un aciano recostado sobre un cántaro y con un remo en la mano es el río Ebro, que es el paso más importante de la vía de ferrocarril hacia Tarragona. El puente sobre el Ebro en Tortosa fue la parte más difícil de construir y la última que se inauguró en 1868.

El modelo de un anciano recostado sobre un cántaro lo encontramos ya en figuras clásicas que representan ríos, pero podríamos considerar que el artista se inspiró otra vez en las personificaciones de los ríos, en este caso la del Ebro, que adornan la Sala de Conferencias del Congreso de los Diputados a la que ya hemos hecho referencia (Fig. 11.20)25. El remo también es atributo de algunos dioses fluviales ${ }^{26}$.

Los dos ríos desembocan en el mar Mediterráneo y está representado en la base de la pieza con unas ondas que simulan olas y amorcillos y pececillos nadan en él. En ellos y en las magníficas guirnaldas de flores diminutas perfectamente ejecutadas que rodean la base, podemos observar la maestría y el buen hacer del artista, constituyendo una excelente muestra del arte de la platería madrileña del siglo XIX.

24 HALL, James, Diccionario de Temas y símbolos artísticos. Madrid: Alianza Editorial, 1987, p. 272 y 307.

${ }^{25}$ Publicada en: https://www.congreso.es/es/cem/BienesInmuebles, consultada el día 10 de diciembre de 2014.

${ }^{26}$ TERVATENT, Guy de. 2002, p. 446. 


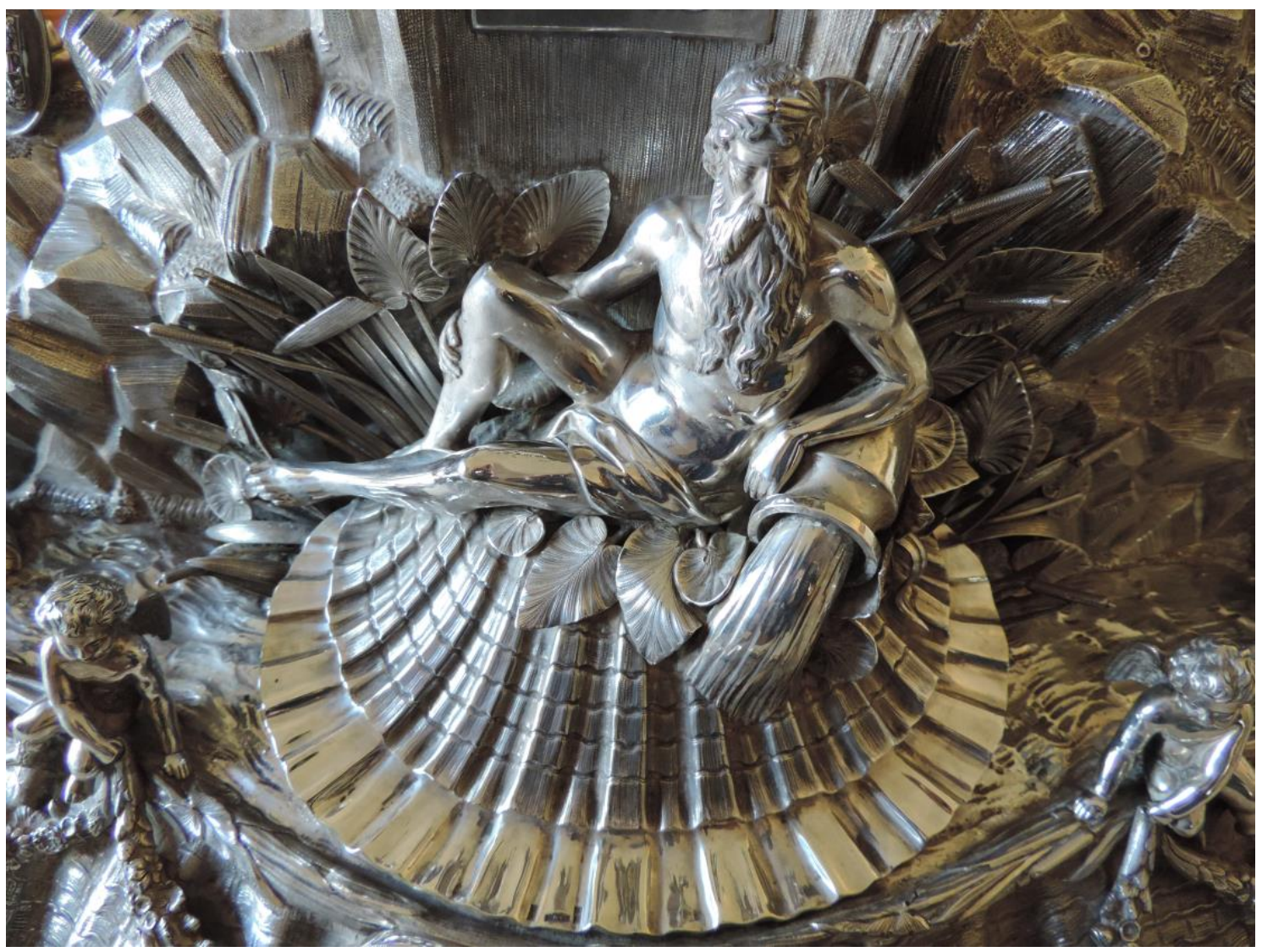

Fig. 11.18. Personificación del río Turia. Colección particular. Fotografía de la autora.

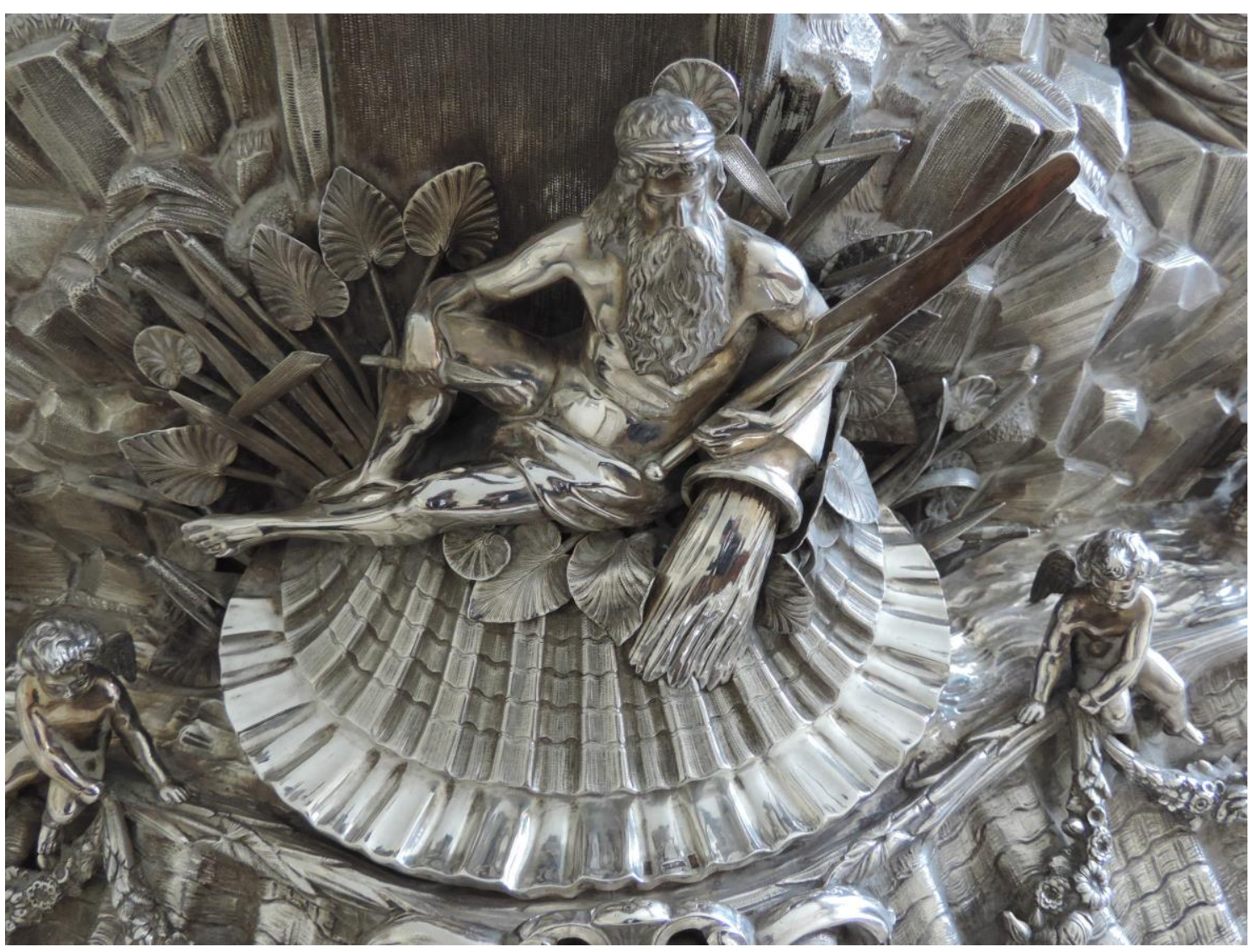

Fig. 11.19 Personificación del río Ebro. Colección particular Fotografía de la autora. 


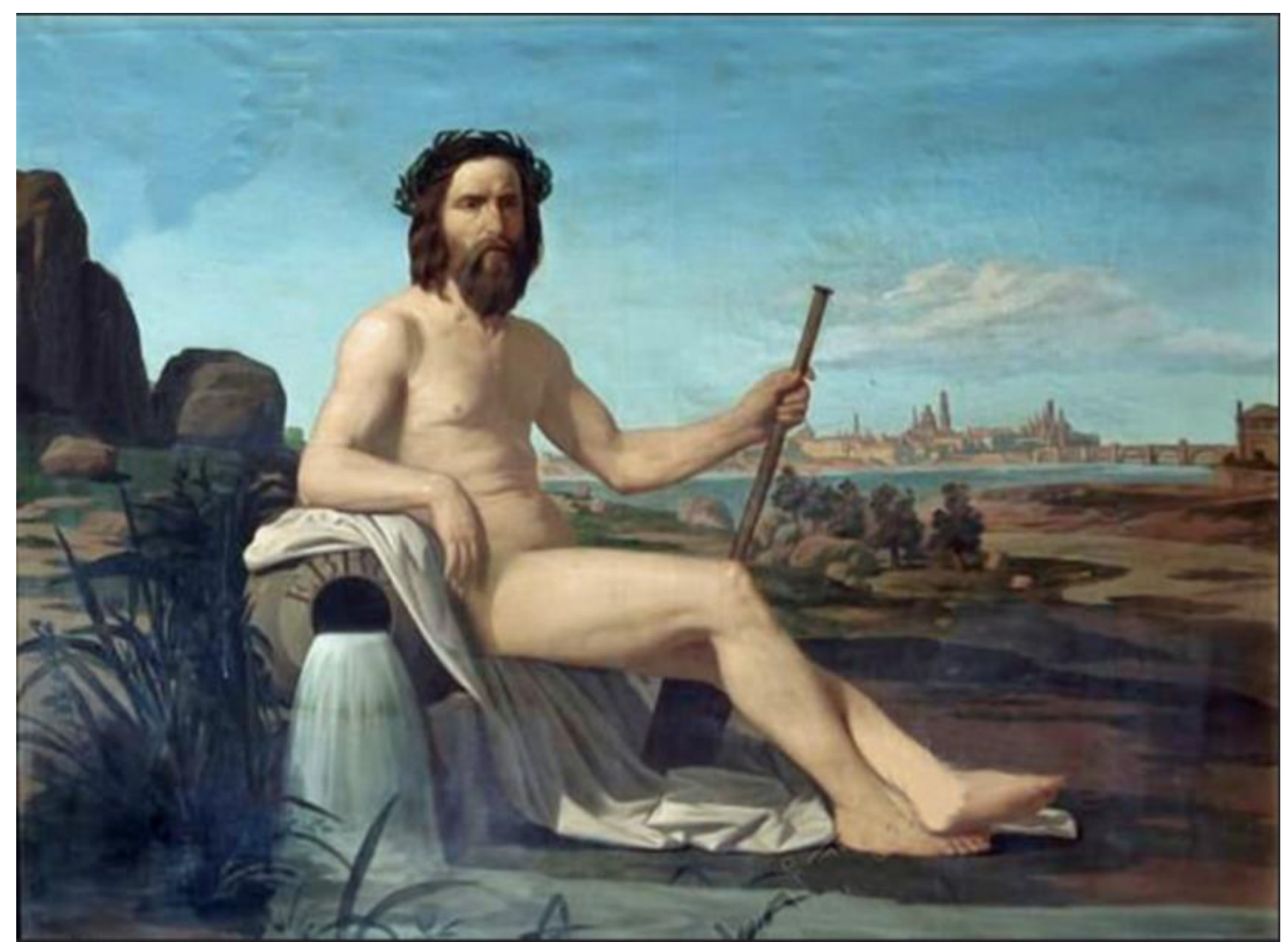

Fig. 11.20 Sala de conferencias del congreso de los Diputados. Madrid.

Detalle de la personificación del río Ebro. Francisco Aznar 1861.

\section{4.- El remate de la escultura (Figs. 11.21 y 11.22)}

La escultura tiene como remate un carro triunfal tirado por dos caballos alados en posición rampante, conducido por un joven romano que lleva una espada desenvainada en su mano derecha. Una figura marcial con rasgos jóvenes que refleja en su rostro y en su actitud la confianza en el futuro.

Si bien es cierto que a primera vista se asocia esta figura con el carro triunfal de Marte, el dios de la guerra que lleva a la victoria, es también cierto que Marte aparece en la iconografía con dos caballos, pero no alados. Para el análisis de esta figura no podemos olvidar que en el siglo XIX las personificaciones, las alegorías y la mitología se reinterpretan, y los artistas ya no se ciñen con rigor a los tratados de emblemas o de iconografía como el de 
$\mathrm{Ripa}^{27}$, como en otras épocas, sino que se permiten licencias y cambios. Si bien la espada es uno de los atributos de Marte y Marte aparece en un carro tirado por dos caballos, no encaja en este caso que los caballos sean alados ${ }^{28}$.

El origen de este tipo de representaciones podemos encontrarlo en los Dioscuros de la fuente del Quirinal de Roma con los caballos en corveta. (Castor y Polux como refundadores de Roma) También vemos este tipo de carro en las ilustraciones de Flaxman para la Ilíada y la Odisea (Fig. 11.23), con los mismos adornos, el mismo tipo de carro y los caballos también en corveta, que realizó en el siglo XVIII'29.

En este caso estaríamos ante una representación de la refundación de España, el reino perdido que se recupera con el fin de la guerra carlista y la vuelta a trono de la monarquía legítima encarnada en la dinastía borbónica y exactamente en la figura de Alfonso XII.

Llama la atención la calidad del cincelado de las alas, la textura de la piel del caballo, los detalles del dios Marte, las vestiduras, la capa, el carro, etc. todo con un perfecto acabado que demuestra la maestría de su autor.

\footnotetext{
${ }^{27}$ RIPA, Cesare, Iconología, Vols. I y II, Madrid: Akal. Arte y estética, 2007 (1 a edición 1603).

28 TERVATENT, Guy de. 2002, p. 127 y 240.

${ }^{29}$ Jhon Flaxman (1755-1826) realizó las ilustraciones para la Ilíada en 1793 y para la Odisea en 1805. 


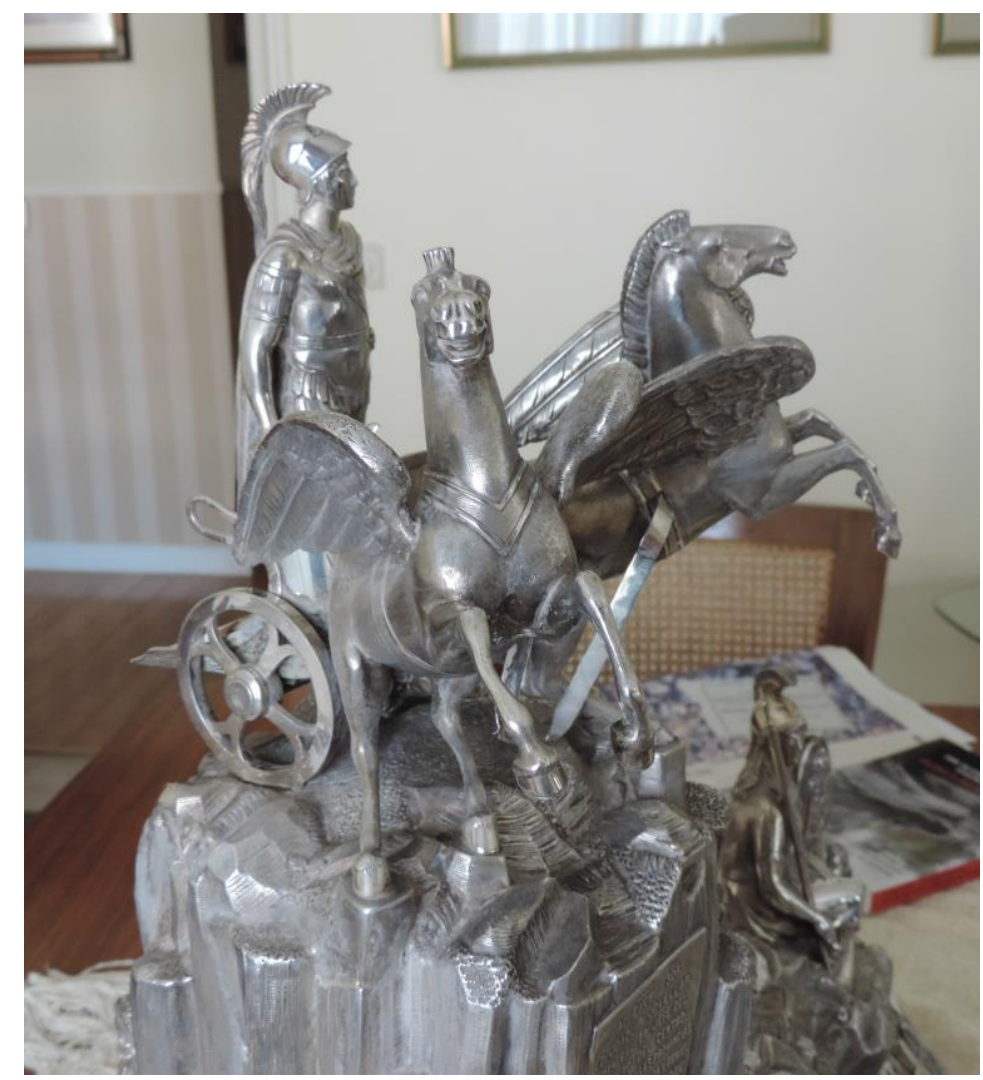

Fig. 11.21 Remate superior. Carro con caballos alados y guerrero con casco y espada. Colección particular. Fotografía de la autora.

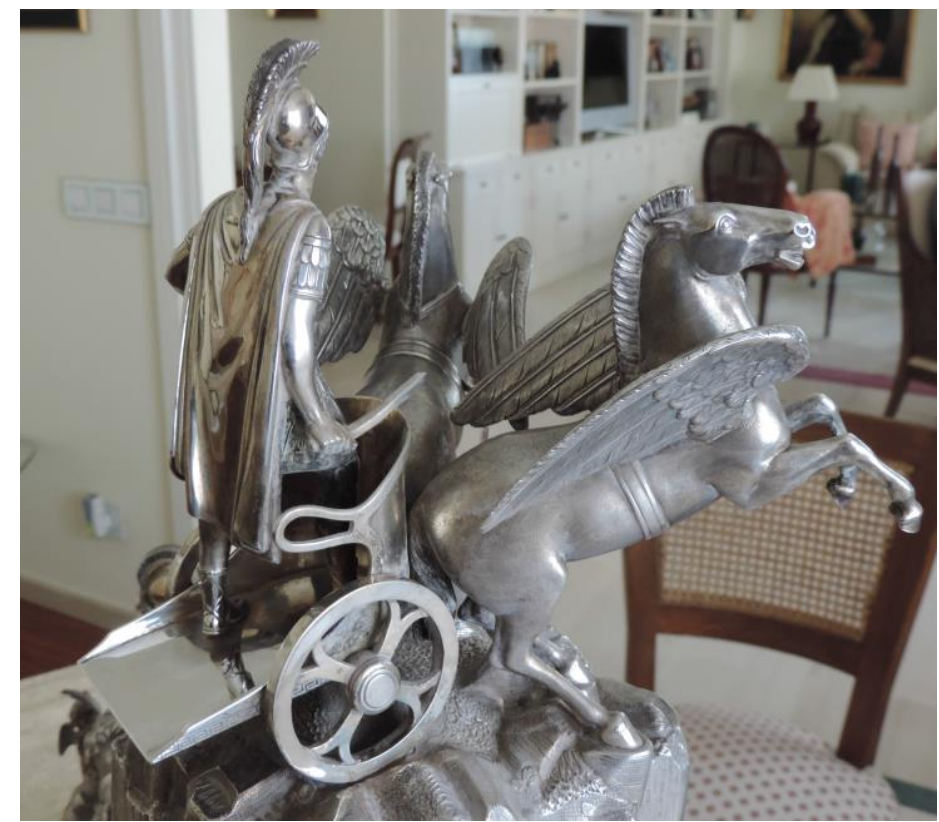

Fig. 11.22 Remate superior vista trasera. Colección particular. Fotografía de la autora. 


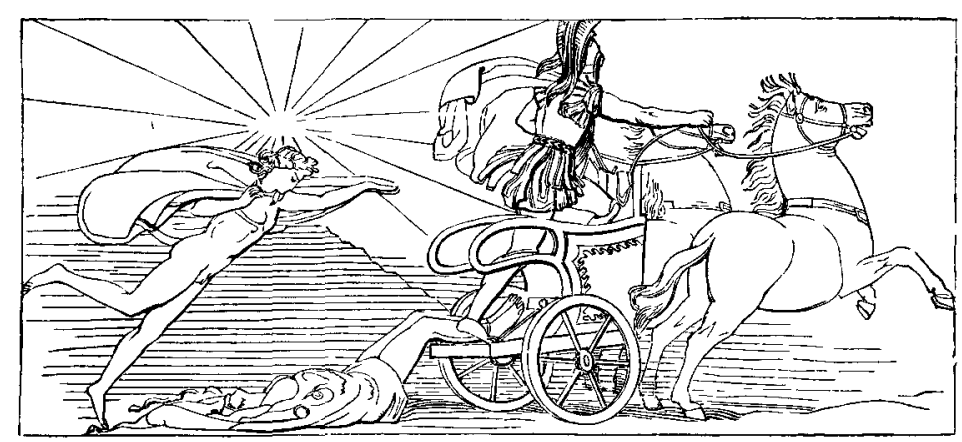

Fig. 11.23 Ilustraciones de Flaxman para la Ilíada y la Odisea.

\section{5.- El escudo de armas del General Jovellar (Fig. 11. 24)}

En la parte delantera de la base, dentro de una cartela barroca decorada con roleos, aparece el escudo de armas del general Jovellar (Fig. 11.24). Llama la atención que lleva la corona de marqués, siendo como es que rechazó el nombramiento de marqués de Cantavieja que le otorgó Alfonso XII ${ }^{30}$.

El escudo aparece dividido en 4 cuarteles y en el de la parte superior derecha vemos una escalera y lo que parece un sol. Estos dos símbolos son parte del escudo de la familia Jovellar que se encuentra en la casa Pericó de Huesca y que lleva la fecha de 1709. Esa misma escalera la encontramos en Badías, en una capilla cercana a la casa familiar, y se ha relacionado con la escalera del descendimiento de Cristo. El oro es el símbolo del Sol, origen de la vida, sus características espirituales corresponden a la fe, clemencia, templanza, caridad y justicia, y por otra parte el sol dorado del más nobel de los metales señala a la familia con la felicidad, el amor, la nobleza y el esplendor (Figs.11. 25, 11.26 y 11.27)

30 CASTRO GIRONA, Alberto, Jovellar. Madrid: Editorial Purcalla, 1947. 
En el cuartel inferior derecho vemos lo que parece una escuadra y que podría indicar la pertenencia del general a la orden de la masonería, pero ningún documento ni prueba alguna conduce a esa conclusión. En el cuartel inferior izquierdo hay una flor, y una flor hay también en las dovelas del arco de entrada de la casa familiar de Pericón que hemos mencionado anteriormente. El escudo está rodeado por banderas militares y bajo podemos ver el collar de la gran Cruz de Isabel la Católica que le concedieron el 20 de noviembre de 1865.

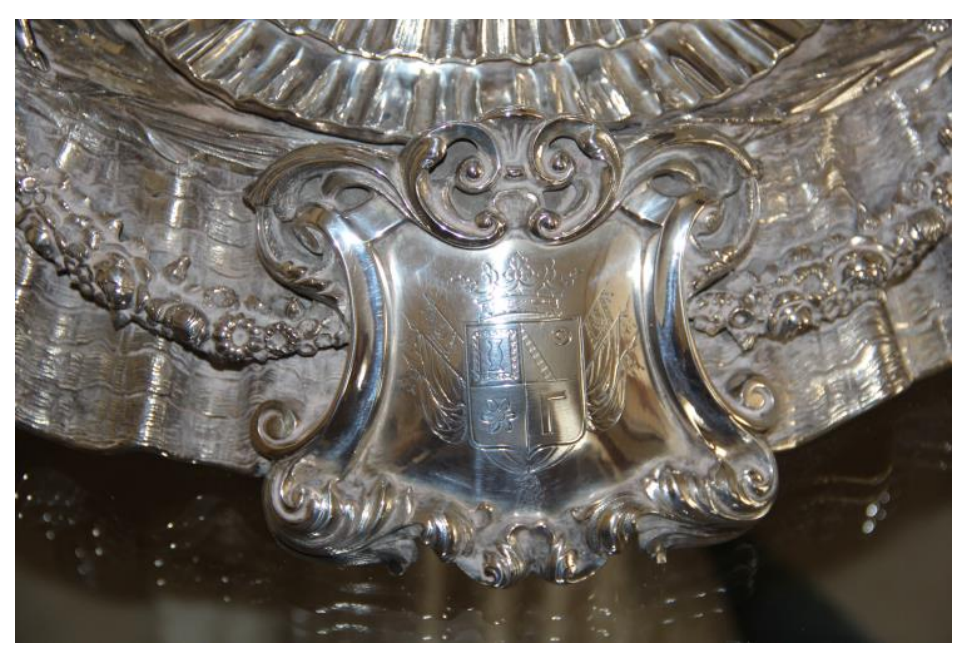

Fig. 11.24 Escudo de armas del general Jovellar. Fotografía de la autora

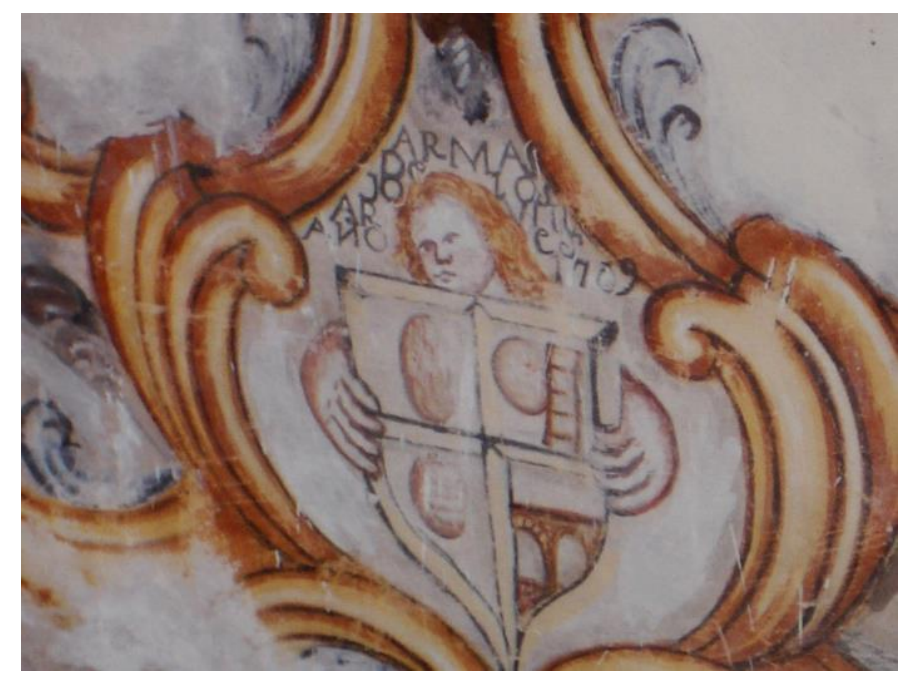

Fig. 11.25 Escudo de los Jovellar. Casa Pericó, Huesca 


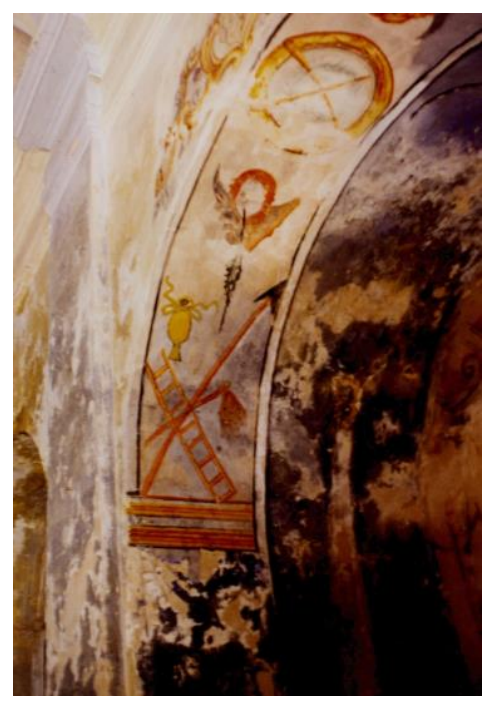

Fig. 11.26 Santuario de Badías. Huesca

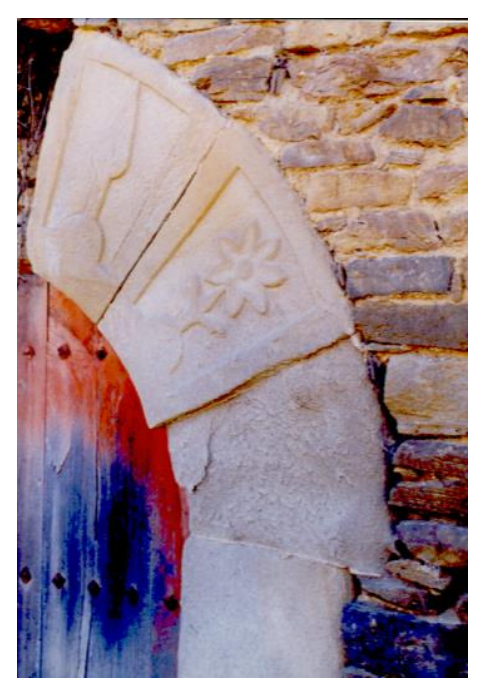

Fig. 11.27Dovelas. Casa Pericó. Huesca

En conclusión, nada se conoce con certeza acerca del encargo y la realización de la pieza en sí.

Se sabe que fue la sociedad de Ferrocarriles quien obsequió al general con la pieza, luego se puede deducir que la sociedad corrió con los costes de la misma. Se desconoce al autor de la obra de platería, pero si se sabe con certeza que la obra fue realizada por un trabajador experto en los talleres de platería Espuñes de Madrid y por ello fue expuesta como tal en la exhibición antes mencionada de 1881. También se desconoce quién fue el ideólogo del programa iconográfico que encierra la pieza y que hemos analizado, pero se podría pensar que la idea del obsequio y de la iconografía fue del propio marqués de Campo. José Campo era el presidente de la compañía y por ello la decisión de crear el objeto fue suya; él tenía claro el mensaje que quería transmitir con la figura y en mi opinión fue quien diseño la iconografía de la pieza, e incluso la forma, pues recuerda mucho a una Falla de Valencia, tanto por la distribución de las figuras como por la forma ovalada, con decoración visible desde todos los puntos y en forma de montaña con un remate en arriesgado equilibrio en lo alto. 
No sería la primera vez que el marqués se encargaba del diseño de una obra de arte. Si tenemos en cuenta por ejemplo el cuadro que José Campo encargó a José Benlliure para el asilo o el altar con retablo de Torrijo del Campo, que hemos analizado en otros capítulos de esta tesis.

En el caso de la pieza de plata que nos ocupa, Campo quiso plasmar una alegoría del fin de la guerra, un ensalzamiento de su tierra, Valencia, y de su patria, España, a la vez que agradecía todo ello al general Jovellar. Es un documento histórico en plata que transmite una emoción retórica y su calidad es representativa del buen hacer de la platería madrileña del siglo XIX.

A su vez no se puede olvidar que la figura es, sin duda, otra muestra del poder económico de José Campo y de su forma de actuar, siempre a lo grande, haciendo ostentación de su status de burgués ennoblecido, enriquecido por los negocios y hombre influyente en el panorama social, económico y político del momento. 



\section{Conclusiones}

Tras la realización de esta tesis doctoral llego a las siguientes:

José Campo Pérez, marqués de Campo, fue un personaje muy importante e influyente de la sociedad española del siglo XIX, no sólo en el ámbito valenciano sino también en el ámbito español e incluso fuera de nuestras fronteras.

Sus actividades económicas y políticas eran el centro de su vida, pero también desarrolló actividades filantrópicas como la construcción de dos asilos y diversas actividades de promoción artística.

A lo largo de su dilatada vida tuvo relación con todo tipo de expertos: artistas, arquitectos, ingenieros, militares, pintores, diseñadores, que trabajaron para él en sus diversos proyectos, ya fuera construir un ferrocarril, alumbrar una ciudad, diseñar y construir un pabellón de una exposición, pintar cuadros de su flota de vapores, fabricar los muebles de sus residencias, reformar y decorar sus palacios, diseñar una medalla, construir edificios, etc.; lo que propició que durante su vida el marqués de Campo ejerciera el mecenazgo artístico favoreciendo $\mathrm{y}$ promocionando la carrera de muchos artistas: pintores, escultores, arquitectos, decoradores, arquitectos, etc. 
Como buen burgués adquirió obras de arte para decorar sus residencias y las exhibió para demostrar su estatus y su poder; y a lo largo de su vida reunió una gran colección de objetos de arte de todo tipo.

El marqués de Campo merece ser considerado como un coleccionista a la altura de otros de la época como el marqués de Salamanca, Lázaro Galdiano o el marqués de Comillas; pues ha quedado demostrado que el marqués de Campo tenía los recursos económicos y la formación cultural suficiente para comprar obras y realizar encargos de obras para coleccionar y promocionar a la vez su imagen de poder.

La figura del marqués de Campo como promotor, mecenas y coleccionista era un estudio que estaba pendiente de desarrollar en la Historia del Arte del siglo XIX. Este estudio ha servido, entre otras cosas, para conocer el contenido del inventario de sus bienes, algunas imágenes inéditas del marqués y también por ejemplo para localizar y conocer la obra de arte en plata que regaló al general Jovellar.

En realidad, nuestro campo de investigación ha dado unos resultados tan sorprendentes que serán precisos nuevos estudios posteriores más detallados, pero con esta tesis ha quedado demostrado que José Campo Pérez es una figura más compleja de lo que parece a primera vista, y que es un claro e indubitado ejemplo de promotor, mecenas y coleccionista de arte de la España de Alfonso XII. 


\section{Bibliografía}

ABBAD, Francisco. Las Inmaculadas de Murillo. Barcelona: Editorial Juventud, S.A., 1948.

AGUILAR Carlos; CASAS, M. ${ }^{a}$ Encarnación. Los Palacetes de la Castellana. Madrid: fundación Cultural COAM, 1999.

ALDANA, Salvador (coord.). Pintura Valenciana del siglo XIX. Valencia: Real Academia de Bellas Artes de San Fernando, 2001.

ALBA PAGÁN, Ester. "El arte efímero y los artistas valencianos en la primera mitad del siglo XIX: de la fiesta barroca a la fiesta político-patriota (1802-1833)”. Cuadernos de arte e iconografía, 1999, Tomo 8, nº 16, p. 493-530.

ALBA PAGÁN, Ester. Pintura y crítica de arte en Valencia (1790-1868). Valencia: Servicio de publicaciones de la Universidad de Valencia, 2017.

ALMELA Y VIVES, Francisco. El Marqués de Campo, Capdavanter de la burguesia valenciana (1814-1889). Valencia: Ajuntament de València, 1989. 
ANDRÉS, Domingo. "El asilo de los marqueses de Campo". En: Almanaque de Las provincias 1885 . Valencia: 1886.

ANÓNIMO. Biografía y descripción del prestigioso Asilo del Excmo. Señor Marqués de Campo. Madrid: Imprenta de Juan Iniesta y Lorenzo, 1888.

ANÓNIMO. Exposición Universal de Barcelona. Catálogo de la instalación del Excmo. Señor Marqués de Campo. Barcelona: A. López Robert Impresor, 1888.

ANTAL, Frederick. Clasicismo y Romanticismo. Madrid: Alberto Corazón, 1978.

ANTIGÜEDAD DEL ASTILLO OLIVARES, M. ${ }^{\mathrm{a}}$ Dolores (dir.). Colecciones, expolio, museos y mercado artístico en España en los siglos XVIII y XIX. Madrid: Editorial Universitaria Ramón Areces, 2001.

ARGÁN, Giulio Claudio. El arte moderno. Valencia: Fernando Torres, 1975.

ARMENGAUD SHUPPISSER, Mario. "El retrato de barcos en el siglo XIX". Revista de Historia Naval, 1999, año 17, núm. 64, p. 119-126.

ARMERO MARTÍNEZ, Antonio. EL PROCESO DE ELECTRIFICACIÓN INICIAL EN LA PROVINCIA DE VALENCIA (1882-1907). Tesis doctoral. Universidad Politécnica de Valencia, Valencia 2015.

ARRECHEA MIGUEL, J. Arquitectura y Romanticismo. El pensamiento arquitectónico en la España del siglo XIX. Valladolid: Secretariado de publicaciones de la Universidad de Valladolid, 1989. 
AVILÉS, José. Ciencia Heroyca; reducida a las leyes heráldicas del blasón, Tomo I. Barcelona: Imprenta de Juan Piferrer, 1725.

AYALA, Nina. Del Greco a Murillo. La pintura española del siglo de oro, 1556170o. Madrid: Alianza, 1991.

AYALA Y RAYA, Manuel. Crónica de los pueblos de la provincia de Madrid. Real Sitio de El Pardo. Madrid 1893. Valladolid: Editorial Maxtor, 2011.

AZORÍN, Francisco; GEA, María Isabel. La Castellana, escenario de poder. Del palacio de Linares a la torre Picasso. Madrid: Biblioteca básica de Madrid, 1990.

BAHAMONDE, Ángel; CAYUELAS, José. Hacer las américas: las élites coloniales españolas en el siglo XIX. Madrid: Alianza, 1992.

BAHAMONDE, Ángel. Historia de España. Siglo XIX. Madrid: Cátedra, 1994.

BARBERÁ NOLLA, Rita. "Evocación de la fábrica de mosaicos de Nolla". En: Meliana, Bodas de oro de la Cooperativa Eléctrica 1923-1973. Meliana: Cooperativa eléctrica de Meliana, 1973, p. 152-156.

BARÓN DE ALCAHALÍ. Diccionario Biográfico de Artistas Valencianos. Valencia: Imprenta Federico Doménech, 1897.

BARONA, José Luís. Salud, enfermedad y muerte. La sociedad valenciana entre 1833 y 1939. Valencia: Institució Alfons el Magnànim, 2002. 
BAYLY, Christopher A. El nacimiento del mundo moderno. 1780-1914. Madrid: Siglo XXI, 2004.

BEATTY, James. “Descripción del Asilo Campo”. En: BOIX, Vicente (coord.). Memoria leída en la inauguración del Asilo de Párvulos de D. José Campo, en el día 19 de noviembre de 1863. Valencia: Imprenta de La Opinión, 1863.

BEAUDELAIRE, Charles. El pintor de la vida moderna. Murcia: Colegio de Arquitectos, 1995.

BENITO DOMÉNECH, Fernando. Pinturas y pintores en el Real Colegio Del Corpus Christi. Valencia: Imprenta de Federico Doménech, 1980.

BENITO GOERLICH, Daniel. La arquitectura del eclecticismo en Valencia. Vertientes de la Arquitectura Valencia entre 1875 y 1925. Valencia: Ayuntamiento de Valencia, 1992.

BENITO GOERLICH, Daniel; CERVERA, Ramón. “Ocupa y socorre: La arquitectura benéfica en la Valencia del siglo XIX. La Casa de la Beneficencia”. En: TABERNER, Francisco. "Historia de la ciudad III. Arquitectura y transformación de la ciudad de Valencia”. Valencia: Ayuntamiento de Valencia, Icaro, Universidad de Valencia y U.P.V., 2003, p. 117-142.

BERUETE y MORET, Aureliano de. Historia de la pintura española en el siglo XIX. Madrid: Hermanos Ruiz, 1926.

BLOM Philipp. El coleccionista apasionado. Una historia íntima. Barcelona: Anagrama. Colección Argumentos, 2013. 
BOIME, Albert. Historia social del arte moderno, Vols. I y II. Madrid: Alianza Editorial, 1994.

BOIRA, José Vicente. Valencia. La ciudad. Valencia: Tirant lo Blanch, 2011.

BOIX, Vicente. Relación de las fiestas reales con que la ciudad de Valencia solemnizó el enlace de S.M. la reina $D^{a}$ Isabel II con Francisco de Asís de Borbón, y el de la infanta María Luisa Fernanda con el Duque de Montpensier. Valencia: Ayuntamiento de Valencia, 1846.

BOIX, Vicente. Fiestas que se celebraron en el siglo IV de la canonización de San Vicente Ferrer en Valencia. Valencia: Imprenta de José Rius, 1855.

BOIX, Vicente. Fiestas Reales. Descripción de la cabalgata y de la procesión del Corpus. Valencia: Imprenta de la Regeneración Tipográfica de Don Ignacio Boix, 1858 .

BOIX, Vicente. Memoria Histórica de las fiestas celebradas en Valencia con motivo del $2^{o}$ centenar de Nuestra Señora de los Inocentes Mártires y Desamparados, en el mes de mayo de 1867. Valencia: Ayuntamiento de Valencia, 1867.

BONET, Victoria E. “José Gallel y Beltrán: Perspectivas y paisajes. Una profesión”. Ars longa: Cuadernos de arte, 1991, n. ${ }^{\circ}$ 2, p. 69-72.

BONET, Victoria. José Benlliure Gil (1855-1937). El oficio de pintor. Valencia: Ayuntamiento de Valencia, 1998. 
BORCHA VILA, Boro (coord.). "PALACIO MARQUÉS DE CAMPO". En: Arquitectura, Comunidad Valenciana: menciones de arquitectura 1973, premios de arquitectura 1985-1989. Valencia: Colegio Oficial de Arquitectos, 1991, p. 98101.

BURKE, Peter. El Renacimiento italiano. Cultura y sociedad en Italia. Madrid: Alianza, 2001.

CADENAS Y VICENT, Vicente de. Diccionario heráldico. $3^{\text {a }}$ edición. Madrid: Editorial Hidalguía, 1983.

CALVO SERRALlER, Francisco. La Imagen Romántica de España. Arte y Arquitectura del siglo XIX. Madrid: Alianza, 1995.

CARBALLO BARRAL, Borja. Los orígenes del Moderno Madrid: El Ensanche Este (1860-17878). Madrid: Universidad complutense de Madrid, 2015.

CASANTE, Ignacio Vicente. Heráldica General y fuentes de las armas en España. Barcelona: Salvat, 1956.

CASTRO GIRONA, Alberto. Jovellar. Madrid: Editorial Purcalla, 1947.

CATALÁ, Miguel Ángel. "Palacio de Berbedel”. En: Catálogo monumental de la ciudad de Valencia. Valencia: Caja de ahorros de Valencia, 1983, p. 146-148.

CATALÁ, Miguel Ángel. "El Museo histórico de la Ciudad. Su pasado, su presente y proyección de futuro". En: Actes del I Congreso d'Història de la Ciutat de València. Valencia: 1988. 
CATALÁ, Miguel Ángel et al. Palacio del Marqués de Campo. Museo de la ciudad. Valencia: Ayuntamiento de Valencia, 1989.

CATALÁ, Miguel Ángel. El museo de la Ciudad. Su historia y colecciones. Valencia: Ajuntament de València, 1997.

CHECA CREMADES, Fernando; MORAN TURINA, Miguel. El coleccionismo en España. De la cámara de las maravillas a la galería de pinturas. Madrid: Ensayos de Arte Cátedra, 1985.

CHIVA BELTRÁN, Juan. "Triunfos de la Casa de Austria: estradas reales en la corte de Madrid”. Potestas, 2011, n 4, p. 211-228.

CHIVA BELTRÁN, Juan. “Arcos efímeros mexicanos. De la herencia hispana al nacionalismo artístico”. En: SEMATA, ciencias humanas y sociales, Santiago de Compostela: Universidad de Santiago de Compostela, 2012, p. 193 y 194.

CHUECA GOITIA, Fernando. Madrid. Ciudad con vocación de capital Santiago de Compostela: Editorial Pico Sacro, 1974.

CHUECA GOITIA, Fernando. Historia de la Arquitectura Occidental. Tomo X: El Eclecticismo. Madrid: Dossat Bolsillo, 1979.

COLLINS, Peter. Los ideales de la arquitectura moderna: su evolución (17501950). Barcelona: Editorial Gili, 1970.

COLL, Isabel. "El panteó d'aleix Vidal i Quadres al cementiri de Sitges”. Butlletí del grup d'estudis sitgetans, 1990, año XIV, n. ${ }^{\circ} 53$. 
CORBÍN, Pilar. La beneficencia en Valencia en el siglo XIX. Valencia: Ayuntamiento de Valencia, 1980.

CORRAL, José del. La vida cotidiana en el Madrid del siglo XIX. Madrid: ediciones La Librería, 2001.

COSTA Y TURELL, Modesto. Tratado completo de la ciencia del blasón, o sea, código heráldico-histórico, $2^{\mathrm{a}}$ edición. Madrid: Librería española, 1858.

CRUILLES, Marqués de. Guía urbana de Valencia. Valencia: Imprenta José Rius, 1867.

CRUSAFONT, Miquel. Medalles conmemoratives dels Països Catalans i de la Corona Catalano-aragonesa (s. XV-XX). Barcelona: Sociedad Catalana d'estudis numismàtics, Institut d'estudis catalans, 2006.

CRUZ VALENCIANO, Jesús. El surgimiento de la cultura burguesa. Personas, hogares y ciudades en la España del siglo XIX. Madrid: Siglo XXI, 2014.

DELGADO BEDMAR, José Domingo et al. Patronos, promotores, mecenas y clientes, Actas del CEHA 1988. Murcia: Universiada de Murcia, 1992.

DELICADO, Francisco Javier. "Historicismo y Racionalismo en la Arquitectura de José Camaña Laymón (1850-1926)”. Archivo de Arte Valenciano, 1991, n. ${ }^{\circ} 72$, p. 88-98. 
DIAZ FRANCÉS, Maite. J. Laurent (1816-1866) un fotógrafo entre el negocio y el arte. Madrid: Ministerio de Educación, Cultura y Deporte, Instituto de patrimonio Cultural de España, 2016.

DIEZ, José Luis. "El retrato español en el siglo XIX" en PORTÚS PÉREZ, Javier (ed.). El retrato español en el Museo del Prado. Madrid: Anaya, 1994.

DIEZ DE VALERÓN, Clementina. Arquitectura y cuestión social en Madrid en la segunda mitad del siglo XIX. Madrid: Universidad Complutense, 1983.

DIEZ DE VALERÓN, Clementina. Arquitectura y clases sociales en el Madrid del siglo XIX. Madrid: Editorial Siglo Veintiuno de España, 1986.

ESTRELA, Juan Carlos. “José Campo Pérez, primer marqués de Campo”. A Todo Vapor, 2003, n. ${ }^{\circ}$ 39, p. 5-11.

FELIU, Joan. Dinero azul cobalto: el negocio americano de la cerámica en la provincia de Castellón en el siglo XIX. Castellón: Universitat Jaume I de Castelló, 2005 .

FERNÁNDEZ ARENAS, José. Las claves del Renacimiento. Barcelona: Ariel, 1986.

FERNÁNDEZ DE LOS RÍOS, Ángel. Guía de Madrid: manual del viajero y el forastero. Madrid: Ilustración Española y Americana, 1876.

FERRER OLMOS, Vicente. Monumentos a valencianos ilustres en la ciudad de Valencia. Valencia, 1987. 
FRASQUET, Ivana. Valencia en la revolución (1834-1843). Sociabilidad, cultura y ocio. Valencia: Universidad de Valencia, 2002.

GARCÍA CARRAFFA, Alberto. Ciencia Heráldica o del Blasón, según el método de los más insignes tratadistas. Madrid: Imprenta de Antonio Marzo, 1919.

GARCÍA MAHÍQUES, Rafael. Iconología e iconografía, Vols. I y II. Valencia: Editorial Encuentro, 2008.

GARCÍA MELERO, José Enrique. Arte español de la Ilustración y del siglo XIX. Madrid: Ediciones Encuentro, 1998.

GARCÍA SÁNCHEZ, Laura. "La fiesta como ejemplo de manifestación plástica y lúdica: Breve recorrido por un arte efímero valenciano a principios del siglo XIX". En: Primer Congreso de Historia del Arte Valenciano. Mayo 1992. Valencia: Generalitat Valenciana, 1992.

GARMA, Francisco Xavier. Adarga catalana. Barcelona: Imprenta de Mauro Martí, 1753.

GARNERÍA, José. José Benlliure Gil, colecciones privadas valencianas. Valencia: Ayuntamiento de Valencia, Área de Cultura, 2000.

GAYA NUÑO, Juan Antonio. Arte del Siglo XIX. Ars Hispaniae. Historia Universal del Arte Hispánico, Vol. XIX. Madrid: editorial Plus Ultra, 1956.

GAYA NUÑO, Juan Antonio, La pintura española fuera de España. Madrid: Espasa Calpe, 1958. 
GAYA NUÑO, Juan Antonio. El arte y los artistas españoles desde 1800. Barcelona: Eugenio Lucas, 1848.

GIL SALINAS, Rafael. "El gusto por la pintura religiosa a través de las colecciones particulares valencianas del siglo XIX. La colección Ferrándiz”. Archivo de Arte Valenciano, 1988, n. $^{\circ} 68$, p. 127-131.

GIL SALINAS, Rafael. El mundo de Goya y López en el museo San Pío V, Catálogo de exposición. Valencia: Generalidad Valenciana, 1992.

GIL SALINAS, Rafael. Arte y coleccionismo privado en Valencia del siglo XVIII a nuestros días. Valencia: Editorial Alfonso el magnánimo, 1994.

GIL SALINAS, Rafael; PALACIOS, Carmen. El ornato urbano. La escultura pública en Valencia. Valencia: Ayuntamiento de Valencia, 2000.

GIL SALINAS, Rafael. "El triomf de l'art entre el públic valencià. El mercat artístic al segle XIX. Art, mercat $i$ societat. Mil anys de relacions i interferències”. En: Afers, fulls de recerca i pensament, Vol. XXVI. Valencia: Editorial Afers, 2011, p. 673-683.

GIORGI, Rosa. Santos. Barcelona, Electa, 2005.

GÓMEZ MORENO, María Elena. Pintura y escultura españolas del siglo XIX. Madrid: Espasa Calpe, 1993. 
GONZÁLEZ, Carlos; MARTí, Montserrat (dir.). El mundo de los Madrazo. Catálogo de exposición. Madrid: Consejería de cultura y deporte de la Comunidad de Madrid, 2007.

GONZÁLEZ DE CANALES, Fernando. "Los dibujos de Rafael Monleón Torres". Archivo de Arte Valenciano, 2008, núm. LXXXIX, p. 163-180.

GONZÁLEZ ECHEGARAY, Ramón. "La flota insólita del Marqués de Campo". Revista general de Marina, 1979, núm. 196, p. 3-16.

GONZÁLEZ VARAS, Ignacio et al. Los palacios de la Castellana, Historia, arquitectura y sociedad. Madrid: Editorial Turner, 2010.

GONZÁLEZ VARAS, Ignacio. Palacios urbanos. La evolución urbana de Madrid través de sus palacios. Madrid: Ayuntamiento de Madrid, 2010.

GRACIA, Carmen. Història de l'Art Valencià. Valencia: Edicions Alfons el Magnànim, 1995.

GRANEL, L. S. Historia de los hospitales en el siglo XVIII. Valladolid, 1980.

HALL, James. Diccionario de Temas y símbolos artísticos. Madrid: Alianza Editorial, 1987.

HAUSER, Arnold. Historia social de la literatura y del arte. Tomo II. Madrid: Ediciones Guadarrama, 1964. 
HASKELL, Francis. Patronos y pintores. Madrid: Catedra, 1988.

HASKELL, Francis. Pasado y presente en el arte y en el gusto. Madrid: Alianza Forma, 1989.

HERNÁNDEZ, Telesforo. Ferrocarriles y capitalismo en el País Valenciano 18431879. Valencia: Ayuntamiento de Valencia, 1983.

HERNÁNDEZ, Telesforo. "Los negocios ultramarinos del marqués de Campo en Cuba y Filipinas (1880-1886)”. En: Los valencianos y América. Valencia: Generalitat Valenciana, 1992.

HERNÁNDEZ, Telesforo. “Tensions familiars i patrimoni: ventura i desventura de la fortuna acumulada pel marquès de Camp en La burgesia dels Països Catalans al segle XIX”. En: Afers, fulls de recerca i pensament, Vol. VIII. Valencia: Editorial Afers, 1993, p. 347-361.

HERNÁNDEZ, Telesforo. "José Campo Pérez". En: Cien Empresarios Valencianos. Madrid: Editorial Empresarial, 2005, p. 53-64.

HONOUR, Hugh. El Neoclasicismo. Madrid: Xarait Ediciones, 1992.

HOROZCO, Sebastián de. El libro de los proverbios glosados I (1570-1580). Kasel: Edition Reichenberger, 1994.

IBÁÑEZ BARBERÁ, Gema (coord.). José Benlliure Gil (1855-1937). Valencia: La Imprenta CG, 2008. 
LACAL, Saturnino. Libro de honor: apuntes para la historia de la Exposición Universal de Barcelona, premios concedidos y dictámenes que los productos expuestos merecieron del jurado. Barcelona: Tipografía de Fidel Giró, 1889.

LAGUNA PLATERO, Antonio. Historia del periodismo valenciano: 200 años en primera plana. Valencia: Dirección General de Relaciones Institucionales e Informativas, 1990.

LOHENGRIN. "El palacio de Los condes de Berbedel". Valencia Atracción, 1974, Núm. 479, Año XLIX, p. 8-12.

LÓPEZ PIÑERO, José María et al. Medicina y sociedad en la España del siglo $X I X$. Madrid: Sociedad de estudios y publicaciones, 1960.

LLORENTE, P. "El alumbrado público en Valencia”. En: Almanaque de Las Provincias 1895.

MADRAZO, Pedro. "Bellas Artes. Su estado actual en la capital de España. Pintura. Exposición del Liceo". El Laberinto, 1844, año 1, n. ${ }^{0}$ 15, p. 107.

MARGARIT, Isabel. La vida y la época de Alfonso XII. Barcelona: Editorial Planeta, 1998.

MARÍN, M. ${ }^{a}$ Isabel. L'obra medallística de l'escultor Eusebi Arnau, Barcelona: Sdad. Catalana d'estudis numismàtics, Institut d'estudis catalans, 2005.

MARQUÉS DE CRUILLES. Guía urbana de Valencia antigua y moderna. Tomo II. Valencia: imprenta de José Rius, 1876. 
MARTÍN, Fernando; SIERRA, Luis. 150 años Platería Espuñes. Madrid: Artes Gráficas Luis Pérez S.A., 1990.

MARTÍNEZ, Pilar et al. "La Feria de Julio y sus accesos". Revista Valenciana de Estudios Históricos, 2016, Vol.3, n. ${ }^{\circ} 5$.

MARTÍNEZ ALOY, José. “Provincia de Valencia”. En: Geografía General del Reino de Valencia. Barcelona: Carreres y Candí, 1918.

MARTÍNEZ PLAZA, Pedro J. El coleccionismo de pintura en Madrid durante el siglo XIX. Madrid: Centro de estudios Europa Hispánica, 2018.

MATEU IBARS, María Dolores. Iconografía de san Vicente Mártir, Tomo I. Pintura. Valencia, Institución Alfonso el Magnánimo, 1990.

McCORQUODALE, Charles. Historia de la decoración. Barcelona: Stylos, 1983.

MESSÍA DE LA CERDA Y PITA, Luis. Heráldica española: el diseño heráldico. $2^{\mathrm{a}}$ edición. Madrid: Aldaba Ediciones, 1998.

MÍNGUEZ CORNELLES, Víctor. Art $i$ arquitectura efímera a la València del s. XVIII. Valencia: Institució Alfons el Magnànim, 1990.

MÍNGUEZ CORNELLES, Víctor. “Arte, espectáculo y poder en la fiesta novohispana”. En: PÉREZ MARTÍNEZ, H. (ed.) México en fiesta, México: El Colegio de Michoacán, Secretaría de Turismo, 1998. 
MÍNGUEZ CORNELLES, Víctor; GONZÁLEZ TORNEL, Pablo; RODRÍGUEZ MOYA, Inmaculada. La fiesta barroca. El Reino de Valencia (1599-1802), Castellón: Universitat Jaume I, Servei de Comunicació i Publicacions, 2010.

MÍNGUEZ CORNELLES, Víctor; RODRÍGUEZ MOYA, Inmaculada. "Un imperio iluminado por el sol y cien mil luminarias”. En: Visiones de un Imperio en Fiesta, Madrid: Fundación Carlos de Amberes, 2016.

MÍNGUEZ CORNELLES, Víctor. La fiesta áurea durante el reinado de Carlos II. El esplendor del barroco efímero. En: Ars \& Renovatio, Alcañiz: CEAR, 2019.

MOMBLANCH GARCÍA, Francisco de Paula. "Un valenciano singular: el marqués de Campo". En: Crónica de la XXX asamblea de cronistas oficiales del reino de Valencia. Valencia, 2016.

MONTOLIU, Violeta. "El Monumento al Marqués de Campo". En: Monumentos Conmemorativos de Valencia: Memoria esculpida de una ciudad: 1875-1936. Valencia: Real Academia de Cultura Valenciana, 2002, p. 79-84.

MORANT GIMENO, Ana María. "La arquitectura benéfica privada valenciana del siglo XIX como muestra del poder burgués”. En: Actas del Congreso Nacional del CEHA 2012. Castellón: Universidad Jaime I, 2012, p. 545-560.

MORANT GIMENO, Ana María. "El conocimiento de otros mundos a través de la literatura de viajes: crónicas y dibujos de las obras del Canal de Panamá en 1886”. En: Actas del Congreso Nacional del CEHA 2014. Toledo: Universidad de Toledo, 2014. 
MORANT GIMENO, Ana. María. "Un coleccionista desconocido en la corte de Alfonso XII: el marqués de Campo (1814-1889)”. Materia, Revista Internacional de Arte, 2015, n. ${ }^{\circ}$ 9, p. 115-127.

MORANT GIMENO, Ana María. “Un regalo del marqués de Campo (1814-1889) al general Jovellar (1819-1892) en 1875: buscando una interpretación iconográfica”. En: BALLESTER, Blanca, BERNAT, Antonio, CULL, John (Eds.). Encrucijada de la palabra y la imagen simbólicas. Estudios de emblemática. Palma de Mallorca, Editorial Marcial Pons, 2018.

MORANT GIMENO, Ana. María. "El segundo centenario de un mecenas y coleccionista valenciano: el marqués de Campo (1814-1889)". Debats, 2015, nº 125, p. 96-105.

MORANT GIMENO, Ana María et al. El marqués de Campo. Empresario, político y coleccionista de obras de arte. Valencia: Ayuntamiento de Valencia, 2015.

MORANT GIMENO, Ana María. "La visión del arte barroco iberoamericano en las crónicas de viajes del siglo XIX: la expedición del Marqués de Campo (1814-1889) al Canal de Panamá en 1886”. En: Arte y Patrimonio en Iberoamérica. Tráficos Transoceánicos. Castellón: Colección América 34, Universitat Jaume I de Castelló, 2016, p. 303-320.

MORANT GIMENO, Ana María. "Un mecenas desconocido de la España decimonónica: el marqués de Campo (1814-1889)”. En: Coleccionismo, mecenazgo y mercado artístico en España e Iberoamérica. Sevilla: Universidad de Sevilla, 2017.

NAVASCUÉS PALACIO, Pedro. "Influencia francesa en la arquitectura madrileña en el siglo XIX: La etapa Isabelina”. Archivo Español de Arte, 1982, 217, p. 59-68. 
NAVASCUÉS PALACIO, Pedro. Un Palacio Romántico. Madrid 1846-1858. Madrid: Ediciones el Viso, 1983.

NAVASCUÉS PALACIO, Pedro. “Castellana: quién te ha visto y quién te ve”. Lápiz, $1985,{ }^{\circ}{ }^{\circ} 28$, p. $28-33$.

NAVASCUÉS PALACIO, Pedro. El siglo XIX, bajo el signo del romanticismo. Madrid: Editorial Sílex, 1992.

NAVASCUÉS PALACIO, Pedro. "Palacios madrileños del ochocientos". En: Casa de América, Rehabilitación del Palacio de Linares. Madrid: Editorial Electa, 1993.

NAVASCUÉS PALACIO, Pedro. “Madrid, ciudad y arquitectura (1808-1898)”. En: Historia de Madrid. Madrid: Editorial Complutense,1994, p. 401-440.

OLMEDO DE CERDÁ, María Fernanda. Anecdotario histórico español. Valencia: Carena Editors, 2004.

OTERO CARVAJAL, Luis; BAHAMONDE, Ángel. Madrid en la sociedad del siglo XIX, Vols. 1 y 2. Madrid: Consejería de Cultura, 1986.

PALOMINO DE CASTRO Y VELASCO, Antonio. El museo pictórico y escala óptica, (1715-1724). Madrid: Aguilar, 1988.

PANIAGUA, Javier. Diccionario biográfico de políticos valencianos 1810-2003. Valencia: Institució Alfons el Magnànim, 2004. 
PANTORBA, Bernardino de. Historia y crítica de las exposiciones nacionales de Bellas Artes celebradas en España. Madrid: Ediciones Alcor, 1948.

PARDO DE GUEVARA, Eduardo. Manual de Heráldica Española. $1^{\text {a }}$ edición. Madrid: Aldaba Ediciones, 1987.

PASTOR RODRÍGUEZ, Julián. Historia de la Milagrosa Imagen de Nuestra Señora de los Desamparados patrona de Valencia desde su origen hasta el presente año. Lérida: Academia Bibliográfico-Mariana, 1868.

PEDRAZA MARTÍNEZ, Pilar. Barroco efimero en Valencia. Valencia: Ayuntamiento de Valencia, 1982.

PERDIGUERO, Enrique (coord.). SALVAD AL NIÑO. Estudios sobre la protección de la infancia en la Europa mediterránea a comienzos del siglo XX. Seminario de estudios sobre la ciencia. Valencia: Publicacions de la Universitat de València, 2004.

PÉREZ SÁNCHEZ, Alfonso. Jerónimo Jacinto de Espinosa (160o-1667). Valencia: Consorcio de Museos de la Generalitat Valenciana, 2002.

PERIS MENCHETA, Francisco. De Madrid a Panamá. Crónica de la Expedición enviada por el Excmo. Sr. Marqués de Campo. Madrid: Antonio de San Martín Editor, 1886.

PERNOUD, Régine. La bourgeoisie. Paris: Presse Universitaires de France, 1985.

PIFERRER, Francisco. Tratado de heráldica y blasón, adornado con láminas, Madrid: El Libro de Oro, 1858. 
PINEDO HERRERO, Carmen; MAS ZURITA, Elvira. Dos artistas valencianos del XIX: los escenógrafos José Vicente Pérez Vela y José Flores Vela, (inédito) Valencia: 2003.

PIQUERAS, María Jesús. "Rafael Monleón: el pintor del mar y su historia”. Ars longa: cuadernos de arte, $1991,{ }^{\circ}{ }^{2}$, p. 49-52.

PIQUERAS, José Antonio. "De Diario Mercantil a El Mercantil Valenciano (1868 - 1874)". En: LAGUNA, Antonio; MARTÍNEZ, Francisco (coord.). Historia de Levante- El Mercantil Valenciano. Valencia: Editorial Prensa Valenciana, 1992, p. 59-78.

PIQUERAS, José Antonio. La revolución democrática (1868-1874). Cuestión social, colonialismo y grupos de presión. Madrid: ministerio de Empleo y Seguridad Social, 1992.

PONS, Anacleto; SERNA, Justo. La ciudad extensa. Valencia: Diputación de Valencia, 1992.

PONS, Anacleto; SERNA, Justo. Los triunfos del burgués. Estampas valencianas del Ochocientos. Valencia: Tirant lo Blanch, 2011.

PORTÚS, Javier. Museo del Prado. Memoria escrita, 1819-1994. Madrid: Calcografía Nacional, 1994.

PRIEGO, Carmen (ed.). Arquitectura y espacio urbano de Madrid en el siglo XIX. Madrid: Museo de Historia de Madrid, 2008. 
QUEVEDO PESANHA, Carlos. Vida artística de Mariano Benlliure. Madrid: Espasa Calpe, 1947.

REGUERO, Jaime. Quién fue Alfonso XII. Barcelona: ediciones G.P. 1959.

REYERO, Carlos. Imagen histórica de España (1850-19oo). Madrid: Espasa Arte, 1987.

REYERO, Carlos. La pintura de historia en España. Madrid: Cuadernos de Arte Cátedra, 1989.

REYERO, Carlos. París y la crisis de la pintura española, 1799-1889. Del Museo del Louvre a la torre Eiffel. Madrid: Ediciones de la Universidad Autónoma de Madrid, 1993.

REYERO, Carlos; FREIXÀ, Mireia. Pintura y Escultura en España, 18oo-191o. Madrid: Cátedra, 1995.

REYERO, Carlos. La escultura conmemorativa en España. La edad de oro del monumento público, 1820-1914. Madrid: Cuadernos de arte Cátedra, 1999.

REYERO, Carlos. "Pasivos, exóticos, vencidos, víctimas. El indígena americano en la cultura oficial española del siglo XIX”. Revista de Indias, 2004, vol. LXIV, núm. 232, p. 721-748.

REYERO, Carlos. Alegoría, nación y libertad. El olimpo constitucional de 1812. Madrid: Siglo XXI, 2010. 
REYERO, Carlos. Introducción al arte occidental del siglo XIX. Madrid: Cátedra, 2014.

REYERO, Carlos. Monarquía y Romanticismo. El hechizo de la imagen regia, 1829-1873. Madrid: Siglo XXI, 2015.

RIDAURA CUMPLIDO, Concepción. Hábitos sociales artísticos en la sociedad valenciana del siglo XIX. Valencia: Tesis doctoral. Universidad de Valencia, 2000. RIDAURA, CUMPLIDO, Concepción. Vida cotidiana y Confort en la Valencia burguesa (1850-19oo). Valencia: Generalitat Valenciana, 2006.

RIPA, Cesare. Iconología (Tomos I y II). Madrid: Ediciones Akal, 1996 (Primera edición italiana 1593).

RODRÍGUEZ MOYA, Inmaculada. 'La Junta de Iconografía Nacional (18761961) y el retrato del poder”. En: Víctor Mínguez (ed.). Las artes y la arquitectura del poder. Castellón: Universitat Jaume I, 2013, p. 271-296.

RODRÍGUEZ MOYA, Inmaculada; MÍNGUEZ CORNELLES, Víctor. El retrato del poder. Castellón: Universitat Jaume I, 2019.

ROIG CONDOMINA, Vicente M. " "La Real Sociedad Económica de Amigos del País de valencia como promotora de las bellas artes: el ejemplo de las exposiciones del siglo XIX”. Ars longa: cuadernos de arte, 2000, n. ${ }^{\circ}$ 9-10, p. 239-246.

ROIG CONDOMINA, Vicente M. ${ }^{\mathrm{a}}$ "El ateneo científico, literario y artístico de Valencia y su aportación a las artes en el último tercio del siglo XX". Ars longa: cuadernos de arte, 1995, n. ${ }^{\circ}$ 6, p. 107-114. 
ROMANELLI, Rafael. A qué llamamos burguesía. Historia social e historia conceptual. Valencia: Episteme, 1997.

ROSENBLUM, Robert; JANSON, J. El arte del siglo XIX. Madrid: Akal, 1992.

SÁNCHEZ DOMINGO, José Ramón. Viñuelas. Crónica de un castillo. Madrid: Lamparanza S.A., 1999.

SANCHEZ, Miguel Ángel. La industria Valenciana en torno a la Exposición Regional de 1909. Tesis Doctoral. Valencia: Universidad politécnica de Valencia, 2009.

SANCHIS GUARNER, Manuel. La ciudad de Valencia: Síntesis de Historia y Geografía Urbana. Valencia: IRTA, 2009. (Primera edición Valencia 1972).

SANCHIZ y BASADRE, Eliseo. Una visita a las obras del Canal de Panamá. Madrid: Imprenta de F. Maroto y Hermano, 1886.

SAZATORNIL RUIZ, Luis. Tomás Campuzano y Aguirre (1857-1934). Santander: Fundación Marcelino Botín, 2000.

SECO SERRANO, Carlos. Sociedad, literatura y política en la España del siglo XIX. Barcelona: Biblioteca Universitaria guadiana, 1973.

SECO SERRANO, Carlos. Alfonso XII. Barcelona: Editorial Ariel, 2007.

SIMÓ, Trinidad. La arquitectura de la renovación urbana en Valencia. Valencia: Albatros Ediciones, 1973. 
SIMÓN DÍAZ, José. Madrid en su prensa del siglo XIX. Madrid: Instituto de Estudios Madrileños, 1981.

SCHLOSSER, Julius von. Las cámaras artísticas y maravillosas del renacimiento tardío. Madrid: Akal Universitaria, 1988.

SOCIAS, Inmaculada; GKOZGKOU, Dimitra (ed.). Nuevas contribuciones en torno al mundo del coleccionismo de arte hispánico en los siglos XIX y XX. Asturias: Ediciones Trea, 2013.

SUSTO, Juan Antonio. "Concepción. Vida y Pasión de la estatua de Colón”. Lotería, 1944, núm. 41, octubre, pp. 8-10.

TABERNER, Francisco et al. Historia de la ciudad III. Arquitectura y transformación de la ciudad de Valencia. Valencia: Ayuntamiento de Valencia, Ícaro, Universidad de Valencia y U.P.V., 2003.

TERVATENT, Guy de. Atributos y símbolos en el arte profano. Diccionario de un lenguaje perdido. Barcelona: Ediciones del Serbal, 2002.

TORMO, Elías. Guía de Levante. Madrid: Editorial Calpe, 1923.

TORMO, Elías. Las iglesias del antiguo Madrid. Madrid: N. A. Edición, 1985.

TORRES, Begoña. Guía del Museo del Romanticismo. Madrid: Ministerio de Cultura y Deporte, Secretaría General Técnica, Subdirección General de Atención al Ciudadano, Documentación y Publicaciones, 2018. 
TOVAR MARTÍN, Virginia. El Real Sitio de El Pardo. Madrid: Editorial Patrimonio Nacional, 1995.

TRAMOYERES BLASCO, Luis. "Salvador Martínez Cubells". Archivo de Arte Valenciano, $1915, \mathrm{n}^{\mathrm{0}} 1$, p. 36-37.

TUDA RODRÍGUEZ, Isabel (ed.) Jean Laurent en el Museo de Historia de Madrid. Retratos Políticos, "tomo IV". Madrid: Editorial del Museo Municipal de Madrid, 2011.

TUÑÓN DE LARA, Manuel. La España del siglo XIX. Barcelona: Editorial Laia, 1977.

UHAGON DE GUARDAMINO, Francisco. Viñuelas. Madrid: Fototipia de Hauser y Menet, 1899.

VALERO DE TORNOS, Juan. Guía ilustrada de la Exposición Universal de Barcelona 1888. Barcelona: Editorial G. De Grau, 1888.

VÁZQUEZ RODRÍGUEZ, Leopoldo. Crónica de los festejos reales celebrados con motivo del regio enlace de S. M. el rey don Alfonso XII con su A.R. la archiduquesa de Austria Doña María Cristina en 29 de noviembre de 1879. Madrid: imprenta de E. Rubiños, 1880.

VIDAL, Javier. (dir.). Cien Empresarios Valencianos. Madrid: Editorial Empresarial, 2005. 
VIDAL CORELLA, Vicente. Valencia antigua y pintoresca. Valencia: Publicaciones del Círculo de Bellas Artes de Valencia, 1971.

VIDAL CORELLA, Vicente. Los Benlliure y su época. Valencia: Prometeo, 1977. VIVAR DEL RIEGO, José Antonio. "Taller de heráldica. Cómo diseñar y describir un escudo”. En: GALENDE DÍAZ, Juan Carlos (coord.). De Sellos y Blasones: miscelánea científica. Madrid: Universidad Complutense de Madrid, 2012, p. 413477.

YARZA LUACES, Joaquín. "Clientes, promotores y mecenas en el are medieval hispano". En: Patronos, Promotores, Mecenas y Clientes. Actas del VII Congreso CEHA, Murcia: Universidad de Murcia 1988.

ZABALA, Fernanda. 125 valencianos en la historia. Valencia: Carrera editors, 2002. 


\section{ÍNDICE DE ILUSTRACIONES}

\section{CAPÍTULO I}

Figura 1.1.- José Campo. Obra de Ricardo Balaca. Fundación marqués de Campo. Valencia.

Figura 1.2.- José Campo. La Ilustración Española y Americana. Publicado en 1888.

Figura 1.3.- José Campo. Litografía de Juan de Alaminos. Posterior a 1850. Publicada en RIDAURA, CUMPLIDO, Concepción. Vida cotidiana y Confort en la Valencia burguesa (1850-19oo). Valencia: Generalitat Valenciana, 2006, p. 34 .

Figura 1.4.- José Campo. Obra de José Struch. Colección Particular. Publicado en MORANT GIMENO, Ana María et al. El marqués de Campo. Empresario, político y coleccionista de obras de arte, Valencia: ayuntamiento de Valencia, 2015.

Figura 1.5.- José Campo. Fotografía publicada en El Dominical en 1884.

Figura 1.6.- José Campo. Fotografía de Jean Laurent. Colección permanente del Museo de Historia de Madrid. Ref. 1991/18/1-481.

Figura 1.7.- José Campo. Fotografía de Jean Laurent. Colección permanente del Museo de Historia de Madrid. Ref. 1991/18/4-137.

Figura 1.8.- José Campo. Fotografía de Jean Laurent. Colección permanente del Museo de Historia de Madrid. Ref. 1991/18/4.138.

Figura 1.9.- José Campo. Fotografía de Jean Laurent. Colección permanente del Museo de Historia de Madrid. Ref. 1991/18/4.140.

Figura 1.10.- José Campo. Fotografía de Jean Laurent. Colección permanente del Museo de Historia de Madrid. Ref. 1991/18/4-142.

Figura 1.11.- José Campo. Fotografía de Jean Laurent. Colección permanente del Museo de Historia de Madrid. Ref. 1991/18/4-145. 
Figura 1.12.- José Campo. Fotografía de Jean Laurent. Colección permanente del Museo de Historia de Madrid. Ref. 1991/18/1-484.

Figura 1.13.- José Campo. Fotografía de Jean Laurent. Colección permanente del Museo de Historia de Madrid. Ref. 1991/18/1-482.

Figura 1.14.- José Campo. Fotografía de Jean Laurent. Colección permanente del Museo de Historia de Madrid. Ref. 1991/18/4-144.

Figura 1.15.- José Campo. Fotografía de Jean Laurent. Colección permanente del Museo de Historia de Madrid. Ref. 1991/18/4-141.

Figura 1.16.- José Campo. Fotografía de Nadar. Posterior 1870. Propiedad de la autora.

Figura 1.17.- Reverso de la fotografía. Propiedad de la autora.

Figura 1.18.- Distribución de premios en el Asilo del marqués de Campo. José Benlliure. Óleo sobre lienzo (1881-1886). Fundación marqués de Campo. Valencia.

Figura 1.19.- José Campo. Inventario del Asilo marqués de Campo. Dirección General de Cultura.

Figura 1.20.- El marqués de Campo. Obra de Manuel Moreno Simarro. 1964. Fundación Bancaja.

Figura 1.21.- Monumento a José Campo. Obra de Mariano Benlliure. 1885.Fotografía de la autora.

Figura 1.22.- Monumento a José Campo. Detalle. Obra de Mariano Benlliure. 1885. Fotografía de la autora.

Figura 1.23.- José Campo. Fotoescultura en bronce. Obra de Giovanni Antonio Lanzirotti. Colección particular. Fotografía de la autora.

Figura 1.24.- José Campo. Fotoescultura en bronce. Detalle del nombre del autor. Fotografía de la autora.

Figura 1.25.- José Campo. Fotoescultura en bronce. Detalle. Fotografía de la autora. 
Figura 1.26.- Medalla conmemorativa de la Expedición del marqués de Campo a las obras del canal de Panamá. 1886. Imagen del Museo del Prado. https://www.museodelprado.es/coleccion/obra-de-arte/al-marques-de-campo-en-laprimera-expedicion/a3a13ab6-9901-4652-bcab-f2dogef995ee.

Figura 1.27.- Rosalía Rey Loisselet, marquesa de Campo. Inventario del Asilo marqués de Campo. Dirección General de Cultura.

Figura 1.28.- Rosalía Rey, marquesa de Campo. Inventario del Asilo marqués de Campo. Dirección General de Cultura.

Figura 1.29.- José Campo. Marqués de Campo. Inventario del Asilo marqués de Campo. Dirección General de Cultura.

Figura 1.30.- Josefa Campo Rey. Hija de los marqueses de Campo. Inventario del Asilo marqués de Campo. Dirección General de Cultura.

Figura 1.31.- Josefa Campo Rey. Detalle. Foto de la autora.

Figura 1.32.- Luis María Bruna. Hijo adoptivo de los marqueses de Campo. Inventario del Asilo marqués de Campo. Dirección General de Cultura.

Figura 1.33.- Luis María Bruna. Detalle. Inventario del Asilo marqués de Campo. Dirección General de Cultura.

Figura 1.34.- Familiar de José Campo. Fecha y autor desconocido. Inventario del Asilo marqués de Campo. Dirección General de Cultura.

Figura 1.35.- Familiar de José Campo. Fecha y autor desconocido. Inventario del Asilo marqués de Campo. Dirección General de Cultura.

Figura 1.36.- Familiar de José Campo. Fecha y autor desconocido. Inventario del Asilo marqués de Campo. Dirección General de Cultura.

Figura 1.37.- Familiar de José Campo. Fecha y autor desconocido. Inventario del Asilo marqués de Campo. Dirección General de Cultura.

Figura 1.38.- Familiar de José Campo. Fecha y autor desconocido. Inventario del Asilo marqués de Campo. Dirección General de Cultura. 


\section{CAPÍTULO II}

Figura 2.1.- Asilo de párvulos del marqués de Campo. Jaime Beatty. 1863. Valencia.

Figura 2.2.- Asilo marqués de Campo. 1888. Fachada principal. Valencia. Fotografía de la autora.

Figura 2.3.- Asilo marqués de Campo. 1888. Detalle de la fachada principal. Valencia. Fotografía de la autora.

Figura 2.4.- Asilo marqués de Campo. 1888. Detalle de la fachada principal. Escudo de armas del marqués. Inventario del Asilo marqués de Campo. Dirección General de Cultura.

Figura 2.5.- Asilo marqués de Campo. 1888. Detalle de la fachada principal. Imagen de san José. Inventario del Asilo marqués de Campo. Dirección General de Cultura.

Figura 2.6.- Asilo marqués de Campo. 1888. Detalle de la fachada principal. Imagen de san Vicente de Paul. Inventario del Asilo marqués de Campo. Dirección General de Cultura.

Figura 2.7.- Capilla del Asilo del marqués de Campo. 1888. Vista actual. Fotografía de la autora.

Figura 2.8.- Capilla del Asilo del marqués de Campo. 1888. Detalle de la bóveda y la cúpula. Vista actual. Fotografía de la autora.

Figura 2.9.- Capilla del Asilo del marqués de Campo. 1888. Detalle del altar mayor. Vista actual. Inventario del Asilo marqués de Campo. Dirección General de Cultura. 


\section{CAPÍTULO III}

Figura 3.1.- Plano del padre Tosca. 1704.

Figura 3.2.- Plano original del palacio Campo antes de la reforma de 1988. Imagen publicada en CATALÁ, Miguel Ángel et al. Palacio del Marqués de Campo. Museo de la ciudad. Valencia: Ayuntamiento de Valencia, 1989.

Figura 3.3.- Palacio del marqués de Campo. Valencia. Fachada. Estado actual. Fotografía de la autora

Figura 3.4.- Palacio del marqués de Campo. Valencia. Detalle del caduceo de la fachada. Estado actual. Fotografía de la autora.

Figura 3.5.- Palacio del marqués de Campo. Valencia. Detalle de la antorcha de la fachada. Estado actual. Fotografía de la autora.

Figura 3.6.- Palacio del marqués de Campo. Patio de Armas. Imagen tras la reforma de 1988.

Figura 3.7.- Palacio del marqués de Campo. Valencia. Escalera principal. Estado actual. Fotografía de la autora.

Figura 3.8.- Palacio del marqués de Campo. Valencia. Cúpula con pechinas. Estado Actual. Fotografía de la autora.

Figura 3.9.- Palacio marqués de Campo. El comedor en la época de los Condes de Berbedel. Imagen publicada en: LOHENGRIN. "El palacio de Los condes de Berbedel”. Valencia Atracción, 1974, Núm. 479, Año XLIX, p. 8-12.

Figura 3.10.- Alegoría de la primavera. Sala Fumoir. Palacio del marqués de Campo. Estado actual. Imagen de la autora.

Figura 3.11.- Alegoría del verano. Sala Fumoir. Palacio del marqués de Campo. Estado actual. Imagen de la autora.

Figura 3.12.- Alegoría del otoño. Sala Fumoir. Palacio del marqués de Campo. Estado actual. Imagen de la autora. 
Figura 3.13.- Alegoría del invierno. Sala Fumoir. Palacio del marqués de Campo. Estado actual. Imagen de la autora.

Figura 3.14.- Palacio del marqués de Campo. Sala de billar en la época de los condes de Berbedel. Imagen publicada en: LOHENGRIN. "El palacio de Los condes de Berbedel”. Valencia Atracción, 1974, Núm. 479, Año XLIX, p. 8-12.

Figura 3.15.-. Palacio del marqués de Campo. Decoración de la bóveda de la Sala de artistas. Estado actual. Fotografía de la autora.

Figura 3.16.- Palacio del marqués de Campo. El gran salón de baile. Época de los condes de Berbedel. Imagen publicada en: LOHENGRIN. "El palacio de Los condes de Berbedel”. Valencia Atracción, 1974, Núm. 479, Año XLIX, p. 8-12.

Figura 3.17.- Palacio del marqués de Campo. Oratorio. Estado actual. Fotografía de la autora.

Figura 3.18.- Palacio del marqués de Campo. Bóveda esquifada de la sala de artistas. Estado actual. Fotografía de la autora.

Figura 3.19.- Palacio del marqués de Campo. Sala de artistas. Alegoría de la escultura. Fotografía de la autora.

Figura 3.20.- Palacio del marqués de Campo. Sala de artistas. Alegoría de la pintura. Fotografía de la autora.

Figura 3.21.- Palacio del marqués de Campo. Sala de artistas. Alegoría de la música. Fotografía de la autora.

Figura 3.22.- Palacio del marqués de Campo. Sala de artistas. Alegoría de la arquitectura. Fotografía de la autora.

Figura 3.23.- Alegoría de la pintura. José del Castillo. Gabinete de la Princesa de Asturias del palacio de El Pardo. Imagen publicada en:

https://www.museodelprado.es/coleccion/obra-de-arte/alegoria-de-lapintura/gaed7935-c11b-43do-85f2-a4a13f6fd15e

Figura 3.24.- Alegoría de la música. José del Castillo. Gabinete de la Princesa de Asturias del palacio de El Pardo. Imagen publicada en:

https://www.museodelprado.es/coleccion/obra-de-arte/alegoria-de-lamusica/1c6a1108-c7ab-412a-8e16-4eoad0193264 
Figura 3.25.- Palacio del marqués de Campo. Sala de artistas. La iluminación. Fotografía de la autora.

Figura 3.26.- Palacio del marqués de Campo. Sala de artistas. Posible representación de La fábrica de gas. Fotografía de la autora.

Figura 3.27.- Palacio del marqués de Campo. Sala de artistas. Posible representación de La navegación. Fotografía de la autora.

Figura 3.28.- Palacio del marqués de Campo. Sala de artistas. Posible representación de El puerto. Fotografía de la autora.

Figura 3.29.- Ceremonia de la colocación por la Reina Isabel II de la primera piedra de la Biblioteca nacional, 24 de enero de 1886. Imagen publicada en 1http://www.bne.es/es/Micrositios/Exposiciones/BNE300/Exposicion/Seccion4/Obra 20.html?origen=galeria

Figura 3.30.- Palacio del sr. Campo. Imagen de la Guía de Madrid, 1876

Figura 3.31.- Madrid: Iluminación del palacio del marqués de Campo durante las noches de Festejos Reales (dibujo al natural por el señor Domec). La Ilustración Española y Americana, 1878.

Figura 3.32.- Palacio del marqués de Campo. Paseo de Recoletos 14. Madrid. Imagen publicada en Un palacio romántico, 1983.

Figura 3.33.- Plano a escala de la verja y la caseta de portero. Manuel Seco Rodríguez. Ayuntamiento de Madrid. Archivo de la villa.

Figura 3.34.- Palacio del marqués de Campo. Dibujo publicado en Los palacetes de la Castellana, 1999.

Figura 3.35.- Expediente del incendio del palacio del marqués. 1869. Detalle. Fotografía de la autora.

Figura 3.36.- Vista del edificio del castillo de Viñuelas a mediados del siglo XIX, antes de las modificaciones y ampliaciones. Dibujo sobre cartulina, realizado por Valentín Carderera y Solano, (1796-1880). Museo Lázaro Galdeano, Madrid, Archivo CERES: COLECCIONES EN RED. 
Figura 3.37.- Diana cazadora. Castillo de Viñuelas. Imagen publicada en UHAGON DE GUARDAMINO, Francisco. Viñuelas. Madrid: Fototipia de Hauser y Menet, 1899, p. 3.

Figura 3.38.- Figura de León alado. Castillo de Viñuelas. Imagen publicada en UHAGON DE GUARDAMINO, Francisco. Viñuelas. Madrid: Fototipia de Hauser y Menet, 1899, p. 3.

Figura 3.39.- Castillo de Viñuelas. Vista del salón de tertulia tras la venta del castillo. Imágen publicada en SÁNCHEZ DOMINGO, José Ramón. Viñuelas. Crónica de un castillo. Madrid: Lamparanza S.A., 1999.

Figura 3.40.- Castillo de Viñuelas. Vista de la sala de armas tras la venta del castillo. Imágen publicada en SÁNCHEZ DOMINGO, José Ramón. Viñuelas. Crónica de un castillo. Madrid: Lamparanza S.A., 1999.

Figura 3.41.- Villa Campo. Arcachon. Francia. Imagen en línea: www.arcachonnostalgie.com/

Figura 3.42.- Gran salón de la Villa Renesse. Arcachon. Imagen en línea: www.arcachon-nostalgie.com/

Figura 3.43.- Habitación Luis XV de la villa Renesse. Arcachon. Imagen en línea: www.arcachon-nostalgie.com/ 


\section{CAPítulo IV}

Figura 4.1.- Arco construido por José Campo para la entrada de la Feria de Julio de 1871. Valencia. Imagen de la Biblioteca Valenciana.

Figura 4.2.- Arco construido por José Campo en el paseo de Recoletos y fachadas engalanadas para la entrada del Alfonso XII en Madrid. 1875. La Ilustración Española y Americana.

Figura 4.3.- Arco de estilo árabe construido por José Campo en el paseo de Recoletos en 1875. Madrid. Imagen publicada en El periódico para todos, enero 1875 .

Figura 4.4.- Carro que representa a Valencia. Imagen publicada en la Crónica de Vicente Boix.1858.

Figura 4.5.- Carro que representa La religión católica y las virtudes teologales. Imagen publicada en la Crónica de Vicente Boix.1858.

Figura 4.6.- Carro que representa La fundación del Colegio Imperial de huérfanos de san Vicente. Imagen publicada en la Crónica de Vicente Boix.1858. Figura 4.7.- Carro que representa Las Cortes de 1412 en Caspe. 1858. Imagen publicada en la Crónica de Vicente Boix.1858.

Figura 4.8.- Instalación de la fábrica de gas del marqués de Campo en la Exposición Regional de 1883. Imagen del archivo del Ateneo de Valencia. 2009.

Figura 4.9.- Instalación de la fábrica de gas del marqués de Campo en la Exposición Regional de 1883. Imagen publicada en La Ilustración Española y Americana.

Figura 4.10.- Palacio del marqués de Campo. Imagen publicada en La Ilustración Española y Americana. 1876.

Figura 4.11.- Madrid Iluminación del palacio del marqués de Campo. Imagen publicada en La Ilustración Española y Americana. 1878. 


\section{CAPÍtULO V}

Figura 5.1.-Distribución de premios en el Asilo del Marqués de Campo. José Benlliure. (1881-1886). Óleo sobre lienzo. Fundación Marqués de Campo.

Figura 5.2.- Distribución de premios en el Asilo del Marqués de Campo. José Benlliure. Boceto ${ }^{0}{ }^{0}$. Casa Museo Benlliure.

Figura 5.3.- Monumento a José Campo. Mariano Benlliure. 1885. Fotografía de la autora.

Figura 5.4.-El Ferrocarril. Mariano Benlliure. 1885. Fotografía de la autora.

Figura 5.5.-La Navegación. Benlliure.1885. Fotografía de la autora.

Figura 5.6.- El Gas. Mariano Benlliure. 1885. Fotografía de la autora.

Figura 5.7.- La Caridad. Mariano Benlliure. 1885. Fotografía de la autora.

Figura 5.8.- José Campo. Mariano Benlliure. 1885. Fotografía de la Autora.

Figura 5.9.-El Baile, Salvador Martínez Cubells. 1864. Imagen de la Fundación Bancaja.

Figura 5.10.- Vapor Magallanes. Grabado de Tomás Campuzano. 1886. Publicado en La Ilustración Española y Americana. 


\section{CAPítulo VI}

Figura 6.1.- San Dionisio. Jerónimo Jacinto de Espinosa. Colección particular. Foto de la Autora.

Figura 6.2.- La Inmaculada Concepción, Murillo.

Figura 6.3.- Obra similar a la inventariada con el número 455: un cuadro pequeño sobre tabla, representando un fraile y varios soldados antiguos, por D. Muñoz

Imagen publicada en: http://www.artnet.com/artists/domingo-mu\%C3\%B10zy-cuesta/figures-by-a-monastery-5i lID86WrlNiAweNeEwBA2

Figura 6.4.- Obra similar a la inventariada con el número 1102: un cuadro tabla, marco dorado, representando dos soldados y dos aragoneses, por M. Alcázar Imagen publicada en: http://wm1640482.web-maker.es/BIOGRAF-AS-DEPINTORES-A/Manuel-Alcazar-Ruiz/mobile/

Figura 6.5.- Obra similar a la inventariada con el número 1116: un cuadro lienzo, representando lección de lectura, por C. Pla Imagen publicada en: http://www.artnet.com/artists/cecilio-pl\%C3\%A1/9

Figura 6.6.- un cuadro de brujas. José Benlliure. Imagen publicada en: http://www.artnet.com/artists/cecilio-pl\%C3\%A1/9

Figura 6.7.- Obra similar a la inventariada con el número 435: un cuadro lienzo, marina, firmado Monleón, representando El puerto de Valencia, un vapor y varias lanchas.

Figura 6.8.- Obra similar a la inventariada con el número 440: un cuadro pequeño apaisado de Agrasot, sobre tabla, representando Una sastrería de la Edad Media. Imagen perteneciente a la colección de fotos Huguet.

Figura 6.9.- Obra similar a la inventariada con el número 440: un cuadro pequeño apaisado de Agrasot, sobre tabla, representando Una sastrería de la Edad Media. Imagen publicada en:http://www.artnet.com/artists/joaqu\%C3\%ADn-agrasoty-juan/sastrer\%C3\%ADa-YaoO8UQPUTWWuzoSFZc1VA2 
Figura 6.10.- Dos obras similares a la inventariada con el número 486: una pandereta pintada Imagen publicada en: http://www.artnet.com/artists/luis$\underline{\text { lluis-franco-salinas/ }}$

Figura 6.11.- Dos obras similares a la inventariada con el número 719: un cuadro paleta, sobre fondo de terciopelo rojo con marco dorado, por Antonio Benlliure y Gil Imagen publicada en: https://www.pinterest.es/pin/353462270738455661/

Figura 6.12.- Obra similar a la inventariada con el número 311: un grupo de bronce "La caza del ciervo. Imagen publicada en: https://www.wikiwand.com/es/Christopher Fratin

Figura 6.13. Obra similar a la inventariada con el número 828: una estatua ecuestre de D. Alfonso XII. Bronce

Figura 6.14.- Obra similar a la inventariada con el número 662: un busto de bronce de Carlos V. Imagen publicada en:

https://www.museodelprado.es/coleccion/obra-de-arte/carlos-v/1decf2096c2c-42d7-b6dd-e3ff2b75c4cb

Figura 6.15.- Diana Cazadora. Viñuelas. Imagen publicada en UHAGON DE GUARDAMINO, Francisco. Viñuelas, Madrid: 1899.

Figura 6.16.- León alado. Viñuelas. Imagen publicada en UHAGON DE GUARDAMINO, Francisco. Viñuelas, Madrid: 1899.

Figura 6.17.- 3658: La Prynne de Pradier. Imagen publicada en: https://www.pamono.es/escultura-phryne-de-bronce-de-james-pradier-parasusse-freres-decada-de-1840

Figura 6.18.- 3596: Caballo de Marly. Bronce. Imagen publicada en: https://es.expertissim.com/segun-guillaume-coustou-marly-caballo-bronce$\underline{12204687}$ 
Figura 6.19.- 3674: Escritorio estilo pompeyano. Imagen publicada en: http://domuspucelae.blogspot.com/2018/04/theatrum-escritorio-el-prestigiotraves.html

Figura 6.20.- 3715: Papelera florentina con marfil. Imagen publicada en: https://arsmagazine.com/una-papelera-florentina-de-ff-s-xvii-sobresale-en-lalicitacion-de-ansorena/

Figura 6.21.- 3697: San Jerónimo. Tiziano. 1575. Imagen publicada en: https://www.artehistoria.com/es/obra/san-jer\%C3\%B3nimo-26

Figura 6.22.- 3728: Magdalena penitente. Guido Reni. 1616. Imagen publicada en:https://es.wahooart.com/@@/8XY62Y-Reni-Guido-(Le-Guide)mar\% $3 \%$ Ada Magdalena 


\section{CAPÍtULO VII}

Figura 7.1.- Portada de la Guía Ilustrada de la Exposición Universal de Barcelona. 1888.

Figura 7.2.- Índice de la Guía Ilustrada de la Exposición Universal de Barcelona. 1888.

Figura 7.3.- Plano de las instalaciones de la Exposición Universal de Barcelona de 1888. Guía Oficial Ilustrada.

Figura 7.4.- Exposición Universal de Barcelona 1888. Vista aérea del pabellón del marqués de Campo. Imagen publicada en:

https://archivo.fundaciomascort.com/inventari/vista-aerea-de-la-exposicionuniversal-de-barcelona-de-1888-desde-el-globo-el-cautivo/

Figura 7.5.- Pabellón del marqués de Campo. Exposición Universal de Barcelona. Imagen publicada en La ilustración, 22 de julio de 1888.

Figura 7.6.- Instalación del marqués de Campo en la Exposiocn Universal de Barcelona de 1888. Imagen publicada en La Ilustracion Española y Americana.

Figura 7.7.- Catálogo de las instalaciones del marqués de Campo en la Exposición universal de Barcelona 1888. Biblioteca Nacional de Cataluña.

Figura 7.8.- Catálogo de las instalaciones del marqués de Campo en la Exposición universal de Barcelona 1888. Biblioteca Nacional de Cataluña.

Figura 7.9.- Catálogo de las instalaciones del marqués de Campo en la Exposición universal de Barcelona 1888. Biblioteca Nacional de Cataluña.

Figura 7.10.- Catálogo de las instalaciones del marqués de Campo en la Exposición universal de Barcelona 1888. Biblioteca Nacional de Cataluña.

Figura 7.11.- Catálogo de las instalaciones del marqués de Campo en la Exposición universal de Barcelona 1888. Biblioteca Nacional de Cataluña. 


\section{CAPítulo VIII}

Figura 8.1.- Iglesia de san Pedro. Torrijo del Campo, Teruel. Fotografía de la autora.

Figura 8.2.- Altar construido a expensas del marqués de Campo. Iglesia de san Pedro, Torrijo del Campo. Teruel. Fotografía de la autora.

Figura 8.3.- Parte superior del retablo. Imagen de san José y escudo de armas del marqués. Iglesia de san Pedro, Torrijo del Campo, Teruel. Fotografía de la autora.

Figura 8.4.- Hornacina central del retablo. La Anunciación. Fotografía de la autora.

Figura 8.5.- Urna del banco del retablo. Santa Rosalía de Palermo. Fotografía de la autora.

Figura 8.6.- Altar del marqués de Campo, Detalle. Iglesia de San Pedro, Torrijo del Campo, Teruel. Fotografía de la autora.

Figura 8.7.- San Vicente Mártir. Fotografía de la autora.

Figura 8.8.- San Andrés. Fotografía de la autora.

Figura 8.9.- El marqués de Campo. Manuel Moreno Simarro 1964, Fundación Bancaja.

Figura 8.10.- Escudo de armas del marqués de Campo. Fachada del asilo. Valencia.

Figura 8.11.- Formas de los escudos. El del marqués es el $n .{ }^{0}$ 2, forma española. Imagen de la Enciclopedia Heráldica y Genealogía de García Carraffa 1919.

Figura 8.12.- Configuración habitual para un escudo de cuatro costados.

Figura 8.13.- Escudo de armas del marqués de Campo. Torrijo del Campo. Teruel. Fotografía de la autora.

Figura 8.14.- Partes y adornos exteriores de un escudo de armas. Imagen del libro CASANTE, Ignacio. Heráldica General y fuentes de las armas en España. Barcelona: Salvat 1956, publicada en VIVAR DEL RIEGO, José Antonio, 2012. 
Figura 8.15.- Imagen con los nombres de los adornos exteriores de un escudo de armas. Imagen del libro GARMA, Francisco Xavier, Adarga catalana, Barcelona: Imprenta de Mauro Martí, 1753. 


\section{CAPÍTULO IX}

Figura 9.1.- Vapor Magallanes. Tomas Campuzano. Imagen publicada en La Ilustración Española y Americana. 1886.

Figura 9.2.- Crónica del Sr. Sanchiz.

Figura 9.3.- Crónica del Sr. Mencheta.

Figura 9.4.- Medalla conmemorativa de la expedición al canal de Panamá. 1886. Anverso. Imagen del Museo del Prado.

Figura 9.5.- Medalla conmemorativa de la expedición al canal de Panamá. 1886. Reverso. Imagen del Museo del Prado. 


\section{CAPÍTULO $\mathbf{X}$}

Figura 10.1.- Vapor Magallanes. Tomas Campuzano. Imagen publicada en La Ilustración Española y Americana. 1886.

Figura 10.2.- Apuntes de viaje. Imagen publicada en La Ilustración Española y Americana. 1886

Figura 10.3.- La desembocadura del canal en el Pacífico. El grupo de Colón y América. Imagen publicada en La Ilustración Española y Americana. 1886

Figura 10.4.- Secciones de las obras y vendedora de licores. Imagen publicada en La Ilustración Española y Americana. 1886

Figura 10.5.- Matachín. Lavanderas en el rio Chagres. Imagen publicada en La Ilustración Española y Americana. 1886

Figura 10.6.- Draga Salven en el Río Mindi. Imagen publicada en La Ilustración Española y Americana. 1886

Figura 10.7.- El Castillo del Morro y la entrada del Magallanes en el puerto de La Habana. Imagen publicada en la crónica de Peris Mencheta

Figura 10.8.- Una Calle del Colón. Imagen publicada en la crónica de Peris Mencheta

Figura 10.9.- Punta de Panamá. Imagen publicada en la crónica de Peris Mencheta

Figura 10.10.- El río Chagres en Matachín. Imagen publicada en la crónica de Peris Mencheta 


\section{CAPÍTULO XI}

Figura 11.1.- Palacio Velázquez. La Ilustración Española y Americana, 1883.

Figura 11.2.- Palacio Velázquez. Madrid. Estado Actual. Imagen publicada en: https://www.madrid.es/portales/munimadrid/es/Inicio/Cultura-ocio-ydeporte/Cultura-y-ocio/Direcciones-y-telefonos/Palacio-deVelazquez/?vgnextfmt $=$ default\&vgnextoid $=$ a34f29ea9281 $\mathrm{co10VgnVCM100000}$ ob205aoaRCRD\&vgnextchannel=76f3efff228fe 410 VgnVCM2000000c20 $5 \mathrm{aOaR}$ $\underline{\mathrm{CRD}}$

Figura 11.3.- Palacio Velázquez, pabellón Zuloaga. Madrid. Estado actual. Imagen publicada en: https://artedemadrid.wordpress.com/2010/08/12/palacio-develazquez/

Figura 11.4.- Figura para el General Jovellar. Platería Espuñes e hijos. 1883. Vista frontal. Colección particular. Fotografía de la autora.

Figura 11.5.- Figura para el General Jovellar. Platería Espuñes e hijos. 1883. Vista trasera. Colección particular. Fotografía de la autora.

Figura 11.6.- General Joaquín Jovellar y Soler. Imagen publicada en La Ilustración Española y Americana, 1982.

Figura 11.7.- Figura para el General Jovellar. Platería Espuñes e hijos. 1883. Inscripción frontal. Fotografía de la autora

Figura 11.8.- Batallas ganadas por el General Jovellar en España. Fotografía de la autora.

Figura 11.9.- Batallas ganadas por el General Jovellar en la Campaña de África. Fotografía de la autora.

Figura 11.10.- Personificación de Valencia. Colección particular. Fotografía de la autora.

Figura 11.11.- Salón de conferencias o de los pasos perdidos. Palacio de congresos, Madrid. 1872. Imagen publicada en:

https://www.congreso.es/es/cem/BienesInmuebles 
Figura 11.12.- Personificación de las provincias españolas. Salón de conferencias o de los pasos perdidos del Congreso, 1872. Imagen publicada en: https://www.congreso.es/es/cem/BienesInmuebles

Figura 11.13.- Personificación de España. Colección particular. Fotografía de la autora.

Figura 11.14.- Moneda de un escudo de 1862.

Figura 11.15.- Sello de Isabel II.

Figura 11.16.- Escudo real del siglo XVIII. Manuel Monfort.

Figura 11.17.- Escudo de España en época de Isabel II.

Figura 11.18.- Personificación del río Turia. Colección particular. Fotografía de la autora.

Figura 11.19.- Personificación del río Ebro. Colección particular. Fotografía de la autora.

Figura 11.20.- Sala de conferencias del congreso de los Diputados. Madrid. Detalle de la personificación del rio Ebro. Francisco Aznar 1861. Imagen publicada en: https://www.congreso.es/es/cem/BienesInmuebles

Figura 11.21.- Remate superior. Carro con caballos alados y guerrero con casco y espada. Colección particular. Fotografía de la autora.

Figura 11.22.- Remate superior vista trasera. Colección particular. Fotografía de la autora.

Figura 11.23.- Ilustraciones de Flaxman para la Ilíada y la Odisea.

Figura 11.24.- Escudo de Armas del General Jovellar. Colección particular. Fotografía de la autora.

Figura 11.25.- Escudo de los Jovellar. Casa Pericó Huesca.

Figura 11.26.- Santuario de Badías. Huesca.

Figura 11.27.- Dovelas de casa Pericó. Huesca. 

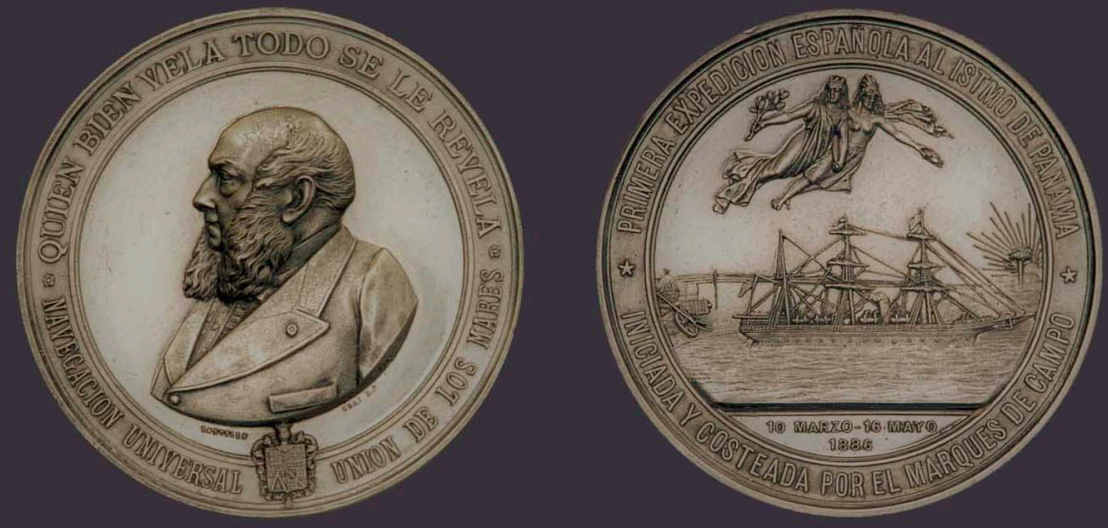

"Quien bien vela todo se le revela" 